BRUNO GREGO DOS SANTOS

\title{
TRANSAÇÃO EXTRAJUDICIAL NA ADMINISTRAÇÃO PÚBLICA
}

\author{
TESE DE DOUTORADO
}

ORIENTADORA: PROFa. TITULAR DR ${ }^{a}$. ODETE MEDAUAR

UNIVERSIDADE DE SÃO PAULO

FACULDADE DE DIREITO

SÃO PAULO

2015 
BRUNO GREGO DOS SANTOS

TRANSAÇÃO EXTRAJUDICIAL NA ADMINISTRAÇÃO PÚBLICA

Tese apresentada à Banca Examinadora do Programa de PósGraduação em Direito da Faculdade de Direito da Universidade de São Paulo, como exigência parcial para a obtenção do título de Doutor em Direito, na área de concentração Direito do Estado, sob a orientação da Profa. Tit. Dr ${ }^{a}$. Odete Medauar.

UNIVERSIDADE DE SÃO PAULO

FACULDADE DE DIREITO

SÃO PAULO

2015 
À Andreia,

por tudo. 


\section{AGRADECIMENTOS}

\section{Agradeço especialmente:}

À minha estimada orientadora, Profa. Odete Medauar, pelo papel decisivo que exerceu e exerce no direcionamento de minha carreira acadêmica, pelo resgate que ativamente promoveu da dignidade de tantos estudantes da Faculdade de Direito da Universidade de São Paulo e por ter sido a grande responsável pela transformação desse despretensioso trabalho em uma tese.

Aos professores que, além do ensino, se mostraram sempre disponíveis a discutir comigo os temas deste trabalho e a colaborar com a excelência na minha formação acadêmica na Faculdade de Direito da Universidade de São Paulo, Prof. Fernando Dias Menezes de Almeida, Prof. Vitor Rhein Schirato, Prof. Floriano de Azevedo Marques Neto e Profa. Maria Sylvia Di Pietro.

Aos professores que comigo compartilharam seus preciosos ensinamentos na Faculdade de Direito da Universidade de São Paulo, Prof. Edmir Netto de Araújo, Prof. José Maurício Conti, Prof. Fernando Facury Scaff, Prof. Mario Losano, Prof. Gustavo Justino de Oliveira, Prof. Alexandre de Morais e Profa Teresa Ancona Lopez, na Faculdade de Filosofia, Letras e Ciências Humanas da Universidade de São Paulo, Prof. Adrian Gurza Lavalle, e no Programa de Mestrado em Gestão de Políticas Públicas, Prof. Enrique José Varella Álvarez.

Ao Prof. Ibsen José Casas Noronha, pela sua inestimável orientação às minhas investigações na Faculdade de Direito da Universidade de Coimbra, e à Profa. Ana Raquel Gonçalves Moniz, ao Prof. José Carlos Vieira de Andrade e ao Prof. Licínio Lopes Martins, pelas decisivas ideias e apontamentos concedidos em nossas entrevistas naquela notável instituição.

Ao Prof. Doug Hodgson, da Faculdade de Direito da University of Notre Dame Australia, aos amigos Peter e Dixie, Jill e Kim, Peter e Melva, Martin, Dan, Bill e Greg, e aos companheiros do Rotary Club de Marialva, que dedicaram seu tempo e esforços para me auxiliar desinteressadamente. 
A todo o pessoal administrativo da Faculdade de Direito da Universidade de São Paulo, representados por Fátima e Mario, cuja disponibilidade foi sempre decisiva para o regular cumprimento de meus compromissos administrativos e acadêmicos.

Aos colegas que contribuíram significativamente para a conclusão dessa tese com a disponibilização de sua produção acadêmica, Prof. Tarcísio Vieira de Carvalho Neto e Profa ${ }^{a}$ Marie-Odile Diemer, e aos colegas do grupo de discussão da Comparative Administrative Law Initiative, Profa ${ }^{a}$ Susan Rose-Ackerman, Prof. Giacinto della Cananea, Prof. Domenico Sorace, Prof. Thomas Perroud, Prof. Oswald Jansen, Prof. Geo Quinot, Prof. André Cyrino e Prof. José Ignacio Hernández, cujos apontamentos foram essenciais para a apreciação do direito administrativo estrangeiro levada a cabo na obra.

Aos amigos conquistados ao longo desses quatro anos de estudos, Rafael, Otávio, Marco Túlio, Tarcísio, Eduardo, Flávia, Ana Rita, Argos, João Marcos, Carlos Vinícius, Regina, e tantos outros, pelas várias preocupações que só com eles pude compartilhar.

Aos colegas professores da Escola de Direito da Pontifícia Universidade Católica do Paraná, Campus Maringá, representados pelos amigos Prof. Marcus Geandré, Prof. Alaércio, Prof. Almir, Prof. Cristian, Profa. Luciana, Profa. Marice,

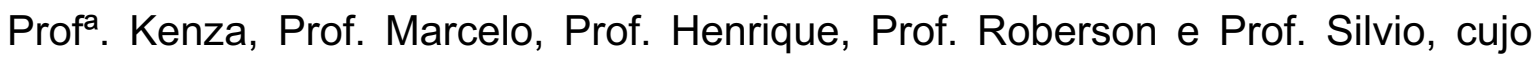
companheirismo foi essencial para que eu pudesse contar com o tempo necessário para a adequada criação da tese.

Aos colegas da Ordem dos Advogados do Brasil, representados pelo Dr. Airton Martins Molina e pelo Dr. Cesar Augusto Moreno, e da Comissão da Advocacia Pública, na pessoa dos amigos Joaquim, Rodrigo, Maurício, Osvaldo, William, Marcos, Alexsander, Francisco, Leandro, Gecilda, Marcia e Pedro.

Aos colegas do GregoSantos, Espíndola \& Gallo Advogados e da Procuradoria-Geral do Município, sempre compreensivos com as inevitáveis ausências. 
Ao amigo, cliente e mentor Valdecir Vicentin, mecenas da minha formação acadêmica.

Aos amigos de toda uma vida, Andrés, Diego, Eric, Fabio, Gabriel, Kaio, Koiti, Matheus, Pedro, Regisson, Ricardo, Rodrigo, Vinícius e Weslley, pelo que sabem.

Aos meus tios Regina e Lindo, e às minhas primas Glenda, Carlen e Cristiane, pelo papel decisivo que exerceram em viabilizar minha carreira acadêmica.

Aos meus sogros, Eudemir e Luci Mara, pelo apoio incondicional, e às famílias Colhado, Gallo, Grego e Santos.

Aos meus pais, Cleusa e Elizeu, e à minha irmã Claudia, verdadeiros artífices da minha formação como pessoa.

A Deus, pelos dons e graças, e a Maria, pela incessante intercessão. 
"Então, se tiverdes negócios em juízo, pertencentes a esta vida, pondes para julgá-los os que são de menos estima na igreja? Para vos envergonhar o digo. Não há, pois, entre vós sábios, nem mesmo um, que possa julgar entre seus irmãos?

[...]

Mas vós mesmos fazeis a injustiça e fazeis o dano, e isto aos irmãos."

(BÍBLIA Sagrada. $1^{a}$ Carta aos Coríntios, capítulo 6 , versículos 4-5/8.) 


\section{RESUMO}

GREGO-SANTOS, Bruno. Transação extrajudicial na administração pública. 2015. Tese (Doutorado em Direito) - Faculdade de Direito, Universidade de São Paulo, São Paulo, 2015.

A Administração Pública contemporânea se orienta por diversos novos paradigmas, entre os quais se identificam a ampliação das bases de legalidade, a processualização administrativa, a ressignificação do interesse público, o direito fundamental à boa administração pública, a adoção de instrumentos privados e uma nova postura relacional do Estado. No entanto, o cenário brasileiro revela o descumprimento desses paradigmas pela Administração, especialmente pela alta judicialização de suas relações com os cidadãos. Diante desse panorama, a adoção de soluções consensuais para os conflitos da Administração Pública se destaca na recuperação da proximidade perdida. Dentre as diversas modalidades de soluções consensuais de conflitos - arbitragem, conciliação, mediação e transação -, a transação extrajudicial se revela como preferencial, por basear-se no protagonismo das partes e revelar, assim, vantagens comparativas. Essas vantagens também se destacam quando a Administração Pública se utiliza da transação extrajudicial, hipótese em que esta se reveste da natureza jurídica de contrato privado da Administração. O trabalho enfrenta os diversos desafios conceituais e operacionais à adoção da transação extrajudicial pelo Estado, que se concentram principalmente em torno da legalidade, da impessoalidade, do interesse público e da postura de resistência dos gestores públicos. Com base no cenário delineado, o trabalho estuda as experiências nacionais e estrangeiras de transação extrajudicial na administração pública, para delas extrair os requisitos de validade e as hipóteses de cabimento de tais contratos. Por fim, o texto delineia diretrizes para que seja intensificado o recurso à transação extrajudicial pela Administração Pública.

PALAVRAS-CHAVE: Administração Pública; Consensualidade; Transação extrajudicial. 


\begin{abstract}
GREGO-SANTOS, Bruno. Extrajudicial contractual dispute settlement in public administration. 2015. Thesis (Doctorate in Law) - Faculty of Law, University of São Paulo, São Paulo, 2015.

The contemporary Public Administration is guided by several new landmarks, some of them being the wider basis for legality, the administrative proceduralization, the new meaning for the public interest, the fundamental right to a good administration, the use of private instruments and a new relationship posture by the State. Nonetheless, the Brazilian scenario reveals the void of theses paradigms by the Administration, specially with the high litigancy of its relations towards citizens. Facing this panorama, the adoption of alternative dispute resolution methods by the Public Administration stands out in the recovery of the lost proximity. Between the several alternative dispute resolution methods - arbitration, conciliation, mediation and settlement -, the extrajudicial settlement stands out as preferential, by basing itself on the parties' initiative and by revealing comparative leverage towards the other methods. Such advantages are also present when the Public Administration utilizes the extrajudicial settlement technique, which holds the legal nature of an Administration's private contract. The thesis faces the several conceptual and operational chalenges for the use of extrajudicial settlement by the State, mainly based on legality, impersonality, public interest and the resistant posture of public officers. Within this scenario, the thesis studies the Brazilian and foreign experiences on the use of extrajudicial settlement on administrative activities, thus obtaining its validity requirements and cases of pertinence. At last, the text lines down directives for the intensification of the use of extrajudicial settlement contracts by the Public Administration.
\end{abstract}

KEYWORDS: Public Administration; Consensuality; Extrajudicial settlement. 


\section{RÉSUMÉ}

GREGO-SANTOS, Bruno. Transaction extrajudiciaire dans l'administration publique. 2015. Thèse (Doctorat en droit) - Faculté de Droit, Université de São Paulo, São Paulo, 2015.

L'Administration Publique contemporaine est'elle guidé par des plusieurs nouveaux paradigmes, parmi qui on identifie l'expansion des bases de juridicitè, la procéduralisation administrative, la redéfinition de l'intérêt public, le droit fondamental à une bonne administration publique, l'adoption d'instruments privés et une nouvelle attitude relationnelle de l'État. Toutefois, le scénario brésilien montre l'échec vers ces paradigmes de la gestion, en particulier pour la haute judiciarisation de leurs relations avec les citoyens. Dans ce contexte, l'adoption de solutions consensuelles à des conflits de l'administration publique se tient important dans la récupération de la proximité perdue. Parmi les diverses formes de solutions consensuelles des conflits - l'arbitrage, la conciliation, la médiation et la transaction - la transaction extrajudiciaire se révèle pour être le plus pratique, car elle est fondée sur le rôle des partis et révèle, ainsi, des avantages comparatifs. Ces avantages se révèlent également lorsque l'Administration Publique en utilisant la transaction extrajudiciaire qui, dans ce cas, révèle la nature juridique de contrat privée de l'Administration. La thèse aborde les différents défis conceptuels et opérationnels à l'adoption de transaction extrajudiciaire par l'État, qui sont concentrées principalement autour de la légalité, l'impersonnalité, l'intérêt public et la résistance des gestionnaires publics. Basé sur le scénario décrit, l'étude analyse l'expérience brésilienne et étrangère dans la transaction extrajudiciaire au sein du gouvernement, d'en extraire les conditions de validité et les chances de pertinence de ces contrats. Enfin, le texte décrit les lignes directrices pour s'intensifier I'utilisation de la transaction extrajudiciaire par l'Administration Publique.

MOTS-CLÉS: Administration Publique; Consensualité; Transaction extrajudiciaire. 


\section{SUMÁRIO}

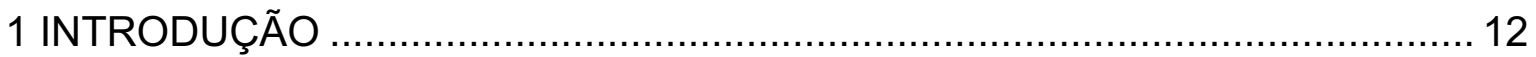

Parte I - DELINEAMENTO TEÓRICO DA TRANSAÇÃO EXTRAJUDICIAL NO DIREITO ADMINISTRATIVO

2 NOVOS PARADIGMAS DA ADMINISTRAÇÃO PÚBLICA ............................. 26

2.1 Crise da legalidade e a ampliação de suas bases ................................. 33

2.2 Passagem do ato para o processo administrativo ................................. 42

2.3 Novos olhares sobre o interesse público ............................................ 46

2.4 Direito fundamental à boa Administração Pública ................................... 49

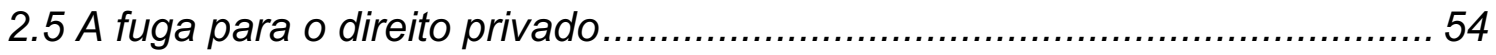

2.6 O novo marco relacional entre Estado e sociedade civil e a missão

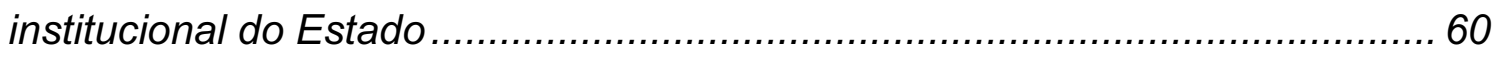

2.7 A judicialização das relações administração-particulares e o distanciamento

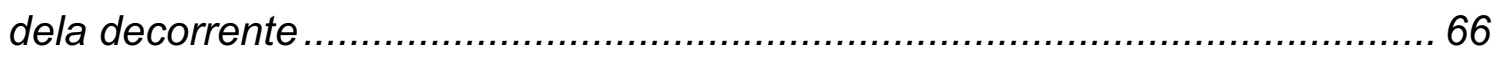

3 SOLUÇÕES CONSENSUAIS DE CONFLITOS NO ÂMBITO ESTATAL............71

3.1 Consenso na relação entre Estado e cidadão .......................................... 73

3.2 Métodos de solução consensual de conflitos ........................................ 77

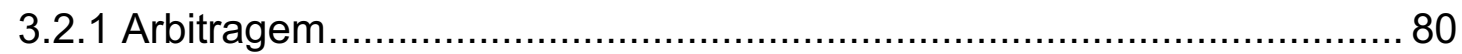

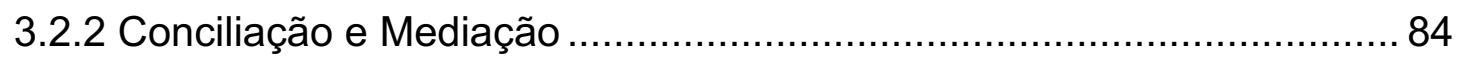

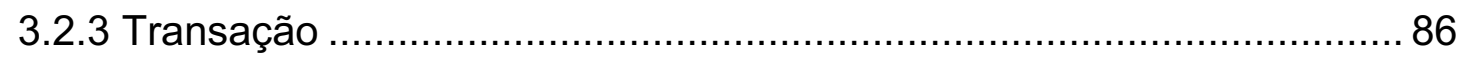

3.2.3.1 Debates sobre a natureza jurídica da transação civil................... 89

3.2.3.2 A transação extrajudicial como meio preferencial de consensuali-

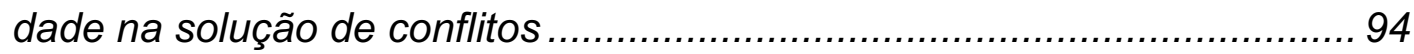

3.3 A inserção da transação extrajudicial no direito administrativo: Natureza jurídica 100

3.3.1 Posicionamentos quanto à natureza jurídica da transação administrativa 102

3.3.2 O dístico essencial do contrato administrativo .............................. 118

3.3.3 Nossa posição.................................................................. 138 
Parte II - EFETIVIDADE DA TRANSAÇÃO EXTRAJUDICIAL NA MISSÃO INSTITUCIONAL DO ESTADO

4 DESAFIOS À RECEPTIVIDADE AO MODELO DE RESOLUÇÃO DE CONFLITOS BASEADO NA CONSENSUALIDADE .................................... 153

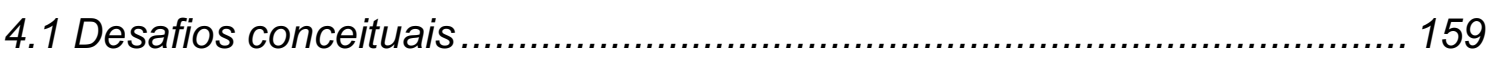

4.1.1 A legalidade administrativa e o seu papel na atuação do Estado contemporâneo .......................................................................... 162

4.1.2 Soluções consensuais de conflitos e impessoalidade na Administração Pública

4.1.3 A consecução do interesse público e a delimitação de seu conteúdo 207

4.1.3.1 Indisponibilidade do interesse público................................. 211

4.1.3.2 Indefinição do interesse público .......................................... 217

4.1.3.3 Prevalência do interesse público .......................................... 226

4.1.3.4 Conteúdo do interesse público .......................................... 240

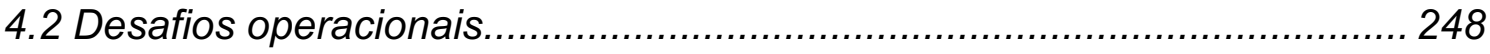

4.2.1 Transação extrajudicial, autotutela administrativa e controle da

Administração Pública. 249

4.2.2 Finanças públicas e orçamento: a questão do regime de precatórios 260

4.2.3 Os riscos da transação extrajudicial do Estado ............................... 265

4.2.4 Transformação da postura administrativa .................................... 269

5 A CAMINHO DA TRANSAÇÃO EXTRAJUDICIAL NA SOLUÇÃO DE CONFLITOS DA ADMINISTRAÇÃO ....................................................... 285

5.1 Experiências estatais na busca da consensualidade ............................ 286

5.1.1 A busca da transação pelo Estado: casos brasileiros........................ 287

5.1.2 A transação extrajudicial pelo Estado no direito estrangeiro ............... 298

5.2 Balizas para a adoção administrativa da transação extrajudicial .............. 309

5.2.1 Requisitos de Validade ...................................................... 312

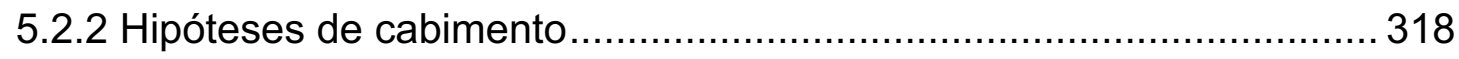

5.3 Diretrizes para a intensificação do recurso à transação extrajudicial pela

Administração Pública ................................................................ 323

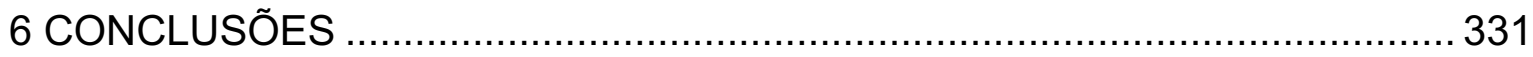

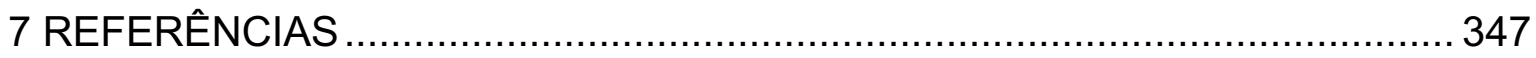




\section{INTRODUÇÃO}

Como ocorre de tempos em tempos, as preocupações com a gestão do Estado brasileiro têm hoje tomado os debates públicos. As vicissitudes da Administração Pública, há tanto investigadas e discutidas pela literatura em direito administrativo, se refletem nesses momentos históricos, num misto de previsão e crítica.

Dentre esses temas toma destaque a enorme judicialização das relações entre Estado e cidadãos observada no Brasil, ${ }^{1}$ e o potencial que os métodos de solução consensual de conflitos guardam para a solução de tal cenário. O tema já é discutido há muito na doutrina brasileira, mas custa a encontrar ressonância na prática diária dos entes estatais de nosso país.

À evidência, não deve ser o objetivo da investigação científica revestirse do caráter efêmero dos jornais, mas sim alcançar a eternidade dos livros. No entanto, ao tratarmos de temas de tamanho impacto sobre a realização concreta da missão institucional do Estado - com relevantíssimo impacto sobre a vida de tantos cidadãos, diga-se -, é essencial a preocupação não só com o delineamento teórico de um instituto, mas também com o enfrentamento dos desafios à sua efetiva aplicação para solucionar tão importante necessidade prática. Tais preocupações marcam profundamente o plano da obra que agora se inicia, como se expõe nessas páginas iniciais.

Diante do panorama exposto, a presente tese adota como objeto de estudo a transação extrajudicial como método de solução consensual de conflitos no âmbito da Administração Pública brasileira. Esse tema se desenvolve sob dois aspectos: um objetivo, comportando aqui a delimitação do cenário em que se insere o tema e do tipo de transação a ser adotada; e outro subjetivo, que se relaciona à influência do elemento volitivo das partes - em especial, do gestor público - e dos desafios postos sob os pontos de vista teórico e prático sobre a prática da transação extrajudicial na administração pública.

\footnotetext{
${ }^{1}$ BRASIL. CONSELHO Nacional de Justiça. Os 100 maiores litigantes. Brasília: CNJ, 2012.
} 
Sob o aspecto objetivo, estuda-se a solução de conflitos envolvendo o Estado como parte por meio da transação celebrada com vistas à prevenção, e não à terminação de litígios, não se tratando, portanto, da transação judicial, da arbitragem, da conciliação ou da mediação - modalidades estas que são abordadas apenas como contraponto e elemento de comparação. Define-se a transação extrajudicial, assim, como o contrato pelo qual as partes previnem um litígio, mediante concessões mútuas, conceito esse contemplado pelo direito positivo brasileiro e corroborado pela literatura. ${ }^{2}$

O cenário delineado em torno da adoção de soluções consensuais de conflitos, em especial a transação extrajudicial, pela Administração Pública, se revela como um reflexo das transformações por que vem passando a gestão estatal, cenário marcado pelas transições entre ato e processo, hierarquia e nivelamento, estrutura e função, autoritarismo e consensualidade. ${ }^{3}$ Nesse sentido, a apreciação das bases da transação extrajudicial pela administração pública depende da análise dessas transições e dicotomias, ${ }^{4}$ que compõem a essência do processo de quebra de paradigmas por que passou e passa o direito administrativo.

\footnotetext{
${ }^{2}$ Vide o art. 840 do Código Civil.

Nesse sentido:
}

DINIZ, Maria Helena. Curso de Direito Civil Brasileiro: Teoria das Obrigações Contratuais e Extracontratuais. Sâo Paulo: Saraiva, 2010. P. 605-610.

MALUF, Carlos Alberto Dabus. Da transação. In: FIUZA, Ricardo. Novo Código Civil comentado. São Paulo: Saraiva, 2003.

JARROSSON, Charles. Les concessions réciproques dans la transaction. Recueil Dalloz, Paris, chroniques, p. 267-273, 1997.

${ }^{3}$ MEDAUAR, Odete. Administração pública: do ato ao processo. In: ARAGÃO, Alexandre Santos de; MARQUES NETO, Floriano de Azevedo. Direito administrativo e seus novos paradigmas. Belo Horizonte: Fórum, 2008.

No mesmo sentido:

SUNDFELD, Carlos Ari. Direito administrativo para céticos. São Paulo: Malheiros, 2012.

BAPTISTA, Patrícia. Transformações do direito administrativo. Rio de Janeiro: Renovar, 2003.

${ }^{4}$ BATISTA JÚNIOR, Onofre Alves. Transações administrativas: um contributo ao estudo do contrato administrativo como mecanismo de prevenção e terminação de litígios e como alternativa à atuação administrativa autoritária, no contexto de uma administração pública mais democrática. São Paulo: Quartier Latin, 2007.

Nesse sentido:

SCHIRATO, Vitor Rhein. PALMA, Juliana Bonacorsi de. Consenso e legalidade: Vinculação da atividade administrativa consensual ao Direito. Revista Eletrônica de Reforma do Estado, Salvador, n. 24, fev. 2011. 
Tal posição leva à análise do aspecto subjetivo do tema proposto, cuja apreciação percorrerá os capítulos da segunda parte da tese: em que medida os desafios teóricos e práticos apresentados - com ênfase sobre concepções contempladas pela doutrina em torno do princípio da legalidade, do interesse público e da impessoalidade administrativa -, bem como a postura pessoal do gestor público, condicionam a adoção de soluções consensuais de conflitos pela Administração Pública. Essa análise se torna ainda mais complexa ao tratarmos da transação extrajudicial - que não depende da existência de uma demanda judicial prévia, sendo preventiva, portanto -, investigando como esses desafios podem ser enfrentados e como essa postura pode ser condicionada pelo Direito.

Poder-se-ia questionar, no entanto, acerca da relevância de um trabalho que se dedique especificamente à transação extrajudicial - enfoque raro, senão único, no direito administrativo brasileiro -, o que reclama o tratamento desse aspecto do tema já nesse momento inicial.

A transação extrajudicial na administração pública se insere num cenário de especial relevo no estudo do direito administrativo nos últimos anos, que gravita em torno da adoção de posturas consensuais pelo Estado. Esse cenário, por sua vez, faz parte das tendências contemporâneas de giros paradigmáticos no direito administrativo, em especial relacionadas com a democratização da Administração Pública e com a sua centralização no cidadão e na consecução dos seus direitos e garantias fundamentais.

Apesar dessa inserção nos debates contemporâneos - ou, talvez, em função dela -, a transação extrajudicial tendo como parte o Estado constitui tema controverso no direito administrativo brasileiro. Dentre as opiniões presentes na literatura sobre a sua adoção, há posições tanto favoráveis quanto contrárias estas últimas, provavelmente, constituindo a sua maioria - e, assim, o tema conserva a sua atualidade, que está longe de esgotar-se.

A importância do tema proposto se revela, ainda, pelo fato de que grande parte da literatura brasileira sobre a adoção de soluções consensuais de conflitos pela Administração Pública se debruça sobre outros métodos que não a transação, como a arbitragem, a mediação e a conciliação. Ademais, os poucos trabalhos 
acerca da transação pelo Estado se dedicam à sua modalidade judicial - sendo que muitos sequer admitem a adoção da transação extrajudicial -, ou conferem à transação judicial e extrajudicial o mesmo tratamento, ${ }^{5}$ abordagem que acaba por confundir a natureza dos institutos e, sobretudo, dificultar a existência de uma prática consolidada de transação extrajudicial pela Administração Pública.

O cenário atual da literatura jurídica brasileira sobre o tema carece, assim, de trabalho que se dedique de modo específico à transação extrajudicial na administração pública, uma vez que a abordagem detida do tema permitirá um tratamento mais adequado das suas peculiaridades que, muitas vezes, o distanciam das outras modalidades de transação e de soluções consensuais de conflitos.

Sob tal aspecto, entre as demais formas de solução negocial de conflitos - arbitragem, conciliação e mediação -, a transação extrajudicial destaca-se por dois motivos: primeiro, por ser um método preventivo à propositura das demandas e, em segundo lugar, por se revestir de simplicidade por prescindir de uma terceira parte que proponha a solução desejada. Nesse sentido, entende-se ser necessária a apreciação da transação extrajudicial em separado da transação judicial por duas razões preponderantes.

Num primeiro momento, a transação extrajudicial comporta maior complexidade na seara administrativa, na medida em que implica na realização de um processo administrativo próprio, que se encerra em si mesmo - sendo, portanto, a única das modalidades de solução consensual de conflitos do Estado em que o procedimento se desenvolve de modo integral no âmbito administrativo. Em outro

\footnotetext{
${ }^{5}$ Nesse sentido, importante é a análise dos seguintes trabalhos:

DALLARI, Adilson Abreu. Viabilidade da transação entre o poder público e particular. Interesse Público, Belo Horizonte, a. 4, n. 13, jan.-mar. 2002.

ESTEVES, Maurício Cramer. Da possibilidade e dos limites da transação em processos judiciais por parte do Poder Público Municipal. Revista Interesse Público, Belo Horizonte, v. 38, jul.-ago. 2006.

BATISTA JÚNIOR, Onofre Alves. Transações administrativas: um contributo ao estudo do contrato administrativo como mecanismo de prevenção e terminação de litígios e como alternativa à atuação administrativa autoritária, no contexto de uma administração pública mais democrática. São Paulo: Quartier Latin, 2007.
}

SCHWANKA, Cristiane. Administração Pública consensual: A transação como método alternativo de solução de conflitos nos contratos administrativos. 2009. Dissertação (Mestrado em direito) UniBrasil, Curitiba, 2009. 
aspecto, tendo em vista a sua natureza de prevenção de litígios, a transação extrajudicial desperta maiores riscos na medida em que se submete a menor controle por agentes externos à relação - uma vez que a transação judicial, a mediação, a conciliação e a arbitragem contam com terceiro agente que formula ou acompanha a solução -, o que leva a uma análise de riscos particular, a que se dedica o trabalho proposto.

O tema a ser delimitado se justifica, ainda, pela importância da chamada análise subjetiva a que se propõe, como descrito no tópico anterior. Isso porque, como a apreciação dos casos brasileiros e da literatura permite concluir, tanto o sucesso de programas e práticas de transação extrajudicial quanto os principais riscos a ela relacionados encontram suas raízes, em grande parte, nas intenções e na postura do gestor públicos que dela lançam mão. Desse modo, a adoção de um modelo viável de transação extrajudicial na administração pública depende da sondagem acerca da postura do gestor como condicionante à sua adoção e da superação dos inúmeros desafios opostos, análise esta que ainda não encontra satisfação específica na literatura jurídica brasileira.

Sob o ponto de vista metodológico, a tese proposta investiga as seguintes hipóteses:

a) qual é o papel da transação extrajudicial como meio preferencial de solução consensual de conflitos, em comparação com as demais modalidades de consensualidade aceitas pela literatura, como arbitragem, conciliação, mediação e transação judicial?

b) qual é a natureza jurídica da transação extrajudicial adotada pela Administração Pública, frente às suas origens no direito privado, uma vez que a parte da literatura que se dedica especificamente ao tema a classifica como contrato administrativo?

c) constitui a transação extrajudicial, de fato, um método consensual de solução de conflitos cuja adoção seja franqueada à Administração Pública, tendo em vista as prerrogativas e sujeições próprias do direito administrativo?

d) como se deve dar a calibragem da transação extrajudicial, com origem no direito civil, para que ela se adeque à juridicidade própria do direito do Estado? 
O tratamento dispensado às hipóteses é predominantemente teórico, calcado na abordagem analítica da literatura que se dedica ao tema de forma direta ou transversal. Considera-se necessário o estudo dialético das posições favoráveis e contrárias à adoção da prática em análise, propondo-se contrapontos para que seja possível estabelecer um arcabouço teórico suficiente à conclusão acerca das questões a serem analisadas. De maneira preponderante, este arcabouço é construído pelo método hipotético-dedutivo, sobretudo diante da carência de fontes especializadas no enfoque adotado.

Sem pretensões de esgotamento, a tese dedica parcela de sua investigação ao aspecto empírico, buscando nas experiências conhecidas de adoção de métodos consensuais de solução de conflitos pela Administração Pública elementos que possam colaborar com o enfrentamento das hipóteses propostas. A eleição de tais experiências se baseia nas referências que a literatura a elas faz, adotando-se assim, como referencial, as práticas que mais ressoam nos debates doutrinários. O estudo de precedentes judiciais se orientou no mesmo sentido, restringindo-se àqueles oriundos de tribunais superiores, com enfoque sobre os que, pelos mecanismos de investigação oficialmente disponibilizados pelos Tribunais, tivessem relação com vocábulos e expressões específicos "transação extrajudicial", "administração pública" etc. -, ou que fossem indicados como relevantes pela literatura especializada.

Ainda, faz-se presente, também em menor escala, a pesquisa normativa, buscando no direito positivo elementos que fundamentem as conclusões tecidas no trabalho, bem como objetos de crítica. Nesse âmbito, a própria controvérsia jurídica acerca da possibilidade de adoção da transação extrajudicial pela Administração Pública é indicativa de que o cenário normativo é rarefeito.

A metodologia adotada para a pesquisa normativa é variada de acordo com a espécie da fonte e com a esfera de poder a que se refira a norma. No âmbito constitucional a metodologia de pesquisa foi intensiva, expondo e analisando ao longo dos capítulos todos os dispositivos tidos como especialmente relacionados à prática em apreço. Já no âmbito infraconstitucional, a pesquisa de normas nacionais e federais se deu de forma ampla, mormente pela ausência de uma norma específica a disciplinar a transação extrajudicial na administração pública. 
A pesquisa de normas estaduais foi sistematizada de modo a obter o panorama mais amplo possível, mesmo em relação às Unidades da Federação sem experiências reconhecidas como relevantes pela literatura. Para tanto, a legislação referente ao processo administrativo de cada um dos entes, quando existente, foi analisada, destacando-se delas as disposições específicas sobre a composição administrativa de conflitos envolvendo a Administração Pública.

Já na esfera municipal, tendo em vista o gigantesco número de municípios no Brasil, a investigação se ateve às normas reconhecidas pela doutrina como relevantes, com a busca e apreciação das fontes originais. Por fim, o estudo de normas de origem estrangeira foi realizado de acordo com as referências a elas feitas pela literatura, buscando-se nas fontes originais, quando possível, o texto normativo referenciado, mas sem o intuito de esgotar, naquele ordenamento específico, as normas referentes ao tema.

Duas ressalvas terminológicas são necessárias. Em primeiro lugar, adotamos o posicionamento de Marçal Justen Filho acerca da distinção entre as expressões Administração Pública e administração pública. Nesse sentido, a primeira é utilizada com significado subjetivo, para designar os entes estatais, enquanto a segunda indica a função de gestão da coisa pública. ${ }^{6}$

Em um segundo momento, é conveniente destacar nosso posicionamento acerca das acepções contemporâneas para a expressão histórica Direito Político - adotada por Montesquieu, por exemplo - designando o direito aplicável aos entes estatais. Preferimos a expressão Direito do Estado em desfavor de Direito Público, considerando que esta última é por demasiado ampla para obter a precisão necessária. Isso se afirma já que, sob o manto do Direito Público, podem-se classificar diversos ramos do Direito que fogem à análise proposta, como o direito penal e o direito do trabalho.

Buscando cumprir a missão proposta, a obra se organiza em duas partes, sendo que a primeira delas se ocupa do delineamento teórico objetivo da adoção da transação extrajudicial pela Administração Pública brasileira. Essa

\footnotetext{
${ }^{6}$ JUSTEN FILHO, Marçal. Curso de direito administrativo. São Paulo: Revista dos Tribunais, 2014. Passim.
} 
primeira parte tem como ponto de partida o referencial democrático da Administração Pública contemporânea e suas transformações, ocupando-se, no capítulo inicial de aproximação ao tema, da estruturação das bases que sustentam os novos paradigmas democráticos e relacionais da Administração Pública.

Assim, a porção inicial do texto aborda a ampliação das bases da legalidade e o efeito desse fenômeno para a regulação do exercício da função pública, que passa da vinculação à Lei para a vinculação ao Direito. ${ }^{7}$ Esse câmbio referencial tem como consequências, entre outras, o protagonismo dos princípios e a constitucionalização do direito administrativo, circunstâncias que alteram o foco da atuação estatal de uma mirada autocentrada para a realização dos direitos fundamentais. ${ }^{8}$

Esses movimentos objetivos das balizas e do escopo da administração pública levam, por conseguinte, a uma mudança instrumental em sua atuação: a evolução do posicionamento autoritário do Estado para uma relação dialógica com os cidadãos desloca a atenção do ato ao processo administrativo, ${ }^{9}$ locus no qual tal diálogo se desenvolve. Revela-se, assim, a importância do aspecto relacional da atuação do Estado na apuração de sua regularidade e legitimidade.

Nesse cenário, a própria definição do interesse público sofre mudanças. $\mathrm{Na}$ medida em que a democratização da Administração Pública exige que a atuação do gestor público seja responsiva à vontade social - momento em que o interesse público não é mais caracterizado pelo agente que o veicula, mas sim pelo suporte democrático que lhe legitima -, também a apuração substancial do interesse público se torna mais etérea. Essas mudanças implicam na adoção de um novo ferramental de soluções pela Administração Pública, que se aproxima

\footnotetext{
${ }^{7}$ MEDAUAR, Odete. Direito administrativo moderno. São Paulo: Revista dos Tribunais, 2015. P. 130-132.

E ainda:

BAPTISTA, Patrícia. Transformações do direito administrativo. Rio de Janeiro: Renovar, 2003. P. 94-119.

8 JUSTEN FILHO, Marçal. Curso de direito administrativo. São Paulo: Revista dos Tribunais, 2014. P. 122-123.

${ }^{9}$ MEDAUAR, Odete. Administração pública: do ato ao processo. In: ARAGÃO, Alexandre Santos de; MARQUES NETO, Floriano de Azevedo. Direito administrativo e seus novos paradigmas. Belo Horizonte: Fórum, 2008. P. 405-419.
} 
daquele à disposição dos agentes privados, na busca da realização plena dos direitos fundamentais - inclusive, daquele relacionado à boa administração pública.

Tais paradigmas trazem como consequência a exigência do consenso na postura do Estado, diante da busca pela responsividade de suas ações à vontade social e, para tanto, de aproximação entre Estado e sociedade, em uma nova postura relacional. ${ }^{10}$ Esta aproximação inicial deságua na demonstração do profundo déficit democrático experimentado hoje no Brasil - fruto, entre outras circunstâncias, da separação entre a Administração e os cidadãos, da conflituosidade, da sobrejudicialização e da desigualdade exacerbada em suas relações - sem, contudo, pretender delinear diagnóstico exaustivo sobre o tema.

Verifica-se, portanto, que a ruptura da Administração Pública com os novos paradigmas para sua atuação leva à conflituosidade das relações entre Estado e cidadãos, confronto este que influi negativamente na legitimidade da atuação estatal. Ora, na medida em que os indivíduos não mais encontram um caminho dialógico para pleitear ao Estado o cumprimento dos referenciais jurídicos a que é adstrito, rompe-se a proximidade entre Administração e sociedade.

O cenário assim delineado, em que o déficit democrático deve-se em parte ao difícil acesso dos cidadãos a instrumentos consensuais para a solução de suas contendas com o Estado, abre oportunidade para a exposição da aplicabilidade das soluções consensuais aos conflitos entre a Administração e os particulares, o que se procede no Capítulo 3 , que conclui a primeira parte do estudo.

Esse capítulo tem início estabelecendo a relação entre a missão institucional do Estado e os seus novos paradigmas relacionais, que tem como principal conteúdo os mecanismos de consensualidade na administração pública, instrumentais ao planejamento, na execução e no controle da função administrativa.

10 MENDOZA, Xavier; VERNIS, Alfred. El Estado relacional y la transformación de las administraciones públicas. In: LONGO, Francisco; YSA, Tamyko (eds.). Los escenarios de la gestión pública del siglo XXI. Barcelona: Bellaterra, 2008. P. 37. 
Essa relação leva a fenômenos como a chamada esfera pública não-estatal, ${ }^{11}$ instrumentos de participação e consensualidade administrativas.

Dentre tais fenômenos se destaca a solução consensual de conflitos da Administração Pública, iniciativa que tem com um de seus efeitos a superação da conflituosidade das relações entre Estado e cidadãos e, portanto, o resgate dos novos paradigmas da Administração Pública expostos no capítulo de aproximação ao tema. $\mathrm{O}$ trabalho desenvolve a diferenciação conceitual entre a transação e os demais métodos de solução consensual de conflitos - mediação, arbitragem e conciliação -, sustentando que a transação extrajudicial se distancia conceitualmente da transação judicial por ser preventiva e prescindir da homologação por ator externo à relação Estado-cidadão.

Nesse sentido, o texto se posiciona no sentido de que o dístico essencial entre a transação extrajudicial e os demais métodos de solução consensual de conflitos reside na ausência de um terceiro agente para a sua celebração e no fato de que todo o seu processamento se esgota na seara administrativa. A transação extrajudicial caracteriza-se, assim, por ser o método que conta com a maior autonomia das partes na busca da solução e, portanto, se revela como o método preferencial de solução consensual de conflitos na Administração Pública.

Com base em tais características, a primeira parte do trabalho culmina com a sondagem e definição da natureza jurídica da transação extrajudicial na administração pública, em contraponto a outras posições adotadas na literatura. ${ }^{12}$ Essa tarefa é cumprida em três etapas: num primeiro momento, o texto se ocupa do levantamento das diversas posições doutrinárias acerca da natureza jurídica da transação que tenha como parte ente estatal. Dessa análise exsurge a necessidade

\footnotetext{
11 VILLORIA MENDIETA, Manuel. La modernización de la administración como instrumento al servicio de la democracia. Madrid: Inap, 1996. P. 94.

No mesmo sentido:

DAGNINO, Evelina. Sociedade civil, espaços públicos e a construção democrática no Brasil: limites e possibilidades. In: DAGNINO, Evelina (org.). Sociedade civil e espaços públicos no Brasil. São Paulo: Paz e Terra, 2002. P. 279 e ss.

${ }^{12}$ Em especial, v. BATISTA JÚNIOR, Onofre Alves. Transações administrativas: um contributo ao estudo do contrato administrativo como mecanismo de prevenção e terminação de litígios e como alternativa à atuação administrativa autoritária, no contexto de uma administração pública mais democrática. São Paulo: Quartier Latin, 2007.
} 
de eleição de um fator de diferenciação essencial entre os contratos administrativos e os contratos privados da Administração que, após definido, permite o movimento final de edificação de um posicionamento autêntico sobre a natureza jurídica do instituto.

Estabelecido, na primeira parte do trabalho, o arcabouço teórico em torno da definição da transação extrajudicial na administração pública, a segunda parte da tese se dedica a investigar e estabelecer balizas para a concretização efetiva, sistemática e perene - do manejo pelos entes estatais da transação extrajudicial para a solução dos conflitos em que se envolvam.

O Capítulo 4 se ocupa dos principais desafios à adoção da postura consensual e da transação extrajudicial pela Administração Pública. Num primeiro momento, são enfrentados os desafios teóricos à aceitabilidade da transação extrajudicial que tenha como parte o Estado, que consistem no papel da legalidade como suposta condição para tanto, em uma nova visão sobre o sentido de impessoalidade como princípio e na questão da compatibilidade entre o interesse público e a transação extrajudicial administrativa, ${ }^{13}$ negada por muitos autores com base na indisponibilidade e em uma dita supremacia do interesse público.

O capítulo se ocupa, também, dos desafios operacionais à aceitabilidade da transação extrajudicial na administração pública. Esses desafios consistem na análise dos aspectos de autotutela administrativa e controle judicial, próprios do direito administrativo, incidentes sobre a figura; também, da adequação do ressarcimento pela via administrativa com o regime de precatórios que se impõe na indenização judicial; e ainda, dos riscos advindos da adoção da transação extrajudicial pelos entes estatais.

A parte final do capítulo expõe a posição de que o maior desafio operacional à adoção da transação extrajudicial reside na própria postura do

\footnotetext{
${ }^{13}$ MARQUES NETO, Floriano de Azevedo. La moderna regulación: entre público y privado la búsqueda del equilibrio. In: DE LA CUÉTERA, J. M; LÓPEZ-MUNIZ, José Luiz Martínez; VILLAR ROJAS, Francisco J. Derecho administrativo y regulación económica: liber amicorum Gaspar Ariño Ortiz. Madrid: La Ley, 2011. P. 1.082.
}

Ver também:

JUSTEN FILHO, Marçal. Curso de direito administrativo. São Paulo: Revista dos Tribunais, 2014. P. 122-123. 
administrador, pelo que se revela a necessidade de transformação da postura combativa de muitos dos gestores públicos brasileiros. Tal posicionamento se alinha com o diagnóstico da ruptura relacional entre Estado e cidadãos realizado no Capítulo 2, e abre espaço para o desenvolvimento do tema no capítulo seguinte.

Superados tais desafios, o trabalho passa a tratar, no Capítulo 5, da viabilidade prática da adoção da transação extrajudicial pela Administração Pública para a solução de seus conflitos, demonstração que se inicia pela breve análise de casos de sucesso do cenário brasileiro, como a Câmara de Conciliação da Administração Federal e o Programa de Transação Extrajudicial do Município de Marialva, no Paraná, e no estrangeiro, em especial a experiência francesa desde os pioneiros estudos do Conselho de Estado francês. ${ }^{14}$

Desenvolve-se, ainda, o papel da postura do gestor público no fomento da adoção das soluções consensuais - em especial, a transação extrajudicial -, detectada como desafio operacional no capítulo anterior, circunstância que faz destacar a intenção democrática como fator de sucesso da consensualidade estatal.

A partir daí, se faz possível a delimitação de requisitos jurídicos para a adoção da transação extrajudicial pela Administração Pública, buscando delinear parâmetros para o processo administrativo correspondente, elencar de forma exemplificativa as diversas hipóteses de cabimento da transação extrajudicial que tenha como parte ente estatal e, assim, propor um modelo de adaptações pontuais do regime tipicamente privatístico de transação extrajudicial para as características e limitações do regime jurídico estatal.

A Administração Pública não pode, enfim, repousar passiva enquanto as consequências de seu posicionamento desnecessariamente combativo, de oposição quase maniqueísta entre público e privado, acabam por minar as bases democráticas de sua própria existência. No cenário atual da Administração Pública, o papel do direito, da democracia e do conhecimento como elementos de legitimidade frequentemente se confundem, apesar de nem sempre serem os

\footnotetext{
${ }^{14}$ FRANÇA. CONSELHO de Estado Francês. Régler autrement les conflits (coleção Les Études du Conseil d'Etat). Paris: Documentation Française, 1993.
} 
mesmos conciliáveis, ${ }^{15}$ nesse sentido, cabe ao direito, ${ }^{16}$ como sustentado na proposição inicial dessa introdução, assumir o protagonismo de diagnose e construção de soluções que venham a moldar o futuro das instituições jurídicas, ${ }^{17}$ das técnicas e das práticas de gestão pública.

É este o desenvolvimento que se propõe.

\footnotetext{
${ }^{15}$ VERMEULE, Adrian. The Administrative State: Law, democracy, and knowledge. In: TUSHNET, Mark; GRABER, Mark A.; LEVINSON, Sanford. The Oxford handbook of the U.S. Constitution. Oxford: Oxford Univertsity Press, 2015.

${ }^{16}$ WALD, Arnoldo. O Direito de parceria e a Nova Lei de Concessões. São Paulo: Revista dos Tribunais, 1996. P. 34.

${ }^{17}$ Como afirma Sabino Cassese: "[...] è difficile distinguere il diritto amministrativo dal suo oggetto (la pubblica amministrazione) e dal modo in cui esso viene studiato (la scienza del diritto amministrativo). Tra questi elementi diversi vi sono molte relazioni reciproche. L'assetto della pubblica amministrazione influenza il diritto che la riguarda: se quella è policentrica o frammentata, il diritto avrà caratteristiche meno uniformi o unitarie. D'altro lato, le norme sono conosciute attraverso l'interpretazione, a mezzo di un ragionamento logico, e la scienza - come è stato spesso osservato - riutilizza sempre una parte delle acquisizioni anteriori della stessa scienza giuridica, per cui nozioni tradizionali, elaborate dalla scienza, come quelle di ente pubblico o di concessione, fungono da selettori e da criteri ordinatori del mariale giuridico nuovo sul quale operano i giuristi" (CASSESE, Sabino. Le trasformazioni del diritto amministrativo dal XI al XXI secolo. Rivista Trimestrale di Diritto Pubblico, Roma, a. 52, n. 1, p. 27-40, $1^{\circ}$ trim. 2002).
} 
Parte I - DELINEAMENTO TEÓRICO DA TRANSAÇÃO EXTRAJUDICIAL NO DIREITO ADMINISTRATIVO 


\section{NOVOS PARADIGMAS DA ADMINISTRAÇÃO PÚBLICA}

É de Jellinek a afirmação de que "todas as investigações sobre o direito público devem começar com a definição do conceito de Estado ou, pelo menos, com uma clara indicação do que sobre ele se postula". ${ }^{18}$

O presente trabalho cumpre essa tarefa não ao formular um conceito próprio de Estado, mas sim ao estabelecer que as lentes através das quais se enxerga o Estado, na investigação proposta, são marcadas pela sensibilidade à transformação. No atual estágio do direito administrativo brasileiro, investigar a transação extrajudicial na administração pública é sondar as possibilidades de câmbio de paradigmas no trato com a coisa pública; nesse sentido, para emprestar em parte a precisa expressão de Odete Medauar, a aproximação ao tema proposto se dá pela breve análise dos aspectos do Estado "em evolução". ${ }^{19}$

A presente tese seria inviabilizada, portanto, se adotássemos como valor a ser defendido a estabilidade, a permanência do direito administrativo em seu estado atual. A adoção de novos paradigmas para a Administração Pública é estágio essencial para a investigação proposta.

O estudo das transformações do direito administrativo lhe acompanha, pode-se dizer, desde muito próximo de seu próprio surgimento. Essa curiosidade, própria da ciência do direito administrativo, faz com que "a história das transformações do direito administrativo seja ela mesma marcada por transformações", na diç̧ão de Sabino Cassese. ${ }^{20}$

Léon Duguit, em 1913, escreveu um "pequeno livro de grande influência", ${ }^{21}$ em que destaca uma "transformação particularmente profunda e

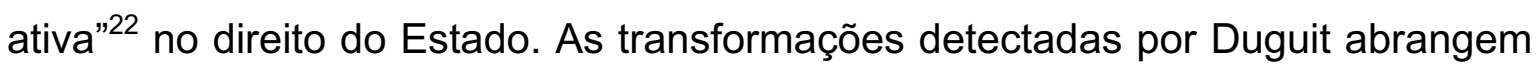

\footnotetext{
${ }^{18}$ JELLINEK, Georg. Gesetz und Verordnung. Freiburg: Mohr, 1887. P. 189. Tradução parcial de Rui Chancerelle de Machete.

${ }^{19}$ MEDAUAR, Odete. O Direito administrativo em evolução. São Paulo: Revista dos Tribunais, 1992.

${ }^{20}$ CASSESE, Sabino. Le trasformazioni del diritto amministrativo dal XI al XXI secolo. Rivista Trimestrale di Diritto Pubblico, Roma, a. 52, n. 1, p. 27-40, $1^{\circ}$ trim. 2002.

${ }^{21}$ CASSESE, Sabino. Le trasformazioni del diritto amministrativo dal XI al XXI secolo. Rivista Trimestrale di Diritto Pubblico, Roma, a. 52, n. 1, p. 27-40, $1^{\circ}$ trim. 2002.

${ }^{22}$ DUGUIT, Léon. Les transformations du Droit Public. Paris: Armand Colin, 1913.
} 
o desaparecimento do sistema imperialista; a substituição da noção de soberania pela noção de serviço público; e a evolução dos conceitos de lei, de ato administrativo, de justiça administrativa e de responsabilidade do Estado.

Esse cenário francês - de evolução do direito administrativo - pode ser confrontado com a dita estabilidade deste ramo no cenário alemão daqueles anos, em que é clássica a lição de Otto Mayer que, na introdução a seu manual, declara: "o Direito Constitucional passa; o Direito Administrativo fica". ${ }^{23}$

Em análise aprofundada, Cassese destaca a importância do confronto entre as afirmações de León Duguit e Otto Mayer para a afirmação de um posicionamento não só jurídico, mas também político: o ponto de vista de Duguit, expresso no ano anterior à eclosão da I Guerra Mundial, reflete a oposição entre França e Alemanha. Duguit, de fato, enfatiza a passagem do direito administrativo da puissance publique - que teria origem na herrschaft alemã - ao service public, noção tipicamente francesa. À base do posicionamento de Duguit repousa, assim, um ponto de vista antiautoritário e nacionalista. O posicionamento de Otto Mayer, por sua vez, refletiria a sua íntima motivação em rejeitar a Constituição de Weimar, à qual permaneceu alheio. Intentava, assim, isolar o direito administrativo do constitucional, protegê-lo das transformações, acolher a ideia de sua imutabilidade. ${ }^{24}$

Esses posicionamentos - pela transformação ou pela estabilidade do direito administrativo - reaparecem em sucessivos momentos históricos, interligando-se e relacionando-se de diversas maneiras.

Já no equador do séc. XX, Charles Eisenmann destacava "a imensidade de transformações que tem sofrido o direito administrativo [...], o que reclama uma necessária revolução doutrinária". ${ }^{25}$ No mesmo sentido por diversas vezes se

\footnotetext{
${ }^{23}$ MAYER, Otto. Deutsches verwaltungsrecht. Berlim: Duncker \& Humblot, 1924.

A importância dessa passagem, reconhecida amplamente no direito administrativo, é destacada por Sabino Cassese ao citá-la como excerto: "Verfassungsrecht vergeht, Verwaltungsrecht besteht: dies hat man anderwaerts schon laengst beobachtet".

${ }^{24}$ CASSESE, Sabino. Le trasformazioni del diritto amministrativo dal XI al XXI secolo. Rivista Trimestrale di Diritto Pubblico, Roma, a. 52, n. 1, p. 27-40, $1^{\circ}$ trim. 2002.

${ }^{25}$ EISENMANN, Charles. Cours de droit administratif: Année 1952-1953. Paris: LGDJ, 1982. Tradução nossa.
} 
manifestou Massimo Severo Giannini, em especial em suas críticas à falta de observação, pela ciência do direito administrativo, às reformas estruturais italianas dos anos $1930 .^{26}$

Vários fatores contribuíram para que, por muito tempo, o argumento de estabilidade de Otto Mayer se mostrasse consolidado: a estabilidade e a sobrevivência das próprias leis administrativas, de considerável longevidade; a estabilidade ou "viscosidade" dos conceitos básicos da jurisprudência; e o posicionamento conservador da ciência jurídica, sobretudo sob influência da pandectística alemã.

No entanto, o direito administrativo contemporâneo é rico em estudos que demonstram o caráter vivo dessa ciência. Já em fins do séc. $X X$, Sabino Cassese destaca as consideráveis transformações do direito administrativo entre dois marcos históricos que considera os mais importantes para esta análise: o cenário germinal do direito administrativo como ciência, na primeira metade do séc. XIX, e a chamada "crise do direito administrativo" na doutrina francesa, ou o "novo direito administrativo" alemão, fenômenos observados na última década do séc. $\mathrm{XX} .^{27}$

Para Cassese, as transformações do direito administrativo contam com duas características essenciais: a sua velocidade e a sua continuidade. ${ }^{28}$ Das mudanças rápidas e contínuas do direito administrativo surge uma verdadeira

${ }^{26}$ GIANNINI, Massimo Severo. Vita e opere di Guido Zanobini. Rivista Trimestrale di Diritto Pubblico, Roma, a. 11, n. 1, p. 15, $1^{\circ}$ trim. 1965.

A identificação de Giannini com esse processo de transformações foi considerável a ponto de constituir o tema de liber amicorum em sua homenagem (AMOROSINO, Sandro (org.). Le trasformazioni del Diritto Amministrativo: Scriti degli allievi per gli ottanta anni di Massimo Severo Giannini. Milano: Giuffrè, 1995).

${ }^{27}$ CASSESE, Sabino. Le trasformazioni del diritto amministrativo dal XI al XXI secolo. Rivista Trimestrale di Diritto Pubblico, Roma, a. 52, n. 1, p. 27-40, $1^{\circ}$ trim. 2002.

${ }^{28}$ Nas palavras de Cassese: “I cambiamenti del passato hanno richiesto secoli. Quelli attuali avvengono in un tempo breve, con grande speditezza. II diritto civile ha avuto una grande stabilità nel corso del tempo. Il diritto amministrativo à, invece, stato caratterizzato da cambiamenti via via più veloci. Negli anni più recenti (l'ultimo quarto di secolo), la velocità si è acompagnata alla continuità: il diritto amministrativo è retto da un disegno che cambia continuamente, perchè la riforma diventa una funzione pubblica permanente, tant'è vero che vengono ovunque istituiti ministeri o uffici centrali variamente denominati, di riforma, modernizzazione, riorganizzazione, ecc. Non tanto di trasformazione, quanto di trasformazioni del diritto amministrativo bisognerebbe parlare" (CASSESE, Sabino. Le trasformazioni del diritto amministrativo dal XI al XXI secolo. Rivista Trimestrale di Diritto Pubblico, Roma, a. 52, n. 1, p. 27-40, $1^{\circ}$ trim. 2002). 
institucionalização da mudança, uma função pública permanente dedicada justamente a analisar e promover as transformações tidas como necessárias na Administração Pública. Dentre elas, sustentamos, faz-se premente o câmbio teórico e de convicções que venha a viabilizar a ampla adoção da transação extrajudicial pelos entes estatais.

Dessas características da transformação resultam numerosas contradições, sustenta Cassese. Em primeiro lugar, apesar da generalidade da tendência, as transformações são não são gerais, mas sim por setores, campos, zonas, gerando uma contradição de natureza interna. Nesse cenário, o novo direito administrativo convive necessariamente com o antigo, surgindo assim o problema: qual deve prevalecer? ${ }^{29}$

Uma segunda contradição advinda das transformações do direito administrativo, no pensamento de Sabino Cassese, é de caráter externo: submetido a transformações, o novo direito administrativo deve conviver com o velho direito constitucional. ${ }^{30}$ Tal cenário traz dificuldades, em especial, na relação do regramento administrativo com os princípios constitucionais, e reclama reinterpretações que são objeto de estudo específico no capítulo deste trabalho que se dedica aos desafios conceituais à adoção da transação extrajudicial pela Administração Pública.

A terceira e mais etérea das contradições de Cassese é aquela que decorre do "transformismo das transformações". Frente ao fato de que as políticas de reforma ou modernização são difusas e nenhum governo as busca evitar, diversos governos mudam tudo para nada mudar, induzindo assim transformações fictícias. ${ }^{31}$ Tratar-se-ia, assim, da cooptação da mudança como bandeira de promoção pessoal; os governos não deixam de mudar para não serem identificados como retrógrados, mas não desejam outrossim mudanças verdadeiras. 0 resultado, gravemente negativo, é o da instrumentalização da mudança pela

${ }^{29}$ CASSESE, Sabino. Le trasformazioni del diritto amministrativo dal XI al XXI secolo. Rivista Trimestrale di Diritto Pubblico, Roma, a. 52, n. 1, p. 27-40, $1^{\circ}$ trim. 2002.

${ }^{30}$ CASSESE, Sabino. Le trasformazioni del diritto amministrativo dal XI al XXI secolo. Rivista Trimestrale di Diritto Pubblico, Roma, a. 52, n. 1, p. 27-40, $1^{\circ}$ trim. 2002.

${ }^{31}$ CASSESE, Sabino. Le trasformazioni del diritto amministrativo dal XI al XXI secolo. Rivista Trimestrale di Diritto Pubblico, Roma, a. 52, n. 1, p. 27-40, $1^{\circ}$ trim. 2002. 
mudança, sem que isso se converta em uma melhora palpável das instituições jurídicas.

Boa parte desses câmbios conceituais e normativos acerca da atuação estatal se reflete nas reformas administrativas na Itália no início dos anos 1990. Como destaca Umberto Allegretti, aquele país experimentou significativas mudanças relativas à participação do particular no procedimento administrativo (Lei Italiana $n^{\circ}$ 241/1990), aproximação entre a Administração e os cidadãos pela autonomia dos governos locais (Lei Italiana $n^{0} 142 / 1990$ ), imparcialidade e bom andamento administrativos garantidos pela definição dos papéis dos setores político e administrativo do Estado (Decreto Italiano $n^{\circ}$ 29/1993), eficientização administrativa e melhoria do controle (Decreto Italiano $n^{\circ} 29 / 1993$ e Lei Italiana ${ }^{\circ}$ $357 / 1993) .^{32}$

Também o direito administrativo brasileiro é rico em obras que destacam e esclarecem esse constante processo, ao mesmo tempo necessário e inevitável, de sua transformação evolutiva. Ainda nos anos iniciais da formação do direito administrativo no Brasil, o Visconde do Uruguay nos apresenta no preâmbulo ao seu "Ensaio sobre o direito administrativo" o poder transformador que o estudo do direito administrativo pode exercer sobre a Administração Pública nacional. ${ }^{33}$

A transformação administrativa tem importante papel no pensamento do Visconde do Uruguay, sob dois aspectos especiais. No primeiro deles, o pioneiro autor demonstra grande inspiração nos estudos do direito administrativo francês para a transformação da Administração Pública brasileira. $O$ autor assim resume o seu sentimento:

Convenci-me ainda mais de que se a liberdade politica he essencial para a felicidade de uma Nação, boas instituições administrativas apropriadas ás suas circumstancias, e convenientemente desenvolvidas não o são menos. Aquella sem estas não póde produzir bons resultados.

O que tive occasião de observar e estudar produzio uma grande revolução nas minhas idéas e modo de encarar as cousas. E se quando parti ia cansado e aborrecido das nossas lutas politicas pessoaes, pouco confiado nos resultados da politica que acabava

\footnotetext{
${ }^{32}$ ALLEGRETTI, Umberto. Amministrazione pubblica e costituzione. Milão: Cedam, 1996. P. 15-16.

${ }^{33}$ URUGUAY, Paulino José Soares de Sousa, Visconde do. Ensaio sobre o direito administrativo. Rio de Janeiro: Typographia Nacional, 1862.
} 
de ser inaugurada, regressei ainda mais firmemente resolvido, a buscar exclusivamente no estudo do gabinete aquella occupação do espirito, sem a qual não podem viver os que se habituárão a trazê-lo occupado. ${ }^{34}$

Num segundo momento, o Visconde do Uruguay lança mão da análise do cenário observado na Inglaterra para edificar o seu entendimento sobre o cenário ótimo de transformações na Administração Pública. Para o autor, o meio mais desejado para o progresso dos processos de transformação, a exemplo do cenário inglês, é a reforma lenta e cuidadosa, que acaba se mostrando a que se assenta mais "solida e definitivamente". ${ }^{35}$ Por fim, com grande sabedoria, o Visconde do Uruguay nos exorta a conhecer o direito administrativo, uma vez que somente pelo seu estudo e conhecimento é que se possibilita a adequada reforma.

Apesar do tempo que sobre elas pesa, as lições do Visconde do Uruguay demonstram uma tendência que se cristalizou na ciência do direito administrativo no Brasil: o intenso recurso a estudos e referências do direito estrangeiro, com a constante importação de institutos. Independentemente das críticas a essa tendência, a mesma se verifica como característica inexorável do nosso direito administrativo, e se reflete de modo especial nas transformações aqui brevemente expostas.

O cenário contemporâneo do direito administrativo brasileiro conta com relevantíssimas obras a tratar desses novos paradigmas de forma mais detida. Inicialmente, destaca-se a pioneira obra de Odete Medauar, "O direito administrativo em evolução", texto seminal que abriu os debates, de forma sistematizada, acerca dos inúmeros aspectos a que se dedica o presente capítulo, em especial a ampliação das bases da legalidade, a processualização e democratização da atuação administrativa e as novas concepções sobre o interesse público. ${ }^{36}$

\footnotetext{
${ }^{34}$ URUGUAY, Paulino José Soares de Sousa, Visconde do. Ensaio sobre o direito administrativo. Rio de Janeiro: Typographia Nacional, 1862. V. 1, p. IV-V.

${ }^{35}$ URUGUAY, Paulino José Soares de Sousa, Visconde do. Ensaio sobre o direito administrativo. Rio de Janeiro: Typographia Nacional, 1862. V. 1, p. XVII.

${ }^{36}$ MEDAUAR, Odete. O direito administrativo em evolução. São Paulo: Revista dos Tribunais, 1992. A obra foi atualizada pela autora em 2003, e a tese se remete às disposições dessa nova edição ao longo de seu desenvolvimento.
} 
A essa obra seguiram outras, individuais ou coletivas, como "Mutações do direito administrativo", de Diogo de Figueiredo Moreira Neto; ${ }^{37}$ "Transformações do direito administrativo", dissertação de Patrícia Baptista; ${ }^{38}$ e "Direito administrativo e seus novos paradigmas", organizada por Alexandre Santos de Aragão e Floriano de Azevedo Marques Neto. ${ }^{39}$ Note-se que o tema mantém a sua constante atualidade, com a recentíssima organização da obra "Direito administrativo: transformações e tendências" por Tiago Marrara. ${ }^{40}$

Transformações tão radicais e contínuas do direito administrativo levam a importantes consequências para a cultura jurídica, como alerta Sabino Cassese. Nesse sentido, a ciência jurídica deve atualizar-se continuamente, acompanhando as mudanças do direito positivo. Como consequência, o estudioso do direito administrativo, para evitar convolar-se em mero narrador ou cronista, deve assumir a liderança desses movimentos, mas sem se perder em seus inúmeros detalhes. Para tanto e a ciência do direito administrativo deve buscar uma nova linguagem, que lhe permita ir além do direito positivo para reconstruir os princípios superiores que inspiram tais movimentos. ${ }^{41}$ É o que se busca, enfim, com as proposições da presente tese.

De mais a mais, deve-se sempre observar que um estudo das transformações do direito administrativo não deve ser analisado de um ponto de vista absolutamente objetivo. O posicionamento acerca das transformações do direito administrativo - ou de sua estabilidade - é frequentemente carregado de historicidade, de valores e até de uma retórica ideológica ou cultural. ${ }^{42}$ Identificar

${ }^{37}$ MOREIRA NETO, Diogo de Figueiredo. Mutações do direito administrativo. Rio de Janeiro: Renovar, 2000.

${ }^{38}$ BAPTISTA, Patrícia. Transformações do direito administrativo. Rio de Janeiro: Renovar, 2003.

39 ARAGÃO, Alexandre Santos de; MARQUES NETO, Floriano de Azevedo (orgs.). Direito administrativo e seus novos paradigmas. Belo Horizonte: Fórum, 2008.

${ }^{40}$ MARRARA, Tiago (org.). Direito administrativo: Transformações e tendências. São Paulo: Almedina, 2014.

${ }^{41}$ CASSESE, Sabino. Le trasformazioni del diritto amministrativo dal XI al XXI secolo. Rivista Trimestrale di Diritto Pubblico, Roma, a. 52, n. 1, p. 27-40, $1^{\circ}$ trim. 2002.

${ }^{42}$ De precisão ímpar é a lição de Sabino Cassese: "Queste brevi osservazioni consigliano sia di storicizzare l'idea stessa di trasformazione del diritto amministrativo, sia di valutarne la portata retorica. Questo non vuol dire che le trasformazioni non esistono in sé e per sé, oppure che il punto di vista di chi ne parla è sempre necessariamente relativo e soggettivo. Vuol dire, piuttosto, che l'idea di trasformazione, nel nostro campo, se è caricata di un sovrappiù di valori, alcuni enfatizzandone la portata, altri sminuendola, per fini diversi, per lo più ideologici e culturali. Per questo motivo, un 
ou não uma transformação, reconhecer ou não uma transformação, é, em última análise, posicionar-se em relação a ela.

A exposição a que se dedica o presente capítulo não tem a intenção de - sequer o aprofundamento necessário para - tratar desses novos paradigmas da Administração Pública de forma exaustiva. Essa ressalva se aplica com maior especialidade sobre as questões relativas à legalidade e ao interesse público, que serão melhor investigadas na segunda parte da tese, no capítulo que se dedica à oposição aos desafios postos em face do modelo proposto. Propõe-se, isso sim, o delineamento em moldes gerais de cada uma das tendências entendidas como essenciais para a compreensão do movimento no qual se insere o recurso da Administração Pública à transação extrajudicial, servindo assim de referencial futuro para as ilações desenvolvidas ao longo do estudo.

\subsection{Crise da legalidade e a ampliação de suas bases}

$\mathrm{Na}$ medida em que tratamos das transformações de um campo da ciência jurídica, é natural que essas mudanças ocorram a partir de suas fontes, em especial em um sistema que se pretenda positivista, como o nosso. Nesse sentido o primeiro desses novos paradigmas a serem aqui expostos consiste na crise do conceito de legalidade e na ampliação de suas bases, fenômeno amplamente estudado pelo direito administrativo e que serve de pressuposto a muitas das suas outras transformações.

O direito administrativo como concebido hoje, nascido do ventre da construção revolucionária do Estado de Direito, tem talvez como seu principal postulado o princípio da legalidade. $O$ direito administrativo só existe, pois, tendo em vista uma vinculação da Administração Pública do ponto de vista jurídico.

Nesse cenário, Cassese define o princípio da legalidade como aquele pelo qual "a atividade administrativa deve tomar base na lei, no senso de que as essere sempre accompagnato da un'analisi del modo in cui le trasformazioni sono individuate, giudicate, valutate, talora sopravalutate, spesso sottovalutate, o talora persino non rilevate" (CASSESE, Sabino. Le trasformazioni del diritto amministrativo dal XI al XXI secolo. Rivista Trimestrale di Diritto Pubblico, Roma, a. 52, n. 1, p. 27-40, $1^{\circ}$ trim. 2002). 
administrações públicas só possam exercitar os poderes indicados na lei e tão somente pelos modos nela prescritos". ${ }^{43}$

Tornaram-se clássicos no direito administrativo os conceitos destacados por Otto Mayer de primazia da lei e reserva de lei. ${ }^{44}$ Nesse binômio, a primazia da lei determina a vinculação da Administração às leis, seja no sentido positivo - de atuar em conformidade com as mesmas - ou no sentido negativo - abster-se o Estado de violá-las. ${ }^{45}$ Já a reserva de lei implica na exigência de autorização da lei para agir, ${ }^{46}$ sendo necessário assim um fundamento legal para a atuação estatal. ${ }^{47}$ Encontramos ainda, com frequência, a citação dos escritos de Seabra Fagundes, para quem administrar compreenderia "aplicar a lei de ofício" ${ }^{48}$

O respeito à lei, pela Administração, seria assim uma obrigação diversa daquela que vincula o particular. Na diç̧ão de Celso Antônio Bandeira de Mello: "enquanto o particular pode fazer tudo aquilo que não the é proibido [...] a administração só pode fazer o que the é permitido". ${ }^{49}$ Essa construção, tida como clássica, é atribuída por muitos como tendo origem nas lições de Hely Lopes Meirelles, para quem "[n]a Administração não há liberdade nem vontade pessoal.

\footnotetext{
${ }^{43}$ CASSESE, Sabino. Corso di Diritto Amministrativo: Istituzioni di Diritto Amministrativo. V. I. Milano: Giuffrè, 2004. P. 8. Tradução nossa.

${ }^{44}$ MAYER, Otto. Derecho administrativo alemán. Buenos Aires: De Palma, 1949. P. 93-98.

${ }^{45}$ MAURER, Hartmut. Direito administrativo geral. São Paulo: Manole, 2006. P. 121.

${ }^{46}$ FLEINER, Fritz. Derecho administrativo. Barcelona: Labor, 1933. P. 109.
}

No mesmo sentido:

ALESSI, Renato. Sistema istituzionale del diritto amministrativo italiano. Milano: Giuffrè, 1958. P. 9.

${ }^{47}$ MAURER, Hartmut. Direito administrativo geral. São Paulo: Manole, 2006. P. 122.

${ }^{48}$ FAGUNDES, Miguel Seabra. O controle dos atos administrativos pelo Poder Judiciário. Rio de Janeiro: Forense, 1979.

A construção de Seabra Fagundes é melhor compreendida, no entanto, quando observada no contexto de sua composição original: "A função legislativa liga-se aos fenômenos de formação do Direito, enquanto as outras duas, administrativa e jurisdicional, se prendem à fase de sua realização. Legislar (editar o Direito Positivo), administrar (aplicar a lei de oficío) e julgar (aplicar a lei contenciosamente) são três fases da atividade estatal, que se completam e que a esgotam em extensão."

49 MELLO, Celso Antônio Bandeira de. Discricionariedade e controle jurisdicional. São Paulo: Malheiros, 2007. P. 12-13. 
Enquanto na administração particular é lícito fazer tudo que a lei não proíbe, na Administração Pública só é permitido fazer o que a lei autoriza". ${ }^{50}$

A concepção de legalidade que se extrai desses ensinamentos, no entanto, não corresponde perfeitamente àquilo que, na realidade, se mostra factível. É que, como destaca Odete Medauar, caso o Estado somente pudesse praticar atos expressamente ordenados por lei, a concepção do princípio da legalidade paralisaria a Administração Pública, na medida em que seria necessário um comando geral direcionado a cada uma das medidas a serem editadas pela Administração, inviabilizando-a. Nesse sentido, a submissão total da Administração à legalidade é irrealizável e, muito provavelmente, nunca foi observada na realidade. ${ }^{51}$

Mesmo que tamanha vinculação fosse possível, a crise de efetividade da lei e o crescimento da influência do direito internacional - e comunitário, no caso da União Europeia - sobre a ordem interna acabam por fragilizar consideravelmente essa dita proeminência da legalidade no direito administrativo. ${ }^{52}$

Esse cenário de crise da legalidade é bem exposto por Binenbojm:

[...] é fato notório que a segunda metade do século $X X$ assistiu a um processo de desprestígio crescente do legislador e de erosão da lei formal [...] - a chamada crise da lei - caracterizada pelo desprestígio e descrédito da lei como expressão da vontade geral, pela sua politização crescente ao sabor dos sucessivos governos, pela crise da representação, pelo incremento progressivo da atividade normativa do Poder Executivo e pela proliferação das agências reguladoras independentes. Com efeito, o surgimento do Estado providência criou para a Administração Pública uma série de novas atribuições que não se encontravam expressamente

\footnotetext{
${ }^{50}$ MEIRELLES, Hely Lopes. Direito administrativo brasileiro. São Paulo: Revista dos Tribunais, 1991. P. 82-83.

${ }^{51}$ MEDAUAR, Odete. O direito administrativo em evolução. São Paulo: Revista dos Tribunais, 2003. P. 144-145.

52 GUEDES, Armando Marques. La loi dans un État de Droit. In: FACULDADE de Direito da Universidade de Lisboa. Estudos em homenagem ao Professor Doutor Marcello Caetano. Coimbra: Coimbra Editora, 2006. P. 229-236. Tradução nossa.
}

Destaca o autor: "[...] toutes les solutions partielles énoncés, comme la prééminence du droit, l'hiérarchie des normes, le respect strictement exige envers cette même hiérarchie, la primanté accordée au droit international sur le droit interne, l'intégration ostensible du droit international dans les ordres juridiques internes, la proclamation de l'État comme un État de Droit et de la forme de gouvernement adoptée comme devant ètre conforme aux exigences de la Démocratie, tout celà n'a aucune valeur s'il n'est réalisé que formellement." 
previstas nas leis. Ademais, o aumento significativo do grau de complexidade das relações econômicas e sociais que vieram a demandar a pronta intervenção e ordenação do Estado passaram a não mais caber dentro da lentidão e generalidade do processo legislativo formal. ${ }^{53}$

São as características da própria lei, portanto, as responsáveis pela deterioração de seu status. Os textos normativos se tornam cada vez menos densos, adotando de forma crescente "conceitos cada vez mais abstratos e indeterminados, enumerações exemplificativas, cláusulas gerais e princípios plurissignificativos, bem como de fórmulas de compromisso político sem viés nítido", fazendo crescer as margens interpretativas do administrador; ao mesmo tempo, as leis são cada vez mais onipresentes, buscando se dedicar a um crescente de assuntos de forma contraditória e fragmentária, no fenômeno denominado de "inflação legislativa". 54

Norberto Bobbio, por sua vez, destaca - em texto publicado nos já distantes anos 1980, um tanto oportuno para a história constitucional brasileira -, com invulgar sinceridade, o papel do ordenamento constitucional no real direcionamento do Estado contemporâneo:

Quem lê uma Constituição acredita que o Estado seja todo contido naqueles órgãos de governo que a carta constitucional disciplina. Tirando os olhos da carta e olhando em volta se verá que, além do governo, existe o subgoverno, que o acompanha como sua sombra, existe o criptogoverno, o poder oculto dos serviços secretos que o controla, e existe ainda, talvez, num Estado de soberania diminuída como o italiano, um supragoverno que o dirige. Tudo isso, subgoverno, criptogoverno e supragoverno, são coisas das quais uma boa e honesta Constituição nada sabe e sobre as quais pudicamente deve silenciar. Uma Constituição, no edifício complicado e exagerado do Estado contemporâneo, mesmo quando perfeita, mostra apenas a fachada. Ela não mostra nada ou quase nada do que está por detrás, sem falar dos subterrâneos. É evidente que toda Constituição se tornou uma roupa apertada para um corpanzil como o do Estado contemporâneo, que cresceu muito rapidamente e mal, para poder ficar numa situação dessas sem rasgar. De nada serve ou serve muito pouco, portanto, chorar sobre uma Constituição que não é cumprida ou é traída, como de pouco serve pensar em reformas ou retoques constitucionais quando se

\footnotetext{
${ }^{53}$ BINENBOJM, Gustavo. A constitucionalização do direito administrativo no Brasil: um inventário de avanços e retrocessos. Revista Eletrônica sobre a Reforma do Estado, Salvador, n. 13, mar.mai. 2008.

${ }^{54}$ MODESTO, Paulo. Autovinculação da Administração Pública. Revista Eletrônica de Direito do Estado, Salvador, n. 24, out.-dez. 2010.
} 
tem a ilusão de que basta mudar a roupa para mudar o temperamento daquele que a veste. Não digo que a Constituição não deva ser respeitada. Infelizmente, porém, o simples respeito formal, mesmo quando total, é apenas a condição necessária para o bom funcionamento de uma democracia. Mas não é uma condição suficiente. Não quero dizer que uma Constituição seja intocável. Colocado de lado, porém, o fato de que deve defenderse dos retoques que a deturpam, retocá-la ou emendá-la serve de pouca coisa, se, por detrás da fachada, os padrões da casa forem sempre os mesmos. ${ }^{55}$

Todos esses elementos delineiam um cenário de "absurdez da lei", em que alguns são soterrados e destruídos por ela, outros permanecem impassíveis por suas disposições - como que por ela "anestesiados" -, enquanto outros mais agem como se a lei simplesmente não existisse. Só o que é raro é o cenário em que a lei, efetivamente, cumpre o seu papel de pacificação social. ${ }^{56}$

Este panorama de crise da noção de legalidade no direito administrativo reclama, assim, uma ressignificação de seu sentido, abrindo-se o caminho às transformações que constituem um dos novos paradigmas aqui estudados.

Pedro Machete, ao analisar o papel da vinculação da Administração Pública à legalidade como elemento dogmático do direito administrativo, expõe o entendimento de que o crescimento da subordinação legal da Administração - em especial a exigência de fundamentação legal específica para cada um de seus atos - não esgota o espectro de circunstâncias no qual se analisa o novo regime constitucional da Administração. Muito além, tais transformações implicam na "integração jurídica plena dos cidadãos particulares na Constituição e no ordenamento do Estado, por via do reconhecimento de direitos fundamentais directamente aplicáveis". 57

\footnotetext{
${ }^{55}$ BOBBIO, Norberto. As ideologias e o poder em crise. Brasília: UnB/Polis, 1988. P. 190-191.

Pedimos vênia para a reprodução do texto de Bobbio em sua extensão, entendendo que a simples paráfrase não faria jus às contundentes palavras do autor.

${ }^{56}$ CARBONNIER, Jean. Flexible Droit: Pour une sociologie du droit sans rigueur. Paris: LGDJ, 2001. P. 432-433.

${ }^{57}$ MACHETE, Pedro. A subordinação da Administração Pública ao direito e a dogmática do Direito Administrativo no âmbito do Estado de direito democrático. In: ATHAYDE, Augusto de; CAUPERS, João; GARCIA, Maria da Glória F. P. D. Em homenagem ao Professor Doutor Diogo Freitas do Amaral. Coimbra: Almedina, 2012. P. 192-238.
} 
Assistimos, assim, a uma subjetivação da relação entre cidadão e Estado: ora, uma vez que "o Estado se funda na dignidade da pessoa humana e na vontade popular", temos um cenário em que o homem constitui o pólo em torno do qual deve girar o direito administrativo, pois o Estado "existe por causa do homem e para o homem". 58

Essa evolução é designada, por Sabino Cassese, como a transição "do princípio de legalidade ao respeito ao Direito". Em sua lição, além da obediência à lei em sentido estrito, a Administração Pública é vinculada primordialmente à Constituição e, por construção jurisprudencial, aos princípios basilares jacentes ao espírito de composição das normas. ${ }^{59}$

Maria Sylvia Di Pietro identifica as origens dessa ideia básica de constitucionalização do direito administrativo na Lei Fundamental de Bonn de 1949, cenário em que "[h]ouve uma ampliação do sentido da lei, no sentido de que ela passou a ser vista sob o aspecto formal, porque emana do Legislativo, e sob o aspecto material, porque ela tem o papel de realizar os valores consagrados na Constituição". 60

Nesse sentido, apesar de não ter adotado fórmula expressa, como a Lei Fundamental de Bonn, a Constituição Federal de 1988 adotou o princípio da juridicidade em sentido amplo, com a sujeição do Estado não só à Lei, mas ao Direito, com a proeminência dos direitos fundamentais e o respeito aos valores e princípios implícita e explicitamente consagrados na Constituição. A carta constitucional brasileira contaria, assim, com dois sentidos para a legalidade: no

Aqui, apesar do contexto português de seu escrito, podemos traçar um paralelo com o cenário constitucional da Administração Pública brasileira, como destacado ao longo do capítulo.

${ }^{58}$ MACHETE, Pedro. A subordinação da Administração Pública ao direito e a dogmática do direito administrativo no âmbito do Estado de direito democrático. In: ATHAYDE, Augusto de; CAUPERS, João; GARCIA, Maria da Glória F. P. D. Em homenagem ao Professor Doutor Diogo Freitas do Amaral. Coimbra: Almedina, 2012. P. 192-238.

59 No contexto comunitário europeu, Cassese destaca ainda a necessidade de respeito, pela Administração Pública, das normas próprias à União Europeia, que derrogam inclusive a normativa doméstica (CASSESE, Sabino. Corso di Diritto Amministrativo: Istituzioni di Diritto Amministrativo. V. I. Milano: Giuffrè, 2004. P. 8-10).

${ }^{60}$ DI PIETRO, Maria Sylvia Zanella. O princípio da supremacia do interesse público: sobrevivência diante dos ideais do neoliberalismo. In: DI PIETRO, Maria Sylvia Zanella; RIBEIRO, Carlos Vinicius Alves (coords.). Supremacia do interesse público e outros temas relevantes do Direito administrativo. São Paulo: Atlas, 2010. P. 180. 
primeiro sentido, restrito, acomodar-se-ia a noção de reserva legal, "para designar a exigência de que determinadas matérias sejam reservadas à lei, porque só podem ser disciplinadas por um dos processos previstos no artigo 59 da Constituição"; já no sentido amplo, abrangendo a lei em sentido formal, a legalidade designaria "os atos normativos do Poder Executivo e de órgãos e entidades que compõem a Administração Direta e Indireta, além dos princípios e valores consagrados de forma expressa ou implícita na Constituição". 61

Uma das principais tendências contemporâneas do princípio da legalidade é, portanto, a sua quase substituição pela constitucionalidade, na medida em que a Constituição contém cada vez mais normas materialmente nãoconstitucionais, com um sistema constitucional de princípios e valores. ${ }^{62}$

Gustavo Binenbojm enxerga nessa transição a origem de quatro grandes câmbios conceituais no direito administrativo, a cujo tratamento o presente trabalho se dedica, oportunamente, ao longo das análises desenvolvidas. Num primeiro momento, vê-se a relativização da submissão total e irrestrita da Administração à vontade do Legislativo consubstanciada no texto legal, na medida em que "a Constituição, e não mais a lei, passa a situar-se no cerne da vinculação administrativa à juridicidade". 63

O segundo grande câmbio identificado por Binenbojm consiste na diferente definição daquilo que se entende por "interesse público", do seu método de apuração e, consequentemente, da relativização da sua suposta supremacia sobre os interesses particulares. A terceira mudança residiria na revisão da amplitude de escolha que é conferida ao campo da discricionariedade administrativa, passando de um âmbito de livre definição pelo administrador à

\footnotetext{
${ }^{61}$ DI PIETRO, Maria Sylvia Zanella. O princípio da supremacia do interesse público: sobrevivência diante dos ideais do neoliberalismo. In: DI PIETRO, Maria Sylvia Zanella; RIBEIRO, Carlos Vinicius Alves (coords.). Supremacia do interesse público e outros temas relevantes do Direito administrativo. São Paulo: Atlas, 2010. P. 182-184.

${ }^{62}$ CABO MARTíN, Carlos. Sobre el concepto de ley. Madrid: Trotta, 2000. P. 79 ss.

${ }^{63}$ BINENBOJM, Gustavo. A constitucionalização do direito administrativo no Brasil: um inventário de avanços e retrocessos. Revista Eletrônica sobre a Reforma do Estado, Salvador, n. 13, mar.mai. 2008.
} 
adoção de "procedimentos técnicos e jurídicos prescritos pela Constituição e pela lei com vistas à otimização do grau de legitimidade da decisão administrativa". ${ }^{4}$

Por fim, Gustavo Binenbojm credita a esta transição o surgimento de "um espaço próprio para as autoridades administrativas independentes no esquema de separação de poderes e na lógica do regime democrático", representado, no direito administrativo brasileiro, pela adoção do modelo de agências à moda estadunidense, em movimento contrário à noção de um Poder Executivo unitário. ${ }^{65}$

Diante desse cenário, Binenbojm delineia o seu entendimento acerca da constitucionalização do direito administrativo, que residiria na adoção de um sistema de direitos fundamentais e de um sistema democrático como "vetores axiológicos", representados por princípios e regras constitucionais, que viriam a pautar a atuação da Administração Pública. ${ }^{66}$

Desse cenário Cassese extrai um novo papel da Administração Pública para trazer efetividade ao Direito:

[...] a administração pública está longe de ser uma executora mecânica de leis. Ela deve analisar e avaliar a norma a aplicar, e deve respeitar os princípios de formação jurisprudencial. Aí porque, em vez do princípio da legalidade, a administração deve respeitar o direito como um todo. ${ }^{67}$

Essa vinculação ao direito, e não somente à lei, abre caminho para o protagonismo dos princípios que se observa no direito em geral, e encontra especial aplicação em face do Estado.

É nesse cenário que, para Paulo Otero, a lei perde parcela do seu papel garantístico em favor da valorização de princípios pela ordem constitucional, no

\footnotetext{
${ }^{64}$ BINENBOJM, Gustavo. A constitucionalização do direito administrativo no Brasil: um inventário de avanços e retrocessos. Revista Eletrônica sobre a Reforma do Estado, Salvador, n. 13, mar.mai. 2008.

${ }^{65}$ BINENBOJM, Gustavo. A constitucionalização do direito administrativo no Brasil: um inventário de avanços e retrocessos. Revista Eletrônica sobre a Reforma do Estado, Salvador, n. 13, mar.mai. 2008.

${ }^{66}$ BINENBOJM, Gustavo. A constitucionalização do direito administrativo no Brasil: um inventário de avanços e retrocessos. Revista Eletrônica sobre a Reforma do Estado, Salvador, n. 13, mar.mai. 2008.

${ }^{67}$ CASSESE, Sabino. Corso di Diritto Amministrativo: Istituzioni di Diritto Amministrativo. V. I. Milano: Giuffrè, 2004. P. 10.
} 
sentido em que "[...] todo este novo modelo de legalidade, envolvendo um 'Direito de princípios', aumenta consideravelmente a conflitualidade social e judicial", uma vez que para cada caso de insatisfação pessoal ou preterição de grupo de interesse haverá um princípio constitucional a fundamentar um novo pleito judicial contra a Administração. Tais pleitos, baseados que são em "princípios constitucionais contraditórios", axabam por arrastar os tribunais "numa discussão políticoconstitucional que, sendo fruto das sucessivas incertezas normativas da Constituição e da legislação ordinária, contribuem para ampliar a presente crise na concretização jurisdicional da justiça". ${ }^{6}$

Paulo Modesto define as consequências desse panorama, no qual

[...] há um aumento expressivo da litigiosidade, com consequência na paralisia do próprio aparato administrativo, contida frequentemente por liminares e medidas de cautela, pois todos os sujeitos jurídicos supostamente lesados pela atuação da Administração sentem-se resguardados por algum princípio para esgrimir. ${ }^{69}$

Forma-se assim um panorama em que se destaca a acepção de Carlos Ari Sundfeld, para quem o recurso imponderado aos princípios, e não a regras, para a solução de litígios envolvendo a Administração Pública, representaria na verdade a preguiça do julgador em fundamentar adequadamente suas decisões. ${ }^{70}$ Constituir-se-ia, assim, um paradoxo no qual a busca pela maior segurança jurídica leva à constitucionalização de valores e princípios que, pela sua interpretação etérea e imprecisão, levam à insegurança jurídica. ${ }^{71}$

De todo modo, verifica-se que a evolução da legalidade administrativa, com a ampliação de suas bases, na direção de uma vinculação ao Direito como um

\footnotetext{
${ }^{68}$ OTERO, Paulo. Legalidade e administração pública: o sentido da vinculação administrativa à juricidade. Coimbra: Almedina, 2003. P. 168.

${ }^{69}$ MODESTO, Paulo. Autovinculação da Administração Pública. Revista Eletrônica de Direito do Estado, Salvador, n. 24, out.-dez. 2010.

${ }^{70}$ SUNDFELD, Carlos Ari. Direito administrativo para céticos. São Paulo: Malheiros, 2012. P. 60-84.

${ }^{71}$ DI PIETRO, Maria Sylvia Zanella. O princípio da supremacia do interesse público: sobrevivência diante dos ideais do neoliberalismo. In: DI PIETRO, Maria Sylvia Zanella; RIBEIRO, Carlos Vinicius Alves (coords.). Supremacia do interesse público e outros temas relevantes do Direito administrativo. São Paulo: Atlas, 2010. P. 195.
} 
todo, é um câmbio inexorável nos paradigmas do direito administrativo. Essa é uma circunstância que ocupa um papel de grande destaque na adoção da transação extrajudicial pela Administração Pública, tema que é aprofundado na porção inicial da segunda parte da tese.

\subsection{Passagem do ato para o processo administrativo}

Tradicionalmente, o ato administrativo foi tido como o instrumento por excelência de atuação da Administração Pública. Considerado a materialização da vontade estatal, o ato administrativo cumpriu, do ponto de vista histórico, o papel de referencial central para o estudo do proceder da Administração.

O ato administrativo simbolizaria, assim, a unilateralidade administrativa, o exercício do poder estatal na plenitude de sua superioridade em relação aos particulares. Vemos, portanto, que os primeiros movimentos de sistematização do direito administrativo acabaram tendo como consequência a adoção, como referencial objetivo, do ato administrativo, figura com a qual culminaria a consecução do mister estatal. Esse referencial encontra-se hoje em uma situação de câmbio, em que exsurge a processualidade como valor.

Apesar de haver notícia de que a expressão "ato administrativo" teria sido adotada pela primeira vez por Merlin em 1812, na quarta edição do Repertório de Guyot, $^{72}$ a sua consolidação como elemento central de estudo do ato administrativo não se deu de imediato. No sentido dessa construção, vemos que alguns dos pioneiros trabalhos franceses a se debruçar sobre o direito administrativo, como as obras de Laferrière, ${ }^{73}$ Pradier-Fodéréé $^{74}$ e Gautier, $^{75}$ se

\footnotetext{
${ }^{72}$ MEDAUAR, Odete. Administração pública: do ato ao processo. In: ARAGÃO, Alexandre Santos de; MARQUES NETO, Floriano de Azevedo. Direito administrativo e seus novos paradigmas. Belo Horizonte: Fórum, 2008. P. 405-419.

${ }^{73}$ LAFERRIĖRE, Firmin. Cours théorique et pratique de droit public et administratif. Paris: Cotillon, 1850.

${ }^{74}$ PRADIER-FODÉRÉ, Paul Louis Ernest. Précis de droit administratif. Paris: Guilaumin, 1872.

${ }^{75}$ GAUTIER, Alfred. Cours de droit administratif: Précis des matières administratives dans leurs rapports avec le droit public. Paris: Lahure, 1880.

Merece destaque que, apesar de não dedicar capítulo específico ao estudo dos atos administrativos, Gautier sistematiza o estudo da estrutura estatal francesa com base na competência de cada um dos órgãos para a prática de "actes administratifs".
} 
dedicaram consideravelmente ao estudo do binômio estrutura administrativaserviços públicos. Dentre as primeiras obras de direito administrativo no Brasil, o trabalho do Visconde do Uruguay tem grande foco sobre o processo de atuação da Administração Pública, sobretudo sob o ponto de vista subjetivo, estrutural; ${ }^{76}$ no entanto, o seu cenário histórico-político, marcado pelo governo imperial, desvia o foco para longe da atuação material do Estado e, assim, sua obra carece de um posicionamento claro em relação ao ato administrativo em si.

Já a partir do início do séc. $X X$, os cultores do direito administrativo passaram a centralizar seus estudos na atuação material do Estado, cenário fértil para a ascensão do ato administrativo como sua figura central. Gaston Jèze, mantendo o estudo em torno dos serviços públicos, edifica a sua obra com um intensivo estudo do "acte juridique", conceito em torno do qual gravita toda a sua construção acerca do direito público. ${ }^{77} \mathrm{Em}$ suas "Noções de Direito Administrativo Brasileiro", de 1910, Alcides Cruz leciona que, "[n]o desempenho de suas multiplas funcções, para a obtenção dos seus fins, o Estado pratica actos de differentes especies. É por meio delles que o Estado manifesta a sua vontade, e portanto estão sujeitos conforme a respectiva natureza, a um especial regimen juridico" ${ }^{78} \mathrm{O}$ seu contemporâneo Viveiros de Castro acaba por não abordar diretamente o tema, atendo-se ao estudo da estrutura da Administração e dos serviços públicos. ${ }^{79}$

Com o mesmo espírito de Alcides Cruz, Eurico de Oliveira Santos edifica suas lições sobre o direito administrativo, ainda no primeiro quartel do séc. $X X$, com grande enfoque sobre o ato administrativo, e sem referências ao processo de sua formação. ${ }^{80}$ Alguns anos após, Aarão Reis, em um trabalho de maior qualidade sistemática e fortemente influenciado pela escola do serviço público francesa de Duguit, elege $\mathrm{o}$ ato administrativo como manifestação central da atividade

\footnotetext{
${ }^{76}$ URUGUAY, Paulino José Soares de Sousa, Visconde do. Ensaio sobre o direito administrativo. Rio de Janeiro: Typographia Nacional, 1862. Passim.

${ }^{77}$ JĖZE, Gaston. Cours de droit public. Paris: Giard, 1924.

${ }^{78}$ CRUZ, Alcides. Noções de Direito administrativo brasileiro: Exposição summaria e abreviada. Porto Alegre: Germano Gundlach, 1910. P. 20-26.

${ }^{79}$ CASTRO, Augusto Olympio Viveiros de. Tratado de sciencia da administração e direito administrativo. Rio de Janeiro: Jacintho Ribeiro dos Santos, 1914. Passim.

${ }^{80}$ OLIVEIRA SANTOS, Eurico de. Direito administrativo e sciencia da administração. Rio de Janeiro: Jacintho Ribeiro dos Santos, 1919. P. 100-119.
} 
administrativa, estudando apenas instrumentalmente o processo como o modo de seu exercício. ${ }^{81}$

Em momento histórico posterior - já sob a égide da Constituição Federal de 1937 -, Themístocles Brandão Cavalcanti publica obra fortemente centralizada no binômio estrutura e função. Seu foco, no entanto, assim como Aarão Reis, se concentra sobre a realização da missão estatal pelos serviços públicos, abordando tanto o papel central dos atos administrativos na sua realização quanto as instituições relacionadas com o contencioso administrativo. ${ }^{82}$ Nas suas palavras:
A vontade do Estado manifesta-se por meio de actos administrativos.
Os direitos e obrigações contrahidas pela administração decorrem dessa manifestação da vontade do Estado.
É, assim, a theoria dos actos administrativos o problema fundamental do direito administrativo e por isso mesmo, tem dado lugar ás mais divergentes doutrinas. ${ }^{83}$

O cenário assim formado - que, obviamente, conta com diversos outros autores de igual grandeza e importância - fez com que o estudo do direito administrativo fosse centrado, especialmente, no ato administrativo, seja como categoria apta a viabilizar o controle da atuação administrativa, seja como potestade própria da Administração dotada de garantias e prerrogativas extraordinárias. $^{84} \mathrm{O}$ ato administrativo assim considerado trouxe ao direito administrativo a concepção de que "[o] modo normal da ação administrativa é o ato unilateral, decisão executória, criadora de direitos e obrigações em relação aos administrados [...]", como expõe Jacqueline Morand-Deviller. ${ }^{85}$

As inúmeras transformações por que passou e tem passado o direito administrativo, aqui amplamente estudadas, não deixaram que se the passasse

\footnotetext{
${ }^{81}$ REIS, Aarão. Direito administrativo brazileiro. Rio de Janeiro: Villas-Boas, 1923. P. 133-140.

82 CAVALCANTI, Themistocles Brandão. Instituições de direito administrativo brasileiro. Rio de Janeiro: Freitas Bastos, 1938. V. 1, p. 379-398; v. 2, p. 71-256.

83 CAVALCANTI, Themistocles Brandão. Instituições de direito administrativo brasileiro. Rio de Janeiro: Freitas Bastos, 1938. V. 2, p. 71.

${ }^{84}$ MEDAUAR, Odete. Administração pública: do ato ao processo. In: ARAGÃO, Alexandre Santos de; MARQUES NETO, Floriano de Azevedo. Direito administrativo e seus novos paradigmas. Belo Horizonte: Fórum, 2008. P. 405-419.

${ }^{85}$ MORAND-DEVILLER, Jacqueline. Cours de droit administratif. Paris: Montchréstien, 2007. P. 337. Tradução parcial de Odete Medauar.
} 
incólume $\mathrm{o}$ ato administrativo. Desse modo, como destaca Odete Medauar, as demandas por democratização administrativa, transparência e efetividade de direitos fundamentais levou a que se deslocasse o foco de estudo não só para o ato final de veiculação da decisão administrativa, mas principalmente para o seu processo de formação. ${ }^{86}$

Ainda nos anos 50 do séc. XX, Marcello Caetano já reconhecia o protagonismo do processo na atividade da Administração Pública, destacando que "a actividade da Administração pública é, em larga escala, uma actividade processual". ${ }^{87}$ Diante de tal panorama, como destaca Vasco Pereira da Silva, "o ato administrativo [...] perdeu seu papel de protagonista exclusivo do relacionamento dos indivíduos com a Administração, para passar a ter de partilhar essa posição com outras formas de atuação, que se tornaram cada vez mais habituais". ${ }^{88}$

Junto da contratualização, assim, a processualização administrativa é vista, por Jacques Chevalier, como um dos elementos que revelam o impacto da noção de governança sobre o Direito - e a sua própria juridicização. ${ }^{89}$

A questão em torno da posição do particular como sujeito do processo administrativo deu origem a interessante debate no direito administrativo italiano do início dos anos 1990, em que se discutiu se haveria contraditório no processo administrativo - em outras palavras, se o particular seria parte ou participante do processo administrativo -, e qual seria a consequência disso para a legitimação processual. ${ }^{90}$ No direito positivo brasileiro é interessante observar que o inciso LV do art. $5^{\circ}$ da Constituição Federal confere ao particular em processo administrativo

\footnotetext{
${ }^{86}$ MEDAUAR, Odete. Administração pública: do ato ao processo. In: ARAGÃO, Alexandre Santos de; MARQUES NETO, Floriano de Azevedo. Direito administrativo e seus novos paradigmas. Belo Horizonte: Fórum, 2008. P. 405-419.

${ }^{87}$ CAETANO, Marcello. Manual de direito administrativo. Coimbra: Coimbra Editora, 1951. P. 675.

${ }^{88}$ SILVA, Vasco Pereira da. Em busca do acto administrativo perdido. Coimbra: Almedina, 1998. P. 5.

${ }^{89}$ CHEVALLIER, Jacques. A governança e o direito. Revista de Direito Público da Economia, Belo Horizonte, a. 3, n. 12, p. 129-146, out.-dez. 2005.

90 VILLATA, Ricardo. Riflessioni in tema di partecipazione al procedimento e legitimazione processuale. Diritto Processuale Amministrativo - Rivista Trimestrale, Milano, a. 10, n. 2, p. 172-205, jun. 1992.
} 
o status de litigante, reconhecendo assim a sua posição e as garantias que advém da processualização do proceder estatal.

É de se destacar que, tal como bem edifica Odete Medauar, o direito administrativo não carece, necessariamente, de um eixo central, e talvez seja tanto melhor que não o possua; ${ }^{91}$ no entanto, é saudável reconhecer, como evolução do direito administrativo, uma redução da importância do ato administrativo em favor do crescimento do valor do processo administrativo em suas análises. Esse câmbio vem, afinal, fomentar o incremento no respeito às garantias de contraditório e ampla defesa dos particulares em face da Administração, aprimorar o processo de conhecimento do ente estatal acerca das circunstâncias relevantes para a decisão a ser adotada, e elevar o grau de consensualidade e legitimação das decisões da Administração Pública. ${ }^{92}$ Tais elementos guardam importante relação com a viabilidade da adoção de soluções consensuais de conflitos pela Administração Pública e, assim, se ligam aos debates que serão expostos no próximo capítulo.

\subsection{Novos olhares sobre o interesse público}

A abordagem dos debates contemporâneos acerca do interesse público, seu papel, sua caracterização e seu conteúdo é de essencial importância para o desenvolvimento central da tese que aqui se desenvolve. Nesse sentido, o estudo detalhado de todas as circunstâncias em torno do tema é realizado no capítulo, integrante da segunda parte da obra, que se dedica aos desafios à adoção da transação extrajudicial pela Administração Pública brasileira.

No entanto, na medida em que o presente capítulo trata detidamente das transformações por que tem passado o direito administrativo, torna essencial a

\footnotetext{
${ }^{91}$ MEDAUAR, Odete. Administração Pública: do ato ao processo. In: ARAGÃO, Alexandre Santos de; MARQUES NETO, Floriano de Azevedo (coords.). Direito administrativo e seus novos paradigmas. Belo Horizonte: Fórum, 2008. P. 405-419.

E ainda:

MEDAUAR, Odete. O direito administrativo em evolução. São Paulo: Revista dos Tribunais, 2003.

${ }^{92}$ BINENBOJM, Gustavo. A constitucionalização do direito administrativo no Brasil: um inventário de avanços e retrocessos. Revista Eletrônica sobre a Reforma do Estado, Salvador, n. 13, mar.mai. 2008.
} 
exposição, ainda que brevíssima, acerca das tendências evolutivas em torno do interesse público.

Parte relevante da literatura brasileira em direito administrativo adota o entendimento de que o interesse público seria o eixo central do chamado regime jurídico administrativo, ${ }^{93}$ expressando-se nas figuras da indisponibilidade do interesse público e da supremacia do interesse público - para muitos, alçadas à categoria de princípios.

Em tal cenário, o Estado se caracterizaria como o protagonista da definição do interesse que justificaria a sua atuação, uma vez que o mesmo é de sua titularidade e o mecanismo democrático lhe confere legitimidade para tanto.

Mesmo nos países da common law o interesse público tem se revelado como potencial eixo central do direito administrativo. No caso do Reino Unido, por exemplo, em um período marcado pelas reformas procedimentais do Judiciário em fins dos anos 1970, juízes reformistas como Lord Diplock e Lord Donaldson moldaram um sistema de direito do Estado baseado em uma ideia central e unificadora de poder público exercido em prol do bem comum e de acordo com princípios axiomáticos de boa administração. ${ }^{94}$ Tal posicionamento marcaria a sua separação em relação ao direito privado, considerando este como sendo focado na proteção de direitos e interesses individuais.

Nesse sentido, tornou-se clássica a definição, formulada por Celso Antônio Bandeira de Mello, de que o interesse público seria o "[...] interesse resultante do conjunto dos interesses que os indivíduos pessoalmente têm quando considerados em sua qualidade de membros da Sociedade e pelo simples fato de o serem". ${ }^{95}$

\footnotetext{
${ }^{93}$ MELLO, Celso Antônio Bandeira de. Curso de direito administrativo. São Paulo: Malheiros, 2014. Passim.

${ }^{94}$ VARUHAS, Jason N. E. The public interest conception of public law: Its procedural origins and substantive implications. Legal Studies Research Paper Series, University of Cambridge, Cambridge, n. 61, out. 2014.

${ }^{95}$ MELLO, Celso Antônio Bandeira de. Curso de direito administrativo. São Paulo: Malheiros, 2014. P. 60.
} 
Continua o autor, fomulando a sua concepção de supremacia do interesse público:

Trata-se de verdadeiro axioma reconhecível no moderno Direito Público. Proclama a superioridade do interesse da coletividade, firmando a prevalência dele sobre o particular, como condição até mesmo da sobrevivência e asseguramento deste último. É pressuposto de uma ordem social estável, em que todos e cada um possam sentir-se garantidos e resguardados. ${ }^{96}$

Tratamos aqui, no entanto, de câmbios de concepções, de mudanças de paradigmas no direito administrativo, e a concepção tida como tradicional do interesse público não está a salvo dessas transformações. Nesse particular destaca-se o posicionamento de Mario Chiti ao sustentar que, mesmo com a permanência do direito administrativo como ramo autônomo, o Estado tem perdido "irremediavelmente" a sua centralidade na realização do interesse social. ${ }^{97}$

Trata-se de uma evolução, portanto, que decorre naturalmente das demais transformações expostas no presente capítulo, em especial da ampliação das bases de legalidade e da mudança no paradigma relacional entre Estado e sociedade.

Como bem destaca Gustavo Binenbojm:

Tributária de concepções organicistas antigas e modernas, a idéia da existência de um interesse público inconfundível com os interesses pessoais dos integrantes de uma sociedade política e superior a eles não resiste à emergência do constitucionalismo e à consagração dos direitos fundamentais e da democracia como fundamentos de legitimidade e elementos estruturantes do Estado democrático de direito. ${ }^{98}$

Frente a esse panorama, torna-se mais difícil tecer uma definição precisa do conteúdo desse interesse público. Ora, na medida em que o Estado perde a prerrogativa de determinar unilateralmente qual é a providência mais adequada à

\footnotetext{
${ }^{96}$ MELLO, Celso Antônio Bandeira de. Curso de direito administrativo. São Paulo: Malheiros, 2014. P. 53.

97 CHITI, Mario P. Monismo o dualismo in diritto amministrativo: vero o falso dilema? Rivista Trimestrale di Diritto Pubblico, Roma, a. 50, n. 2, p. 301-320, $2^{\circ}$ trim. 2000.

${ }^{98}$ BINENBOJM, Gustavo. A constitucionalização do direito administrativo no Brasil: um inventário de avanços e retrocessos. Revista Eletrônica sobre a Reforma do Estado, Salvador, n. 13, mar.mai. 2008.
} 
consecução do bem comum, o entendimento de o que seria o interesse público se dissipa na sociedade, tornando-o praticamente indefinível.

Essa natureza etérea do interesse público, contraditoriamente, pode ser manipulada pela própria Administração para escapar do controle social que dela adviria já que, como não há um interesse público definível, qualquer de suas ações poderia ser rotulada como tal. Na dicção de Lênio Streck, "o 'interesse público' [...] não passa de uma expressão que sofre de intensa 'anemia significativa', nela 'cabendo qualquer coisa', mormente se for a partir do 'princípio' da razoabilidade". 99

Diante de todos esses aspectos, não se pode mais falar em interesse público, mas sim em interesses públicos, como destaca Floriano de Azevedo Marques Neto. ${ }^{100} \mathrm{O}$ reconhecimento dessa multiplicidade é essencial para o enfrentamento aos desafios teóricos abordados no início da segunda parte da tese.

Vislumbra-se, pois, um cenário de necessária revisão das concepções mais arraigadas na literatura em direito administrativo no Brasil em torno do interesse público, em especial sobre a sua suposta supremacia. Frente à importância central desse tema para a solução dos desafios que a tese desperta, o seu enfrentamento adequado será desenvolvido na segunda parte do trabalho, em capítulo especialmente dedicado à tarefa.

\subsection{Direito fundamental à boa Administração Pública}

O cenário de transformação administrativa pela importação de institutos, em especial do direito europeu - como exposto na porção introdutória do presente capítulo - encontra uma das suas mais importantes expressões na defesa, pela literatura, da existência de um direito fundamental à boa Administração Pública.

\footnotetext{
99 STRECK, Lênio Luiz. Ministros do STJ não devem se aborrecer com a lei. Revista Consultor Jurídico, São Paulo, 7 jun. 2012.

José Eduardo Faria teve posicionamento pioneiro ao destacar a cooptação do discurso vazio acerca do interesse público, classificando-o como "um conceito quase mítico, cujo valor se assenta justamente na indefinição de seu sentido e que, por ser facilmente manipulável por demagogos, populistas e tiranos da vida pública, acaba sendo analiticamente pobre" (FARIA, José Eduardo. Antinomias jurídicas e gestão econômica. Lua Nova, São Paulo, n. 25, p. 167-184, abr. 1992).

100 MARQUES NETO, Floriano de Azevedo. Regulação Estatal e Interesses Públicos. São Paulo: Malheiros, 2002.
} 
A rigor, tal figura não encontra expressa previsão na ordem constitucional brasileira. No entanto, como demonstrado adiante - em posição à qual aderimos -, a literatura sustenta que as diversas disposições principiológicas constitucionais acerca da Administração Pública brasileira constituiriam, em plenitude, o dever de boa administração também em nosso ordenamento.

Rhita Bousta, em monografia dedicada ao tema, conceitua a noção de boa administração como "a adaptação equilibrada dos meios de que dispõe a administração". Tal conceito visa a distinguir a figura das noções de boa governança e bom governo por apor seu foco sobre o estudo da aplicação dos meios à disposição do Estado, caracterizando-a, segundo a autora, como uma vinculação típica ao poder discricionário. ${ }^{101}$

De igual importância, no conceito de Rhita Bousta, é o elemento "equilíbrio" pois, por meio deste, se afirma que a boa administração designa o equilíbrio ótimo entre os interesses dos cidadãos e os interesses da Administração. Interessante também é destacar a visão da autora sobre a instrumentalidade das formas na atuação administrativa, designando de "bom formalismo" a consecução do procedimento administrativo não contencioso livre de formalismos excessivos. ${ }^{102}$

Elegeu-se tal conceito por se mostrar como um dos mais restritos, uma vez que a expressão "boa administração", naturalmente polissêmica, é interpretada das mais diversas maneiras pela literatura. Para alguns autores, seria justamente essa característica a emprestar maior força à figura, que permitiria em si serem considerados diversos aspectos, conforme assim demande o caso concreto. ${ }^{103}$

\footnotetext{
${ }^{101}$ BOUSTA, Rhita. Essai sur la notion de bonne administration en droit public. Paris: L'Harmattan, 2010. P. 461-469. Tradução nossa.

No original: "[...] la notion de bonne administration signifie l'adaptation équilibrée des moyens dont dispose l'administration. Par contraste avec la 'bonne gouvernance' ou au 'bon gouvernement', cette notion désigne exclusivement le bon usage de ses moyens."

102 BOUSTA, Rhita. Essai sur la notion de bonne administration en droit public. Paris: L'Harmattan, 2010. P. 461-469.

${ }^{103}$ KUUSIKKO, Kirsi. Advice, good administration and legitimate expectations: some comparative aspects. European Public Law, Hull, v. 7, n. 3, p. 455-472, 2001.
} 
Apesar de já contemplado pela doutrina administrativista de alguns países, como a Itália, o direito fundamental à boa administração pública ganhou os primeiros contornos de positivação constitucional na Carta de Direitos Fundamentais da União Europeia, tida como "inovadora, talvez até revolucionária" nesse sentido. ${ }^{104}$

Assim dispõe a Carta de Direitos Fundamentais da União Europeia de 2000 acerca desse direito:

Artigo $41^{\circ}$
Direito a uma boa administração

1. Todas as pessoas têm direito a que os seus assuntos sejam tratados pelas instituições e órgãos da União de forma imparcial, equitativa e num prazo razoável.

2. Este direito compreende, nomeadamente:

- o direito de qualquer pessoa a ser ouvida antes de a seu respeito ser tomada qualquer medida individual que a afecte desfavoravelmente,

- o direito de qualquer pessoa a ter acesso aos processos que se Ihe refiram, no respeito dos legítimos interesses da confidencialidade e do segredo profissional e comercial,

- a obrigação, por parte da administração, de fundamentar as suas decisões.

3. Todas as pessoas têm direito à reparação, por parte da Comunidade, dos danos causados pelas suas instituições ou pelos seus agentes no exercício das respectivas funções, de acordo com os princípios gerais comuns às legislações dos Estados-Membros.

4. Todas as pessoas têm a possibilidade de se dirigir às instituições da União numa das línguas oficiais dos Tratados, devendo obter uma resposta na mesma língua.

O pioneirismo da Carta de Direitos Fundamentais da União Europeia na garantia do direito à boa administração é destacado por Mario Chiti, de cujo pensamento extrai-se a perspicaz construção conceitual da Carta como uma "constituição sem Estado". ${ }^{105}$ É dizer, a Carta Europeia constitui, de fato, um "ato

104 WAKEFIELD, Jill. The Right to Good Administration. Amsterdam: Kluwer Law, 2007. P. 63. Tradução nossa.

Nas palavras da autora, o pioneirismo da Carta é "novel, perhaps revolutionary, as this is the first time that any legal system has proclaimed it and then sought to constitutionalise it".

${ }^{105} \mathrm{Na}$ expressão original, "costituzione senza Stato". (CHITI, Mario P. La carta europea dei diritti fondamentali: Una carta di carattere funzionale? Rivista Trimestrale di Diritto Pubblico, Roma, a. 52, n. 1 , p. $1-26,1^{\circ}$ trim. 2002 ). 
constitucional" mas, dissociada da estrutura própria de um Estado específico, não se cerca da soberania própria das Constituições dos Estados. Na falta de uma categoria específica, Chiti classifica tal cenário como "um ordenamento jurídico de novo gênero". 106

Tais características levam a um cenário singular acerca da efetividade das disposições da Carta - o que se reflete, evidentemente, sobre a própria efetividade do direito à boa administração -, uma vez que a obtenção de seu "efeito útil" depende, essencialmente, da adesão dos operadores do direito e dos agentes públicos dos países da União Europeia. A força jurídica de tais disposições ainda carece de uma definição, portanto. ${ }^{107}$

É de se ressaltar que a busca pela boa administração pública se trata, de fato, de um direito fundamental - ao menos no cenário positivo da União Europeia -, uma vez que ultrapassa o plano axiológico de representação de valor e, no plano deontológico, exerce força normativa mais incisiva do que a de um princípio, uma vez que, como ilustra o pensamento de Cintia Morgado, sua densidade implica em uma "forte nota procedimental e organizatória" a condicionar a atuação da Administração Pública em seus misteres. ${ }^{108}$

Voltando à discussão do conteúdo do direito fundamental à boa administração pública, tomando como referencial as disposições do art. 41 da Carta de Direitos Fundamentais da União Europeia, pode-se apurar que ele encerra diversos aspectos principiológicos tratados separadamente pelo direito administrativo brasileiro. Nesse sentido, o parágrafo $1^{\circ}$ trata dos princípios da imparcialidade, da equidade e da duração razoável do processo; o parágrafo $2^{\circ}$ abrange os princípios do contraditório, ampla defesa, dever de fundamentação e

\footnotetext{
${ }^{106} \mathrm{CHITI}$, Mario P. La carta europea dei diritti fondamentali: Una carta di carattere funzionale? Rivista Trimestrale di Diritto Pubblico, Roma, a. 52, n. 1, p. 1-26, $1^{\circ}$ trim. 2002.

${ }^{107}$ Continua Mario Chiti: "Con un giudizio di favore per questa circonstanza si è detto che la Carta dei diritti fondamentali rappresenterà comunque una bussola di riferimento per la giurisprudenza comunitaria, nella prospettiva - simile a quella tipica degli Stati a costituzione rigida e controllo di costituzionalità affidato a Corti costituzionali - di una funzione giurisdizionale condizionata da principi di valenza costituzionale" (CHITI, Mario P. La carta europea dei diritti fondamentali: Una carta di carattere funzionale? Rivista Trimestrale di Diritto Pubblico, Roma, a. 52, n. 1, p. 1-26, $1^{\circ}$ trim. 2002). 108 MORGADO, Cíntia. Direito à boa administração: Recíproca dependência entre direitos fundamentais, organização e procedimento. Revista de Direito da Procuradoria Geral, Rio de Janeiro, n. 65, p. 68-94, 2010.
} 
transparência; o parágrafo $3^{\circ}$ constitui a responsabilidade civil do Estado e, finalmente, o parágrafo $4^{\circ}$ trata de uma característica muito peculiar à União Europeia, relacionada à multiplicidade de idiomas que aquelas instâncias adotam como oficiais.

Diante de tal multiplicidade, Sabino Cassese entende que o direito à boa Administração Pública se insere, no cenário italiano, como um dos elementos do princípio de bom andamento da Administração, juntamente dos princípios de economicidade e eficácia (elementos da eficiência) e do princípio da boa gestão financeira previstos no ordenamento da União Europeia. ${ }^{109}$

Já Celso Antônio Bandeira de Mello entende que, no cenário brasileiro, o princípio da eficiência, contemplado pelo art. 37 da Constituição Federal, seria uma das faces do princípio da boa administração. ${ }^{110}$

Independentemente dos extensos debates acerca da sua importação para o cenário brasileiro - tema que foge ao escopo desse trabalho -, pode-se sustentar que, mais do que um dever, a noção de boa administração constitui um modelo de funcionamento administrativo, um modelo de normalidade. Nesse sentido, Bousta entende que a objetividade da noção de boa administração dificulta a sua conversão em um direito subjetivo ou, ainda mais, em um direito fundamental. ${ }^{111}$ Apesar disso, a noção de boa administração viria a enriquecer o

109 CASSESE, Sabino. Corso di Diritto Amministrativo: Istituzioni di Diritto Amministrativo. V. I. Milano: Giuffrè, 2004. P. 11-12.

Umberto Allegretti, por sua vez, delineia um paralelo entre o princípio de bom andamento da Administração Pública e a prevalência do interesse público, em posicionamento abordado adiante no capítulo que se dedica aos desafios conceituais à adoção da transação pela Administração Pública (ALLEGRETTI, Umberto. Amministrazione pubblica e costituzione. Milão: Cedam, 1996. P. 79-99).

${ }^{110}$ MELLO, Celso Antônio Bandeira de. Curso de direito administrativo. São Paulo: Malheiros, 2014. P. 104.

${ }^{111}$ Assim a autora se posiciona por entender que, em essência, a noção de boa administração não constituiria o antônimo de má administração; nesse sentido, o descumprimento desse parâmetro não constituiria, necessariamente, a "faute de service" necessária a caracterizar a responsabilidade do Estado no direito administrativo francês (BOUSTA, Rhita. Essai sur la notion de bonne administration en droit public. Paris: L'Harmattan, 2010. P. 461-469). 
controle de legalidade da atuação administrativa, em especial no tocante ao procedimento cabível e aos motivos do ato praticado. ${ }^{112}$

Esses elementos se mostram de grande importância para a apreciação do modo pelo qual a Administração Pública seria não só autorizada, mas acima de tudo obrigada à adoção de medidas consensuais de solução de conflitos - em especial, a transação extrajudicial - sempre que isso se mostre possível e viável. Essa postura seria essencial para que se qualifique uma administração como "boa" e, portanto, havendo o dever de boa administração, haveria também o dever de recursos às soluções consensuais de conflitos. Essa breve exposição se torna instrumental, portanto, para os desenvolvimentos levados a cabo na segunda parte do texto, no tocante ao enfrentamento dos desafios à adoção da transação extrajudicial pela Administração Pública.

\subsection{A fuga para o direito privado}

A autonomia do direito administrativo, construída ao longo de sua história, justificou-se em grande parte pela alegada necessidade de edificação de um regime jurídico próprio que, por meio de prerrogativas e sujeições, contivesse a Administração Pública pelo uso instrumental de figuras jurídicas próprias.

As transformações por que tem passado o direito administrativo, no entanto, envolvem a tendência contemporânea de recurso, pela Administração Pública, a instrumentos de atuação próprios do regime privatístico, no que se convencionou chamar de "fuga para o direito privado", na consagrada expressão de Maria João Estorninho. ${ }^{113}$

O posicionamento da literatura se divide em torno do tema: enquanto alguns veem um caráter positivo no fenômeno, com a flexibilização das amarras

\footnotetext{
112 BOUSTA, Rhita. Essai sur la notion de bonne administration en droit public. Paris: L'Harmattan, 2010. P. 461-469.

${ }^{113}$ ESTORNINHO, Maria João. Fuga para o Direito privado: Contributo para o estudo da atividade de direito privado da Administração Pública. Coimbra: Almedina, 1999.

De acordo com Gustavo Binenbojm, a expressão teria buscado inspiração na Flucht in das Privatrecht estudada pela doutrina alemã (BINENBOJM, Gustavo. A constitucionalização do direito administrativo no Brasil: um inventário de avanços e retrocessos. Revista Eletrônica sobre a Reforma do Estado, Salvador, n. 13, mar.-mai. 2008).
} 
próprias do direito administrativo em prol de uma atuação mais célere e eficiente da Administração Pública, há os que nisso enxerguem grave risco decorrente do enfraquecimento dos mecanismos de controle consistentes nas mesmas limitações. ${ }^{114} \mathrm{O}$ presente tópico aborda brevemente este complexo fenômeno, que se mostra instrumental para a análise da adoção da transação extrajudicial pela Administração Pública.

Como já tivemos oportunidade de analisar em texto anterior, ${ }^{115}$ a distinção entre o direito administrativo - marcado pela verticalidade e subordinação - e o direito privado - notadamente horizontal e coordenado - vem da apreciação do tipo de relação jurídica regrada por tais ramos do Direito, ${ }^{116}$ e já se fazia presente nos escritos dos glosadores do Corpus Juris Civilis de Justiniano. ${ }^{117}$

No direito moderno, verifica-se que a questão da autonomia do direito administrativo tem suas raízes na França, tendo servido de justificativa jurídica (a suceder a justificativa política) para a existência do contencioso administrativo. Ora, no momento em que se cogita de um regramento autônomo, com aplicação por uma justiça especializada, surgiria a necessidade de fixação de critérios distintivos para a sua incidência. ${ }^{118} \mathrm{~A}$ distinção entre regimes, deste modo, significaria também uma distinção de competências jurisdicionais, um instrumento fundamental, portanto, para o funcionamento de um sistema de jurisdição dualista. ${ }^{119}$

Nesse cenário, a autonomia do direito administrativo foi gradualmente construída pela jurisprudência administrativa, em fins do séc. $X I X{ }^{120} \mathrm{O}$

\footnotetext{
${ }^{114}$ BACELLAR FILHO, Romeu Felipe. Direito administrativo e o novo Código Civil. Belo Horizonte: Forum, 2007. P. 106.

115 GREGO-SANTOS, Bruno. Nivelamento versus igualdade: Aspectos subjetivo e objetivo do posicionamento da Administração Pública em relação ao particular. In: DI PIETRO, Maria Sylvia Zanella (org.). Direito privado administrativo. São Paulo: Atlas, 2013. P. 122-147.

${ }^{116}$ DI PIETRO, Maria Sylvia Zanella. Do Direito privado na Administração Pública. São Paulo: Atlas, 1989. P. 93.

117 MERRYMAN, John Henry; PÉREZ-PERDOMO, Rogelio. The Civil Law tradition: An introduction to the legal systems of Europe and Latin America. Stanford: Stanford University Press, 2007. P. 92.

${ }^{118}$ ESTORNINHO, Maria João. Fuga para o Direito privado: Contributo para o estudo da atividade de direito privado da Administração Pública. Coimbra: Almedina, 1999. P. 333.

119 EISENMANN, Charles. Cours de droit administratif: Année 1952-1953 (Editado por S. Rials). Paris: LGDJ, 1982. P. 564.

${ }^{120}$ ESTORNINHO, Maria João. Fuga para o Direito privado: Contributo para o estudo da atividade de direito privado da Administração Pública. Coimbra: Almedina, 1999. P. 335.
} 
delineamento histórico da interface entre o direito administrativo e o direito privado se estende, assim, desde as próprias origens do direito do Estado, como exposto mui claramente por Marco D'Alberti em artigo especialmente dedicado ao tema. Naquele texto, o autor sustenta que o problema das relações entre o direito administrativo e o direito privado - e, em particular, a questão da aplicabilidade do direito privado à Administração Pública - tem ocupado as normas, a jurisprudência e a doutrina desde a segunda metade do séc. XIX. Para D'Alberti, a primeira tendência, sobretudo no direito francês, foi a separação entre os dois campos: o direito administrativo era tido como o regime especial publicístico, autônomo em relação ao Código Civil e ao regime privado. Um marco dessa separação seria, justamente, o icônico caso Blanco, no qual instituiu-se a particularidade publicística inclusive para um caso de responsabilidade civil do Estado. ${ }^{121}$

Nesse sentido, sustentam alguns autores que o direito administrativo teria nascido dependente do direito civil, como um conjunto de normas excepcionais que a este derrogavam. ${ }^{122}$ Observe-se, no entanto, que a autonomia do direito administrativo não implica em diferenciação absoluta em relação ao direito privado - trata-se de autonomia, não de isolamento. Não se deve, além disso, conceber o direito administrativo como derivado ou dependente do direito privado. Da lição de Cretella Júnior:

A verdade é que o Direito Civil, importante e tradicional ramo da ciência jurídica, não é nem raiz, nem tronco principal da árvore jurídica, mas um dos ramos em que o tronco-matriz se biparte; é o cadinho comum, em que se misturam os ingredientes jurídicos, a principiar pela nomenclatura; é o ramo que despontou em primeiro lugar, que cresceu mais depressa e que se projetou no tempo. Nunca, entretanto, o tronco-mestre, do qual se foram desgalhando os outros ramos.

A irradiação é sucessiva, convenhamos. Não sendo concomitante, deu a impressão de que uns ramos emergiram de outros, gerando a ideia de que o Direito Civil é o centro propulsor da própria ciência do Direito. Cabe ao cultor do Direito Público reformular a

\footnotetext{
121 D'ALBERTI, Marco. Diritto amministrativo e diritto privato: nuove emersioni di una questione antica. Rivista Trimestrale di Diritto Pubblico, Roma, a. 68, n. 4, p. 1.019-1.028, out-dez. 2012.

${ }^{122}$ ESTORNINHO, Maria João. Fuga para o Direito privado: Contributo para o estudo da atividade de direito privado da Administração Pública. Coimbra: Almedina, 1999. P. 334.
} 
experiência jurídica à luz de princípios próprios e não à luz do Direito Privado. ${ }^{123}$

No pensamento histórico de Mario Chiti, sob a perspectiva jurídica, o séc. XX pode ser definido como o século do direito administrativo. Esse período assistiu uma profusão dentre os estados de um direito particular à Administração Pública, instrumental à realização de políticas públicas e à regulação das relações entre as esferas pública e privada - diferentemente do século anterior, caracterizado pelo liberalismo político e econômico - com a prevalência do interesse público e a busca de um Estado de bem estar. ${ }^{124}$

Do mesmo modo, Chiti sustenta que, entre as ciências jurídicas, o direito administrativo foi, naquele século, o ramo mais essencial, com contribuições teóricas tão originais quanto sistemáticas, que acabam por servir de exemplo a outras disciplinas. Para Chiti, este cenário não se replica tão somente nos países de tradição europeia continental, mas se espraia consideravelmente nos sistemas da common law e no cenário transnacional - marcado, nesse último caso, pelo questionamento sobre a necessidade da relação Estado-direito administrativo. ${ }^{125}$

No entanto, apesar de tamanho favor histórico - tido por Chiti como seu "apogeu" -, o direito administrativo passa por dificuldades e parece, aos olhos do autor, não poder resistir na posição de ramo hegemônico do Direito, por razões ora sistêmicas, ora particulares à disciplina. As razões sistêmicas residem na crescente tendência de limitação do âmbito e das formas de intervenção administrativa, revertendo a tendência precedente; já as razões particulares a este ramo da ciência do Direito residem na sua própria retração, com a chamada crise da forma

\footnotetext{
${ }^{123}$ CRETELLA JUNIOR, José. Dos contratos administrativos. Rio de Janeiro: Forense 1997. P. 39.

${ }^{124}$ CHITI, Mario P. Monismo o dualismo in diritto amministrativo: vero o falso dilema? Rivista Trimestrale di Diritto Pubblico, Roma, a. 50, n. 2, p. 301-320, $2^{\circ}$ trim. 2000.

${ }^{125}$ CHITI, Mario P. Monismo o dualismo in diritto amministrativo: vero o falso dilema? Rivista Trimestrale di Diritto Pubblico, Roma, a. 50, n. 2, p. 301-320, $2^{\circ}$ trim. 2000.

Cabe aqui apresentar a particular ressalva de que o autor destaca-se pela sua investigação em torno do chamado "direito administrativo europeu" e, assim, sua visão se apresenta claramente inclinada a conferir uma grande importância ao ordenamento jurídico supranacional representado pelas instâncias administrativas da união Europeia (V. CHITI, Mario P. Diritto amministrativo europeo. Milano: Giuffrè, 1999).
} 
autoritária de atuação, as novas configurações do serviço público, os fenômenos da privatização e da fuga para o direito privado. ${ }^{126}$

Ao longo do séc. $X X$ até os dias atuais, observou-se a transição deste descolamento acentuado para uma gradual aproximação entre 0 direito administrativo e o direito privado, marcada por oscilações, questionamentos e contratendências. O cenário da virada do séc. XXI foi caracterizado por uma aplicação ampla de institutos do direito privado pela Administração Pública em seus principais campos de atuação - no cenário italiano, organização administrativa, funcionalismo público, bens públicos, obrigações e contratos da Administração, responsabilidade dos funcionários e da estrutura administrativa e processo administrativo. ${ }^{127}$ É nesse cenário que se caracteriza o fenômeno da "fuga para o direito privado".

Como destaca Romeu Felipe Bacellar Filho, enquanto no passado absolutista o regime público tinha conotação negativa, por representar excesso de discricionariedade atinente a gerar desrespeito às garantias individuais, hoje sua presença é positiva, representando a possibilidade de controle da Administração enquanto o regime privado seria válvula de escape a essas sujeições. ${ }^{128}$ Não se pode dizer, no entanto, que uma "fuga para o direito privado" seja um aspecto negativo da contemporaneidade da atuação estatal; a utilização de instrumentos de direito privado vem, justamente, viabilizar a atuação da Administração Pública, que se vê cada vez mais e mais compelida a atuar em áreas que não integram as concepções originais de governo, serviços públicos etc.

Marco D'Alberti destaca três consequências advindas dessa transição: a perda de protagonismo do ato administrativo, com sua substituição por instrumentos privatísticos, contratuais ou consensuais; a importação ao direito

\footnotetext{
${ }^{126}$ CHITI, Mario P. Monismo o dualismo in diritto amministrativo: vero o falso dilema? Rivista Trimestrale di Diritto Pubblico, Roma, a. 50, n. 2, p. 301-320, $2^{\circ}$ trim. 2000.

${ }^{127}$ D'ALBERTI, Marco. Diritto amministrativo e diritto privato: nuove emersioni di una questione antica. Rivista Trimestrale di Diritto Pubblico, Roma, a. 68, n. 4, p. 1.019-1.028, out.-dez. 2012.
}

No mesmo sentido:

CERULLI IRELLI, Vincenzo. Amministrazione pubblica e diritto privato. Torino: Giappichelli, 2011.

${ }^{128}$ BACELLAR FILHO, Romeu Felipe. Direito administrativo e o novo Código Civil. Belo Horizonte: Forum, 2007. P. 106. 
administrativo de princípios com origem civilística; e a ressignificação da atuação e da competência do contencioso administrativo, nos sistemas em que esteja presente. $^{129}$

No cenário estrutural da Administração Pública brasileira, essas consequências são bem sintetizadas por Gustavo Binenbojm:

Se o regime administrativo se caracteriza por uma combinação de prerrogativas e restrições, a fuga para o direito privado permite que as administrações centrais (ou diretas) conservem suas prerrogativas, despindo-se das restrições por meio da constituição de entidades administrativas com personalidade de direito privado. [...]

Assiste-se, assim, à emergência de filhotes híbridos da vetusta dicotomia entre a gestão pública e a gestão privada: a atividade de gestão pública privatizada (regime administrativo flexibilizado) e a atividade de gestão privada publicizada ou administrativizada (regime privado altamente regulado). Essa hibridez de regimes jurídicos, caracterizada pela interpenetração entre as esferas pública e privada, representa um dos elementos da crise de identidade do direito administrativo. ${ }^{130}$

Já sob o ponto de vista dos instrumentos contratuais privados, internacionalmente registram-se duas teorias em torno da sua utilização pela Administração Pública, o que toca especialmente à análise do instituto objeto da presente tese. A teoria do ato destacável, de origens francesas, sustenta que a utilização de um instrumento privado se divide em duas partes: um ato administrativo que decide pela sua adoção, e um ato privado que consubstancia a sua adoção; o primeiro reger-se-ia pelo direito administrativo, e o segundo pelo direito privado. ${ }^{131}$ Já a teoria do direito administrativo privado, de base alemã, identifica como autônoma a adoção de instrumentos privados pela Administração,

129 D'ALBERTI, Marco. Diritto amministrativo e diritto privato: nuove emersioni di una questione antica. Rivista Trimestrale di Diritto Pubblico, Roma, a. 68, n. 4, p. 1.019-1.028, out.-dez. 2012.

${ }^{130}$ BINENBOJM, Gustavo. A constitucionalização do direito administrativo no Brasil: um inventário de avanços e retrocessos. Revista Eletrônica sobre a Reforma do Estado, Salvador, n. 13, mar.mai. 2008.

${ }^{131}$ BELLANGER, François. La légalité lorsque l'Etat agit par des moyens de Droit Privé. In: MORAND, Charles-Albert. La légalité: Un principe à géométrie variable. Genève: Helbing \& Lichtenhahn, 1992. P. 67-90.

Nesse sentido:

LAUBADĖRE, André de; MODERNE, Franck; DELVOLVÉ, Pierre. Traité des contrats administratifs. Paris: LGDJ, 1983.

RIVERO, Jean. Droit administratif. Paris: Dalloz, 1987. P. 291. 
em uma situação regida pelo direito privado, com as derrogações aplicáveis do direito administrativo, em especial de fundo constitucional. ${ }^{132}$

Analisando o posicionamento jurídico da Administração ao lançar mão de figuras contratuais tipicamente privadas, François Bellanger conclui que a incorporação de instrumentos de direito privado, utilizados como meios de ação do Estado, ao quadro geral do direito público, permite a garantia excepcional do respeito ao princípio da legalidade. Com efeito, a decisão por esta incorporação impõe, do ponto de vista da validade material, exigências análogas às de uma decisão ou de um contrato de direito privado. Assim, a vinculação à legalidade, própria do direito administrativo, viria sobremaneira dos princípios constitucionais regentes da atividade administrativa. ${ }^{133}$

De mais a mais, o que apreendemos dessa evolução histórico-conceitual é que o direito administrativo, seja qual for o seu critério de adoção, acaba por ser permeado de normas de direito privado - circunstância que se torna regra ao analisarmos os contratos de direito privado celebrados pela Administração Pública. Podemos concluir, portanto, que a adoção de instrumentos privados especialmente contratuais - pela Administração Pública é movimento que faz parte do inexorável progresso da história, o que contribui para a construção do cenário no qual a adoção da transação extrajudicial pelos entes estatais exsurge como adequada e, até, obrigatória, sempre que possível e viável.

\subsection{0 novo marco relacional entre Estado e sociedade civil e a missão institucional do Estado}

O estudo da adoção de métodos consensuais de solução de conflitos pela Administração Pública não pode se concentrar tão somente sobre a relação

\footnotetext{
${ }^{132}$ BELLANGER, François. La légalité lorsque l'Etat agit par des moyens de Droit Privé. In: MORAND, Charles-Albert. La légalité: Un principe à géométrie variable. Genève: Helbing \& Lichtenhahn, 1992. P. 67-90.

Nesse sentido:

EICHENBERGER, Kurt. Verwaltungsprivatrecht. Festgabe sum Schweizerischen Juristentag, Basel, p. 79 ss., 1985.

${ }^{133}$ BELLANGER, François. La légalité lorsque l'Etat agit par des moyens de Droit Privé. In: MORAND, Charles-Albert. La légalité: Un principe à géométrie variable. Genève: Helbing \& Lichtenhahn, 1992. P. 67-90.
} 
pormenorizada entre Estado e cidadão na lide a ser solucionada, sob pena de se tornar empreendimento fracassado. $E$ isso aqui se sustenta pelo fato de que, como a investigação empreendida ao longo da segunda parte desse estudo faz transparecer, a efetividade na adoção da transação extrajudicial pela Administração Pública, de forma sistemática e consistente, não depende somente da análise caso a caso para a sua aplicação. Mostra-se de premente necessidade a transformação da postura administrativa como um todo, criando-se uma nova cultura relacional na Administração que inclua, entre outros elementos, a receptividade às soluções consensuais de conflitos.

Por esses motivos é que se nos mostra de essencial necessidade uma breve ilação acerca das novas conformações das fronteiras entre público e privado, trazendo a lume posicionamentos contemporâneos que, orientando os debates em torno das soluções consensuais de conflitos na Administração, permitirão ao estudo conformar um cenário mais adequado à perenidade do modelo proposto.

O debate em torno da dicotomia entre espaço público e espaço privado apresenta-se como a evolução das discussões entre direito público e direito privado, o que denota a necessária interdisciplinaridade para compreensão deste campo. ${ }^{134}$ Isso decorre principalmente da complexidade destas inter-relações e das fronteiras cada vez mais fluídas entre o público e o privado, ${ }^{135}$ o que nos leva além dos conceitos clássicos de Estado e sociedade civil no sentido da edificação de um novo panorama da interação entre estes atores. Tem-se, assim, como sustenta Luís Roberto Barroso, um contexto em que o público não mais se confunde com o estatal e o exercício do jogo democrático evoluiu de uma data certa com fixação da vontade majoritária - o processo eleitoral - para uma feição deliberativa, em que a legitimidade do poder depende da participação social: a "esfera pública não estatal". 136

\footnotetext{
${ }^{134}$ BARROSO, Luís Roberto. Curso de direito constitucional contemporâneo. São Paulo: Saraiva, 2009. P. 60.

135 MENDOZA, Xavier; VERNIS, Alfred. EI Estado relacional y la transformación de las administraciones públicas. In: LONGO, Francisco; YSA, Tamyko (eds.). Los escenarios de la gestión pública del siglo XXI. Barcelona: Bellaterra, 2008. P. 39-40.

${ }^{136}$ BARROSO, Luís Roberto. Curso de direito constitucional contemporâneo. São Paulo: Saraiva, 2009. P. 61-62.
} 
Para este estudo uma breve perspectiva histórica ganha importância na medida em que, variando no tempo o entorno social, econômico e político, igualmente varia o papel do Estado, o que condiciona a evolução do modelo organizativo adotado por ele. ${ }^{137}$ Historicamente, o espaço público, como instância de substanciação da missão estatal pela via coletiva, tem passado por um movimento pendular de surgimento, desaparecimento e resgate, desde as origens gregas da democracia, passando pelo Estado absolutista até a sua retração no modelo liberal, ${ }^{138}$ fazendo emergir a sociedade civil no espaço resultante.

No entanto, o intervencionismo do Estado volta a crescer no início do séc. XX, com o surgimento do Estado social, visando à atuação estatal no papel de provedor de bens e serviços públicos. ${ }^{139}$ Neste momento histórico, o conceito de sociedade civil ainda a dissocia totalmente do Estado, que é o detentor da representação do interesse coletivo; dizer Estado é dizer Administração. ${ }^{140}$ Vislumbra-se, portanto, que a crise do Estado social decorre principalmente da sua formação, forjada pela pressão social para a expansão de suas atividades, o que gera endividamento e o aumento da pressão fiscal. A consequência é a insustentabilidade do Estado social diante da nova realidade econômica internacional, levando ao questionamento acerca de sua eficácia social e de sua viabilidade econômica. ${ }^{141}$

De mesmo giro, apresenta-se a crise de legitimidade do governo liberal representativo, frente à frustração popular com partidos políticos e grupos de interesse, com o consequente crescimento de novos movimentos sociais e a

\footnotetext{
137 MENDOZA, Xavier; VERNIS, Alfred. El Estado relacional y la transformación de las administraciones públicas. In: LONGO, Francisco; YSA, Tamyko (eds.). Los escenarios de la gestión pública del siglo XXI. Barcelona: Bellaterra, 2008. P. 40.

${ }^{138}$ BARROSO, Luís Roberto. Curso de direito constitucional contemporâneo. São Paulo: Saraiva, 2009. P. 64.

${ }^{139}$ BARROSO, Luís Roberto. Curso de direito constitucional contemporâneo. São Paulo: Saraiva, 2009. P. 65-66.

140 VILLORIA MENDIETA, Manuel. La modernización de la administración como instrumento al servicio de la democracia. Madrid: Inap, 1996. P. 93-95.

141 MENDOZA, Xavier; VERNIS, Alfred. EI Estado relacional y la transformación de las administraciones públicas. In: LONGO, Francisco; YSA, Tamyko (eds.). Los escenarios de la gestión pública del siglo XXI. Barcelona: Bellaterra, 2008. P. 45-48.
} 
necessidade de um novo paradigma comunicativo para a democracia. ${ }^{142} \mathrm{O}$ relativo rechaço ao Estado social - experimentado de forma desigual entre os diversos países - cria uma lacuna de atuação pública, o que leva ao crescimento da importância da sociedade civil nesta atividade.

Este fenômeno de variação na amplitude da intervenção estatal leva, na concepção de Xavier Mendoza e Alfred Vernis, a uma relação de "gangorra" entre estado e sociedade civil em que, crescendo a participação de um, automaticamente reduz-se a atuação do outro. ${ }^{143}$ Esta relação exclui a interação de qualidade entre os setores, na medida em que adota como pressuposto a separação - talvez até incompatibilidade - da atuação do Estado e da sociedade.

No âmbito da crise do Estado social, surgem correntes que creem na autonomia e auto-organização da sociedade civil, que atuaria independentemente da existência de um agente central; ${ }^{144}$ no entanto, torna-se evidente que a atuação da sociedade civil independentemente da legitimidade envolvida no exercício do poder estatal - pelos motivos mesmos que levaram ao surgimento do Estado social - levaria ao atendimento parcial de interesses, tendo em vista a fragmentariedade da sociedade. Tem-se assim que a sociedade civil, frente à sua multifatorialidade $e$ seu caráter contraditório, estamentário e fragmentado, não pode ser tida como artífice do aprofundamento democrático, ${ }^{145}$ o que reforça o papel fundamental do Estado neste processo.

Ao fim e ao cabo, o impasse da prática democrática constituído pela insuficiência da articulação política e do processo eleitoral para produzir políticas públicas legítimas revela que nem o modelo liberal nem o social servem de pleno

\footnotetext{
142 VILLORIA MENDIETA, Manuel. La modernización de la administración como instrumento al servicio de la democracia. Madrid: Inap, 1996. P. 91.

143 MENDOZA, Xavier; VERNIS, Alfred. El Estado relacional y la transformación de las administraciones públicas. In: LONGO, Francisco; YSA, Tamyko (eds.). Los escenarios de la gestión pública del siglo XXI. Barcelona: Bellaterra, 2008. P. 51.

144 VILLORIA MENDIETA, Manuel. La modernización de la administración como instrumento al servicio de la democracia. Madrid: Inap, 1996. P. 95-96.

145 DAGNINO, Evelina. Sociedade civil, espaços públicos e a construção democrática no Brasil: limites e possibilidades. In: DAGNINO, Evelina (org.). Sociedade civil e espaços públicos no Brasil. São Paulo: Paz e Terra, 2002. P. 279-280.
} 
modelo democrático contemporâneo, ${ }^{146}$ fazendo-se premente o surgimento de um Estado que abandone a atuação burocrática e gerencial em favor do papel de empreendedor social, que atua pelo encontro participativo entre sociedade e estado. ${ }^{147}$ Diante da crise do Estado social, surge nos governos o interesse pela sociedade civil em um novo paradigma relacional, decorrente da busca por legitimação da atuação pública e por parcerias na consecução dos interesses da coletividade. $^{148}$

No entanto, como exsurge da breve contextualização exposta, a simples retração estatal para dar lugar à atuação da iniciativa privada não se apresenta como modelo viável para a participação da sociedade civil em favor do interesse público. Um novo modelo é necessário, um modelo que viabilize a convivência entre os setores, evitando a relação de gangorra de exclusão mútua.

Surge assim uma esfera pública em que o Estado e a sociedade civil debatem assuntos e realizam atividades públicas, ${ }^{149}$ caracterizada pelo aumento quantitativo e qualitativo das colaborações entre a Administração Pública e organizações privadas, num fenômeno tido como "publicização da sociedade" ou "privatização do Estado". O Estado contemporâneo apto a lidar com este cenário é aquele que abandona a onipotência e autossuficiência, reconhecendo que dificilmente substituirá com eficiência a sociedade na defesa do interesse coletivo 146 VILLORIA MENDIETA, Manuel. La modernización de la administración como instrumento al
servicio de la democracia. Madrid: Inap, 1996. P. 92-93.
147 MENDOZA, Xavier; VERNIS, Alfred. EI Estado relacional y la transformación de las
administraciones públicas. In: LONGO, Francisco; YSA, Tamyko (eds.). Los escenarios de la gestión
pública del siglo XXI. Barcelona: Bellaterra, 2008. P. 42-43.

E ainda:

DAGNINO, Evelina. Sociedade civil, espaços públicos e a construção democrática no Brasil: limites e possibilidades. In: DAGNINO, Evelina (org.). Sociedade civil e espaços públicos no Brasil. São Paulo: Paz e Terra, 2002. P. 287.

${ }^{148}$ VILLORIA MENDIETA, Manuel. La modernización de la administración como instrumento al servicio de la democracia. Madrid: Inap, 1996. P. 91.

149 VILLORIA MENDIETA, Manuel. La modernización de la administración como instrumento al servicio de la democracia. Madrid: Inap, 1996. P. 94.

No mesmo sentido:

DAGNINO, Evelina. Sociedade civil, espaços públicos e a construção democrática no Brasil: limites e possibilidades. In: DAGNINO, Evelina (org.). Sociedade civil e espaços públicos no Brasil. São Paulo: Paz e Terra, 2002. P. 279 e ss. 
que só a ela cabe, ${ }^{150}$ como nos exemplos da educação familiar e da conscientização ambiental.

A relação Estado-sociedade é permeada por tensão e conflituosidade, inversamente proporcional à coincidência de objetivos nas suas atuações. Frente às suas peculiaridades, não há equivalência de forças entre estas partes, cabendo ao Estado buscar o encontro tendente à viabilização dos espaços públicos. A obtenção de resultados passa, portanto, pelo alinhamento entre Estado e sociedade, para o qual a postura do agente público é essencial. ${ }^{151}$

Surge, assim, um novo modelo de atuação governamental: o Estado relacional, na dicção de Mendoza e Vernis, tido como aquele que tem como papel a articulação de relações de colaboração e corresponsabilidade entre atores públicos e privados, num processo de fortalecimento institucional e gerencial da Administração Pública. ${ }^{152}$

Surge, assim, um governo que se pauta pela lógica relacional, buscando a máxima sinergia entre os recursos, conhecimento e capacidade dos atores do processo democrático. ${ }^{153}$ Governar, pois, não é mais aplicar recursos; é liderar em busca do consenso.

É esse o cenário que, para Umberto Allegretti, desperta o surgimento de fenômenos como a superação da subjetivação administrativa, a participação procedimental, a busca pela imparcialidade em substituição ao espírito policial e a otimização do controle a da tutela jurisdicional. ${ }^{154}$

150 MENDOZA, Xavier; VERNIS, Alfred. El Estado relacional y la transformación de las administraciones públicas. In: LONGO, Francisco; YSA, Tamyko (eds.). Los escenarios de la gestión pública del siglo XXI. Barcelona: Bellaterra, 2008. P. 50-51.

151 DAGNINO, Evelina. Sociedade civil, espaços públicos e a construção democrática no Brasil: limites e possibilidades. In: DAGNINO, Evelina (org.). Sociedade civil e espaços públicos no Brasil. São Paulo: Paz e Terra, 2002. P. 287.

152 MENDOZA, Xavier; VERNIS, Alfred. El Estado relacional y la transformación de las administraciones públicas. In: LONGO, Francisco; YSA, Tamyko (eds.). Los escenarios de la gestión pública del siglo XXI. Barcelona: Bellaterra, 2008. P. 37.

153 MENDOZA, Xavier; VERNIS, Alfred. El Estado relacional y la transformación de las administraciones públicas. In: LONGO, Francisco; YSA, Tamyko (eds.). Los escenarios de la gestión pública del siglo XXI. Barcelona: Bellaterra, 2008. P. 54.

${ }^{154}$ ALLEGRETTI, Umberto. Amministrazione pubblica e costituzione. Milão: Cedam, 1996. P. 108134. 
Ocorre, no entanto, que a democratização da Administração Pública, apesar de se mostrar como uma tendência concreta, tem sido contraposta em um movimento de distanciamento decorrente da judicialização das relações entre Administração e cidadãos, o que desperta o debate a que se dedica o tópico final do presente capítulo.

\subsection{A judicialização das relações administração-particulares e o distanciamento dela decorrente}

O estudo das tendências evolutivas da Administração Pública - e do direito administrativo, por consequência ${ }^{155}$ - empreendido nesse capítulo revela um caminho de progressão, de melhora substancial do Estado. Ressalvadas algumas posições contrárias - como se observa, por exemplo, em relação à utilização de instrumentos de direito privado -, o cenário delineado se reveste de um aumento qualitativo do valor da atuação estatal.

No entanto, ao analisarmos o panorama que envolve o tema adotado para a presente tese, consistente na busca por meios consensuais de conflitos que envolvam a Administração Pública, percebe-se que essas notas evolutivas são opostas por uma contratendência que em muito prejudica a melhora da Administração Pública e a realização dos direitos fundamentais.

É que, em paralelo a todos os câmbios que constituem esses novos paradigmas do direito administrativo, o Estado brasileiro vem adotando, já há muito, uma postura desnecessariamente combativa, que tem por consequência a grande judicialização das relações entre a Administração e os particulares. Essa judicialização tem por consequência o distanciamento entre o Estado e a sociedade

\footnotetext{
${ }^{155}$ Como afirma Sabino Cassese: "[...] è difficile distinguere il diritto amministrativo dal suo oggetto (la pubblica amministrazione) e dal modo in cui esso viene studiato (la scienza del diritto amministrativo). Tra questi elementi diversi vi sono molte relazioni reciproche. L'assetto della pubblica amministrazione influenza il diritto che la riguarda: se quella è policentrica o frammentata, il diritto avrà caratteristiche meno uniformi o unitarie. D'altro lato, le norme sono conosciute attraverso l'interpretazione, a mezzo di un ragionamento logico, e la scienza - come è stato spesso osservato - riutilizza sempre una parte delle acquisizioni anteriori della stessa scienza giuridica, per cui nozioni tradizionali, elaborate dalla scienza, come quelle di ente pubblico o di concessione, fungono da selettori e da criteri ordinatori del mariale giuridico nuovo sul quale operano i giuristi" (CASSESE, Sabino. Le trasformazioni del diritto amministrativo dal XI al XXI secolo. Rivista Trimestrale di Diritto Pubblico, Roma, a. 52, n. 1, p. 27-40, $1^{\circ}$ trim. 2002).
} 
e, justamente por isso, representa grave retrocesso em relação aos ganhos evolutivos demonstrados.

Assim, com vistas à melhor apreciação desse cenário, o tópico derradeiro do presente capítulo inicia por delinear, brevemente, o paradigma democrático substancial que deve marcar a gestão do Estado na contemporaneidade. De posse desse referencial, o texto passa a demonstrar em que medida a judicialização das relações entre a Administração e os particulares acaba por implicar no distanciamento, o que abre caminho para os debates acerca da busca de uma reaproximação democrática pela adoção de métodos consensuais de solução de conflitos, objeto do capítulo seguinte.

Um primeiro passo para apurar a democraticidade da postura do gestor público passa pela definição de qual conteúdo seria hábil a definí-la como democrática. Só podemos intentar tal tarefa partindo do entendimento de o que seria democracia - ao menos, o que seria democracia no sentido adequado para a análise proposta. Neste particular, utilíssima se faz a lição de Canotilho, para quem o elemento democrático, além de servir de limite ao poder, também constitui sua justificativa de legitimidade. Para o autor, a soberania popular seria o elemento de ligação entre o Estado de direito e o Estado democrático, "possibilitando a compreensão da moderna fórmula Estado de direito democrático". ${ }^{156}$

O Estado guarnecido destas qualidades é, assim, o Estado Constitucional, que ao mesmo tempo garante a liberdade negativa - Estado de Direito, em que a Lei domestica o domínio público - e a liberdade positiva - Estado democrático, em que o conteúdo da atuação administrativa alinha-se com o interesse social, de onde emana o poder, tornando-se assim legítimo. ${ }^{157}$ A opção constitucional pela democracia impende à obrigação de legitimação material nas

\footnotetext{
${ }^{156}$ CANOTILHO, J. J. Gomes. Direito constitucional e teoria da constituição. Coimbra: Almedina, 2003. P. 100.

157 SCHMIDT-ASSMANN, Eberhard. La teoría general del derecho administrativo como sistema. Madrid: INAP, 2003. P.100-101/110.

E também:
}

MOREIRA NETO, Diogo de Figueiredo. O direito administrativo do século XXI: um instrumento de realização da democracia substantiva. A\&C Revista de Direito Administrativo \& Constitucional, Belo Horizonte, a. 11, n. 45, p. 13-37, jul./set. 2011. 
decisões estatais com vistas à atenção à vontade popular, no entender de SchmidtAssmann. Justifica o autor:

Essa decisão tem como objetivo a organização de uma "ordem orientada ao bem comum através de decisões livres da comunidade sobre si mesma". Desde o princípio estão, pois, postos em jogo, mais do que fenômenos isolados, contextos e estruturas de atuação. $^{158}$

Com vistas à concretização desta legitimidade, a democracia representativa - pelo voto - é insuficiente para a responsividade da ação administrativa, a partir do momento em que os representantes deixam de atender à vontade dos representados. Ora, se a legitimidade material exige a responsividade, só se atinge a democracia substantiva com o conteúdo responsivo da atuação estatal, o que solicita uma solução comunicativa de proximidade.

Não basta, portanto, a casca frágil da legitimidade formal: só se atinge a democracia quando o conteúdo da decisão estatal é responsivo, pois se exige atingir o melhor resultado possível para o bem comum. ${ }^{159}$ Assim, só podemos concluir pela democraticidade da atuação estatal quando o seu conteúdo guardar estreita relação com os anseios populares, cenário no qual a proximidade relacional entre o Estado e a sociedade assume papel de centralidade. À evidência, na medida em que se pretende responder ao interesse social, faz-se necessário ouvir à sua vocalização. ${ }^{160} \mathrm{E}$ para ouvir à mesma é necessário estar-lhe próximo, para

158 SCHMIDT-ASSMANN, Eberhard. La teoría general del derecho administrativo como sistema. Madrid: INAP, 2003. P. 99. Tradução nossa.

No original: "Dicha decisión tiene como objetivo la organización de um 'orden orientado al bien común a través de decisiones libres de la comunidade sobre sí misma'. Desde el principio están, pues, aqui em juego, más que fenómenos aislados, contextos y estructuras de actuación".

159 LONGO, Francisco. Introducción. Los directivos públicos ante los retos de la gobernanza contemporánea. In: LONGO, Francisco; YSA, Tamyko (eds.). Los escenarios de la gestión pública del siglo XXI. Barcelona: Bellaterra, 2008. P. 19.

E ainda:

SMITH, Andy. Governança de múltiplos níveis: o que é e como pode ser estudada. In: PETERS, Guy; PIERRE, Jon (orgs.). Administração pública: coletânea. São Paulo: UNESP; Brasília: ENAP, 2010. P. 620-632.

${ }^{160}$ Sobre a formação deliberativa do interesse social na esfera pública, pela captação dos anseios da periferia pela sociedade civil, indispensável é a lição de Habermas.

Neste particular:

HABERMAS, Jürgen. Direito e Democracia: entre facticidade e validade. V. II. Rio de Janeiro: Tempo Brasileiro, 1997. P. 88. 
que a possa ter palpável, ao alcance. Mostra-se imprescindível, portanto, um movimento de aproximação entre Estado e sociedade.

No importante campo relacional da solução de conflitos, apesar de todas as tendências estudadas, Estado e sociedade civil experimentam um distanciamento cada vez mais grave e profundo. Os entes estatais já se constituem, a longa data, como os maiores litigantes no Judiciário brasileiro, ${ }^{161}$ e diversas posturas adotadas pela Administração Pública nesse campo, a exemplo da inadimplência contumaz dos precatórios, acabaram por criar uma chaga que macula gravemente as relações público-privadas.

Nesse sentido, por muitas vezes o comportamento da Administração Pública em relação aos conflitos de que faz parte se caracteriza de gravíssima máfé. É o exemplo que destaca Alice Gonzalez Borges acerca da prática recorrente de lançar mão o Estado "de todos os privilégios processuais, de todos os recursos judiciais disponíveis, para protelar, ad infinitum, a solução final dos litígios, deixando os compromissos financeiros correspondentes para as próximas gestões dos sucessores". 162

À evidência, esse comportamento da Administração não coaduna com a missão institucional do Estado constitucionalmente definida. Portanto, a judicialização exacerbada das relações entre o Estado e os cidadãos constitui absoluto descumprimento do mecanismo democrático pois, além de ser adotada em desfavor das disposições constitucionais, ocasiona grave descolamento entre a Administração e suas bases de legitimação, o que vem reclamar um mecanismo alternativo para solução do cenário exposto.

A concretização da democracia pela solução consensual dos conflitos tem, assim, como movimento característico, a aproximação entre o público e o privado, o comum e o particular, a civilidade e o civismo. ${ }^{163}$ É nesse sentido que o Comitê de Ministros do Conselho da Europa formulou recomendação aos estados-

\footnotetext{
${ }^{161}$ BRASIL. CONSELHO Nacional de Justiça. Os 100 maiores litigantes. Brasília: CNJ, 2012.

162 BORGES, Alice Gonzalez. Reflexos do Código Civil dos contratos administrativos. Revista Eletrônica de Direito Administrativo Econômico, Salvador, n. 9, fev.-abr. 2007.

${ }^{163}$ HANICOTE, Robert. Devoirs de l'homme et constituitions: contribuition à une théorie générale du devoir. Paris: L'Harmattan, 2007. P. 99.
} 
membros da União Europeia, no sentido de que "[...] a ampla adoção de meios alternativos para solução de disputas públicas pode permitir a resolução desses problemas, trazendo as autoridades públicas para mais perto do público [grifo nosso]". 164

Atinge-se, portanto, ponto nodal da exposição que se leva a cabo na presente tese: as tendências contemporâneas do direito administrativo representam importantes movimentos de evolução da Administração Pública; no entanto, tais tendências são gravemente prejudicadas pela exacerbada judicialização dos conflitos entre Estado e particulares que, além de trazer graves consequências práticas, representa inaceitável descumprimento do paradigma democrático que vincula a Administração Pública brasileira.

Este cenário reclama, portanto, a adoção de métodos consensuais de solução de conflitos pela Administração Pública, não de modo pontual, mas sim sistêmico, numa nova postura relacional, de modo a recuperar essa proximidade e dar efetividade a todos os novos paradigmas expostos como relevantes. A esse desenvolvimento se dedica o próximo capítulo.

\footnotetext{
164 UNIÃO EUROPEIA. CONSELHO da Europa. Recommendation 2001-9 of the Committee of Ministers to member states on alternatives to litigation between administrative authorities and private parties. Estrasburgo: Éditions du Conseil de l'Europe, 2001. Tradução nossa.
}

No original: "[...] that the widespread use of alternative means of resolving administrative disputes can allow these problems to be dealt with and can bring administrative authorities closer to the public". 


\section{SOLUÇÕES CONSENSUAIS DE CONFLITOS NO ÂMBITO ESTATAL}

O capítulo de aproximação ao tema, dedicando-se ao estudo dos novos paradigmas que a contemporaneidade imprime à Administração Pública, traçou um caminho composto por movimentos e tendências que, apesar de não ser linear, permite perceber convergências.

Partindo de um câmbio pós-positivista que evolui da vinculação da Administração Pública à lei para a obediência ao direito, expôs-se a crescente processualização dos mecanismos de tomada de decisão estatal, em um movimento que gradualmente abandona posicionamentos adotados por ato unilateral em favor de soluções construídas dialogicamente com os interessados.

Essa evolução denota uma mudança essencial no entendimento acerca do interesse público, abrangendo especialmente a titularidade e o método para a sua definição. Assim como na passagem do ato para o processo administrativo, a nova visão acerca do interesse público implica no reconhecimento de que a Administração Pública não detém a prerrogativa de - sequer a legitimidade para definir unilateralmente o que seria o interesse público a ser promovido por si, mesmo porque o estado atual da sociedade implica na multiplicidade de interesses aos quais pode ser aposto tal rótulo e aplicada a proteção dele consequente. A boa gestão desses interesses públicos, com vistas à melhor realização possível dos misteres estatais, passa a ser vista como um direito que assiste ao cidadão, fazendo surgir a figura do direito fundamental à boa administração pública.

A realização desse novo interesse público - ou desses novos interesses públicos -, em busca da realização do direito fundamental à boa administração pública, demanda um ferramental que não está plenamente à disposição da Administração Pública pela simples aplicação das figuras tradicionais contempladas pelo direito administrativo. Surge, assim, o recurso às formas tipicamente privadas, especialmente em matéria contratual, que abrem caminho para um relacionamento mais próximo entre entes públicos e particulares. 
Essa aproximação vem cumprir um papel curativo do descolamento ocorrido entre a Administração Pública e as suas bases de legitimação democrática. Um importante elemento dessa reaproximação consiste na busca pelo aprofundamento das relações entre os entes estatais e os cidadãos, abandonando-se os velhos posicionamentos marcados pela oposição público versus privado em favor da postura cooperativa em busca da realização dos interesses públicos legitimamente definidos.

Esse cenário é ameaçado, no entanto, por uma tendência contraditória a todos os elementos evolutivos expostos: o cenário brasileiro é marcado por uma crescente judicialização das relações entre os entes estatais e os cidadãos, ao ponto em que a Administração Pública se caracteriza, hoje, como o maior litigante no judiciário nacional. A situação posta reclama por uma nova postura da Administração Pública voltada à crescente adoção de métodos consensuais de solução de conflitos, dentre os quais se destaca a transação extrajudicial, objeto central do desenvolvimento proposto.

Esse capítulo se dedica, portanto, ao delineamento do cenário em torno da adoção de métodos de solução consensual de conflitos pela Administração Pública. O cumprimento de tal tarefa tem início com uma breve exposição acerca do aprofundamento consensual entre Estado e sociedade civil, marcado por um novo papel da Administração Pública em relação à realização dos misteres estatais constitucionalmente instituídos.

Com base nesse novo referencial, a segunda parte do capítulo cuida das diversas modalidades de solução consensual de conflitos, em um gradual recorte objetivo que parte das soluções consensuais em geral, passando pela transação em direção à abordagem pormenorizada da transação extrajudicial e de seu papel de protagonismo dentre as diversas metodologias estudadas.

Frente a tais fundamentos, o terço final do capítulo se dedica ao estudo da transação extrajudicial que tenha por parte a Administração Pública, com especial enfoque sobre a definição de sua natureza jurídica. Cumprida essa tarefa, conclui-se a primeira parte do plano da obra, dedicado ao delineamento teórico acerca da inserção da transação extrajudicial no direito adminstrativo, abrindo 
caminho para a investigação dos fatores em torno da sua efetiva adoção e fomento, objeto da segunda parte do estudo.

\subsection{Consenso na relação entre Estado e cidadão}

As tendências contemporâneas da gestão pública já bordadas no capítulo anterior denotam um importante câmbio nas relações entre o Estado e os particulares. Por meio da processualização da atuação administrativa, Administração Pública e cidadão passam a se relacionar de forma dialógica, permitindo-se ao particular apresentar contraponto ao posicionamento estatal e formatando-se um caminho mais claro e aberto para a tomada de decisões.

Já em decorrência das novas concepções de interesse público, a Administração deixa o posto de protagonista na definição desse interesse, passando-se de uma visão autocentrada do Estado para um posicionamento voltado à composição de interesses e à realização de direitos fundamentais. Por fim, o direito fundamental à boa Administração Pública confere aos cidadãos a prerrogativa de exigir uma gestão pública de qualidade, titulares que são do poder exercido representativamente pelo Estado.

A exposição desse novo relacionamento entre os cidadãos e o Estado carece, no entanto, de aprofundamento ainda mais apurado, que denote as transformações de caráter geral, e não só pontual, que se imprimem a este cenário. Nesse sentido, Umberto Allegretti destaca que o câmbio no exercício da função pública é decorrência direta de uma mudança estrutural no poder administrativo. Assim, o exercício central e unilateral do poder não perde somente a sua posição de absolutez no exercício da atividade administrativa propriamente dita, uma vez que essa mudança de posição se espraia pelas "operações materiais e serviços, atividades contratuais e outras de direito comum". ${ }^{165}$ Para Allegretti, este giro

\footnotetext{
${ }^{165}$ ALLEGRETTI, Umberto. Amministrazione pubblica e costituzione. Milão: Cedam, 1996. P. 12-15. Tradução nossa.
}

No mesmo sentido:

CERULLI IRELLI, Vincenzo. Corso di diritto amministrativo. Torino: Giappichelli, 2001. P. 3-4. 
estrutural faz cessar a própria unilateralidade no exercício do poder, em especial com as experiências italianas de participação procedimental. ${ }^{166}$

Tratamos, portanto, de um fenômeno de consensualidade geral, que acaba por permear, em maior ou menor medida, todos os campos de atuação da Administração Pública. O fenômeno da consensualidade imprime, assim, uma ampla mudança no modo como Estado e sociedade se relacionam, para além das tendências concentradas que já foram objeto de estudo no capítulo anterior.

A importância da consensualidade na gestão estatal atinge grande intensidade em fins do séc. $X X$, quando são construídos modelos teóricos visando à análise qualitativa de instituições e processos com base na qualidade com que dão voz à diversidade de interesses um certo campo de atuação. ${ }^{167}$ No direito administrativo italiano, Domenico Sorace identifica a existência de um verdadeiro "princípio de consensualidade". Este, na formulação do autor, consistiria na previsão geral de que "as autoridades públicas são permanentemente vinculadas a buscar o consentimento das partes interessadas antes de tomar decisões unilaterais". ${ }^{168}$

Nesse sentido é esclarecedor o pensamento de Pedro Machete, para quem Estado e cidadão são sujeitos a normas jurídicas necessariamente vinculativas a ambos e, por esse motivos, guardam uma relação de direitos e deveres recíprocos. Disso decorre o dever, por parte da Administração, de "privilegiar o diálogo e o consenso em ordem à resolução de eventuais conflitos de

\footnotetext{
${ }^{166}$ ALLEGRETTI, Umberto. Amministrazione pubblica e costituzione. Milão: Cedam, 1996. P. 14.

${ }^{167}$ KOMESAR, Neil K. Imperfect Alternatives: Choosing institutions in Law, Economics and Public Policy. Chicago: University of Chicago Press, 1997.
}

No mesmo sentido:

WAGNER, Wendy E. The Participation-Centered Model meets administrative process. Wisconsin Law Review, Madison, n. 671, p.671-692, 2013.

168 SORACE, Domenico. Diritto delle amministrazioni pubbliche: Una introduzione. Bologna: II Mulino, 2000. P. 302-303. Tradução nossa.

No original: "[...]le pubbliche amministrazioni sono tenute ordinariamente a ricercare il consenso degli interessati prima di prendere decisioni unilaterali". 
interesses entre a Administração e os particulares". Em se tratando de Estado de Direito democrático, este não pode dispor da posição jurídica dos particulares. ${ }^{169}$

Esta relação entre regime jurídico e consensualidade nos mostra que a sujeição do particular em relação ao Estado vai sendo substituída por uma relação de mutualidade. Não de igualdade, uma vez que as características e as vinculações diferem; mas de considerável nivelamento, uma vez que ambos contam com direitos e deveres próprios e necessários ao atual regime constitucional.

Irene Nohara questiona - indevidamente, como será demonstrado adiante - a abrangência da consensualização da Administração Pública, sustentando que, frente à sua impossível ubiquidade, já que supostamente não seria aplicável à tributação, ou ao poder de polícia, não teríamos a caracterização plena da ultrapassagem do ideário unilateral pela consensualidade. ${ }^{170}$ De todo modo, Sabino Cassese destaca que, na experiência italiana, o ordenamento jurídico tem buscado ostensivamente favorecer a substituição da atuação unilateral da Administração Pública por soluções consensuais, como é o caso dos acordos de programa, conferências de serviço, pactos territoriais e acordos procedimentais. $^{171}$

Diante de tal cenário, dois fenômenos se destacam de forma relacionada à consensualidade na Administração Pública: a concertação e a democratização material.

\footnotetext{
${ }^{169}$ MACHETE, Pedro. A subordinação da Administração Pública ao direito e a dogmática do direito administrativo no âmbito do Estado de direito democrático. In: ATHAYDE, Augusto de; CAUPERS, João; GARCIA, Maria da Glória F. P. D. Em homenagem ao Professor Doutor Diogo Freitas do Amaral. Coimbra: Almedina, 2012. P. 192-238.

Continua o autor: "A Administração Pública do Estado de Direito democrático já não pode, assim, ser perspectivada como um poder ou uma instância decisória à qual os particulares se encontram submetidos e a partir de cuja natureza se podem inferir corolários não expressamente previstos nas normas jurídicas aplicáveis a cada caso. Hoje a Administração é um sujeito de direito que, tal como os particulares, e no quadro de relações jurídicas determinadas, exerce os seus direitos e cumpre seus deveres".

${ }^{170}$ NOHARA, Irene Patricia. Reflexões críticas acerca da tentativa de desconstrução do sentido da supremacia do interesse público no direito administrativo. In: DI PIETRO, Maria Sylvia Zanella; RIBEIRO, Carlos Vinicius Alves (coords.). Supremacia do interesse público e outros temas relevantes do Direito administrativo. São Paulo: Atlas, 2010. P. 123.

${ }^{171}$ CASSESE, Sabino. Corso di Diritto Amministrativo: Istituzioni di Diritto Amministrativo. V. I. Milano: Giuffrè, 2004. P. 225-231.
} 
Na Itália, o fenômeno da concertação tem suas origens na experiência de reforma estatal democratizante com raízes nos anos 1950, visando sobretudo ao aprofundamento das relações institucionais entre as instâncias estatais e sociais - consubstanciando, como opina Capotosti, a visão de Carl Schmidt sobre o papel do Estado social. ${ }^{172}$

A concertação vem, assim, substituir a atuação contratual bilateral da Administração por uma configuração triangular do relacionamento do Estado com as instâncias sociais - no exemplo clássico, o desenvolvimento de pactos laborais entre a Administração, os sindicatos e as entidades patronais nos anos 1990 -, com foco na construção de consensos, como expressão do "pluralismo social organizado", na dicção de Edoardo Ghera. ${ }^{173}$

Por meio da concertação, o Poder Público - político ou administrativo, na dicção de Marco D’Alberti - trava diálogo com grupos sociais de naturezas variadas, buscando a melhor solução possível no confronto de interesses. D'Alberti destaca ao menos cinco âmbitos de consecução deste diálogo: a progressiva contratualização do funcionalismo público italiano, a participação dos administrados nos procedimentos administrativos, a participação em procedimentos legislativos, a participação "orgânica" de representantes de grupos sociais em organismos coletivos públicos, e as concertações trilaterais mediadas pelo Estado. ${ }^{174}$

O pacto social italiano pela concertação seria, assim, um pacto de confiança: confiança nos objetivos comunitários; confiança na responsabilidade dos atores sociais, gravada de tarefas frequentemente delicadas; e confiança no governo e no parlamento, chamados a ter em equilíbrio as exigências da concertação e as razões do pluralismo. ${ }^{175}$

\footnotetext{
172 CAPOTOSTI, Piero Alberto. Concertazione e riforma dello Stato sociale nelle democrazie pluraliste. Quaderni Costituzionali, Bologna, a. 11, n. 3, p. 475-490, dez. 1999.

${ }^{173}$ GHERA, Edoardo. La pratica della concertazione in Italia. Quaderni Costituzionali, Bologna, a. 11, n. 3, p. 501-521, dez. 1999.

174 D`ALBERTI, Marco. La concertazione fra Costituzione e amministrazione. Quaderni Costituzionali, Bologna, a. 11, n. 3, p. 491-500, dez. 1999.

175 D`ALBERTI, Marco. La concertazione fra Costituzione e amministrazione. Quaderni Costituzionali, Bologna, a. 11, n. 3, p. 491-500, dez. 1999.
} 
De igual importância se revela o fenômeno da democratização da Administração Pública, já que, como sustenta Umberto Allegretti em uma fórmula simples, porém plena de significado, uma Administração Pública democrática pressupõe um ordenamento jurídico democrático e, em sentido recíproco, um ordenamento jurídico democrático depende de uma Administração Pública democrática. ${ }^{176} \mathrm{~A}$ essência dessa relação circular que, apesar de constante, evolui com o desenvolvimento das práticas administrativas, constitui a transição "do poder à função": as antigas estruturas conceituais que tinham o poder administrativo como a "energia jurídica que explica [...] a atuação e a organização da Administração Pública" são substituídas pela noção de que a administração pública é a "atividade de realização das tarefas estatais, voltada para um fim, que dá a ideia de função". ${ }^{177}$

Diante de tal cenário, principia-se a apreciação dos métodos de solução consensual de conflitos imbuída do entendimento de que não basta, para a sua efetividade, a simples aplicação casuística de cada uma de suas modalidades - em especial, da transação extrajudicial, tida aqui como preferencial. Essa exposição acerca do novo papel de consensualidade do Estado tem a intenção de condicionar a investigação do modelo proposto para que se leve em consideração a postura do gestor público e o câmbio na cultura administrativa, tidos aqui como fatores essenciais para o sucesso das mudanças esperadas.

\subsection{Métodos de solução consensual de conflitos}

O cenário até aqui exposto nos leva a um estágio no qual a adoção de métodos consensuais de solução de conflitos pela Administração Pública se apresenta não como opção, mas sim como um dever atrelado axialmente à realização plena da missão institucional do Estado.

Abre-se caminho, pois, para a apreciação das diversas modalidades de solução consensual de conflitos à disposição das partes no direito brasileiro, buscando dentre eles os elementos que permitam investigar qual seria a mais

\footnotetext{
${ }^{176}$ ALLEGRETTI, Umberto. Amministrazione pubblica e costituzione. Milão: Cedam, 1996. P. 100101.

${ }^{177}$ ALLEGRETTI, Umberto. Amministrazione pubblica e costituzione. Milão: Cedam, 1996. P. 105108. Tradução nossa.
} 
adequada para servir de padrão à atuação estatal. Nesse sentido, revela-se de grande importância o referencial oriundo do direito civil e do direito processual civil. Como Jean Rivero ensina, a busca de contraponto comparativo no direito privado é de grande importância para o estudo do direito administrativo, ${ }^{178}$ circunstância que se mostra ainda mais relevante na análise sobre contratos administrativos e contratos privados da Administração levada a cabo na porção final deste capítulo.

A solução consensual de conflitos na Administração Pública tem sido matéria de crescente interesse das instituições europeias. Além dos diferentes instrumentos normativos acerca do tema - como a Recomendação R(2001)9 do Comitê de Ministros do Conselho da Europa e a Diretiva 2008/52/CE -, a Rede Europeia de Formação Judiciária tem envidado grandes esforços para a consolidação da adoção de métodos extrajudiciais de composição de conflitos pelo Estado. $^{179}$

Esse cenário acaba por refletir no direito administrativo brasileiro, mas não com a mesma intensidade. A cultura administrativa ainda é fortemente refratária à solução consensual de conflitos, e as iniciativas normativas nesse sentido acabam por se mostrar incipientes e parciais.

É certo, pois, que o recurso da Administração Pública aos métodos de solução consensual de conflitos é fruto de um contexto de crise. Para Sabino Cassese, a adoção de soluções extrajudiciais de conflitos pela Administração Pública se destaca pela confluência de dois problemas fundamentais do Estado: a crise da justiça e as limitações do regime jurídico da Administração Pública. ${ }^{180}$

Voltando nosso escopo de análise às pormenoridades dos diversos métodos consensuais de solução de conflitos, verifica-se que a linha central entre eles - arbitragem, conciliação, mediação e transação - seria "[...] a procura

\footnotetext{
${ }^{178}$ RIVERO, Jean. Cours de Droit Administratif comparé. Paris: Dalloz, 2011. P.17-18.

${ }^{179}$ CARVALHO, Ana Celeste. A mediação em matéria administrativa: uma possibilidade com futuro. Cadernos de Justiça Administrativa, Braga, n. 109, p. 3-12, jan./fev. 2015.

Destaque-se a realização pela REFJ, em 8 e 9 out. 2015, do Seminário sobre Meios Alternativos de Resolução de Litígios no Direito Administrativo, em Bautzen, Saxônia, Alemanha.

${ }^{180}$ CASSESE, Sabino. L'arbitrato nel Diritto Amministrativo. Rivista Trimestrale di Diritto Pubblico, Roma, a. 46, n. 2, p. 311-328, $2^{\circ}$ trim. 1996.
} 
voluntária e espontânea, constituindo formas extrajudiciais, que ocorrem fora do meio judicial e que acrescem aos meios tradicionais, junto dos tribunais estaduais". ${ }^{181}$ Esse papel de alternatividade das soluções consensuais em relação ao recurso ao judiciário é que leva Carnelutti a forjar sua clássica concepção de "equivalentes processuais" para os métodos consensuais. ${ }^{182}$

Cabe aqui apresentar uma ressalva terminológica: nosso posicionamento é no sentido de designar tais métodos como consensuais, e não alternativos. Isso porque os métodos consensuais aqui investigados não são vistos como uma alternativa secundária à solução judicial, que seria hipoteticamente preferencial. Pelo contrário, o trabalho posiciona-se no sentido de que os métodos consensuais de solução de conflitos devem ser a primeira opção a ser considerada para a composição do litígio, recorrendo-se à intervenção judicial tão somente na absoluta impossibilidade de solução consensual.

Há aqueles que não considerem a arbitragem como solução consensual de conflitos, por ser heterocompositiva, o que a distancia das demais figuras mediação, conciliação e transação -, que são autocompositivas. Isso não faz da arbitragem, no entanto, método não consensual de solução de conflitos; a consensualidade da arbitragem reside na convenção para a sua instituição, e não no controle das partes sobre o resultado do procedimento.

A exposição adota, assim, uma escala crescente de autonomia das partes na composição do litígio. Parte-se da arbitragem, método consensual heterocompositivo, para posteriormente analisar-se brevemente a conciliação e a mediação, métodos que, apesar de autocompositivos, dependem da intervenção de terceiro para que a solução seja alcançada. Essas três primeiras modalidades são apreciadas sem pretensões exaustivas, com o intuito de formação de um referencial comparativo para a análise das figuras transativas.

Por fim, o tópico se dedica mais detidamente ao estudo da transação, tida como método autocompositivo por excelência por prescindir de terceiro

\footnotetext{
${ }^{181}$ CARVALHO, Ana Celeste. A mediação em matéria administrativa: uma possibilidade com futuro. Cadernos de Justiça Administrativa, Braga, n. 109, p. 3-12, jan./fev. 2015.

${ }^{182}$ CARNELUTTI, Francesco. Instituições do Processo Civil. São Paulo: Classic Book, 2000. P. 157.
} 
estranho à relação controvertida para que a mesma seja pacificada. Essa característica se acentua consideravelmente na transação extrajudicial, de caráter preventivo, figura que constitui o objeto principal da investigação.

\subsubsection{Arbitragem}

$\mathrm{Na}$ escala crescente de autonomia das partes, a arbitragem se apresenta como estágio inicial de análise, frente à sua natureza heterocompositiva: em busca da pacificação do conflito, as partes elegem terceiro - ou terceiros - que formulam ato decisório, determinando materialmente a composição do litígio em substituição das próprias partes.

Arbitragem, para Carlos Alberto Carmona, é o "meio alternativo de solução de controvérsias através da intervenção de uma ou mais pessoas que recebem seus poderes de uma convenção privada, decidindo com base nela, sem intervenção estatal, [com a mesma] eficácia da sentença judicial". ${ }^{183}$

Tratando especificamente da arbitragem em contratos estatais, Elisson Pereira da Costa adota como conceito o entendimento de que a "[...] arbitragem é meio extrajudicial de solução de conflitos, por meio do qual os árbitros resolvem divergências relativas a direitos patrimoniais disponíveis, com base na convenção da arbitragem pactuada entre as partes". ${ }^{184}$ Em um recorte objetivo sugerido por Paulo Otero, cabe especificar que este tópico trata dos procedimentos arbitrais considerados públicos não por seu objeto, mas sim pela participação, como parte, de um ente estatal. ${ }^{185}$

Aprofundando um debate já exposto na porção introdutória deste tópico, como Pedro Gonçalves conclui ao analisar a jurisprudência do Tribunal Constitucional português, a jurisdição arbitral pode, de fato, ser caracterizada como

\footnotetext{
${ }^{183}$ CARMONA, Carlos Alberto. Arbitragem e processo: Um comentário à Lei n 9.307/96. São Paulo: Atlas, 2007. P. 51.

${ }^{184}$ COSTA, Elisson Pereira da. O alcance da arbitragem nos contratos administrativos de concessão de serviço público. Revista Síntese Direito Administrativo, n. 94, p. 28, out. 2013.

185 OTERO, Paulo. Arbitragem interna de litígios de Direito público: a publicização da arbitragem interna de Direito privado. Revista Internacional de Arbitragem e Conciliação, Lisboa, a. 5, n. especial, p. 180-193, 2012.
} 
“inteiramente 'privada' e 'consensual'”. ${ }^{186}$ Isso porque, apesar de o processo de jurisdição arbitral em si ser contencioso - caracterizado pela realização da justiça distributiva ou equitativa com a sujeição das partes ao direito dito -, a opção pelo mesmo é consensual e decorre, em plenitude, da livre vontade das partes em recorrer a esta modalidade de solução de conflitos. É justamente esta característica, que constitui, ao fim e ao cabo, o caráter consensual da arbitragem, que faz com que essa figura não ofenda à "reserva de jurisdição estadual", ${ }^{187}$ por não desafiar o acesso à justiça.

$\mathrm{Na}$ incipiente literatura em direito administrativo no Brasil da segunda metade do séc. XIX, Henrique do Rego Barros já destacava o manejo de cláusulas arbitrais em contratos da Administração Pública, apesar de se posicionar contrário à sua adoção em desfavor da competência do contencioso administrativo. ${ }^{188}$ Esse questionamento, no entanto, é superado pelo ordenamento jurídico de nossos dias.

Nesse sentido, no direito positivo contemporâneo brasileiro, a Lei $\mathrm{n}^{\circ}$ $9.307 / 1996$ veicula, em seu art. $1^{\circ}, \S \S 1^{\circ}$ e $2^{\circ}$, expressa autorização para que os entes estatais se socorram da arbitragem para a solução de litígios em que se envolvam, com a única ressalva de que a arbitragem seja exclusivamente de direito, ${ }^{189}$ como dispõe o $\S 3^{\circ}$ de seu art. $2^{\circ}$.

\footnotetext{
${ }^{186}$ GONÇALVES, Pedro Costa. Administração Pública e arbitragem: em especial, o princípio legal da irrecorribilidade de sentenças arbitrais. In: CORREIA, Fernando Alves; SILVA, João Calvão da; VIEIRA DE ANDRADE, José Carlos; CANOTILHO, Joaquim José Gomes; CARDOSO DA COSTA, José Manuel M. Estudos em Homenagem a António Barbosa de Melo. Coimbra: Almedina, 2013. P. 777-801.
}

Nesse sentido:

UNIÃO EUROPEIA. CONSELHO da Europa. Recommendation 2001-9 of the Committee of Ministers to member states on alternatives to litigation between administrative authorities and private parties. Estrasburgo: Éditions du Conseil de l'Europe, 2001.

187 "Estadual", aqui, como expressão utilizada em um contexto português, seria melhor grafada - e não traduzida, por óbvio - como "estatal" no contexto brasileiro. (GONÇALVES, Pedro Costa. Administração Pública e arbitragem: em especial, o princípio legal da irrecorribilidade de sentenças arbitrais. In: CORREIA, Fernando Alves; SILVA, João Calvão da; VIEIRA DE ANDRADE, José Carlos; CANOTILHO, Joaquim José Gomes; CARDOSO DA COSTA, José Manuel M. Estudos em Homenagem a António Barbosa de Melo. Coimbra: Almedina, 2013. P. 777-801).

${ }^{188}$ BARROS, Henrique do Rego. Apontamentos sobre o contencioso administrativo e sobre os privilegios e prerogativas da administração nos contractos e transacções que celebra como poder publico. Rio de Janeiro: Laemmert, 1874. P. 194-264/294-320.

${ }^{189}$ Nesse particular, interessante é o posicionamento de Paulo Otero acerca da possibilidade de flexibilização desta reprimenda no cenário português (OTERO, Paulo. Equidade e arbitragem 
Acerca dessa previsão legal, Pedro Gonçalves, em posicionamento que coaduna com a lição de Sabino Cassese, ${ }^{190}$ bem destaca que a existência de critérios de arbitrabilidade subjetiva e objetiva especificamente estabelecidos em Lei não descaracterizam o acesso da Administração à arbitragem, nem criam um regime de "arbitragem de direito público", uma vez que estes critérios e limites de recurso à arbitragem são previstos, inclusive, na arbitragem realizada entre partes privadas. $^{191}$

No caso particular do direito positivo brasileiro, uma questão crucial para a transposição da arbitragem ao direito administrativo reside na problemática em torno da irrecorribilidade das sentenças arbitrais, contemplada no direito brasileiro, segundo diversos autores, pelo art. 18 da Lei de Arbitragem (Lei n 9.307/1996). Como se vê das oposições à adoção, pela Administração Pública, das demais modalidades de soluções consensuais de conflitos, neste caso muito se diz que a Administração Pública não estaria sujeita, nem mesmo de forma expressa ou voluntária, à irrecorribilidade da sentença arbitral, frente à indisponibilidade dos direitos deixados à sua guarda.

Essa crítica se fundaria em um juízo duplamente errado, na dicção de Pedro Gonçalves.

Num primeiro plano, verifica-se que a permissão jurídica à Administração Pública para recorrer à arbitragem é dada "em bloco". Nesse sentido, exceção feita somente às reservas especificadas em Lei, a Administração recebe a arbitragem como uma possibilidade de ferramental completo, não havendo restrições quaisquer advindas de uma sua qualidade intrínseca. Em um segundo momento, Pedro Gonçalves destaca ser equivocado o posicionamento por basear-se em uma espécie de "desgraduação", de inferioridade do tribunal arbitral. Não há motivos

administrativa. In: CORDEIRO, António Menezes. Centenário do nascimento do Professor Doutor Paulo Cunha: Estudoe em homenagem. Coimbra: Almedina, 2012. P. 827-854).

${ }^{190}$ CASSESE, Sabino. L'arbitrato nel Diritto Amministrativo. Rivista Trimestrale di Diritto Pubblico, Roma, a. 46, n. 2, p. 311-328, $2^{\circ}$ trim. 1996.

191 GONÇALVES, Pedro Costa. Administração Pública e arbitragem: em especial, o princípio legal da irrecorribilidade de sentenças arbitrais. In: CORREIA, Fernando Alves; SILVA, João Calvão da; VIEIRA DE ANDRADE, José Carlos; CANOTILHO, Joaquim José Gomes; CARDOSO DA COSTA, José Manuel M. Estudos em Homenagem a António Barbosa de Melo. Coimbra: Almedina, 2013. P. 777-801. 
para pensar que "o tribunal arbitral e a arbitragem administrativa [...] constituem os parentes pobres do sistema de resolução de litígios que envolvam a Administração Pública", uma vez que o sistema de arbitragem permite a adoção de medidas que garantam a qualidade, confiabilidade e força jurídica de suas decisões. ${ }^{192}$

Afinal, como sustenta Paula Costa e Silva,

[...] se as partes têm o poder de escolher aqueles que julgam ser as pessoas mais aptas a proferir a decisão correcta, mal se compreende que possam depois questionar a solução efectivamente encontrada para o caso concreto. ${ }^{193}$

Nesse sentido, por força da própria coerência e harmonia que devem permear qualquer sistema jurídico, considerar-se-ia ao menos contraditório um regime que, mesmo viabilizando o acesso à arbitragem pela Administração Pública, simultaneamente lhe impusesse o recurso das sentenças arbitrais ao Poder Judiciário. ${ }^{194}$

Por fim, pode-se concluir que a arbitragem "vigora na atualidade como uma alternativa adequada e eficaz para os contratos administrativos", seja por ser mais célere e econômica que a solução judicial, seja por pressupor a maior expertise dos árbitros, "reduzindo a assimetria de informações entre os agentes de mercado e os julgadores". ${ }^{195}$ Diante das demais modalidades de solução consensual de conflitos, no entanto, a arbitragem acaba por contar com reduzida autonomia das partes - elemento eleito pelo trabalho como de essencial importância -, como se apresenta a seguir.

\footnotetext{
192 GONÇALVES, Pedro Costa. Administração Pública e arbitragem: em especial, o princípio legal da irrecorribilidade de sentenças arbitrais. In: CORREIA, Fernando Alves; SILVA, João Calvão da; VIEIRA DE ANDRADE, José Carlos; CANOTILHO, Joaquim José Gomes; CARDOSO DA COSTA, José Manuel M. Estudos em Homenagem a António Barbosa de Melo. Coimbra: Almedina, 2013. P. 777-801.

193 COSTA E SILVA, Paula. Os meios de impugnação de decisões proferidas em arbitragem voluntária no direito interno português. Revista da Ordem dos Advogados, Lisboa, a. 56, v. 1, p. 188, 1996.

194 GONÇALVES, Pedro Costa. Administração Pública e arbitragem: em especial, o princípio legal da irrecorribilidade de sentenças arbitrais. In: CORREIA, Fernando Alves; SILVA, João Calvão da; VIEIRA DE ANDRADE, José Carlos; CANOTILHO, Joaquim José Gomes; CARDOSO DA COSTA, José Manuel M. Estudos em Homenagem a António Barbosa de Melo. Coimbra: Almedina, 2013. P. 777-801.

${ }^{195}$ TIMM, Luciano Benetti; SILVA, Thiago Tavares e. Os contratos administrativos e a arbitragem. Revista Síntese Direito Administrativo, n. 94, p. 23, out. 2013.
} 


\subsubsection{Conciliação e Mediação}

Procedendo com a metodologia de exposição proposta, a arbitragem é seguida, na escala crescente de autonomia das partes, pela conciliação e pela mediação, respectivamente, aqui estudadas em conjunto por guardarem grande semelhança, apesar de distintas. ${ }^{196}$ As figuras são aqui expostas com grande brevidade já que, fugindo ao objeto de estudo da tese, servem tão somente de referencial comparativo para que se apreciem as modalidades de transação.

Conciliação e mediação são apreciadas em conjunto uma vez que, apesar de dependerem as duas figuras da intervenção de terceiro para a busca da solução para a lide, inexiste nelas o "poder heterocompositivo" que caracteriza a arbitragem. $^{197}$ Nesse sentido, na conciliação e na mediação as partes são auxiliadas no processo de busca pela pacificação, mas o conteúdo final do processo não é determinado de forma vinculativa pelo conciliador ou mediador.

Alexandre Freitas Câmara conceitua a conciliação como um processo consensual de solução de litígios em que um terceiro assume uma atividade de comando de negociação, "aparando as arestas existentes entre os litigantes, para que cheguem a uma solução de consenso". Já a mediação é tida pelo autor como uma técnica de solução de conflitos por meio da qual terceiro às partes exerce a função de aproximá-las, a fim de que os próprios litigantes ponham termo ao litígio, pessoalmente. $^{198}$

A expressão mediação tem etimologia de raízes latinas (medium, medius, mediator), designando a intervenção humana entre duas partes. Conceitualmente, relacionando-a à solução de litígios estatais:

A mediação é o procedimento por meio do qual os litigantes buscam o auxílio de um terceiro imparcial, que irá contribuir para a solução do conflito, na obtenção de um acordo, o qual não tem função de

\footnotetext{
${ }^{196}$ É esse o método de estudo adotado pelo Comitê de Ministros do Conselho da Europa na recomendação aos estados membros para a adoção de alternativas ao litígio (UNIÃO EUROPEIA. CONSELHO da Europa. Recommendation 2001-9 of the Committee of Ministers to member states on alternatives to litigation between administrative authorities and private parties. Estrasburgo: Éditions du Conseil de l'Europe, 2001).

${ }^{197}$ MARTINS, Alexandre de Soveral. Processo e direito processual: Processos heterocompositivos. Coimbra: Centelha, 1986. V. 2, passim.

${ }^{198}$ CÂMARA, Alexandre Freitas. Arbitragem. Rio de Janeiro: Lumen Juris, 1997. P. 128-129.
} 
decidir, nem the foi dado poder para tanto, apenas auxiliando as partes na obtenção da solução consensual. ${ }^{199}$

Verifica-se, assim, que os conceitos usualmente adotados pela literatura para a mediação e a conciliação em que são partes a Administração Pública não divergem daqueles referentes às partes privadas em geral.

Do ponto de vista procedimental e de seus resultados, é interessante o posicionamento de José Maria Garcez:

[Na mediação] um terceiro, imparcial, auxilia as partes a chegarem, elas próprias, a um acordo entre si, através de um processo estruturado.

As partes, assim auxiliadas, são as autoras das decisões e o mediador apenas as aproxima e faz com que possam melhor compreender as circunstâncias do problema existente e aliviar-se das pressões irracionais e do nível emocional elevado, que thes embaraça a visão realista do conflito, impossibilitando uma análise equilibrada e afastando a possibilidade de acordo. ${ }^{200}$

É relevante observar que, no Brasil, a mediação tem sido frequentemente relacionada a procedimentos judiciais, sendo neles exercida por juízes, togados ou leigos, ou por conciliadores, numa deformação do processo de mediação propriamente dito. ${ }^{201}$ Quanto à sua adoção em juízo por entes estatais, a literatura converge em admitir a sua possibilidade, desde que obedecidas as regras de competência legalmente estabelecidas, não restando, portanto, controvérsia relevante sobre o caso, especialmente diante das diversas autorizações veiculadas em instrumentos do direito positivo.

${ }^{199}$ CARVALHO, Ana Celeste. A mediação em matéria administrativa: uma possibilidade com futuro. Cadernos de Justiça Administrativa, Braga, n. 109, p. 3-12, jan./fev. 2015.

Interessante trazer em nota, à continuação, o entendimento de Ana Celeste Carvalho sobre os elementos essenciais da mediação: "Através da mediação existe o confronto das diferenças entre as partes, por meio de um terceiro interveniente, o mediador, que é neutro relativamente à solução, imparcial nos seus interesses e independente nas suas relações, desempenhando a função de intermediário e garantindo a confidencialidade do processo mediativo. A essência da mediação reside na autonomia da vontade das partes, pois são as partes que chegam livremente a acordo, embora auxiliadas por um terceiro, que actua com imparcialidade [grifos da autora]."

${ }^{200}$ GARCEZ, José Maria Rossani. Negociação, ADRS, Mediação, Conciliação e Arbitragem. Rio de Janeiro: Lumen Juris, 2004. P. 39.

201 GARCEZ, José Maria Rossani. Negociação, ADRS, Mediação, Conciliação e Arbitragem. Rio de Janeiro: Lumen Juris, 2004. P. 54. 


\subsubsection{Transação}

Devidamente diferenciadas as modalidades aqui eleitas como categorias de soluções consensuais de conflitos, e tendo o estudo procedido com o breve delineamento conceitual daquelas modalidades que não constituem o seu objeto central, passa-se à abordagem propriamente da transação. Como já exposto, optase por tal organização com o intuito de se possibilitar o estudo da transação já de posse do ferramental comparativo oriundo do conhecimento das demais modalidades, o que permite o gradual aprofundamento a que se propõe o presente capítulo: das soluções consensuais de conflitos à transação, desta à transação extrajudicial, e da sua adoção geral à sua caracterização como instrumento à disposição da Administração Pública.

Transação, para Maria Helena Diniz, é o "negócio jurídico bilateral, pelo qual as partes interessadas, fazendo-se concessões mútuas, previnem ou extinguem obrigações litigiosas ou duvidosas". Seu pensamento é no sentido de caracterizar a transação como um negócio jurídico declaratório, indivisível e de interpretação restrita. ${ }^{202}$

Já para Carlos Alberto Dabus Maluf, transação é "a faculdade concedida às partes de prevenirem ou terminarem o litígio (o mesmo que demanda, lide, pendência, questão) mediante concessões recíprocas". O autor the define os elementos, portanto, como a existência de um litígio surgido ou por surgir; a intenção das partes em findá-lo; e a existência de concessões mútuas. ${ }^{203}$

A literatura civilista converge em sustentar que o instituto da transação tem suas raízes no direito romano, com origem no Código de Justiniano, ${ }^{204}$ que já contemplava a transactionibus como contrato apto a, mediante concessões

202 DINIZ, Maria Helena. Curso de Direito Civil Brasileiro: Teoria das Obrigações Contratuais e Extracontratuais. Sâo Paulo: Saraiva, 2010. P. 605-610.

203 MALUF, Carlos Alberto Dabus. Da transação. In: FIUZA, Ricardo. Novo Código Civil comentado. São Paulo: Saraiva, 2003.

204 JARROSSON, Charles. Les concessions réciproques dans la transaction. Recueil Dalloz, Paris, chroniques, p. 267-273, 1997.

Como destaca Pontes de Miranda, Ulpiano trata da transação no L. 11, D., de transactionibus (MIRANDA, Francisco Cavalcanti Pontes de. Tratado de Direito privado: Parte especial. V. 25. Rio de Janeiro: Borsoi, 1959. P. 122). 
recíprocas, dar fim a contenda. Também no direito luso-brasileiro a transação já figurava dentre as espécies contratuais nas Ordenações Filipinas que, em seu Livro IV, Título XIII, trata "[d]o que quer desfazer a venda, por ser enganado em mais da metade do justo preço", fazendo expressa referência à solução de transação contratual em seu $\S 6^{\circ} .205$

No direito moderno, o gérmen das figuras transativas é identificado no instituto do negócio de acertamento, concebido pela literatura do padectismo alemão - que as extraiu, pois, diretamente do direito romano de Justiniano. ${ }^{206}$ Do direito alemão emanou a influência que levou tais estudos ao direito civil e ao direito processual civil italianos nos quais, "após décadas de intenso debate", consolidouse o negócio de acertamento como figura de direito privado. ${ }^{207}$

No direito italiano, o conceito de acertamento teria por essência a eliminação da lide ou do conflito entre as partes. Nesse sentido, a lição de Carnelutti acaba por delinear uma aproximação entre a solução contratual da lide e o seu arbitramento judicial, uma vez que, em ambos os casos, as partes obteriam o acertamento de sua controvérsia, eliminando seu estado de incerteza. ${ }^{208}$ Tornouse célebre, assim, a afirmação de Carnelutti de que "a transação é a solução contratual da lide", na medida em que o autor a tinha como o "equivalente contratual da sentença", ${ }^{209}$ de onde extraímos a relação umbilical, no direito italiano, entre negócio de acertamento e contrato de transação, que exerce importantíssimo papel nos debates acerca da natureza jurídica deste último, apreciados adiante.

${ }^{205}$ PORTUGAL. Codigo Philippino ou Ordenações e Leis do Reino de Portugal Recopiladas por Mandado D'El-Rey D. Philippe I. Rio de Janeiro: Typographia do Instituto Philomathico, 1870. V. 4, p. 793.

Nesse sentido, ver:

RODRIGUES, Silvio. Direito Civil: Dos contratos e das declarações unilaterais da vontade. São Paulo: Saraiva, 2004. P. 369.

${ }^{206}$ WINDSCHEID, Bernhard. Diritto delle pandette. Torino: Torinese, 1902. Passim.

${ }^{207}$ CHATEAUBRIAND FILHO, Hindemburgo. Negócio de acertamento: Uma abordagem históricodogmática. Belo Horizonte: Del Rey, 2005. Passim.

${ }^{208}$ CARNELLUTTI, Francesco. Note sull'accertamento negoziale. Rivista di Diritto Processuale Civile, v. 1, p.3-24, 1940

${ }^{209}$ CARNELUTTI, Francesco. Sulla causa della transazione. Rivista di Diritto Comerciale, Roma, p. $575,1914$. 
Do ponto de vista objetivo, portanto, o negócio de acertamento seria aquele pelo qual as partes "suprimem uma incerteza decorrente de situação negocial preexistente, acertando algum aspecto relevante que gere dúvida capaz de dificultar ou impedir a produção de seus regulares efeitos"; desse modo, por não criar, modificar ou extinguir relação jurídica, sustenta-se que o negócio de acertamento teria mera natureza declaratória. ${ }^{210} \mathrm{O}$ direito espanhol também conhece da figura contratual voltada à eliminação de incerteza material sem qualquer contraprestação, em especial em matéria de direito do Estado, com os convenios de fijación. ${ }^{211}$

Não se pode olvidar, como resta claro, a considerável similitude entre a transação e o acertamento, ${ }^{212}$ uma vez que, por meio de tais contratos, as partes de modo consensual dão fim a controvérsia entre si. As diferenças entre o negócio de acertamento e a transação residiriam, particularmente, na possibilidade de que o acertamento se dedique tão somente à matéria fática, enquanto a transação é sempre de direito; na informalidade do acertamento, em face da solenidade imposta à transação, que é sempre escrita; e na criação, modificação ou extinção de obrigações que podem decorrer das "concessões recíprocas" próprias da transação, estando ausentes no acertamento. ${ }^{213}$ Alguns autores, no entanto, se opõem a essa última distinção, sustentando que a vedação positiva à transmissão de direitos prevista no art. 843 do Código Civil brasileiro aproximaria a transação da natureza declaratória do negócio de acertamento. ${ }^{214}$

\footnotetext{
${ }^{210}$ NANNI, Giovanni Ettore. O negócio de acertamento como espécie de negócio jurídico. Letrado IASP, São Paulo, n. 100, p. 78-79, mai.-jun. 2012.

211 SERRANO, Maria Luisa González-Cuellar. Los procedimientos tributarios: Su terminación transaccional. Madrid: Colex, 1998. P. 37.

${ }^{212}$ NERY JUNIOR, Nelson; NERY, Rosa Maria de Andrade. Código Civil Comentado. São Paulo: Revista dos Tribunais, 2013. P. 886.

${ }^{213}$ NANNI, Giovanni Ettore. O negócio de acertamento como espécie de negócio jurídico. Letrado IASP, São Paulo, n. 100, p. 78-79, mai.-jun. 2012.

${ }^{214}$ MALUF, Carlos Alberto Dabus. Da transação. In: FIUZA, Ricardo. Novo Código Civil comentado. São Paulo: Saraiva, 2003. P. 758-760.
}

No mesmo sentido:

NERY JUNIOR, Nelson; NERY, Rosa Maria de Andrade. Código Civil Comentado. São Paulo: Revista dos Tribunais, 2013. P. 886. 
Fato é que, ao contrário da transação, o negócio de acertamento é figura praticamente desconhecida no direito brasileiro, ${ }^{215}$ apesar de influenciar diversos aspectos de sua natureza jurídica, como se expõe adiante.

Frente a todo o exposto, podemos eleger como elementos essenciais da transação o efeito de prevenção ou terminação do litígio entre as partes, a forma contratual escrita e o sinalagma oneroso constituído pelas concessões recíprocas. Comparativamente às demais modalidades de solução consensual de conflitos, a transação destaca-se especialmente por prescindir de terceira pessoa que participe direta ou indiretamente da solução da contenda, traço que contribui para a sua preferencialidade, como exposto adiante.

\subsubsection{Debates sobre a natureza jurídica da transação civil}

Nas raízes históricas do instituto da transação - tanto quando tratamos do Código de Justiniano quanto em relação às Ordenações Filipinas, citados destaca-se sobremaneira a natureza contratual da transação.

No entanto, um debate notável acerca da natureza jurídica da transação - e, aqui, ainda tratamos da transação sob o aspecto de direito civil -, com o questionamento dessa natureza contratual, se desenvolveu no direito italiano, especialmente na primeira metade do séc. XX. Tais debates se refletiram sobremaneira no entendimento que acabou por se consolidar no direito brasileiro e, desse modo, sua análise é considerada de relevada importância para o desenvolvimento proposto. Em especial, tais debates influenciaram a literatura europeia sobre a natureza da transação adotada pela Administração Pública, que tem sido importada sem maiores cuidados no direito administrativo brasileiro, o que desperta a revisão e o posicionamento a que se propõe o movimento final da primeira parte deste estudo.

Este cenário se formou, especialmente, com as disputas jurisprudenciais acerca do tema nos anos 1930. Destacam-se, nesse período, os debates acerca

\footnotetext{
${ }^{215}$ CHATEAUBRIAND FILHO, Hindemburgo. Negócio de acertamento: Uma abordagem históricodogmática. Belo Horizonte: Del Rey, 2005. Passim.
} 
dos efeitos declaratórios ou constitutivos do ato de transação, bem exemplificados pelos seguintes julgados da Corte de Cassação do Reino da Itália:

TRANSAZIONE - ATTO DICHIARATIVO - OPPONIBILITÀ AI TERZI - TRASCRIZIONE NON NECESSARIA (Cod. Civ., art. 632, 1314, 1764, 1772, 1932, 1942, 2105).

La transazione è un atto dichiarativo e quindi, a norma del codice civile, non ha bisogno di essere trascritta per essere opponibile ai terzi. $^{216}$

TRANSAZIONE - EFFETTO NOVATIVO - AMMISSIBILITÀ (Cod. Civ., art. 1267, 1764).

La transazione può contenere in sè stessa una convenzione che si sostituisce ad ogni precedente rapporto, che rimane estinto, e in tal caso perciò importa una vera e propria novazione ai sensi dell'art. 1267 n. 1 cod. Civile. ${ }^{217}$

Como fruto desse debate se desenvolveu a questão em torno da natureza jurídica da transação: ora, na medida em que a transação poderia ter ou não efeitos declaratórios - uma vez que, para alguns, seus efeitos seriam propriamente constitutivos, como a sentença judicial -, seria a transação um contrato, ou mera modalidade de extinção da obrigação, como o pagamento? Esse debate, no já citado cenário italiano, se intensificou consideravelmente e encontrou seu ápice já no equador do séc. $X X$, envolvendo de modo notável a doutrina em torno do tema.

As diversas teorias sobre a questão se agrupavam em dois grandes grupos: aqueles que entendiam pela existência de duas figuras - o "negócio de acertamento" e o "contrato de transação", relacionados porém diferenciados no tópico anterior -, a depender dos seus efeitos sobre a situação jurídica que dá origem à lide; e aqueles que sustentavam a unicidade de conceito entre as figuras transativas. $^{218}$

Essa dualidade de posições acabou por resultar em uma tripartição de teorias acerca dos efeitos da transação, o que se mostrou instrumental para a

\footnotetext{
${ }^{216}$ ITÁLIA. CORTE di Cassazione del Regno d'Italia. Sezione II civile: Scotto di Santolo $v$ Secondo. II Foro Italiano, Roma, v. 60, n. 13, p. 907, 1935.

217 ITÁLIA. CORTE di Cassazione del Regno d'Italia. Sezione III civile: Fantoni v Alfieri. II Foro Italiano, Roma, v. 61, n. 14, p. 1.141, 1936.

${ }^{218}$ CARRESI, Franco. Concetto e natura giuridica della transazione. Rivista Trimestrale di Diritto e Procedura Civile, Milano, a. 8, p. 62-104,1954.
} 
solução posterior da questão: um primeiro grupo aderiu à natureza declaratória da transação, mais próxima da caracterização contratual; outro, defendeu a sua natureza constitutiva, aproximando-a da sentença, com efeitos substitutivos de uma situação litigiosa por outra não litigiosa; e um terceiro grupo de juristas entendeu que o efeito da transação seria a eliminação da incerteza naquela relação jurídica, tendo portanto efeitos extintivos. ${ }^{219}$

Posicionamentos mistos se apresentaram, como o de Emilio Valsechi, criticado por Carlo Furno, que declarou não haver sentido em se aderir à natureza constitutiva sob os olhos da razão prática, tampouco à natureza declarativa por força da razão pura, abandonando pois tal distinção em favor da simples aplicação casuística do instituto. ${ }^{220}$ Paolo D'Onofrio, por sua vez, negou a utilidade do debate, mas sem chegar a formular um posicionamento alternativo que pudesse suprir a necessidade doutrinária de estabelecimento de uma natureza jurídica para a transação. ${ }^{221}$

O fruto dessa disputa pode ser apreciado no entendimento de Carnelutti, expresso em artigo de 1953 sobre o tema. Em seu texto clássico, Carnelutti dá solução à histórica contenda ao edificar 0 entendimento de que, independentemente dos efeitos declaratórios ou constitutivos, a natureza da transação se sustenta pela posição das partes em compor negocialmente o litígio. ${ }^{222}$ A eliminação da incerteza como efeito principal da transação, proposta por

${ }^{219}$ CARRESI, Franco. Concetto e natura giuridica della transazione. Rivista Trimestrale di Diritto e Procedura Civile, Milano, a. 8, p. 62-104,1954.

${ }^{220}$ FURNO, Carlo. Intorno alla natura della transazione. Rivista di Diritto Commerciale, Milano, a. 48, n. 1, p. 453-468, 1950.

A disputa doutrinária acabou por gerar acalorados debates entre Carlo Furno e Emilio Valsecchi, com sucessivas réplicas na literatura, como se vê em artigo apresentado por Valsecchi na mesma edição da Rivista di Diritto Commerciale em que Furno teceu algumas de suas mais vorazes críticas (VALSECCHI, Emilio. Ancora sulla natura della transazione. Rivista di Diritto Commerciale, Milano, a. 48, n. 1 , p. $468-483,1950)$.

${ }^{221}$ D'ONOFRIO, Paolo. La transazione e il contratto. Rivista di Diritto Commerciale, Milano, a. 51, n. 1, p. 490-493, 1953.

${ }^{222}$ CARNELUTTI, Francesco. La transazione è un contratto? Rivista di Diritto Processuale, Padova, v. 8, t. 1, p. 185-190, 1953.

Sempre digna de nota é a formulação original de Carnelutti: "Mi sbaglio o con la soluzione da me proposta la questione concernente il carattere dichiarativo o costitutivo della transazione non è più un rompicapo? La difficoltà era che, se la transazione equivale alla sentenza, non può non avere efficacia dichiarativa; ma invece, almeno nei casi previsti dal capoverso dell'art. 1965, non può non avere efficacia costitutiva: e i due tipi di efficacia si excludono a vicenda. Ma la difficoltà esiste solo 
Carnelutti, se espraiou pela literatura jurídica subsequente, como se tornou notável nos escritos de Francesco Santoro-Passarelli. ${ }^{223}$

No Brasil, a inovação de tais posicionamentos se apura também nos escritos de Pontes de Miranda, que trata a transação como negócio jurídico bilateral - contrariando as literais disposições do Código Civil de 1916, que tinha a transação como modo de extinção da obrigação -, pelo qual "duas ou mais pessoas acordam em concessões recíprocas, com o propósito de pôr têrmo a controvérsia sôbre determinada, ou determinadas relações jurídicas, seu conteúdo, extensão, validade, ou eficácia." ${ }^{224}$ Nesse sentido, também o autor brasileiro sustenta que

A extinção da dívida, da obrigação, da ação ou da exceção pode dar-se pela transação. Não é necessário que se dê. $O$ que a transação tem por fito não é extinguir dívidas, obrigações, ações ou exceções, direitos ou pretensões. O que a caracteriza é eliminação de litígio ou de inseguridade [grifo nosso]. ${ }^{225}$

Para Pontes de Miranda, caso não houvesse controvérsia, estar-se-ia a tratar de um contrato de acomodação, próprio do direito alemão, ou de desinteressamento, mas não de transação. ${ }^{226}$

No direito português, à mesma época se posicionava Luiz da Cunha Gonçalves pela natureza contratual da transação, demonstrando que também

se la transazione si considera come un negozio unico. Essa era perciò il sontomo dell'errore contenuto in questo modo di concepirla. II vero è che in quanto la transazione se risolve in rinuncia alla pretesa $\mathrm{o}$ in riconoscimento della pretesa non ha e non può non avere se non efficacia dichiarativa. Ma se l'altro negozio collegato con la rinuncia o con il riconoscimento costituisce, modifica o estingue un rapporto diverso da quello, che era oggetto della lite, del pari l'efficacia costitutiva no può essere negata. II segreto della soluzione sta in ciò che l'efficacia dichiarativa o costitutiva no è della transazione, la quale non costituisce se non il collegamento di due negozi al fine di comporre una lite, ma di ciascuno dei negozi collegati."

${ }^{223}$ SANTORO-PASSARELLI, Francesco. Nozione della transazione. Rivista di Diritto Civile, Padova, a. 2, p. 303-313, 1956.

E ainda:

SANTORO-PASSARELLI, Francesco. L'accertamento negociale e la transazione. Rivista Trimestrale di Diritto e Procedura Civile, Milano, a. 10, p. 1-26,1956.

${ }^{224}$ MIRANDA, Francisco Cavalcanti Pontes de. Tratado de Direito privado: Parte especial. V. 25. Rio de Janeiro: Borsoi, 1959. P. 117.

${ }^{225}$ MIRANDA, Francisco Cavalcanti Pontes de. Tratado de Direito privado: Parte especial. V. 25. Rio de Janeiro: Borsoi, 1959. P. 118.

${ }^{226}$ MIRANDA, Francisco Cavalcanti Pontes de. Tratado de Direito privado: Parte especial. V. 25. Rio de Janeiro: Borsoi, 1959. P. 118-119. 
naquele país se refletiam os debates da controvérsia italiana, com reflexos inclusive sobre o Código Civil português. ${ }^{227}$

A tendência de se reconhecer a natureza negocial da transação consolidou-se naquele momento histórico, mas não pelos mesmos fundamentos; ao contrário de Carnelutti, que reconhece a natureza contratual da transação independentemente de seus efeitos, Franco Carresi mostrou notável apego ao conceito de "negócio declarativo" para a transação. ${ }^{228}$ De todo modo, mesmo com a diversidade de entendimentos acerca dos efeitos da transação, consolidar-se-ia o entendimento pela natureza contratual da transação, que se espraia até o direito de nossos dias.

No direito brasileiro contemporâneo, merece destaque o posicionamento de Maria Helena Diniz - refletindo os debates históricos italianos aqui expostos -, para quem a transação é instituto jurídico sui generis, uma vez que, consistindo em modalidade especial de negócio jurídico bilateral, reuniria características de contrato quanto à sua constituição, e de pagamento quanto a seus efeitos. Assim, apesar de classificar a transação como negócio jurídico bilateral declaratório, a autora acaba por reconhecer tanto a natureza extintiva quanto a natureza contratual do instituto. ${ }^{229}$

Do ponto de vista do direito positivo, adotou-se no Brasil, tanto no Código Civil de 1916 quanto no de 2002, o posicionamento pela natureza extintiva da transação, constituindo inclusive coisa julgada quando homologada judicialmente. ${ }^{230}$ Essa extinção, é de se destacar, dar-se-á pela via contratual somente no novel Código Civil - no que o direito brasileiro acompanha os

${ }^{227}$ GONÇALVES, Luiz da Cunha. Tratado de Direito Civil. São Paulo: Max Limonad, 1956. V. 9, t. 1, p. 437-439.

${ }^{228}$ CARRESI, Franco. Concetto e natura giuridica della transazione. Rivista Trimestrale di Diritto e Procedura Civile, Milano, a. 8, p. 62-104,1954.

${ }^{229}$ DINIZ, Maria Helena. Curso de Direito Civil Brasileiro: Teoria das Obrigações Contratuais e Extracontratuais. Sâo Paulo: Saraiva, 2010. P. 611.

${ }^{230}$ NERY JUNIOR, Nelson; NERY, Rosa Maria de Andrade. Código Civil Comentado. São Paulo: Revista dos Tribunais, 2013. P. 886.

No mesmo sentido:

LOPES, Miguel Maria de Serpa. Curso de Direito Civil: Obrigações em Geral. Rio de Janeiro: Freitas Bastos, 1989. P. 275-278. 
ordenamentos francês, italiano e espanhol -, sendo consolidado, na literatura pátria, o entendimento pela natureza sinalagmática da transação. ${ }^{231}$

Pode-se concluir, pois, pela natureza contratual da transação, cujo sinalagma tem por objeto a extinção ou prevenção de litígio. O estabelecimento de tal posição abre caminho ao estreitamento do tema, na medida em que o estudo passa do campo da transação em geral para a análise da transação especificamente extrajudicial, preferencialmente preventiva de litígio, como se analisa no tópico a seguir.

3.2.3.2 A transação extrajudicial como meio preferencial de consensualidade na solução de conflitos

Antes de proceder com a análise da inserção da transação extrajudicial no direito administrativo, cabe aqui concluir brevemente o recorte objetivo a que se dedicou a primeira parte deste capítulo. Apreciando os principais métodos consensuais de solução de conflitos, o texto adotou, não por acaso, uma escala de preferencialidade ${ }^{232}$ entre as modalides, baseada sobretudo no papel de terceiros estranhos à relação controvertida no construir da solução buscada.

Ao iniciar pela breve análise da figura da arbitragem, desvelou-se uma modalidade que, para muitos, sequer seria consensual, uma vez que a efetiva solução à lide é formulada vinculativamente pelos árbitros. Defendemos, aderindo à posição de Pedro Gonçalves, a natureza consensual da arbitragem, não necessariamente em relação ao conteúdo da solução final alcançada, mas sim no

\footnotetext{
${ }^{231}$ MALUF, Carlos Alberto Dabus. Da transação. In: FIUZA, Ricardo. Novo Código Civil comentado. São Paulo: Saraiva, 2003. P. 757.

${ }^{232}$ Adotamos aqui o vocábulo preferencialidade, não um neologismo mas também não um termo de uso frequente, para designar a qualidade daquilo que é preferencial. Preferimos preferencialidade a outros termos, como precedência, primazia, prioridade, por entender que designar a modalidade como preferencial Ihe empresta uma carga de opção, de escolha, que não se obtém tão claramente pela adoção das outras expressões. Buscamos, desse modo, designar a transação extrajudicial como uma modalidade cuja escolha se mostra mais adequada dentre as diversas opções possíveis, sem haver, no entanto, a obrigatoriedade de sua adoção, como o uso das outras expressões poderia deixar transparecer.
} 
tocante à convenção entabulada entre as partes para a ela recorrer - em especial, quando da presença de cláusula compromissória. ${ }^{233}$

De todo modo, o posicionamento da arbitragem como primeira modalidade consensual exposta se fez tendo em vista o grau de dependência das partes em relação a terceiros para a obter-se a solução para a lide. Nesse sentido, a arbitragem acaba sendo a mais complexa e, por consequência, a mais dispendiosa das modalidades, com a probabilidade de se mostrar, também, como a mais vagarosa.

A escala de preferencialidade avança para abordar, num segundo momento, a conciliação e a mediação. Em tais modalidades, as partes já não dependem de terceiro para a composição do conteúdo da solução buscada, mas ainda o terceiro é essencial para o progresso do procedimento no sentido da sua obtenção. Entre essas duas modalidades, a conciliação guarda maior dependência do terceiro, já que o conciliador assume o comando do processo de negociação; já a mediação tem essa dependência relativamente reduzida, uma vez que o terceiro atua tão somente na aproximação entre as partes, que procedem por si mesmas com as negociações em busca da solução.

Por fim, o capítulo expõe a transação como o método de solução consensual de conflitos em que as partes, por sua própria iniciativa, adotam concessões mútuas com o fim de prevenir ou terminar o litígio. O confronto entre a transação e as demais modalidades abordadas mostra que ela está no estágio mais avançado na escala de preferencialidade proposta, uma vez que, na transação, as partes obtêm a solução para o seu potencial ou efetivo litígio sem depender da atuação de terceiros, sejam eles árbitros, conciliadores ou mediadores. Tais características guardam o potencial de tornar a transação na modalidade mais célere, menos dispendiosa e que - com o protagonismo das partes - obtenha a maior adesão dos envolvidos à solução alcançada.

\footnotetext{
${ }^{233}$ GONÇALVES, Pedro Costa. Administração Pública e arbitragem: em especial, o princípio legal da irrecorribilidade de sentenças arbitrais. In: CORREIA, Fernando Alves; SILVA, João Calvão da; VIEIRA DE ANDRADE, José Carlos; CANOTILHO, Joaquim José Gomes; CARDOSO DA COSTA, José Manuel M. Estudos em Homenagem a António Barbosa de Melo. Coimbra: Almedina, 2013. P. 777-801.
} 
Estabelece-se, assim, um cenário de preferencialidade dos mecanismos que é inversamente proporcional à dependência de terceiros para se chegar à solução. Em outras palavras, a escala crescente de preferência entre as modalidades de solução consensual de conflitos se organiza em uma escala decrescente de protagonismo de terceiros para a obtenção de um provimento final da lide.

Em nosso posicionamento, pois, a preferencialidade na adoção de métodos consensuais de solução de litígios está intimamente ligada ao protagonismo das partes na pacificação do caso. Trata-se de posicionamento que atende às próprias características axiológicas da consensualidade: ora, na medida em que o valor da consensualidade consista na convergência comportamental das partes em busca de uma solução para a lide, tanto mais valorosa será a metodologia consensual adotada quanto mais as partes assumirem posições pessoais de convicção em busca do consenso.

O presente estudo intenta ir mais além: mesmo considerando a transação como método preferencial de solução consensual de litígios, ainda resta apreciar qual dentre as espécies de transação melhor cumpriria os objetivos ínsitos à sua natureza e mais adequadamente se inseriria no cenário de evolução de paradigmas da Administração Pública exposto no primeiro capítulo do trabalho.

Como já abordado, o conceito doutrinário de transação, acolhido pelo direito positivo brasileiro e de diversos outros países, compreende o ajuste entre as partes tanto para prevenir quanto para terminar o litígio. Em ambos os casos, o litígio se faz presente, seja de forma potencial ou concreta; no entanto, ao considerarmos as diversidades quanto à cogência situacional entre os dois cenários, transparece grande diferença que deve ser considerada para fins de análise.

Ao transacionar para terminar litígio, as partes - ou uma delas, mais precisamente - já acorreram ao Judiciário e, vislumbrando a possibilidade de solucionar a questão, se compõem e dão fim ao mesmo. Nesse cenário, uma vez instaurada a instância, faz-se necessária a homologação judicial da transação que, por isso mesmo, tem força de coisa julgada. 
Já ao tratarmos da transação com vistas à prevenção de litígio, delineiase um cenário em que as partes extrajudicialmente buscam sua composição, antes de qualquer recurso ${ }^{234}$ ao Judiciário. A transação extrajudicial vincula as partes por sua própria foça contratual - com as modulações próprias a um contrato, evidentemente - e, assim, esse se torna o campo onde o protagonismo das partes ressoa com máxima intensidade.

A adoção do critério do protagonismo das partes para o estabelecimento da primazia entre os métodos consensuais de solução de conflitos não se justifica tão somente por si só, mas também pelas consequências que dele decorrem. Quanto maior o protagonismo das partes na solução do conflito, com a redução da dependência de terceiros para o equacionamento da demanda, tanto mais célere e menos dispendioso o procedimento se torna. À evidência, isso se afirma não em termos estatísticos, mas sim prospectivos; é de se esperar que, com a menor dependência das partes em relação a terceiros - sejam árbitros, conciliadores, mediadores ou mesmo o juízo homologatório -, o procedimento seja simplificado.

É o que se observa ao compararmos, por exemplo, a complexidade do procedimento arbitral, a formalidade dos procedimentos de conciliação e mediação e a celebração contratual da transação. Mais uma vez, pode-se delinear uma escala descendente de complexidade, desde um procedimento judicialiforme como a arbitragem até a simples firmatura de um contrato de transação. Esta diferente complexidade entre os métodos de solução consensual de conflitos acaba por implicar na celeridade do procedimento e nos custos a ele relacionados.

Ainda, é de se observar que soluções mais simples e informais guardam uma tendência - ainda que não plenamente realizada no cenário brasileiro - de maior adesão das partes. Nesse sentido, destaca-se que as soluções consensuais adotadas no âmbito judicial, sejam elas obrigatórias, incidentais ou procedimentais - como é o caso da realização compulsória de audiências de conciliação na nova ordem processual civil brasileira -, acabam por descaracterizar a essência das soluções consensuais de conflitos. Isso ocorre uma vez que, ao exigir um momento

${ }^{234}$ À evidência, adota-se a expressão recurso no sentido de manejo, reclamo. Apesar de tratar-se aqui de relações contenciosas, não se aplica a expressão no sentido próprio da teoria geral do processo, como o ato da parte próprio à instauração do duplo grau de jurisdição. 
de composição, tendem a não ir ao encontro da vontade ou dos interesses das partes - por uma questão de oportunidade temporal, ou timing, talvez -, tendo assim pouco efeito na redução da carga processual da Justiça. ${ }^{235}$

Diante de tal cenário, pode-se concluir que a transação extrajudicial é a modalidade de solução consensual de conflitos que guarda a maior carga de voluntariedade das partes. O seu caráter preventivo único, não observado em qualquer dos outros métodos - na cláusula compromissória, quando muito -, aliado ao absoluto protagonismo das partes na busca da solução, prescindindo de terceira parte que a homologue, viabilize, proponha ou determine, acabam por consolidar a prevalência da transação extrajudicial em relação à transação judicial, à mediação, à conciliação e à arbitragem.

\section{Também a Administração Pública é alcançada pela premente} necessidade de adotar métodos consensuais de solução de conflitos e, dentre eles, se destaca especialmente a transação extrajudicial. A solução consensual de conflitos na Administração Pública é o meio mais efetivo para a concretização do direito fundamental de acesso à justiça ${ }^{236} \mathrm{e}$, nesse âmbito, é papel das instâncias de gestão estatal promover transformações e criar instrumentos para que os agentes públicos competentes possam buscar, sempre que possível e

${ }^{235}$ CARVALHO, Ana Celeste. A mediação em matéria administrativa: uma possibilidade com futuro. Cadernos de Justiça Administrativa, Braga, n. 109, p. 3-12, jan./fev. 2015.

${ }^{236}$ CARVALHO, Ana Celeste. A mediação em matéria administrativa: uma possibilidade com futuro. Cadernos de Justiça Administrativa, Braga, n. 109, p. 3-12, jan./fev. 2015.

É de valiosa citação a ressalva feita pela autora: "Não defendendo uma jurisdição mínima, nem aceitando uma pretensa inaptidão ou incapacidade do poder judiciário para apreciar e decidir os processos que os cidadãos the entendam apresentar, resolvendo eficazmente os conflitos e recusando a ideia de uma actual crise da Justiça, nada obsta a que se criem formas alternativas de resolução de litígios que, por vontade das partes, ponham fim ao conflito, com baixos custos e em pouco tempo, em paralelo ou em complemento com a justiça pública e a jurisdição, enquanto função pública do Estado. Não se trata da incapacidade da justiça pública em assegurar a resolução dos litígios, mas de conceder que a justiça pública não esgota os meios de resolução dos litígios e que, em larga escala, os cidadãos recorrem aos tribunais, com e sem motivo. Embora ao dizer o Direito os tribunais contribuam para a paz social, não está ao seu alcance eliminar todas as injustiças ou resolver as próprias crises da sociedade, nem a capacidade de evitar as causas de uma litigiosidade crescente." 
recomendável, uma solução consensual para conflito que envolva a Administração Pública. $^{237}$

Buscando realizar essa missão, o manejo da transação extrajudicial pelos entes estatais não é fenômeno recente. Na raiz das diversas experiências internacionais e brasileiras - expostas em capítulo integrante da segunda parte do trabalho - residem as pioneiras iniciativas do séc. XIX e da primeira metade do séc. $X X$ na França e na Itália. Dentre elas, ganham destaque os primeiros casos de transação na Administração Pública em matéria fiscal (1822) e em matéria de direitos subjetivos (1887) na França, ${ }^{238}$ bem como a utilização de soluções transativas pelo Estado italiano para a solução de conflitos com seus servidores públicos. ${ }^{239}$ No cenário brasileiro, no entanto, a literatura contemporânea em direito administrativo ainda é repleta de posicionamentos contrários à adoção da transação extrajudicial pela Administração Pública, o que consolida a demanda pelo estudo aqui realizado.

Além da preferencialidade da transação extrajudicial já demonstrada de modo geral - o maior protagonismo das partes, que atuam preventivamente, num procedimento mais simples, célere e econômico -, quando tem como parte o Estado a transação extrajudicial reveste-se ainda de vantagens específicas. Como se extrai da análise das experiências de transação extrajudicial na administração pública a que se dedicará a parte inicial do último capítulo dessa obra, ao transacionar preventivamente é evitada a incidência dos encargos materiais e procedimentais de eventual execução contra a Fazenda Pública pelo regime de precatórios. ${ }^{240}$ Ainda, a adoção da transação extrajudicial pelo Estado se reveste de importante valor simbólico ao incentivar, pelo exemplo, a adoção de postura

\footnotetext{
${ }^{237}$ UNIÃO EUROPEIA. CONSELHO da Europa. Recommendation 2001-9 of the Committee of Ministers to member states on alternatives to litigation between administrative authorities and private parties. Estrasburgo: Éditions du Conseil de l'Europe, 2001.

${ }^{238}$ CHAVRIER, Géraldine. Réflexions sur la transaction administrative. Revue Française de Droit Administratif, Paris, n. 3, p. 548-566, mai.-jun. 2000.

${ }^{239}$ PROSPERETTI, Ubaldo. Le rinunce e le transazioni del pubblico impiegato. Rivista Trimestrale di Diritto Pubblico, Roma, a. 5, p. 349-359, 1955.

${ }^{240}$ ESTEVES, Maurício Cramer. Da possibilidade e dos limites da transação em processos judiciais por parte do poder público municipal. Interesse Público, Belo Horizonte, a. 8, n. 38, jul./ago. 2006.
} 
consensual por toda a sociedade, além de fomentar a reaproximação democrática pela superação de posturas desnecessariamente combativas.

A presença da Administração Pública como parte na transação extrajudicial desperta, ainda, particularidades no estudo a empreender, que o diferencia substancialmente da investigação acerca do manejo de outros métodos consensuais de solução de conflitos por entes estatais, tal como já exposto na introdução ao trabalho.

Num primeiro momento, destaca-se que a transação extrajudicial comporta maior complexidade na seara administrativa, na medida em que implica na realização de um processo administrativo próprio, que se encerra em si mesmo - sendo, portanto, a única das modalidades de solução consensual de conflitos do Estado em que o procedimento se desenvolve de modo integral no âmbito administrativo. Em outro aspecto, tendo em vista a sua natureza de prevenção de litígios, a transação extrajudicial desperta maiores riscos na medida em que se submete a menor controle por agentes externos à relação - uma vez que a transação judicial, a mediação, a conciliação e a arbitragem contam com terceiro agente que participa ou acompanha a solução-, o que leva a uma análise de riscos particular. A essas particularidades se dedica a segunda parte do trabalho.

Considerando-se, assim, por restar suficientemente demonstrado que a transação extrajudicial é o meio preferencial de solução consensual de conflitos na Administração Pública - diferenciando-se substancialmente, assim, da transação judicial, da mediação, da conciliação e da arbitragem -, passa-se à análise da inserção dessa modalidade no ferramental de medidas à disposição do Estado para a realização de seus misteres, o que constitui o movimento conclusivo do presente capítulo e da primeira parte do trabalho.

\subsection{A inserção da transação extrajudicial no direito administrativo: Natureza jurídica}

A exposição até aqui levada a cabo abordou detidamente o conceito e a natureza jurídica da transação, delimitando-Ihe as hipóteses e os efeitos. Com base nesses fundamentos, empreendeu-se análise que demonstra a notável 
preferencialidade da transação extrajudicial como método consensual de solução de conflitos, seja por envolver tão somente as partes do litígio, seja por concentrarse em uma posição preventiva em relação à contenda.

No entanto, mesmo diante dos diversos benefícios apresentados, são efervescentes - e, entendemos, ainda não conclusivos - os debates acerca da admissibilidade da transação extrajudicial tendo como parte a Administração Pública. Numa visão que se entende, no presente trabalho, poder ser revisada, há ainda diversos posicionamentos na literatura e na jurisprudência refratários à adoção da transação extrajudicial por entes estatais, entendo-a como contrária ao chamado regime jurídico administrativo.

Uma análise mais atenta do tema revela que, na verdade, a negativa de admissibilidade à transação extrajudicial na administração pública acaba por obter efeito contrário, negando a efetivação da missão institucional do Estado, relacionada umbilicalmente à realização dos direitos fundamentais. Ora, na medida em que os contratos da Administração não abrangem somente contratos administrativos, mas também os contratos privados da Administração - regidos, como se verifica, por normas de direito privado -, haveria vedação à adoção de tal figura para a obtenção de melhores resultados na gestão pública?

Trata-se de tema naturalmente delicado, principalmente ao assumirmos consciência dos preconceitos que gravitam em torno de decisões estratégicas em gestão pública. Ao considerarmos as resistências e vedações à adoção da transação extrajudicial mesmo entre contratantes privados - que pautam a sua atuação, numa visão simplificada, por uma legalidade negativa, onde é permitido aquilo que a Lei não proíbe -, tais resistências se multiplicam em muito quando um dos contratantes é a Administração Pública, com atuação supostamente vinculada a uma legalidade estrita, positiva, e sobre a qual ainda recaem muitos conceitos, corretos ou não, como o de uma supremacia do interesse público. ${ }^{241}$

\footnotetext{
${ }^{241} \mathrm{O}$ estudo se dedica a apreciar e enfrentar o papel da legalidade e a suposta supremacia do interesse público, entre outros temas controvertidos, no capítulo empenhado aos desafios à receptividade do modelo de transação extrajudicial na administração pública proposto, capítulo este integrante da segunda parte do trabalho.
} 
Com vistas a responder tais questionamentos, o terço final do presente capítulo principia por abordar os posicionamentos contemporâneos acerca da natureza jurídica da transação extrajudicial na administração pública - inclusive com a análise dos raros posicionamentos presentes na literatura pátria -, verificando por ser essencial, para sua análise crítica, a eleição de um marco diferencial entre o contrato administrativo e o contrato privado da Administração.

Com base nessa distinção, vislumbra-se ser possível a edificação de posicionamento original acerca da natureza da transação extrajudicial firmada pela Administração Pública, tarefa que é cumprida no tópico que encerra a primeira parte do estudo. A segunda parte do trabalho, por sua vez, dedicar-se-á à investigação da efetiva aplicabilidade de contratos transativos na administração pública, principiando pelo enfrentamento das oposições a que se refere o princípio do presente tópico.

\subsubsection{Posicionamentos quanto à natureza jurídica da transação administrativa}

O terço médio do presente capítulo se dedicou a traçar linhas gerais acerca dos diversos métodos de solução consensual de conflitos, tendo como movimento final a definição de transação e a exposição dos debates, no âmbito do direito civil e do direito processual civil, acerca da sua natureza jurídica.

Nessa análise de ângulo aberto, pode-se sustentar como elementos essenciais da transação o efeito de prevenção ou terminação do litígio entre as partes, a forma contratual escrita e o sinalagma oneroso constituído pelas concessões recíprocas. Ainda, restou demonstrada a natureza contratual da transação no âmbito privado, tema que foi objeto de acalorados debates naquela seara. Esta natureza se torna ainda mais destacada ao tratarmos da transação extrajudicial, preferencialmente preventiva.

A conferência do qualificativo administrativa à transação extrajudicial acrescenta um degrau na escala de aprofundamento no tema proposto, estreitando o escopo de análise. O tópico que ora se inicia se dedica, assim, à exposição e apreciação dialógica dos posicionamentos acerca da natureza jurídica da transação extrajudicial que tenha como parte ente estatal, adicionando aos debates acerca da 
natureza jurídica das transações em geral os aspectos próprios ao direito administrativo. Esse desenvolvimento se mostra essencial para que, no movimento conclusivo do presente capítulo, se torne possível a formulação de tese acerca da natureza jurídica da transação extrajudicial na administração pública.

Num primeiro momento, cabe expor o debate acerca da natureza de ato administrativo ou de contrato da Administração a ser conferida à transação. Tal debate acaba por, em certa medida, representar retrocesso à pacificação do entendimento acerca da natureza contratual da transação na seara privada mas, de modo simbólico, a sua simples existência já denota uma série de resistências à própria adoção da transação pelos entes estatais.

No direito administrativo francês, apesar de a transação integrar o espectro ferramental de soluções do contencioso administrativo, a noção conceitual da transação - judicial ou extrajudicial - entabulada pela Administração Pública decorre do disposto no Código Civil daquele país. Este, em seu art. 2.044, determina que "a transação é um contrato pelo qual as partes terminam um litígio nascido, ou previnem um litígio a nascer. Este contrato deve adotar a forma escrita”. 242

Nesse sentido, Géraldine Chavrier sustenta que a autonomia do direito administrativo em relação ao direito privado não impede o juiz administrativo - no caso brasileiro, também o agente administrativo - de emprestar do Código Civil disposições e princípios transponíveis ao direito administrativo. Em tal cenário, o estudo da adoção da transação civil pelo juiz e pela autoridade administrativos "ilustra perfeitamente" a ligação entre regime público e privado que acaba por impedir uma autonomia absoluta entre tais ramos do Direito, ${ }^{243}$ tema sobre o qual já nos debruçamos no capítulo de aproximação ao tema, ao tratar do fenômeno da "fuga para o direito privado".

${ }^{242}$ ASSO, Bernard; MONERA, Frédéric. Contentieux Administratif. Paris: Panorama du Droit, 2009. P. 326.

No original: "La transaction est un contrat ar lequel les parties terminent une contestation née, ou préviennent une contestation à naître. Ce contrat doit être rédigé par écrit".

${ }^{243}$ CHAVRIER, Géraldine. Réflexions sur la transaction administrative. Revue Française de Droit Administratif, Paris, n. 3, p. 548-566, mai.-jun. 2000. 
Delineia-se, portanto, um quadro de considerável volatilidade da natureza da transação extrajudicial da Administração Pública francesa, enfrentado por Chavrier sob três aspectos: o impacto do desequilíbrio relacional entre Estado e cidadão; o grau de consensualidade efetivamente obtido; e a questão da espécie de ato ou contrato.

Sob o primeiro prisma, Chavrier destaca o debate em torno de uma possível "unilateralidade" da transação pela Administração Pública. Haveria, em hipótese, um grande desnivelamento relacional entre Estado e cidadão em um acordo transacional, uma vez que não caberia à contraparte privada "negociar", mas tão somente "consentir" no processo de transação; em outras palavras, a contraparte privada "não dispõe mais do que de um 'poder sobre si', e não de um 'poder sobre o outro"'.244

Por-se-iam diante de nós, assim, três possíveis naturezas jurídicas da transação no direito administrativo francês: ato de deferimento; ato administrativo unilateral de renúncia à suspensão da indenização até uma decisão judicial; ou contrato de transação.

Chavrier rechaça o primeiro posicionamento - de que a transação consistiria em mero ato administrativo de indenização - uma vez que, apesar de a contraparte privada não contar com poderes de real negociação, esta pode simplesmente não aderir à transação e buscar a via judicial. Não há que se falar, portanto, que a transação constituiria "prerrogativa própria do poder público", de modo a ser exercida unilateralmente. ${ }^{245}$ Tal circunstância acaba por afastar, igualmente, a aceitabilidade da segunda hipótese - ato administrativo de renúncia a uma prerrogativa - uma vez que, além de ter-se afastado a suposta unilateralidade do ato já na primeira hipótese, a eventual renúncia da Administração

${ }^{244}$ CHAVRIER, Géraldine. Réflexions sur la transaction administrative. Revue Française de Droit Administratif, Paris, n. 3, p. 548-566, mai.-jun. 2000.

No original: "[...] le contravenant ne dispose que d'un 'puvoir sur soi' (consentir) et non 'd'un pouvoir sur l'autre' (négocier) tandis que l'Administration réunit les deux caractéristiques".

${ }^{245}$ CHAVRIER, Géraldine. Réflexions sur la transaction administrative. Revue Française de Droit Administratif, Paris, n. 3, p. 548-566, mai.-jun. 2000. 
a uma sua prerrogativa consistiria, justamente, em um elemento da típica transação contratual, a título de concessão recíproca.

No entanto, para Jean-Claude Ricci, a transação entabulada pela Administração Pública "é um ato unilateral particularmente discricionário que se relaciona consideravelmente com o direito de graça tradicionalmente exercido pelo chefe de Estado". ${ }^{246}$ Essa lógica é acolhida, também, por diversos precedentes do contencioso administrativo francês em matéria de transação não-fiscal da primeira metade do séc. XX. ${ }^{247}$

Foi este o posicionamento defendido, nos primórdios do direito administrativo no Brasil, pelo Visconde do Uruguay, que entendia que as indenizações estatais a particulares constituiriam parte da administração graciosa, um "attributo e instrumento essencial do Poder Executivo, [que com ele] procede discricionariamente, e com arbitrio". 248

Esse debate também se reflete no direito administrativo italiano e no direito administrativo português, nos quais se discute se a transação seria um ato administrativo, em razão do deferimento de uma graça ou indenização, ou se ela seria um contrato da Administração, frente ao sinalagma próprio do regime de concessões mútuas.

Para Mário Aroso de Almeida - ao analisar o processo administrativo português - a pretensão administrativa condenatória em face da Administração Pública independe da prática de ato administrativo. Isso decorreria do fato de que "o direito decorre directamente de normas jurídico-administrativas", o que se observa na solução administrativa de relações contratuais ou de crédito junto à Administração (que já contam com marco normativo pré-estabelecido) ou da responsabilidade civil extracontratual do Estado uma vez que, em relação a esta última, "a Administração não tem o poder de dizer o Direito através da emissão de

\footnotetext{
${ }^{246} \mathrm{RICCl}$, Jean-Claude. Le pouvoir discrétionnaire de l'administration fiscale. Marseille: Presses Universitaires d'Aix-Marseille, 1977. P. 332.

${ }^{247}$ CHAVRIER, Géraldine. Réflexions sur la transaction administrative. Revue Française de Droit Administratif, Paris, n. 3, p. 548-566, mai.-jun. 2000.

${ }^{248}$ URUGUAY, Paulino José Soares de Sousa, Visconde do. Ensaio sobre o direito administrativo. Rio de Janeiro: Typographia Nacional, 1862. V. 1, p. 79-81.
} 
um acto administrativo que determine se deve ou não proceder à reparação dos danos"; mesmo regramento caberia aos casos de indenizações pela imposição de sacrifícios ou aplicação do instituto do enriquecimento sem causa. ${ }^{249}$

Já Sabino Cassese destaca que, apesar de o ato de firmatura do acordo não ser um ato administrativo - visto que não dotado de unilateralidade -, pode ser considerado como tal o ato que, compondo o procedimento preliminar, proceda com a adjudicação ou o deferimento do acordo. ${ }^{250}$

Sérvulo Correia também reconhece a relação umbilical entre o contrato celebrado e o ato administrativo que defere a sua celebração, de tal modo a sustentar que "acarreta a nulidade do contrato privado a anulação contenciosa do acto administrativo destacável que tiver habilitado a Administração à respectiva outorga". ${ }^{251}$ Esse posicionamento não é, no entanto, pacífico na doutrina portuguesa; tal como destaca Maria João Estorninho, a posição tradicional da literatura e da jurisprudência naquele país é a de que os atos da Administração preparatórios à celebração de um contrato privado da Administração guardam a natureza de "actos de direito privado", não podendo, portanto, ser estes considerados "actos destacáveis" para fins de controle jurisdicional. ${ }^{252}$

O pensamento de Chavrier esclarece, ainda, importante ponto acerca da natureza dos acordos administrativos em que seja veiculado conteúdo próprio do poder de polícia - como nos termos de ajustamento de conduta e termos de cessação, no Brasil -, sustentando que, apesar de suas cláusulas consistirem em exercício do poder de polícia e da puissance publique, naturalmente unilateral, sua

${ }^{249}$ ALMEIDA, Mário Aroso de. Manual de Processo Administrativo. Coimbra: Almedina, 2015. P. 115-125.

Procede o autor: "[...] não está em causa a prática de actos administrativos, mas a realização de simples actuações ou actos reais, para utilizar a terminologia alemã, isto é, a realização de prestações a que a a Administração se encontra obrigada, sem dispor do poder de as recusar através de uma pronúncia susceptível de ser qualificada como um acto administrativo de indeferimento [grifo do autor]".

${ }^{250}$ CASSESE, Sabino. Corso di Diritto Amministrativo: Istituzioni di Diritto Amministrativo. V. I. Milano: Giuffrè, 2004. P. 240-241.

251 CORREIA, José Manuel Sérvulo. Legalidade e autonomia contratual nos contratos administrativos. Coimbra: Almedina, 1987. P. 782.

252 ESTORNINHO, Maria João. Algumas questões de contencioso dos contratos da Administração Pública. Cadernos de Ciência da Legislação, Lisboa, n. 15, p. 36-37, jan.-mar. 1996. 
presença não tem o condão de "desqualificar" a natureza contratual de tais acordos. $^{253}$

Conclui-se, portanto, pela natureza contratual da transação em que é parte a Administração Pública. No entanto, apesar de reconhecer a contratualidade da transação realizada pela Administração Pública, Géraldine Chavrier sustenta que este seria um contrato de adesão. Nesse sentido, destaca ela mesma a contradição de que, apesar de serem as cláusulas de tal "contrato de adesão transativo" integralmente determinadas pela Administração, seu conteúdo só será adequado se nele se encontram e harmonizam os interesses de ambas as partes. $^{254}$

Estabelecida a natureza contratual da transação que tem como parte ente da Administração Pública, se desvela o desafio de definir tal contrato como contrato privado ou contrato administrativo. Nesse cenário, Géraldine Chavrier destaca três pontos essenciais - com referência no direito administrativo francês para a definição de tal natureza: a presença de cláusulas exorbitantes, a relação do objeto com a consecução de um serviço público e a sujeição da avença ao contencioso administrativo.

Quanto ao último critério, a unicidade de jurisdição consolidada no direito administrativo brasileiro afasta a sua aplicação no cenário nacional, objeto da presente investigação. Resta-nos a apreciação, assim, dos dois primeiros critérios.

No tocante à presença de cláusulas exorbitantes, Chavrier aponta a existência de duas linhas de entendimento: por um lado, poder-se-ia sustentar que a presença de cláusulas exorbitantes do direito comum seria contrária ao espírito e ao objeto da transação; sob outro viés, alegar-se-ia que a presença das cláusulas exorbitantes é que permitiria a firmatura da transação pela Administração Pública.

\footnotetext{
${ }^{253}$ CHAVRIER, Géraldine. Réflexions sur la transaction administrative. Revue Française de Droit Administratif, Paris, n. 3, p. 548-566, mai.-jun. 2000.

${ }^{254}$ CHAVRIER, Géraldine. Réflexions sur la transaction administrative. Revue Française de Droit Administratif, Paris, n. 3, p. 548-566, mai.-jun. 2000.
} 
A autora não enxerga, no entanto, neste critério um ponto relevante para a determinação da natureza administrativa ou privada. ${ }^{255}$

Chavrier acaba por concluir, assim, que a natureza da transação - de jaez contratual, como já concluído pela exposição dos debates francês, italiano e português - concluída pelo ente público dependerá, essencialmente, da natureza do litígio que se pretende evitar ou terminar. Desse modo, transações visando à correção de violações a "direito objetivo" teriam natureza privada, enquanto as transações em matéria fiscal, por exemplo, poderiam ter natureza pública ou privada, de acordo com a matéria fiscal versada. ${ }^{256}$ Nesse sentido, sustentava Pontes de Miranda que "[a] transação rege-se, como contrato que tem eficácia extintiva, pelo estatuto ou ramo do direito que rege a obrigação". 257

A análise acurada do posicionamento de Chavrier nos revela, no entanto, que a sua postura em preferir o critério do objeto contratual para a definição da natureza pública ou privada da transação, em detrimento dos critérios da presença de cláusulas exorbitantes ou da sujeição do contrato ao contencioso administrativo, apesar de declarada pela autora, não é clara.

É que, ao posicionar-se nesse sentido, Chavrier acaba por direcionar a sua análise ao terceiro critério, e não propriamente ao critério do objeto. A análise do texto - referencial na matéria - faz transparecer que o objeto da transação só

\footnotetext{
${ }^{255}$ CHAVRIER, Géraldine. Réflexions sur la transaction administrative. Revue Française de Droit Administratif, Paris, n. 3, p. 548-566, mai.-jun. 2000.

${ }^{256}$ CHAVRIER, Géraldine. Réflexions sur la transaction administrative. Revue Française de Droit Administratif, Paris, n. 3, p. 548-566, mai.-jun. 2000.

No original: "La nature de la transaction conclue par une personne publique dépendrait donc bien de celle du litige qu'elle tente d'éviter. Les contrats portant règlement de la violation d'un droit objectif, passible des tribunaux correctionnels, ont donc une nature privée et relèvent de la jurisdiction judiciaire. Parmi eux, les contrats réparant une infraction aux règles fiscales seront administratifs lorsqu'ils porteront sur des contestations relatives aux taxes sur le chiffre d'affaires ou à l'assiette et au calcul des impôts directs, et civils lorsqu'ils concerneront l'établissement de l'impôt et son recouvrement, les contribuitions indirectes, ou la régularité en la forme des actes de poursuites."

${ }^{257}$ MIRANDA, Francisco Cavalcanti Pontes de. Tratado de Direito privado: Parte especial. V. 25. Rio de Janeiro: Borsoi, 1959. P. 159.

Acerca do critério estatutário para a qualificação de um contrato como administrativo o trabalho se dedica no próximo tópico, com especial atenção ao pensamento de Sérvulo Correia, buscando justamente a definição de um marco diferencial para a apuração de tal natureza.
} 
determina a natureza da mesma, no pensamento de Chavrier, de maneira instrumental à sua submissão ao contencioso administrativo ou à justiça comum. ${ }^{258}$

Sua análise não se concentra, pois, sobre o objeto em si da transação, mas sim sobre os efeitos que tal objeto guarda em relação à distribuição do contrato entabulado no sistema de jurisdição dual. Desse modo, apesar da declarada opção pelo critério do objeto para a definição da natureza da transação, o pensamento da autora revela, de fato, um posicionamento que combina a análise do objeto e a submissão jurisdicional da transação para que se obtenha uma definição acerca de sua natureza.

Podemos concluir, assim, que para Chavrier a transação que tenha objeto que se aproxime ao direito privado apresentará natureza de direito privado em razão de o litígio prevenido ou terminado submeter-se à justiça comum; de mesmo modo, a transação cujo objeto se caracterize como de direito público guardará natureza de direito público uma vez que o litígio prevenido ou terminado submeter-se-ia ao contencioso administrativo.

Essa construção, apesar da elaboração sofisticada, não contribui sobremaneira para a definição da natureza jurídica do contrato transacional entabulado pela Administração Pública brasileira. Aqui, aderimos à ressalva feita por Rhein Schirato acerca da importação, para o direito administrativo brasileiro, de conceitos oriundos da teoria francesa dos contratos administrativos; ${ }^{259}$ podemos considerar, pois, que a preocupação demasiada com a solução das questão de atribuição de competências entre a justiça comum e o contencioso administrativo prejudica a transposição do entendimento exposto ao cenário pátrio, diferentes que são as circunstâncias a considerar e os problemas a resolver.

\footnotetext{
${ }^{258}$ É de se destacar que, em acórdão de 11 de julho de 1908, o Tribunal de Conflitos francês, responsável por solucionar conflitos de jurisdição entre a Justiça Comum e o Contencioso Administrativo, decidiu que as transações são sujeitas ao controle da Justiça Comum ainda que sejam entabuladas por pessoas de direito público (FRANÇA. CENTRE National de la Recherce Scientifique. Accords transactionnels. Paris: CNRS, 2003).

${ }^{259}$ SCHIRATO, Vitor Rhein. A interação entre Administração Pública e particulares nos contratos administrativos. Fórum de Contratação e Gestão Pública, Belo Horizonte, a. 12, n. 138, p. 51-69, jun. 2013.
} 
Há outros posicionamentos, no entanto, que podem esclarecer mais adequadamente o cenário francês em torno das transações entabuladas pela Administração Pública. Dentre eles se destaca a tese de Marie-Odile Diemer, para quem os accords transactionnels firmados pela Administração contam com legítima natureza de contrato administrativo de transação e, portanto, o seu controle atrairia a atuação do contencioso administrativo, ainda que em um estágio de "jurisdição graciosa". 260

É esse o posicionamento, de fato, adotado pela jurisprudência administrativa francesa, tendendo para a classificação da transação em que figure a Administração Pública como contrato administrativo, como destaca Julie Cornu:

[...] a jurisprudência se fixou em favor da naturesa administrativa da transação que tenha por objeto a solução de um litígio relacionado à competência do juiz administrativo. Mas os questionamentos não param por aí; com efeito, a introdução de uma nova categoria de contratos administrativos, por determinação jurisprudencial, por força de seu objeto, tem revivido intensas controvérsias. ${ }^{261}$

Não se pode sustentar, no entanto, a existência de um posicionamento consolidado sobre a matéria no direito administrativo francês, em especial frente às já expostas divergências entre a literatura e a jurisprudência daquele país.

Talvez por esse motivo é que a esparsa literatura no direito administrativo brasileiro sobre o tema tenha se apoiado em fontes e figuras italianas para formular seu posicionamento sobre o tema, como transparece ser o caso da seminal monografia de Onofre Alves Batista Júnior, ${ }^{262}$ à qual o trabalho se dedica

${ }^{260}$ DIEMER, Marie-Odile. La jurisdiction gracieuse en droit administratif. 2013. Tese (Doutorado em direito) - École Doctorale de Droit, Université Montesquieu-Bordeaux IV, Bordeaux, 2013. P. 409472.

${ }^{261}$ CORNU, Julie. La transaction en matière administrative. 2008. Dissertação (Mestrado em direito público) - Université Panthéon-Assas Paris II, Paris, 2008. P. 19. Tradução nossa.

No original: "Ainsi, après de longs atermoiements, la jurisprudence est désormais fixée en faveur de la nature administrative de la transaction ayant pour objet le règlement d'un litige relevant de la compétence du juge administratif. Les interrogations ne cessent pas pour autant. En effet, l'introduction d'une nouvelle catégorie de contrats administratifs, par détermination de la jurisprudence, à raison de leur objet a relancé de vives controverses".

262 BATISTA JÚNIOR, Onofre Alves. Transações administrativas: um contributo ao estudo do contrato administrativo como mecanismo de prevenção e terminação de litígios e como alternativa à atuação administrativa autoritária, no contexto de uma administração pública mais democrática. São Paulo: Quartier Latin, 2007. 
detidamente adiante. Destaque-se que, igualmente animados pela Recomendação $\mathrm{n}^{\circ} \operatorname{Rec}(2001) 9$ do Comitê de Ministros do Conselho da Europa, ${ }^{263}$ Alemanha e Espanha mantiveram em seu direito administrativo modelos prévios semelhantes ao italiano, fortemente ligados à natureza procedimental ou substitutiva do acordo, de modo que adotamos aqui o referencial italiano como contraponto ao cenário francês. $^{264}$

No direito administrativo italiano, Sabino Cassese destaca a existência de duas modalidades de acordos a serem firmados pela Administração Pública: o acordo procedimental (integrador ou preliminar), que determina ou condiciona o conteúdo discricionário da medida administrativa e pode sempre ser firmado; e acordo substitutivo, que substitui a própria medida a ser adotada e só pode ser firmado nos casos legalmente previstos. ${ }^{265}$ Explica Giovanni Sala:

Como acordos entre pessoas privadas e a Administração Pública o art. 11 da Lei 241 contempla duas espécies distintas: os acordos direcionados a determinar o conteúdo discricionário do provimento final e aqueles estipulados, nos casos previstos em Lei, em substituição do provimento final. ${ }^{266}$

Os acordos substitutivos de provimentos (ou atos decisórios) administrativos, no direito administrativo italiano, constituem hipóteses nas quais a decisão final de um procedimento administrativo - ordinariamente veiculada por meio de ato administrativo decisório, o provvedimento ${ }^{267}$ na expressão italiana - é

${ }^{263}$ UNIÃO EUROPEIA. CONSELHO da Europa. Recommendation 2001-9 of the Committee of Ministers to member states on alternatives to litigation between administrative authorities and private parties. Estrasburgo: Éditions du Conseil de l'Europe, 2001.

${ }^{264}$ BATISTA JÚNIOR, Onofre Alves. Transações administrativas: um contributo ao estudo do contrato administrativo como mecanismo de prevenção e terminação de litígios e como alternativa à atuação administrativa autoritária, no contexto de uma administração pública mais democrática. São Paulo: Quartier Latin, 2007. P. 330-360.

${ }^{265}$ CASSESE, Sabino. Corso di Diritto Amministrativo: Istituzioni di Diritto Amministrativo. V. I. Milano: Giuffrè, 2004. P. 222-223.

${ }^{266}$ SALA, Giovanni. Accordi sul contenuto discrezionale del provvedimento e tutela delle situazioni soggetive. Diritto Processuale Amministrativo, Milano, a. 10, n. 2, p. 206-254, jun. 1992. Tradução nossa.

No original: "Per gli accordi tra privati e pubblica amministrazione l'art. 11 della I. 241 contempla due fattispecie distinte: gli accordi diretti a determinare il contenuto discrezionale del provvedimento finale e quelli invece stipulati, nei casi previsti dalla legge, in sostituzione di questo."

${ }^{267}$ OPPO, Giorgio. Diritto privato e interessi pubblici. Studi Economico-Giuridici, Napoli, v. 55, p. 430, 1993-1994. 
substituída, nos casos legalmente previstos, por um acordo entabulado entre a Administração e os interessados. ${ }^{268}$ A natureza substitutiva de tais acordos, assim, Ihes confere uma característica específica, central, como veremos, para a definição da natureza jurídica da transação extrajudicial da Administração Pública no direito brasileiro: eles se submetem aos mesmos instrumentos e regras de controle a que se submeteriam os atos unilaterais substituídos. ${ }^{269}$

É o que, de fato, se vê no direito administrativo italiano, como destaca Domenico Sorace, em que os acordos integradores e substitutivos contam com natureza jurídica de direito público, frente à sua tipicidade. ${ }^{270}$

Essa tipologia, própria do direito administrativo italiano, tem claras raízes nos debates históricos, no âmbito do direito privado, acerca da natureza jurídica da transação, expostos com maior propriedade em tópico anterior deste capítulo. Resta claro que a distinção entre acordos procedimentais e acordos substitutivos guarda notável paralelismo com a distinção entre negócios de acertamento e contratos de transação. De mesmo giro, verifica-se uma aproximação do acordo procedimental com os entendimentos, nos citados debates, acerca da natureza declaratória dos atos transacionais, enquanto o acordo substitutivo se identifica mais propriamente com a natureza constitutiva, sustentada por outros autores naquele momento histórico.

A estreita relação, no direito administrativo italiano, entre o acordo substitutivo e o ato administrativo substituído é exaustivamente analisada na monografia de Fabrizio Fracchia sobre o tema. Segundo o autor, mesmo com a previsão, já exposta, do art. 11 da Lei Italiana $n^{\circ}$ 241/1990, a literatura italiana por

\footnotetext{
${ }^{268}$ SORACE, Domenico. Diritto delle amministrazioni pubbliche: Una introduzione. Bologna: II Mulino, 2000. P. 303.

269 SORACE, Domenico. Diritto delle amministrazioni pubbliche: Una introduzione. Bologna: II Mulino, 2000. P. 303.

270 SORACE, Domenico. Diritto delle amministrazioni pubbliche: Una introduzione. Bologna: II Mulino, 2000. P. 316.
} 
vezes resiste em conferir aos acordos substitutivos a natureza contratual, uma vez que os mesmos acabam por tomar o lugar do ato administrativo unilateral. ${ }^{271}$

No entanto, de acordo com Fracchia, em sendo reconhecida a natureza contratual do acordo substitutivo, esse contrato atrai o regime público e se caracterizaria como contrato administrativo, sobretudo pelo caráter estatutário que o identifica. Fabrizio Fracchia lança mão, para tal análise, de uma caracterização contrario sensu do acordo substitutivo: ora, uma vez que o mesmo se distingue substancialmente dos contratos privados da Administração, seja por seus efeitos mais próximos do ato administrativo do que de qualquer outra figura -, seja pelo seu regime de controle e desfazimento, a atração de normas publicísticas caracterizaria o acordo substitutivo como contrato administrativo. ${ }^{272}$

Dentre os poucos trabalhos que tratam da adoção da transação pelos entes estatais, menos ainda são aqueles que se dedicam à definição de sua natureza jurídica. ${ }^{273}$ Cristiane Schwanka, em trabalho dedicado à transação para solução de conflitos em matéria de contratos administrativos, adere tão somente à demonstração da natureza contratual da transação, sem abordar suficientemente a sua caracterização como contrato administrativo ou contrato privado da Administração. ${ }^{274}$

271 FRACCHIA, Fabrizio. L'accordo sostitutivo: Studio sul consenso disciplinato dal diritto amministrativo in funzione sostitutiva rispetto agli strumenti unilaterali di esercizio del potere. Padova: Cedam, 1998. Passim.

272 FRACCHIA, Fabrizio. L'accordo sostitutivo: Studio sul consenso disciplinato dal diritto amministrativo in funzione sostitutiva rispetto agli strumenti unilaterali di esercizio del potere. Padova: Cedam, 1998. P. 74-81/169-175.

${ }^{273}$ Veja-se, por exemplo, que os seguintes trabalhos, apesar de sua indiscutível relevância, não se debruçam suficientemente sobre o tema o sequer o abordam:

ESTEVES, Maurício Cramer. Da possibilidade e dos limites da transação em processos judiciais por parte do poder público municipal. Interesse Público, Belo Horizonte, a. 8, n. 38, jul./ago. 2006.

DALLARI, Adilson Abreu. Viabilidade da transação entre o poder público e particular. Interesse Público, Belo Horizonte, a. 4, n. 13, jan.-mar. 2002.

SOUZA, Carlos Alberto Sobral de. Da Transação e da Indisponibilidade do Interesse Público. Fórum Administrativo Direito Público, Belo Horizonte, a. 1, n. 8, out. 2001.

${ }^{274}$ SCHWANKA, Cristiane. Administração Pública consensual: A transação como método alternativo de solução de conflitos nos contratos administrativos. 2009. Dissertação (Mestrado em direito) UniBrasil, Curitiba, 2009. Passim. 
Já Vitor Rhein Schirato e Juliana Bonacorsi de Palma levam a cabo interessante exercício de classificação dos instrumentos consensuais previstos no direito administrativo brasileiro de acordo com o modelo italiano - que se aproxima dos modelos alemão e espanhol, como visto -, conforme a sua divisão entre acordos de procedimento, acordos de integração (equivalentes aos acordos substitutivos) e acordos de complementação (estes últimos transprocedimentais, visando à efetividade de uma decisão administrativa já adotada em procedimento próprio). No estudo, os autores acabam por analisar tão somente figuras típicas de direito do Estado já previstas no direito positivo brasileiro, o que acaba por ratificar as conclusões tecidas neste tópico acerca da adoção das figuras do direito italiano, sem maior foco sobre a figura da transação extrajudicial. ${ }^{275}$

Diante desse rarefeito cenário, ganha grande destaque a tese de Onofre Alves Batista Júnior sobre as "transações administrativas". ${ }^{276}$ No trabalho, o autor busca identificar no direito administrativo brasileiro o conceito de contrato administrativo alternativo, sendo aqui necessário, para a adequada crítica, expor a sua concepção sobre a figura:

O contrato administrativo alternativo é uma forma de a Administração Pública resolver determinados casos concretos, como alternativa a uma atuação unilateral, colocando-se como possível mecanismo (mais democrático) para a persecução otimizada do melhor interesse público possível. O fundamento de sua aplicação centra-se exatamente na possibilidade de maior eficiência da atuação administrativa quando desenvolvida com a colaboração do administrado.

Mediante o manejo dos contratos administrativos alternativos, a Administração renuncia ao emprego de potestades de imposição unilateral e, buscando maior eficiência administrativa, persegue o melhor interesse público possível mediante o estabelecimento de solução concertada com o administrado. Parte-se, entretanto, do pressuposto de que, caso não seja possível o acordo, a solução escolhida será imposta unilateralmente pela Administração,

${ }^{275}$ SCHIRATO, Vitor Rhein; PALMA, Juliana Bonacorsi de. Consenso e Legalidade: vinculação da atividade administrativa consensual ao direito. Revista Eletrônica sobre a Reforma do Estado, Salvador, n. 24, jan.-fev. 2011.

${ }^{276}$ BATISTA JÚNIOR, Onofre Alves. Transações administrativas: um contributo ao estudo do contrato administrativo como mecanismo de prevenção e terminação de litígios e como alternativa à atuação administrativa autoritária, no contexto de uma administração pública mais democrática. São Paulo: Quartier Latin, 2007. 
fazendo uso de seus poderes que, para tanto, tenham sido outorgados pela lei. ${ }^{277}$

O pensamento de Batista Júnior adota como pilar, assim, o modelo de acordo substitutivo adotado na Itália, na Alemanha e na Espanha, trazendo consigo, consequentemente, o entendimento pela necessária tipicidade da figura, o seu papel de substituição de um ato administrativo unilateral e a natureza jurídica de contrato administrativo, atraindo assim o regramento de direito público.

Mais especificamente, a tese de Batista Júnior sustenta a existência, no direito administrativo brasileiro, do gênero "contratos administrativos alternativos" ou "contratos administrativos de transação lato sensu", que compreenderia as espécies "contrato administrativo de transação stricto sensu" e "contrato administrativo complexo" ${ }^{278} \mathrm{Na}$ concepção do autor, o contrato administrativo de transação stricto sensu aproximar-se-ia da transação civil, mas com natureza de contrato administrativo, frente à presença da Administração Pública como parte; já o contrato administrativo complexo teria elementos do negócio de acertamento já que, mesmo sem prevenir ou terminar litígio, seria direcionado à eliminação de incertezas na relação jurídica contratual entre a Administração e o particular. ${ }^{279}$

O que transparece no pensamento de Onofre Alves Batista Júnior é que, para ambas as figuras, seria pressuposto lógico a existência de um ato administrativo ou de uma solução administrativa unilateral a serem substituídos pela solução consensual. As figuras por ele propostas, assim, guardam grande proximidade com a natureza substitutiva dos acordos no modelo italiano, porém

277 BATISTA JÚNIOR, Onofre Alves. Transações administrativas: um contributo ao estudo do contrato administrativo como mecanismo de prevenção e terminação de litígios e como alternativa à atuação administrativa autoritária, no contexto de uma administração pública mais democrática. São Paulo: Quartier Latin, 2007. P. 325-326.

278 BATISTA JÚNIOR, Onofre Alves. Transações administrativas: um contributo ao estudo do contrato administrativo como mecanismo de prevenção e terminação de litígios e como alternativa à atuação administrativa autoritária, no contexto de uma administração pública mais democrática. São Paulo: Quartier Latin, 2007. P. 325-330.

279 BATISTA JÚNIOR, Onofre Alves. Transações administrativas: um contributo ao estudo do contrato administrativo como mecanismo de prevenção e terminação de litígios e como alternativa à atuação administrativa autoritária, no contexto de uma administração pública mais democrática. São Paulo: Quartier Latin, 2007. P. 360-382. 
confundindo a natureza e a finalidade diversas entre os institutos civis do contrato de transação e do negócio de acertamento.

Ainda, seu posicionamento toma como certo o fato de que a transação administrativa constituiria contrato administrativo, atraindo o regime jurídico publicístico em sua plenitude e aplicando de maneira apenas subsidiária as normas civis sobre a transação. Haveria, portanto, uma regra de competência para a celebração do "contrato administrativo alternativo" atrelada à competência do ato administrativo unilateral a ser substituído, ${ }^{280} \mathrm{com}$ grande enfoque sobre o critério orgânico-subjetivo para a caracterização da transação administrativa como contrato administrativo e para a consequente atração do regime público.

Nas palavras do autor:

No Direito Administrativo brasileiro, as transações administrativas são contratos administrativos alternativos, pois a Administração Pública se faz presente, além do que a qualificação do contrato resulta de ser constituída, modificada ou extinta, pelo acordo de vontades, relação jurídica típica de direito administrativo. ${ }^{281}$

Detecta-se, no entanto, uma certa fragilidade no argumento de definição da natureza jurídica das transações administrativas em Batista Júnior. Isso se afirma diante da considerável contradição dessa afirmação com capítulo anterior da obra, em que o autor, após exaustiva exposição dos diversos critérios para a caracterização dos contratos administrativos tal como sistematizados por Maria João Estorninho, acaba por concluir pela pouca utilidade da distinção entre contratos administrativos e contratos privados da Administração, classificando a dicotomia como artificial - "sem grandes correspondências com a realidade" - e o eventual critério de distinção como mítico. ${ }^{282}$

\footnotetext{
280 BATISTA JÚNIOR, Onofre Alves. Transações administrativas: um contributo ao estudo do contrato administrativo como mecanismo de prevenção e terminação de litígios e como alternativa à atuação administrativa autoritária, no contexto de uma administração pública mais democrática. São Paulo: Quartier Latin, 2007. P. 330.

281 BATISTA JÚNIOR, Onofre Alves. Transações administrativas: um contributo ao estudo do contrato administrativo como mecanismo de prevenção e terminação de litígios e como alternativa à atuação administrativa autoritária, no contexto de uma administração pública mais democrática. São Paulo: Quartier Latin, 2007. P. 370.

282 BATISTA JÚNIOR, Onofre Alves. Transações administrativas: um contributo ao estudo do contrato administrativo como mecanismo de prevenção e terminação de litígios e como alternativa
} 
Assim, diante de um alegado esgarçamento da ideia de contrato administrativo, "perante uma ideia mais ampla de contrato administrativo", o autor acaba por considerar a transação administrativa como contrato administrativo. Ora, ao caracterizar o contrato administrativo puramente pela presença da Administração, não estaria o autor a aplicar justamente o critério orgânicosubjetivo?

Ao negar a utilidade de um critério distintivo, Batista Júnior acaba por, justamente, aplicar um dos critérios menos adequados para a correta caracterização do regime jurídico aplicável ao contrato em análise, negando inclusive, como se verá adiante, validade ao entendimento de Maria João Estorninho, autora que the serviu de suporte à exposição.

Ainda, apesar de negar a própria dicotomia, o autor assume inúmeras posições que denotam a adoção expressa da natureza clássica de contrato administrativo, que não coaduna com uma correspondência geral com a figura dos contratos privados da Administração. Nesse sentido, Batista Júnior sustenta, entre outros posicionamentos, a necessidade de tipicidade e autorização legal para a transação, em claro traço estatutário, além de defender a aplicação do regime jurídico público às transações, com a adoção tão somente subsidiária de normas privatísticas. ${ }^{283}$

Diante de tal cenário, mostra-se de grande necessidade estudo mais aprofundado acerca dos critérios para a caracterização do contrato administrativo, o que se procede no tópico seguinte. Tal desenvolvimento permitirá a formulação de posicionamento original acerca da natureza jurídica da transação que tenha como parte a Administração Pública, tarefa a que se dedica o movimento final do presente capítulo.

à atuação administrativa autoritária, no contexto de uma administração pública mais democrática. São Paulo: Quartier Latin, 2007. P. 275-296.

${ }^{283}$ Batista Júnior se reporta por diversas vezes, inclusive, à aplicação plena do regramento da Lei de Licitações e Contratos Administrativos, a Lei no 8.666/1993 (BATISTA JÚNIOR, Onofre Alves. Transações administrativas: um contributo ao estudo do contrato administrativo como mecanismo de prevenção e terminação de litígios e como alternativa à atuação administrativa autoritária, no contexto de uma administração pública mais democrática. São Paulo: Quartier Latin, 2007. P. 327). 


\subsubsection{O dístico essencial do contrato administrativo}

O estudo da natureza jurídica da transação em que seja parte a Administração Pública, passo essencial para o desenvolvimento proposto, tem como importante campo de análise a distinção entre os contratos administrativos e os contratos de direito privado celebrados pela Administração Pública.

Como exposto em tópico anterior, os debates sobre a natureza jurídica da transação se estendem por toda a existência do próprio instituto. Passando por diversos momentos históricos, observamos movimentos pendulares acerca da caracterização da transação ora como contrato, ora como modalidade de extinção da obrigação, e de volta à natureza contratual, que acabou por consolidar-se no direito civil. $\mathrm{O}$ direito brasileiro não destoa de tal posicionamento.

Transportando esse cenário para o estudo da transação extrajudicial no âmbito estatal, pudemos apreciar os posicionamentos próprios do direito administrativo acerca da natureza jurídica dessa modalidade particular do instituto, âmbito no qual os debates oscilaram entre a natureza de ato ou de contrato da transação e, quanto à natureza contratual, acerca da sua caracterização como contrato administrativo.

A definição da natureza jurídica da transação extrajudicial da Administração Pública carece, no entanto, de um aprofundamento teórico que entendemos não ter sido atingido pelos posicionamentos expostos, o que se levantará no tópico seguinte. Por um lado, verifica-se que algumas posições são por demais restritas, deixando assim de abarcar todas as hipóteses em que a Administração se socorra da transação para prosseguir com seus misteres. De outro ponto, há autores que falham em explicar em profundidade o fenômeno da transação extrajudicial no campo administrativo, uma vez que não Ihe exploram todos os aspectos e inter-relações.

Faz-se oportuno, portanto, antes de prosseguir com a edificação de nosso posicionamento acerca da natureza jurídica da transação extrajudicial na administração pública - o que se realiza no tópico final desse capítulo -, construir breve ilação acerca do marco de distinção entre o contrato administrativo e as figuras contratuais ordinárias. 
Como já pudemos analisar em texto anterior, ${ }^{284}$ frente à precedência cronológica do Direito privado em relação ao Direito administrativo, entende parte relevante da literatura que este último recebe daquele institutos por transposição. O processo de transposição de institutos jurídicos seria descrito por Hauriou em três passos: a transposição pura da teoria ou regra, que caracterizaria uma cópia do instituto tal como concebido no âmbito privado; a reação conforme as necessidades da Administração, em que são diagnosticadas e formatadas as adequações necessárias para transpor o instituto ao âmbito público; e, por fim, as adaptações finais para o direito administrativo, fase na qual o instituto acaba por receber contornos próprios ao direito do Estado. ${ }^{285}$ Não se pode tratar, no entanto - como reconhece-se, evidentemente, que Hauriou de fato não trata -, de simples cópia de institutos pelo direito administrativo tomando por base o direito privado. $A$ precedência temporal do direito privado - se assumimos as origens revolucionárias francesas como marco histórico de nascença do direito administrativo - acarreta a circunstância de que o mesmo se deteve primeiro sobre o regramento dos institutos, como é o caso do contrato, mas não faz do contrato um instituto exclusivo ou originado no direito privado.

Nesse sentido, outros autores há que entendem que o estudo de figuras jurídicas em certa medida compartilhadas pelo direito privado e pelo direito administrativo deve se dedicar às "categorias jurídicas" 286 - na dicção de Cretella Júnior, ou "superconceitos"287, como prefere Retortillo - sem vinculação a qualquer ramo do Direito específico, considerando-se que cada ramo do Direito estuda, com visão própria, o mesmo instituto. Assim,

[t]omando-se como referência o Direito Civil, corre-se o risco de captar o instituto privado já trabalhado e diferenciado - a espécie e de transpô-lo para o âmbito público, a fim de apresentar a outra

\footnotetext{
284 GREGO-SANTOS, Bruno. Nivelamento versus igualdade: Aspectos subjetivo e objetivo do posicionamento da Administração Pública em relação ao particular. In: DI PIETRO, Maria Sylvia Zanella. Direito privado administrativo. São Paulo: Atlas, 2013. P. 122-147.

${ }^{285}$ HAURIOU, Andre. A utilização em direito administrativo das regras e princípios do direito privado. Revista de Direito Administrativo, Rio de Janeiro, v. 1, n. 2, p. 465-473, 1945.

${ }^{286}$ CRETELLA JÚNIOR, José. As categorias jurídicas e o direito público. Revista da Faculdade de Direito da USP, São Paulo, a. 62, n. 2, 1967.

${ }^{287}$ RETORTILLO, Sebastián. II diritto civile nella genesi del diritto amministrativo e dei suoi istituti. Rivista Trimestrale di Diritto Pubblico, Milano, a. 9, n. 4, p. 698-735, out.-dez. 1959.
} 
espécie paralela, No caso, a espécie é alçada à categoria de gênero; na verdade, pseudogênero.

Ao contrário, partindo-se do gênero - a categoria jurídica -, trabalhar-se-á com a matriz, com o molde, com o arquétipo, com a fórmula pura, com o modelo genérico, que se flexionará às modalidades peculiares aos diferentes ramos do Direito. ${ }^{288}$

Desse modo, poder-se-ia concluir que a edificação de características especiais do instituto em cada ramo do Direito não descaracterizaria o superconceito ao qual o mesmo se vincula, ${ }^{289}$ do que decorre que o contrato administrativo e o contrato de direito privado da Administração Pública, apesar de especialmente caracterizados, não deixam por isso de ser contratos.

Essa modulação especial da categoria jurídica contrato para adaptá-la ao direito administrativo se fia nas chamadas derrogações do regime privado pelo regime publicístico. Tais derrogações despertam críticas aos contratos da Administração Pública frente à presença das chamadas cláusulas exorbitantes, o que leva autores a questionar a natureza contratual de tal instituto, pelo suposto desrespeito à igualdade entre as partes e aos princípios gerais dos contratos bilateralidade, autonomia da vontade, força obrigatória e relatividade das disposições.

Nesse sentido, as lições clássicas de Otto Mayer e Fritz Fleiner não admitem a atuação da Administração Pública por contrato, uma vez que, na concepção própria daquele momento histórico, só se poderia falar em contrato numa situação em que ambas as partes contassem com a mesma força na relação jurídica. $^{290}$ Cabe destacar, porém, que os princípios que tradicionalmente liberalmente, talvez - regulam o sinalagma contratual vêm sendo derrogados

\footnotetext{
${ }^{288}$ CRETELLA JUNIOR, José. Dos contratos administrativos. Rio de Janeiro: Forense 1997. P. 39.

${ }^{289}$ DI PIETRO, Maria Sylvia Zanella. Ainda existem os chamados contratos administrativos? In: DI PIETRO, Maria Sylvia Zanella; RIBEIRO, Carlos Vinicius Alves (coords.). Supremacia do interesse público e outros temas relevantes do Direito administrativo. São Paulo: Atlas, 2010. P. 399/400.

${ }^{290}$ FLEINER, Fritz. Instituciones de derecho administrativo. Madrid: Labor, 1933. P. 168-169.

Nesse sentido, interessante o posicionamento de Oswaldo Aranha Bandeira de Mello, para quem os contratos administrativos constituiriam ato aministrativo unilateral modulado por convenções bilaterais acerca do equilíbrio econômico-financeiro aplicável (MELLO, Oswaldo Aranha Bandeira de. Princípios gerais de Direito administrativo. Rio de Janeiro: Forense, 1969. P. 668-672).
} 
inclusive nos contratos privados entre particulares, o que enfraquece em muito o seu potencial de caracterização da natureza contratual das relações. ${ }^{291}$

Assim, num primeiro momento pode-se estabelecer que a aproximação entre os regimes - a privatização do regime público e a publicização do direito privado, como abordadas no capítulo que se dedica ao fenômeno da "fuga para o direito privado" -, que acaba imprimindo aos contratos privados, por exemplo, deveres de boa fé e cumprimento da função social, ${ }^{292}$ reduz a importância desses fatores para a caracterização de um contrato como privado ou administrativo. A presença em um contrato de normas de busca pelo interesse público, como o dado exemplo do dever de cumprimento da função social, não é mais suficiente a descaracterizar o seu caráter privado, do mesmo modo que a adoção da categoria jurídica contrato - entendida por alguns, como visto, por ser originária do direito privado - não tem o condão de descaracterizar a natureza pública da atuação estatal.

Independentemente de tais discussões, o direito positivo brasileiro reconhece a natureza legitimamente contratual das avenças da Administração Pública, com as derrogações do regime publicístico, ${ }^{293}$ o que denota a caracterização do superconceito independentemente do ponto de vista do ramo específico. Carece-se, assim, de um critério que venha a, de fato, delimitar as fronteiras entre contrato privado e contrato administrativo.

Diante de tal cenário, faz-se oportuno expor que a distinção entre as espécies do gênero "contratos da administração" vem da tradição francesa, contemplando, de um lado, os "contratos administrativos" e, de outro, os "contratos de direito privado celebrados pela Administração Pública", ou "contratos

\footnotetext{
${ }^{291}$ DI PIETRO, Maria Sylvia Zanella. Ainda existem os chamados contratos administrativos? In: DI PIETRO, Maria Sylvia Zanella; RIBEIRO, Carlos Vinicius Alves (coords.). Supremacia do interesse público e outros temas relevantes do Direito administrativo. São Paulo: Atlas, 2010. P. 401-402/407408.

292 BORGES, Alice Gonzalez. Reflexos do Código Civil dos contratos administrativos. Revista Eletrônica de Direito Administrativo Econômico, Salvador, n. 9, fev.-abr. 2007.

${ }^{293}$ DI PIETRO, Maria Sylvia Zanella. Ainda existem os chamados contratos administrativos? In: DI PIETRO, Maria Sylvia Zanella; RIBEIRO, Carlos Vinicius Alves (coords.). Supremacia do interesse público e outros temas relevantes do Direito administrativo. São Paulo: Atlas, 2010. P. 402.
} 
semipúblicos", ${ }^{294}$ como preferem Medauar e Hely Lopes Meirelles. Tal distinção coaduna com o Direito positivo brasileiro - em especial a Lei nº 8.666/1993. ${ }^{295}$

No caso brasileiro poder-se-ia afirmar ser, por vezes, pouco instrumental ou até desnecessária a distinção, tendo em vista a unicidade de jurisdição - circunstância fundamentalmente diversa da francesa, donde surgiu a sua necessidade. ${ }^{296} \mathrm{O}$ pensamento de Vitor Rhein Schirato, como exemplo do aprofundado trato que se dá à matéria nesse campo, se direciona no sentido de uma "contratualidade plena a vincular Administração Pública e iniciativa privada". Assim, o contrato administrativo viria a ser interpretado de forma ampla, contemplando "a contratualidade hodierna da Administração Pública", ou seja, exercendo o papel de substituto da autoridade unilateral que outrora caracterizou como padrão a atuação administrativa. Esse entendimento tem por premissa o esvanecimento das necessidades a sustentar a adoção de cláusulas exorbitantes e de relacionalidade verticalizada na contratualidade administrativa. ${ }^{297}$

\footnotetext{
${ }^{294}$ MEDAUAR, Odete. Direito administrativo moderno. São Paulo: Revista dos Tribunais, 2015. P. 225.

295 ALMEIDA, Fernando Dias Menezes de. Teoria do contrato administrativo: Uma abordagem histórico-evolutiva com foco no Direito Brasileiro. 2010. Tese (Livre-docência em direito) Faculdade de Direito, Universidade de São Paulo, São Paulo, 2010. P. 224.

${ }^{296}$ ALMEIDA, Fernando Dias Menezes de. Teoria do contrato administrativo: Uma abordagem histórico-evolutiva com foco no Direito Brasileiro. 2010. Tese (Livre-docência em direito) Faculdade de Direito, Universidade de São Paulo, São Paulo, 2010. P. 225.

Veja-se que, no direito comunitário europeu, são amplos os debates acerca das normativas da União Europeia sobre os contratos públicos no sentido de homogeneizar, dentre os seus membros, o abandono das distinções próprias aos contratos administrativos. Nesse sentido:
}

MARTINS, Licínio Lopes. Empreitada de obras públicas: O modelo normativo do regime do contrato administrativo e do contrato público (em especial, o equilíbrio económico-financeiro). Coimbra: Almedina, 2015. Passim.

${ }^{297}$ SCHIRATO, Vitor Rhein. A interação entre Administração Pública e particulares nos contratos administrativos. Fórum de Contratação e Gestão Pública, Belo Horizonte, a. 12, n. 138, p. 51-69, jun. 2013.

De especial interesse é o entendimento do autor quanto ao cenário brasileiro, que dá azo às suas conclusões: "Ademais, quanto à contradição existente no Brasil na atualidade, procuro, com afinco, entender as razões, mas não logro êxito. Veja-se: quando o Estado age no mercado como comprador de bens e serviços, goza ele de prerrogativas exorbitantes e exerce para com os particulares relação de supremacia. Em sentido contrário, quando disciplina a prestação de um serviço público é coatado por normas que o aproximam dos particulares. E, de forma ainda mais paradoxal, quando maneja poderes soberanos típicos do Estado, equipara-se aos particulares, ou seja, a teoria dos contratos administrativos no Brasil, além de pouco consistente com a ordem constitucional, é aplicada aos casos errados, exatamente em relação aos quais o Estado deveria estar equiparado aos particulares. Parece-me claro que essa realidade se trata de um último suspiro da doutrina defensora da teoria francesa do contrato administrativo." 
No presente estudo, no entanto, a distinção entre contrato administrativo e contrato privado da administração ganha momento, sobretudo ao analisarmos as limitações adotadas por parte da literatura e da jurisprudência como condicionantes à adoção da transação extrajudicial pela Administração Pública, a que nos dedicamos no capítulo que trata dos desafios à receptividade ao modelo proposto.

Importantíssima é, nesse sentido, a lição de Franco Sobrinho, que faz interessantes ilações em torno da pertinência dos contratos de direito privado da Administração:

Na verdade, não existem leis-contratos, mas partes que fazem lei
entre si. É o contrato e não a lei que cria a relação jurídica. [...] a
Administração, ou o agente público, como partes integrantes de um
contrato, quando usam da liberdade de contratar, assim o fazem
num regime de competência, isto é, no uso permitido da função
administrativa pertinente [grifo nosso]. ${ }^{298}$

Assim, como Alessi destaca, um órgão estatal pode, além de exercer as prerrogativas inerentes à soberania, postar-se diante do particular na sua qualidade de pessoa jurídica, agindo assim em posição equiparada à dos sujeitos privados. ${ }^{299}$ É nessa qualidade que a Administração firma contratos de direito privado. Ocorre que, como já exposto em texto anterior, ao lançar mão de contratos privados o Estado se coloca em situação objetiva de nivelamento em relação ao particular, ${ }^{300}$ cabendo à Administração Pública, em tal cenário, atuar como se particular fosse, sem prejuízo da sua vinculação subjetiva à persecução de finalidades de interesse público. $^{301}$

Esse não é um entendimento recente em nosso direito administrativo, visto que já era reconhecido nas primeiras obras sobre este ramo aqui publicadas ainda no final do séc. XIX. Henrique do Rego Barros, em obra de 1874, já indicava os debates brasileiros sobre o conflito de competência entre a justiça comum e o

\footnotetext{
${ }^{298}$ FRANCO SOBRINHO, Manoel de Oliveira. Contratos administrativos. São Paulo: Saraiva, 1981. P. 43.

${ }^{299}$ ALESSI, Renato. Instituciones de derecho administrativo. Barcelona: Bosch, 1970. P. 212-219.

300 GREGO-SANTOS, Bruno. Nivelamento versus Igualdade: Aspectos subjetivo e objetivo do posicionamento da Administração Pública em relação ao particular. In: DI PIETRO, Maria Sylvia Zanella (org.). Direito Privado Administrativo. São Paulo: Atlas, 2013. P. 122-147.

${ }^{301}$ FRANCO SOBRINHO, Manoel de Oliveira. Contratos administrativos. São Paulo: Saraiva, 1981. P. 43.
} 
contencioso administrativo sobre causas relativas à utilização de figuras contratuais privadas pelo Estado, onde se entendia que "[q]uando o Estado funcciona como pessoa civil, contractando com um particular a respeito de um direito individual, sujeita-se como qualquer cidadão á lei privada, ao poder judiciario." ${ }^{302}$

É importante destacar ainda que, enquanto nos contratos administrativos - de natureza pública - o regime privatístico tem aplicação apenas subsidiária, em relação aos contratos privados celebrados pela Administração Pública verifica-se a presença do direito privado como regra, ${ }^{303}$ sendo gradualmente derrogado pelas normas aplicáveis do direito administrativo. ${ }^{304}$ Consideramos tal ilação essencial para a análise da posição da transação extrajudicial no ferramental contratualístico à disposição da Administração Pública e, de modo especial, para a oposição à tese de Onofre Alves Batista Júnior acerca do tema.

Atinge-se aqui estágio que permite formular uma afirmação essencial à análise da distinção tal como proposta: a Administração Pública pode, para a consecução de seu mister, lançar mão de contratos de direito privado celebrados com particulares, submetidos em regra ao regime privatístico derrogado, quando cabível, por normas do direito administrativo. No entanto, independentemente do grau de derrogação pública do regime privado de tais contratos, o interesse público - ou a consecução dos direitos fundamentais, como prefere relevante literatura -

302 BARROS, Henrique do Rego. Apontamentos sobre o contencioso administrativo e sobre os privilegios e prerogativas da administração nos contractos e transacções que celebra como poder publico. Rio de Janeiro: Laemmert, 1874. P. 71-90/278-294.

${ }^{303}$ A utilização do direito privado pela Administração Pública constitui, na visão de Giorgio Berti, uma antinomia de direito público relativa às suas fontes. Dessa antinomia decorreria a perda da superioridade hierárquica entre normas públicas e privadas para a atuação estatal, que levaria a um novo modelo de administração e de direito administrativo (BERTI, Giorgio. Le antinomie del diritto pubblico. Diritto Pubblico, Padova, a. 2, n. 2, p. 273-292, mai.-ago. 1996).

304 GRANZIERA, Maria Luiza Machado. Contratos Administrativos. São Paulo: Atlas, 2002. P. 98.

Podemos definir assim que o Direito administrativo é o conjunto de normas disciplinadoras da função administrativa e, desse modo, por sua autonomia, o Direito administrativo apresenta-se como o "Direito normal" da administração, enquanto o Direito privado é o seu "Direito excepcional" (BACELLAR FILHO, Romeu Felipe. Direito administrativo e o novo Código Civil. Belo Horizonte: Forum, 2007. P. 97-98). 
sempre será o bem jurídico que caracteriza a legitimidade da avença, prevalecendo, pois. ${ }^{305}$

De mesmo giro, pode-se sustentar ser vedado ao Estado, pelos mesmos motivos, derrogar o regime privatístico nos contratos privados da Administração Pública, a ponto de descaracterizá-los. Gaspar Ariño Ortiz - forte nas históricas lições de Vásquez de Menchaca e de Suárez, do final do séc. XVI, e de Alexander Hamilton no séc. XVIII - sustenta que o poder político não tem o condão de desfazer aquilo que restou estabelecido entre o príncipe e o seu súdito por instrumento do contrato cujas bases são buscadas no direito privado. Nesse sentido, nem poderia o soberano descumprir o regramento contratual, quanto menos uma nova lei, aplicável ao ente público, teria a faculdade de modificar o contrato privado previamente firmado. ${ }^{306}$

É dizer: com vistas à própria mantença da ordem pública de que o Estado se apropria como justificativa existencial, é defeso a este mesmo Estado, ao atuar pelos instrumentos outorgados aos particulares, descumprir as regras que ele mesmo estipulou.

Importantíssima é a lembrança de Cassese de que, em se tratando de acordos celebrados pela Administração Pública, aplicar-se-ão os princípios do direito civil em matéria de obrigações e contratos tanto quanto compatíveis disposição que está expressa, no direito administrativo italiano, em dispositivo específico da norma relativa aos processos administrativos. ${ }^{307}$

Assim, apesar das relevantíssimas razões que levam porção considerável da literatura a defender que se abandone a distinção entre contratos administrativos e contratos privados da Administração Pública, fato é que nosso

\footnotetext{
${ }^{305}$ A prevalência do interesse público, tal como aqui se pretende seja compreendida, não se confunde com a dita supremacia do interesse público, tal como enfrentado no capítulo que dedica aos desafios teóricos ao modelo proposto.

${ }^{306}$ ARIÑO ORTIZ, Gaspar. Lecciones de Administración y políticas públicas. Madrid: lustel, 2013. P. 508-510.

307 CASSESE, Sabino. Corso di Diritto Amministrativo: Istituzioni di Diritto Amministrativo. V. I. Milano: Giuffrè, 2004. P. 223.

Especifica o autor: “E un'indicazione importante: in via generale (per esempio, ai fini dell'interpretazione o in caso di inadempimento di una delle parti) si applicano le regole del contratto e non quelle del provvedimento amministrativo".
} 
ordenamento Ihes impõe regimes jurídicos diversos, tal como destaca Fernando Dias Menezes de Almeida. ${ }^{308}$ Nesse sentido, a diversidade de regime jurídico impende à diversidade de tratamento, tal como sustenta Marçal Justen Filho ao referir-se a um regime próprio para os contratos de concessão de serviço público:

O argumento fundamental a favor da distinção entre diferentes espécies de contratos administrativos reside, portanto, na diversidade do regime jurídico aplicável.

[...] É necessário efetivar a distinção entre as diferentes espécies de contratos administrativos porque inúmeras regras não são uniformemente aplicáveis a todas elas. O regime jurídico característico dos contratos administrativos propriamente ditos não é integralmente aplicável aos contratos privados da Administração Pública. Quanto a esses, produz-se um regime jurídico especial, que conjuga ora os postulados originais do Direito Privado, ora as regras do Direito Público. ${ }^{309}$

Posicionando-nos, pois, pela pertinência da distinção entre contratos administrativos e contratos privados da Administração - como espécies do gênero contrato da Administração -, passa-se à análise dos posicionamentos eleitos como os mais relevantes para a apuração do dístico essencial, do marco diferencial decisivo, para a caracterização do contrato administrativo, o que nos permitirá, por eliminação, delimitar o campo próprio à caracterização dos contratos privados da Administração.

No cenário estrangeiro destacam-se, dentre vários, três modelos para a diferenciação entre contratos administrativos e contratos privados da administração: o francês adota a possibilidade de contratos da Administração com cláusulas exorbitantes; ${ }^{310}$ o alemão e o italiano só admitem a firmatura de contrato

\footnotetext{
${ }^{308}$ ALMEIDA, Fernando Dias Menezes de. Mecanismos de consenso no direito administrativo. In: ARAGÃO, Alexandre Santos de; MARQUES NETO, Floriano de Azevedo. Direito administrativo e seus novos paradigmas. Belo Horizonte: Fórum, 2008. P. 345.

309 JUSTEN FILHO, Marçal. Teoria geral das concessões de serviço público. São Paulo: Dialética, 2003. P. 158.

${ }^{310}$ A íntima relação que é conferida ao trinômio interesse público-contrato administrativo-cláusulas exorbitantes é presente tanto na literatura nacional quanto estrangeira: "Dal quadro interpretativo analizzato si evince che gli interessi dei partecipanti alle procedure ad evidenza pubblica siano a lungo tempo letti come mero riflesso dell'interesse pubblico per la cui esclusiva tutela sarebbero state poste le norme disciplinanti le forme contrattuali e i metodi di scelta del contraente. La predominanza del momento pubblicistico è altresì percepibile dalla presenza di profili di specialità nella regolazione dei contratti pubblici, che, sebbene formalmente assoggettati al regime di diritto privato, sono sistematicamente caratterizzati da clausole esorbitanti, esprimenti la tendenza del legislatore a privilegiare gli interessi della stazione appaltante nella esecuzione del contratto e nella regolazione degli aspetti economico-patrimoniali del rapporto" (AZZARITI, Antonella. I principi
} 
em posições de igualdade, devendo disposições exorbitantes ser veiculadas por meio de outra espécie de ato; e o do sistema da common law que, apesar do discurso de um regime único, contempla o reconhecimento de prerrogativas da Administração e, inclusive, um sistema de solução de controvérsias aparte do sistema judicial. ${ }^{311}$

Ao buscar traduzir o "enigma do contrato administrativo", Gaspar Ariño Ortiz destaca que, mesmo em países cujos ordenamentos jurídicos não reconhecem a existência da figura do contrato administrativo - a exemplo da Alemanha, Grã-Bretanha, Itália e Estados Unidos da América -, os "contratos de Estado" são repletos de particularidades, de exceções ao direito comum, seja por sua composição peculiar, seja ainda pela "projeção, sobre o contrato, de um conjunto de privilégios subjetivos que acompanham sempre o Estado". 312

Jean Rivero sintetiza, com propriedade, as categorias gerais em que se distribuem as diversas opiniões acerca da distinção entre contratos administrativos e contratos privados da Administração. Alguns critérios são de cunho subjetivo, relacionados com as partes que figuram no contrato, sendo possível que o contrato seja administrativo caso uma das partes seja pessoa estatal. Outros critérios são de cunho objetivo, podendo ser considerado administrativo o contrato que tenha por objeto atividade de competência administrativa, relacionada à consecução de serviços públicos. Por fim, há os critérios relacionados às cláusulas do contrato, podendo ser considerados administrativos os contratos que contem com as chamadas cláusulas exorbitantes. No pensamento de Rivero, o primeiro critério é insuficiente, e os demais são relativos, só sendo possível caracterizar-se o contrato

generali in materia di affidamento dei contratti pubblici. 2007. Tese (Doutorado em Direito Público orient. Prof. Girolamo Sciullo) - Università degli Studi di Bologna, Bolonha. 2007. P. 33).

${ }^{311}$ DI PIETRO, Maria Sylvia Zanella. Ainda existem os chamados contratos administrativos? In: DI PIETRO, Maria Sylvia Zanella; RIBEIRO, Carlos Vinicius Alves (coords.). Supremacia do interesse público e outros temas relevantes do Direito administrativo. São Paulo: Atlas, 2010. P. 403-406.

No mesmo sentido:

ESTORNINHO, Maria João. Algumas questões de contencioso dos contratos da Administração Pública. Cadernos de Ciência da Legislação, Lisboa, n. 15, p. 18-44, jan.-mar. 1996.

${ }^{312}$ ARIÑO ORTIZ, Gaspar. Lecciones de Administración y políticas públicas. Madrid: lustel, 2013. P. 506-526. Tradução nossa. 
administrativo com a combinação entre o primeiro critério e ao menos um dos demais. $^{313}$

Maria João Estorninho sistematiza os diversos critérios presentes na literatura para fixar seu entendimento. Classificando os critérios distintivos entre substanciais e formais, inclui dentre os primeiros os critérios que tomam por base o conteúdo dos contratos para apurar a publicidade de sua natureza jurídica, o que abrangeria: o critério orgânico-subjetivo, relativo à natureza das partes; o critério da prossecução do fim de de interesse público; o critério objetivo, abrangendo a relação do objeto contratual com serviço público; o critério da presença de cláusulas exorbitantes; e o critério da relação jurídica de natureza publicística. Já dentre os critérios formais, baseados na análise do regramento jurídico aplicável à figura, compreender-se-iam: o critério da exigência de formalidades especiais; o critério estatutário; e o critério da distribuição de competência jurisdicional. ${ }^{314}$

Após a apreciação de cada um dos critérios expostos - dentre si, mais ou menos relevantes -, Maria João Estorninho acaba por fixar entendimento, refletido inclusive em obras posteriores, ${ }^{315}$ em favor da prevalência do critério substantivo da prossecução de fins de interesse público para caracterizar os contratos propriamente administrativos, sujeitos ao regime publicístico.

Para Sérvulo Correia, o que distingue o ato administrativo do contrato administrativo é o papel da manifestação de vontade do administrado na sua constituição. Enquanto no ato administrativo a manifestação de vontade do administrado "apenas constitui requisito de legalidade ou de eficácia", no contrato administrativo a manifestação de vontade do particular, no plano estrutural, surge como requisito de existência. ${ }^{316}$

\footnotetext{
${ }^{313}$ RIVERO, Jean. Droit administratif. Paris: Dalloz, 1975. P. 132-137.

${ }^{314}$ ESTORNINHO, Maria João. Réquiem pelo contrato administrativo. Coimbra: Almedina, 2003. P. 71-81.

315 ESTORNINHO, Maria João. Direito europeu dos contratos públicos: um olhar português. Coimbra: Almedina, 2006. P. 317.

316 CORREIA, José Manuel Sérvulo. Legalidade e autonomia contratual nos contratos administrativos. Coimbra: Almedina, 1987. P. 773-775.
} 
Já para distinguir os contratos administrativos dos demais contratos da Administração, Sérvulo Correia entende por ser insuficiente o critério da sujeição. Expõe o autor que

[a] hodierna aproximação entre o Direito Público e o Direito Privado e a indefinição que persiste na demarcação de algumas das suas áreas confinantes contraindica o emprego isolado do objecto mediato do contracto - sobretudo das prestações - para estabelecer a partir dele a qualificação separadora. ${ }^{317}$

Com tal posicionamento, Sérvulo Correia acaba por afastar o critério do "fim de imediata utilidade pública" como critério único de qualificação do contrato como administrativo, apesar de reconhecer que a prossecução direta do fim de interesse público constitui "o critério distintivo lógico nos casos em que a lei ou a prática hajam definido um tipo de contrato com modalidades paralelas de direito administrativo e de direito privado". 318

Após tais reflexões, o autor acaba por definir que o critério estatutário é o mais adequado para a classificação de um contrato da Administração como contrato administrativo. Assim, considerar-se-ão administrativos os contratos da Administração que se submetam a um processo próprio de agir estatal, constante de normas estatutárias da Administração. ${ }^{319}$

Com base no mesmo critério estatutário, Marcello Caetano analisa a enumeração normativa portuguesa dos contratos administrativos e delineia um eixo central comum a todos eles, composto por três elementos: a participação subjetiva

\footnotetext{
317 CORREIA, José Manuel Sérvulo. Legalidade e autonomia contratual nos contratos administrativos. Coimbra: Almedina, 1987. P. 774.

318 CORREIA, José Manuel Sérvulo. Legalidade e autonomia contratual nos contratos administrativos. Coimbra: Almedina, 1987. P. 773-775.

${ }^{319}$ Nas precisas palavras do professor português: "O critério básico de qualificação dos contratos como administrativos é aquele que assenta na natureza estatutária do Direito Administrativo. À sua luz, devem considerar-se contratos administrativos os que constituem um processo próprio de agir da Administração e que criam, modificam ou extinguem relações jurídicas, disciplinadas em termos específicos do sujeito administrativo. No caso concreto, o autor da qualificação deverá atender primeiramente aos efeitos de direito pactuados pelas partes. Da natureza destes, resulta a definição das normas jurídicas directamente aplicáveis, Se se tratar de normas estatutárias da Administração, o contrato é administrativo. Da qualificação do contrato como administrativo resulta por sua vez a aplicação de outras normas estatutárias da Administração que abrangem aspectos do regime contratual que as partes não tenham regulado expressamente e das quais resultam efeitos de direito não pactuados" (CORREIA, José Manuel Sérvulo. Legalidade e autonomia contratual nos contratos administrativos. Coimbra: Almedina, 1987. P. 773-775).
} 
de ente de direito público; a assunção objetiva de fim administrativo; e um fator relacional consiste na associação duradoura e especial da contraparte à realização dos fins públicos do ente contratante. ${ }^{320}$

O terceiro elemento de Marcello Caetano, apesar de corresponder à metodologia de ciência do direito administrativo por si defendida, ${ }^{321}$ acaba por conferir uma importância considerável ao posicionamento da contraparte contratual da qual discordamos. Apesar de termos como importantíssima essa adesão da contraparte privada à realização da missão institucional do Estado, entendemos que o eventual descolamento da parte privada em relação a esse mister especial não tem o condão de descaracterizar a "administratividade" do contrato. Esse fenômeno pode ser observado ao analisarmos, em sentido inverso, que a presença do ente estatal como parte de um contrato privado não descaracteriza este qualificativo, senão pelas derrogações eventualmente impostas.

Giorgio Oppo é preciso em delimitar quais são os efeitos da presença de um ente público como parte em um contrato privado. Para o autor, como em todos os atos da Administração Pública, o contrato privado firmado por esta não pode dissociar-se do interesse público; diversa é, no entanto, a incidência dessa vinculação sobre a posição das partes, sobre o modo de formação do contrato e sobre o direito aplicável à avença. ${ }^{322}$

\footnotetext{
${ }^{320}$ CAETANO, Marcello. Manual de direito administrativo. Coimbra: Coimbra Editora, 1951. P. 274.

${ }^{321}$ Em extensa exposição, Marcello Caetano defende a racionalização do método de investigação do direito administrativo, criticando os métodos meramente exegéticos, casuísticos e positivistas. Por meio da razão é que o cultor do direito administrativo poderá buscar a justiça, por meio do equilíbrio de interesses e da busca do bem comum. Essa racionalização se organizaria em etapas, com a determinação do direito positivo aplicável, a extração da sua dogmática genética e formação histórica, e a apreciação crítica do resultado dessa análise. O método de direito administrativo de Marcello Caetano envolveria, assim, as faces de conhecimento sistemático, conhecimento genético e conhecimento crítico (CAETANO, Marcello. Manual de direito administrativo. Coimbra: Coimbra Editora, 1951. P. 32-61).

O método da ciência do Direito administrativo assim definido por Marcello Caetano foi denominado de "jusnaturalismo racionalista" por Sérvulo Correia, e acabou posteriormente por ser negado em sua neutralidade pela Escola de Coimbra, no que foi liderada por Afonso Queiró e Rogério Ernhardt Soares (FONSECA, Rui Guerra da. Identificações metodológicas da doutrina jusadministrativa portuguesa na parte central do séc. XX: Marcello Caetano, José Carlos Moreira, Armando Marques Guedes e Afonso Queiró. In: FACULDADE de Direito da Universidade de Lisboa. Estudos em homenagem ao Prof. Doutor Sérvulo Correia. V. II. Coimbra: Coimbra Editora, 2010. P. 1.127-1.145).

322 OPPO, Giorgio. Diritto privato e interessi pubblici. Studi Economico-Giuridici, Napoli, v. 55, p. 421-446, 1993-1994.
} 
Nesse sentido, a diferença de "força" entre as partes não descaracterizaria as posições adotadas contratualmente no direito privado, uma vez que, mesmo nas relações entre particulares - como nas relações de consumo e trabalho -, pode haver diferenças entre as partes. Da mesma forma, a necessidade de um procedimento administrativo próprio para a firmatura de um contrato pela Administração pode repetir-se também, com as devidas adaptações, na esfera privada, além de ser crescente a importância dos próprios particulares como partes e até autores de procedimentos administrativos. Por sua vez, a presença da Administração como parte no contrato não altera a natureza privada do direito que lhe seja aplicável, ainda que com as derrogações próprias do direito administrativo. ${ }^{323}$

O posicionamento de Marcello Caetano conta, no entanto, com uma fórmula decorrente deste terceiro elemento que ressoa nos escritos de inúmeros administrativistas que o sucederam, inclusive no Brasil: para o autor, esse elemento implicaria em "uma especial cláusula de sujeição do contratante particular ao interesse público", que não desequilibraria a relação, uma vez que o contratante público estaria igualmente vinculado ao mesmo fim. ${ }^{324}$

Marcello Caetano assim formula o critério distintivo por si eleito:

O que há de característico no contrato administrativo é a sujeição especial do particular ao interesse público traduzida no dever de acatamento, durante a respectiva execução, às leis, regulamentos e actos administrativos que alterem as suas condições jurídicas e técnicas de carácter circunstancial (não essencial), desde que seja mantido o princípio da colaboração livre e remunerada [grifos do autor]. ${ }^{325}$

Em peculiar posicionamento, Ariño Ortiz elege como elemento essencial de diferenciação entre o contrato administrativo e o contrato privado da Administração "a importância política do setor, a operação ou atividade de que se trate e a especial proteção que este demande". Justifica tal posicionamento expondo que, em determinados momentos históricos, setores politicamente

\footnotetext{
${ }^{323}$ OPPO, Giorgio. Diritto privato e interessi pubblici. Studi Economico-Giuridici, Napoli, v. 55, p. 421-446, 1993-1994.

${ }^{324}$ CAETANO, Marcello. Manual de direito administrativo. Coimbra: Coimbra Editora, 1951. P. 275.

${ }^{325}$ CAETANO, Marcello. Manual de direito administrativo. Coimbra: Coimbra Editora, 1951. P. 276.
} 
importantes da atuação estatal foram "protegidos" do regramento privado pela sua caracterização como contratos administrativos, a exemplo das obras e serviços públicos desde meados do séc. XIX. Entende, nesse sentido, por ser inútil pretender determinar a essência do contrato administrativo em abstrato. ${ }^{326}$

No cenário brasileiro inúmeros autores se destacam na eleição de critérios distintivos entre os contratos administrativos e os contratos privados da administração. Opta-se, no entanto, pela apreciação dialógica entre os posicionamentos de Fernando Dias Menezes de Almeida e de Marçal Justen Filho, tendo a seleção como critério especial o tratamento que estes autores dão ao direito positivo brasileiro. À evidência, o direito positivo ${ }^{327}$ não é o principal foco da investigação teórica proposta, em especial pelo entendimento delineado adiante, acercados desafios relacionados à legalidade administrativa; cabe destacar, no entanto, que o tratamento dispensado ao direito positivo acaba por permitir conclusões teóricas essenciais ao presente estudo.

Veja-se que, por exemplo, que o art. 62 , § $3^{\circ}$, da Lei n ${ }^{\circ} 8.666 / 1993$ acaba por impor regras publicísticas gerais aos contratos de direito privado da Administração, enquanto o art. 54 da mesma Lei dá margem à aplicação do direito privado nos contratos administrativos.

No primeiro caso - do art. 62 , $\S 3^{\circ}$, da Lei n $8.666 / 1993-$, a disposição de aplicação das normas especiais dos contratos administrativos aos contratos de direito privado da Administração "no que couber" traz, na visão de Menezes de Almeida, forte carga contraditória. É dizer, se predomina o direito privado em certo contrato, não haveria cabimento de qualquer margem para normas publicísticas; de outro giro, se são aplicadas as normas gerais publicísticas, não haveria que se falar

\footnotetext{
${ }^{326}$ ARIÑO ORTIZ, Gaspar. Lecciones de Administración y políticas públicas. Madrid: lustel, 2013. P. 519-521.

Em uma feliz expressão, Ariño Ortiz sustenta que o contrato administrativo não é uma "essência", mas sim uma "existência".

${ }^{327}$ Destaque-se, nesse particular, o entendimento de Vitor Rhein Schirato, para quem o contrato administrativo, no direito administrativo brasileiro, não encontra fundamento constitucional, mas tão somente legal. (SCHIRATO, Vitor Rhein. A interação entre Administração Pública e particulares nos contratos administrativos. Fórum de Contratação e Gestão Pública, Belo Horizonte, a. 12, n. 138, p. 51-69, jun. 2013.)
} 
em contrato de direito privado. ${ }^{328}$ Nesse sentido, para Odete Medauar, a referida disposição acaba por "publicizar" os contratos privados da Administração. ${ }^{329}$

Já Justen Filho propõe a distinção de regimes conforme a finalidade público-coletiva ou não da avença, ou com o seu grau de vinculação à satisfação dos interesses fundamentais, ${ }^{330}$ hipótese de difícil discernimento frente à necessária posição de promoção do interesse público em toda atuação da Administração.

Já na segunda hipótese - acerca da permissão de aplicação "[d]os princípios da teoria geral dos contratos e [d]as disposições de direito privado" aos contratos administrativos -, entende Menezes de Almeida que, apesar de prever a Lei a aplicação de normas contratuais gerais de direito privado nos contratos administrativos, vê-se que o regime da Lei de Licitações e Contratos Administrativos é tão detalhado que não resta margem normativa para as normas privatísticas, de que decorre o fato de pouco restar a dizer sobre existirem verdadeiros contratos de direito privado celebrados pela Administração Pública. ${ }^{331}$

Ressaltamos, no entanto, que mesmo em alguns poucos aspectos a adoção de instrumentos de direito privado pode distanciar substancialmente os contratos privados da Administração dos contratos administrativos. Nesse sentido, é interessante o posicionamento de Justen Filho ao sustentar que a garantia de adoção do regime privado insculpida no $\S 3^{\circ}$ do art. 62 da Lei $n^{\circ} 8.666 / 1993$ vem em defesa da própria viabilidade da atividade econômica do particular - a exemplo

${ }^{328}$ ALMEIDA, Fernando Dias Menezes de. Teoria do contrato administrativo: Uma abordagem histórico-evolutiva com foco no Direito Brasileiro. 2010. Tese (Livre-docência em direito) Faculdade de Direito, Universidade de São Paulo, São Paulo, 2010. P. 224-226.

${ }^{329}$ MEDAUAR, Odete. Direito administrativo moderno. São Paulo: Revista dos Tribunais, 2015. P. 235.

330 JUSTEN FILHO, Marçal. Comentários à Lei de licitações e contratos administrativos. São Paulo: Revista dos Tribunais, 2014. P. 989-994.

${ }^{331}$ ALMEIDA, Fernando Dias Menezes de. Teoria do contrato administrativo: Uma abordagem histórico-evolutiva com foco no Direito Brasileiro. 2010. Tese (Livre-docência em direito) Faculdade de Direito, Universidade de São Paulo, São Paulo, 2010. P. 226-227. 
das atividades de seguro, de financiamento e de locação de imóveis - o que exige a existência de um mínimo de condições "de mercado". 332

Tal problematização nos leva, ainda, a verificar que a aplicação da maior parte das regras indicadas na Lei de Licitações e Contratos Administrativos aos contratos privados da Administração não gera incompatibilidades de regime, como destaca Justen Filho, uma vez que em sua maior parte "disciplinam requisitos de forma na contratação"; o problema residiria, de fato, "nas prerrogativas unilaterais asseguradas à Administração Pública”. ${ }^{333}$

Atuando na consecução de sua missão de representação da coletividade, a Administração Pública está constantemente imbuída da persecução ao interesse público, do que decorre sustentarem alguns autores a posição de superioridade que se the confere em suas relações com os particulares. A presença do Estado como contratante, na busca pela realização do interesse público, faz com que o regime geral de contratos seja derrogado por normas do direito administrativo, o que dá origem a cláusulas exorbitantes ${ }^{334}$ nos contratos, que os "publicizam" ${ }^{335}$ para adequá-los à presença do Estado como parte, conferindo-lhe o "caráter administrativo". ${ }^{336}$

Assim, define o Conselho de Estado Francês a cláusula exorbitante como "[...] cláusula que tem por objeto conferir às partes direitos, ou incumbir-lhes de obrigações, estranhas por sua natureza àquelas que são suscetíveis de ser livremente pactuadas de acordo com a legislação civil e comercial". ${ }^{337}$ As cláusulas

\footnotetext{
332 JUSTEN FILHO, Marçal. Comentários à Lei de licitações e contratos administrativos. São Paulo: Revista dos Tribunais, 2014. P. 992.

333 JUSTEN FILHO, Marçal. Comentários à Lei de licitações e contratos administrativos. São Paulo: Revista dos Tribunais, 2014. P. 993.

${ }^{334}$ De acordo com a origem da derrogação do regime privatístico - seja ela decorrente da própria condição estatutária da Administração (aplicável, portanto, independentemente de previsão contratual ou, em casos como o norteamericano, dispensando inclusive previsão legal) ou derive da natureza inerente da atuação estatal (confundindo-se assim com atos soberanos, fatos do príncipe, de influência indireta sobre a avença) - a exorbitância pode ser tida como interna (ou direta) ou externa (ou indireta) (GIACOMUZZI, José Guilherme. Estado e contrato: Supremacia do interesse público versus igualdade. São Paulo: Malheiros, 2011. P. 45-55.).

${ }^{335}$ CRETELLA JUNIOR, José. Dos contratos administrativos. Rio de Janeiro: Forense 1997.P. 3536.

${ }^{336}$ VEDEL, Georges. Droit administratif. Paris: Presses Universitaires de France, 1984. P. 372.

${ }^{337}$ RICHER, Laurant. Les contrats administratifs. Paris: Dalloz, 1991. P. 23.
} 
exorbitantes ou derrogatórias, deste modo, presentes em maior ou menor medida nos contratos administrativos,

[...] não seriam lícitas num contrato privado, porque desigualariam as partes na execução do avençado, mas são absolutamente válidas no contrato administrativo, uma vez que decorrem da lei ou dos princípios que regem a atividade administrativa, já que visam a estabelecer prerrogativas em favor de uma das partes para o perfeito atendimento do interesse público, que se sobrepõe sempre aos interesses dos particulares. ${ }^{338}$

Ocorre que a natureza contratual, sinalagmática, das avenças privadas tem como característica a presença das partes em um mesmo plano, um mesmo nível de posicionamento. ${ }^{339}$ No entanto, o ordenamento jurídico brasileiro prevê dispositivos que asseguram as prerrogativas e sujeições estatais mesmo quando adotados institutos de direito privado, fazendo com que a simples presença de

${ }^{338}$ MEIRELLES, Hely Lopes. Licitação e contrato administrativo. São Paulo: Malheiros, 1990. P. 162.

${ }^{339}$ Observe-se, no entanto, que o desnivelamento entre partes é hoje característica frequente de alguns contratos firmados exclusivamente entre particulares, o que faz com que a presença de cláusulas exorbitantes não seja, por si só, suficiente à caracterização de um contrato como administrativo (FRANCO SOBRINHO, Manoel de Oliveira. Contratos administrativos. São Paulo: Saraiva, 1981. P. 151-156.).

É o que ocorre, por exemplo, em contratos de elevado caráter protetivo ou coletivista, como as avenças consumeristas ou a função social dos contratos sobre a propriedade que, apesar de contarem com verdadeiras cláusulas exorbitantes, de natureza publicística, não se caracterizam como contratos da Administração.

Trata-se do fenômeno de "socialização" ou "publicização" do direito privado - como, por exemplo, pela limitação dos direitos individuais pela sua função social - ocorrida desde a constituição mexicana de 1917 e a constituição de Weimar de 1919, em paralelo à "privatização" do Direito público decorrente da atuação estatal no mercado, utilizando-se de instrumentos e institutos privados (MERRYMAN, John Henry; PÉREZ-PERDOMO, Rogelio. The Civil Law tradition: An introduction to the legal systems of Europe and Latin America. Stanford: Stanford University Press, 2007. P. 96.).

Como destaca Richer:

[...] il arrive fréquemment que les clauses des contrats administratifs soient identiques à celles de contrats entre particuliers. [...] Inversement, d'ailleurs,il est parfaitement loisible à des particuliers d'introduire dans leurs conventions des clauses rappelant celles des contrats administratifs, inusuelles em droit privé sans y être pour autant illégales, ou de recourir à des procédures de mise en concurrence semblables à celles utilisées pour les marchés publics. (RICHER, Laurant. Les contrats administratifs. Paris: Dalloz, 1991. P. 6.). 
cláusulas exorbitantes ${ }^{340}$ em geral seja insuficiente para caracterizar o contrato administrativo. ${ }^{341}$

A obra de Menezes de Almeida se destaca, nesse diálogo, pelo seminal entendimento que edifica em torno do dístico essencial do contrato administrativo. Após extensa ilação em torno da importação do direito administrativo francês em matéria de contratos administrativos - cenário em que se destacam os contratos de concessão de serviços públicos como exemplo da instrumentalidade das prerrogativas contratuais para que o Estado lançasse mão da contratualização com os particulares garantindo a mantença de suas prerrogativas -, o autor analisa em detalhes as diversas opiniões sobre o tema, concluindo que, no direito brasileiro, prevaleceria a distinção orgânica sobre o critério material para a diferenciação entre os contratos administrativos e os contratos privados da Administração. ${ }^{342}$

É curioso destacar, no entanto, que o autor se posiciona - em mais de uma oportunidade, inclusive - contrário à própria existência de uma distinção entre contratos administrativos e contratos da administração, sustentando que, tal como sugere Duguit, dever-se-ia abolir tal distinção para falar-se tão somente em contratos. ${ }^{343}$ Nesse sentido, Menezes de Almeida se posiciona no sentido de que um regime de prerrogativas especiais nos contratos administrativos serviria tão somente de instrumento de estímulo à ineficiência estatal, de geração de contratos com equação de custos mais onerosa, de legitimação de práticas autoritárias dos

${ }_{340}^{340 a n t o ~ a ̀ ~ c a r g a ~ s i m b o ́ l i c a ~ d a ~ e x p r e s s a ̃ o ~ " c l a ́ u s u l a s ~ e x o r b i t a n t e s " ~ e ~ o ~ s e u ~ p o t e n c i a l ~ a b a n d o n o, ~}$ veja-se:

MOREIRA NETO, Diogo de Figueiredo. O futuro das cláusulas exorbitantes nos contratos administrativos. In: ARAGÃO, Alexandre Santos de; MARQUES NETO, Floriano de Azevedo. Direito administrativo e seus novos paradigmas. Belo Horizonte: Fórum, 2008. P. 571-592.

${ }^{341}$ Cabe ressaltar, no entanto, que enquanto nos contratos administrativos as prerrogativas e limites decorrem da própria natureza do agente, nos contratos privados da Administração tais balizas exigem expressa disposição legal para sua vigência, em homenagem ao princípio da legalidade (DI PIETRO, Maria Sylvia Zanella. Do Direito privado na Administração Pública. São Paulo: Atlas, 1989. P. 95-97).

${ }^{342}$ ALMEIDA, Fernando Dias Menezes de. Teoria do contrato administrativo: Uma abordagem histórico-evolutiva com foco no Direito Brasileiro. 2010. Tese (Livre-docência em direito) Faculdade de Direito, Universidade de São Paulo, São Paulo, 2010. P. 224-227.

${ }^{343}$ ALMEIDA, Fernando Dias Menezes de. Mecanismos de consenso no direito administrativo. In: ARAGÃO, Alexandre Santos de; MARQUES NETO, Floriano de Azevedo. Direito administrativo e seus novos paradigmas. Belo Horizonte: Fórum, 2008. P. 343-344. 
governantes e de facilitação de desvios decorrentes da improbidade administrativa nos contratos. ${ }^{344}$

Menezes de Almeida tece uma conclusão, no entanto, que demonstra o caráter também empírico do estudo que empreende, uma vez que reconhece que, "[t]odavia, posto que o ordenamento jurídico brasileiro acolheu as tais cláusulas exorbitantes, caracterizadores de um regime especial dos contratos administrativos, é preciso interpretá-las de modo coerente com o contexto constitucional de um Estado que se pretende democrático e de Direito". 345

Nesse sentido, atendo-nos ao critério material aqui buscado, o pensamento de Menezes de Almeida permite-nos se posicionar, afinal, com a definição da autoexecutoriedade como o dístico essencial do contrato administrativo - em expressa referência à obra de Duguit e Kelsen acerca da distinção entre Direito público e privado -, no sentido em que o "aspecto das prerrogativas de auto-executoriedade, seria, em tese, a única diferença que se pode notar em termos de regime jurídico de execução entre contrato administrativo e contrato privado da Administração". ${ }^{346}$

Esse elemento reflete a compreensão contemporânea da legalidade, ligando a ação do Estado à ação do Direito e, assim, posiciona-se no sentido de que somente nos contratos administrativos contaria a Administração com a prerrogativa de autoexecutoriedade. O posicionamento de Menezes de Almeida corrigiria, assim, os problemas da adoção das cláusulas exorbitantes como indicativo da publicidade do contrato, ao eleger a autoexecutoriedade como a cláusula exorbitante que estaria presente exclusivamente nos contratos

${ }^{344}$ ALMEIDA, Fernando Dias Menezes de. Mecanismos de consenso no direito administrativo. In: ARAGÃO, Alexandre Santos de; MARQUES NETO, Floriano de Azevedo. Direito administrativo e seus novos paradigmas. Belo Horizonte: Fórum, 2008. P. 344.

${ }^{345}$ ALMEIDA, Fernando Dias Menezes de. Mecanismos de consenso no direito administrativo. In: ARAGÃO, Alexandre Santos de; MARQUES NETO, Floriano de Azevedo. Direito administrativo e seus novos paradigmas. Belo Horizonte: Fórum, 2008. P. 345.

${ }^{346}$ ALMEIDA, Fernando Dias Menezes de. Teoria do contrato administrativo: Uma abordagem histórico-evolutiva com foco no Direito Brasileiro. 2010. Tese (Livre-docência em direito) Faculdade de Direito, Universidade de São Paulo, São Paulo, 2010. P. 226-227.

Menezes de Almeida reforça a sua ressalva: "É diferença verdadeira, mas talvez leve a que permaneça nos ditos contratos privados da Administração grau demasiado restrito de 'regime privatístico', para que se justifique a distinção das espécies de contratos da Administração no regime brasileiro vigente". 
administrativos, e nunca nos contratos privados da Administração, por força do direito positivo, ainda que essa não seja a melhor solução frente à sua dogmática.

Ressalvamos que a nossa posição é no sentido de extrair o conteúdo material do posicionamento de Menezes de Almeida, e não o interpretar. Tem-se a plena ciência de que o seu posicionamento original é pela impertinência da distinção e, caso esta seja reconhecida, que o critério orgânico prevaleceria. No entanto, a busca por um critério material aqui empreendida se apoia justamente no entendimento de Menezes de Almeida acerca do tema, o que nos permite a eleição de um elemento seguro para a distinção objetiva entre os contratos administrativos e os contratos privados da administração.

O cenário aqui delineado permite, enfim, proceder com a edificação de tese acerca da natureza jurídica da transação extrajudicial entabulada pela Administração Pública no direito administrativo brasileiro, em exercício a que se dedica o capítulo seguinte, concluindo a primeira parte do estudo.

\subsubsection{Nossa posição}

Expostos os posicionamentos na literatura acerca do critério distintivo entre contratos administrativos e contratos privados da Administração, e sobre a natureza jurídica da transação extrajudicial que tenha como parte um ente estatal, é chegado o ponto de formular entendimento original sobre o tema proposto.

Esta providência é necessária pois, como a extensa exposição realizada faz transparecer e restará demonstrado adiante, os diversos posicionamentos acerca da natureza jurídica da transação extrajudicial na administração pública carecem de substância a suficientemente traduzir o cenário constante do direito administrativo brasileiro. Nesse sentido, o texto passa a, com base na eleição dos critérios distintivos do contrato administrativo, tecer tese acerca da natureza jurídica do instituto que lhe serve de objeto.

Nesse exercício, busca-se a aplicação da "navalha de Ockham" para reduzir a análise da natureza jurídica da transação extrajudicial na administração 
pública aos seus elementos essenciais, evitando assim incursionar em áreas que, apesar de interessantes, não sejam decisivas para a sua adequada definição. ${ }^{347}$

Quanto à eleição de um dístico fundamental a caracterizar o contrato administrativo, adotamos por premissa, pelos fundamentos expostos no tópico anterior, a possibilidade do manejo de figuras contratuais pela Administração Pública, bem como a pertinência da distinção entre os contratos administrativos e os contratos privados da Administração.

Para que a transação extrajudicial possa dar vazão a toda a sua potencialidade na consecução do interesse público, é essencial que o seu manejo se dê contemplando todas as qualidades do instituto que, intrinsecamente, decorrem de sua natureza privatística. Ainda, consideramos ser possível sustentar que não há perspectiva, no atual horizonte de transformações do direito administrativo, de consolidação majoritária de literatura que postule, no cenário brasileiro, a submissão de todos os contratos entabulados pela Administração Pública a um regime essencialmente privado. Concluímos, pois - em uma antecipação parcial do entendimento edificado ao final desse tópico -, que a distinção entre contratos administrativos e contratos privados da administração é essencial para a própria viabilidade da transação que tenha como parte ente estatal.

É dizer, caso a consubstanciação entre contrato administrativo e contrato privado da Administração não trouxesse consequências outras que não a sua nomenclatura, não haveria oposição a este entendimento. No entanto, o que se observa é que a figura do contrato administrativo traz consigo diversas características ainda não superadas ou modificadas, como a subsistência de algumas prerrogativas drásticas da Administração, a sua característica tipicidade legal e, por consequência, o papel da autorização legislativa na possibilidade de seu manejo.

\footnotetext{
${ }^{347}$ É creditado ao filósofo Guilherme de Ockham (1285-1347) o pensamente de que "se em tudo o mais forem idênticas as várias explicações de um fenómeno, a mais simples é a melhor". (SPADE, Paul Vincent. William of Ockham. In: ZALTA, Edward N. (ed.). The Stanford Encyclopedia of Philosophy. Stanford: Stanford University, 2008.)
} 
Tal como se posiciona Sérvulo Correia, ${ }^{348}$ entendemos por rechaçar, para a caracterização do contrato administrativo, o critério da prossecução de "fins de interesse público" - tal como formulado por Maria João Estorninho ${ }^{349}$ - ou da sujeição a um "fim de imediata utilidade pública", frente à presença, cada vez mais relevante, de finalidades de interesse público em contratos civis. É o caso, por exemplo, das regras gerais de boa fé e de função social do contrato presentes no direito positivo brasileiro que, como exposto nos tópicos anteriores, acabam por aproximar substancialmente nesse particular os contratos públicos e privados.

Nesse sentido, aderimos em parte à eleição do critério estatutário para a distinção do contrato administrativo, tal como construída por Sérvulo Correia. ${ }^{350}$ Essa adesão não é plena, no entanto: observamos a existência de outros critérios mais relevantes, que contam com uma carga lógica maior do que a simples previsão do direito positivo. De mais a mais, o critério estatutário se revela presente no direito administrativo brasileiro e, desse modo, se torna instrumental para a futura definição da natureza jurídica da transação.

Rejeitamos igualmente o critério subjetivo e o fator relacional eleitos por Marcello Caetano, ${ }^{351}$ já tendo rechaçado o seu terceiro critério, de jaez objetivo. Nesse sentido, tal como sustenta Giorgio Oppo, ${ }^{352}$ a presença do ente público como parte em um contrato não tem o condão de torná-lo de pronto público, uma vez que tal assunção equivaleria à própria negativa de existência de contratos privados da administração. Ainda, o fator relacional indicado por Marcello Caetano carece igualmente de aplicação concreta, uma vez que, mesmo que a contraparte privada não adira às intenções da Administração ao fazer parte de um contrato administrativo, tal circunstância não tem o condão de descaracterizar a publicidade do contrato. Nesse sentido, basta que a contraparte privada cumpra as suas

\footnotetext{
348 CORREIA, José Manuel Sérvulo. Legalidade e autonomia contratual nos contratos administrativos. Coimbra: Almedina, 1987. P. 773-775.

${ }^{349}$ ESTORNINHO, Maria João. Direito europeu dos contratos públicos: um olhar português. Coimbra: Almedina, 2006. P. 317.

350 CORREIA, José Manuel Sérvulo. Legalidade e autonomia contratual nos contratos administrativos. Coimbra: Almedina, 1987. P. 773-775.

${ }^{351}$ CAETANO, Marcello. Manual de direito administrativo. Coimbra: Coimbra Editora, 1951. P. 274.

352 OPPO, Giorgio. Diritto privato e interessi pubblici. Studi Economico-Giuridici, Napoli, v. 55, p. 421-446, 1993-1994.
} 
atribuições no sinalagma, sendo irrelevante se as suas intenções são egoísticas ou não.

O critério proposto por Marçal Justen Filho - a distinção de regimes conforme a finalidade público-coletiva ou não da avença, ou com o seu grau de vinculação à satisfação dos interesses fundamentais ${ }^{353}$-, apesar de se alinhar com os entendimentos contemporâneos acerca da missão institucional do Estado, carece de substância para a definição, em casos concretos, da natureza pública ou não da avença.

Entendemos que tal critério se adequaria melhor como uma apreciação dos motivos que levam o legislador a, estatutariamente, alçar determinada avença à categoria de contrato administrativo. No entanto, esse critério carece de potência para estabelecer, em caso de real dúvida acerca da natureza do contrato em discussão, a sua publicidade, uma vez que a Administração se utiliza para a satisfação de direitos fundamentais de contratos privados. Nesse cenário, o critério de Justen Filho acabaria por atrair indevidamente o regime publicístico a um contrato necessariamente privado, contrariando o seu próprio entendimento acerca da necessidade de existência da figura dos contratos privados da Administração para certos casos específicos, ${ }^{354}$ ferindo assim as desejadas condições "de mercado".

Por fim, junto do critério estatutário eleito por Sérvulo Correia, aderimos mais intensamente ao posicionamento de Menezes de Almeida, ${ }^{355}$ feitas as devidas ressalvas, que, dentre as cláusulas exorbitantes potencialmente presentes - que, como visto, são por si só insuficientes a caracterizar um contrato como administrativo -, elege a prerrogativa de autoexecutoriedade como dístico

353 JUSTEN FILHO, Marçal. Comentários à Lei de licitações e contratos administrativos. São Paulo: Revista dos Tribunais, 2014. P. 989-994.

354 JUSTEN FILHO, Marçal. Comentários à Lei de licitações e contratos administrativos. São Paulo: Revista dos Tribunais, 2014. P. 992.

${ }^{355}$ ALMEIDA, Fernando Dias Menezes de. Teoria do contrato administrativo: Uma abordagem histórico-evolutiva com foco no Direito Brasileiro. 2010. Tese (Livre-docência em direito) Faculdade de Direito, Universidade de São Paulo, São Paulo, 2010. P. 226-227.

Mesmo que isso possa se mostrar contraditório com o que sustenta o próprio autor, no cenário apresentado no tópico anterior, uma vez que, apesar de rechaçar a pertinência dogmática da distinção, demonstra a propriedade prática do critério indicado. 
essencial do contrato administrativo. Esse critério se mostra, de fato, como aquele que mais precisamente diferencia, do ponto de vista material, os contratos administrativos dos contratos privados da Administração, uma vez que, por força das disposições estatutárias, estará sempre presente nos contratos administrativos e, pelo nivelamento que impera nos contratos privados, nestes nunca será observada.

O posicionamento assim edificado, pela adoção mista do critério estatutário e do critério da autoexecutoriedade para distinguir o contrato administrativo do contrato privado da administração, nos permite analisar com propriedade a natureza jurídica da transação extrajudicial da administração pública, principiando pela crítica aos posicionamentos já existentes na literatura.

De plano, diante de todo o exposto no presente capítulo, o posicionamento pela caracterização da transação extrajudicial como ato administrativo não se sustenta. Talvez tal conclusão pudesse ser diferente noutro momento histórico - aquele da composição do Código Civil de 1916, ou dos debates italianos acerca da natureza jurídica da transação - mas, no atual estado da arte da ciência jurídica sobre o tema, a natureza contratual da transação se destaca como consolidada, tanto na literatura quanto no direito positivo. E é justamente o desconhecimento - ou a desconsideração - desse cenário histórico que atrai equívocos aos posicionamentos adiante analisados.

Os posicionamentos franceses acerca da natureza de "contrato de adesão transativo" ou de "contrato administrativo de transação" carecem de solidez, uma vez que se baseiam tão somente na instrumentalidade dessas concepções em favor da competência do contencioso administrativo. Nesse sentido, além de tais concepções carecerem de densidade científica - como restou demonstrado na extensa análise dos posicionamentos de Chavrier ${ }^{356}$ realizada em tópico anterior , verifica-se que sua acepção é de difícil transposição para o cenário brasileiro, que não carece de manobras para a sujeição dos atos estatais ao contencioso

\footnotetext{
${ }^{356}$ CHAVRIER, Géraldine. Réflexions sur la transaction administrative. Revue Française de Droit Administratif, Paris, n. 3, p. 548-566, mai.-jun. 2000.
} 
administrativo, em desfavor da justiça comum, frente à opção institucional pelo sistema de jurisdição una.

Já a concepção de acordo substitutivo no direito administrativo italiano, apesar de perfeitamente adequada àquele país - que conta, inclusive, com expressa previsão legal da figura, que Ihe constitui a publicidade estatutária ${ }^{357}$-, é igualmente intransponível para o direito administrativo brasileiro.

Como já sustentado nos tópicos anteriores, o conhecimento dos extensos debates históricos italianos acerca da natureza da transação constitui claramente a origem da figura no direito administrativo daquele país. Resta claro, como exposto, que a distinção entre acordos procedimentais e acordos substitutivos guarda notável paralelismo com a distinção entre negócios de acertamento e contratos de transação, sendo que aquele sequer é contemplado no direito brasileiro. Disso decorrem dois impeditivos à transposição dos conceitos italianos ao direito administrativo brasileiro.

Em um primeiro momento, a confusão com o conceito de negócio de acertamento impede o reconhecimento de todas as transações como acordos substitutivos. Isso se afirma uma vez que, sendo a transação nos moldes brasileiros sempre relativa a direitos, e não a fatos, e contando com efeitos extintivos específicos, ela não se confunde com o negócio de acertamento e, assim, muitas das suas hipóteses de aplicação restam alijadas do conceito de acordo substitutivo.

Sob uma segunda análise, verifica-se que o acordo substitutivo pressupõe a existência de um ato administrativo unilateral a ser substituído, o que estreitaria o seu escopo ao ponto de, tal como no argumento anterior, excluir a maior parte dos casos de transação contemplados no direito civil e de utilidade prática. Essas circunstâncias nos levam a dissociar a natureza pública dos acordos substitutivos da figura da transação extrajudicial, e abre caminho para a análise do posicionamento de Onofre Alves Batista Júnior.

357 FRACCHIA, Fabrizio. L'accordo sostitutivo: Studio sul consenso disciplinato dal diritto amministrativo in funzione sostitutiva rispetto agli strumenti unilaterali di esercizio del potere. Padova: Cedam, 1998. Passim. 
A tese de Batista Júnior constitui obra de inegável pioneirismo. Ao mesmo tempo em que se caracteriza por ser uma das primeiras - senão a primeira - obras de fôlego a tratar da transação pela Administração Pública, conecta-a à figura do acordo substitutivo (relacionando-os aos atos de acertamento na Itália, Alemanha e Espanha), unindo-os sob a égide do que chama de contrato administrativo alternativo.

Ocorre que, sendo imperfeita a coincidência entre o acordo substitutivo e o contrato de transação, o seu conceito acaba por carecer de coerência lógicojurídica.

Faz-se necessário, portanto, revisitar a sua construção original sobre as "transações administrativas":

O contrato administrativo alternativo é uma forma de a Administração Pública resolver determinados casos concretos, como alternativa a uma atuação unilateral, colocando-se como possível mecanismo (mais democrático) para a persecução otimizada do melhor interesse público possível. O fundamento de sua aplicação centra-se exatamente na possibilidade de maior eficiência da atuação administrativa quando desenvolvida com a colaboração do administrado.

Mediante o manejo dos contratos administrativos alternativos, a Administração renuncia ao emprego de potestades de imposição unilateral e, buscando maior eficiência administrativa, persegue o melhor interesse público possível mediante o estabelecimento de solução concertada com o administrado. Parte-se, entretanto, do pressuposto de que, caso não seja possível o acordo, a solução escolhida será imposta unilateralmente pela Administração, fazendo uso de seus poderes que, para tanto, tenham sido outorgados pela lei [grifos nossos].

Como já analisado, a tese de Batista Júnior sustenta a existência, no direito administrativo brasileiro, do gênero "contratos administrativos alternativos" ou "contratos administrativos de transação lato sensu", que compreenderia as espécies "contrato administrativo de transação stricto sensu" e "contrato administrativo complexo". ${ }^{359} \mathrm{Na}$ concepção do autor, o contrato administrativo de

\footnotetext{
358 BATISTA JÚNIOR, Onofre Alves. Transações administrativas: um contributo ao estudo do contrato administrativo como mecanismo de prevenção e terminação de litígios e como alternativa à atuação administrativa autoritária, no contexto de uma administração pública mais democrática. São Paulo: Quartier Latin, 2007. P. 325-326.

359 BATISTA JÚNIOR, Onofre Alves. Transações administrativas: um contributo ao estudo do contrato administrativo como mecanismo de prevenção e terminação de litígios e como alternativa
} 
transação stricto sensu aproximar-se-ia da transação civil, mas com natureza de contrato administrativo, frente à presença da Administração Pública como parte; já o contrato administrativo complexo teria elementos do negócio de acertamento já que, mesmo sem prevenir ou terminar litígio, seria direcionado à eliminação de incertezas na relação jurídica contratual entre a Administração e o particular. ${ }^{360} \mathrm{Em}$ ambas as figuras, no entanto, o elemento de substituição, referido pelo autor como a alternatividade dos contratos, far-se-ia presente por força de definição.

Ao buscar origem para suas concepções nos acordos substitutivos e figuras análogas em outros ordenamentos, Batista Júnior acaba por adotar pressupostos incompatíveis com o direito administrativo e com o direito civil brasileiros. Essa proximidade conceitual com os acordos de natureza substitutiva do modelo italiano traz consigo a confusão entre as naturezas e finalidades diversas entre os institutos civis do contrato de transação e do negócio de acertamento.

Essa circunstância crucial faz ruir a correspondência entre a figura dos contratos administrativos alternativos e os contratos de transação. $E$ isso se pode concluir por um caminho singelo: a maior parte - e a parte mais importante - dos contratos de transação não é concebível como uma avença que venha a substituir um ato administrativo unilateral.

Em parte, alguns casos de transação podem ser analisados sob a ótica substitutiva ou alternativa, como aqueles em matéria de tributação, exercício do poder de polícia e sanções em contratos administrativos. O que dizer, no entanto, daquela que consideramos indiscutivelmente a hipótese mais importante de manejo da transação pela Administração Pública: a solução de sua responsabilidade civil? Ou mesmo em relação às transações judiciais, que tenham como objeto a terminação de litígio?

Qual é o ato administrativo unilateral a ser substituído nesses casos?

à atuação administrativa autoritária, no contexto de uma administração pública mais democrática. São Paulo: Quartier Latin, 2007. P. 325-330.

360 BATISTA JÚNIOR, Onofre Alves. Transações administrativas: um contributo ao estudo do contrato administrativo como mecanismo de prevenção e terminação de litígios e como alternativa à atuação administrativa autoritária, no contexto de uma administração pública mais democrática.

São Paulo: Quartier Latin, 2007. P. 360-382. 
Com exceção da hipótese em que se adote uma concepção inaceitavelmente elástica de ato administrativo unilateral, para considerar a inércia da Administração em tomar a iniciativa para a firmatura de transação como um ato administrativo, não há qualquer margem para que se aceite a natureza de contrato administrativo alternativo nesses casos.

Verifica-se, pois, que ao edificar o seu entendimento, Batista Júnior deixa de considerar todo o cenário de formação histórica dos conceitos que maneja. Ao assumir a alternatividade como um elemento das "transações administrativas", o autor acabou por vincular o seu conceito a elementos de direito administrativo e, principalmente, de direito civil a si indisponíveis no direito brasileiro, por uma incompatibilidade sistêmica, como aqui já exaustivamente exposto.

Ainda que não considerássemos o elemento alternativo eleito por Batista Júnior para a formação de seu conceito de "transações administrativas", a sua caracterização da transação como contrato administrativo faz despertar algumas considerações.

Como já exposto, seu posicionamento pressupõe o fato de que a transação administrativa constituiria contrato administrativo, atraindo o regime jurídico publicístico em sua plenitude e aplicando de maneira apenas subsidiária as normas civis sobre a transação. Isso decorreria, como consequência do caráter alternativo já abordado, de uma regra de competência para a celebração do "contrato administrativo alternativo" atrelada à competência do ato administrativo unilateral a ser substituído, ${ }^{361}$ com grande enfoque sobre o critério orgânicosubjetivo para a caracterização da transação administrativa como contrato administrativo e para a consequente atração do regime público.

Diante de tal cenário, faz-se prudente reapresentar a concepção original do autor:

No Direito Administrativo brasileiro, as transações administrativas são contratos administrativos alternativos, pois a Administração

361 BATISTA JÚNIOR, Onofre Alves. Transações administrativas: um contributo ao estudo do contrato administrativo como mecanismo de prevenção e terminação de litígios e como alternativa à atuação administrativa autoritária, no contexto de uma administração pública mais democrática. São Paulo: Quartier Latin, 2007. P. 330. 
Pública se faz presente, além do que a qualificação do contrato resulta de ser constituída, modificada ou extinta, pelo acordo de vontades, relação jurídica típica de direito administrativo. ${ }^{362}$

Nesse sentido, ao ampliar sua concepção de contrato administrativo para abarcar nela o contrato de transação, Batista Júnior atrai para este diversas consequências da natureza publicística, como a necessidade de tipicidade e autorização legal para a transação, em claro traço estatutário, além de defender a aplicação do regime jurídico público às transações, com a adoção tão somente subsidiária de normas privatísticas. ${ }^{363}$

Cabe aqui apresentar questionamento já anteriormente exposto: como se resolveriam, nesse cenário, as necessidades mais prementes e úteis de manejo da transação, como a solução da responsabilidade civil do Estado? Não existiria a possibilidade de adoção desse instrumento até que se constituísse autorização legislativa expressa para tanto, constituindo essa suposta modalidade de contrato administrativo?

Como demonstra a segunda parte dessa tese, no capitulo que se ocupa do enfrentamento às oposições teóricas à adoção da transação extrajudicial pela Administração Pública, o recurso dos entes estatais à transação independe de autorização legislativa - o que não se confunde com as leis que fixem a competência funcional para a sua firmatura -, cenário em que o posicionamento de Batista Júnior exclui de seu bojo a própria essência da transação.

Não se sustenta, aqui, a impropriedade do conceito de contrato administrativo alternativo; de fato, consideramos a figura extremamente útil como instrumento de consensualidade na atuação administrativa, já estudada sob a égide

\footnotetext{
${ }^{362}$ BATISTA JÚNIOR, Onofre Alves. Transações administrativas: um contributo ao estudo do contrato administrativo como mecanismo de prevenção e terminação de litígios e como alternativa à atuação administrativa autoritária, no contexto de uma administração pública mais democrática. São Paulo: Quartier Latin, 2007. P. 370.

${ }^{363}$ Batista Júnior se reporta por diversas vezes, inclusive, à aplicação plena do regramento da Lei de Licitações e Contratos Administrativos, a Lei no 8.666/1993 (BATISTA JÚNIOR, Onofre Alves. Transações administrativas: um contributo ao estudo do contrato administrativo como mecanismo de prevenção e terminação de litígios e como alternativa à atuação administrativa autoritária, no contexto de uma administração pública mais democrática. São Paulo: Quartier Latin, 2007. P. 327).
} 
da contratualização e da processualização como tendências contemporâneas da gestão pública.

Ocorre que o conceito de contrato administrativo alternativo muito pouca ou nenhuma relação guarda com o de contrato de transação.

Em síntese, acreditamos ser salutar o fomento à adoção de figuras como o contrato administrativo alternativo ao ato administrativo unilateral pela Administração Pública. No entanto, todo o cenário exposto é extremamente contundente em rechaçar a coincidência de natureza jurídica entre a transação firmada pela administração pública e o contrato administrativo alternativo. De mesmo giro, se torna extremamente questionável a caracterização da transação firmada pela Administração Pública como contrato administrativo, não se the aplicando o regime jurídico de direito público.

Essa construção, aliada aos critérios eleitos para a distinção dos contratos administrativos, leva finalmente à edificação de contribuição original quanto à natureza jurídica da transação extrajudicial na administração pública.

Em primeiro lugar, a aplicação do critério estatutário não permite a inclusão da transação extrajudicial entre as figuras de contratos administrativos, e isso decorre de uma apuração muito simples. Ora, na medida em que não há regras específicas criando um regime publicístico próprio para a transação extrajudicial na administração pública - fator este crucial, inclusive, para a própria razão de ser da presente tese -, não há como sustentar a existência de um estatuto público da transação extrajudicial na administração pública, medida na qual não pode ela ser considerada contrato administrativo.

É de se ressaltar, nesse sentido, que a existência de meras autorizações legislativas específicas para a transação, que em nada derrogam o regime privatístico do instituto, não têm o condão de constituir um regime estatutário. Muito pelo contrário, como bem exposto no inciso I do $\S 3^{\circ}$ do art. 62 da Lei n 8.666/1993, o contrato da Administração "regido, predominantemente, por norma de direito privado" não deixa de ser contrato privado para se tornar contrato administrativo, ainda que se lhe apliquem, subsidiariamente, algumas disposições da Lei de Licitações e Contratos Administrativos. 
Já em relação ao critério da autoexecutoriedade, a transação de que faça parte a Administração Pública, assim como outros métodos de solução consensual de conflitos, constitui a epítome do nivelamento objetivo entre o Estado e o cidadão. Diante de toda a construção levada a cabo ao longo da primeira parte dessa obra, é impossível conceber que a adoção de soluções consensuais de conflitos pela Administração Pública se justifique, justamente, pelo poderio unilateral que essa postura busca combater.

O atual cenário da adoção de transações extrajudiciais pela Administração Pública revela, assim, ser marcado por um forte traço de relativa liberdade contratual para que o ente estatal opte por figuras contratuais privadas, sempre que essa medida se mostre a mais adequada para a realização da missão institucional do estado constitucionalmente definida. Nesse sentido, é muito mais razoável permitir ao administrador que decida sobre a adoção ou não de medidas de nivelamento que abrir mão da possibilidade do seu exercício. ${ }^{364}$

Assim, demonstrada a vantajosidade para o Estado na firmatura de transação extrajudicial, em não havendo derrogação do direito administrativo em relação a tal possibilidade, a Administração se nivela ao particular e como ele age. ${ }^{365}$ É de se considerar, pois, diante de todo o exposto, que ainda que a transação administrativa seja, em sua lógica e em seu procedimento, diversa da transação entabulada entre particulares, seus efeitos são correspondentes: visase, pela reparação pré-contenciosa, à terminação definitiva do litígio por extinguir o interesse prático no provimento jurisdicional, poupando-se assim o recurso aos tribunais. ${ }^{366}$

${ }^{364}$ DI PIETRO, Maria Sylvia Zanella. Ainda existem os chamados contratos administrativos? In: DI
PIETRO, Maria Sylvia Zanella; RIBEIRO, Carlos Vinicius Alves (coords.). Supremacia do interesse
público e outros temas relevantes do direito administrativo. São Paulo: Atlas, 2010. P. 409-410.
365 VENOSA, Silvio de Salvo. Direito Civil: Teoria Geral das Obrigações e Teoria Geral dos
Contratos. São Paulo: Atlas, 2005. P. 597. No mesmo sentido:

DI PIETRO, Maria Sylvia Zanella. Do Direito privado na Administração Pública. São Paulo: Atlas, 1989. P. 98.

${ }^{366}$ CHAVRIER, Géraldine. Réflexions sur la transaction administrative. Revue Française de Droit Administratif, Paris, n. 3, p. 548-566, mai.-jun. 2000. Tradução nossa.

No original: "La transaction administrative, ainsi limitée dans son objet et ses modalités, semble donc être particulièrement éloignée de ce que le code civil peut entendre par 'transaction'. L'objectif de la 
Tratando-se a transação extrajudicial de um contrato da Administração Pública que não pode ser caracterizado como contrato administrativo, estamos a falar de um contrato privado da Administração, figura conceituada por Carvalhaes Neto como

[...] contratos regidos predominantemente pelo direito privado, que são os negócios jurídicos típicos da vida privada (tais como os de compra e venda, locação, doação, comodato, contratação de obra artística, seguro etc.), que o Poder Público celebra enquanto pessoa jurídica, e não como parte do exercício de sua função pública. ${ }^{367}$

Discordamos do pensamento de Carvalhaes Neto no sentido de que o recurso da Administração Pública a contratos privados não constituiria "parte do exercício de sua função pública". De fato, o manejo de figuras privadas pelo Estado deve sempre se relacionar diretamente à realização de sua missão institucional, e é justamente esse cenário que justifica a adoção da transação extrajudicial pela Administração Pública.

No entanto, o conceito do autor é instrumental para demonstrarmos que, lançando mão de um contrato de transação, de moldes tipicamente privados, à disposição dos entes estatais como decorrência de sua personalidade jurídica, a transação extrajudicial entabulada pelo Estado se caracteriza como contrato privado da Administração, trazendo consigo as implicações referentes a regime jurídico próprios dessa figura.

Concluímos, assim, a primeira parte da presente tese, definindo que a transação extrajudicial que tenha como parte ente da Administração Pública conta com natureza jurídica de contrato privado da Administração, a ela se aplicando, em

circulaire [de 6 de fevereiro de 1995, em que o Primeiro Ministro francês recomenda a adoção da transação para solucionar conflitos da Administração Pública], qui ne traite d'ailleurs que des litiges dans lesquels la personne publique est débitrice, n'était donc vraisemblablement pas de favoriser les arrangements avec l'Administration, mais bien de conseiller aux personnes publiques de répondre favorablement aux demandes préalables d'indemnisation, lorsque la créance publique est certaine. Toutefois, si les transactions civiles et administratives sont d'essence et de logique différentes, leurs effets devraient être semblables: la réparation précontentieuse doit mettre un terme définitif au litige pour ne pas rendre sans intérêt pratique une procédure dont l'objet est d'économiser le recours au juge."

${ }^{367}$ CARVALHAES NETO, Eduardo Hayden. Contratos privados da Administração Pública: Uma análise do regime jurídico aplicável. 2011. Tese (Doutorado em direito) - Faculdade de Direito, Universidade de São Paulo, São Paulo, 2011. 
regra, as disposições do regime privatístico, moduladas por eventuais derrogações que, mesmo presentes no direito administrativo, não desvirtuam ou descaracterizam a natureza privada da transação extrajudicial entabulada. 
Parte II - EFETIVIDADE DA TRANSAÇÃO EXTRAJUDICIAL NA MISSÃO INSTITUCIONAL DO ESTADO 


\section{DESAFIOS À RECEPTIVIDADE AO MODELO DE RESOLUÇÃO DE CONFLITOS BASEADO NA CONSENSUALIDADE}

A primeira parte desse trabalho dedicou-se a delinear o quadro teórico da inserção da transação extrajudicial no direito a que se submete a - ou, talvez melhor, que está à disposição da - Administração Pública. Partindo da análise dos câmbios referenciais que formam o caminho que nos levou ao cenário contemporâneo do direito administrativo, pudemos detectar uma grave contradição entre a atual conformação das relações entre Estado e sociedade com os paradigmas que traduzem o verdadeiro papel da Administração Pública na sociedade de hoje.

Nesse sentido, com base numa nova visão sobre a ampliação das bases de juridicidade na Administração Pública - em que a gestão estatal não se vincula somente à lei, mas sim ao Direito como um todo - assistimos a uma ressignificação do interesse público, que não se posta mais em oposição aos direitos dos particulares e em cuja definição a Administração Pública já não tem legitimidade para, unilateralmente, exercer protagonismos.

Tal panorama tem levado a uma maior instrumentalização do atuar estatal com vistas à realização dos direitos fundamentais. Esse movimento implica em um maior foco sobre o processo de formação da atuação estatal, deslocando o papel central na consecução dos seus misteres do ato para o processo administrativo. No mesmo cenário, mirando à melhor realização de sua missão institucional, a Administração Pública tem buscado os meios que tragam o melhor resultado possível nesse sentido, recorrendo, inclusive, a instrumentos de atuação considerados como tipicamente relacionados ao regime jurídico privado.

Essa instrumentalização caracteriza, portanto, a busca por uma boa administração pública, elemento de juridicidade que tem sido alçado à categoria de direito fundamental a assistir aos cidadãos que, ao fim e ao cabo, devem constituir o núcleo principal de proteção em função do qual opera a Administração Pública e vige o Direito como um todo. Nessa busca, a Administração Pública passa a exercer um novo papel relacional com a sociedade, em um cenário no qual não mais se admite o monopólio estatal sobre a definição e a realização do bem comum. 
No entanto, o capítulo inicial da primeira parte do trabalho é concluído com a constatação de que, apesar de todo esse novo ferramental de paradigmas a guiar uma realização ótima do papel do Estado na sociedade contemporânea, a Administração Pública brasileira tem se descolado com grande gravidade das suas bases de legitimação. Esse fenômeno, tido como consideravelmente contraditório em face desses paradigmas, tem como um de seus mais importantes aspectos 0 distanciamento entre Estado e cidadãos decorrente da altíssima judicialização de suas relações, em um cenário no qual a Administração Pública lidera os quadros dos maiores litigantes do Brasil.

Diante de tal contradição, o manejo de mecanismos consensuais de solução de conflitos pela Administração Pública se destaca como potencial caminho de reaproximação democrática entre os entes estatais e a sociedade. Nesse sentido, a busca pelo consenso entre o Estado e os cidadãos se constitui como corolário da própria realização de todos os novos paradigmas relacionados no capítulo inicial da primeira parte do texto, e constitui a matéria prima para os debates levados a cabo no capítulo que completa aquela parte.

Partindo, portanto, da apreciação desse cenário ótimo de consensualidade e transportando-o para o campo dos conflitos jurídicos entre a Administração Pública e os particulares, o segundo movimento daquele capítulo aprecia, comparativamente, as diversas modalidades de solução consensual de conflitos contempladas pelo Direito brasileiro - arbitragem, conciliação, mediação e transação - para, estabelecendo uma escala crescente de autonomia das partes, construir o entendimento de que a transação é o meio preferencial de solução consensual de conflitos. Ainda, lançando mão do mesmo critério, apura-se que, dentre as modalidades de transação, a transação extrajudicial é preferível à judicial - e, portanto, igualmente à mediação, à conciliação e à arbitragem -, uma vez que prescinde da atuação de um terceiro que a homologue, viabilize, comande ou decida.

Sustenta-se, assim, que a maior autonomia das partes traria à transação extrajudicial vantagens operacionais de maior celeridade, menores custos e, com o seu desenvolvimento, uma maior adesão das partes à solução dialogicamente construída. 
O movimento final do capítulo constrói o entendimento acerca da inserção da transação extrajudicial no regime jurídico da Administração Pública. Ora, tendo em vista todo o novo referencial teórico e de valores apresentado no capítulo de aproximação ao tema, a transação extrajudicial, munida das vantagens comparativas expostas, destaca-se como meio preferencial de solução consensual de conflitos a ser manejado pela Administração Pública para reverter o processo de judicialização das suas relações com os particulares.

Nesse sentido, o capítulo foi concluído com um exercício de definição da natureza jurídica da transação inserida no contexto estatal. Partindo da análise dos inúmeros entendimentos esposados na literatura estrangeira, procedeu-se com a apreciação do posicionamento adotado pela doutrina nacional sobre o tema, criticando-o. Concluiu-se, afinal, que a transação extrajudicial manejada pelo Estado conta com a natureza jurídica de contrato privado da Administração Pública.

Ocorre que, apesar de sua extensão e dos fundamentos esposados na primeira parte do trabalho, a sua construção teórica não se mostra suficiente para a plena efetividade da adoção da transação extrajudicial pela Administração Pública brasileira. Isso porque a literatura e a jurisprudência nacionais são pródigas em construir oposições à aceitabilidade da transação extrajudicial no direito administrativo, oposições estas ora conceituais, ora operacionais.

A segunda parte do trabalho tem início, portanto, com o enfrentamento sistemático a estes desafios.

O direito administrativo brasileiro tem se mostrado consideravelmente árido à adoção de métodos de solução consensual de conflitos pela Administração Pública, o que se agrava quando tratamos da transação extrajudicial. Num cenário em que "não se tem admitido que a Fazenda Pública reconheça a procedência do pedido" ${ }^{368}$ sequer judicialmente - apesar das diversas opiniões favoráveis -, a análise da inserção da transação extrajudicial no regime jurídico da Administração Pública, procedida na primeira parte do trabalho, deve ser necessariamente

${ }_{368}^{36}$ CUNHA, Leonardo José Carneiro da. A Fazenda Pública em juízo. São Paulo: Dialética, 2008. P. 90. 
seguida do enfrentamento a estas oposições antes que se prossiga com o delineamento de um modelo.

No cenário brasileiro, abundam as oposições à adoção da transação extrajudicial pela Administração Pública com base em uma suposta supremacia e indisponibilidade insuperáveis do interesse público; na exigência de lei autorizativa para a celebração da avença; na submissão dos efeitos da transação ao regime de precatórios; na incompatibilidade entre a transação extrajudicial e o direito administrativo quanto à certeza jurídica; na incompatibilidade entre a transação extrajudicial e o princípio da impessoalidade administrativa; ${ }^{369}$ entre tantos outros motivos, aqui expostos em detalhes e enfrentados individualmente.

Na verdade, como diversos estudos indicam, mesmo naquelas hipóteses em que há expressa autorização legislativa para que a Administração adote um método de solução consensual de conflitos, ainda resta grande resistência ao reconhecimento dessa possibilidade, tanto por parte de agentes administrativos quanto por parte de órgãos de controle e, o mais grave, por parte da literatura especializada. $^{370}$

Não faltam, portanto, autores a sustentar que, cumpridos os requisitos legais, a transação seria possível no âmbito do direito privado, entre particulares; já quando a contenda envolve ente da Administração Pública, pelo fato de que esta "está sujeita a um regime jurídico próprio, informado por normas e princípios que o distinguem do direito privado - o regime jurídico administrativo", ${ }^{371}$ sofreriam os entes estatais limitações proibitivas ao recurso à transação.

\footnotetext{
369 Tais argumentos são especialmente caros aos órgãos de controle externo da Administração Pública, com notável destaque para a postura de alguns setores do Ministério Público, como se vê do seguinte documento:

SCHIRMER, Mário Sérgio de Albuquerque. Impossibilidade de realização de acordos no âmbito do direito administrativo sem a existência de lei expressamente autorizando a avença. Repositório do Centro de Apoio Operacional das Promotorias de Justiça de Proteção ao Patrimônio Público e à Ordem Tributária. Curitiba: CAOP-MPPR, [s.d.].

${ }^{370}$ FARIA, Roberto Gil Leal. Por que são efetivados poucos acordos nos Juizados Especiais Federais? Revista da SJRJ, Rio de Janeiro, n. 24, p. 93-103, 2009.

${ }^{371}$ SCHIRMER, Mário Sérgio de Albuquerque. Impossibilidade de realização de acordos no âmbito do direito administrativo sem a existência de lei expressamente autorizando a avença. Repositório do Centro de Apoio Operacional das Promotorias de Justiça de Proteção ao Patrimônio Público e à Ordem Tributária. Curitiba: CAOP-MPPR, [s.d.].
} 
Questiona-se: seria esse realmente o intuito e o conteúdo do direito administrativo?

Na fundamentação de posicionamentos contrários, de modo absoluto, à transação extrajudicial na administração pública, é recorrente a referência a parecer exarado por José Saulo Pereira Ramos no exercício da Consultoria-Geral da República e, posteriormente, publicado na Revista de Direito Administrativo, o qual aqui excepcionalmente reproduzimos:

A indisponibilidade do interesse público é incompatível com a
transação preventiva, posto que esta configura mediante
recíprocas concessões das partes interessadas, verdadeiro
accertamento negoziale [...].
O negócio jurídico da transação, que conduz à extinção das
obrigações e faz cessar o estado de litigiosidade existente entre os
sujeitos de uma dada relação jurídica, importa, sempre, renúncia de
direitos. $^{372}$

Este posicionamento reflete um pensamento próprio de uma dogmática que entendemos poder ser superada no direito administrativo brasileiro, medida em que, obviamente, não julgamos o valor do trabalho à época de sua publicação. $O$ teórico e o operador do Direito não podem descuidar da sua evolução - tema a que nos dedicamos detidamente na apresentação ao capítulo que tratou dos novos paradigmas da gestão pública - e, nesse sentido, diversos posicionamentos, apesar de respeitáveis, devem ser reconsiderados.

Trata-se, assim, não só de um posicionamento puramente teórico, estéril; o tratamento de todo o cenário exposto demanda que o jurista se posicione, compreendendo a importância da sua postura para a realização do papel do próprio direito.

Nesse sentido, mui pertinente é a admoestação de Adilson Abreu Dallari:

Afaste-se o intérprete sério e realmente preocupado com a realização da Justiça segundo a Constituição, daqueles que [...] entendem o sistema jurídico como uma máquina de impedir, orientada pelo código do fracasso, cujos mandamentos são: art. $1^{\circ}$. - não pode; art. $2^{\circ}$. - no caso de dúvida, abstenha-se; art. $3^{\circ}$. - se é

$\overline{372}$ RAMOS, José Saulo Pereira. Responsabilidade civil do Estado - Culpa recíproca - Transação. Revista de Direito Administrativo, Rio de Janeiro, v. 166, p. 156-166, 1986. 
urgente, espere; art. $4^{\circ}$. - sempre é mais prudente não fazer coisa alguma. ${ }^{373}$

Aqui, pois, a realização da missão acadêmica não prescinde de um posicionamento acerca da própria razão de ser do direito administrativo, sob pena de a academia fomentar os comportamentos contraditórios com os valores do Estado contemporâneo, tal como expostos no tópico que tratou do descolamento entre Estado e cidadãos, exemplificadas por Alice Gonzalez Borges com a prática recorrente de lançar mão o Estado "de todos os privilégios processuais, de todos os recursos judiciais disponíveis, para protelar, ad infinitum, a solução final dos litígios, deixando os compromissos financeiros correspondentes para as próximas gestões dos sucessores". ${ }^{374}$

O enfrentamento aos desafios expostos se posiciona, assim, contra a consolidação do "inconsciente coletivo" que busca sustentar, em prol de uma suposta vinculação jurídica estatal, que a representação judicial da Administração Pública tenha de "sustentar o insustentável, ou contestar o incontestável, pois não Ihes caberia dispor sobre os interesses deduzidos em Juízo pelo poder público". ${ }^{375}$

Esse posicionamento, antigo preconceito $^{376}$ arraigado no direito administrativo brasileiro, carece de adequado enfrentamento. Procede-se, portanto, com a oposição aos desafios conceituais, num primeiro momento, e aos desafios operacionais, posteriormente.

Concluído o enfrentamento aos desafios conceituais e operacionais, o que se procede por contribuição original esposada ao longo dos tópicos, o capítulo seguinte se dedica, já livre das oposições, a delinear um modelo para a consolidação da transação extrajudicial na administração pública.

\footnotetext{
${ }^{373}$ DALLARI, Adilson Abreu. Viabilidade da transação entre o poder público e particular. Interesse Público, Belo Horizonte, a. 4, n. 13, jan.-mar. 2002.

${ }^{374}$ BORGES, Alice Gonzalez. Reflexos do Código Civil dos contratos administrativos. Revista Eletrônica de Direito Administrativo Econômico, Salvador, n. 9, fev.-abr. 2007.

${ }^{375}$ MADUREIRA, Claudio Penedo. Poder público, litigiosidade e responsabilidade social. Fórum Administrativo, Belo Horizonte, a. 11, n. 126, p. 9-22, ago. 2011.

${ }^{376}$ SUNDFELD, Carlos Ari; CÂMARA, Jacintho Arruda. Acordos na execução contra a Fazenda Pública. Revista Brasileira de Direito Público, Belo Horizonte, a. 8, n. 30, jul.-set. 2010.
} 


\subsection{Desafios conceituais}

Como a sua porção introdutória expõe, o presente capítulo se dedica a oferecer enfretamento às oposições, consideravelmente comuns na literatura e na jurisprudência em direito administrativo no Brasil, à adoção da transação extrajudicial pela Administração Pública. O tópico que agora se inicia tratará dos desafios de ordem conceitual, teórica, opostos nesse âmbito.

A análise e o enfrentamento de tais oposições se fiarão consideravelmente nos novos paradigmas do direito administrativo contemporâneo, expostos no capítulo de aproximação ao tema deste trabalho. Como se observa nas páginas seguintes, os desafios postos à adoção da transação extrajudicial pela Administração Pública decorrem de argumentos que se descuram da necessária observância a esses novos marcos valorativos do direito do Estado no Brasil e, nesse sentido, a demonstração do anacronismo de suas visões é o instrumento mais contundente para a sua desconstrução.

Gaspar Ariño Ortiz destaca que o direito administrativo não é uma criação pacífica e lógica da razão, mas sim uma resposta a um desafio social, às mudanças sociais. A sua interpretação, portanto, estará sempre vinculada ao entorno econômico, político e social em que se insere e, por isso mesmo, adotará sentidos diferentes de acordo com as necessidades, as ideias e as exigências sociais do momento. ${ }^{377}$

A lição de Ariño Ortiz é precisa em definir o papel dessa visão na preparação das discussões jurídicas acerca da Administração Pública:

Um dos riscos do administrativista é justamente este: responder a perguntas que já não mais se formulam, ou o que é o mesmo, tratar de resolver falsos problemas, que não são suscitados, ignorando os verdadeiros. Daí que uma das chaves na elaboração de um Direito Administrativo que vise o futuro (não o passado) é esta: investigar as tensões entre interesses, as demandas atuais de nossa sociedade (mais ainda: as demandas futuras), pois certo é

377 ARIÑO ORTIZ, Gaspar. Lecciones de Administración y políticas públicas. Madrid: Iustel, 2013. P. 29-31. 
que as técnicas e instituições administrativas devem responder hoje a elas, e não aos anseios de nossos avós [grifo do autor]. ${ }^{378}$

Com base em tal entendimento, Ariño Ortiz elenca os qualificativos que entende mais adequados a caracterizar o direito administrativo: mobilidade e instabilidade; conflituosidade; caráter realizativo; natureza concreta e viva. ${ }^{379} \mathrm{O}$ presente capítulo se dedica, portanto, ao enfrentamento aos ditos desafios conceituais, à luz dos novos paradigmas delineados no capítulo que deu início à primeira parte do texto, com vistas à realização de um direito administrativo que, se ocupando de solucionar legitimamente os conflitos da contemporaneidade, se mostre dúctil, flexível, vivo, apto a trazer concretude ao seu papel abraçando um caráter realizativo.

A resistência à adoção da transação extrajudicial pela Administração Pública se insere no último dos quatro paradoxos contemporâneos sobre a relação entre poder público e autonomia privada destacados por Sabino Cassese: a expansão do direito comunitário frente à retração estatal; a liberalização econômica e a regulação; as privatizações e a nova regulação; e a decadência e reexpansão da atuação convencional. ${ }^{380}$

Destaca Cassese que, particularmente na experiência italiana, o passado foi pródigo na adoção de posicionamentos consensuais - ou do "módulo convencional" - em substituição às intervenções autoritárias. ${ }^{381}$ No entanto, apesar do crescimento dos incentivos à adoção da consensualidade administrativa, experimentou-se uma estabilidade de posicionamentos unilaterais na tomada das

${ }^{378}$ ARIÑO ORTIZ, Gaspar. Lecciones de Administración y políticas públicas. Madrid: lustel, 2013. P. 30. Tradução nossa.

No original: "Uno de los riesgos del administrativista es precisamente éste: responder a preguntas que ya no se formulan, o lo que es lo mismo, tratar de resolver falsos problemas, que no se plantean, olvidando los verdaderos. De ahí que una de las claves em la elaboración de un Derecho Administrativo que mire hacia delante (no hacia atrás) es ésta: ahondar en las tensiones de intereses, en las demandas actuales de nuestra sociedad (más aún: en las demandas futuras), pues es locierto que las técnicas e instituciones administrativas deben responder hoy a ellas, y no a los anhelos de nuestros abuelos [grifo do autor]."

${ }^{379}$ ARIÑO ORTIZ, Gaspar. Lecciones de Administración y políticas públicas. Madrid: lustel, 2013. P. 32-49.

${ }^{380}$ CASSESE, Sabino. Quattro paradossi sui rapporti tra poteri pubblici ed autonomie private. Rivista Trimestrale di Diritto Pubblico, Roma, a. 50, n. 2, p. 389-394, $2^{\circ}$ trim. 2000.

${ }^{381}$ CASSESE, Sabino. Quattro paradossi sui rapporti tra poteri pubblici ed autonomie private. Rivista Trimestrale di Diritto Pubblico, Roma, a. 50, n. 2, p. 389-394, $2^{\circ}$ trim. 2000. 
decisões tidas como mais importantes, restando alguns institutos, inclusive, quase inutilizados, como o pacto territorial da experiência italiana. ${ }^{382}$

No cenário brasileiro, o trabalho se dedicou a este paradoxo ao demonstrar, na sua primeira parte, que o inexorável movimento no sentido de uma maior consensualização nas relações entre Estado e cidadãos tem sido gravemente desafiado por uma postura desnecessariamente combativa da Administração Pública, que inflige enfrentamento e judicialização desnecessários aos pleitos dos particulares em face de si. Essa postura é em grande parte incentivada e justificada pelas oposições que ora o texto enfrenta.

Ana Celeste Carvalho bem resume o cenário de oposições teóricas à adoção de mecanismos consensuais de resolução de litígios pela Administração Pública:

Durante muito tempo existiu a ideia de que [a forma alternativa] de resolução de litígios, seria incompatível com as questões administrativas, devido à indisponibilidade do interesse público, a submissão da Administração Pública ao princípio da legalidade e a relação de poder estabelecida entre o Estado e o administrado [grifos da autora]. ${ }^{383}$

De fato, como detidamente enfrentado adiante, as oposições conceituais à adoção da transação extrajudicial pela Administração Pública têm encontrado como polos gravitacionais entendimentos - que entendemos superados - acerca do papel da legalidade no direito administrativo, do dever de impessoalidade na gestão pública e da suposta supremacia do interesse público.

O entendimento tido como clássico, no direito administrativo brasileiro, acerca de tais aspectos de juridicidade, é em grande parte - se não totalmente fruto de importações de institutos jurídicos de outros ordenamentos, principalmente do direito administrativo francês. ${ }^{384}$ Ocorre que, como conclui com propriedade

${ }^{382}$ CASSESE, Sabino. Quattro paradossi sui rapporti tra poteri pubblici ed autonomie private. Rivista Trimestrale di Diritto Pubblico, Roma, a. 50, n. 2, p. 389-394, $2^{\circ}$ trim. 2000.

${ }^{383}$ CARVALHO, Ana Celeste. A mediação em matéria administrativa: uma possibilidade com futuro. Cadernos de Justiça Administrativa, Braga, n. 109, p. 3-12, jan./fev. 2015.

${ }^{384}$ Não nos esqueçamos de um dos grandes paradoxos do direito administrativo, destacado por Di Pietro: o direito administrativo francês, que estabelece o princípio da legalidade como um dos principais eixos de validação do direito administrativo, tem na jurisprudência, e não na lei, a sua principal fonte. (DI PIETRO, Maria Sylvia Zanella. Introdução: Existe um novo direito administrativo? 
Fernando Dias Menezes de Almeida, o caráter dogmático e imutável dado a tais concepções no Brasil é substancialmente mais rígido do que aquele que se observa nos seus países de origem, onde o tratamento a elas dispensado é consideravelmente mais flexível e direcionado à mudança evolutiva. ${ }^{385}$

O texto passa a se dedicar, assim, à análise e à crítica a cada um dos posicionamentos expostos, ora desconstituindo-os, ora ressiginificando-os, abrindo caminho para o posterior enfrentamento aos desafios operacionais que igualmente se postam a impedir, sem razão, o caminho da Administração Pública à consensualidade por meio da transação extrajudicial.

\subsubsection{A legalidade administrativa e o seu papel na atuação do Estado contemporâneo}

A ressignificação do princípio da legalidade no direito administrativo atual é tarefa a que se dedicou o tópico inicial do capítulo de aproximação ao tema deste trabalho. Essa posição primaz do tratamento ao aspecto de legalidade se justifica, tanto naquele momento quanto neste, uma vez que as fontes ocupam um papel central em sistema jurídico positivista como se pretende o nosso.

Naquele momento, o primeiro dos novos paradigmas exposto consistiu na crise do conceito de legalidade e na ampliação de suas bases, fenômeno amplamente estudado pelo direito administrativo e que serve de pressuposto a muitas das suas outras transformações. Construiu-se o entendimento de que, no direito administrativo contemporâneo, o Estado não se vincula tão somente à lei, mas sim ao Direito como um todo, cenário no qual as disposições constitucionais, direitos fundamentais e princípios assumem um papel de protagonismo.

In: DI PIETRO, Maria Sylvia Zanella; RIBEIRO, Carlos Vinicius Alves (coords.). Supremacia do interesse público e outros temas relevantes do Direito administrativo. São Paulo: Atlas, 2010. P. 5.) ${ }^{385}$ ALMEIDA, Fernando Dias Menezes de. Teoria do contrato administrativo: Uma abordagem histórico-evolutiva com foco no Direito Brasileiro. 2010. Tese (Livre-docência em direito) Faculdade de Direito, Universidade de São Paulo, São Paulo, 2010. P. 226-227.

Menezes de Almeida reforça a sua ressalva: "É diferença verdadeira, mas talvez leve a que permaneça nos ditos contratos privados da Administração grau demasiado restrito de 'regime privatístico', para que se justifique a distinção das espécies de contratos da Administração no regime brasileiro vigente". 
Como visto, esse pode nem sempre ser um cenário positivo, na medida em que a maior abstração das normas - com o favorecimento de princípios em detrimento de regras - acaba por permitir uma maior flexibilidade interpretativa das disposições jurídicas, especialmente daquelas veiculadas pela constituição, enfraquecendo as peias legais de contenção da Administração Pública.

No entanto, como demonstra o presente tópico, essa nova juridicidade serve também - e principalmente, dir-se-ia - à ampliação do papel estatal na realização de sua missão institucional, no atingimento substancial do interesse público que é, ao fim e ao cabo, a realização dos direitos fundamentais do cidadão. $E$ isso se concretiza, no campo da solução dos conflitos em que figura a Administração Pública, pela ferramenta da transação extrajudicial.

Jean Rivero enxerga a essência do Direito Administração nas limitações impostas ao exercício do poder, considerando, inclusive, que tal traço seria o único traço universal a se observar em todos os modelos de direito administrativo observados nos mais diversos países. ${ }^{386}$ A solução a ser formulada no presente tópico centra-se, assim, na ressignificação dessas limitações, apurando justamente em que sentido elas exercem esse papel essencial destacado por Rivero no direito administrativo brasileiro.

Como se trata, aqui, do enfrentamento das oposições à adoção da transação extrajudicial pela Administração Pública, a metodologia mais adequada se constitui pela exposição de tais posicionamentos - que exsurgem das mais variadas origens - para, posteriormente, proceder-se com o tratamento teórico necessário.

São poucos, no direito administrativo brasileiro, os textos que tratam do recurso à transação pela Administração Pública e, como visto, o cenário atual carece de um tratamento dedicado e adequado à transação extrajudicial, profundamente diversa que é dos demais métodos de solução consensual de conflitos. Dentre esses trabalhos, são ainda mais raros aqueles que não se

${ }^{386}$ RIVERO, Jean. Cours de Droit Administratif comparé. Paris: Dalloz, 2011. P. 166. 
posicionam pela exigência de autorização legislativa para a firmatura de transação - seja judicial, seja extrajudicial - pelos entes estatais. ${ }^{387}$

Como visto, parcela considerável dos textos que abordam o tema se opõem à adoção da transação extrajudicial pela Administração Pública frente a uma suposta ofensa ao princípio da legalidade, uma vez ausente autorização legislativa que se dedique ao caso. ${ }^{388}$ Seria de se esperar, portanto, que a oposição baseada no princípio da legalidade fosse própria dos autores que se posicionam contra a própria possibilidade de recurso à transação extrajudicial, mesmo por outros motivos. $^{389}$

O surpreendente, no entanto, é que boa parte dos autores que admitem a possibilidade de transação extrajudicial na administração pública o fazem de forma condicionada, posicionando-se pela necessidade de existência de

387 Nesse sentido:

DALLARI, Adilson Abreu. Viabilidade da transação entre o poder público e particular. Interesse Público, Belo Horizonte, a. 4, n. 13, jan.-mar. 2002.

FARIA, Roberto Gil Leal. Por que são efetivados poucos acordos nos Juizados Especiais Federais? Revista da SJRJ, Rio de Janeiro, n. 24, p. 93-103, 2009.

388 É de se destacar que muitos autores, mesmo nos casos em que há expressa autorização legislativa - como para a transação em matéria tributária, ou para a transação judicial nos Juizados Especiais da Fazenda Pública - se posicionam pela sua inconstitucionalidade, ou pela necessidade de autorização legislativa específica para cada ente.

Nesse sentido:

MACHADO, Hugo de Brito; MACHADO SEGUNDO, Hugo de Brito. Transação em matéria tributária: Limites e inconstitucionalidades. Tributação em Revista, Brasília, a. 16, n. 56, p. 14-22, jan.-jun. 2010.

389 SCHIRMER, Mário Sérgio de Albuquerque. Impossibilidade de realização de acordos no âmbito do direito administrativo sem a existência de lei expressamente autorizando a avença. Repositório do Centro de Apoio Operacional das Promotorias de Justiça de Proteção ao Patrimônio Público e à Ordem Tributária. Curitiba: CAOP-MPPR, [s.d.].

Como exemplo de tais posicionamentos, aprecie-se o seguinte julgado: AGRAVO DE INSTRUMENTO. TRANSAÇÃO ENTRE MUNICÍPIO E PARTICULAR VISANDO INDENIZAÇÃO TRABALHISTA NÃO HOMOLOGADA PELO JUIZ A QUO. INEXISTÊNCIA DE AUTORIZAÇÃO LEGISLATIVA PARA A TRANSAÇÃO EFETUADA. RECURSO DESPROVIDO. "Por essa razão, há necessidade de lei para alienar bens, para outorgar concessão de serviço público, para transigir, para renunciar, para confessar, para relevar a prescrição (RDA, 107:278) e para tantas outras atividades a cargo dos órgãos e agentes da Administração Pública" (GASPARINI, Diogenes. Direito administrativo. 6a ed. Rev. Atual. E aum. São Paulo: Saraiva, 2001. Pp. 16/17). "À Fazenda Pública é defeso firmar 'transação', negócio jurídico de direito privado, salvo com autorização legal" (STJ $1^{\text {a }}$ Turma, REsp 68.177-4/RS, Min. Milton Luiz Pereira, j. 2.9.96. In NEGRÃO, Theotonio. Código de processo civil e legislação processual em vigor. 33 ed. Atual. São Paulo: Saraiva, 2002). (SANTA CATARINA. TRIBUNAL de Justiça de Santa Catarina. Agravo de Instrumento n. 2000.001639-0. Rel. Des. Francisco Oliveira Filho. Diário de Justiça de Santa Catarina, Florianópolis, n. 11.113, 20 jan. 2003). 
autorização legislativa específica para o caso, com base em uma acepção geral do princípio da legalidade, baseada em doutrinas tidas como clássicas. ${ }^{390}$

Nesse panorama, mesmo no caso da transação judicial entabulada nos Juizados Especiais da Fazenda Pública - cuja lei de criação, destaca-se, veicula autorização legislativa expressa para o recurso à transação -, há autores que sustentam que "tais disposições não são passíveis de aplicação imediata, pois a Administração Pública está adstrita ao princípio da legalidade, devendo assim editar lei [própria] autorizadora da transação judicial nos casos acima elencados". ${ }^{391}$

Destaque-se, ainda, que a pioneira tese de Onofre Alves Batista Júnior posiciona-se pela necessidade de autorização legislativa para o manejo da figura, sustentando que "[é] a lei, assim, que poderá estabelecer a possibilidade de transação administrativa preventiva ou terminativa" ${ }^{392}$

Nesse sentido, se mostra crucial o estudo que concluiu a primeira parte deste trabalho, analisando e definindo a natureza jurídica da transação extrajudicial na administração pública. É que, ao sustentar a natureza de contrato administrativo alternativo para o instituto, Onofre Alves Batista Júnior acaba por lhe emprestar o caráter estatutário próprio a essa figura, com a consequência de ter de exigir, por coerência lógica, a existência de autorização legislativa pela tipicidade que é característica aos contratos administrativos.

${ }^{390}$ Nesse sentido:

COUTINHO, Nilton Carlos de Almeida. Supremacia do interesse público e celebração de acordos pelo poder público: Juizados Especiais e eficiência administrativa. In: CONGRESSO NACIONAL DE PROCURADORES DE ESTADO, 37, 2011, Belo Horizonte. Anais... Brasília: ANAPE, 2011.

CUNHA, Leonardo José Carneiro da. A Fazenda Pública em juízo. São Paulo: Dialética, 2008. P. 90.

GAZDA, Emmerson. Administração Pública em juízo: poder-dever de transigir. Revista da Associação dos Juízes Federais do Brasil, Brasília, v. 23, n. 83, p.131-158, jan.-mar. 2006.

MADUREIRA, Claudio Penedo. Poder público, litigiosidade e responsabilidade social. Fórum Administrativo, Belo Horizonte, a. 11, n. 126, p. 9-22, ago. 2011.

${ }^{391}$ ESTEVES, Maurício Cramer. Da possibilidade e dos limites da transação em processos judiciais por parte do poder público municipal. Interesse Público, Belo Horizonte, a. 8, n. 38, jul./ago. 2006.

392 BATISTA JÚNIOR, Onofre Alves. Transações administrativas: um contributo ao estudo do contrato administrativo como mecanismo de prevenção e terminação de litígios e como alternativa à atuação administrativa autoritária, no contexto de uma administração pública mais democrática. São Paulo: Quartier Latin, 2007. P. 327. 
Ao nos posicionarmos pela natureza de contrato privado da Administração a ser conferida ao instituto, deixamos de aderir à opinião de tantos autores que, mesmo com a existência de previsão expressa da transação e de sua regulamentação pelos arts. 840 a 850 do Código Civil - ao alcance de todas as partes que detenham capacidade civil -, entendem que a adoção da transação pela Administração Pública dependeria de norma específica. Sustentariam esses autores, assim, que a autorização geral, veiculada na Lei Civil, não aproveitaria ao Estado, como que castrando a sua capacidade civil.

Esse posicionamento, nem sempre fundamentado suficientemente pelos seus cultores - que se rementem simplesmente ao "conceito clássico" do princípio da legalidade -, reflete os temores relacionados à dita "fuga para o direito privado", bem traduzidos por Maria Sylvia Di Pietro:

O direito administrativo brasileiro não é de elaboração pretoriana; a Administração Pública, se quiser criar figuras contratuais novas, tem que procurar seu fundamento no direito positivo.

Não é possível, pura e simplesmente, ignorar o regime jurídico de direito público, sem que se promovam as alterações legislativas necessárias a essa finalidade ${ }^{393}$

Como destaca Di Pietro, a Constituição Federal de 1988, fruto de um momento de transição histórica e política que delineou um cenário de desconfiança sobre a Administração - até hoje não superado - acabou por adotar com exagero formalismos limitantes à Administração Pública. Delineia-se assim um "paradoxo da legalidade" no direito brasileiro, consistente no descolamento entre direito posto e direito aplicado; nesse sentido, em vez de flexibilizar ou alterar a norma positiva, o gestor prefere manter a norma e descumprí-la, adotando o regime privado. ${ }^{394}$

Como demonstrar-se-á nessas páginas, esse descolamento não se observa ao adotar-se a transação extrajudicial na administração pública, já que não há fuga do regime constitucional, mas sim sua efetivação em plenitude. Não restam

\footnotetext{
${ }^{393}$ DI PIETRO, Maria Sylvia Zanella. Parcerias na Administração Pública: Concessão, permissão, franquia, terceirização, parceria público-privada e outras formas. São Paulo: Atlas, 2012. P. 304308.

${ }^{394}$ DI PIETRO, Maria Sylvia Zanella. Parcerias na Administração Pública: Concessão, permissão, franquia, terceirização, parceria público-privada e outras formas. São Paulo: Atlas, 2012. P. 305.
} 
motivos, portanto, para que seja alterado o direito positivo, que já regulamenta à suficiência o contrato de transação.

Em continuidade à sua crítica ao modelo de reforma estatal privatista da segunda metade dos anos 1990, Maria Sylvia Di Pietro revela o cerne de sua preocupação com a juridicidade das medidas inovadoras no cenário brasileiro:

\begin{abstract}
Enquanto no direito norte-americano e em outros direitos filiados ao sistema da common law os institutos novos podem ir sendo criados com maior facilidade, porque a sua validade jurídico-constitucional vai sendo analisada e afirmada ou negada pelo Judiciário apenas em face de princípios genéricos constantes da Constituição ou em face de standards contidos em leis também genéricas, no Brasil a adoção desses mesmos institutos esbarra a todo momento em normas constitucionais expressas.

$[\ldots]$

Em vez do direito administrativo desenvolver ou aplicar normas programáticas contidas na Constituição, ele vem se elaborando na frente e, muitas vezes, à margem da Constituição. ${ }^{395}$
\end{abstract}

Fica evidente que a preocupação com a adoção de novos institutos residiria na sua suposta oposição - ou em um presumido desrespeito - ao direito administrativo constitucionalmente posto. Os riscos à legalidade, supostamente advindos do uso de institutos inovadores, residiria então na "fuga para o direito privado" - na expressão já clássica de Maria João Estorninho ${ }^{396}$-, sempre que institutos de direito privado fossem adotados pela Administração Pública para, posteriormente, serem contemplados em diplomas legais e, finalmente, desaguarem na adequação das disposições constitucionais.

Maria Sylvia Di Pietro enxerga, assim, um cenário de inversão da hierarquia das normas e, portanto, de sua própria efetividade. O procedimento juridicamente adequado, frente à necessidade de inovação, seria a prévia adequação do regime constitucional estatuído para aquele campo em particular; a

\footnotetext{
395 DI PIETRO, Maria Sylvia Zanella. Parcerias na Administração Pública: Concessão, permissão, franquia, terceirização, parceria público-privada e outras formas. São Paulo: Atlas, 1999. P. 30-31.

${ }^{396}$ ESTORNINHO, Maria João. Fuga para o Direito privado: Contributo para o estudo da atividade de direito privado da Administração Pública. Coimbra: Almedina, 1999.

De acordo com Gustavo Binenbojm, a expressão teria buscado inspiração na Flucht in das Privatrecht estudada pela doutrina alemã (BINENBOJM, Gustavo. A constitucionalização do direito administrativo no Brasil: um inventário de avanços e retrocessos. Revista Eletrônica sobre a Reforma do Estado, Salvador, n. 13, mar.-mai. 2008).
} 
partir daí, proceder-se-ia com a edição de norma infraconstitucional adequada a trazer efetividade a estas novas disposições constitucionais e, com base nelas, passar-se-ia à prática administrativa destes novos institutos. O dito cenário de inversão, para a autora, consistiria na sua visão de que a inovação na Administração Pública tem sido, de início, consistente na adoção de práticas relacionadas àquela medida inovadora; num segundo momento é que seria editada a lei adequada para a sua regulação. Por último, seria reformada a Constituição para que tal medida fosse acomodada, providência que em vários casos sequer seria adotada. $^{397}$

Tratam-se, de fato, de preocupações legítimas, mas que não se revelam verdadeiras em relação à adoção da transação extrajudicial pela Administração Pública. Para prosseguir com tal demonstração, faz-se premente a análise do real papel da legalidade no Estado contemporâneo, à luz dos paradigmas já apresentados no capítulo de aproximação ao tema, para então formular-se posicionamento conclusivo.

O direito administrativo tem assistido, nos últimos anos, a um acirrado debate acerca da natureza deste próprio ramo do Direito em suas origens. Discutese, em um debate relacionado aos conceitos de supremacia enfrentados adiante, se o direito administrativo teria surgido, na Revolução Francesa, como instrumento autoritário, de afirmação e consolidação do poder, ou como símbolo liberal, de garantias do cidadão em face do Estado. ${ }^{398}$

Tais debates se refletem de modo especial sobre as concepções dos administrativistas acerca do papel a ser exercido pela Lei e pelo princípio de

\footnotetext{
397 DI PIETRO, Maria Sylvia Zanella. Parcerias na Administração Pública: Concessão, permissão, franquia, terceirização, parceria público-privada e outras formas. São Paulo: Atlas, 2012. P. 31-32.

${ }^{398}$ Nesse sentido, faz-se interessante o estudo dos debates acadêmicos entre os seguintes trabalhos:

BINENBOJM, Gustavo. Da supremacia do interesse público ao dever de proporcionalidade: um novo paradigma para o direito administrativo. In: SARMENTO, Daniel (org.). Interesses públicos versus interesses privados: desconstruindo o princípio da supremacia do interesse público. Rio de Janeiro: Lumen Juris, 2007.

GABARDO, Emerson; HACHEM, Daniel Wunder. O suposto caráter autoritário da supremacia do interesse público e das origens do direito administrativo: uma crítica da crítica. In: DI PIETRO, Maria Sylvia Zanella; RIBEIRO, Carlos Vinicius Alves (coords.). Supremacia do interesse público e outros temas relevantes do Direito administrativo. São Paulo: Atlas, 2010.
} 
legalidade em relação ao Estado contemporâneo, cujos frutos se refletem diretamente sobre a solução da questão aqui posta.

No direito administrativo brasileiro, o Visconde do Uruguay já sustentava, em meados do séc. XIX, que a "lei não póde prevêr e regular com anticipação a sua applicação a cada um dos casos que se hão de apresentar, avaliando, com prevenção, os interesses, que, em cada hypothese particular, hão de surgir e entrar em jogo". ${ }^{399}$ Verifica-se de plano, que não se justifica um argumento que tenha como clássico o entendimento de que a Administração Pública somente poderia fazer aquilo que lhe fosse permitido por lei - tema já enfrentado no capítulo que se dedica aos novos paradigmas da Administração Pública -, sentido no qual o verdadeiro papel da legalidade deve ser resgatado.

Apesar da difundida concepção de que o papel institucional do direito como instrumento dedicado à legitimação e contenção do poder tenha surgido com as constituições modernas, Harold Berman destaca que, já nos sécs. XI e XII as cidades europeias foram focos isolados de constitucionalismo em meio à organização política feudal que grassava na Idade Média. De acordo com o autor, a cidade europeia da Idade Média guardava certa analogia com o Estado moderno - e, consequentemente, com o regime de prerrogativas e sujeições próprio do direito administrativo, destacamos nós. Harold Berman sustenta tal posicionamento ao expor que este gérmen estatal contava com prerrogativas estatais típicas potestades de soberania e políticas que caracterizavam, especialmente, o poder de polícia -, sendo sujeito, em razão disso, a variadas restrições jurídicas. ${ }^{400}$

É do ponto de vista histórico que Vasco Pereira da Silva, em sua visão sempre peculiar, vê no nascimento do direito administrativo uma função puramente protecionista do Estado. Nesse sentido, interpretando o arrêt Blanco, entende que o surgimento do direito administrativo foi voltado única e exclusivamente à formação de um corpo jurídico que permitisse ao Estado evadir-se do dever de

\footnotetext{
399 URUGUAY, Paulino José Soares de Sousa, Visconde do. Ensaio sobre o direito administrativo. Rio de Janeiro: Typographia Nacional, 1862. V. 1, p. 79-81.

400 BERMAN, Harold J. Law and Revolution: The Formation of the Western Legal Tradition. Cambridge: Harvard University Press, 1983. Passim.
} 
indenizar os particulares, o que seria devido pela aplicação do direito privado comum. ${ }^{401}$

No entanto, ainda que as origens do direito administrativo fossem autoritárias - o que foi sugerido pelos autores citados mas a que não adere o presente trabalho -, verifica-se que o sentido de legalidade na Administração Pública foi sendo desenvolvido com vistas à edificação de um sistema de garantias em favor do cidadão. Como se posiciona Marcello Caetano:

Em presença deste poder da Administração de declarar e executar
unilateralmente aquilo que julga ser o seu direito, - qual é a posição
dos particulares? Como hão-de defender os seus interesses
legítimos, obstar à arbitrariedade ou aos abusos administrativos,
reivindicar os seus direitos?
A organização da garantia dos direitos dos particulares é, afinal, o
ponto essencial do Direito administrativo: sem ela não existem
relações jurídicas, porque não haverá possibilidade de obrigar a
Administração a cumprir as obrigações assumidas segundo a lei. ${ }^{402}$

Nesse sentido, Léon Duguit destaca que, no ápice da Revolução Francesa, com a realização da Assembleia Nacional de 1789 , a proclamação e definição do "dogma da soberania estatal" foi levada a cabo em um binômio com os direitos de liberdade individual, delineados na Declaração dos Direitos do Homem e do Cidadão. O surgimento do poderio estatal é, assim, imediatamente limitado pela autonomia da vontade individual, de modo que só existe a soberania estatal na medida em que ela respeite a liberdade do indivíduo. ${ }^{403}$

Celso Antônio Bandeira de Mello bem destaca que a legalidade, como princípio integrante do dito regime jurídico administrativo, não surge tão somente como instrumento de estruturação e organização da Administração Pública, mas bem assim como limite ao poder e garantia aos cidadãos. A consolidação do princípio da legalidade revela que "o que se pretendeu e se pretende, a toda

\footnotetext{
401 SILVA, Vasco Pereira da. É sempre a mesma cantiga: o contencioso da responsabilidade civil pública. In: FACULDADE de Direito da Universidade de Lisboa. Estudos em homenagem ao Prof. Doutor Sérvulo Correia. V. II. Coimbra: Coimbra Editora, 2010. P. 1.205-1.229.

${ }^{402}$ CAETANO, Marcello. Manual de direito administrativo. Coimbra: Coimbra Editora, 1951. P. 323.

${ }^{403}$ DUGUIT, Léon. Les transformations du droit public. Paris: Armand Colin, 1913. P. 27.
} 
evidência, foi e é, sobretudo, estabelecer em prol de todos os membros do corpo social uma proteção e uma garantia" ${ }^{404}$

Verifica-se, pois, que a legalidade constitui justamente "uma das garantias essenciais do administrado, a que se deve manter intangível e conservar como uma das mais preciosas conquistas da luta frente às arbitrariedades dos governantes". 405

Verifica-se, portanto, que a legalidade na Administração Pública - ou juridicidade, como apurado no capítulo que se dedica aos novos paradigmas estatais - só encontra a sua razão de ser quando manejada na qualidade de garantia da realização dos direitos fundamentais do cidadão. A apreciação acrítica da vinculação à legalidade, esperando nela encontrar uma vinculação pela simples vinculação ou, ainda pior, sustentando a vinculação à legalidade em detrimento das garantias fundamentais do cidadão, constitui uma deformação inaceitável do sentido da legalidade administrativa.

Assim, o posicionamento que venha a defender uma vinculação desmedida da Administração à lei consolidaria um descolamento democrático entre o exercício do Poder Legislativo e as bases de sua legitimação, com a perda da "infalibilidade do legislador", nos moldes da Revolução de 1789, quando o mesmo encarnaria a vontade geral do povo. ${ }^{406}$

A extrapolação desse papel da lei como veículo de valor intrínseco da vontade geral, no comentário de Maria Sylvia Di Pietro, leva a um caminho de autossuficiência da lei que desvirtua essa sua qualidade; assim, "idealizada como

\footnotetext{
${ }^{404}$ MELLO, Celso Antônio Bandeira de. Grandes temas de Direito Administrativo. São Paulo: Malheiros, 2010. P. 186.

${ }^{405}$ PÉREZ, Jesús Gonzales. El administrado. Madrid: Abella, 1966. P. 31. Tradução nossa.

No original: "una de las garantías esenciales del administrado que es necesario mantener intangible y conservar como una de las más preciosas conquistas de la lucha frente a las arbitrariedades de los gobernantes".

No mesmo sentido:

GARRIDO FALLA, Fernando. Las transformaciones del régimen administrativo. Madrid: Instituto de Estudios Politicos, 1962. P. 20.

${ }^{406}$ FIORAVANTI, Maurizio. Los derechos fundamentales: Apuntes de historia de las constituciones. Madrid: Trotta, 2007. P. 73.
} 
instrumento de proteção das liberdades individuais, [a lei] acaba por colocar em risco essas mesmas liberdades, tornando-se instrumento de opressão" ${ }^{407}$

Faz-se necessário, assim, delinear um caminho pelo qual o espírito da vinculação à legalidade próprio dos primórdios do Estado de Direito possa ser transportado à contemporaneidade, adequando-se à mui diversa realidade social e, principalmente, aos novos papéis exercidos pela Administração Pública de nosso tempo.

Em busca dessa noção contemporânea de legalidade na Administração Pública, Jeremy Waldron constrói a sua teoria do rule of law no Direito do Estado ${ }^{408}$, edificando quatro teses com vistas à compreensão da particularidade do fenômeno jurídico na seara pública.

Em primeiro lugar, sustenta que "é necessário que haja uma concepção dedicada de rule of law que possa ser aplicada particularmente ao Direito do Estado". ${ }^{409}$ Nesse sentido, Waldron repudia a ideia de que seria possível alcançar um sistema jurídico homogêneo, abraçando a possibilidade de que o fenômeno jurídico se desvele de modo diferente em relação aos entes estatais e, em especial, com efeitos diferentes.

Sua segunda tese estatui, assim, que "foge ao escopo do rule of law no Direito do Estado evitar a interferência da atuação estatal sobre o exercício de direitos privados". ${ }^{410}$ Com tal afirmativa, Waldron se posiciona em favor de um conceito de rule of law que não seja tão somente instrumental à garantia de direitos

\footnotetext{
${ }^{407}$ DI PIETRO, Maria Sylvia Zanella. O princípio da supremacia do interesse público: sobrevivência diante dos ideais do neoliberalismo. In: DI PIETRO, Maria Sylvia Zanella; RIBEIRO, Carlos Vinicius Alves (coords.). Supremacia do interesse público e outros temas relevantes do Direito administrativo. São Paulo: Atlas, 2010. P. 90.

${ }^{408}$ Como pensador universal, porém inserido nos sistemas jurídicos da common law, Waldron adota, em seu idioma nativo, a expressão rule of law tanto para referir-se ao Estado de Direito quanto para designar o primado do Direito, o império da Lei. Optamos, pois, por manter a expressão no idioma inglês, rule of law, de modo a não perder tal polissemia e conservar sua riqueza de sentido.

${ }^{409}$ WALDRON, Jeremy. Public rule of Law. Public Law \& Legal Theory Research Paper Series, New York University, New York, n. 14-41, set. 2014.

${ }^{410}$ WALDRON, Jeremy. Public rule of Law. Public Law \& Legal Theory Research Paper Series, New York University, New York, n. 14-41, set. 2014.
}

Em uma ilustrativa metáfora, Waldron sustenta que o rule of law não deve servir tão somente de "cavalo de Tróia" a inserir os interesses privados no campo do Direito do Estado. 
individuais como ideal político, entendendo que se deve diferenciar a interferência estatal arbitrária da não-arbitrária. Seu pensamento vem assim negar, explicitamente, a concepção erigida por Montesquieu de que "não se deve regular pelos princípios de direito do Estado as coisas que se submetem aos princípios do direito civil". 411

A terceira tese de Waldron busca imprimir uma "publicidade" sobre a parte privada em suas relações com o Estado, expondo que "a parte privada em uma relação de Direito do Estado deveria ser vista e ver-se como um cidadão ou membro do público, e não somente o detentor de um interesse privado". 412 Ao sustentar tal tese, o autor expõe que, em suas pretensões perante o Estado, a parte privada se apresenta como cidadão e, portanto, como um membro do todo público, dotado que é, assim, também de um caráter público.

Tal posicionamento nos remete à acurada definição de Clèmerson Merlin Cléve para a expressão "cidadão", de necessária reprodução:

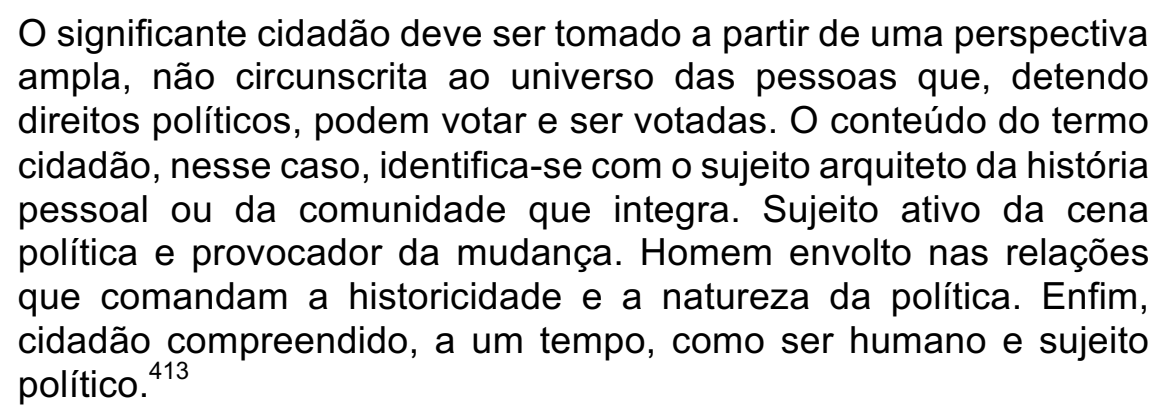

Assim, para Waldron, nunca haveria, numa relação de Direito do Estado, uma parte totalmente privada: mesmo a contraparte "não estatal" da relação deve ser interpretada como tendo um compromisso pessoal com a realização do interesse público. Waldron define tal relação, portanto, como uma relação entre uma autoridade pública e um membro do público, e não como uma relação entre

\footnotetext{
${ }^{411}$ MONTESQUIEU, Charles de Secondat de. De L'Esprit des Lois. Genéve: Barilot et Fils, 1.758. P. 322. Tradução nossa.

No original: "[II] ne faut point régler par les principes du droit politique les choses qui dépendent des principes du droit civil".

${ }^{412}$ WALDRON, Jeremy. Public rule of Law. Public Law \& Legal Theory Research Paper Series, New York University, New York, n. 14-41, set. 2014.

${ }^{413}$ CLÉVE, Clèmerson Merlin. O cidadão, a administração pública e a Constituição. Revista Eletrônica de Direito do Estado, Salvador, n. 31, jul.-set. 2012.
} 
uma parte pública e outra privada. Esse pensamento se alinha com os ensinamentos de Rousseau acerca da formação do poder soberano pela totalidade dos indivíduos que o compõem, delineando uma relação permanente entre o todo e as partes. ${ }^{414}$

Justamente pelo exposto nas três primeiras teses é que Jeremy Waldron repudia a análise de agentes externos a um certo sistema jurídico acerca de sua classificação ou não como Estado de Direito. Ora, na medida em que a própria parte não-estatal da relação jurídica de natureza pública faz parte do Estado como cidadão, somente um integrante experimentado em tal relação pode avaliá-la com propriedade em sua qualidade de rule of law, aferindo se a mesma cumpre os requisitos próprios daquela dada sociedade para a aceitabilidade da relação construída. Nesse sentido, Waldron edifica sua quarta tese sustentando que "a perspectiva de um agente estrangeiro não é apropriada para o desenvolvimento de uma concepção acerca do rule of law em uma dada sociedade". ${ }^{415}$

Evidentemente, as teses de Jeremy Waldrow acerca do papel do Direito do Estado em uma dada sociedade se voltam, com especial atenção, à modulação das relações internacionais, particularmente em relação ao fomento e ao investimento. No entanto, as suas três primeiras teses são de considerável utilidade para a compreensão do papel do Direito do Estado nas relações entre a Administração e os particulares.

É dizer, na medida em que uma concepção publicística do fenômeno jurídico abarque a compreensão de que, num jaez Rousseauniano, as partes privadas integram indissociavelmente o todo, o Direito a ser aplicado na regulação das relações entre tais partes - que, para Waldron, sequer podem ser tidas como privadas - e a Administração passa a ter um papel muito diverso daquele de simples contenção estatal.

\footnotetext{
${ }^{414}$ ROUSSEAU, Jean-Jacques. Du Contract Social, ou principes du Droit Politique. Amsterdam: Marc Michel, 1762. Passim.

${ }^{415}$ WALDRON, Jeremy. Public rule of Law. Public Law \& Legal Theory Research Paper Series, New York University, New York, n. 14-41, set. 2014.
} 
Em outras palavras, é necessário edificar a concepção de que, fazendo a contraparte privada parte do todo público, ${ }^{416}$ o Direito do Estado - e, em especial para o presente estudo, o direito administrativo - não deve ser visto tão somente como um direito de contenção, mas sim como um direito de realização. $A$ interpretação do direito aplicável à Administração Pública não deve consistir, pois, em um fim em si mesmo, de modo que a aplicação puramente positiva desse direito tenha como resultado a própria negação dos seus fundamentos.

De outro giro, a análise do papel contemporâneo da legalidade administrativa não prescinde da apreciação de seu papel simbólico. No campo da análise da metalinguagem da Lei, o pensamento de Jacques Chevallier é referencial por destacar com clareza e sistematicidade a dimensão simbólica do princípio da legalidade. Nesse particular, o autor parte da premissa - em uma metáfora arquitetônica - de que o princípio da legalidade constituiria a pedra angular da construção jurídica e política nos países que se pretendam liberais. Ao cumprir esse papel, tal princípio adota como conteúdo a afirmação de que o direito se apresenta sob a forma de uma ordem estruturada e hierarquizada, composta por níveis sobrepostos e subordinados - a normas jurídicas inferiores são válidas sob a condição de satisfazerem, formal e materialmente, às determinações das normas de nível superior -, e por mecanismos de regulação especializados - com vistas a verificar tal conformidade e eliminar as normas indevidas. ${ }^{417}$

Correspondendo a tal conteúdo, Jaques Chevallier caracteriza o princípio da legalidade como "polícia interna da ordem jurídica", como regra geral que determina as condições de produção das normas e definição dos termos de sua articulação. É a partir deste papel que o princípio da legalidade implicaria na sujeição do poder estatal às regras jurídicas. ${ }^{418}$

O pensamento de Jacques Chevallier guarda a notável peculiaridade de analisar, num segundo momento, o papel do princípio da legalidade na contenção

\footnotetext{
${ }^{416}$ Tal cenário teórico tem claras repercussões, também, sobre a concepção de interesse público, o que se abordará em capítulo adiante.

${ }^{417}$ CHEVALLIER, Jacques. La dimension symbolique du principe de légalité. Revue du Droit Public et de la Science Politique, Paris, v. 106, p. 1.652-1.677, 1990.

${ }^{418}$ CHEVALLIER, Jacques. La dimension symbolique du principe de légalité. Revue du Droit Public et de la Science Politique, Paris, v. 106, p. 1.652-1.677, 1990.
} 
estatal. O domínio do poder pela Lei, assim, seria considerado quase que como um subproduto da coerência interna do sistema legal, na medida em que a organização do sistema jurídico - em níveis sobrepostos e subordinados, regulados por mecanismos especializados - se refletiria na ação administrativa por constituir "seu fundamento, seu quadro e seu limite". 419

Nesse cenário de efetividade derivada, e não necessariamente direta, do princípio da legalidade na fundamentação e no controle do exercício do poder, Jacques Chevallier edifica o entendimento de que, além de sua função instrumental, o princípio da legalidade exerce uma função simbólica ${ }^{420}$ - não exclusiva, por evidente, deste princípio, mas patente e mais facilmente verificável nele.

É que, para Chevallier, o Direito extrai a sua força obrigatória não tanto do constrangimento, da restrição, mas sim da própria adesão daqueles a ele sujeitos. A aura simbólica da Lei, consubstanciada por uma representação idealizada da mesma - "a Lei mitificada" -, compõe e acumula o seu "capital de autoridade" que lhe permite obter não só a obediência, mas principalmente a adesão dos sujeitos. Tal circunstância tem a particularidade de constituir um cenário de paradoxo, em que com a racionalização e a laicização da sociedade cresce justamente um referencial simbólico, com valor que não advém de uma racionalidade demonstrada mas sim de uma "razão imanente", quase religiosa. O mesmo se desenvolve com as ideias de justiça, ordem e infalibilidade que, guardadas as suas particularidades, decorrem em maior ou menor grau do mito, e não da realidade da Lei.

Este cenário é fértil para o surgimento de dificuldades relacionadas justamente à própria natureza da construção mitológica. Na medida em que a força do princípio da legalidade vem desse seu valor mítico, o reforço de seu poder, mito

\footnotetext{
${ }^{419}$ CHEVALLIER, Jacques. La dimension symbolique du principe de légalité. Revue du Droit Public et de la Science Politique, Paris, v. 106, p. 1.652-1.677, 1990.

${ }^{420}$ Nas precisas palavras do autor: "[...] la norme juridique, n'est jamais un simple dispositif technique d'encadrement des rapports sociaux; véhiculant un ensemble de représentations, de valeurs, d'images, elle participe pleinement au système de références symboliques sur lequel repose l'ordre social" (CHEVALLIER, Jacques. La dimension symbolique du principe de légalité. Revue du Droit Public et de la Science Politique, Paris, v. 106, p. 1.652-1.677, 1990).
} 
que também é, acaba por ser uma projeção além do real, o que exclui a própria possibilidade da sua realização. No entanto, o mito tem de se apoiar na realidade para produzir seus efeitos. É essa tensão entre o mito e a realidade que gera as fragilidades do princípio da legalidade, um déficit simbólico que deve ser superado com fins a garantir a eficácia do Direito. ${ }^{421}$

A crise da legalidade, para Chevallier, decorreria pois de uma "demonização" da Lei, decorrente de sua dessacralização - a perda de seu caráter solene pela banalização de seus temas e degradação de seu conteúdo - e da constituição de um caráter opressivo - a quebra de confiança geral nas suas qualidades intrínsecas. Injusta, a Lei passa a ser desafiada e perde, ao fim, o seu "privilégio de incontestabilidade". ${ }^{422}$

Podemos extrair do pensamento de Jacques Chevallier uma afirmação que dele, ao menos expressamente, não consta: o uso simbólico da Lei acaba por esgotar e fazer ruir o valor simbólico da Lei - ou mesmo do princípio da legalidade.

Eles elementos nos levam, ainda, a uma análise do câmbio no papel da legalidade administrativa em decorrência das mudanças no próprio papel do Estado, entre suas faces "de Direito" e "social", momento em que retomamos alguns dos pontos levantados no capítulo de aproximação ao tema. Nesse cenário, com a intenção de formatar-se um Estado de Direito Social e Democrático - cuja fórmula é detectada por Maria Sylvia Di Pietro no art. $1^{\circ}$ e em diversas disposições da Constituição Federal de 1988 -, tem-se a transição entre o Estado Legal, de juridicidade puramente formalista, para o Estado de Direito, vinculado aos ideais de justiça material. $^{423}$

\footnotetext{
${ }^{421}$ CHEVALLIER, Jacques. La dimension symbolique du principe de légalité. Revue du Droit Public et de la Science Politique, Paris, v. 106, p. 1.652-1.677, 1990.

${ }^{422}$ Conclui o autor: "Le principe de légalité est donc indissociable d'une construction symbolique qui est à la fois le soubassement sur lequel il s'appuie et a condition de son efficacité. Si cette symbolique a évolué, en relation avec les transformations du droit et de la société, elle est structurée autour d'un fonds commun de représentations dont le système purifique ne saurait se passer: la dogmatique purifique ne peut fonctionner en effet sans la croyance dans le bien-fondè de la norme: aussi le culte de la Loi survit-il en dépit des changements de rituels imposés par les mutations de l'ordre social" (CHEVALLIER, Jacques. La dimension symbolique du principe de légalité. Revue du Droit Public et de la Science Politique, Paris, v. 106, p. 1.652-1.677, 1990).

${ }^{423}$ DI PIETRO, Maria Sylvia Zanella. Parcerias na Administração Pública: Concessão, permissão, franquia, terceirização, parceria público-privada e outras formas. São Paulo: Atlas, 2012. P. 14/26.
} 
Nesse cenário de transição entre a vinculação à lei e a vinculação ao direito, a constituição de um Estado exerce papel central. Dieter Grimm destaca, assim, que aos efeitos da constituição poderiam ser apostos três qualificativos: primeiramente, a constituição teria efeito constitutivo, uma vez que não só descreve, mas constitui, dá origem, à legitimidade no exercício do poder; num segundo momento, a constituição teria efeitos completos, já que regula todos os aspectos do poder estatal; e, finalmente, a constituição moderna teria efeitos universais, frente à amplitude de seus benefícios, que imperam em favor de todos aqueles que estiverem submetidos ao poder. ${ }^{424}$

Esse papel da ordem constitucional sobre a legalidade administrativa não pode ser ignorado, em especial quando tratamos da solução consensual de conflitos pela Administração Pública. Nesse cenário, incidem transversalmente sobre o debate aqui proposto as questões de hermenêutica constitucional relacionadas à força normativa da constituição e à eficácia direta dos direitos fundamentais, a cuja apreciação o trabalho muito brevemente se dedica.

Consoante as lições de Lassalle, a concepção clássica de constituição a tem como um texto político, e não jurídico, cuja força viria das relações fáticas consubstanciadas nas potestades políticas e sociais. ${ }^{425}$ Daí advém a análise do conteúdo de um texto constitucional para apurar se é o mesmo materialmente constituição - ou seja, se trata do poder estatal e dos direitos e garantias fundamentais - ou se apenas formalmente se integra ao texto constitucional. A adoção de tal posicionamento implicaria em que, a rigor, o texto constitucional não contasse com eficácia direta do ponto de vista jurídico, uma vez que o sistema jurídico positivo, baseando-se na centralidade da norma, dependeria de texto normativo em sentido estrito para o exercício de sua força obrigatória.

${ }^{424}$ GRIMM, Dieter. Constitucionalismo y derechos fundamentales. Madrid: Trotta, 2006.

No mesmo sentido:

GABARDO, Emerson; HACHEM, Daniel Wunder. O suposto carater autoritário da supremacia do interesse público e das origens do direito administrativo: uma crítica da crítica. In: DI PIETRO, Maria Sylvia Zanella; RIBEIRO, Carlos Vinicius Alves (coords.). Supremacia do interesse público e outros temas relevantes do Direito administrativo. São Paulo: Atlas, 2010. P. 18-22.

${ }^{425}$ LASSALLE, Ferdinand. A Essência da Constituição. Rio de Janeiro: Liber Juris,1985. Passim. 
Konrad Hesse se opõe ao pensamento de Lassalle sem, no entanto, aderir a um positivismo constitucional que isole a norma da realidade, como sustentaram, de pontos de vista diversos, Laband, Jellinek e Carl Schmitt. ${ }^{426} \mathrm{O}$ autor defende que a realização do conteúdo constitucional reside no condicionamento de comportamentos e na imposição de tarefas, traços que trariam um tom histórico e social, atrelado ao seu tempo e à sua realidade, para que o conteúdo constitucional se torne verdade. ${ }^{427}$

Nesse contexto, destaca-se o pensamento de Konrad Hesse quanto à importância da interpretação constitucional para a efetividade de suas disposições. Para o autor, nos sistemas nos quais há uma jurisdição constitucional que exerce um protagonismo no sistema jurídico, ${ }^{428}$ a vinculatividade do conteúdo constitucional depende essencialmente do sentido dado pela corte constitucional ao mesmo. Só existiria, assim, o texto constitucional tal como interpretado pela corte constitucional. ${ }^{429}$

Diante de tal cenário, Umberto Allegretti destaca o papel da missão estatal para a extração ${ }^{430}$ das disposições constitucionais acerca da Administração Pública. Destaca que é pela ordem dos valores - que é, de fato, a ordem do Direito - inscritos no corpo constitucional que a Administração deve ser conformar, no fenômeno a que chama "adesão à ideia constitucional" ${ }^{431}$

\footnotetext{
${ }^{426}$ HESSE, Konrad. A Força Normativa da Constituição. Porto Alegre: Sérgio Antônio Fabris, 1991. P. 13-14.

${ }^{427}$ MAGALHÃES, Marco Túlio Reis. Hermenêutica constitucional: comparação das teorias de Konrad Hesse e Friedrich Müller. Revista Jurídica da Presidência da República, Brasília, v. 7, n. 75, p. 1-25, out.-nov. 2005.

${ }^{428}$ Marco Túlio Reis Magalhães identifica no Supremo Tribunal Federal brasileiro a marca distintiva que o enquadraria no tipo de jurisdição constitucional a que Hesse se refere (MAGALHÃES, Marco Túlio Reis. Hermenêutica constitucional: comparação das teorias de Konrad Hesse e Friedrich Müller. Revista Jurídica da Presidência da República, Brasília, v. 7, n. 75, p. 1-25, out.-nov. 2005).

${ }^{429}$ HESSE, Konrad. Elementos de Direito Constitucional da República Federal da Alemanha. Porto Alegre: Sérgio Antônio Fabris, 1998. P. 54.

${ }^{430}$ Allegretti destaca que trata de um processo reconstrutivo, e não simplesmente exegético, de extração das disposições constitucionais que condicionam à Administração Pública além daquilo que se pode, de modo expresso, extrair do texto constitucional (ALLEGRETTI, Umberto. Amministrazione pubblica e costituzione. Milão: Cedam, 1996. P. 10-11).
}

${ }^{431}$ ALLEGRETTI, Umberto. Amministrazione pubblica e costituzione. Milão: Cedam, 1996. P. 10-11. 
Assim, a correlação entre a Administração e a constituição, em um Estado "democrático, liberal e social", deve ser fruto desta "adesão à ideia constitucional", aliada à força crítica, sabedoria histórica e tenacidade construtiva; a aplicação de tais critérios para a extração do sentido constitucional é que permitirá definir corretamente o binômio tarefas do Estado-direitos do cidadão. ${ }^{432}$

$\mathrm{Na}$ primeira parte deste binômio, a Administração Pública é condicionada constitucionalmente por ser a porção terminal do processo de atuação realizativa das tarefas estatais - nesse sentido, pois, a grande tarefa da Administração Pública é "servir aos homens". 433

Desse ponto mesmo é que exsurge a contraparte do binômio, uma vez que os direitos do homens - ao qual servirá, incondicionalmente, a Administração - é que fundamentam "a origem, a essência e o finalismo do Estado Democrático e Social". ${ }^{434}$ A realização desses direitos se convola, pois, no "íntimo dinamismo" que move a atividade dos titulares do poder. ${ }^{435}$

Sem qualquer pretensão de constituir-se em análise aprofundada ou de esgotar o assunto abordado, essa brevíssima exposição vem demonstrar que, para a formação de um panorama das normas de direito administrativo - uma vez que discutimos, aqui, a vinculação da Administração Pública à juridicidade -, é essencial o reconhecimento do papel normativo que a Constituição exerce, constituindo efetivamente parcela importante do que se compreende como direito administrativo no Brasil.

Como expõe Fabrício Motta:

[...] do ponto de vista filosófico e político, permanece o princípio da legalidade como marco de extinção do livre arbítrio da vontade pessoal do administrador público [...].

\footnotetext{
${ }^{432}$ ALLEGRETTI, Umberto. Amministrazione pubblica e costituzione. Milão: Cedam, 1996. P. 10-11. ${ }^{433}$ ALLEGRETTI, Umberto. Amministrazione pubblica e costituzione. Milão: Cedam, 1996. P. 11-14. ${ }^{434}$ ALLEGRETTI, Umberto. Amministrazione pubblica e costituzione. Milão: Cedam, 1996. P. 12-17.

${ }^{435}$ Nesse sentido, o binômio é resumido por Allegretti em uma analogia dinâmica circular, em que "[...] come partendo dai compiti dello stato si trova l'amministrazione, così esta ha il suo posto alla fine della sequenza che parte dalle proclamazioni dei diritti. Anzi le due filiere si incontrano; poiché compito dello stato è servizio dei diritti e i diritti richiedono un compito allo stato, la sequenza è in realtà unitaria: dai diritti dei cittadini derivano i compiti dello stato e la missione dell'amministrazione." (ALLEGRETTI, Umberto. Amministrazione pubblica e costituzione. Milão: Cedam, 1996. P. 12).
} 
[...] como princípio que habilita e possibilita as atuações do Estado (vinculação positiva à lei formal), tornando objetivo o exercício do poder, a legalidade sofre importantes alterações em razão da força normativa da Constituição. Passa-se a admitir a supremacia constitucional, a impositividade dos direitos fundamentais e a normatividade dos princípios. Em consequência, admite-se a atuação administrativa fundada diretamente na Constituição, com o intuito de aplicá-la, sem a intermediação da lei. ${ }^{436}$

Essa importância da Constituição para a conformação da normatividade administrativa nos remete aos novos paradigmas do direito administrativo, em especial à caracterização do direito fundamental à boa administração pública e à assunção de um novo modelo relacional entre o Estado e os cidadãos, que nesse sentido são caracterizados efetivamente como normas de direito administrativo. Apreciar o princípio da legalidade no tocante à adoção da transação pelos entes estatais passa, assim, pelo reconhecimento de que tais paradigmas constituem conteúdo indissociável do referencial jurídico para tal legalidade.

Retomando a construção lógica inicial deste tópico, verificamos que o sentido do princípio da legalidade no direito administrativo é garantista. Em relação à problemática própria ao Estado de Direito, trata-se de uma garantia negativa, de contenção estatal; já no tocante às funções do Estado social, tratamos de uma garantia positiva, de realização dos direitos sociais. Independentemente do aspecto sob o qual tratamos a legalidade, tratamos de garantia, pois.

Transportando toda a construção exposta para o cenário da oposição aqui enfrentada, negar a possibilidade de transação extrajudicial pela Administração Pública quando ausente autorização legislativa específica corresponde a negar vigência ao próprio princípio da legalidade. Isso porque, ao verificarmos que o recurso à transação extrajudicial serve à realização da missão institucional do Estado - garantia essencial, portanto, da centralidade dos direitos fundamentais -, a legalidade-garantia só se realiza quando sirva à realização dos direitos do cidadão.

${ }^{436}$ MOTTA, Fabrício. O paradigma da legalidade e o Direito Administrativo. In: DI PIETRO, Maria Sylvia Zanella; RIBEIRO, Carlos Vinicius Alves (coords.). Supremacia do interesse público e outros temas relevantes do Direito administrativo. São Paulo: Atlas, 2010. P. 184. 
Opor à realização dos direitos do cidadão, instrumentalizada pela transação extrajudicial, a falta de uma autorização legislativa - a legalidade pela legalidade, portanto -, não encontra qualquer suporte na essência do princípio da legalidade.

Tome-se, por exemplo, o caso da responsabilidade extracontratual do Estado em que, mesmo diante das disposições do $\S 6^{\circ}$ do art. 37 da Constituição Federal - que estabelece a responsabilidade extracontratual objetiva do Estado, independentemente de comprovação de dolo ou culpa -, muitos autores sustentam a imprescindibilidade de autorização legal específica para a sua solução por meio consensual. Adotando tal caso como provocação, resta claro que sustentar a impossibilidade de a Administração indenizar o particular lesionado manejando a transação extrajudicial pela simples falta de lei que a autorize é a epítome da negativa à realização de uma garantia fundamental, constituindo uma distorção inaceitável do princípio da legalidade que só pode ter origem no absoluto desconhecimento das raízes desse princípio do direito administrativo.

Isso se afirma uma vez que, como destaca Carlos Maximiliano em sua hermenêutica, não se pode conferir à lei um sentido que contrarie diametralmente a sua essência, a sua intenção última. ${ }^{437}$ Constitui uma questão lógica, pois, evitar que a interpretação dada ao princípio da legalidade venha a negar o próprio espírito de garantia que orienta e fundamenta o mesmo princípio.

Assim, não há sentido em sustentar que o apego ao princípio da legalidade sirva para negar, pela falta de lei autorizativa, a realização dos direitos fundamentais pela ultimação da função institucional do Estado. Como destaca Sabino Cassese, a função principal do princípio da legalidade é a tutela dos cidadãos: o parlamento, por intermédio da lei, garante aos cidadãos, "defendendoos" da Administração Pública. ${ }^{438}$

\footnotetext{
${ }^{437}$ MAXIMILIANO, Carlos. Hermenêutica e aplicação do Direito. Rio de Janeiro: Forense, 1984. Passim.

${ }^{438}$ CASSESE, Sabino. Corso di Diritto Amministrativo: Istituzioni di Diritto Amministrativo. V. I. Milano: Giuffrè, 2004. P. 8.
} 
Cabe aqui, portanto, delinear o cenário que permita concluir pela desnecessidade de autorização legislativa para que a Administração se socorra à transação extrajudicial para pacificar as suas relações.

Para Cassese, o princípio da legalidade exerce ainda, além do papel de garantia dos cidadãos, uma outra tarefa: a de assegurar o funcionamento do circuito democrático, tanto pela eleição popular do parlamento quanto pela execução administrativa da lei. Esta segunda função relacionar-se-ia mais com o direcionamento da Administração Pública do que com as garantias do cidadão. ${ }^{439}$

Sérvulo Correia destaca com precisão a polissemia do princípio da legalidade. O sentido de legalidade administrativa designa a disciplina das "relações entre as normas jurídicas e o desempenho da função administrativa, desdobrando-se nos princípios da precedência de lei e da reserva de lei. ${ }^{440}$

A precedência de lei, ou compatibilidade, significa que "os actos da Administração não devem contrariar as normas legais que se lhe aplicam". Já a reserva de lei, ou conformidade, exige que "a prática de um acto pela Administração corresponda à prévia estatuição de uma norma jurídica", seja no sentido formalprocedimental ou material. A legalidade no sentido de reserva de lei seria ligada, histórica e primordialmente, ao sentido liberal e garantista - negativo, portanto - do princípio. $^{441}$

Sérvulo Correia interpreta estas duas faces da legalidade como reflexos dos posicionamentos francês e alemão acerca do tema. Enquanto no direito administrativo francês contemporâneo a lei parlamentar vem perdendo o

439 CASSESE, Sabino. Corso di Diritto Amministrativo: Istituzioni di Diritto Amministrativo. V. I. Milano: Giuffrè, 2004. P. 8-9.

440 CORREIA, José Manuel Sérvulo. Legalidade e autonomia contratual nos contratos administrativos. Coimbra: Almedina, 1987. P. 755-756.

${ }^{441}$ Avança Sérvulo Correia na exposição: "A ideia liberal de que as intervenções ablativas concretas na liberdade e na propriedade dos cidadãos carecem de uma base constituída por normas jurídicas gerais e abstractas votadas pelo órgão electivo de representação nacional ou popular encontra as suas raízes na doutrina jusnaturalista dos direitos do homem, na ideia da separação de poderes e no princípio da soberania popular. Para o pensamento jusnaturalista racionalista, a exigência de que os comandos concretos do poder encontrem a sua base na lei salvaguarda a liberdade individual originária porque assegura a coincidência entre a sujeição ao comando e a sua autoria e garante a justiça deste graças à identificação da generalidade da norma com a sua racionalidade e, logo, com o seu valor ético" (CORREIA, José Manuel Sérvulo. Legalidade e autonomia contratual nos contratos administrativos. Coimbra: Almedina, 1987. P. 756). 
protagonismo, frente à delimitação não só do âmbito, mas também da própria natureza do princípio da legalidade pelo fenômeno da discricionariedade, o direito administrativo alemão experimenta a conversão da "lei-limite" em "lei-critério" uma vez que, pela teoria da essencialidade (Wesentlichkeitstheorie), somente o Parlamento tem a legitimidade para definir por lei os parâmetros jurídicos das questões essenciais da vida em comunidade. ${ }^{442}$

Independentemente da função adotada para o princípio da legalidade, Cassese destaca que, no direito administrativo marcado pela bilateralidade, este princípio tem noção diversa da de reserva legal. Ora, nesse sentido, somente quando houver a previsão constitucional expressa acerca da reserva legal é que se exigirá a intervenção do legislador no sentido de autorizar determinada conduta por parte da Administração, regulando-a suficientemente. Cassese estabelece, assim, que a aplicação do princípio da legalidade não implica, necessariamente, na adoção de uma regra de tipicidade ou normatividade dos atos da administração, frente aos poderes implícitos conferidos ao Estado e à sua autotutela e autoadministração. ${ }^{443}$

Isso decorre, no caso específico analisado por esta tese, da aplicação da autonomia contratual - compreendendo tanto a liberdade de celebração quanto a liberdade de estipulação - ao regime jurídico da Administração Pública.

442 CORREIA, José Manuel Sérvulo. Legalidade e autonomia contratual nos contratos administrativos. Coimbra: Almedina, 1987. P. 757-761.

${ }^{443}$ CASSESE, Sabino. Corso di Diritto Amministrativo: Istituzioni di Diritto Amministrativo. V. I. Milano: Giuffrè, 2004. P. 9.

Estamos a falar aqui, especificamente, da adoção de contratos de natureza tipicamente privada pela Administração Pública, com o fim precípuo de dar efetividade à sua missão institucional. É de se destacar que, em se tratando de contratos administrativos, a tipicidade legal se caracteriza, em especial se adotarmos o critério estatutário eleito por Sérvulo Correia para a caracterização dos contratos administrativos, tal como exposto no capítulo 3.5. Quanto a essa dualidade de aplicação ou não da tipicidade legal - cabível nos contratos administrativos mas não nos contratos privados da administração - instrumental é a lição de Sérvulo Correia: "As atribuições da pessoa colectiva pública desempenham uma indispensável função directa na delimitação da respectiva capacidade contratual de direito público quando se trate de contratos administrativos atípicos com objecto passível de contrato privado. Pelo contrário, a determinação de efeitos jurídico-administrativos através de contratos administrativos atípicos com objecto passível de acto administrativo encontra na norma jurídica atributiva de competência material a indispensável permissão específica e uma directiva teleológica unidimensional" (CORREIA, José Manuel Sérvulo. Legalidade e autonomia contratual nos contratos administrativos. Coimbra: Almedina, 1987. P. 782-783). 
Sérvulo Correia transporta essa autonomia contratual, própria do regime privado, ao direito administrativo, pela figura que denomina de autonomia pública contratual, que seria "a permissão da criação, no âmbito dos actos administrativos e dos contratos administrativos, de efeitos de direito não predeterminados por normas jurídicas", ou seja, a "margem de livre decisão na criação de efeitos de direito nas situações concretas regidas pelo Direito Administrativo". 444

Se tal autonomia é possível no regime dos contratos administrativos, tanto mais no recurso aos contratos privados pela Administração, ainda mais quando a medida pela qual se opta é expressamente prevista no regime privado.

Esta autonomia não se revela, evidentemente, nos casos em que haja a plena vinculação da atuação administrativa. O que destacamos aqui é que, ao contrário do que ocorre com a atuação autoritária da Administração, a ausência de autorização legislativa expressa não constitui vinculação negativa de vedação à adoção de figuras contratuais externas ao direito administrativo, havendo, nesse caso, liberdade decisória da Administração quanto à adoção ou não daquela figura contratual para a consecução de sua missão institucional.

Isso não significa dizer, no entanto, que a ausência de disposição legal expressa levaria a uma liberdade contratual absoluta em favor da Administração; como em todos os campos de atuação administrativa - e não só no âmbito contratual -, "a autonomia pública conhece, a par dos limites negativos, limites positivos de finalidade, imparcialidade e proporcionalidade". ${ }^{445}$

Como já sustentado neste trabalho, apesar das concepções tidas como clássicas no direito administrativo brasileiro, o princípio da legalidade não implica em que a Administração Pública só possa fazer aquilo que a lei the permite,

\footnotetext{
${ }^{444}$ Não se trata, no entanto, de sustentar a equivalência entre as liberdades contratuais privada e pública; a "natureza positivamente heterodeterminada da autonomia pública distingue-a da autonomia privada que se desenvolve através de comportamentos aos quais basta a licitude" (CORREIA, José Manuel Sérvulo. Legalidade e autonomia contratual nos contratos administrativos. Coimbra: Almedina, 1987. P. 776-792).

445 CORREIA, José Manuel Sérvulo. Legalidade e autonomia contratual nos contratos administrativos. Coimbra: Almedina, 1987. P. 779.
} 
principalmente porque "[...] a lei não tem condições de prever todas as situações possíveis de ocorrer e apontar as respectivas decisões". ${ }^{446}$

Assim, Sabino Cassese expõe que, ao contrário do que amplamente se Ihe atribui a literatura, o princípio da legalidade - nos moldes do direito administrativo - tem um âmbito de aplicação consideravelmente restrito. A legalidade que implicaria em uma tipicidade estrita dos atos administrativos se aplica à administração autoritária, unilateral, e não aos atos da administração que lançam mão do direito privado. ${ }^{447}$

Analisando este tema sob o ponto de vista da adoção da arbitragem pela Administração Pública, Sabino Cassese expõe a questão de maneira magistral: em havendo disposição civil acerca da possibilidade, à disposição de quaisquer partes, da adoção da solução consensual, esta disposição satisfaz o princípio da legalidade próprio do direito administrativo. A Administração não careceria, portanto, de uma autorização legislativa ad hoc; o poder de adotar a solução extrajudicial do conflito é reconhecido pela própria Lei, para todas as partes com capacidade civil. Caso assim não fosse, diz Cassese, estaríamos em um cenário que causa estranhamento, uma vez que o sujeito mais importante do ordenamento não poderia lançar mão de uma possibilidade reconhecida pelo Código Civil a todos os sujeitos - o que levaria, propriamente, a uma diminuição da capacidade do sujeito público frente aos privados. ${ }^{448}$

\footnotetext{
${ }^{446}$ DI PIETRO, Maria Sylvia Zanella. Da constitucionalização do Direito Administrativo: Reflexos sobre o princípio da legalidade e a discricionariedade administrativa. In: DI PIETRO, Maria Sylvia Zanella; RIBEIRO, Carlos Vinicius Alves (coords.). Supremacia do interesse público e outros temas relevantes do Direito administrativo. São Paulo: Atlas, 2010. P. 176-178.

${ }^{447}$ CASSESE, Sabino. L'arbitrato nel Diritto Amministrativo. Rivista Trimestrale di Diritto Pubblico, Roma, a. 46, n. 2, p. 311-328, $2^{\circ}$ trim. 1996.

${ }^{448}$ CASSESE, Sabino. L'arbitrato nel Diritto Amministrativo. Rivista Trimestrale di Diritto Pubblico, Roma, a. 46, n. 2, p. 311-328, $2^{\circ}$ trim. 1996.

Nas precisas palavras de Cassese: "Il ricorso all'arbitrato, nei conflitti di cui sia parte la pubblica amministrazione, è stato negato, in primo luogo, in base al principio di legalità. Quest'ultimo, tuttavia, è stato invocato erroneamente. Da un lato, infatti, il principio di legalità non è violato, perchè l'arbitrato è previsto dall'art. $806 \mathrm{ss}$. Del codice di proceduta civile. II principio di legalità è, dunque, soddisfatto dalle stesse norme del codice. La pubblica amministrazione non ha bisogno di un'autorizzazione legislativa ad hoc. Se c'è la legge, la pubblica amministrazione può utilizzare le potestà riconosciute dalla legge. Sarebbe strano se così non fosse: il soggetto più importante dell'ordinamento non potrebbe utilizzare le potestà riconosciute dal codice a tutti i soggetti. Ciò comporterebbe una diminuzione della capacità del soggetto pubblico rispetto ai privati".
} 
Isso não significaria que não hajam limites à adoção da transação pela Administração Pública; tais limites, no entanto, decorrem de normas expressas que os instituam, sejam essas de caráter público ou privado. Não há que se falar, portanto, em uma impossibilidade ínsita de adoção da transação extrajudicial pela Administração Pública pela simples ausência de autorização legislativa específica. $^{449}$

Cabe aqui uma importante diferenciação, essencial para que o posicionamento aqui exposto não se torne contrário à sistematicidade do direito administrativo: discutir a norma acerca da possibilidade de transação extrajudicial na administração pública é tema profundamente diverso da discussão acerca de norma que fixe a competência para a firmatura de um contrato de transação. Diferencia-se, assim, uma norma acerca da função da Administração de uma norma que trate de sua estrutura.

Nesse sentido, admitimos ser possível a exigência de uma regra para que certo agente público tenha a competência para celebrar transações em nome do órgão a que pertença. ${ }^{450}$ No entanto, isso não implica em uma necessidade $a$ priori de norma que fixe a competência já que, na sua ausência, o chefe de poder - ocupante, portanto, da mais alta posição hierárquica na Administração - sempre contará com a competência para tanto.

Assim, no tocante à legalidade relativa à competência, Adilson Abreu Dallari expõe o entendimento de que a atribuição genérica de competência para representar o ente em relações jurídicas ou para celebrar contratos, comumente presente em constituições e leis orgânicas de entes da Administração Direta, seria

\footnotetext{
${ }^{449}$ Com o pioneirismo em matéria de direito administrativo que Ihe é peculiar, a França já assiste desde 1887, em seu ordenamento, o entendimento do Conselho de Estado de que, mesmo sem previsão ou autorização legal, a Administração Pública pode adotar a transação para solucionar ou prevenir litígios em matéria de direitos subjetivos, como definido no caso Evêque des Moulins (CHAVRIER, Géraldine. Réflexions sur la transaction administrative. Revue Française de Droit Administratif, Paris, n. 3, p. 548-566, mai.-jun. 2000).

${ }^{450}$ Ana Celeste Carvalho entende que a adoção de métodos de solução consensual de conflitos pela Administração Pública dependeria de autorização legislativa, não pela incidência pura do princípio da legalidade, mas sim por uma necessidade de fixação adequada de competência para que a Administração Pública recorresse à solução consensual (CARVALHO, Ana Celeste. A mediação em matéria administrativa: uma possibilidade com futuro. Cadernos de Justiça Administrativa, Braga, n. 109, p. 3-12, jan./fev. 2015).
} 
autorização legal suficiente para que o chefe do Poder Executivo celebrasse contratos de transação extrajudicial em nome do ente. ${ }^{451}$

O posicionamento exposto carece de uma pontual ressalva, ainda, em relação à transação em matéria tributária, uma vez que a sua natureza peculiar exige, tal como expressamente disposto nas normas positivas concernentes, a emissão de autorização legislativa específica para que a Fazenda Pública recorra à transação nessa seara.

Não estamos a sustentar, aqui o "direito administrativo libertário" edificado recentemente na jurisprudência dos Estados Unidos da América, no sentido de considerar inconstitucional a interferência regulatória estatal sobre os negócios privados e retomar uma visão puramente garantista do princípio da legalidade na Administração Pública. ${ }^{452}$ No entanto, a robustez do cenário delineado nos permite edificar entendimento acerca da existência de um duplo regime de legalidade no direito administrativo, cuja modalidade é determinada pelo tipo de limitação que se pretende ver observada pelo Estado.

Diante de tal panorama, entendemos ser a lei obrigatória para o exercício das prerrogativas estatais, num regime de legalidade estrita; a lei não pode ser exigida, no entanto, para a plena efetividade das sujeições estatais, num modelo próximo ao da legalidade ampla.

É dizer, quando tratamos das limitações negativas, que buscam conter o Estado, protegendo o cidadão de seus possíveis arbítrios, o princípio da legalidade se caracteriza pelo sentido de reserva de lei, ou conformidade - na terminologia adotada por Sérvulo Correia $^{453}$-, aplicando-se um regime de legalidade estrita em que a administração somente poderia proceder nos termos daquilo que lhe é expressamente franqueado por Lei. No entanto, quando tratamos de limitações positivas, que visam a conformar a condita estatal no sentido de

\footnotetext{
${ }^{451}$ DALLARI, Adilson Abreu. Viabilidade da transação entre o poder público e particular. Interesse Público, Belo Horizonte, a. 4, n. 13, jan.-mar. 2002.

452 SUSTEIN, Cass R.; VERMEULE, Adrian. Libertarian Administrative Law. University of Chicago Law Review, Chicago, n. 82, p. 393-473, 2015.

453 CORREIA, José Manuel Sérvulo. Legalidade e autonomia contratual nos contratos administrativos. Coimbra: Almedina, 1987. P. 756.
} 
prestações à sociedade, o princípio da legalidade se caracteriza pelo sentido de precedência de lei, ou compatibilidade, sendo elemento essencial do cumprimento de sua missão institucional do Estado o recurso a todos os meios possíveis para a realização dos direitos fundamentais do cidadão, desde que a Administração não contrarie as eventuais proibições legais.

Concluímos portanto que, na medida em que o recurso à transação extrajudicial se relaciona axialmente à realização da missão institucional do Estado - tratando-se, assim, do campo das limitações positivas, que impõem prestações materiais à Administração -, o duplo regime de legalidade aqui definido se aplica em sua face de precedência de lei, sendo apenas vedado que a Administração Pública contrarie eventual proibição legal. Não subsiste qualquer necessidade de autorização legislativa específica para que a Administração Pública recorra à transação extrajudicial para a melhor realização de seus misteres constitucionais, sendo-lhe tão somente vedado o recurso a tal modalidade contratual quando a lei assim expressamente proíba.

4.1.2 Soluções consensuais de conflitos e impessoalidade na Administração Pública

O segundo desafio conceitual a ser enfrentado no presente capítulo consiste na oposição que parcela da literatura apresenta em face da adoção de soluções consensuais de conflitos pela Administração Pública, especificamente do contrato de transação, tendo por base o argumento de que, assim procedendo, a Administração estaria por ferir o princípio de impessoalidade que constitucionalmente a vincula.

Tal oposição é aqui desconstruída em três etapas. Na primeira, que de pronto se inicia, são brevemente apresentados posicionamentos que assim se opõem à transação extrajudicial na administração pública. Num segundo momento, o tópico se debruça sobre a definição e uma possível ressignificação das noções de impessoalidade e imparcialidade no direito administrativo. Por fim, o tópico é concluído com a edificação de posicionamento que aplica a impessoalidade e a imparcialidade ressignificadas à análise da transação extrajudicial na administração pública. 
Assim como nas questões em torno da exigência de autorização legislativa específica para que a Administração celebre transações - desconstruída no tópico anterior -, a oposição fundada na suposta quebra de imparcialidade conta com um fundo normativo que, numa análise superficial, the confere ares de insuperabilidade. É que, tal como no caso da legalidade, a impessoalidade é prevista como princípio da Administração Pública pelo caput do art. 37 da Constituição Federal e, diante do cenário de protagonismo dos princípios como referencial de juridicidade estatal exposto no capítulo de aproximação ao tema, a sua aplicação leva, por vezes, a extrapolações inadequadas.

Diante de tal panorama, alguns autores entendem que, ao optar por firmar transação com um particular, a Administração estaria a escolher um cidadão para tal benefício em detrimento de outros. Num cenário extremo, o recurso à transação seria cooptado por uma sistemática de privilégios direcionados a pessoas escolhidas pelo gestor de ocasião.

Como enfrentado adiante, eventual direcionamento é um risco a ser prevenido na adoção da transação extrajudicial pela Administração Pública. No entanto, isso não implica em que a transação seja impedida, a priori, com base no princípio da impessoalidade.

Hugo de Brito Machado e Hugo de Brito Machado Segundo, ao tratarem especificamente da transação em matéria tributária - para a qual, destaque-se, há expressa autorização legal -, sustentam a sua inconstitucionalidade frente a uma suposta incompatibilidade entre o manejo do instituto e o princípio da isonomia no tratamento dos particulares. Os autores suportam seu posicionamento alegando que, em sendo a atividade tributária uma atividade administrativa plenamente vinculada, onde "a liberdade escraviza e só a lei libera", a transação se mostra inconstitucional ainda que "possa ser, em certos casos, melhor do que a decisão judicial". 454

${ }^{454}$ MACHADO, Hugo de Brito; MACHADO SEGUNDO, Hugo de Brito. Transação em matéria tributária: Limites e inconstitucionalidades. Tributação em Revista, Brasília, a. 16, n. 56, p. 14-22, jan.-jun. 2010. 
Para os autores, diante dos riscos de direcionamento político da concessão da transação como benefício, poder-se-ia configurar cenário próprio dos Estados absolutistas, em que o monarca cobrava os tributos de acordo com seu arbítrio.

Cabe aqui, antes de prosseguir, apresentar igual ressalva àquela exaustivamente edificada no tópico anterior: assim como o princípio da legalidade, a impessoalidade e a responsabilidade objetiva do Estado são institutos garantistas do direito administrativo. Seu surgimento se deu e só se justifica em função da defesa dos direitos fundamentais do cidadão. ${ }^{455}$

O questionamento de decisões administrativas baseadas no viés pessoal do responsável pela decisão se mostra mais evidente ao apreciarmos cenários em que a impessoalidade do decisor seria naturalmente questionável. Num caso que, em tese, seria vedado no direito administrativo brasileiro - a concessão do exercício do poder de polícia a agentes privados - há interessante pesquisa sobre o cenário jurídico de Israel.

Naquele país, a adoção de práticas de "privatized decision making" e "outsourced discretion" - em tradução livre, "processo decisório privatizado" e "discricionariedade terceirizada" - pelo Estado, no seio do movimento da "nova administração pública", trouxe grandes impactos à percepção social de confiabilidade das decisões adotadas nos processos administrativos da sua justiça administrativa. Tais impactos se observam, em especial, de acordo com o estudo de Avishai Benish, tendo em vista o fato de a discricionariedade ser terceirizada não somente ao terceiro setor, mas também a agentes do mercado econômico. ${ }^{456}$

A experiência israelense é significativa pois permite a análise de um cenário extremo de parcialidade administrativa, uma vez que o estudo de caso realizado se debruça sobre a particularidade de o sistema administrativo de

\footnotetext{
455 DI PIETRO, Maria Sylvia Zanella. Introdução: Existe um novo direito administrativo? In: DI PIETRO, Maria Sylvia Zanella; RIBEIRO, Carlos Vinicius Alves (coords.). Supremacia do interesse público e outros temas relevantes do Direito administrativo. São Paulo: Atlas, 2010. P. 6.

${ }^{456}$ BENISH, Avishai. Outsourcing, discretion, and administrative justice: exploring the acceptability of privatized decision making. Jerusalem Papers in Regulation \& Governance, Jerusalem, The Hebrew University, n. 64, mar. 2014. P. 1-7.
} 
previdência social - em especial, dos benefícios que seriam análogos ao segurodesemprego e ao auxílio-doença brasileiros - ser profundamente delegado a licitantes privados, ao ponto de a decisão administrativa acerca da suspensão de pagamento do benefício e da aplicação de sanções ao beneficiário ser atividade discricionária do contratado. Os questionamentos públicos ao modelo surgiram, especialmente, do mecanismo de remuneração que levava ao aumento de faturamento das empresas contratadas de forma diretamente proporcional à redução nos benefícios previdenciários concedidos. ${ }^{457}$

A drástica solução adotada para o caso - a redução das margens de discricionariedade ao ponto de tornar impossível a plena realização da missão institucional das instâncias previdenciárias -, no entanto, mostrou-se igualmente desastrosa, na medida que só fez diminuir a qualidade dos serviços prestados e acabou por inviabilizar a atuação daqueles agentes cujas decisões não se deixavam levar pelo viés institucional. ${ }^{458}$

Benish conclui o seu estudo delineando que a confiabilidade social das decisões administrativas - a sua legitimidade, portanto - sofre grande impacto advindo da percepção pública de que a instituição responsável pela decisão tem interesses afetados pelo seu resultado. ${ }^{459}$ Essa construção será essencial,

${ }^{457}$ BENISH, Avishai. Outsourcing, discretion, and administrative justice: exploring the acceptability of privatized decision making. Jerusalem Papers in Regulation \& Governance, Jerusalem, The Hebrew University, n. 64, mar. 2014. P. 10-15.

O cenário é muito bem delineado no seguinte trecho: "The exploration of the Israeli welfare-to-work program provides an empirical glimpse into the realities of administrative justice in the age of privatization. The study suggests that although discretion in administrative decision making always raises legitimacy concerns, the outsourcing of discretion creates new challenges to acceptability of decisions. It demonstrates the fundamental tension between the new economic and self-interested logic endorsed by NPM and the traditional conceptions of administrative justice, in which the trustworthiness of decisions relies on the idea that decision makers have no personal interest in the outcome of their decisions."

${ }^{458}$ BENISH, Avishai. Outsourcing, discretion, and administrative justice: exploring the acceptability of privatized decision making. Jerusalem Papers in Regulation \& Governance, Jerusalem, The Hebrew University, n. 64, mar. 2014. P. 21-24

${ }^{459}$ BENISH, Avishai. Outsourcing, discretion, and administrative justice: exploring the acceptability of privatized decision making. Jerusalem Papers in Regulation \& Governance, Jerusalem, The Hebrew University, n. 64, mar. 2014. P. 10-15.

Nas palavras do autor: "This perceived conflict of interest of the program's frontline decision makers highlights a fundamental tension between the traditional models of administrative justice and privatized models of service delivery. According to NPM ideas, the fact that street-level service providers (organizations or individuals) have an economic interest in how the service is delivered, is not only legitimate but even a desirable feature of public services and is essential for boosting service quality and efficiency. However, as the case indicates, this model of self-interested decision makers 
também, para o debate que adiante se propõe acerca da importância da postura pessoal do gestor no fomento à transação extrajudicial na administração pública.

Voltando nossa análise à relação entre impessoalidade administrativa e a adoção de soluções consensuais de conflitos na administração pública, verificamos que as oposições apresentadas tomam por base uma visão um tanto distorcida deste princípio. Assim, vislumbra-se a necessidade de delineamento e, até, ressignificação do conceito de impessoalidade, para que se tenha um referencial adequado à análise proposta.

A literatura em direito administrativo brasileira é rica em acepções do princípio da impessoalidade, como bem sintetizado por Odete Medauar. Nesse sentido, a impessoalidade poderia ser relacionada à vedação de promoção pessoal pelos agentes públicos, que devem agir sem tomar para si os créditos das benesses públicas. Impessoalidade significaria ainda a vinculação das atividades estatais à persecução de uma finalidade pública, e não dos objetivos pessoais dos seus gestores. De mesmo modo, pela impessoalidade a Administração Pública é vedada de favorecer ou prejudicar injustificadamente quaisquer cidadãos, devendo tratálos de forma isonômica, com as modulações constitucionalmente estabelecidas. Por fim, a impessoalidade se relaciona ao princípio da imputação volitiva, integrante da teoria do órgão de Otto Gierke, significando que os atos administrativos praticados por um agente da Administração Pública não são imputáveis àquele, mas si a esta. ${ }^{460}$

may undermine the acceptability of decisions. The absence of self-interest on the part of the decision maker is usually associated with the notion of impartiality, part of Mashaw's moral judgment model, but the case demonstrates that the existence of self- interest may also undermine the acceptability of professionals' decision making [...]. Interestingly, in the case studied, the privatized setting eroded trust not only in the professional judgment of case managers (whose professional status is still relatively weak, as will be discussed below), but also in the professional judgment of medical doctors, who are considered the prime example of the professional treatment model of administrative justice. The doctors' organizational commitment to the contractors' financial interests severely undermined what Mashaw describes as the 'trusteeship implicit in professional-client relationships' [...]. In fact, if we think about it, the absence of personal interest actually underlies all Mashaw's normative models of administrative justice. We accept the decisions of bureaucrats, professionals, or judges because we believe that they have no personal interest in the outcome of their decisions. This reflects a long established norm in public service, according to which decision makers are not to use their powers for personal gain [...], and decisions involving personal interest should be treated as expressions of corruption. It seems that this principle is so obvious in the 'old' logic of the public administrations that it is usually taken for granted. But the case highlights that this can no longer be taken for granted."

${ }^{460}$ MEDAUAR, Odete. Direito administrativo moderno. São Paulo: Revista dos Tribunais, 2015. P. 
Rhita Bousta relaciona, ainda, a impessoalidade à noção de boa administração pública, sustentando que a Administração Pública tem o "dever de não se opor sem propor", ou seja, as decisões estatais que sejam contrárias a uma solução específica para um caso dado devem sempre apresentar a solução que entenda mais adequada, nunca se posicionando, com pessoalidade, pela simples negativa de solução. ${ }^{461}$

Em posicionamento próprio, relacionamos também o princípio da impessoalidade com o dever de continuidade administrativa no Estado. Nesse sentido, apesar da mudança de projetos políticos que é ínsita à alternância de poder, o dever de impessoalidade implica em que a transição entre governos não prejudique a continuidade de práticas e políticas constituídas anteriormente e que sejam objeto de expectativas legítimas dos cidadãos. Esse tema é essencial para a edificação de nosso posicionamento acerca da importância da postura pessoal dos gestores para o sucesso de programas de transação extrajudicial na administração pública e, assim, receberá adequado tratamento do tópico que se dedica ao tema.

Em tese de rigoroso tratamento científico do tema da impessoalidade administrativa, Tarcísio Vieira de Carvalho Neto sustenta que do princípio da impessoalidade exsurge, para a Administração Pública, uma "dupla preocupação". ${ }^{462}$ Nesse sentido, primeiramente a impessoalidade teria uma implicação estrutural, devendo "se organizar, do ponto de vista de sua estrutura, para ser impessoal". De mesmo giro, haveria uma conotação funcional da impessoalidade, no sentido em que "a Administração Pública, devidamente organizada, deve ser impessoal em suas ações". Continua o autor:

\section{2-133.}

\section{No mesmo sentido:}

GRANDO, Artur Antônio. O princípio da imparcialidade como limite ao exercício do poder discricionário. Polis, Lisboa, n. 18/21, p. 31-55, 2012.

${ }^{461}$ BOUSTA, Rhita. Essai sur la notion de bonne administration en droit public. Paris: L'Harmattan, 2010. P. 462.

462 CARVALHO NETO, Tarcísio Vieira de. O princípio da impessoalidade nas decisões administrativas. 2014. Tese (Doutorado em direito) - Faculdade de Direito, Universidade de São Paulo, São Paulo, 2014. P. 172. 
Entrelaçam-se, então, garantias instrumentais e substanciais de impessoalidade. As garantias instrumentais estão ligadas ao primeiro aspecto, de organização administrativa impessoal, ao passo que as garantias substanciais estão relacionadas ao agir administrativo impessoal, incluído o agir decisório.

$[\ldots]$

Decisão administrativa impessoal é, pois, aquela que se apresenta como produto de uma criteriosa iteração entre os interesses envolvidos numa disputa. ${ }^{463}$

Para Vieira de Carvalho, assim, a impessoalidade que se constitua em sua vertente objetiva - a que se mostra mais relevante para o tratamento aqui proposto - implica em que a decisão administrativa se revista de três garantias fundamentais: a sua adequada motivação, cumprimento do dever de fundamentação; a processualização do seu iter decisório; ${ }^{464}$ e a participação dos interessados em sua formação, seja como garantia de contraditório e ampla defesa, seja como mecanismo de colaboração para a maior qualidade possível da ponderação de interesses realizada. ${ }^{465}$

463 CARVALHO NETO, Tarcísio Vieira de. O princípio da impessoalidade nas decisões administrativas. 2014. Tese (Doutorado em direito) - Faculdade de Direito, Universidade de São Paulo, São Paulo, 2014. P. 172-173/184.

464 O papel da processualização para a garantia de impessoalidade na transação extrajudicial da Administração Pública já foi reconhecido pelo Tribunal de Contas da União, em sede de consulta:

O Tribunal Pleno, diante das razões expostas pelo Relator, e com fundamento no art. $1^{\circ}$, inciso XVII e $\S 2^{\circ}$, da Lei $n^{\circ} 8.443 / 92$ c/c o art. 216, inciso I, do Regimento Interno, DECIDE:

8.1. conhecer da presente consulta, por preencher os requisitos de admissibilidade, para responder à autoridade consulente que a indenização a terceiros, pela Administração Pública, de danos causados por agentes públicos nessa condição pode se dar:

8.1.1. judicialmente, em cumprimento de sentença transitada em julgado;

8.1.2. administrativamente, por meio de processo administrativo devidamente constituído para apuração dos fatos, identificação dos responsáveis e quantificação dos danos efetivamente comprovados, desde que haja dotação orçamentária apropriada, respeitados os princípios orçamentários constitucionais e as regras e limites da legislação específica, em especial aqueles inseridos na Lei do Orçamento Anual;

8.2. informar, ainda, à autoridade consulente, que deve a Administração, em ambas as hipóteses acima citadas, buscar a reparação do valor indenizatório pago mediante regresso contra o agente responsável nos casos de dolo ou culpa, apurados por intermédio de sindicância ou processo administrativo;

8.3. encaminhar cópia desta Decisão e dos correspondentes Relatório e Voto ao Presidente do TST; e

8.4. determinar o arquivamento do presente processo.

(BRASIL. TRIBUNAL de Contas da União. Consulta no 007.425/2000-3. Rel. Min. Guilherme Palmeira. Diário de Justiça da União, Brasília, 24 jan. 2001).

465 CARVALHO NETO, Tarcísio Vieira de. O princípio da impessoalidade nas decisões administrativas. 2014. Tese (Doutorado em direito) - Faculdade de Direito, Universidade de São Paulo, São Paulo, 2014. P. 198-240.

No mesmo sentido, Paul Daly defende que sejam adotados, como parâmetros de razoabilidade para as decisões administrativas, a sua justificação, a sua transparência e a sua intelegibilidade (DALY, 
Por fim, a impessoalidade pode ser relacionada à imparcialidade acepção que, talvez, seja coincidente com alguma daquelas já expostas -, como se posiciona Edmir Netto de Araújo. ${ }^{466}$ Nesse sentido, sustenta Lúcia Valle Figueiredo que "[...] o princípio [da impessoalidade] também pode ser tido como indicativo da imparcialidade, que condiciona a atividade administrativa a deferir tratamento igual a todos, independente de qualquer interesse público". ${ }^{467}$

Tarcísio Vieira de Carvalho Neto se posiciona pela impossibilidade de considerarem-se coincidentes os conceitos de impessoalidade e imparcialidade, sustentando que "[s]e impessoalidade, imparcialidade, objetividade e neutralidade política fossem círculos, teriam tamanhos distintos. A impessoalidade seria o círculo maior, abrangente dos demais". 468 O autor ressalva, no entanto, a importante conexão entre impessoalidade e imparcialidade, expondo que "a visão italiana de imparcialidade, bastante moderna, aberta e abrangente, se conecta com o alcance que se quer conferir ao princípio da impessoalidade, próprio do regime constitucional brasileiro". ${ }^{469}$

Frente à importância desse debate para a solução do desafio exposto uma vez que se pretende ressignificar a impessoalidade de modo que ela abranja uma isonomia não só entre os cidadãos, mas também entre o cidadão e a própria Administração -, faz-se aqui necessário também tecer breve cenário em torno do aspecto de imparcialidade do princípio da impessoalidade, no que aderimos à dissecação proposta por Tarcísio Vieira de Carvalho Neto.

Parcela importante da literatura internacional em direito administrativo relaciona as origens da imparcialidade administrativa ao Direito do Estado no

Paul. Prescribing greater protection for rights: Administrative Law and Section 1 of the Canadian Charter of Rights and Freedoms. University of Ottawa Working Paper Series, Ottawa, n. 13, nov. 2013).

${ }^{466}$ ARAÚJO, Edmir Netto de. Curso de direito administrativo. São Paulo: Saraiva, 2010. P. 77-78.

${ }^{467}$ FIGUEIREDO, Lúcia Valle. Curso de direito administrativo. São Paulo: Malheiros, 2008. P. 59.

468 CARVALHO NETO, Tarcísio Vieira de. O princípio da impessoalidade nas decisões administrativas. 2014. Tese (Doutorado em direito) - Faculdade de Direito, Universidade de São Paulo, São Paulo, 2014. P. 164.

469 CARVALHO NETO, Tarcísio Vieira de. O princípio da impessoalidade nas decisões administrativas. 2014. Tese (Doutorado em direito) - Faculdade de Direito, Universidade de São Paulo, São Paulo, 2014. P. 167. 
sistema da common law. Nos países anglo-saxões, a imparcialidade surgiu como uma regra de neutralidade política dos servidores públicos e da Administração Pública - numa analogia, no caso inglês, com a imparcialidade dos julgadores -, em um cenário que segrega os interesses políticos do interesse público, dos interesses da nação. ${ }^{470}$ Essa neutralidade política refletir-se-ia, assim, na independência da Administração Pública em relação ao Governo, num traço de tal modo constituído que conforma, por exemplo, o modelo estadunidense de administração por agências.

A consolidação do conceito da imparcialidade como princípio geral da atuação da Administração Pública se deu, no entanto, no direito administrativo italiano, com a disposição expressa no art. 97 da Constituição da República Italiana de 1947 - que refletiu decisões do Conselho de Estado italiano do início do séc. XX - e a dedicação de diversos autores para a construção de densa literatura sobre o tema. ${ }^{471}$

Diante de tal panorama, ao contrário daquilo que o jurista desavisado ou melhor, descuidado de uma visão histórica - poderia concluir, a adoção do princípio da imparcialidade como parâmetro de atuação da Administração Pública nem sempre foi tema pacífico. Disputas doutrinárias houve em tempos outros, e sua análise, ainda que breve, é instrumental para aclarar os presentes debates sobre o sentido da impessoalidade no direito administrativo.

No calor dos debates acerca da elevação da imparcialidade à categoria de princípio constitucional na nova Carta que se avizinhava em Portugal, Vieira de Andrade elaborou interessante estudo acerca dos diversos aspectos dessa decisão política. Naquele texto, apesar de defender a medida, Vieira de Andrade realizou notável trabalho de exposição dos desafios e riscos relacionados à vinculação da Administração Pública à imparcialidade. ${ }^{472}$

\footnotetext{
${ }^{470}$ CASSESE, Sabino. Imparzialità amministrativa e sindacato giurisdizionale. Milano: Giuffrè, 1973. P. 73-74.

${ }^{471}$ RIBEIRO, Maria Teresa de Melo. O princípio da imparcialidade da Administração Pública. Coimbra: Almedina, 1996. P. 74-86.

472 VIEIRA DE ANDRADE, José Carlos. A imparcialidade da Administração como princípio constitucional. Boletim da Faculdade de Direito, Coimbra, v. 50, p. 219-246, 1974.
} 
As primeiras oposições à constitucionalização do princípio da imparcialidade, próprias daquele momento histórico - meados dos anos 1970 -, se fundavam numa suposta desnecessidade de sua adoção, frente a todo o arcabouço do direito administrativo até então edificado. Nesse sentido, questionava-se qual seria a utilidade da constitucionalização do princípio da imparcialidade, uma vez que a moderação, a segurança e a liberdade estariam asseguradas pelo sistema de freios e contrapesos entre os poderes; para que seria útil o princípio da imparcialidade, se a lei à qual se subordinava a Administração já era geral e heterônoma? Suscitar-se-ia, assim, ser supérfluo, desnecessário, redundante tal princípio. $^{473}$

Outros questionamentos relacionar-se-iam à própria razão de ser da imparcialidade. Deveria mesmo a Administração ser imparcial? Uma vez que, no Estado social, o papel da Administração Pública seria justamente dar execução a leis que prevejam medidas desejavelmente parciais - posto que determinadas de modo geral e abstrato -, característica que lhe dotaria de legitimidade democrática, sustentar a imparcialidade seria contraproducente. Nesse sentido, ao eliminar os vieses da parcialidade legitimamente institucionalizada na Lei, agravar-se-ia o custo político do Estado de Direito, o que poderia levar de Estado de Direito Legal para um Estado dos Juízes. ${ }^{474}$

Ao tratar da imparcialidade administrativa - que aqui relacionamos, como dito, à impessoalidade - como princípio constitucional da Administração Pública na Itália, Umberto Allegretti confere à mesma o conteúdo de "corretude no relacionamento lei-administração-cidadão", com reflexos sobre a abertura dos procedimentos administrativos a sujeitos externos, a completude da sua instrução, a articulação organizativa do próprio procedimento e a publicidade da atividade administrativa. ${ }^{475}$

\footnotetext{
473 VIEIRA DE ANDRADE, José Carlos. A imparcialidade da Administração como princípio constitucional. Boletim da Faculdade de Direito, Coimbra, v. 50, p. 219-246, 1974.

474 VIEIRA DE ANDRADE, José Carlos. A imparcialidade da Administração como princípio constitucional. Boletim da Faculdade de Direito, Coimbra, v. 50, p. 219-246, 1974.

${ }^{475}$ ALLEGRETTI, Umberto. Amministrazione pubblica e costituzione. Milão: Cedam, 1996. P. 98-99. Tradução nossa.
} 
Para Sabino Cassese o princípio da imparcialidade é a base para as normas sobre inelegibilidade, incompatibilidade de agentes públicos e conflitos de interesses na Administração. ${ }^{476}$

Já no pensamento de Vieira de Andrade, o âmbito de aplicação da imparcialidade administrativa é tão somente o plano da execução, e não o da direção estatal; é dizer, somente o plano efetivamente administrativo, e não o político. A imparcialidade seria o norte, assim, da atividade executiva, dependente, funcionalmente vinculada às decisões políticas exaradas pelos "órgãos de soberania" - estes, naturalmente parciais, por sua própria legitimidade democrática. Nesse sentido, uma vez que o estrato administrativo "actua dentro do sistema [e] pressupõe a sua bondade", a imparcialidade administrativa seria, na dimensão axiológico-política, uma imparcialidade relativa. ${ }^{477}$

O posicionamento de Vieira de Andrade - conscientemente, note-se tem a consequência de possibilitar que eventuais desigualdades já institucionalizadas na esfera política sejam reproduzidas pela atuação da esfera administrativa. O autor não entende, no entanto, que a eliminação de tais distorções seja o papel do princípio da imparcialidade.

Diverso é o entendimento de Umberto Allegretti. Para este, a vigência do princípio da imparcialidade implica em que, para que a decisão administrativa seja adequada, devam ser adequadamente considerados todos os fins contemplados pelo ordenamento jurídico. ${ }^{478}$

Analisando os princípios da Constituição Italiana sobre a organização e atuação estatais, Umberto Allegretti destaca ser somente aparente a antítese entre os princípios da imparcialidade (que podemos alinhar com a impessoalidade) e do

${ }^{476}$ CASSESE, Sabino. Corso di Diritto Amministrativo: Istituzioni di Diritto Amministrativo. V. I. Milano: Giuffrè, 2004. P. 11.

477 VIEIRA DE ANDRADE, José Carlos. A imparcialidade da Administração como princípio constitucional. Boletim da Faculdade de Direito, Coimbra, v. 50, p. 219-246, 1974.

${ }^{478}$ ALLEGRETTI, Umberto. L'imparzialità amministrativa. Padova: Cedam, 1965.

O posicionamento exposto por Allegretti é chamado, por alguns autores, de princípio da totalidade, como observa o próprio Vieira de Andrade (VIEIRA DE ANDRADE, José Carlos. A imparcialidade da Administração como princípio constitucional. Boletim da Faculdade de Direito, Coimbra, v. 50, p. 219-246, 1974). 
bom andamento (que faz paralelo com a prevalência do interesse público). ${ }^{479} \mathrm{Na}$ sua lição, ainda que "este último [seja entendido] como a persecução do fim público e a primeira como o respeito aos interesses dos cidadãos, sendo que o bom andamento é equiparado à eficiência e a imparcialidade à justiça", ${ }^{480}$ não há razão em sustentar que entre ambos haveria qualquer contraposição, frente ao caráter circular do binômio formado pelas tarefas do Estado e pelos direitos do cidadão. ${ }^{481}$

Além dos aspectos negativos - de contenção de favoritismos, preferências e discriminações estatais -, Sabino Cassese destaca quatro consequências materiais positivas da adoção do princípio da imparcialidade pelo direito administrativo: a obrigação de fixação prévia de critérios e modalidades à atuação administrativa, visando à objetivação das decisões; a obrigação de análise precisa, completa e imparcial de todos os elementos relevantes para a decisão administrativa; a obrigação de cumprir, de modo objetivo, um exame comparativo entre os interesses a avaliar e os resultados relativos; e a obrigação de o agente administrativo abster-se de decidir quando tenha interesse no objeto da decisão. ${ }^{482}$

O percurso histórico e as particularidades práticas levaram a um equilíbrio entre tais entendimentos, no sentido em que a imparcialidade vincularia

${ }^{479}$ ALLEGRETTI, Umberto. Amministrazione pubblica e costituzione. Milão: Cedam, 1996. P. 79-99.

Apesar de esclarecedor e instrumental para a edificação de um entendimento acerca da relação entre prevalência do interesse público e direitos dos cidadãos, o posicionamento de Allegretti acerca do princípio do bom andamento da Administração não é unânime entre os autores italianos. Dentre os diversos entendimentos, há os que sustentem que o bom andamento se relaciona com a tempestividade da ação administrativa; já outros entendem que o princípio vem impor economicidade, eficácia e eficiência da atividade administrativa. Já a Corte Constitucional Italiana entende que o princípio do bom andamento implica na obrigação de a Administração perseguir a melhor realização possível do interesse público, pela coerência e congruência entre a ação administrativa e os fins perseguidos (CASSESE, Sabino. Corso di Diritto Amministrativo: Istituzioni di Diritto Amministrativo. V. I. Milano: Giuffrè, 2004. P. 12).

${ }^{480}$ ALLEGRETTI, Umberto. Amministrazione pubblica e costituzione. Milão: Cedam, 1996. P. 15. Tradução nossa.

${ }^{481}$ A visão de Umberto Allegretti sobre a relação entre a missão estatal e os direitos do cidadão em sua conformação constitucional já foi por nós analisada no tópico anterior, como parte da construção acerca do papel da legalidade na consecução dessa missão. (ALLEGRETTI, Umberto. Amministrazione pubblica e costituzione. Milão: Cedam, 1996. P. 11-14).

${ }^{482}$ CASSESE, Sabino. Corso di Diritto Amministrativo: Istituzioni di Diritto Amministrativo. V. I. Milano: Giuffrè, 2004. P. 11. 
a Administração a considerar, em suas decisões administrativas, de todos os interesses concretos relacionados ao caso e que sejam juridicamente relevantes. ${ }^{483}$

Observa-se no percurso histórico de consolidação do papel do princípio da imparcialidade, assim, um movimento de concretização, de objetivação. Partese do entendimento geral, remoto, que tem a pretensão de abarcar a totalidade dos interesses contemplados pelo Direito, para um panorama concreto, relacionado ao caso em análise e que busca contemplar somente os interesses juridicamente relevantes para a sua solução. Evolui-se de um posicionamento etéreo para um ponto de vista mais objetivo.

Poderíamos confrontar, desse modo, duas linhas ou teses: aqueles que entendem, negativamente, que a imparcialidade implica na vedação à consideração de interesses irrelevantes; e os que sustentam, positivamente, que a imparcialidade obriga à ponderação adequada de todos os interesses juridicamente relevantes. $^{484}$

Em extenso trabalho sobre o tema, Maria Teresa de Melo Ribeiro apresenta vários corolários, ou acepções, do princípio da imparcialidade. Enquanto objetividade, a imparcialidade pressupõe a adoção de critérios jurídicos e lógicos para a decisão administrativa. Como exclusividade, a imparcialidade implica na prossecução exclusiva do interesse público pela Administração. No sentido de isenção, a imparcialidade exige o distanciamento do agente público em relação ao interesse prosseguido, pelo exercício desinteressado da função estatal. ${ }^{485}$

Já como independência, a imparcialidade implicaria na vedação de influências políticas ou de interesses alheios sobre a decisão administrativa, resgatando o seu significado anglo-saxão original. No sentido de neutralidade, a imparcialidade implicaria num posicionamento da Administração com idêntico distanciamento em face dos diversos interesses da forças político-partidárias. Por

\footnotetext{
${ }^{483}$ CERRI, Augusto. Imparzialitè ed indirizzo politico nella Pubblica Amministrazione. Padova: Cedam, 1973. P. 124.

${ }^{484}$ RIBEIRO, Maria Teresa de Melo. O princípio da imparcialidade da Administração Pública. Coimbra: Almedina, 1996. P. 153-156.

${ }^{485}$ RIBEIRO, Maria Teresa de Melo. O princípio da imparcialidade da Administração Pública. Coimbra: Almedina, 1996. P. 153-193.
} 
fim, enquanto transparência, acompanharia ao dever de imparcialidade a obrigação de garantir a imparcialidade, por meio de mecanismos idôneos para a sua verificação, para que os cidadãos acreditem na efetividade dessa imparcialidade. ${ }^{486}$

Em alguns momentos, no entanto, as acepções propostas por Ribeiro são demasiado flexíveis. Nos parece um tanto quanto elástico entender que o princípio da imparcialidade comportaria automaticamente, por exemplo, um dever intrínseco de transparência, mesmo porque, ainda que a transparência não seja obrigatória no caso - como se observaria no tratamento administrativo de questões confidenciais -, o dever de imparcialidade remanesceria pleno; quiçá, com intensidade ainda maior.

Feita tal ressalva, os múltiplos corolários conferidos pela autora à imparcialidade servem uma dupla função: ao mesmo tempo em que reforçam consideravelmente a relação entre imparcialidade e impessoalidade proposta frente às inúmeras intersecções que podemos traçar entre os dois conceitos -, permitem consolidar de forma mais ampla os diversos elementos que dão sentido ao binômio impessoalidade-imparcialidade, abrindo caminho para traçarmos a nossa posição sobre o tema, mais adiante.

Domenico Sorace, por sua vez, constrói um rol de acepções do princípio da imparcialidade mais restrito que aquele de Maria Teresa de Melo Ribeiro, mas que também acaba por ampliar o seu conceito para os campos próprios de outros princípios de direito administrativo. A principal face da imparcialidade administrativa, para Sorace, seria aquela da vinculação à norma, no sentido de que a atividade administrativa deveria buscar o seu conteúdo nas escolhas previamente positivadas pelo legislador; seria esta, para o autor, uma imparcialidade judicialiforme. ${ }^{487}$

Uma segunda acepção da imparcialidade, para Sorace, seria aquela relacionada à organização administrativa, em dois aspectos: um, relacionado à independência do aparato administrativo; outro, de natureza subjetiva, tocante à

\footnotetext{
${ }^{486}$ RIBEIRO, Maria Teresa de Melo. O princípio da imparcialidade da Administração Pública. Coimbra: Almedina, 1996. P. 153-193.

487 SORACE, Domenico. Diritto delle amministrazioni pubbliche: Una introduzione. Bologna: II Mulino, 2000. P. 51-54.
} 
imparcialidade pessoal do agente público - terzietà na expressão do direito italiano -, que deverá isentar-se de decidir as matérias nas quais seja parte ou que lhe gerem conflito de interesse. ${ }^{488}$

Outros sentidos dados por Sorace à imparcialidade administrativa incluem o de igualdade e não discriminação, o de composição dos interesses relacionados à matéria em apreço e o de participação dos interessados no procedimento decisório - este último, como método de concretização material do conceito abstrato de interesse público. ${ }^{489}$

Pode-se enxergar, assim a polissemia da concepção europeia de imparcialidade administrativa, que Vieira de Carvalho busca transportar, com propriedade, para o conceito brasileiro de impessoalidade. ${ }^{490}$

No direito administrativo brasileiro, é de se destacar ainda o posicionamento de Marçal Justen Filho, que enxerga na imparcialidade um princípio específico do direito administrativo, que "impõe que a autoridade encarregada de decidir e todos os demais agentes estatais envolvidos no processo estejam em condições de formar a sua vontade e manifestá-la sem preferência ou oposição aos interesses envolvidos". Nesse sentido, a exigência de imparcialidade implicaria tanto em que o decisor administrativo se abstivesse de atuar em processos em relação aos quais guardasse um conflito de interesses pessoais, quanto na vedação a que este agente aplicasse, na decisão do conflito de interesses que lhe foi confiada, "sentimentos, propostas e outros posicionamentos subjetivos", como que imunizando o conteúdo da decisão administrativa das convicções pessoais do agente. $^{491}$

\footnotetext{
${ }^{488}$ SORACE, Domenico. Diritto delle amministrazioni pubbliche: Una introduzione. Bologna: II Mulino, 2000. P. 51-54.

489 SORACE, Domenico. Diritto delle amministrazioni pubbliche: Una introduzione. Bologna: II Mulino, 2000. P. 51-54.

490 CARVALHO NETO, Tarcísio Vieira de. O princípio da impessoalidade nas decisões administrativas. 2014. Tese (Doutorado em direito) - Faculdade de Direito, Universidade de São Paulo, São Paulo, 2014. Passim.

491 JUSTEN FILHO, Marçal. Curso de direito administrativo. São Paulo: Revista dos Tribunais, 2014. P. 316-318.
} 
Todo esse panorama recebe apurado tratamento de síntese por Tarcísio Vieira de Carvalho Neto, concluindo o exercício de relacionamento entre impessoalidade e imparcialidade:

[...] o princípio da impessoalidade ostenta arquétipo aberto. E é bom que assim seja.

Comparável às noções de imparcialidade (Itália e Portugal), de objetividade (Espanha) e de neutralidade política (França), o Princípio da Impessoalidade, porém, com elas não se confunde. É o resultado da soma das ideias encetadas em cada uma das noções acima reveladas. $E$, por isso mesmo, em relação a cada uma, é mais completo e abrangente, conferindo maiores cobertura e proteção aos valores tutelados pelo texto constitucional.

Revelar sua textura aberta é comprovar sua natureza de princípio e permitir ao exegeta uma atuação construtiva de maior envergadura, compatível com os desafios hermenêuticos da contemporaneidade. Tratar a impessoalidade a partir de uma noção abrangente obtida da soma das ideias de imparcialidade, objetividade e neutralidade política, próprias do direito estrangeiro, é também celebrar a República, resgatar a necessidade de maior cuidado no trato da coisa pública. ${ }^{492}$

Essa acepção de impessoalidade, intimamente ligada à imparcialidade - apesar de com ela não se confundir a título de sinônimo -, leva a um cenário que implica em verdadeira obrigatoriedade na adoção de mecanismos consensuais de solução de conflitos pela Administração Pública, com notável preferência pela transação extrajudicial.

Retomando a responsabilidade civil do Estado como exemplo de provocação para as construções teóricas propostas, destaca-se o posicionamento de Tarcísio Vieira de Carvalho Neto sobre o tema. O autor entende que a impessoalidade implica no principal fundamento da responsabilidade objetiva do Estado, uma vez que é a imputação do dano à Administração, e não ao agente, que permite a sua formulação. Nesse sentido, a própria quebra da impessoalidade pode levar, ela mesma, à responsabilidade estatal como uma de suas consequências. ${ }^{493}$ Diante de tal cenário,

492 CARVALHO NETO, Tarcísio Vieira de. O princípio da impessoalidade nas decisões administrativas. 2014. Tese (Doutorado em direito) - Faculdade de Direito, Universidade de São Paulo, São Paulo, 2014. P. 56.

493 CARVALHO NETO, Tarcísio Vieira de. O princípio da impessoalidade nas decisões administrativas. 2014. Tese (Doutorado em direito) - Faculdade de Direito, Universidade de São Paulo, São Paulo, 2014. P. 317. 
[a] impessoalidade também estimula o reconhecimento dos direitos dos administrados na via administrativa. Se a Administração teima em reconhecer administrativamente direitos dos administrados, remetendo questões ao crivo do Judiciário, sem necessidade, está aí configurada lesão à impessoalidade. Não é favor ou liberalidade, mas dever concreto da Administração empreender posturas facilitadoras do reconhecimento. As decisões administrativas não podem ser formas legais de produção de injustiças. ${ }^{494}$

Frente a tal panorama, Vieira de Carvalho sustenta que o ente estatal, "quando decide lides administrativas, conflitos de interesses com referibilidade ao Direito Administrativo, já juridicamente estabilizados, deve reconhecer, sem temor, administrativamente, direitos legítimos dos administrados”, abstendo-se assim de forçar o particular a buscar remédio junto ao Poder Judiciário para a sua situação nas "questões perfeitamente suscetíveis de serem equacionadas de antemão, no próprio seio do Poder Executivo, com sabor de definitividade". 495

A resistência injustificada da Administração Pública em proceder com o pronto reconhecimento de direitos legítimos dos cidadãos em face de si constituiria, como se posiciona Alice Gonzalez Borges, ato ilícito consistente em abuso de direito, ${ }^{496}$ contemplado, no direito positivo, pelo art. 187 do Código Civil.

É nesse sentido, também, o posicionamento de Odete Medauar:

A autoridade administrativa deve deixar de lado a recalcitrância ante direitos claramente identificados, muitas vezes já reconhecidos pelo Poder Judiciário em casos semelhantes, e rever, reexaminar decisões e medidas espontaneamente ou mediante recurso administrativo do interessado, o que permitirá maior confiança na Administração Pública, atuação mais justa, atendimento ao interessado da coletividade, evitando, por outro lado, sobrecarga do Poder Judiciário. ${ }^{497}$

\footnotetext{
494 CARVALHO NETO, Tarcísio Vieira de. O princípio da impessoalidade nas decisões administrativas. 2014. Tese (Doutorado em direito) - Faculdade de Direito, Universidade de São Paulo, São Paulo, 2014. P. 317.

495 CARVALHO NETO, Tarcísio Vieira de. O princípio da impessoalidade nas decisões administrativas. 2014. Tese (Doutorado em direito) - Faculdade de Direito, Universidade de São Paulo, São Paulo, 2014. P. 260-261.

496 BORGES, Alice Gonzalez. Reflexos do Código Civil dos contratos administrativos. Revista Eletrônica de Direito Administrativo Econômico, Salvador, n. 9, fev.-abr. 2007.

${ }^{497}$ MEDAUAR, Odete. Controle da Administração Pública. São Paulo: Revista dos Tribunais, 2012. P. 53.
} 
Constituir-se-ia, assim, um dever da Administração de reconhecer administrativamente os pleitos dos cidadãos que se mostrem justos, com base nessa leitura atualizada da impessoalidade administrativa. Entende-se, no presente trabalho, que a via por excelência de cumprimento desse dever reside no recurso à transação extrajudicial, método preferencial de solução consensual de conflitos na Administração Pública, como já demonstrado.

Vislumbramos, pois, que todo o panorama aqui delineado sobre as diversas acepções da impessoalidade - em especial, diante de sua íntima relação com a imparcialidade - e os seus impactos sobre o posicionamento da Administração ao decidir os pleitos de particulares em face de si, permitem a edificação de uma nova acepção do princípio da impessoalidade.

Atuando no campo da impessoalidade decisória, tal como construído no pensamento de Tarcísio Vieira de Carvalho Neto, ${ }^{498}$ entendemos ser possível delinear uma acepção de impessoalidade que atue além dos sentidos de impessoalidade subjetiva, impessoalidade objetiva, impessoalidade conviccional, impessoalidade-neutralidade, impessoalidade-isonomia e impessoalidadeimputação, todos já expostos e analisados.

Nesse sentido, a presente tese se posiciona pela existência de uma impessoalidade relacional a vincular a Administração Pública, de modo que, ao decidir administrativamente pleitos de cidadãos em face de si, o Estado seja obrigado a julgar a relação entre si e o interessado como se terceiro fosse. Tratase, portanto, de uma acepção de impessoalidade da Administração em relação a si mesma, que entendemos diferenciada em relação aos demais sentidos de impessoalidade contemplados pela literatura por exigir um distanciamento da Administração em relação a si para julgar os processos administrativos em que seja parte de modo pessoal, como no exemplo dos pleitos indenizatórios.

Conclui-se, portanto, que a aplicação do princípio da impessoalidade, muito longe de impedir o recurso da Administração Pública à transação

498 CARVALHO NETO, Tarcísio Vieira de. O princípio da impessoalidade nas decisões administrativas. 2014. Tese (Doutorado em direito) - Faculdade de Direito, Universidade de São Paulo, São Paulo, 2014. Passim. 
extrajudicial, a obriga a assim proceder sempre que se apure a procedência do pleito do particular. Esse pleito deverá ser apreciado, na seara administrativa, com uma postura de impessoalidade relacional da Administração, que deverá julgá-lo como se terceiro fosse, abstendo-se de adotar uma posição defensiva que seja injusta em relação aos direitos efetivamente detidos pelo cidadão.

\subsubsection{A consecução do interesse público e a delimitação de seu conteúdo}

O terceiro desafio conceitual a ser enfrentado pelo presente capítulo consiste nos posicionamentos daqueles que, com base nas diversas faces do interesse público no direito administrativo - em especial, sua indisponibilidade -, sustentam a impossibilidade de reconhecimento voluntário dos direitos de particulares em face do Estado, o que impossibilitaria, por via de consequência, o recurso à transação extrajudicial pela Administração Pública.

A complexidade do tema e a centralidade que parte considerável da literatura Ihe confere como parâmetro-mor de juridicidade da Administração Pública despertaram a necessidade de que fosse abordado como movimento final do tratamento dos desafios conceituais à admissibilidade da transação administrativa. Frente a estas circunstâncias, esse tratamento se desenvolve em etapas, cada uma dedicada a um dos aspectos do interesse público no regime estatal.

Apresentam-se, inicialmente, linhas gerais acerca do conceito e da posição do interesse público no direito administrativo, expondo as principais oposições deles advindas; sendo a maioria destas baseadas na indisponibilidade do interesse público, este aspecto é o primeiro a ser abordado. Em sequência, outros três aspectos necessários à construção de um posicionamento acerca da transação extrajudicial na administração pública são enfrentados: a indefinição do interesse público é exposta; a supremacia do interesse público é desconstruída; e o conteúdo do interesse público é ressignificado.

Jean Rivero, ao edificar seu método comparado de estudo do direito administrativo, conclui por uma onipresença da "potestade pública" como valor 
universal nos diversos modelos de direito administrativo adotados por todo $\mathrm{o}$ mundo. 499

Maria Sylvia Di Pietro, por sua vez, lançando mão das lições de Norberto Bobbio, Hegel e Aristóteles, identifica as origens do interesse público como elemento central legitimante da atuação estatal na antiguidade grega. Em tal pensamento, o bem comum perseguido pelo homem como objetivo e em função da vida em sociedade, desde a antiguidade, constituiria o gérmen do interesse público estudado pelo direito administrativo, consistindo desde então um todo não redutível à simples soma dos interesses individuais. ${ }^{500}$

Essa concepção do bem comum, originada assim na antiguidade, perpassaria a idade média para chegar aos nossos dias, não sem antes ter de sobreviver ao utilitarismo individual das teses contratualistas de Estado e sociedade dos sécs. XVII e XVIII. ${ }^{501}$

Nesse sentido, como bem destaca Odete Medauar, a noção de interesse público "aparece, ao mesmo tempo, como fundamento, limite e instrumento do poder; configura medida e finalidade da função administrativa". ${ }^{502}$ Diante de tal ubiquidade, Hector Jorge Escola vincula o seu conceito de direito administrativo ao interesse público, firmando posição de que o direito administrativo não é o direito da Administração Pública, mas sim o direito da realização do interesse público pela instrumental atividade administrativa. ${ }^{503}$

Interesse público, sob uma perspectiva normativa - na acepção da ciência política sobre o termo -, seria "aquilo que presumivelmente [o povo]

\footnotetext{
${ }^{499}$ RIVERO, Jean. Cours de Droit Administratif comparé. Paris: Dalloz, 2011. P. 166.

${ }^{500}$ DI PIETRO, Maria Sylvia Zanella. O princípio da supremacia do interesse público: sobrevivência diante dos ideais do neoliberalismo. In: DI PIETRO, Maria Sylvia Zanella; RIBEIRO, Carlos Vinicius Alves (coords.). Supremacia do interesse público e outros temas relevantes do Direito administrativo. São Paulo: Atlas, 2010. P. 86.

${ }^{501}$ DI PIETRO, Maria Sylvia Zanella. O princípio da supremacia do interesse público: sobrevivência diante dos ideais do neoliberalismo. In: DI PIETRO, Maria Sylvia Zanella; RIBEIRO, Carlos Vinicius Alves (coords.). Supremacia do interesse público e outros temas relevantes do Direito administrativo. São Paulo: Atlas, 2010. P. 87-91.

${ }^{502}$ MEDAUAR, Odete. O direito administrativo em evolução. São Paulo: Revista dos Tribunais, 2003. P. 189.

${ }^{503}$ ESCOLA, Hector Jorge. El interés publico como fundamento del derecho administrativo. Buenos Aires: Depalma, 1989. P. 240-249.
} 
escolheria se visse claramente, pensasse racionalmente e atuasse desinteressada e benevolentemente", na fórmula apresentada por Walter Lippmann. ${ }^{504}$ Esta concepção teria o desejável efeito de inviabilizar manipulações do conteúdo do interesse público ditada pela regra de maioria, como bem assinala Ana Raquel Gonçalves Moniz. ${ }^{505}$

A expressão "interesse público" é de frequente uso na linguagem do direito administrativo e, por muitas vezes, Ihe é conferido um significado enfático e quase mítico, relacionado ao "bem comum", como bem destaca Domenico Sorace. A construção do mito do interesse público acaba por legitimar todas as manifestações da Administração Pública e, em particular, logra sustentar a ideia de que a Administração seria legitimada a fazer prevalecer esse "interesse público" sobre os interesses privados, por quaisquer meios. ${ }^{506}$

Desde há muito conceitos correlatos ao de interesse público figuram como centrais na literatura em direito administrativo brasileira. Exemplo notável é o da obra de Aarão Reis, que assim se expressa acerca do papel dos interesses coletivos para a conformação da Administração Pública:

[...] desde que - assim formulada e traduzida a vontade nacional mistér se tórna dar-lhe a devida e imprecindivel execução prática, para que, da ação governamental do Estado, rezúlte, afinal, a satisfação das múltiplas necessidades que estimulam as manifestações daquéla vontade, - carece o Estado de desdôbrarse, para o satisfatório dezempênho dessa função, num conjunto compléxo e complicado - de órgãos secundários, constituindo a administração pública, que áje por meio de múltiplos, vários e diversos serviços públicos, cuja orgânização e cujo funciónamento são regulados pelas prescrições do Direito Administrativo e pelos preceitos e regras gerais da Arte da Administração Pública. ${ }^{507}$

\footnotetext{
${ }^{504}$ LIPPMANN, Walter. The Public Philosophy. New Jersey: Transaction, 2009. P. 42. Tradução de Ana Raquel Gonçalves Moniz.

${ }^{505}$ MONIZ, Ana Raquel Gonçalves. Direito, ética e Estado: Brevíssimas reflexões em diálogo com Barbosa de Melo. In: CORREIA, Fernando Alves; SILVA, João Calvão da; VIEIRA DE ANDRADE, José Carlos; CANOTILHO, Joaquim José Gomes; CARDOSO DA COSTA, José Manuel M. Estudos em Homenagem a António Barbosa de Melo. Coimbra: Almedina, 2013. P. 33-71.

506 SORACE, Domenico. Diritto delle amministrazioni pubbliche: Una introduzione. Bologna: ॥ Mulino, 2000. P. 25-27.

${ }^{507}$ REIS, Aarão. Direito administrativo brazileiro. Rio de Janeiro: Villas-Boas, 1923. P. 174.
} 
Assim também se manifesta Eurico de Oliveira Santos, projetando ilações em busca de um fator central que explique o sucesso das administrações públicas na França, na Inglaterra e nos Estados Unidos da América - exercício frequente na literatura em direito administrativo brasileira de fins do séc. XIX e início do séc. $X X$ :

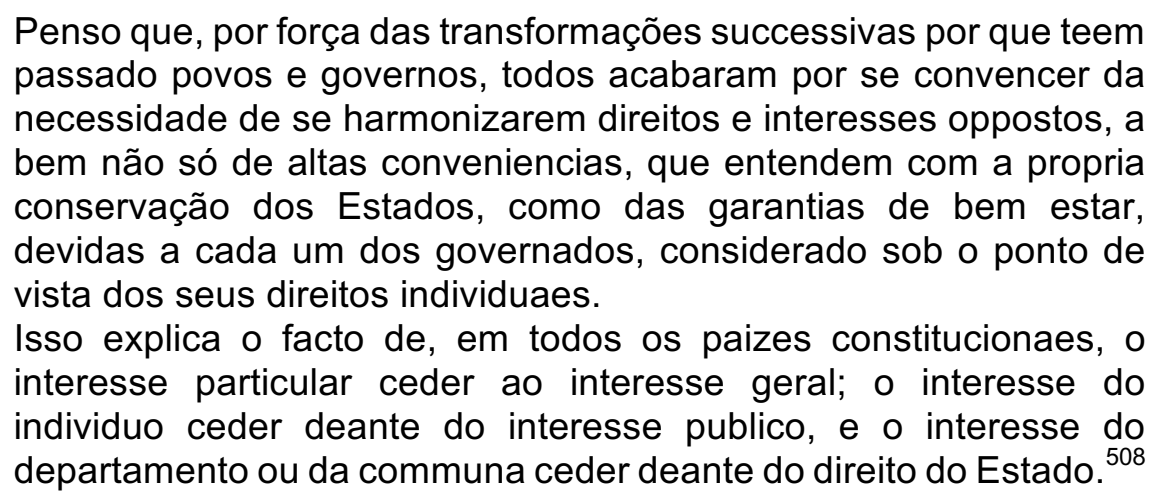

É amplamente consolidado, assim, no direito administrativo brasileiro, o entendimento de que o interesse público exerce papel central no direito administrativo. Suas faces de supremacia do interesse público e indisponibilidade do interesse público relacionar-se-iam com as prerrogativas e sujeições próprias do chamado regime jurídico administrativo, constituindo-lhes o cerne.

Esta centralidade do interesse público gera entendimentos equivocados diversos acerca da impossibilidade de transação extrajudicial pela Administração Pública. Como destaca Adilson Abreu Dallari, tais posicionamentos fundar-se-iam "em um antigo preconceito", que milita pela "necessária oposição entre o interesse público e o particular", entendendo alguns autores "que a Administração Pública em juízo não pode transigir, não pode desistir e está obrigada a prosseguir em qualquer feito, indefinidamente, enquanto houver algum recurso abstratamente possível". 509

Como já exposto, no entanto, no capítulo de aproximação ao tema dessa tese, o interesse público vem sendo visado por novos olhares no direito administrativo brasileiro. As páginas seguintes se dedicam a imprimir essa nova

\footnotetext{
${ }^{508}$ OLIVEIRA SANTOS, Eurico de. Direito administrativo e sciencia da administração. Rio de Janeiro: Jacintho Ribeiro dos Santos, 1919. P. 259.

${ }^{509}$ DALLARI, Adilson Abreu. Viabilidade da transação entre o poder público e particular. Interesse Público, Belo Horizonte, a. 4, n. 13, jan.-mar. 2002.
} 
perspectiva às prementes questões que envolvem o interesse público e a transação extrajudicial na administração pública.

\subsubsection{Indisponibilidade do interesse público}

A indisponibilidade do interesse público coincide com o cerne republicano do Estado contemporâneo. Nesse sentido, tal face do direito administrativo é condensada na fórmula tão frequentemente atribuída a Rui Cirne Lima de que "administrar não é atividade de quem é senhor de coisa própria, mas gestor de coisa alheia". 510

Nesse sentido, a indisponibilidade do interesse público implicaria em que o gestor público, ao atuar na administração pública, não possa por vontade própria dispor, no sentido civil, do interesse de titularidade da Administração Pública. Não caberia ao agente público decidir acerca do exercício ou não dos direitos e prerrogativas estatais, mas tão somente cumprí-lo, uma vez que, a rigor, a sua titularidade não lhe pertence.

É tida como clássica, nesse sentido, a lição de Celso Antônio Bandeira de Mello, aqui reproduzida para que não falte o texto com a devida fidelidade:

A indisponibilidade dos interesses públicos significa que, sendo interesses qualificados como próprios da coletividade - internos ao setor público -, não se encontram à livre disposição de quem quer que seja, por inapropriáveis. O próprio órgão administrativo que os representa não tem disponibilidade sobre eles, no sentido de que Ihe incumbe apenas curá-los - o que é também um dever - na estrita conformidade do que predispuser a intentio legis.

$[\ldots]$

Em suma, o necessário - parece-nos - é encarecer que na administração os bens e os interesses não se acham entregues à livre disposição da vontade do administrador. Antes, para este, coloca-se a obrigação, o dever de curá-los nos termos da finalidade a que estão adstritos. É a ordem legal que dispõe sobre ela. ${ }^{511}$

No mesmo sentido, sustenta Maria Sylvia Di Pietro que “[...] a autoridade não pode renunciar ao exercício das competências que lhe são outorgadas por lei".

\footnotetext{
${ }^{510}$ MORAES, Alexandre. Direito constitucional administrativo. São Paulo: Atlas, 2007. P. 145-146.

${ }^{511}$ MELLO, Celso Antônio Bandeira de. Curso de direito administrativo. São Paulo: Malheiros, 2014. P. 69.
} 
Tal disposição implicaria na impossibilidade de abster-se a Administração de punir ilícito administrativo que constate, ou de deixar de coibir o exercício de direitos individuais que ameacem o bem-estar coletivo, por meio do poder de polícia. Pela indisponibilidade do interesse público, assim, a Administração "não pode deixar de exercer os poderes decorrentes da hierarquia; não pode fazer liberalidade com o dinheiro público. Cada vez que ela se omite no exercício de seus poderes, é o interesse público que está sendo prejudicado". 512

No tocante à gestão específica dos bens e direitos do Estado, destaca Diógenes Gasparini que estes "[n]ão se acham [...] à livre disposição dos órgãos públicos, a quem apenas cabe curá-los, ou do agente público, mero gestor da coisa pública". Nesse sentido, conclui o autor que as instâncias de gestão pública não possuem qualquer propriedade ou domínio sobre os bens, direitos ou interesses públicos, "cabendo-lhes por isso tão-só o dever de guardá-los e aprimorá-los para a finalidade a que estão vinculados". ${ }^{513}$

Sistematicamente têm diversos autores, com maior ou menor propriedade, exercido oposição à possibilidade de transação pela Administração Pública, tanto pela via judicial quanto mais pela via extrajudicial, sustentando que tal comportamento violaria o princípio da indisponibilidade do interesse público. ${ }^{514}$ É que, no seu entendimento, na medida em que a transação implica em concessões mútuas por parte dos contratantes, não poderia o gestor público transigir em nome do Estado, já que não estaria ao seu alcance conceder - dispor - bens ou direitos públicos. $^{515}$

${ }^{512}$ DI PIETRO, Maria Sylvia Zanella. Direito administrativo. São Paulo: Atlas, 2014. P. 67-68.

${ }^{513}$ GASPARINI, Diogenes. Direito administrativo. São Paulo: Saraiva, 2008. P. 17.

514 GAZDA, Emmerson. Administração Pública em juízo: poder-dever de transigir. Revista da Associação dos Juízes Federais do Brasil, Brasília, v. 23, n. 83, p.131-158, jan.-mar. 2006.

${ }^{515}$ Nesse sentido, vide o seguinte julgado do Superior Tribunal de Justiça:

ADMINISTRATIVO E PROCESSUAL CIVIL. RECURSO ESPECIAL. ALÍNEA "C" DO PERMISSIVO CONSTITUCIONAL. AUSÊNCIA DE INDICAÇÃO DO DISPOSITIVO LEGAL SOBRE O QUAL SUPOSTAMENTE RECAI A CONTROVÉRSIA. SÚMULA N. 284 DO STF, POR ANALOGIA. IMPOSSIBILIDADE DE CARACTERIZAÇÃO DE DISSÍDIO COM JULGADOS DO STF. PRECEDENTES. AÇÃO DE COBRANÇA E REPETIÇÃO DE INDÉBITO. ACORDO FIRMADO. HOMOLOGAÇÃO JUDICIAL. REEXAME NECESSÁRIO. TRANSAÇÃO. DIREITO INDISPONÍVEL. IMPOSSIBILIDADE.

1. É impossível conhecer do especial interposto com fundamento na alínea "c" do permissivo constitucional, pois, mesmo nestes casos, é necessária a indicação do dispositivo da legislação 
É o que sustenta, por exemplo, João Carlos Souto, para que, a Administração Pública, sendo titular de direito indisponível, não poderia sujeitá-lo à transação - exceção feita aos casos expressamente previstos em lei - ou à renúncia por ato de seus gestores. ${ }^{516}$ Ora, se tanto fosse verdade, como se

infraconstitucional federal sobre o qual recai a divergência, sob pena de atração da Súmula n. 284 do Supremo Tribunal Federal, por analogia (fundamentação deficiente).

2. Por outro lado, também não merece conhecimento o recurso pelo alegado dissídio jurisprudencial já que foram trazidos aos autos somente julgados do Supremo Tribunal Federal - STF. A uniformização da interpretação de matéria constitucional nos Tribunais pátrios não está dentre os objetivos alcançáveis via recurso especial, cabendo tal tarefa ao Supremo Tribunal Federal via recurso extraordinário e outros instrumentos jurídicos postos à disposição dos interessados, sob pena de usurpação de funções daquela Corte por este Tribunal.

3. Discute-se nos autos a legalidade de acordo firmado entre o recorrente e o Município de Goioerê/PR, no qual se transacionou a compensação dos débitos existentes na Ação Civil Pública de n. 97/2001 com os créditos que seriam apurados na Ação Ordinária de Cobrança n. 300/2004, decorrentes de subsídios a que o autor teria direito pelo exercício do cargo de Vereador e Presidente da Câmara Municipal na gestão 1993/1996, além do pagamento de crédito remanescente a ser pago pelo Município no valor de R $\$ 15.000,00$.

4. A insurgência especial está embasada na alegada ofensa ao disposto nos artigos 475 , I, e 269 , III, ambos do CPC, asseverando o recorrente que a sentença homologatória extinguiu o processo com julgamento de mérito, inexistindo qualquer nulidade, na medida em que teve anuência do Ministério Público. Acrescenta que a sentença exarada não contraria os interesses do Município, e, por tal razão, não se sujeita ao reexame necessário.

5. Na hipótese dos autos, o Município, com a realização do acordo, admitiu como devidos valores que sequer foram apurados judicialmente, e ainda terá que desembolsar mais uma quantia de $\mathrm{R} \$$ $15.000,00$ a serem pagos ao ora recorrente em prestações de $R \$ 1.000,00$. Em sendo assim, revelase notoriamente desfavorável ao ente público a decisão homologatória da transação formulada entre as partes, que ostenta a natureza de sentença de mérito, dando ensejo a sua submissão ao duplo grau de jurisdição, segundo a regra do artigo 475 , inciso I, do CPC.

6. Outro aspecto relevante a ser apreciado diz respeito à impossibilidade de Municipalidade firmar acordo semelhante ao que fora celebrado nos autos, em que reconheceu a existência de uma dívida e compensou-a com créditos discutidos em ação civil pública, vez que se tratam de direitos patrimoniais de caráter indisponível.

7. Segundo o disposto nos arts. 840 e 841 do novo Código Civil, a transação que previne ou põe fim ao litígio tem como características (i) a existência de concessões recíprocas entre as partes, o que pressupõe se tratar de direito disponível e alienável; (ii) ter por objeto direitos patrimoniais de caráter privado, e não público.

Assim, in casu, por se tratar de direito indisponível, referente a dinheiro público, é manifestamente ilegítima a transação pecuniária homologada em primeiro grau.

8. Há, ainda, aspecto de suma importância atinente ao fato de que o acordo teve como finalidade compensar créditos provenientes de condenação sofrida pelo ex-edil em ação de improbidade administrativa proposta pelo Ministério Público, que tem como objeto a aplicação das demais penalidades previstas no art. 12, II, da Lei 8.429/92, inclusive o pagamento de multa civil de até duas vezes o valor desviado. Considerando esse dado, o acordo firmado entre as partes é expressamente vedado pelo art. $17, \S 1^{\circ}$, da Lei 8.429/92.

Portanto, a sentença que homologou transação realizada entre a Fazenda Pública Municipal e o recorrente, reconhecendo débito para com este último, mostra-se totalmente eivada de nulidade insanável.

9. Recurso especial parcialmente conhecido, e, nesta parte, não provido [grifos nossos].

(BRASIL. SUPERIOR Tribunal de Justiça. Recurso Especial $n^{\circ}$ 1.198.424/PR. Rel. Min. Mauro Campbell Marques. Diário de Justiça Eletrônico, Brasília, 18 abr. 2012).

${ }^{516}$ SOUTO, João Carlos. A União Federal em juízo. São Paulo: Saraiva, 2000. P.177. 
justificaria que, em alguns casos, o interesse público seria disponível - por força de Lei - e em outros casos, não?

Em texto dedicado ao tema, mas de análise consideravelmente superficial, Carlos Alberto Sobral de Souza sustenta que, frente à indisponibilidade do interesse público - em especial sob a acepção a ela dada por Celso Antônio Bandeira de Melo -, a transação de que seja parte a Administração Pública só seria considerada regular se entabulada em juízo, após ouvido o Ministério Público. ${ }^{517}$

Não questionamos aqui a existência de uma norma principiológica de indisponibilidade do interesse público, desde que observadas as modulações adiante apresentadas acerca da adequada caracterização desse interesse público. De fato, em um regime republicano, o princípio da indisponibilidade implica em que o gestor público abstenha-se de administrar a coisa pública como se sua fosse. Essa disposição é corolário, inclusive, da boa administração pública, elevada a direito fundamental por parte relevante da literatura.

No entanto, é evidente que, ao transacionar, o administrador não está a dispor do interesse público, mas sim a defendê-lo, conferindo-lhe máxima efetividade. Para tal conclusão, é necessária a exposição dos aspectos em torno da definição do interesse público, tarefa levada a cabo a seguir.

Nesse sentido, Giorgio Oppo não vislumbra qualquer desafio à indisponibilidade do interesse público na utilização de contratos tipicamente privados pela Administração, dentre os quais se inclui a transação extrajudicial na administração pública, como nos posicionamos na primeira parte da tese. Na sua dicção, ao lançar mão de instrumentos contratuais privados, a Administração Pública não está a dispor do interesse público, no sentido privatístico, mas sim exercita o poder de avaliar e realizar o interesse que lhe é confiado. Verifica-se, pois, que a firmatura de contratos privados pela Administração é sempre

517 SOUZA, Carlos Alberto Sobral de. Da transação e da indisponibilidade do interesse público. Fórum Administrativo, Belo Horizonte, a. 1, n. 8, out. 2001. 
acompanhada dos deveres de "objetividade, coerência e imparcialidade" que permanentemente vinculam sua conduta. ${ }^{518}$

Muito além dos debates em torno da indisponibilidade do interesse público, Géraldine Chavrier destaca ser um "dever moral” da Administração Pública indenizar o particular em relação ao qual está em débito. ${ }^{519}$

É importante destacar que, no direito positivo brasileiro, a expressa restrição da transação somente a "direitos patrimoniais de caráter privado", presente no art. 841 do Código Civil, não constitui óbice à adoção da transação extrajudicial pela Administração Pública, ${ }^{520}$ uma vez que tal dispositivo trata dos direitos objeto de transação, e não da qualidade das partes que a entabulam. ${ }^{521}$

Nesse sentido se posicionam Carlos Ari Sundfeld e Jacintho Arruda Câmara, cujo posicionamento analítico se faz de reprodução necessária para que seja precisa a sua exposição:

Serviria supostamente de abono a essa tese [de impossibilidade de transação pela indisponibilidade do interesse público] a previsão contida no art. 841 do Código Civil, segundo a qual "só quanto a direitos patrimoniais de caráter privado se permite a transação". A referida interpretação, todavia, se mostra incorreta.

No caso, o legislador não estava preocupado em disciplinar especialmente a atuação de entidades estatais, afastando da esfera pública o instituto da transação. A regra é de caráter geral, e atinge igualmente entes públicos e particulares. $O$ que a lei pretendeu foi afastar a transação dos chamados direitos de ordem pública (em contraposição aos de "caráter privado"). [...]

De um modo geral, é possível afirmar que os interesses estatais (direitos) que podem ser objeto de contratos também são passíveis, em caso de conflitos, de solução amigável. Deveras, quando firma um contrato qualquer, a Administração está assumindo um determinado ônus, com a perspectiva de receber a contrapartida

518 OPPO, Giorgio. Diritto privato e interessi pubblici. Studi Economico-Giuridici, Napoli, v. 55, p. 421-446, 1993-1994.

${ }^{519}$ CHAVRIER, Géraldine. Réflexions sur la transaction administrative. Revue Française de Droit Administratif, Paris, n. 3, p. 548-566, mai.-jun. 2000.

${ }^{520}$ NERY JUNIOR, Nelson; NERY, Rosa Maria de Andrade. Código Civil Comentado. São Paulo: Revista dos Tribunais, 2013. P. 888.

Nesse sentido, Pontes de Miranda, ainda em meados do séc. XX, já admitia a possibilidade de transação pertencente ao ramo "do direito público" (MIRANDA, Francisco Cavalcanti Pontes de. Tratado de Direito privado: Parte especial. V. 25. Rio de Janeiro: Borsoi, 1959. P. 141).

${ }^{521}$ MALUF, Carlos Alberto Dabus. Da transação. In: FIUZA, Ricardo. Novo Código Civil comentado. São Paulo: Saraiva, 2003. P. 758. 
estipulada. Nesse caso, algum direito de caráter patrimonial daquela entidade está sendo negociado; por isso há de ser considerado, para efeito de aplicação da transação, um direito disponível da entidade estatal, ou seja, um direito negociável. ${ }^{522}$

Onofre Alves Batista Junior, por sua vez, expõe que mesmo em relação aos direitos indisponíveis poderá haver transação se, sem serem tais direitos prejudicados, a via transacional se mostrar a mais adequada para que "a tutela àquele bem ou direito, holisticamente verificada, seja, de forma mais eficiente, garantida" ${ }^{523}$ Tratar-se-ia, na dicção de Nelson Nery Junior e Rosa Maria de Andrade Nery, da chamada transação parcial. ${ }^{524}$

Como bem expõe Diogo Leite de Campos ao tratar da possibilidade de arbitragem em matéria tributária mesmo diante da indisponibilidade dos créditos tributários, negar a possibilidade de soluções extrajudiciais de conflitos tendo por base a indisponibilidade do interesse público seria negar, também, a possibilidade de escrutínio judicial desses interesses. É que, uma vez que se trata de apreciar a derrogação ou não do interesse público, essa eventual derrogação concretizará a sua relativização, independentemente da esfera, juízo ou instância em que ocorra. O que importa, pois, para a regularidade dessa derrogação, é o cumprimento das normas e parâmetros aplicáveis, e não a natureza pessoal de quem procede com tal julgamento. ${ }^{525}$

Verifica-se, pois, que muitas das vezes é justamente o princípio da indisponibilidade do interesse público que recomenda a firmatura da transação

522 SUNDFELD, Carlos Ari. CÂMARA, Jacintho Arruda. Acordos na execução contra a Fazenda Pública. Revista Eletrônica de Direito Administrativo Econômico, Salvador, n. 23, ago.-out. 2010.

${ }^{523}$ BATISTA JÚNIOR, Onofre Alves. Transações administrativas: um contributo ao estudo do contrato administrativo como mecanismo de prevenção e terminação de litígios e como alternativa à atuação administrativa autoritária, no contexto de uma administração pública mais democrática. São Paulo: Quartier Latin, 2007. P. 521.

${ }^{524}$ NERY JÚNIOR, Nelson. NERY, Rosa Maria de Andrade. Código de processo civil comentado. São Paulo: Revista dos Tribunais, 2007. P. 602.

${ }^{525}$ CAMPOS, Diogo Leite de. A indisponibilidade dos créditos tributários e a arbitragem. Revista de Finanças Públicas e Direito Fiscal, Lisboa, a. 2, n. 2, p. 63-73, prim. 2009.

Assim expõe o autor: "Com efeito, se julgar por um juiz togado os créditos tributários não põe em causa a indisponibilidade destes, não se vê como o julgamento, segundo os mesmos parâmetros de legalidade, por juízes não togados, pode pôr em causa a indisponibilidade dos créditos tributários." 
extrajudicial pela Administração Pública, ${ }^{526}$ uma vez que, por meio desse instrumento, o interesse público é mais eficientemente protegido do que se o gestor público relegasse a solução da contenda ao Poder Judiciário.

Diante de tal cenário, faz-se necessário aprofundar o debate acerca de qual seria esse conteúdo de interesse público a ser objeto de proteção indisponível ao administrador público, tarefa a que o texto se dedica a seguir.

\subsubsection{Indefinição do interesse público}

Toda a exposição até aqui desenvolvida demonstrou que o manejo da transação extrajudicial pela Administração Pública não implica na disposição, mas sim na defesa, do interesse público. Quais seriam, portanto, os motivos que levariam tantos autores a posicionar-se pela oposição entre interesse público e transação extrajudicial?

Verifica-se que tal oposição se fundaria em três fatores relacionados ao interesse público, sendo o primeiro deles uma concepção injustificável da sua suposta unicidade. Cabe aqui demonstrar, portanto, a indefinição do interesse público em si, ${ }^{527}$ fundada principalmente na sua concreta multiplicidade. É dizer, na precisa lição de Floriano de Azevedo Marques Neto, que "[...] não passa de um

${ }^{526}$ FERNANDES, Jorge Ulisses Jacoby. Acordos administrativos e judiciais. Forum Administrativo, Belo Horizonte, a. 6, n. 59, jan. 2006.

O Supremo Tribunal Federal já se posicionou nesse sentido, em precedente frequentemente referenciado pela literatura:

PODER PÚBLICO. TRANSAÇÃO. VALIDADE.

Em regra, os bens e o interesse público são indisponíveis, porque pertencem à coletividade. É, por isso, o Administrador, mero gestor da coisa pública, não tem disponibilidade sobre os interesses confiados à sua guarda e realização. Todavia, há casos em que o princípio da indisponibilidade do interesse público deve ser atenuado, mormente quando se tem em vista que a solução adotada pela Administração é a que melhor atenderá à ultimação deste interesse. Assim, tendo o acórdão recorrido concluído pela não onerosidade do acordo celebrado, decidir de forma diversa implicaria o reexame da matéria fático-probatória, o que é vedado nesta instância recursal (Súm. 279/STF). Recurso extraordinário não conhecido.

(BRASIL. SUPREMO Tribunal Federal. Recurso Extraordinário n 253.885. Rel. Min. Ellen Gracie. Diário de Justiça da União, Brasília, p. 118, 21 jun. 2002).

${ }^{527}$ Essa questão é tida, por Eros Roberto Grau, como a grande questão a ser resolvida no direito administrativo (GRAU, Eros Roberto. O direito posto e o direito pressuposto. São Paulo: Malheiros, 2000. P. 25). 
dogma a formulação de que exista um só interesse público a motivar, no caso concreto, a atuação estatal". ${ }^{528}$

A origem das concepções acerca da definição do interesse público podem ser identificada no conceito de vontade geral no contrato social de Rousseau, que seria transmutada no conteúdo da Lei a vincular a atuação administrativa. ${ }^{529}$ Ocorre que, como se percebe na contemporaneidade, a patente abstração do interesse público é uma das principais origens de críticas a este conceito. $^{530}$

O papel do fator abstração, indefinição ou mesmo multiplicidade do interesse público na modulação da sua força normativa é mui habilmente demonstrado por diversos autores. No contexto que aqui se nos apresenta, no entanto, toma destaque um pequeno texto de Mario Spasiano que, após delinear o cenário de crise decorrente de tais circunstâncias, apresenta o "dúplice fenômeno" dele decorrente, cuja análise é instrumental para a construção teórica proposta.

De acordo com Spasiano, apesar da considerável centralidade do interesse público como eixo conformador da Administração Pública na tradição do direito administrativo, se verifica que tal conceito carece de aprofundamento de seu conteúdo substancial, mormente frente a estudos que, tratando do tema de modo incidental, falham em lhe sondar o aspecto teleológico. ${ }^{531}$

\footnotetext{
${ }^{528}$ MARQUES NETO, Floriano de Azevedo. Interesses públicos e privados na atividade estatal de regulação. In: MARRARA, Thiago (org.). Princípios de direito administrativo: legalidade, segurança jurídica, impessoalidade, publicidade, motivação, eficiência, moralidade, razoabilidade, interesse público. São Paulo: Atlas, 2012. P. 425.

${ }^{529}$ ROUSSEAU, Jean-Jacques. Du Contract Social, ou principes du Droit Politique. Amsterdam: Marc Michel, 1762.

No mesmo sentido:

GABARDO, Emerson; HACHEM, Daniel Wunder. O suposto carater autoritário da supremacia do interesse público e das origens do direito administrativo: uma crítica da crítica. In: DI PIETRO, Maria Sylvia Zanella; RIBEIRO, Carlos Vinicius Alves (coords.). Supremacia do interesse público e outros temas relevantes do Direito administrativo. São Paulo: Atlas, 2010. P. 22-27.

${ }^{530}$ CLAMOUR, Guylain. Intérêt général et concurrence: essai sur la pérennité du droit public en économie de marché. Paris: Dalloz, 2006. P. 16-19.

531 SPASIANO, Mario R. L'interesse pubblico e l'attività della P.A. nelle sue diverse forme. I/ Foro Amministrativo, Milano, v. 4, n. 5, p. 1.820-1.829, mai. 2005.
} 
Adicionamos à dicção de Mario Spasiano o entendimento de que, no direito administrativo brasileiro, quando tal análise teleológica é empreendida, o é de modo vazio, ou ainda pior, distorcido. Se analisarmos o fim do direito administrativo como a realização do interesse público, mas não considerarmos para tanto as características indissociáveis do conceito real de interesse público - em especial, a sua multiplicidade -, e a necessidade de que o mesmo seja realizado com a constante prevalência dos direitos fundamentais do cidadão, estamos tão somente criando um fim inalcançável ou pior, prejudicial à própria realização da missão institucional do Estado.

Voltando à lição de Mario Spasiano, podemos sustentar que a ausência de uma elaboração completa do conceito substancial de interesse público, a falta de clareza sobre o seu conteúdo jurídico e alcance prático, juntamente com o fenômeno da "empatia substancial subjetiva" e, portanto, da dissolução do mesmo na subjetividade do agente administrativo, levam o conceito de interesse público a ser objeto do que Spasiano denomina de "dúplice fenômeno". Esse "dúplice fenômeno" consistiria na mitificação e na instrumentalização do conceito de interesse público, que acaba mobilizado para fins outros que não a consecução de legítimos fins estatais. ${ }^{532}$

Continua o autor:

Sabe-se que no Estado liberal monoclasse, a priori, o interesse público coincide com aquele de toda a comunidade, sendo principalmente o resultado de um método de produção do tipo legal autocrático. Mas o aumento gradual e constante na assunção, por entidades públicas, de exercício de funções e da gestão de serviços de interesse da comunidade, começou a determinar a crise progressiva do caráter monolítico do significado de interesse público.

A desintegração da concepção monolítica determinou, desde o início do séc. $X X$, o início de um processo lento e não sem contradições, inexoravelmente voltado à progressiva tomada de consciência da necessidade de uma nova configuração do conceito em questão: da concepção abstrata e monolítica, ao produto de uma ação complexa na composição entre situações jurídicas opostas (mesmo que todas de natureza pública) e à síntese subsequente das mesmas.

As tensões por que passou a noção de interesse público, logo na segunda metade do séc. XX, determinaram a redefinição

532 SPASIANO, Mario R. L'interesse pubblico e l'attività della P.A. nelle sue diverse forme. II Foro Amministrativo, Milano, v. 4, n. 5, p. 1.820-1.829, mai. 2005. 
substancial de suas conotações precípuas, pela consciência - de fato apenas gradualmente adquirida e a que ainda se opõem - de que o interesse público não apresenta um conteúdo universal e exclusivamente definível. ${ }^{533}$

Nessa perspectiva, pelo pensamento de Spasiano - que consubstancia, como dito, o entendimento sobre o tema de diversos juristas de destaque -, os interesses públicos são o resultado projetado de relações dialéticas sobre a verdade, consubstanciado na história, resultando - em vez de regras - em políticas, programas, planos de ação ou medidas específicas, envolvidos em um processo de materialização de resultados concretos ou bens relacionados com necessidades coletivas. $^{534}$

A mitificação do interesse público ocorre pelo seu descolamento da realidade, consistindo assim em um conceito indefinível, impassível de receber conteúdo concreto, que busca o seu valor justamente na sua natureza etérea. Sob tal perspectiva, o interesse público seria o eixo central e fundante do dito regime jurídico administrativo tão somente por ser o valor maior deste regime jurídico administrativo, em uma construção que nos leva, ao fim e ao cabo, a uma tautologia. ${ }^{535}$

${ }^{533}$ SPASIANO, Mario R. L'interesse pubblico e l'attività della P.A. nelle sue diverse forme. /l Foro Amministrativo, Milano, v. 4, n. 5, p. 1.820-1.829, mai. 2005. Tradução nossa.

No original: "É noto che nello stato liberale monoclasse, l'interesse pubblico coincide aprioristicamente con quello della intera collettività, trattandosi per lo più del frutto di un metodo di produzione giuridica di tipo autocratico. Ma il graduale e costante incremento dell'assunzione diretta, da parte di soggetti pubblici, dell'esercizio di funzioni e della gestione di servizi interessanti a la comunità cominciò a determinare la progressiva crisi del carattere monolitico dell'accezione di interesse pubblico. Lo sgretolamento della concezione monolitica determinò, a partire dagli inizi del '900, l'avvio di un processo lento e non privo di contraddizioni, inesorabilmente volto alla progressiva presa di coscienza della necessità di una nuova configurazione della nozione in esame: da accezione astratta e monolitica, a prodotto di una complessa azione di composizione tra situazioni giuridiche contrapposte (anche tutti di natura pubblica) e di successiva sintesi tra le stesse. Le tensioni che hanno attraversato la nozione di interesse pubblico già nel corso della seconda metà del '900 hanno determinato una sostanziale ridefinizione di suoi connotati precipui, nella consapevolezza, invero solo gradualmente acquisita e comunque avversata, che l'interesse pubblico non presenti un contenuto universale ed univocamente denifibile."

${ }^{534}$ SPASIANO, Mario R. L'interesse pubblico e l'attività della P.A. nelle sue diverse forme. /l Foro Amministrativo, Milano, v. 4, n. 5, p. 1.820-1.829, mai. 2005.

${ }^{535}$ Acerca do papel do mito no Direito Administrativo, detemo-nos de forma mais aprofundada em capítulo anterior, dedicado à ressignificação do princípio da legalidade. A respeito da mitificação e do simbolismo no Direito Administrativo, valiosíssima é a contribuição de Jacques Chevallier (CHEVALLIER, Jacques. La dimension symbolique du principe de légalité. Revue du Droit Public et de la Science Politique, Paris, v. 106, p. 1.652-1.677, 1990). 
Já a segunda parte do "dúplice fenômeno" - a instrumentalização do interesse público - decorre em parte, dos próprios efeitos da mitificação. Ao buscar alcance prático ao conceito de interesse público, a sua "empatia substancial subjetiva" - que leva à diluição do interesse público na subjetividade do agente administrativo - dá azo a diversos padrões de comportamento administrativo, que muitas vezes conferem significados utilitários de ordem metajurídica ao conceito e Ihe emprestam, numa cooptação política da finalidade estatal, a carga ideológica inerente às diversas doutrinas políticas. ${ }^{536}$

O cenário delineado por Spasiano é observado com lamentável frequência na administração pública brasileira. Enquanto a doutrina se debruça em buscar meios para garantir, pelos argumentos os mais abstratos possíveis, a centralidade do interesse público no direito administrativo, os gestores públicos de ocasião - muitos, mas não todos, de má-fé - acabam por manejar esse conceito tão etéreo da maneira que mais se adeque aos seus propósitos pessoais. Nesse sentido, a concepção tida como tradicional de interesse público acaba por fazer ruir as bases já expostas da impessoalidade administrativa e, desse modo, condena à morte o próprio interesse público que declaram seus cultores defender.

Domenico Sorace bem sustenta a razão para o fenômeno da indefinição do interesse público ao expor que, de fato, não é possível lhe conferir um conteúdo substancial, mas tão somente jurídico formal. É dizer, com o esgotamento ou a ineficiência de critérios que venham a diferenciar o interesse público do interesse privado, acabam por ser considerados públicos aqueles interesses assim qualificados pelo aparato político (quando tratamos de um sistema de governo democrático) ou, talvez, pela Administração Pública; assim, poder-se-ia definir como público, no sentido jurídico-formal, aquele que assim seja qualificado por quem tenha a competência de o qualificar. ${ }^{537}$

Tal concepção destaca que, em sendo impossível a precisa qualificação, como regra geral, de certo interesse como interesse público em sentido substancial,

\footnotetext{
${ }^{536}$ SPASIANO, Mario R. L'interesse pubblico e l'attività della P.A. nelle sue diverse forme. /l Foro Amministrativo, Milano, v. 4, n. 5, p. 1.820-1.829, mai. 2005.

537 SORACE, Domenico. Diritto delle amministrazioni pubbliche: Una introduzione. Bologna: II Mulino, 2000. P. 25-27.
} 
material - e não meramente jurídico-formal, na expressão de Sorace -, a expressão acaba por carecer de utilidade prática para constituir uma categoria de interesses que seria absolutamente incontrastável em relação aos interesses privados.

O fenômeno da globalização também exerce seu impacto para a crescente indefinição do interesse público. Na globalização, os mercados acabam por exercer um papel de referência fundamental de ideologias e práticas; diante de tal cenário, "não só o espaço de sustentação do interesse público diminuiu como na sua definição se foi tornando cada vez mais difícil expressar a vontade autónoma das instituições democráticas do Estado de direito". ${ }^{538}$ Este contexto não faz desaparecer o papel do discurso oficial em nome do interesse público, mas faz com que o mesmo surja "diluído na sociedade, definido por uma rede de actores públicos e privados com intervenção nos vários níveis da governação, protagonistas de lógicas distintas e, frequentemente, contraditórias". ${ }^{539}$

O caráter indeterminado do interesse público é visto com relativismo por Maria Sylvia Di Pietro, que delineia uma escala de indeterminação das várias manifestações do interesse público; assim, haveria grande diferença na indeterminação do interesse público quando tido como sinônimo de bem comum, como fim de Estado, mas tal indeterminação seria muito menos intensa ao tratarmos do interesse público consubstanciado em casos concretos. Nesse sentido, a determinabilidade do interesse público no momento de sua apuração faria com que a sua indeterminação intrínseca não lhe prejudicasse a aplicação prática. ${ }^{540}$

É perante este argumento - não diretamente, já que a crítica antecederia ao objeto - que Gustavo Binenbojm tece a sua crítica central sobre o tema, expondo

538 GOMES, João Salis. Interesse público, controle democrático do Estado e cidadania. In: ATHAYDE, Augusto de; CAUPERS, João; GARCIA, Maria da Glória F. P. D. Em homenagem ao Professor Doutor Diogo Freitas do Amaral. Coimbra: Almedina, 2012. P. 352-378.

539 GOMES, João Salis. Interesse público, controle democrático do Estado e cidadania. In: ATHAYDE, Augusto de; CAUPERS, João; GARCIA, Maria da Glória F. P. D. Em homenagem ao Professor Doutor Diogo Freitas do Amaral. Coimbra: Almedina, 2012. P. 352-378.

${ }^{540}$ DI PIETRO, Maria Sylvia Zanella. O princípio da supremacia do interesse público: sobrevivência diante dos ideais do neoliberalismo. In: DI PIETRO, Maria Sylvia Zanella; RIBEIRO, Carlos Vinicius Alves (coords.). Supremacia do interesse público e outros temas relevantes do Direito administrativo. São Paulo: Atlas, 2010. P. 97-99. 
com precisão lógica que "[u]m princípio que se presta a afirmar que o que há de prevalecer sempre prevalecerá não é um princípio, mas uma tautologia”. ${ }^{541}$

Prosseguindo com os debates, Carlos Vinicius Alves Ribeiro sustenta que a indeterminação linguística não importa em indeterminação jurídica. ${ }^{542}$ Lançando mão dos ensinamentos de Fernando Sainz Moreno, caracteriza a imprecisão dos conceitos não como defeito, mas sim como qualidade funcional a servir à instrumentalização do direito. Expõe o autor a controvérsia entre Eros Grau e Celso Antônio Bandeira de Mello, em que aquele sustentou que a imprecisão da linguagem nunca implicaria na imprecisão do conceito jurídico; este, por sua vez, entendeu que "a imprecisão, fluidez ou indeterminação residem no próprio conceito e não na palavra que os rotula". Esses entendimentos seriam condensados na posição de Eduardo García de Enterría e Tomás-Ramón Fernández, para quem haveriam tanto situações de indeterminação superficial, somente da expressão, quanto de indeterminação essencial, do conceito jurídico em si; de qualquer modo, tal indeterminação serviria justamente à viabilização da existência de textos normativos que tomassem por objeto conceitos que não admitam, a priori, "quantificação ou determinação rigorosa na própria norma". 543

Carlos Vinicius Alves Ribeiro enxerga, assim, a possibilidade de consolidação de tais entendimentos em um sistema de zonas de certeza positiva e negativa, onde há ou não há a caracterização do conceito jurídico; entre tais polos restaria uma zona cinzenta, de incerteza, onde a caracterização ou não do conceito dependeria do trabalho de interpretação, de substanciação jurídica, de valoração subjetiva. Partindo de tais pressupostos, analisa em que medida seria possível delinear a zona de certeza negativa do conceito de interesse público e, lançando mão da categoria junguiana de tipos, conclui por ser o interesse público um conceito

\footnotetext{
${ }^{541}$ BINENBOJM, Gustavo. Da supremacia do interesse público ao dever de proporcionalidade: um novo paradigma para o direito administrativo. In: SARMENTO, Daniel (org.). Interesses públicos versus interesses privados: desconstruindo o princípio da supremacia do interesse público. Rio de Janeiro: Lumen Juris, 2007. P. 167.

${ }^{542}$ RIBEIRO, Carlos Vinicius Alves. Interesse público: um conceito jurídico determinável. In: DI PIETRO, Maria Sylvia Zanella; RIBEIRO, Carlos Vinicius Alves (coords.). Supremacia do interesse público e outros temas relevantes do Direito administrativo. São Paulo: Atlas, 2010. P. 106.

${ }^{543}$ RIBEIRO, Carlos Vinicius Alves. Interesse público: um conceito jurídico determinável. In: DI PIETRO, Maria Sylvia Zanella; RIBEIRO, Carlos Vinicius Alves (coords.). Supremacia do interesse público e outros temas relevantes do Direito administrativo. São Paulo: Atlas, 2010. P. 101-118.
} 
jurídico determinável, não de maneira descritiva e certa, mas como "noçãoquadro" 544

Vislumbramos que a solução para tal cenário reside no reconhecimento da multiplicidade dos interesses públicos, cuja ponderação consistiria o cerne da atuação da Administração Pública, conforme a já clássica lição de Floriano de Azevedo Marques Neto. ${ }^{545}$

O autor assim define o cenário de multiplicidade dos interesses públicos e, por via de consequência, os motivos de resistência por parte da literatura para o seu reconhecimento:

Há sempre uma miríade de interesses relevantes, muitas vezes conflitantes, a disputar a ação estatal. Se é possível um controle negativo (ou seja, a verificação de que a um dado interesse não corresponde uma relevância justificadora de uma ação estatal portanto, a verificação de que se trata de um interesse não público), de outro lado não é possível se aferir o que ou qual seja o interesse público único, singular, que justifique a intervenção estatal na esfera privada. Mas o discurso do interesse público é dependente dessa noção de singularidade, pois sem ela teria de assumir que toda ação do poder público demanda, previamente, uma arbitragem de interesses, o que enfraqueceria a sua função legitimadora e operacional. ${ }^{546}$

Esta solução de ponderação para a problemática decorrente da indefinição do interesse público, que reconhece a sua multiplicidade, seria aplicável, de acordo com Odete Medauar, "[...] sempre que a própria Constituição ou a lei (desde que incidindo constitucionalmente) não houver esgotado os juízos possíveis de ponderação entre interesses públicos e privados". Diante de tal

\footnotetext{
${ }^{544}$ RIBEIRO, Carlos Vinicius Alves. Interesse público: um conceito jurídico determinável. In: DI PIETRO, Maria Sylvia Zanella; RIBEIRO, Carlos Vinicius Alves (coords.). Supremacia do interesse público e outros temas relevantes do Direito administrativo. São Paulo: Atlas, 2010. P. 109.

${ }^{545}$ MARQUES NETO, Floriano de Azevedo. Regulação Estatal e Interesses Públicos. São Paulo: Malheiros, 2002. Passim.

${ }^{546}$ MARQUES NETO, Floriano de Azevedo. Interesses públicos e privados na atividade estatal de regulação. In: MARRARA, Thiago (org.). Princípios de direito administrativo: legalidade, segurança jurídica, impessoalidade, publicidade, motivação, eficiência, moralidade, razoabilidade, interesse público. São Paulo: Atlas, 2012. P. 425.
} 
cenário, "[...] caberá à Administração lançar mão da ponderação de todos os interesses e atores envolvidos na questão, buscando a sua máxima realização". 547

Quanto ao procedimento da Administração Pública para a definição dos interesses públicos por ponderação, é interessante o pensamento de Gustavo Binenbojm:

De modo análogo às Cortes Constitucionais, a Administração Pública deve buscar utilizar-se da ponderação, guiada pelo princípio da proporcionalidade, para superar as regras estáticas de preferência, atuando circunstancial e estrategicamente com vistas à formulação de standards de decisão. Tais standards permitem a flexibilização das decisões administrativas de acordo com as peculiaridades do caso concreto, mas evitam o mal reverso, que é a acentuada incerteza jurídica provocada por juízos de ponderação produzidos sempre caso a caso. ${ }^{548}$

Do ponto de vista racional, a questão acerca da indefinição e da multiplicidade dos interesses públicos pode ser melhor analisada sob a luz dos elementos de lógica não-clássica, ou heterodoxa. Sob tal prisma, uma afirmação pode ser contemplada positivamente pela lógica ainda que contenha uma contradição aparente, já que uma sentença e sua contradição podem ser igualmente verdadeiras.

Nesse sentido, a aplicação da lógica paraconsistente ${ }^{549}$ nos permite concluir que um certo interesse pode ser, ao mesmo tempo, interesse público e interesse não-público. Na mesma análise, o seu par paracompleto pode não ser, ao mesmo tempo, nem interesse público nem interesse não-público. Caberá à análise ponderativa, executada nas instâncias competentes - no caso em análise, à Administração Pública, em colaboração com os atores sociais - definir se, naquele caso específico, o dito interesse paraconsistente caracteriza-se ou não como interesse público e, dentre os interesses que se caracterizam como interesse

\footnotetext{
${ }^{547}$ MEDAUAR, Odete. O Direito administrativo em evolução. São Paulo: Revista dos Tribunais, 2003. P. 183.

${ }^{548}$ BINENBOJM, Gustavo. A constitucionalização do direito administrativo no Brasil: um inventário de avanços e retrocessos. Revista Eletrônica sobre a Reforma do Estado, Salvador, n. 13, mar.mai. 2008.

${ }^{549}$ COSTA, Newton Carneiro Affonso da. On the theory of inconsistent formal systems. Notre Dame Journal of Formal Logic, Notre Dame, n. 15, p. 497-510, 1974.
} 
público, eleger qual ou quais deverão prevalecer, na busca pela melhor realização da missão institucional do Estado.

Essa conclusão nos leva ao próximo ponto de análise: caso prevaleça, sobre o quê prevalece o dito interesse público? Com base em quais fundamentos? Sobre esse tema se debruça o texto a seguir.

\subsubsection{Prevalência do interesse público}

Talvez o mais radical dos conceitos em torno do interesse público, tido como dogma do direito administrativo, seja a dita supremacia do interesse público. Com base na suposta supremacia do interesse público, sustentam diversos autores que seria à Administração Pública vedado lançar mão da transação extrajudicial ou, por qualquer via, reconhecer direitos dos particulares - o que inviabilizaria o recurso estatal a qualquer dos métodos de solução consensual de conflitos -, uma vez que o interesse público nunca poderia ser relativizado para dar lugar à satisfação de um interesse privado.

Como será demonstrado no presente tópico, trata-se de uma visão equivocada, decorrente da própria distorção do conceito de interesse público e da desconsideração dos diversos aspectos aqui abordados acerca de sua indisponibilidade, indefinição e prevalência.

Celso Antônio Bandeira de Mello assim formula o seu entendimento sobre o tema, sustentando que a supremacia do interesse público

[t]rata-se de verdadeiro axioma reconhecível no moderno Direito
Público. Proclama a superioridade do interesse da coletividade,
firmando a prevalência dele sobre o particular, como condição, até
mesmo, da sobrevivência e asseguramento deste último. É
pressuposto de uma ordem social estável, em que todos e cada um
possam sentir-se garantidos e resguardados. ${ }^{550}$

A radicalidade com que essa supremacia do interesse público é sustentada - e criticada, diga-se - por diversos autores acabou por gerar notável disputa doutrinária no direito administrativo brasileiro, ainda não pacificada. Além

\footnotetext{
${ }^{550}$ MELLO, Celso Antônio Bandeira de. Curso de direito administrativo. São Paulo: Malheiros, 2014. P. 69.
} 
de diversos artigos e livros sobre o tema, se destacam de modo especial as obras coletivas "Interesses públicos versus interesses privados: Desconstruindo o princípio da supremacia do interesse público", ${ }^{551}$ organizada por Daniel Sarmento, e "Supremacia do interesse público e outros temas relevantes do direito administrativo", ${ }^{52}$ coordenada por Maria Sylvia Di Pietro e Carlos Vinícius Alves Ribeiro.

Maria Sylvia Di Pietro situa os acalorados debates em torno da sobrevivência ou não da supremacia do interesse público num cenário de crise de sobrevivência do próprio direito administrativo. Tal cenário seria, em sua visão, análogo àquele experimentado pelos civilistas em meados do séc. $X X$, o que poderia prever o resultado dos debates: se o direito civil sobreviveu à sua crise e hoje ainda existe, assim também haveria o direito administrativo de sobreviver aos debates atuais. ${ }^{553}$ Ao contrário do que sustenta Maria Sylvia Di Pietro, ${ }^{554}$ ousamos respeitosamente discordar do entendimento de que a negação do qualificativo supremacia ao interesse público seria a negação dos próprios fins do Estado. Quando muito, a negação da supremacia do interesse público seria a própria negação do caráter autoritário do direito administrativo, para nos apropriarmos parcialmente da análise de Gustavo Binenbojm. ${ }^{555}$

Não se pode considerar, portanto, que os debates em torno da supremacia do interesse público importem, numa análise maniqueísta, (i.) em

551 SARMENTO, Daniel (org.). Interesses públicos versus interesses privados: Desconstruindo o princípio da supremacia do interesse público. Rio de Janeiro: Lumen Juris, 2007.

552 DI PIETRO, Maria Sylvia Zanella; RIBEIRO, Carlos Vinicius Alves (coords.). Supremacia do interesse público e outros temas relevantes do Direito administrativo. São Paulo: Atlas, 2010.

${ }^{553}$ DI PIETRO, Maria Sylvia Zanella. Introdução: Existe um novo direito administrativo? In: DI PIETRO, Maria Sylvia Zanella; RIBEIRO, Carlos Vinicius Alves (coords.). Supremacia do interesse público e outros temas relevantes do Direito administrativo. São Paulo: Atlas, 2010. P. 1-4.

${ }^{554}$ DI PIETRO, Maria Sylvia Zanella. O princípio da supremacia do interesse público: sobrevivência diante dos ideais do neoliberalismo. In: DI PIETRO, Maria Sylvia Zanella; RIBEIRO, Carlos Vinicius Alves (coords.). Supremacia do interesse público e outros temas relevantes do Direito administrativo. São Paulo: Atlas, 2010. P. 100.

${ }^{555}$ BINENBOJM, Gustavo. A constitucionalização do direito administrativo no Brasil: um inventário de avanços e retrocessos. Revista Eletrônica sobre a Reforma do Estado, Salvador, n. 13, mar.mai. 2008.

No mesmo sentido:

BINENBOJM, Gustavo. Uma teoria do direito administrativo. Rio de Janeiro: Renovar, 2014. P. 917. 
defesa da prevalência do interesse privado ou (ii.) em desafio à própria existência do direito administrativo. Ora, na medida em que a evolução do direito administrativo desde suas origens é incontestável ${ }^{556}$ - e até inevitável, na própria lição de Maria Sylvia Di Pietro -, repensar os seus institutos é processo que faz parte da sua própria sobrevivência.

A existência do direito administrativo, pois, depende umbilicalmente de sua evolução.

A concepção filosófica do serviço ao Estado como ideal moral posta a Administração Pública como protagonista da aglutinação do interesse coletivo e de sua tradução em ações que concretizem o que concebemos como interesse público $^{557}$ - seja esse interesse público vocalizado pelo Estado como alocação dos diversos interesses da coletividade, seja como a personificação do interesse do nacional em face do outro, do externo. ${ }^{558}$ É nessa missão que, por vezes, deve o Estado lançar mão de institutos e instrumentos de direito privado - como aqui se defende -, relacionando-se com os particulares para a consecução de seus objetivos.

Frente a tais circunstâncias, para alguns autores, o caráter coletivo do interesse público, frente à individualidade do interesse privado, é que conferiria supremacia daquele em relação a este último. ${ }^{559}$

As raízes do interesse geral como eixo fundamental do direito administrativo, fincadas na Revolução Francesa de 1789, o caracterizam como limite fundamental ao exercício do poder legislativo e, nesse sentido, do poder de sujeição geral; ora, na medida em que a atuação do legislador resultar na edição de lei que se afaste da satisfação do interesse geral, torna-se ilegítimo o exercício

${ }^{556}$ DI PIETRO, Maria Sylvia Zanella. Introdução: Existe um novo direito administrativo? In: DI PIETRO, Maria Sylvia Zanella; RIBEIRO, Carlos Vinicius Alves (coords.). Supremacia do interesse público e outros temas relevantes do Direito administrativo. São Paulo: Atlas, 2010. P. 4.

${ }^{557}$ MABBOTT, J. D. The State and the Citizen: An introduction to political philosophy. Londres: Hutchinson, 1965. P. 113.

${ }^{558}$ POGGI, Gianfranco. The development of the modern State: A sociological introduction. Stanford: Stanford University Press, 1978. P. 16-29.

${ }^{559}$ GRANZIERA, Maria Luiza Machado. Contratos Administrativos. São Paulo: Atlas, 2002. P. 33. 
do poder, uma vez que a lei tinha o papel de consubstanciar, pelo interesse geral, a limitação ao exercício do poder em favor da liberdade e felicidade do povo. ${ }^{560}$

Para Emerson Gabardo e Daniel Wunder Hachem, assim, a estreita relação do princípio da legalidade com a consecução do interesse público teria suas origens fortemente calcadas na necessidade de contraposição ao arbítrio estatal e de proteção ao indivíduo, apesar de destacar-se uma aparente evolução da noção de interesse público, no séc. XXI, para mais além dessas funções. ${ }^{561}$

O interesse público - intérêt géneral na França Revolucionária - dos primeiros movimentos de formação do direito administrativo seria caracterizado por um conteúdo liberal, individualista. A fixação do interesse público pela Lei dar-se-ia em um cenário de suposta homogeneidade social, em que, em tese, seria possível garantir-se a felicidade geral pela contenção do Estado, confiando-se assim na autonomia do indivíduo para buscar a sua satisfação pessoal. ${ }^{562}$ No direito administrativo contemporâneo, esse conteúdo seria substituído pelo viés social, caracterizado pela função prestacional do Estado, que protagoniza com titularidade pública a realização do bem estar geral. ${ }^{563}$

Tomando por suporte concepções do direito francês, argentino e espanhol sobre o papel do interesse público, ${ }^{564}$ Emerson Gabardo e Daniel Wunder

${ }^{560}$ MERLAND, Guillaume, L'interêt général dans la jurisprudence du Conseil Constitutionnel. Paris: LGDJ, 2004. P. 27.

${ }^{561}$ GABARDO, Emerson; HACHEM, Daniel Wunder. O suposto carater autoritário da supremacia do interesse público e das origens do direito administrativo: uma crítica da crítica. In: DI PIETRO, Maria Sylvia Zanella; RIBEIRO, Carlos Vinicius Alves (coords.). Supremacia do interesse público e outros temas relevantes do Direito administrativo. São Paulo: Atlas, 2010. P. 22-27.

562 GABARDO, Emerson; HACHEM, Daniel Wunder. O suposto carater autoritário da supremacia do interesse público e das origens do direito administrativo: uma crítica da crítica. In: DI PIETRO, Maria Sylvia Zanella; RIBEIRO, Carlos Vinicius Alves (coords.). Supremacia do interesse público e outros temas relevantes do Direito administrativo. São Paulo: Atlas, 2010. P. 32-45.

${ }^{563}$ GABARDO, Emerson; HACHEM, Daniel Wunder. O suposto carater autoritário da supremacia do interesse público e das origens do direito administrativo: uma crítica da crítica. In: DI PIETRO, Maria Sylvia Zanella; RIBEIRO, Carlos Vinicius Alves (coords.). Supremacia do interesse público e outros temas relevantes do Direito administrativo. São Paulo: Atlas, 2010. P. 37.

${ }^{564}$ Nesse sentido:

BÓLGAR, Vera. L'intérêt général dans la théorie et dans la pratique. Revue Internationale de Droit Comparé, Paris, v. 17, n. 2, p. 335,1965.

BIELSA, Rafael. Principios de derecho administrativo. Buenos Aires: Depalma, 1963. 
Hachem sustentam, pelo exposto, uma diferenciação essencial entre o interesse público original, liberal e individualista, do interesse público contemporâneo, social e prestacional. A noção contemporânea de interesse público estaria ligada, assim, ao interesse individual na efetiva consecução da missão estatal, e não somente no interesse individual na garantia da contenção estatal. ${ }^{565}$

Este entendimento busca fundamento na lição de Maria Sylvia Di Pietro, que por sua vez expõe:

Assim como o princípio da legalidade saiu de sua fórmula rígida e
formalista, própria do Estado legal e chegou a uma fórmula muito
mais ampla que se ajusta ao Estado de Direito propriamente dito,
também o princípio do interesse público começou como proposição
adequada ao Estado liberal, não intervencionista (com o já
assinalado cunho utilitarista) e assume feição diversa para adaptar-
se ao Estado social e democrático de Direito, adotado na
Constituição de $1988 .{ }^{566}$

Apesar do relevante suporte invocado, com notável propriedade, por Emerson Gabardo e Daniel Wunder Hachem para sustentar um câmbio, uma transposição do conceito de interesse público, não enxergamos que os citados fundamentos possam levar a um descolamento, distanciamento ou diferenciação de jaez essencial entre o interesse público contemporâneo e o interesse público das origens do direito administrativo. Quando muito, observaríamos a sua ampliação de escopo, algo um tanto diferente.

Não obstante ser acertada a concepção de que o interesse público, em sua concepção hodierna, seja mais amplo que o interesse público original, não se concebe que haja entre eles uma diferença essencial, que lhes atinja a natureza

ESCOLA, Héctor Jorge. El interés público como el fundamento del derecho administrativo. Buenos Aires: Depalma, 1989.

SALOMONI, Jorge Luis. Interés público y emergencia. Actualidad en Derecho Publico, Buenos Aires, n. 18-20, p. 136, jan.-dez. 2002.

MUÑOZ, Jaime Rodríguez-Arana. Derecho Administrativo y Constitución. Granada: CEMCI, [s.d.]. P. 103.

${ }^{565}$ GABARDO, Emerson; HACHEM, Daniel Wunder. O suposto carater autoritário da supremacia do interesse público e das origens do direito administrativo: uma crítica da crítica. In: DI PIETRO, Maria Sylvia Zanella; RIBEIRO, Carlos Vinicius Alves (coords.). Supremacia do interesse público e outros temas relevantes do Direito administrativo. São Paulo: Atlas, 2010. P. 39.

${ }^{566}$ DI PIETRO, Maria Sylvia Zanella. O princípio da supremacia do interesse público. Revista Interesse Público, Belo Horizonte, n. 56, p. 43, jul./ago. 2009. 
em si. O entendimento de que haveria uma evolução ampliativa do conceito de interesse público não pode ser extrapolado ao ponto de resultar na concepção de que existiria um câmbio entre a concepção de interesse público dita liberal e o interesse público de moldes sociais.

Se há uma ampliação no conteúdo do interesse público, esta ampliação não prejudica a perfeita caracterização do interesse público, em nossos dias, com os mesmos ideais que deram origem a tal concepção. Dizer que o interesse público não é mais somente liberal não implica em dizer que o interesse público deixou absolutamente de ser liberal.

Caso assim não fosse, abandonados teriam sido os direitos fundamentais à liberdade e à propriedade, que guardam profunda e notável origem liberal e, não obstante, se perpetuam solenemente até os nossos dias.

Gustavo Binenbojm se opõe ao posicionamento de Gabardo e Hachem - não cronologicamente, já que a resposta, em termos literários, foi inversa -, sustentando que, na verdade, a noção de interesse público no direito administrativo guardaria fortes traços autoritários em suas origens. Seu entendimento se baseia na constatação de que o direito administrativo, em suas raízes revolucionárias francesas, não se baseou na submissão do Estado ao Direito, mas sim numa autovinculação da própria Administração Pública, frente à formação pretoriana da disciplina, centrada nos precedentes do Conselho de Estado francês. Ainda, a sua submissão tão somente ao contencioso administrativo teria "imunizado" o Poder Executivo do controle dos demais poderes e, em especial, do controle dos cidadãos. ${ }^{567}$

Assim edifica o autor o seu entendimento:

Nesse contexto, é correto afirmar que a dogmática administrativista estruturou-se a partir de premissas teóricas comprometidas com a preservação do princípio da autoridade, e não com a promoção das

${ }^{567}$ BINENBOJM, Gustavo. A constitucionalização do direito administrativo no Brasil: um inventário de avanços e retrocessos. Revista Eletrônica sobre a Reforma do Estado, Salvador, n. 13, mar.mai. 2008.

No mesmo sentido:

BINENBOJM, Gustavo. Uma teoria do direito administrativo. Rio de Janeiro: Renovar, 2014. P. 917. 
conquistas liberais e democráticas. O direito administrativo, nascido da superação histórica do Antigo Regime, serviu como instrumento retórico para a preservação daquela mesma lógica de poder.

[...]

Uma das categorias forjadas desde essa origem autoritária foi o chamado princípio da supremacia do interesse público sobre o interesse particular. Embora decantado pela literatura brasileira como fundamento e princípio normativo do direito administrativo, são patentes sua inconsistência teórica e sua incompatibilidade visceral com a sistemática constitucional dos direitos fundamentais. Com efeito, uma norma que preconiza a supremacia a priori de um valor, princípio ou direito sobre outros não pode ser qualificado como princípio. Ao contrário, um princípio, por definição, é norma de textura aberta, cujo fim ou estado de coisas para o qual aponta deve ser sempre contextualizado e ponderado com outros princípios igualmente previstos no ordenamento jurídico. A prevalência apriorística e descontextualizada de um princípio constitui uma contradição em termos. ${ }^{568}$

Gabardo e Hachem combatem o entendimento de que a supremacia do interesse público seria um traço autoritário do Estado contemporâneo, mas não justificam a adoção do vocábulo "supremacia" para a sua qualificação. Nesse sentido, cabe ressaltar que a oposição a que ora se adere não o é à prevalência e ao protagonismo do interesse público na atuação estatal, mas sim à sua adjetivação como supremo, absoluto, construção que não encontra os seus fundamentos claramente expostos na linha de argumentação dos diversos autores que a defendem. É o que se verá mais adiante.

Voltando aos autores que defendem a qualificação do interesse público como supremo, José dos Santos Carvalho Filho procura caracterizar como ingênuo, ou até insolente, o debate sobre a aposição do qualificativo "supremo" ao interesse público. ${ }^{569}$ No entanto, não basta defender o interesse público para caracterizar a sua supremacia; a adoção de um posicionamento que prefira referir-se à prevalência do interesse público, nesse sentido, não implica em desafio à sobrevivência do interesse público, mas sim em fortalecimento da sua aplicação real, e não meramente retórica.

\footnotetext{
${ }^{568}$ BINENBOJM, Gustavo. A constitucionalização do direito administrativo no Brasil: um inventário de avanços e retrocessos. Revista Eletrônica sobre a Reforma do Estado, Salvador, n. 13, mar.mai. 2008.

${ }^{569}$ CARVALHO FILHO, José dos Santos. Interesse público: verdades e sofismas. In: DI PIETRO, Maria Sylvia Zanella; RIBEIRO, Carlos Vinicius Alves (coords.). Supremacia do interesse público e outros temas relevantes do Direito administrativo. São Paulo: Atlas, 2010. P. 67-83.
} 
É dizer, no atual cenário constitucional - de central importância para a juridicidade do direito administrativo contemporâneo, como exposto no capítulo de aproximação ao tema - o "esforço de harmonização [de interesses] não se coaduna com qualquer regra absoluta de prevalência a priori dos papéis institucionais do Estado sobre os interesses individuais privados".

Para Gustavo Binenbojm, a adoção de um posicionamento pela supremacia do interesse público seria absolutamente incompatível com a atual ordem constitucional. A sua superação decorreria, pois, da constitucionalização do conceito de interesse público, "que fere de morte a idéia de supremacia como um princípio jurídico ou um postulado normativo que afirme peremptoriamente a preponderância do coletivo sobre o individual ou do público sobre o particular". Para o autor, o modelo de ponderação de interesses - tal como exposto no tópico anterior -, baseado no critério de racionalidade do direito, demonstra "a inconsistência da idéia de um princípio jurídico (ou um postulado normativo aplicativo) que preconize a supremacia abstrata e a priori do coletivo sobre o individual ou do público sobre o privado". 571

No mesmo sentido se posiciona Humberto Ávila, ao sustentar a incompatibilidade entre um interesse público qualificado como supremo e a atual ordem constitucional, calcada que é em princípios que fazem forçosa a ponderação de interesses para que se confira regularidade à atuação estatal. ${ }^{572}$

Ao produzir as ilações que supostamente dariam origem à concepção de supremacia do interesse público, em nenhum momento os autores sustentam ou demonstram porque é que o interesse público seria absoluto, incontrastável; o interesse público deve ser perseguido, é verdade, em toda a atuação

\footnotetext{
${ }^{570}$ BINENBOJM, Gustavo. Da supremacia do interesse público ao dever de proporcionalidade: um novo paradigma para o direito administrativo. In: BINENBOJM, Gustavo. Temas de direito administrativo e constitucional. Rio de Janeiro: Renovar, 2008.

${ }^{571}$ BINENBOJM, Gustavo. A constitucionalização do direito administrativo no Brasil: um inventário de avanços e retrocessos. Revista Eletrônica sobre a Reforma do Estado, Salvador, n. 13, mar.mai. 2008.

572 ÁVILA, Humberto Bergmann. Teoria dos princípios: Da definição à aplicação dos princípios jurídicos. São Paulo: Malheiros, 2005. P. 70.
} 
administrativa, sob pena de ilegitimidade. Isso levaria a que, no entanto, o interesse público fosse literalmente supremo?

O que os respeitáveis autores que sustentam a suposta supremacia do interesse público - e aqui se questiona a supremacia, não o interesse público em si - deixam de explicar é como essa supremacia, na literal acepção da palavra, se operacionaliza num mundo minimamente real. Ora, se o interesse público é supremo, absoluto, incontrastável, como se resolvem as demandas de provimento individual de serviços e benesses públicos em detrimento do atendimento à coletividade, como é o caso do fornecimento de medicamentos de alto custo, dos conflitos entre interesses coletivos, sociais e ambientais, entre tantos outros casos em que não se pode favorecer um interesse tido como público sem o sacrifício de outro?

Se o princípio implícito decorre da interpretação lógica do sistema positivo, ${ }^{573}$ o que fazer se a interpretação lógica do sistema positivo acaba por, muitas vezes, negar tal princípio? Subsistiria o suposto princípio pela simples vontade dos jurisconsultos?

Nesse sentido, seria muito mais adequado adotar o entendimento de Hector Jorge Escola de que, em caso de conflito, o interesse público pode afastar ou substituir o interesse privado que a si se lhe oponha sem, no entanto, aniquilálo. ${ }^{574}$

Diante dessas contundentes razões, relevantes autores que defendem com propriedade a supremacia do interesse público acabam por, em lugar de abandonar o vocábulo "supremacia", buscar alterar-lhe o significado.

Maria Sylvia Di Pietro, ao sustentar o princípio da supremacia do interesse público no direito administrativo, aduz que

O direito administrativo nasceu no período do Estado liberal. Por isso mesmo impregnou-se, em parte, do cunho individualista que

\footnotetext{
${ }^{573}$ CARVALHO FILHO, José dos Santos. Interesse público: verdades e sofismas. In: DI PIETRO, Maria Sylvia Zanella; RIBEIRO, Carlos Vinicius Alves (coords.). Supremacia do interesse público e outros temas relevantes do Direito administrativo. São Paulo: Atlas, 2010. P. 77.

${ }^{574}$ ESCOLA, Hector Jorge. El interés publico como fundamento del derecho administrativo. Buenos Aires: Depalma, 1989. P. 31.
} 
dominava as várias ciências humanas. Mas, paradoxalmente, o direito administrativo trouxe em si traços de autoritarismo, de supremacia sobre o indivíduo, com vistas à consecução de fins de interesse público. Pode-se dizer que o princípio do interesse público se desenvolveu no período do Estado Social de Direito, quando a atuação do Estado cresceu em todos os setores, com o objetivo de corrigir a profunda desigualdade social gerada pelo liberalismo. [...] a ideia de que o interesse público sempre, em qualquer situação, prevalece sobre o particular jamais teve aplicação (a não ser, talvez, em regimes totalitários). Exagera-se o seu sentido, para depois combatê-lo, muitas vezes de forma inconsequente, irresponsável e sob falsos pretextos [grifo nosso]. ${ }^{575}$

$\mathrm{Na}$ mesma linha, Irene Patrícia Nohara procura ressignificar o qualificativo "supremacia" aposto ao interesse público, estudando-o não do ponto de vista relacional, mas do ponto de vista da legitimação subjetiva da atuação estatal:

[...] a supremacia do interesse público não será analisada da perspectiva de parâmetro irrefreado de sopesamento de direitos fundamentais, mas como fundamento de legitimidade do manejo do regime jurídico administrativo, que caracteriza o Direito Administrativo como disciplina integrante do "ramo" do direito público [grifo da autora]. ${ }^{576}$

Em continuação, Nohara afirma que o suposto papel central da supremacia do interesse público no direito administrativo viria simplesmente da sua inserção como disciplina do Direito do Estado. ${ }^{577}$

Alice Gonzalez Borges, por sua vez, sustenta que os defeitos decorrentes da indevida apropriação da atuação estatal por gestores públicos mal intencionados não deve levar à desconstrução da noção de supremacia do interesse público - o que levaria, em sua opinião, a "sérias consequências para a

${ }^{575}$ DI PIETRO, Maria Sylvia Zanella. O princípio da supremacia do interesse público: sobrevivência diante dos ideais do neoliberalismo. In: DI PIETRO, Maria Sylvia Zanella; RIBEIRO, Carlos Vinicius Alves (coords.). Supremacia do interesse público e outros temas relevantes do Direito administrativo. São Paulo: Atlas, 2010. P. 92/94.

${ }^{576}$ NOHARA, Irene Patricia. Reflexões críticas acerca da tentativa de desconstrução do sentido da supremacia do interesse público no direito administrativo. In: DI PIETRO, Maria Sylvia Zanella; RIBEIRO, Carlos Vinicius Alves (coords.). Supremacia do interesse público e outros temas relevantes do Direito administrativo. São Paulo: Atlas, 2010. P. 120-121.

577 NOHARA, Irene Patricia. Reflexões críticas acerca da tentativa de desconstrução do sentido da supremacia do interesse público no direito administrativo. In: DI PIETRO, Maria Sylvia Zanella; RIBEIRO, Carlos Vinicius Alves (coords.). Supremacia do interesse público e outros temas relevantes do Direito administrativo. São Paulo: Atlas, 2010. P. 126. 
estabilidade e segurança dos cidadãos em uma sociedade organizada" -, apegando-se ao conceito de interesse público primário. ${ }^{578}$

Seu pensamento, no entanto, sustenta uma indissociável ligação entre o interesse público e os interesses individuais, na medida em que se apoia no entendimento de que a satisfação do interesse público pressupõe a satisfação dos interesses individuais, que daquele fazem parte de forma inseparável. Diante de tal cenário, a autora elege os direitos fundamentais do cidadão como "o grau mais elevado possível de interesses públicos, que devem, em regra, prevalecer sobre todos os demais interesses, públicos e individuais". 579

Nessa medida, Alice Gonzalez Borges acaba por, ao ressignificar, desconstituir o próprio conceito de supremacia do interesse público, especialmente ao sustentar que,

[quando] o direito administrativo faz da supremacia do interesse público - isto é, a habitual (mas não absoluta, nem eterna) prevalência do querer valorativo majoritário dos integrantes da sociedade - o (único) fundamento e justificativa para o exercício das chamadas prerrogativas de potestade pública, é para manter o mínimo de estabilidade e ordem necessárias para a vida em sociedade.

$[\ldots]$

Às vezes, o interesse da coletividade vem a demandar, do cidadão, um sacrifício de direitos. Tal somente pode ocorrer quando haja previsão legal, mediante cuidadosa e fundamentada motivação, e com a conversão final do direito sacrificado em justa indenização [grifos no original]. ${ }^{580}$

Não há sentido, no entanto, em buscarem os autores sustentar a supremacia do interesse público, se isso não significa que o interesse público seria supremo. Ora, se para sustentar a suposta supremacia do interesse público é necessário construir "[...] respostas interpretativas à necessidade de adaptação da supremacia do interesse público aos desafios do pós-positivismo e do Estado Democrático de Direito, na intenção de preservar aspectos que refletem um direito

\footnotetext{
${ }^{578}$ BORGES, Alice Gonzalez. Supremacia do interesse público: desconstrução ou reconstrução? Revista Eletrônica de Direito Administrativo Econômico, Salvador, n. 26, mai.-jul. 2011.

${ }^{579}$ BORGES, Alice Gonzalez. Supremacia do interesse público: desconstrução ou reconstrução? Revista Eletrônica de Direito Administrativo Econômico, Salvador, n. 26, mai.-jul. 2011.

${ }^{580}$ BORGES, Alice Gonzalez. Supremacia do interesse público: desconstrução ou reconstrução? Revista Eletrônica de Direito Administrativo Econômico, Salvador, n. 26, mai.-jul. 2011.
} 
administrativo equilibrado", 581 a manutenção do qualificativo "supremo" constitui preciosismo ou, ao menos, apego injustificado a uma forma de conceber o interesse público unitário, em momento prévio à consciência de sua multiplicidade e indefinição, demonstradas no tópico anterior.

Tal é o significado da expressão "supremo", em termos léxicos:

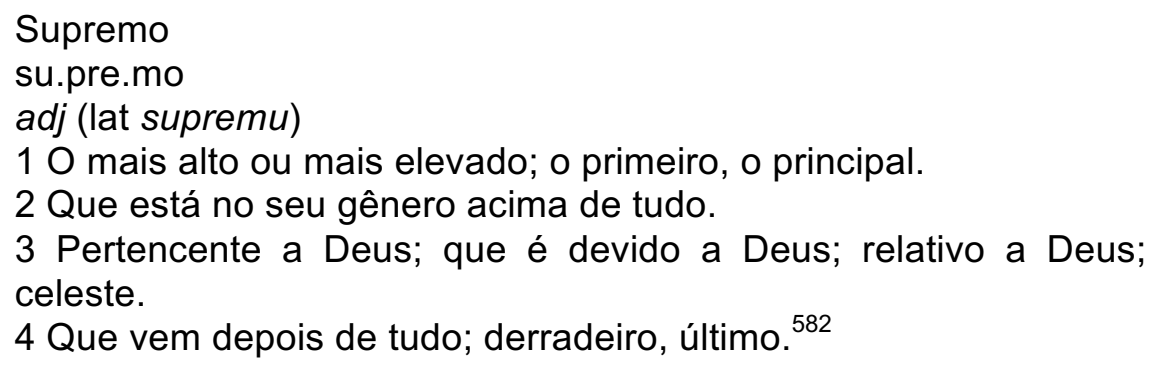

Ao sustentar, assim, que o interesse público é supremo, os autores que desse modo se posicionam estão se apropriando de um vocábulo cheio de significado. Dizer supremo é dizer absoluto, aquilo que "está no seu gênero acima de tudo". Um interesse público que fosse supremo não admitiria ponderação, sequer a convivência com outros interesses públicos igualmente qualificados como supremos.

Diante de tal cenário, faz-se oportuno trazer à tona o alerta de Umberto Allegretti, para quem "[...] os conceitos jurídicos não são neutros, mas são (sempre, se pode dizer) o reflexo histórico de uma certa estrutura". ${ }^{583}$

Nesse sentido, o pensamento de Rhita Bousta:

O direito é, com efeito, sobretudo uma linguagem que não pode produzir seus efeitos normativos senão quando compreendido e integrado por seus destinatários. As redundâncias nessa linguagem não colaboram com a inteligibilidade do Direito, sequer com a evolução tangível dos direitos. Desse modo, as tentativas de

\footnotetext{
${ }^{581}$ NOHARA, Irene Patricia. Reflexões críticas acerca da tentativa de desconstrução do sentido da supremacia do interesse público no direito administrativo. In: DI PIETRO, Maria Sylvia Zanella; RIBEIRO, Carlos Vinicius Alves (coords.). Supremacia do interesse público e outros temas relevantes do Direito administrativo. São Paulo: Atlas, 2010. P. 121-122.

582 DICIONÁRIO Michaelis da Língua Portuguesa. Supremo. São Paulo: Melhoramentos, 2015.

${ }^{583}$ ALLEGRETTI, Umberto. Amministrazione pubblica e costituzione. Milão: Cedam, 1996. P. 106. No original: "[...] i concetti giuridici non sono neutri, ma sono (sempre, si direbbe) il reflesso storico d'una certa struttura".
} 
definição das noções jurídicas contribuem, indiretamente, com o reconhecimento de novos direitos. ${ }^{584}$

Ressalte-se assim que o exercício de significação precisa das palavras e expressões jurídicas não constitui "alardes de erudição" ou de excesso crítico;"585 pelo contrário, se dedica a solucionar questões que acabam por complicar e prejudicar a aplicação do direito administrativo - como bem sustenta Rafael Bielsa -, contribuindo com o aprimoramento dos entendimentos sobre questão tão complexa e que comporta análises tanto sob o viés objetivo quanto sob o subjetivo.

Diante de todo o exposto, não basta buscar conferir um novo significado para a supremacia que se busca apor ao interesse público; se o interesse público não é supremo, incontrastável, absoluto, é recomendável que ele seja qualificado de forma diversa, de modo a manter a sua atualização com os mais caros fundamentos constitucionais do direito administrativo.

A resolução desse cenário carece, portanto, da definição de um novo qualificativo para o interesse público no direito administrativo brasileiro, tarefa para a qual o direito italiano e o direito português apresentam relevantes colaborações.

Interpretando a realidade constitucional italiana, Umberto Allegretti expõe com notável propriedade que a prevalência do interesse público ${ }^{586}$ só encontra sentido quando diretamente relacionada à imparcialidade administrativa, sua contraparte essencial no binômio relacionado às funções estatais e aos direitos dos cidadãos. A aplicação desta regra de prevalência do interesse público, pois, deve sempre submeter-se à expressão de grande exigência moral e prática - que condiciona do desenvolvimento dinâmico da realidade administrativa -

${ }^{584}$ BOUSTA, Rhita. Essai sur la notion de bonne administration en droit public. Paris: L'Harmattan, 2010. P. 468. Tradução nossa.

No original: "Le Droit est en effet avant tout un langage qui ne peut produire ses effets normatifs que s'il est compris et intégré par ses destinataires. Les redondances de ce langage ne participent ni à l'intelligibilité du Droit ni à l'evolution tangible des droits. Aussi les tentatives de définition des notions juridiques contribuente-elles, indirectement, à la reconnaissance de nouveaux droits".

${ }^{585}$ BIELSA, Rafael. Los conceptos juridicos y su terminología. Buenos Aires: DePalma, 1954. P. 17.

${ }^{586} \mathrm{Na}$ lição de Allegretti, o princípio do bom andamento da Administração Pública, previsto no art. 97 da Constituição Italiana, é reflexo direto da prevalência do interesse público, representando assim a instrumentalidade necessária para a consecução dos fins estatais (ALLEGRETTI, Umberto. Amministrazione pubblica e costituzione. Milão: Cedam, 1996. P. 15). 
consubstanciada na conformidade aos valores permanentes que identificam 0 ordenamento republicano, inspirados no cânone da liberdade e da solidariedade. ${ }^{587}$

Já o direito administrativo português nos apresenta o conceito de prossecução do interesse público - vinculação que distinguiria o agente público do agente privado ${ }^{588}$ - alçada ao status de princípio constitucional no ordenamento daquele país. Por força desse qualificativo, como destaca Sérvulo Correia, a busca pela realização do interesse público - a sua prossecução - levaria a Administração Pública a delimitar a sua atuação por esse objetivo, ainda que Ihe seja conferida a discricionariedade. Caberia à Administração, no caso concreto, analisar o interesse que lhe é posto à apreciação, verificando se o mesmo possui "um grau de intensidade que justifique, face ao interesse público, determinada actuação administrativa". ${ }^{589}$

Podemos nos posicionar, portanto, no sentido de que impera no direito administrativo brasileiro um princípio de prevalência do interesse público. A atuação da Administração Pública está sempre vinculada à realização dos interesses públicos, e deles nunca poderá se afastar; no entanto, não se pode alegar que um certo interesse público seja supremo, incontrastável, absoluto.

No caso específico da transação extrajudicial na administração pública, a prevalência do interesse público faz com que o ente estatal nunca possa deixar de buscar o interesse público onde ele se revelar mais premente, ainda que isso signifique deferir administrativamente um pleito do particular. Constituir-se-ia, assim, pela prevalência do interesse público - que vincula permanentemente à Administração -, verdadeiro dever estatal de transigir, sempre que esta se mostre a solução mais adequada para a correta ponderação dos interesses públicos que se apresentam no caso.

\footnotetext{
${ }^{587}$ ALLEGRETTI, Umberto. Amministrazione pubblica e costituzione. Milão: Cedam, 1996. P. 79-99.

${ }^{588}$ MONIZ, Ana Raquel Gonçalves. Direito, ética e Estado: Brevíssimas reflexões em diálogo com Barbosa de Melo. In: CORREIA, Fernando Alves; SILVA, João Calvão da; VIEIRA DE ANDRADE, José Carlos; CANOTILHO, Joaquim José Gomes; CARDOSO DA COSTA, José Manuel M. Estudos em Homenagem a António Barbosa de Melo. Coimbra: Almedina, 2013. P. 33-71.

${ }^{589}$ CORREIA, José Manuel Sérvulo. Os princípios constitucionais da administração pública. In: MIRANDA, Jorge. Estudos sobre a Constituição. Lisboa: Petrony, 1979. P. 661-664.
} 
Diante de tal cenário, faz-se necessário um movimento final, apto a caracterizar o interesse público prevalente onde quer que ele resida. É o que se desenvolve em seguida.

\subsubsection{Conteúdo do interesse público}

Como se vê do até aqui exposto, as diversas oposições à adoção da transação extrajudicial pela Administração Pública com base nos diversos aspectos do interesse público decorrem de conflitos geracionais e até de equívocos temporais em relação ao seu verdadeiro conteúdo. Cabe aqui alegar, na feliz dicção de Ariño Ortiz, que "as respostas que dão hoje as instituições e técnicas de direito administrativo são, em muitos casos, anacrônicas e insuficientes, porque são tão somente respostas a velhos problemas". 590

O último dos aspectos do interesse público a ser analisado é, talvez, o que mais representa esse caráter atávico da problemática do direito administrativo e, curiosamente, aparenta ser aquele que menos oposições atrai na literatura. Entendemos, pois, que um posicionamento final acerca da conciliação entre interesse público e transação extrajudicial na Administração carece de um reestabelecimento do método de apuração do conteúdo dos interesses públicos e, especialmente, da qualificação desses diversos interesses.

Nesse cenário, exsurgem os entendimentos, frequentes na literatura em direito administrativo no Brasil, que defendem a bipartição do interesse público em interesse público primário (chamado também simplesmente interesse público) e interesse público secundário (referido por alguns como interesse secundário), que

\footnotetext{
${ }^{590}$ ARIÑO ORTIZ, Gaspar. Lecciones de Administración y políticas públicas. Madrid: Iustel, 2013. P. 30. Tradução nossa.

No original: "Las respuestas que dan hoy las instituciones y técnicas del Derecho Administrativo clásico son, en muchos casos, anacrónicas e insuficientes, poruqe son sólo respuestas a viejos problemas. Por supuesto que hay metas definitivamente conquistadas que jamás se abandonarán. Pero es preciso percatarse de que hoy son nuevas cotas las que la sociedad reclama y que el Derecho Administrativo debe servir a ellas. Y es preciso preguntarse: ¿ son aptos para estas nuevas tareas los instrumentos que hemos heredado?"
} 
têm origem nos escritos de Carnelutti e Piccard, ${ }^{591}$ tornada célebre na lição de Renato Alessi, ${ }^{592}$ hoje reproduzida nos mais diversos trabalhos.

Nesse sentido, alegar-se-ia que o interesse que poderia ser tido como verdadeiramente público corresponderia ao "interesse coletivo primário considerado como sujeito de tutela direta para a ação administrativa"; por outro lado, entendem diversos autores que "o interesse da Administração, enquanto entidade organizada, não representa senão um dos interesses secundários que existem no grupo social". ${ }^{593}$

Mais amplamente expõe Hugo de Nigro Mazzilli:

[...] interesse público que, no dizer de Renato Alessi, compreende o interesse público primário e o secundário: não há confundir o interesse do bem geral (interesse público primário) com o interesse da administração (interesse público secundário), pois este último é apenas o modo como os órgãos governamentais vêem o interesse público.

A distinção de Alessi permite evidenciar que nem sempre coincidem o interesse público primário e o secundário. [...] Nesse sentido, o interesse público primário (bem geral) pode ser identificado com o interesse social, o interesse da sociedade ou da coletividade, e mesmo com os mais autênticos interesses difusos [...]. ${ }^{594}$

A introdução da bipartição do interesse público em interesse público primário e interesse público secundário no direito administrativo brasileiro é frequentemente creditada a Celso Antônio Bandeira de Mello. Em seus escritos, o autor sustenta que o interesse público primário "é o pertinente à sociedade como um todo e só ele pode ser validamente objetivado, pois este é o interesse que a lei consagra e entrega à compita do Estado como representante do corpo social". Já o interesse público secundário seria aquele "que atina tão-só ao aparelho estatal

\footnotetext{
${ }^{591}$ NOHARA, Irene Patricia. Reflexões críticas acerca da tentativa de desconstrução do sentido da supremacia do interesse público no direito administrativo. In: DI PIETRO, Maria Sylvia Zanella; RIBEIRO, Carlos Vinicius Alves (coords.). Supremacia do interesse público e outros temas relevantes do Direito administrativo. São Paulo: Atlas, 2010. P. 131.

${ }^{592}$ ALESSI, Renato. Diritto amministrativo. Milano: Giuffrè, 1949. P. 117-136.

${ }^{593}$ FERRARI, Regina Maria Macedo Nery. Efeitos da declaração de inconstitucionalidade. São Paulo: Revista dos Tribunais, 2004. P. 313.

${ }^{594}$ MAZZILLI, Hugo Nigro. Regime jurídico do Ministério Público. São Paulo: Saraiva, 2000. Passim.
} 
enquanto entidade personalizada e que por isso mesmo pode lhe ser referido e nele encarna-se pelo simples fato de ser pessoa". 595

Apesar de ter exposto suficientemente o entendimento homogêneo sobre o tema, reproduzimos aqui também o entendimento de Luís Roberto Barroso, como instrumento para o dimensionamento da interpenetração de tais conceitos na literatura nacional:

O interesse público primário é a razão de ser do Estado e sintetiza-
se nos fins que cabe a ele promover: justiça, segurança e bem-estar
social. Estes são os interesses de toda a sociedade. O interesse
público secundário é o da pessoa jurídica de direito público que seja
parte em determinada relação jurídica - quer se trate da União,
quer se trate do Estado-membro, do Município ou de suas
autarquias. Em ampla medida, pode ser identificado como interesse
do erário, que é o de maximizar a arrecadação e minimizar as
despesas. ${ }^{596}$

Alguns autores, inclusive, entendem ser absoluta a separação entre os conceitos de interesse público primário e interesse público secundário, classificando como erro a sua "confusão". 597

No direito administrativo português, a introdução da distinção entre interesse público primário e interesse público secundário se deu por obra de Rogério Soares. ${ }^{598}$ No entanto, a concepção portuguesa acerca de tal bipartição não sofre dos preconceitos que têm contaminado tantos posicionamentos no direito brasileiro, uma vez que o interesse público primário é tido como o bem comum, o fim primordial do Estado de promoção da dignidade da pessoa humana pela segurança, justiça e bem-estar, enquanto o interesse público secundário seria caracterizado como um interesse instrumental ao primeiro e efetivamente concretizado pelo legislador. 599

\footnotetext{
${ }^{595}$ MELLO, Celso Antônio Bandeira de. Curso de direito administrativo. São Paulo: Malheiros, 2014. P. 57.

596 BARROSO, Luís Roberto. Curso de direito constitucional contemporâneo: os conceitos fundamentais e a construção do novo modelo. São Paulo: Saraiva, 2009. P. 71.

${ }^{597}$ Nesse sentido: FERNANDES, Jorge Ulisses Jacoby. Acordos administrativos e judiciais. Forum Administrativo, Belo Horizonte, a. 6, n. 59, jan. 2006.

${ }^{598}$ SOARES, Rogério. Interesse público, legalidade e mérito. Coimbra: Atlântida, 1955. P. 101 ss.

${ }^{599}$ MONIZ, Ana Raquel Gonçalves. Direito, ética e Estado: Brevíssimas reflexões em diálogo com Barbosa de Melo. In: CORREIA, Fernando Alves; SILVA, João Calvão da; VIEIRA DE ANDRADE,
} 
Apesar dos extensos fundamentos e das vultosas vozes que expõem tal distinção, ao delegar à secundariedade os interesses de titularidade da administração, a atual teoria da bipartição - talvez a contragosto de seus autores, mas ainda assim - gera diversos efeitos negativos que repercutem no pensamento e na prática jurídicos da atualidade.

Posicionamentos equivocados levam, ao fim e ao cabo, à concepção de que é vedado à Administração solucionar questões relativas à sua responsabilidade por métodos consensuais - arbitragem, mediação, conciliação e transação - o que não se extrairia dos textos originais da teoria da bipartição do interesse público. Isso decorre da natureza de ciência social do Direito, que é criado, difundido e evoluído por indivíduos e, muitas vezes, Ihes foge ao controle.

A interpretação amplamente adotada à atual teoria da bipartição do interesse público leva à hierarquização entre o interesse público primário e o secundário - em decorrência, inclusive, da própria terminologia adotada -, incutindo a noção de que todo interesse patrimonial do Estado é secundário.

De mesmo giro, ao afastar o conceito de interesse público primário dos interesses de titularidade do Estado, a atual bipartição do interesse público afasta conceitualmente a Advocacia Pública - e, consequentemente, toda a representação judicial do Estado - do papel de defesa do interesse público primário, já que àquela cabe a "defesa dos interesses estatais", ${ }^{600}$ tendo em vista, inclusive, as disposições dos arts. 131 e seguintes da Constituição Federal.

Gravíssima consequência decorre da secundarização dos interesses patrimoniais do Estado para o próprio cumprimento de seus misteres. Ora, em tempos em que os debates sobre o tema das políticas públicas ganham grande popularidade, em um Estado que se pretende social como o brasileiro, é urgente que se tome consciência de que, sem recursos financeiros, nada se realiza na Administração. Para se apropriar do posicionamento que ora se critica, sem a

José Carlos; CANOTILHO, Joaquim José Gomes; CARDOSO DA COSTA, José Manuel M. Estudos em Homenagem a António Barbosa de Melo. Coimbra: Almedina, 2013. P. 33-71.

600 GRANZOTTO, Claudio Geoffroy. Advogado de Estado. Defesa do interesse público. Independência funcional mitigada. Jus Navigandi, Teresina, ano 12, n. 1334, 25 fev. 2007. 
salvaguarda dos interesses públicos secundários não é possível a concretização dos interesses públicos primários.

O campo das soluções consensuais de conflitos, como já exposto, não se faz infenso a tais consequências. A adoção indiscriminada dos conceitos de interesse público primário e secundário acaba, inclusive, por edificar posicionamentos que confundem gravemente as suas disposições com a definição do real interesse a prevalecer no caso concreto, como que em um método de ponderação prévia. Nesse sentido, há quem sustente que "[o] instituto jurídico da arbitragem é admitido em contratos administrativos, desde que o conflito se refira a direitos disponíveis (interesse público secundário), como é o caso, por exemplo, do reequilíbrio econômico-financeiro do contrato administrativo [grifo nosso]". ${ }^{601}$

Para sugerir solução à questão, apresentamos a tese de que, pela aplicação de uma lógica paraconsistente, o interesse público é ao mesmo tempo único e múltiplo. Só há um interesse público: a plena realização da missão institucional do Estado, constitucionalmente definida; essa missão conta com conteúdo múltiplo de busca pelo bem comum e pela efetividade dos direitos fundamentais.

Ao apreciarmos toda a construção apresentada anteriormente acerca da definição e da multiplicidade dos interesses públicos, fica claro o motivo pelo qual, para diversos autores, não há qualquer sentido em se sustentar uma bipartição do interesse público, seja ela qual for.

No entanto, entendemos que a edificação de um novo referencial dual para a apuração do conteúdo do interesse público guarda consideráveis vantagens metodológicas. A principal delas, muito provavelmente, é o forte caráter didático que uma tal demonstração representa, pois colabora consideravelmente, como se verá, com a compreensão de que o interesse público pode se configurar em vários interesses públicos, conforme o caso concreto se os apresente à ponderação.

${ }^{601}$ COPOLA, Gina. A arbitragem nos contratos administrativos. Fórum de Contratação e Gestão Pública, Belo Horizonte, a. 13, n. 146, p. 34-40, fev. 2014. 
A superação de alguns paradigmas em torno do tema também impende à renovação de conceitos. Na voz de Consuelo Yoshida:

A partir da Constituição de 1988 está superado aquele entendimento que preconiza que o interesse público não se confunde com 0 interesse meramente patrimonial da Fazenda Pública. Havendo lesão ou ameaça de lesão ao patrimônio público, deixa de haver interesse meramente estatal, o chamado interesse público secundário, e concomitantemente surge o interesse público primário ou interesse social, ou, ainda, interesse difuso, de toda a coletividade $[\ldots] .{ }^{602}$

Visando a adaptar a teoria da bipartição a conceitos que contemplem a coexistência e não a oposição das categorias - não se tratando, a rigor, de bipartição, mas sim de dualidade de natureza -, propôe-se a adoção da categorização do interesse público entre interesse público formal e interesse público material, abandonando-se as categorias de interesse público primário e interesse público secundário.

Conceitua-se assim o interesse público formal como aquele interesse que tenha como titular o Estado, enquanto detentor de direitos ou do dever de cuidado objetivo. Não resta adstrito aos interesses patrimoniais, portanto, mas abrange todos aqueles que tenham ente estatal como seu titular.

Por sua vez, o interesse público material abrange os interesses de qualquer titularidade que sejam permeados pelos objetivos da coletividade e tenham relação com a missão institucional do Estado. Nesse sentido, o interesse público é caracterizado pelo seu conteúdo, de acordo com as ponderações valorativas realizadas pela Constituição Federal.

Disso decorre o primeiro ponto positivo da caracterização do interesse público como interesse público formal e interesse público material: o perímetro que delimita a abrangência dos dois conceitos interage como círculos secantes, e não como campos de oposição - sendo que este último se verifica na teoria tradicional da bipartição, tal como interpretada por diversos autores.

${ }^{602}$ YOSHIDA, Consuelo Yatsuda Moromizato. O Ministério Público e sua função institucional de defesa do patrimônio público lesado ou ameaçado de lesão. Boletim dos Procuradores da República, Brasília, v. 2, n. 18, 1999. 
É dizer, ao contrário dos conceitos de interesse público primário e de interesse público secundário, que a rigor são tidos como opostos, as acepções de interesse público formal e interesse público material, na grande maioria dos casos, serão em sua maior parte coincidentes.

Assim, à guisa de exemplo, a atuação na segurança pública é interesse que coaduna com os princípios constitucionais a que se submete a Administração Pública e, desse modo, é interesse público material; de mesmo giro, esta atuação é de titularidade da Administração, sendo portanto interesse público formalmente considerado.

De outro modo, o interesse do particular em ser indenizado pela Administração quando inconteste seu direito é de sua titularidade, motivo pelo qual, formalmente, não é interesse público formal, tampouco interesse público secundário (por não ser interesse patrimonial do Estado) sequer interesse público primário - já que não constitui interesse da coletividade, mas sim interesse individual.

No entanto, este direito à indenização é interesse público material, já que é imbuído de um dos aspectos da missão constitucional do Estado - cumprir seu mister sem causar prejuízo injusto aos particulares -, o que afasta plenamente a hipótese de se opor à indenização voluntária o argumento da indisponibilidade, da supremacia ou de qualquer outro qualificativo do interesse público.

Indenizar, no exemplo dado, não é dispor do interesse público ou descumprí-lo, mas sim implementá-lo em sua plenitude, uma vez que "o interesse público se realiza quando o Estado cumpre satisfatoriamente o seu papel, mesmo que em relação um único particular". ${ }^{603}$

A convivência das duas naturezas no mesmo interesse, mais amplamente viabilizada por esta categorização, afasta a hierarquização e oposição nocivas entre interesse público primário e secundário, caracterizando-se, por meio dos novos conceitos, a caracterização dos objetivos administrativos e patrimoniais

${ }^{603}$ BARROSO, Luís Roberto. Prefácio. In: SARMENTO, Daniel (org.). Interesses públicos versus interesses privados: Desconstruindo o princípio da supremacia do interesse público. Rio de Janeiro: Lumen Juris, 2007. P. XV. 
da Administração como interesse público legítimo. Esta consequência toma grande vulto ao considerarmos que, como exposto, a defesa do patrimônio público viabiliza a consecução das políticas públicas e a defesa dos próprios interesses públicos tidos hoje como primários.

Sobremaneira, como sói reconhecer, a bipartição entre interesse público formal e material faz com que o confronto entre interesses públicos primários e secundários se torne tão somente conflito aparente de interesses e, na medida em que a coexistência entre interesse público formal e material permite caracterizar a satisfação do interesse do particular como interesse público material, estabelecese a vantajosidade na resolução pacificadora de conflitos.

Conclui-se assim que, na medida em que cumpre a missão constitucional do Estado em ser defensor imparcial do interesse coletivo abstendose de neste mister causar prejuízos aos Administrados ao mesmo tempo em que gera resultados de economicidade à Administração, a transação extrajudicial cumpre integralmente $o$ interesse público tanto formal quanto materialmente considerado, revelando-se assim como meio legítimo de resolução de conflitos no setor público.

É dizer, como expõe Romeu Felipe Bacellar Filho, que "[t]ransacionar não importa abrir mão do interesse público. A transação existe para permitir a concretização do interesse público, sem excluir a participação dos particulares interessados na solução da contenda". 604

A presente tese conclui a sua análise acerca do princípio do interesse público sustentando, assim, que o seu conteúdo pode ser caracterizado tanto do ponto de vista material - interesse público material, de conteúdo constitucional quanto do ponto de vista formal - interesse público formal, de titularidade estatal.

Nesse sentido, sustenta-se, enfim, não haver conflito entre aqueles que entendem que o elemento central do direito administrativo se constitui pelo interesse público e aqueles que enxergam na satisfação dos direitos fundamentais

\footnotetext{
${ }^{604}$ BACELLAR FILHO, Romeu Felipe. Direito Administrativo e o Novo Código Civil. Belo Horizonte: Fórum. 2007. P. 192.
} 
o papel último do Estado. O verdadeiro papel a que deve se dedicar o Estado é a sua missão institucional constitucionalmente definida: tanto interesses públicos quanto direitos e garantias fundamentais são constituintes dessa missão já que, ao fim e ao cabo, todos eles constituem interesses públicos materialmente considerados.

Diante de tal cenário, a transação extrajudicial se mostra como instrumento por excelência para a realização adequada do interesse público na solução de conflitos que envolvam a Administração, pois atende duplamente ao interesse público: ao mesmo tempo em que implica em patentes vantagens patrimoniais para o Estado, constituindo pois interesse público material (relacionado à missão institucional do Estado) e interesse público formal (de titularidade do ente público), atende da melhor forma possível o cidadão, interesse público material por excelência por relacionar-se com a plena satisfação dos direitos fundamentais.

\subsection{Desafios operacionais}

Enfrentados e devidamente superados os desafios conceituais à adoção da transação extrajudicial pela Administração Pública, é aberto o caminho para que o presente trabalho se debruce sobre os desafios operacionais à aplicação de tal modalidade contratual privada na administração pública.

Se revela, e é natural que assim seja, que o tratamento dos desafios operacionais se constitui em tarefa consideravelmente mais singela do que aquela relacionada aos desafios conceituais. É que, superados os entraves dogmáticos a que se dedicou a primeira parte deste capítulo, o enfrentamento aos desafios tidos como operacionais consiste em uma análise consideravelmente mais objetiva dos fundamentos da disciplina, aproximando-se de questões de direito positivo.

Não se deve desprezar, no entanto, a importância do enfrentamento a estes desafios de ordem operacional. O que se observa na Administração Pública brasileira é que, independentemente da relevância dos fundamentos que constituam as bases para determinada prática, estará ela fadada ao fracasso caso não se consolide na prática administrativa. Nesse sentido, a abordagem proposta 
tem início com a exposição das questões operacionais em torno da real efetividade do contrato privado de transação da Administração Pública - frente ao regime de controle e desfazimento de seus atos - e da superação do suposto confronto entre as soluções consensuais de conflitos e o regime de precatórios judiciais.

Num segundo momento, são expostos, como demonstração da consciência autocrítica que deve permear toda ilação científica, os diversos riscos relacionados com a adoção da transação extrajudicial na administração pública brasileira. Por fim, a análise é concluída com uma exposição acerca da importância do papel da postura pessoal dos gestores públicos para o sucesso da prática, em construção que nos permitirá proceder, no último capítulo do trabalho, com a apreciação dos caminhos que levarão à efetividade da consensualização administrativa pela transação extrajudicial.

\subsubsection{Transação extrajudicial, autotutela administrativa e controle da Administração Pública}

Como exposto na primeira parte deste trabalho, o recurso pela Administração Pública à transação extrajudicial deve ter como premissa básica a busca pela prevenção de litígio. Pretende-se, portanto, por meio deste contrato privado da Administração, conquistar a pacificação social, constituindo-se assim segurança jurídica tanto para o Estado quanto para o particular que são partes na avença.

Nesse sentido, retomamos o entendimento de que a linha central entre os métodos consensuais de solução de conflitos seria "[...] a procura voluntária e espontânea, constituindo formas extrajudiciais, que ocorrem fora do meio judicial e que acrescem aos meios tradicionais, junto dos tribunais estaduais". ${ }^{605}$ Esse papel de alternatividade das soluções consensuais em relação ao recurso ao judiciário é que leva Carnelutti a forjar sua clássica concepção de "equivalentes processuais" para os métodos consensuais. ${ }^{606}$

\footnotetext{
${ }^{605}$ CARVALHO, Ana Celeste. A mediação em matéria administrativa: uma possibilidade com futuro. Cadernos de Justiça Administrativa, Braga, n. 109, p. 3-12, jan./fev. 2015.

${ }^{606}$ CARNELUTTI, Francesco. Instituições do Processo Civil. São Paulo: Classic Book, 2000. P. 157.
} 
Nesse sentido, a efetividade da transação como método de solução consensual de conflitos reside no seu caráter definitivo ou, ao menos, resilientemente duradouro. Por esse motivo é que o art. 849 do Código Civil, regulando a espécie, determina que "[a] transação só se anula por dolo, coação, ou erro essencial quanto à pessoa ou coisa controversa", enquanto o parágrafo único do mesmo dispositivo estatui que "[a] transação não se anula por erro de direito a respeito das questões que foram objeto de controvérsia entre as partes".

Esse cenário é fértil para o surgimento de desafios à receptividade da transação extrajudicial na administração pública uma vez que, restando a Administração Pública sujeita a rígida sistemática de controle interno e externo, além de contar com o poder de autotutela sobre seus atos, a definitividade da transação poderia ser prejudicada, corroendo o seu efeito de pacificação de conflitos. $^{607}$

Faz-se necessário, assim, tecer breve análise sobre o cenário de revisão dos atos administrativos - considerados, aqui, em sua acepção ampla, para abarcar o recurso da Administração a contrato privados -, para posteriormente atingirmos um posicionamento quanto à caracterização ou não de desafio à receptividade da transação na administração pública.

A possibilidade de revisão dos atos administrativos, seja por anulação (invalidação, para alguns) ou revogação, ${ }^{608}$ como lista Maria Sylvia Di Pietro, é ínsita ao direito administrativo. A desnecessidade, a priori, de que a Administração Pública busque provimento jurisdicional para a revisão dos próprios atos já foi solidamente reconhecida pelas Súmulas nº 346 e 473 do Supremo Tribunal Federal

\footnotetext{
${ }^{607}$ Nesse sentido:

MOTA Júnior, João Francisco da. A transação administrativa e a SUSPAD mineira: Medidas alternativas e o sistema punitivo disciplinar. Série Biblioteca Virtual sobre Corrupção. Brasília: Controladoria-Geral da União, 2007.

GODOY, Arnaldo Sampaio de Moraes. Transação tributária: contexto, texto e argumentos. Revista Fórum de Direito Tributário, Belo Horizonte, a. 7, n. 39, mai.-jun. 2009.

ASSUNÇÃO, Matheus Carneiro. Transação em matéria tributária. Revista Fórum de Direito Tributário, Belo Horizonte, a. 9, n. 53, set.-out. 2011.

${ }^{608}$ DI PIETRO, Maria Sylvia Zanella. Direito Administrativo. São Paulo: Atlas, 2014. P. 88-90/238240.
} 
e positivada em dispositivos legais como o art. 53 da Lei $n^{\circ}$ 9.784/1999, além de diversos diplomas específicos, tanto federais quanto estaduais e municipais.

A distinção entre as hipóteses de revisão dos atos administrativos vem consolidada na própria Súmula $n^{\circ} 473$ do Supremo Tribunal Federal, que reconhece a possibilidade de anulação de atos "eivados de vícios que os tornam ilegais", ou de revogação de atos "por motivo de conveniência e oportunidade". Assim, uma primeira distinção entre as duas modalidades viria da natureza facultativa da revogação e obrigatória da anulação já que, no posicionamento de Odete Medauar, acompanhado por Di Pietro, pautando-se pelo princípio da legalidade, não poderia a Administração Pública simplesmente optar por manter um ato ilegal. ${ }^{609}$

Baseando-se, assim, num poder-dever, haveria limites à possibilidade de revisão dos atos administrativos e, consequentemente, das transações entabuladas pela Administração Pública? Para resposta a esta questão, cabe inicialmente destacar que, apesar da vinculatividade da anulação, cabe no caso concreto sopesar os efeitos da anulação do ato e até a possibilidade fática de operar-se a anulação. ${ }^{610}$ Assim, mesmo que Súmula n 473 do Supremo Tribunal Federal sustente que dos atos ilegais "não se originam direitos", é possível a sua consolidação temporal ou mesmo irretratabilidade por absoluta impossibilidade fática. ${ }^{611}$ Desse modo, tais limites consubstanciam-se principalmente na fixação de prazos para a revisão e na imposição de limites materiais para tanto.

${ }^{609}$ MEDAUAR, Odete. Direito administrativo moderno. São Paulo: Revista dos Tribunais, 2015. P. 166-167.

No mesmo sentido:

DI PIETRO, Maria Sylvia Zanella. Direito Administrativo. São Paulo: Atlas, 2014. P. 239.

${ }^{610}$ MEDAUAR, Odete. Direito administrativo moderno. São Paulo: Revista dos Tribunais, 2015. P. 166-167.

${ }^{611}$ MELLO, Celso Antônio Bandeira de. Curso de direito administrativo. São Paulo: Malheiros, 2014. P. 487.

Nesse sentido:

MEDAUAR, Odete. Direito administrativo moderno. São Paulo: Revista dos Tribunais, 2015. P. 167. 
No cerne dos limites a esta revisão reside o princípio da segurança jurídica, que nasce no seio da própria origem e justificativa do Direito contemporâneo. ${ }^{612}$

Como exposto de início, a revisão dos atos administrativos pode se dar por sua ilegalidade, quando falamos em anulação (ou invalidação), ou por motivos de conveniência e oportunidade, quando se trata de revogação. ${ }^{613}$ Ainda, como visto, os limites a tal revisão são estabelecidos mormente pela fixação de prazos para tanto. Assim, como bem destaca Celso Antônio Bandeira de Mello, os limites acabam por se aplicar homogeneamente tanto à anulação quanto à revogação, ${ }^{614}$ motivo pelo qual são ambas as hipóteses tratadas aqui como revisão dos atos administrativos.

Cabe ressaltar ainda que, de modo instrumental, as previsões da possibilidade de revisão dos atos administrativos frequentemente se fazem acompanhar do estabelecimento de limites. Assim, em busca de uma regra geral, cabe aqui expor o conteúdo das Súmulas 346 e 473 do Supremo Tribunal Federal:

Súmula 346: A Administração Pública pode declarar a nulidade dos seus próprios atos.

Súmula 473: A Administração pode anular seus próprios atos quando eivados de vícios que os tornam ilegais, porque deles não se originam direitos; ou revogá-los, por motivo de conveniência e oportunidade, respeitando os direitos adquiridos e ressalvada, em todos os casos, a apreciação judicial.

Na esfera federal, os limites temporais para a revisão são expressos no art. 54 da Lei $n^{\circ} 9.784 / 1999^{615}$ - que se aplica tanto à anulação quanto à

${ }_{612}$ VAINER, Bruno Zilberman. Aspectos básicos da segurança jurídica. Revista de Direito Constitucional e Internacional, São Paulo, ano 14, n. 56, p. 5-26, jul./set. 2006.

${ }^{613}$ DI PIETRO, Maria Sylvia Zanella. Direito Administrativo. São Paulo: Atlas, 2014. P. 88-90/238240.

${ }^{614}$ MELLO, Celso Antônio Bandeira de. Curso de direito administrativo. São Paulo: Malheiros, 2014. P. 491-493.

615 Julgou o Supremo Tribunal Federal que o regime da Lei $n^{\circ} 9.784 / 1999$ se coordena com o disposto nas Súmulas 346 e 473 (BRASIL. SUPREMO Tribunal Federal. Recurso no Mandado de Segurança $n^{\circ}$ 27.998. Rel. Min. Dias Toffoli. Diário de Justiça Eletrônico, Brasília, 21 set. 2012). 
revogação ${ }^{616}$-, estabelecendo o prazo decadencial ${ }^{617}$ de cinco anos, exceto em caso de má-fé do beneficiário quando, para Bandeira de Mello, aplicar-se-ia a regra geral civil de dez anos. ${ }^{618} \mathrm{Na}$ falta de previsão específica (a exemplo da previsão decenal do art. 10, I, da Lei Estadual 10.177/1998-SP), em outras esferas, aplicase o mesmo prazo quinquenal, nos termos do Decreto $n^{\circ} 20.910 / 1932,{ }^{619}$ como sustenta Maria Sylvia Di Pietro.

Tendo, no entanto, a Administração julgado administrativamente, de modo litigioso, em última instância, uma certa matéria - como no caso de um processo administrativo que culmine na firmatura de transação extrajudicial -, não poderia a própria Administração questionar tal posicionamento nem administrativa nem judicialmente, ${ }^{620}$ o que alguns chamariam de coisa julgada administrativa ${ }^{621}$ expressão imprópria para Di Pietro e que, se adotada, significa tão somente que a decisão é "irretratável pela própria administração" ${ }^{622}$ Tal irrevogabilidade alcançaria casos como "os atos vinculados, os que exauriram seus efeitos, os meros atos administrativos, os que geraram direitos subjetivos". 623

A adoção de limites temporais e materiais à revisão dos atos administrativos toma por base princípios como a segurança jurídica, ${ }^{624}$ a boa-fée

\footnotetext{
${ }^{616}$ MELLO, Celso Antônio Bandeira de. Curso de direito administrativo. São Paulo: Malheiros, 2013. P. 493.

${ }^{617}$ DI PIETRO, Maria Sylvia Zanella. Direito Administrativo. São Paulo: Atlas, 2014. P. 240.

Em sentido contrário (natureza de prazo prescricional):

ARAÚJO, Edmir Netto de. Curso de direito administrativo. São Paulo: Saraiva, 2010. P. 522-523.

${ }^{618}$ MELLO, Celso Antônio Bandeira de. Curso de direito administrativo. São Paulo: Malheiros, 2013. P. 493.

${ }^{619}$ DI PIETRO, Maria Sylvia Zanella. Direito Administrativo. São Paulo: Atlas, 2014. P. 240/749.

${ }^{620}$ MELLO, Celso Antônio Bandeira de. Curso de direito administrativo. São Paulo: Malheiros, 2013. P. 467-469.

${ }^{621}$ ARAÚJO, Edmir Netto de. Curso de direito administrativo. São Paulo: Saraiva, 2010. P. 510-513. ${ }^{622}$ DI PIETRO, Maria Sylvia Zanella. Direito Administrativo. São Paulo: Atlas, 2014. P. 746-747. ${ }^{623}$ DI PIETRO, Maria Sylvia Zanella. Direito Administrativo. São Paulo: Atlas, 2014. P. 747. ARAÚJO, Edmir Netto de. Curso de direito administrativo. São Paulo: Saraiva, 2010. P. 510-513. ${ }^{624}$ DI PIETRO, Maria Sylvia Zanella. Direito Administrativo. São Paulo: Atlas, 2014. P. 239-240. ${ }^{625}$ MEDAUAR, Odete. Direito administrativo moderno. São Paulo: Revista dos Tribunais, 2015. P. 167.
} 
e a lealdade ${ }^{626}$ - o que se reflete, por exemplo, no disposto nos arts. 49 , $\S 1^{\circ}$, e 59 , parágrafo único, da Lei $n^{\circ} 8.666 / 1993{ }^{627}$

Como já exposto, é da própria natureza do Direito e faz parte de sua justificativa a busca pela estabilização das relações interpessoais. ${ }^{628}$ Assim, do ponto de vista do Estado, como destaca Edmir Netto de Araújo, "o interesse da estabilidade das relações jurídicas entre Administração e administrado [...] é interesse público tão relevante quanto os demais". ${ }^{629}$ Esse acepção do interesse público - feitas aqui todas as ressalvas acerca de sua caracterização, tal como expostas na primeira parte desse capítulo - é que rege, portanto, a aplicação dos princípios da segurança jurídica, da boa-fé e da proteção à confiança como limite à revisão dos atos administrativos. ${ }^{630}$

Dentre tais princípios, destaca-se a segurança jurídica que, como expressão da busca pela estabilidade das relações, rege as disposições de direito administrativo em geral, ${ }^{631}$ como já reconhecido pela jurisprudência brasileira. ${ }^{632}$ Da lição de Maria Sylvia Di Pietro, temos que o princípio da segurança jurídica, no âmbito do direito administrativo, pode ser analisado sob os vieses objetivo e

\footnotetext{
${ }^{626}$ MELLO, Celso Antônio Bandeira de. Curso de direito administrativo. São Paulo: Malheiros, 2013. P. 467-469.

${ }^{627}$ BRASIL. SUPERIOR Tribunal de Justiça. Mandado de Segurança $n^{\circ} 18.522 / D F$. Rel. Min. Arnaldo Esteves Lima. Diário de Justiça Eletrônico, Brasília, 21 out. 2013.

${ }^{628}$ MELLO, Celso Antônio Bandeira de. A estabilidade dos Atos Administrativos e a Segurança Jurídica, Boa-Fé e Confiança Legítima ante os atos estatais. In: Grandes Temas de Direito Administrativo. São Paulo: Malheiros, 2010. P. 168-180.
}

CARVALHO E SOUZA, Guilherme. A responsabilidade civil do Estado e o princípio da confiança legítima. Revista de Direito Administrativo, Rio de Janeiro, v. 258, p. 115-140, set./dez. 2011.

${ }^{629}$ ARAÚJO, Edmir Netto de. Curso de direito administrativo. São Paulo: Saraiva, 2010. P. 522-523.

${ }^{630}$ DI PIETRO, Maria Sylvia Zanella. Os princípios da proteção à confiança, da segurança jurídica e da boa-fé na anulação do ato administrativo. Fórum Administrativo, Belo Horizonte, ano 9, n. 100, p. 155-166, jun. 2009..

${ }^{631}$ MELLO, Celso Antônio Bandeira de. A estabilidade dos Atos Administrativos e a Segurança Jurídica, Boa-Fé e Confiança Legítima ante os atos estatais. In: Grandes Temas de Direito Administrativo. São Paulo: Malheiros, 2010. P. 168-180.

${ }^{632}$ BRASIL. SUPREMO Tribunal Federal. Mandado de Segurança $n^{\circ}$ 29.305. Rel. Min. Marco Aurélio. Diário de Justiça Eletrônico, Brasília, p. 200, 11 out. 2012.

BRASIL. SUPREMO Tribunal Federal. Mandado de Segurança $n^{\circ}$ 28.720. Rel. Min. Ayres Britto. Diário de Justiça Eletrônico, Brasília, p. 66, 2 abr. 2012. 
subjetivo sendo que, objetivamente, trata-se da citada função estabilizadora das relações jurídicas. ${ }^{633}$

Já no sentido subjetivo a segurança jurídica toma expressão como a proteção à confiança, surgido no direito alemão, ${ }^{634}$ que "leva em conta a boa-fé do cidadão, que acredita e espera que os atos praticados pelo Poder Público sejam lícitos e, nessa qualidade, serão mantidos e respeitados pela própria Administração e por terceiros". ${ }^{635}$ A aplicação do princípio da segurança jurídica com limite à revisão dos atos administrativos não seria, no entanto, absoluta, reconhecendo os precedentes jurisprudenciais que aquele princípio não vigeria, por exemplo, em face de manifesta inconstitucionalidade. ${ }^{636}$

Verifica-se, assim, que o princípio da segurança jurídica pode ser contemplado como o principal fundamento para a adoção de limites à revisão dos atos administrativos. A sua aplicação se reflete, pois, nos diversos dispositivos sobre o tema - fonte que são da maior parte dos desafios operacionais aqui estudados -, e marca profundamente o papel do direito administrativo como instrumento de estabilização das relações entre a Administração Pública e os particulares.

Nesse sentido, a segurança jurídica se aplica como limite à revisão dos atos administrativos tanto pela aplicação de balizas temporais - prazos decadenciais ou prescricionais - como pela presença de proibitivos materiais e fáticos à revisão. Tais limites se expressam tanto num jaez objetivo, representando a função do Direito como estabilizador das relações jurídicas, como numa natureza subjetiva, que se consubstancia na proteção à confiança legítima do particular na regularidade da atuação da Administração Pública.

\footnotetext{
${ }^{633}$ DI PIETRO, Maria Sylvia Zanella. Direito Administrativo. São Paulo: Atlas, 2014. P. 239-240.

${ }^{634}$ GARCIA LUENGO, Javier. El principio de protección de la confianza em el derecho administrativo. Madrid: Civitas, 2002.

${ }^{635}$ DI PIETRO, Maria Sylvia Zanella. Direito Administrativo. São Paulo: Atlas, 2014. P. 86-88.

${ }^{636}$ BRASIL. SUPREMO Tribunal Federal. Recurso Extraordinário $n^{\circ}$ 216.443. Rel. Min. Marco Aurélio. Diário de Justiça Eletrônico, Brasília, p. 26, 7 fev. 2013.

BRASIL. SUPERIOR Tribunal de Justiça. Recurso em Mandado de Segurança n 36.294/RS. Rel. Min. Benedito Gonçalves. Diário de Justiça Eletrônico, Brasília, 19 ago. 2013.
} 
Esses limites se aplicam, igualmente, à revisão de posicionamentos da Administração Pública no manejo da transação extrajudicial. Diante de todo o exposto, este se mostra como o campo por excelência para a defesa da segurança jurídica, uma vez que a pacificação das relações sociais constitui o seu objetivo último.

Nesse sentido, o direito administrativo italiano, com o pioneirismo que Ihe é peculiar, já há muito estabelece que o ato administrativo que contenha o reconhecimento de um direito privado é irrevogável:

COMPETENZA E GIURISDIZIONE - Comissione per le rivendiche instituita presso I'A.R.A.R. con D. L. 28 febbraio 1947, n. 119 Carattere giurisdizionale - Conseguente irrevocabilità delle pronuncie.

REVOCAZIONE - Esclusione del carattere di rimedio generale contro tutte le decisioni giurisdizionali - Esclusione della revocazione rispetto alle decisioni della Commissione per le rivendiche, istituita presso l'A.R.A.R.

ATTI AMMINISTRATIVI - Provvedimento che contenga il riconoscimento di un diritto privato - Irrevocabilità.

ATTI AMMINISTRATIVI - Decisione su ricorso gerarchico improprio ad organo sfornito d'attribuzioni d'amministrazione attiva Irrevocabilità. ${ }^{637}$

Também o direito administrativo francês é contundente nesse sentido. $O$ documento "Régler autrement les conflits", editado pelo Conselho de Estado Francês no início dos anos 1990 e considerado um estudo pioneiro acerca da adoção de soluções consensuais de conflitos pela Administração Pública, já sustentava que "as transações são especialmente dotadas de um efeito extintivo". ${ }^{638}$ Seria vedado à Administração, assim, repristinar voluntariamente a questão resolvida por meio da transação, uma vez que os seus efeitos extintivos seriam judicialiformes.

Géraldine Chavrier, no entanto, enxerga com reservas a força obrigatória da transação, sob o mesmo prisma de direito administrativo francês. Para a autora,

637 ITÁLIA. TRIBUNALE Milano. Soc. Fratelli Borletti $v$ Azienda Rilievo Alienazione Residuati A.R.A.R. Giurisprudenza Italiana, Torino, v. 103, p. 139-147, 1951.

638 FRANÇA. CONSELHO de Estado Francês. Régler autrement les conflits: conciliation, transaction, arbitrage (coleção Les Études du Conseil d'Etat). Paris: Documentation Française, 1993. Tradução nossa.

No original: "[...] les transactions ont plus particulièrement un effet extinctif". 
frente ao poder de autotutela da Administração e, ainda, diante da possibilidade de controle externo da legalidade e regularidade dos atos estatais, a transação teria força de "coisa julgada relativa". Conclui Chavrier, assim, que a transação administrativa, para atingir a mesma força obrigatória da transação entre partes privadas, reclamaria uma homologação judicial que Ihe confira a condição de coisa julgada. $^{639}$

Não comungamos do entendimento de Chavrier, seja por carecer de fundamentos teóricos nesse sentido, seja também por não ser ele integralmente transponível ao cenário constitucional e ao contexto de direito positivo do Brasil. Nesse sentido, entendemos que a análise deve ser, a partir desse ponto, cindida entre as figuras da anulação e da revogação, já conceituadas no início do tópico.

Em relação à revogação, crê-se no presente posicionamento que não há margem para o desfazimento da transação extrajudicial, pela Administração, por motivo de conveniência ou oportunidade. Ao lançar mão da transação extrajudicial, o ente estatal adere ao regime privado que lhe é característico, o que importa como extensamente exposto na conclusão da primeira parte da presente tese - em que este ente se dispa da prerrogativa de autoexecutoriedade. São aplicáveis ao caso, portanto, tão somente as disposições expressamente previstas no regime privado do contrato, com as modulações instituídas pela Lei de Licitações e Contratos Administrativos, naquilo que seja aplicável.

Retomando disposições de direito positivo já expostas, verificamos que o regramento civilista da transação estabelece que, no cumprimento do seu papel de estabilização das relações sociais, seu desfazimento só poderá ser operado por motivo de nulidade, não sendo sequer possível opor-lhe eventual "erro de direito a respeito das questões que foram objeto de controvérsia entre as partes".

${ }^{639}$ CHAVRIER, Géraldine. Réflexions sur la transaction administrative. Revue Française de Droit Administratif, Paris, n. 3, p. 548-566, mai.-jun. 2000.

Esse é o entendimento esposado pelo Conselho de Estado Francês, como consolidado no acórdão de 19 de março de 1971 que decidiu o caso Sieur Mergui, confirmado posteriormente pelo acórdão de 11 de julho de 1980, sobre o caso Compagnie d'Assurances La Concorde, e pelo acórdão de 25 de janeiro de 1995, julgando o caso Commune de Simiane-Collongue. 
Remetendo-nos ao regime publicístico dos contratos administrativos, aplicável subsidiariamente aos contratos privados da Administração, verifica-se que a revogação por motivo de conveniência e oportunidade só pode ser veiculada no curso do procedimento, mas não após a firmatura do contrato que, mesmo quando anulado, ainda respeita os direitos adquiridos pelo particular.

Pode-se concluir, portanto, que a transação extrajudicial entabulada pela Administração Pública não está sujeita a revogação por motivos de conveniência ou oportunidade, em defesa da segurança jurídica e como corolário da busca pela pacificação das relações jurídicas que lhe constitui o cerne.

Já no tocante à anulação - seja por iniciativa da Administração, seja por ato de controle externo ${ }^{640}$ - vislumbramos que a sua possibilidade, apesar de concreta, deve em muito ser restrita, justamente tendo em vista a preservação dos efeitos últimos pelos quais se recorre às soluções consensuais de conflitos, assim como exaustivamente exposto.

Nesse sentido, remetemo-nos à lição de Adilson Abreu Dallari, para quem sequer com decisão judicial poder-se-ia afirmar que a solução obtida realizou, concreta e objetivamente, o interesse público. Em seu pensamento, o interesse

\footnotetext{
${ }^{640}$ A anulação da transação extrajudicial da Administração Pública por órgãos de controle externo foi recentemente apreciada pelo Supremo Tribunal Federal, que se posicionou pela sua possibilidade quando a transação não tiver sido homologada em juízo, inclusive com a promoção de responsabilidade pessoal dos gestores públicos:
}

MANDADO DE SEGURANÇA. COMPETENNCIA DO TRIBUNAL DE CONTAS DA UNIÃO. INCLUSÃO DOS IMPETRANTES EM PROCESSO DE TOMADA DE CONTAS ESPECIAL. RESPONSABILIDADE SOLIDÁRIA. RESSARCIMENTO AO ERÁRIO. ILEGALIDADE E ABUSO DE PODER NÃO CONFIGURADOS. DENEGAÇÃO DA SEGURANÇA.

1. Ao auxiliar o Congresso Nacional no exercício do controle externo, compete ao Tribunal de Contas da União a relevante missão de julgar as contas dos administradores e dos demais responsáveis por dinheiros, bens e valores públicos da administração direta e indireta, incluídas as fundações e sociedades instituídas e mantidas pelo Poder Público federal, e as contas daqueles que derem causa a perda, extravio ou outra irregularidade de que resulte prejuízo ao erário (art. 71 , II, da Constituição Federal).

2. Compete à Corte de Contas da União aplicar aos responsáveis, em caso de ilegalidade de despesa ou irregularidade de contas, as sanções previstas em lei, que estabelece, entre outras cominações, multa proporcional ao dano causado ao Erário (art. 71, VIII, da Constituição Federal). 3. Em decorrência da amplitude das competências fiscalizadoras da Corte de Contas, tem-se que não é a natureza do ente envolvido na relação que permite, ou não, a incidência da fiscalização da Corte de Contas, mas sim a origem dos recursos envolvidos, conforme dispõe o art. 71 , II, da Constituição Federal

4. Denegação da segurança.

(BRASIL. SUPREMO Tribunal Federal. Mandado de Segurança n 24.379. Rel. Min. Dias Toffoli. Diário de Justiça Eletrônico, Brasília, n. 108, 8 jun. 2015). 
público é atingido, nesse caso, com a pacificação da relação controvertida - o que nos remete ao posicionamento de Carnelutti quanto à natureza da transação ${ }^{641}-$, mesmo que o conteúdo da decisão não se conforme da melhor maneira possível em termos materiais. ${ }^{642}$

Aplica o autor essa mesma concepção ao recurso, pela Administração, à transação:

\begin{abstract}
A parceria entre agentes públicos e particulares tem como base a confiança recíproca. Os contratos firmados entre particulares e o Poder Público também dependem de uma confiança recíproca. Não há por que sepultar essa confiança em caso de algum eventual litígio, pois dúvidas interpretativas sempre podem ocorrer, mesmo quando ambas as partes estão imbuídas dos melhores e mais honestos propósitos. Ao contrário, a confiança inicial que justificou a celebração do ajuste deve ser invocada e utilizada para resolver o conflito. ${ }^{643}$
\end{abstract}

Por fim, aderimos à posição de Antônio Carlos Cintra do Amaral no sentido de que não existe ato administrativo nulo de pleno direito. Nesse sentido, ainda que se trate de caso de potencial anulação, "[e]nquanto não anulado, todo ato administrativo é válido". ${ }^{644}$ Disso decorre que, diante da possibilidade jurídica de transação extrajudicial na administração pública, demonstrada na primeira metade do presente capítulo, em sendo a nulidade superável poderá o ato ser convalidado.

Entendemos, assim, pelo mesmo método de apreciação dialógica entre os diplomas de direito positivo relativos ao regime civil e ao regime administrativo, pela existência de três hipóteses distintas para a apuração da possibilidade ou não de anulação de transação extrajudicial na administração pública.

\footnotetext{
${ }^{641}$ CARNELUTTI, Francesco. La transazione è un contratto? Rivista di Diritto Processuale, Padova, v. 8 , t. 1 , p. $185-190,1953$.

642 DALLARI, Adilson Abreu. Viabilidade da transação entre o poder público e particular. Interesse Público, Belo Horizonte, a. 4, n. 13, jan.-mar. 2002.

${ }^{643}$ DALLARI, Adilson Abreu. Viabilidade da transação entre o poder público e particular. Interesse Público, Belo Horizonte, a. 4, n. 13, jan.-mar. 2002.

644 AMARAL, Antônio Carlos Cintra do. Validade e Invalidade do Ato Administrativo. Revista Eletrônica de Direito do Estado, Salvador, n. 9, jan.-mar. 2007.
} 
Em havendo, no contrato de transação, erro ou ilegalidade que implique em sua nulidade, caso não se configure dolo, má-fé, culpa ou qualquer reponsabilidade do agente administrativo ou da contraparte privada, não caberá a anulação do contrato de transação. Isso porque a presença de tal nulidade não tem o condão de desconstituir o verdadeiro interesse público obtido, consistente na prevenção do litígio, e a boa-fé do particular lhe protege o direito adquirido com o ato jurídico perfeito.

Na segunda hipótese, em se configurando a nulidade do contrato privado de transação da Administração por dolo ou culpa do agente administrativo, mas estando o particular imbuído de boa-fé, igualmente caberá a manutenção da transação entabulada, pugnando-se pela realização do interesse público consistente na pacificação da contenda e protegendo-se a segurança jurídica do cidadão. Nesse caso, no entanto, caberá a responsabilização pessoal do agente pelos danos eventualmente causados ao Estado, de acordo com apuração adequada.

Por fim, entendemos que a única possibilidade de anulação da transação extrajudicial da Administração Pública reside na hipótese em que o agente público, em conluio com o particular, ou este último fazendo aquele incorrer em erro, acarretam de má-fé a nulidade do contrato. Nessa restrita hipótese não há interesse do administrado a ser protegido, como estabelecem o caput do art. 849 do Código Civil e a parte final do parágrafo único do art. 59 da Lei no 8.666/1993. Procederse-ia ainda, nesse caso, com a responsabilização daqueles que tenham dado causa a prejuízo ao erário. No entanto, mesmo diante de tais circunstâncias, poderia ser a transação mantida caso se constate que os benefícios dela advindos superam a necessidade de seu desfazimento, tendo em vista o interesse público residir, verdadeiramente, na pacificação das relações da Administração pela solução da contenda.

\subsubsection{Finanças públicas e orçamento: a questão do regime de precatórios}

O segundo desafio operacional que se posta à superação é o entendimento, esposado por parcela considerável da literatura em torno do tema, de que seria defeso à Administração Pública recorrer à transação, quando dela 
decorrer o pagamento de créditos pelo erário, uma vez que tal consequência feriria a ordem cronológica que é ínsita ao regime de precatórios requisitórios instituído pela Constituição Federal como metodologia única de execução judicial contra a Fazenda Pública.

O art. 100, caput e parágrafos, da Constituição Federal, determina que a execução de créditos judiciais contra a Fazenda Pública se processa pelo regime de precatórios. Mediante tal sistemática, estabelece-se uma ordem cronológica de pagamentos que não pode ser desrespeitada, exceto nos raros casos constitucionalmente permitidos. Esse mecanismo visa à garantia da impessoalidade-isonomia - a que nos referimos na parcela do texto que se dedicou aos desafios conceituais -, de modo a impedir que a Administração, procurando privilegiar credor específico, liquide o seu crédito antes de outro anteriormente constituído.

A sistemática de pagamentos, sintetizada por Adilson Abreu Dallari, consiste em que, "uma vez transitada em julgado a sentença condenatória, o Presidente do Tribunal correspondente enviará à entidade pública devedora um precatório judiciário, determinando que o orçamento do exercício financeiro subseqüente contemple dotação suficiente para o pagamento", ${ }^{645}$ contando o ente com até o fim do exercício em cujo orçamento foi inserido o precatório para o seu pagamento.

Na medida em que, em alguns casos - a exemplo da solução da responsabilidade civil do Estado -, a prevenção de litígio da Administração Pública pela transação extrajudicial implica em pagamentos por parte do erário público em favor do particular, entendem diversos autores que os pagamentos oriundos de transação extrajudicial ofenderiam o regime de precatórios, por representar burla à sua ordem cronológica. Cabe aqui expor somente alguns deles, exemplificativos da controvérsia.

Nesse sentido, o Ministério Público do Estado do Paraná sustenta que o pagamento decorrente de transação extrajudicial na administração pública ofende

645 DALLARI, Adilson Abreu. Acordo para recebimento de crédito perante a Fazenda Pública. Revista de Direito Público da Economia, Belo Horizonte, a. 3, n. 9, p. 9-26, jan.-mar. 2005. 
à impessoalidade administrativa, uma vez que representaria a escolha de um credor específico para pagamento. Por tal posicionamento, somente uma autorização legislativa específica supriria a suposta falha, regularizando o pagamento. ${ }^{646}$

Já para Jorge Ulisses Jacoby Fernandes, "[0] acordo judicial que envolve entidade da Administração direta ainda teria a agravante de obviar a execução forçada do crédito, privilegiando um credor". Sustenta o autor, assim, que o princípio da isonomia deveria prevalecer sobre o princípio da economicidade, de modo que, se de fato se verifica tamanha vantajosidade no recurso à transação, esta deve ser autorizada expressamente por lei específica. ${ }^{647}$

O entendimento de Maurício Cramer Esteves se diferencia por admitir o recurso da Administração Pública à transação, mas com a ressalva de que os valores a serem pagos não ultrapassem os limites para requisições de pequeno valor, ou seja, aqueles que, por serem reduzidos, são excluídos do regime de precatórios e poderiam ser pagos independentemente de obediência à ordem cronológica de apresentação, nos termos do $\S 3^{\circ}$ do art. 100 da Constituição Federal. Mesmo diante de tal cenário, para o autor, seria necessária autorização legislativa específica para que a Administração entabulasse transações. ${ }^{648}$

Não há, no entanto, qualquer motivo razoável para que se sustentem os argumentos dos autores, com exceção de um infundado receio quanto às intenções e à capacidade de gestão do Estado.

Os dois primeiros posicionamentos assumem que o recurso à transação pela Administração Pública, seja em decorrência do princípio da impessoalidade ou por força do princípio da isonomia, feririam o regime de precatórios. No entanto, aceitam os autores que assim se proceda, desde que haja autorização legislativa.

\footnotetext{
${ }^{646}$ SCHIRMER, Mário Sérgio de Albuquerque. Impossibilidade de realização de acordos no âmbito do direito administrativo sem a existência de lei expressamente autorizando a avença. Repositório do Centro de Apoio Operacional das Promotorias de Justiça de Proteção ao Patrimônio Público e à Ordem Tributária. Curitiba: CAOP-MPPR, [s.d.].

${ }^{647}$ FERNANDES, Jorge Ulisses Jacoby. Acordos administrativos e judiciais. Fórum Administrativo, Belo Horizonte, a. 6, n. 59, jan. 2006.

${ }^{648}$ ESTEVES, Maurício Cramer. Da possibilidade e dos limites da transação em processos judiciais por parte do poder público municipal. Interesse Público, Belo Horizonte, a. 8, n. 38, jul./ago. 2006.
} 
Ora, caso tratássemos aqui de execução de decisões judiciais transitadas em julgado, poderia uma lei autorizar que fosse descumprida a ordem cronológica para o pagamento dos precatórios respectivos imposta pela própria Constituição Federal?

Ora, a inconsistência lógica desses posicionamentos representa, ao fim e ao cabo, simplesmente uma injustificada recalcitrância em aceitar que a Administração recorra à transação extrajudicial para prevenir litígios.

Para que se esclareça a celeuma, basta a simples leitura do disposto no caput do art. 100 da Constituição Federal, uma vez que o dispositivo restringe expressamente o regime de precatórios aos "pagamentos devidos pelas Fazendas Públicas Federal, Estaduais, Distrital e Municipais, em virtude de sentença judiciária”. Uma vez que o pagamento na transação extrajudicial decorre de um contrato, e não de "sentença judiciária", é absurdo sustentar, por absoluta impropriedade terminológica e conceitual, que o mesmo se submeta à mesma ordem dos precatórios.

Nesse sentido, Adilson Abreu Dallari sustenta, com base na jurisprudência, que o pagamento de compromissos assumidos em transação pela Administração Pública não se submete ao regime de precatórios, uma vez que a sentença que eventualmente a homologaria teria natureza declaratória, e não condenatória. ${ }^{649}$ Continua o autor, desenvolvendo seus argumentos em torno da transação judicial:

[...] o acordo, é um todo, dotado de autonomia, de natureza própria. Feito o acordo, o que existe é somente o acordo, pois o antigo litígio, as discussões sobre parcelas, particularidades, etc. desaparecem. O acordo é feito exatamente para pôr fim ao litígio, criando um novo direito. O que o particular pretende e tem o direito de receber são as parcelas resultantes do acordo, e não do extinto litígio. ${ }^{650}$

${ }^{649}$ DALLARI, Adilson Abreu. Viabilidade da transação entre o poder público e particular. Interesse Público, Belo Horizonte, a. 4, n. 13, jan.-mar. 2002.

650 DALLARI, Adilson Abreu. Viabilidade da transação entre o poder público e particular. Interesse Público, Belo Horizonte, a. 4, n. 13, jan.-mar. 2002. 
Da mesma sorte padece o terceiro posicionamento, que sustenta que os pagamentos decorrentes de transação deveriam ser adstritos aos limites de exclusão do regime deprecatórios, correspondentes à figura das requisições de pequeno valor.

Além dos argumentos já opostos aos dois primeiros posicionamentos, cabe aqui ressaltar que a natureza contratual da transação, já invocada, corresponde à natureza dos demais contratos privados da Administração. Ainda, em se tratando em regime de pagamentos - unificado, no bojo da contabilidade pública e do direito financeiro, pela Lei $n^{\circ} 4.320 / 1964$-, o contrato de transação compartilha o mesmo tratamento dispensado a todos os contratos da Administração.

Caso fosse verdade o alegado nos argumentos, ter-se-ia um cenário em que a Administração não poderia firmar qualquer contrato que ultrapassasse o valor das requisições de pequeno valor pois, nesse caso, o contratado credor só teria seu crédito definitivamente liquidado com a sua inserção na ordem cronológica de precatórios. Decrete-se a morte da atuação contratual do Estado, pois.

É nesse sentido que se posicionam Carlos Ari Sundfeld e Jacintho Arruda Câmara:

Seria um sem sentido imaginar que débitos quitados administrativamente devessem obedecer à ordem cronológica dos precatórios. Por este caminho, qualquer obrigação oriunda de contrato celebrado pela Administração haveria de ser cobrada em juízo, a fim de preservar esta suposta "unicidade" na ordem de pagamentos efetuados pela Administração. Débitos judiciais incluídos no orçamento, por esta via, precederiam necessariamente ao pagamento de qualquer dívida oriunda da execução de um contrato administrativo.

$[\ldots]$

Enfim, a ordem cronológica é aplicável apenas aos créditos executados por força de precatório. Não se submetem a este sistema créditos de origem diversa, como são os derivados de acordos firmados entre o Poder Público e particulares no curso de ação judicial, mesmo que em fase de execução. ${ }^{651}$

651 SUNDFELD, Carlos Ari; CÂMARA, Jacintho Arruda. Acordos na execução contra a Fazenda Pública. Revista Brasileira de Direito Público, Belo Horizonte, a. 8, n. 30, jul.-set. 2010. 
Os posicionamentos que se opõem à transação extrajudicial pela Administração Pública alegando ofensa ao regime de precatórios deixam transparecer, enfim, um profundo desconhecimento dos mecanismos de direito financeiro - disciplina jurídica, aliás, muito pouco estudada no Brasil -, uma vez que, pelo regime de empenho, liquidação e pagamento, as despesas decorrentes de obrigações contratuais da Administração Pública brasileira já se submetem a um rígido regime de controle.

Ademais, é de se considerar que, muito pelo contrário de violá-la, o recurso da Administração à transação extrajudicial vem viabilizar a sistemática de precatórios, já que previne a inclusão de mais credores na fila virtualmente impossível de cumprimento em que se converteu a ordem cronológica de precatórios de tantos entes da Administração direta brasileiros. Assim, nas palavras de Dallari,

\begin{abstract}
[n]uma perspectiva econômica, evidencia-se como de indiscutível interesse público o propósito de reduzir o estoque de precatórios, para controlar o volume do endividamento público, de molde a não exceder os limites da Lei de Responsabilidade Fiscal e viabilizar financiamentos para novos empreendimentos necessários à realização de políticas públicas. ${ }^{652}$
\end{abstract}

Conclui-se, portanto, que a natureza contratual da transação extrajudicial na administração pública a exclui terminantemente do regime de precatórios - exceto, evidentemente, no caso de recorrer o credor à sua execução pela via judicial -, medida em que o recurso a tal figura contratual não encontra qualquer óbice advindo dessa sistemática.

\title{
4.2.3 Os riscos da transação extrajudicial do Estado
}

Diante de tantas oposições que levanta a literatura à adoção da transação extrajudicial pela Administração Pública, a tese que ora se desenvolve não poderia prosseguir sem uma brevíssima, porém necessária, abordagem dos principais riscos relacionados à prática proposta.

652 DALLARI, Adilson Abreu. Acordo para recebimento de crédito perante a Fazenda Pública. Revista de Direito Público da Economia, Belo Horizonte, a. 3, n. 9, p. 9-26, jan.-mar. 2005. 
Verifica-se, no entanto, que são raros os autores que se dedicam mais detidamente ao tema, motivo pelo qual a exposição é feita em duas etapas: num primeiro momento, o trabalho se posiciona, junto de alguns autores, por produzir uma síntese de impressões acerca dos riscos relacionados à transação extrajudicial na administração pública. Em seguida, alguns riscos específicos serão tratados mais detidamente no tópico seguinte, que se dedica à investigação da importância da postura do gestor público no fomento à transação extrajudicial na administração pública.

A modalidade extrajudicial da transação - preventiva de litígio, portanto - não repousa, como não poderia deixar de ser, livre de questionamentos legítimos. Géraldine Chavrier, ao tratar da adoção de tal figura pela Administração Pública francesa, destaca que a falta concreta de um litígio instalado - corolário, por óbvio, da transação preventiva -, ou seja, a mera expectativa de litígio, poderia ser considerado motivo insuficiente para que a transação seja entabulada. É que, ao considerarem-se as regras de direito financeiro relativas às despesas públicas, semelhantes às vigentes no Brasil, faltaria ao litígio em perspectiva a certeza necessária para a liquidação do pagamento que seja objeto da transação. ${ }^{653}$

Chavrier busca solucionar tal questão ao sustentar que a justificativa para a transação estatal residiria em diferenciar um litígio incerto de um litígio embrionário, diferenciando-os pela previsibilidade dos efeitos da celeuma. Assim, neste último caso, apesar de o litígio ainda não estar instalado, haveria a justificativa para a transação judicial, baseada na necessária pacificação que dela exsurge. $^{654}$

${ }^{653}$ CHAVRIER, Géraldine. Réflexions sur la transaction administrative. Revue Française de Droit Administratif, Paris, n. 3, p. 548-566, mai.-jun. 2000.

Tal problema não seria apurado, evidentemente, nas transações que tenham por objeto a prevenção de litígios para cuja solução não seja necessária a realização de despesa pública, mas é exemplo pertinente acerca das dúvidas que podem irradiar da adoção de modelos transativos de solução de conflitos pela Administração Pública por força de determinações ou indeterminações legais diversas. Sobre esse último tema nos debruçaremos em capítulo da segunda parte do estudo.

${ }^{654}$ CHAVRIER, Géraldine. Réflexions sur la transaction administrative. Revue Française de Droit Administratif, Paris, n. 3, p. 548-566, mai.-jun. 2000.

No original: "Il apparaît donc que l'existence d'un litige, non pas incertain mais en germe, est un critère identificateur de la transaction administrative". 
Tal cenário poderia dar azo, no entanto, a dois riscos diferentes decorrentes da transação extrajudicial na administração pública, cujo conhecimento é essencial para a sua prevenção. O primeiro deles, menos grave, consistiria em eventual desídia dos servidores na apuração da existência de real litígio em potencial a justificar a firmatura de transação extrajudicial, o que poderia levar a indenizações desnecessárias e, portanto, lesivas ao patrimônio público. Nesse caso, entendemos que a processualização do deferimento da transação é elemento chave para o sucesso da prática. ${ }^{655}$

Nesse sentido, a atuação de diversos agentes na formação do entendimento do ente estatal sobre o caso - com a combinação de pareceres técnicos e jurídicos - e a participação dinâmica de órgãos de controle interno permitiriam a mitigação desse risco, sem se descuidar, no entanto, de que os mecanismos de regularidade não prejudiquem a celeridade que constitui um dos pilares da preferencialidade da transação extrajudicial.

O segundo perigo, de maior gravidade, consistiria na atuação de má-fé dos agentes públicos no sentido de, fomentando fraudes em favor de particulares, deem origem ao seu enriquecimento ilícito ${ }^{656}$ e a danos ao erário pelo deferimento

655 O papel da processualização para a garantia de regularidade na transação extrajudicial da Administração Pública já foi reconhecido pelo Tribunal de Contas da União, em sede de consulta:

O Tribunal Pleno, diante das razões expostas pelo Relator, e com fundamento no art. $1^{\circ}$, inciso XVII e $\S 2^{\circ}$, da Lei $n^{\circ} 8.443 / 92$ c/c o art. 216, inciso I, do Regimento Interno, DECIDE:

8.1. conhecer da presente consulta, por preencher os requisitos de admissibilidade, para responder à autoridade consulente que a indenização a terceiros, pela Administração Pública, de danos causados por agentes públicos nessa condição pode se dar:

8.1.1. judicialmente, em cumprimento de sentença transitada em julgado;

8.1.2. administrativamente, por meio de processo administrativo devidamente constituído para apuração dos fatos, identificação dos responsáveis e quantificação dos danos efetivamente comprovados, desde que haja dotação orçamentária apropriada, respeitados os princípios orçamentários constitucionais e as regras e limites da legislação específica, em especial aqueles inseridos na Lei do Orçamento Anual;

8.2. informar, ainda, à autoridade consulente, que deve a Administração, em ambas as hipóteses acima citadas, buscar a reparação do valor indenizatório pago mediante regresso contra o agente responsável nos casos de dolo ou culpa, apurados por intermédio de sindicância ou processo administrativo;

8.3. encaminhar cópia desta Decisão e dos correspondentes Relatório e Voto ao Presidente do TST; e

8.4. determinar o arquivamento do presente processo.

(BRASIL. TRIBUNAL de Contas da União. Consulta n 007.425/2000-3. Rel. Min. Guilherme Palmeira. Diário de Justiça da União, Brasília, 24 jan. 2001).

656 DALLARI, Adilson Abreu. Acordo para recebimento de crédito perante a Fazenda Pública. Revista de Direito Público da Economia, Belo Horizonte, a. 3, n. 9, p. 9-26, jan.-mar. 2005. 
de indenizações por transação em casos em que não se faz presente litígio em potencial a prevenir, ou ainda pelo deferimento de indenizações desproporcionais à responsabilidade da Administração. No caso de transação extrajudicial para a solução de conflitos em contratos administrativos ou no exercício do poder de polícia, tais riscos envolveriam a dispensa indevida do particular de obrigações que efetivamente tenha de cumprir para com a coletividade.

Nesse segundo caso, a atuação dos órgãos de controle interno se faz mais relevante, junto, é claro, da processualização já abordada. Essa atuação serviria, ainda, à garantia da observância da impessoalidade-isonomia no deferimento de transação extrajudicial em processos administrativos, buscando assim evitar eventuais privilégios e perseguições que poderiam ser facilitados pela maior flexibilidade com que conta o gestor público ao lançar mão de soluções consensuais de conflitos. ${ }^{657}$

Um outro risco da transação extrajudicial na administração pública, que se mostra menos lesivo mas, talvez, com possibilidade de maior frequência, é que a assunção direta e voluntária pela Administração da responsabilidade pela solução de conflitos relacionados à atuação de seus agentes acabe por gerar uma maior desídia dos servidores em suas atividades diárias, que acabariam por descumprir deveres de cuidado objetivo no cumprimento de suas competências. Vislumbramos o melhor enfrentamento a este risco pela cuidadosa atenção dos entes estatais com o exercício do direito de regresso em relação aos servidores que tenham dado causa ao litígio, curando para que a apuração dessa responsabilidade se dê, tanto quanto possível, no próprio processo administrativo que culmine com a firmatura de transação extrajudicial.

Também pode ser considerado como risco relevante, em sentido inverso aos primeiros expostos, a possibilidade de injusta responsabilização dos agentes administrativos envolvidos no processe administrativo que culmina com a transação extrajudicial. Nesse sentido, um importante elemento a gerar resistência por parte dos representantes da Administração Pública em relação à adoção de métodos consensuais de solução de conflitos - em especial, os membros da Advocacia

\footnotetext{
${ }^{657}$ MACHADO, Hugo de Brito. Transação e arbitragem no âmbito tributário. Revista Forum de Direito Tributário, Belo Horizonte, a. 5, n. 28, jul.-ago. 2007.
} 
Pública - reside no temor de responsabilização administrativa e judicial, tanto por parte de superiores hierárquicos, quanto por ação dos órgãos de controle externo. $^{658}$

Encontramos importante iniciativa - ainda não testada na prática, por sua recência - no art. 40 da Lei $n^{\circ} 13.140 / 2015$, que determina que os agentes públicos que tomem parte no processo administrativo que culmine em solução consensual de conflitos na seara administrativa "[...] somente poderão ser responsabilizados civil, administrativa ou criminalmente quando, mediante dolo ou fraude, receberem qualquer vantagem patrimonial indevida, permitirem ou facilitarem sua recepção por terceiro, ou para tal concorrerem".

Verifica-se, pois, que os riscos mais relevantes advindos da transação extrajudicial na administração pública se relacionam com os desafios teóricos levantados na primeira parte deste capítulo, em especial os relacionados à impessoalidade e à defesa dos interesses públicos. Conclui-se, no entanto, que o caráter prático desses riscos não implica na impossibilidade teórica de recurso da Administração à transação extrajudicial; assim como em toda atividade administrativa, os riscos existem e devem ser combatidos pelos instrumentos de controle interno e externo à disposição do Estado.

O sucesso da prática depende, pois, consideravelmente da postura dos agentes estatais que a ela se dediquem. Diante de tal cenário, o movimento final do presente capítulo se dedica à investigação do papel da postura do gestor público no fomento à transação extrajudicial pela Administração Pública, em exercício que se desenvolve nas páginas seguintes.

\subsubsection{Transformação da postura administrativa}

Todo o desenvolvido até esse estágio do presente trabalho leva a uma natural convergência do escopo de análise para o campo da postura do gestor estatal e sua importância para o sucesso das práticas de solução consensual de

658 FARIA, Roberto Gil Leal. Por que são efetivados poucos acordos nos Juizados Especiais Federais? Revista da SJRJ, Rio de Janeiro, n. 24, p. 93-103, 2009. 
conflitos na administração pública - em especial, no tocante à transação extrajudicial.

No capítulo de aproximação ao tema, apurou-se que os novos paradigmas que serve de referencial à Administração Pública contemporânea com especial destaque para a ampliação das bases de legalidade, a processualização da atividade administrativa, a ressignificação do interesse público e de sua apuração, a alvorada do direito fundamental à boa administração pública, e os novos parâmetros relacionais entre Estado e sociedade - conduziriam o Estado, por consentâneo lógico, a uma considerável democratização do seu atuar.

No entanto, como detectado na conclusão daquele capítulo, a administração pública brasileira conta hoje com um cenário de grave descolamento do Estado em relação às suas bases de legitimação que é agravado, em grande medida, pela sua postura desnecessariamente combativa, que leva a uma sobrejudicialização das relações entre Administração e particulares. Assim, de locus da democraticidade, as instâncias estatais se convertem em referencial de conflituosidade, consagrando-se como os maiores litigantes do Judiciário brasileiro.

O segundo capítulo da primeira parte da tese dedicou-se a demonstrar que a reversão desse cenário de descolamento democrático pode ser levada a cabo pela consensualização das relações entre Estado e cidadãos, cenário no qual os mecanismos de solução consensual de conflitos exercem protagonismo. Dentre as modalidades de solução consensual de conflitos - arbitragem, conciliação, mediação e transação -, restou demonstrada a preferencialidade da transação em sua modalidade extrajudicial, preventiva de litígios, uma vez que, por prescindir de terceiro que a decida, lidere, facilite ou homologue, conta com vantagens comparativas em termos de economicidade, celeridade e adesão das partes.

O cenário atual, no entanto, se mostra consideravelmente árido à adoção da transação extrajudicial pela Administração Pública.

Todo o capítulo que ora se encerra se dedicou ao enfrentamento das diversas oposições, conceituais ou operacionais, que fomentam a resistência à adoção da transação extrajudicial pela Administração Pública. Todos os desafios restaram enfrentados, no entanto: demonstrou-se que o acesso à transação na 
administração pública não carece de autorização legislativa específica, por tratarse de manejo de contrato privado pela Administração que se mostra consentâneo com a atual ordem constitucional; de mesmo giro, não há impeditivo baseado na impessoalidade administrativa, já que, no exercício da impessoalidade relacional, cabe ao Estado julgar administrativamente as demandas contra si como se terceiro fosse; ainda, não restam impedimentos relacionados às diversas faces do interesse público, uma vez que a transação extrajudicial é um dos meios mais adequados à realização do interesse público material.

No tocante aos desafios operacionais, estabeleceu-se entendimento acerca do adequado regime de anulação dos contratos de transação, afastando-se a possibilidade de sua revogação; afastou-se, cabalmente, qualquer traço da submissão dos pagamentos deles decorrentes ao regime de precatórios; e ofereceu-se tratamento aos riscos que a eles são relacionados, como é natural em qualquer atividade administrativa.

No entanto, apesar dos tão sólidos fundamentos expostos ao longo dessas páginas, verifica-se que a concreta adoção da transação extrajudicial como solução preventiva aos litígios da Administração Pública ainda padece de enormes dificuldades para se consolidar. Tal cenário pode ser creditado, em pequena parte, à ausência até aqui de trabalho que confira tratamento científico específico à figura - tal como exposto na introdução à obra -, mas essa circunstância não pode ser tida como o ponto decisivo para a falta de efetividade observada.

Todo esse cenário nos leva a concluir que a Administração Pública brasileira carece de uma transformação da postura de seus gestores em direção ao acolhimento da transação extrajudicial como instrumento a serviço da realização de sua missão institucional constitucionalmente substanciada. O movimento final desse capítulo se dedica, pois, à investigação desse fenômeno, buscando formular respostas às relevantes questões que se apresentam.

O papel da liderança e do exemplo se revela essencial para o fomento da consensualidade na Administração Pública, irradiando tal postura para toda a 
sociedade. ${ }^{659}$ Esse papel se relaciona axialmente, em nosso entender, à democraticidade ${ }^{660}$ da postura do gestor público.

O exercício do poder em um Estado democrático por um gestor sem intenção democrática nos leva ao "paradoxo democrático" descrito por Manuel Gonçalves Ferreira Filho, em que "a Democracia está em toda parte, a Democracia não existe em parte alguma”. ${ }^{661}$ É dizer, apesar de profundamente permeado pelo ideal democrático, em nosso Estado, o povo não se governa, mas simplesmente é governado. Isso nos leva a questionar a "intenção democrática dos democratas". ${ }^{6}$

Assim, a superação do "paradoxo democrático" está ligada axialmente às intenções democráticas do gestor público:

A realização da democracia possível, no grau máximo possível, exige que as instituições políticas caiam sob a direção de uma elite de origem democrática, selecionada de baixo para cima, movida pelo interesse comum. ${ }^{663}$

Num sistema de separação de poderes, a questão da intenção democrática ganha corpo na medida em que, enquanto no parlamento a representação democrática é mais direta e a postura individual do representante é menos relevante, no executivo, apesar de sua vinculação aos lindes da juridicidade, a intenção do gestor pode cercear a democraticidade da atuação estatal pela sua relevância no exercício pessoal do poder. Isto explica Kelsen:

\footnotetext{
${ }^{659}$ Não falamos aqui de função paternal da autoridade, na definição de Yves Simon, que impende à incapacidade ou deficiência dos cidadãos. Pelo contrário, busca-se delimitar a atuação do gestor de acordo com a autonomia do corpo social. (SIMON, Yves. Philosophie de le gouvernement démocratique. (Filosofia do governo democrático / trad. Edgard Godói de Mata-Machado). Rio de Janeiro: Agir, 1955. P. 15-55.)

${ }^{660}$ Pedimos vênia para adotar o vocábulo "democraticidade" neste texto, ainda considerado um neologismo por muitos léxicos, apesar de seu uso difundido em Portugal. Entendemos que a apreciação da natureza democrática de determinado posicionamento, instituto ou ato, sem lhe sondar especificamente a intensidade, não é suficientemente representada pela expressão "grau democrático", e "democracia" consolidou-se como substantivo alusivo aos valores, ao exercício e às instituições daquilo que é gerido de acordo com a vontade comum. Assim, aplicamos "democraticidade" como o substantivo feminino que designa a qualidade daquilo que é democrático. ${ }^{661}$ FERREIRA FILHO, Manuel Gonçalves. A democracia possível. São Paulo: Saraiva, 1979. P. 15.

662 KEANE, John. Democracy: the rule of nobody? Berlim: Wissenschaftszentrum Berlin für Sozialforschung, 2004. P. 8-10.

${ }^{663}$ FERREIRA FILHO, Manuel Gonçalves. A democracia possível. São Paulo: Saraiva, 1979. P. 79.
} 
Não se deve crer, como poderia parecer à primeira vista, que a democracia da execução seja apenas a consequência da democracia da legislação e que a ideia democrática seja tanto mais satisfeita quanto maior é a abrangência do processo da execução pela forma democrática da formação da vontade... ${ }^{664}$

O funcionamento satisfatório da administração democrática seria, assim, condicionado à existência de um amplo poder discricionário, mas essa discricionariedade faz com que o conteúdo democrático da atuação estatal esteja mais amplamente sujeito à intenção do gestor público. A intenção democrática pode ser delimitada, nesse cenário, como a postura do indivíduo que, fazendo parte de um sistema deliberativo posto, aceite o resultado da deliberação como vocalização do interesse público, disponibilize-se a adotar este resultado como sua vontade própria - seja ele correspondente ou não à sua vontade inicial - e comprometa-se a agir de acordo com esta visão de necessária proximidade relacional para a concretização do interesse público, de acordo com a "vontade coletiva", num movimento de responsividade mútua. ${ }^{665}$

Tratar-se-ia, portanto, do comprometimento do gestor público com o princípio da soberania popular, influenciado pelas ideias e sentimentos democráticos, tal como apreciado por Tocqueville. ${ }^{666}$ Ocorre que, no cenário contemporâneo, a previsão e vigência de princípios ${ }^{667}$ já não é suficiente a distinguir

${ }^{664}$ KELSEN, Hans. A democracia. São Paulo: Martins Fontes, 2000. P. 80.

Quanto às raízes históricas desse fenômeno:

MANFRO, Lorenzo. I reati di falso tra staturaria Veronese e diritto comune. 1997. Tese (Doutorado em Direito - orient. Prof. Giorgio Zordan) - Facoltà di Giurisprudenza, Università degli Studi di Padova, Padua. 1997.

${ }^{665}$ RICHARDSON, Henry S. Democratic intentions. In: BOHMAN, James; REHG, William (eds.). Deliberative democracy: essays on reason and politics. Cambridge: MIT, 1997. P. 349-382.

${ }^{666}$ TOCQUEVILLE, Alexis de. Democracy in America. New York: Vintage Books, 1945. V. I, p. 5760; V. II, p. 303 ss.

${ }^{667}$ VALLE, Vanice Regina Lírio do. Controle social: promovendo a aproximação entre administração pública e a cidadania. In: BRASIL. Tribunal de Contas da União. Prêmio Serzedello Corrêa 2001: monografias vencedoras: perspectivas para o controle social e a transparência da administração pública. Brasília: TCU, 2002. P. 80-81. 
a discricionariedade do arbítrio, ${ }^{668}$ e a democraticidade da atuação estatal acaba por depender profundamente da intenção democrática do gestor público. ${ }^{669}$

Estas conclusões serão de suma importância para os desenvolvimentos posteriores acerca da postura do gestor público no sucesso de práticas de transação extrajudicial na administração pública, uma vez que, sem a sua adesão à ideia central, controles meramente formais e procedimentais são ineficazes em fomentar o recurso aos métodos de solução consensual de conflitos ainda na seara administrativa.

A manutenção e operação efetivas de práticas de transação extrajudicial envolve, assim, um complexo de meios informativos, organizativos e técnicos, ${ }^{670}$ o que depende da criação da estrutura legal, política e institucional necessárias à sua realização. ${ }^{671}$ Assim,

[...] na questão da transparência e da participação da sociedade, estes elementos se tornam cada vez mais centrais e requerem postura muito nítida no sentido de se abrir espaços a essa participação e de se estabelecer instrumentos institucionais que a viabilizem. ${ }^{672}$

Esta postura proativa da administração em relação aos instrumentos de consensualidade pode ser sintetizada num conceito de "abertura sincera" do gestor público à solução consensual de conflitos com os particulares. Abertura, porque a Administração deve tanto permitir o acesso dos cidadãos a processos

\footnotetext{
${ }^{668}$ Função dos princípios de Direito administrativo definida em GARCÍA DE ENTERRÍA, Eduardo; FERNANDES, Tomas-Ramón. Curso de derecho administrativo. Madri: Civitas, 2000.

${ }^{669}$ Este cenário leva, por exemplo, ao uso de testes de avaliação de intenções democráticas de candidatos nos processos eleitorais de alguns governos locais, como no caso da redemocratização senegalesa (EASTON, Peter. Sénégal: Fonctionnement de la démocratie à la base. Notes CA, Paris, Banque Mondiale, n. 16, p. 3, jan. 2000.)

670 ALLEGRETTI, Umberto. Basi giuridiche della democrazia partecipativa in Italia: alcuni orientamenti. Democrazia e diritto, Roma, n. 3, p. 151-166, 2006. P. 159.

671 OCDE. Citizens as partners: OECD handbook on information, consultation and public participation in policy-making. Paris: OCDE, 2001. P. 27-43.

Ver também:

GOMES, Maria Teresa Salis. Comunicação pública para uma democracia participada. In: GOMES, Maria Teresa Salis (coord.). A face oculta da governança: cidadania, Administração pública e sociedade. Coimbra: INA, 2003. P. 206-210.

${ }^{672}$ SANTOS, Luiz Alberto dos. Desafios da Governança regulatória no Brasil. In: RAMALHO, Pedro Ivo Sebba (org.). Regulação e Agências Reguladoras: Governança e Análise de Impacto Regulatório. Brasília: ANVISA, 2009. p. 177-178.
} 
administrativos para tanto direcionados, quanto deve buscar a relação consensual com a sociedade; sincera, pois esse relacionamento há de ser pautado pela verdadeira intenção democrática de conferir consensualidade à atuação estatal, abandonando as práticas cooptativas.

O caminho traçado para alcançar a legitimidade material da atuação estatal, que passa pela consensualidade como resultado da aproximação relacional entre Estado e sociedade, nos tem revelado a essencialidade da postura do gestor público - qualificada pela intenção democrática - para a consecução de práticas e programas de transação extrajudicial na Administração Pública. Assim, o sucesso da transação administrativa depende da abertura sincera da gestão aos mecanismos consensuais, fomentando-os e absorvendo o seu resultado como condicionante de suas ações.

Ocorre que, como representantes do povo, os gestores públicos vêm do seio da própria sociedade, fazendo parte dela. Assim, imprimir a intenção democrática ao gestor público depende da percepção da democracia pelo mesmo na qualidade de cidadão. Por via de consequência, faz-se imprescindível superar a falta de democracia da própria sociedade em que ele se insere, onde se deveria originar a intenção democrática do representante político, pois

[...] a esfera política está contida em uma esfera mais ampla, que é a sociedade como um todo, que, por sua vez, condiciona e determina a decisão política. Portanto, há de se reconhecer que embora em íntima conexão, uma é a esfera política e sua democratização, outra coisa é a democratização da sociedade civil. ${ }^{673}$

A mudança de posturas depende assim da fixação de um referencial, de um totem externo, já que, no âmbito comportamental, não podemos deixar a contenção das ações do gestor público tão somente ao equilíbrio entre sua própria

${ }^{673}$ FERRARI, Regina Nery. Desenvolvimento da democracia como resultado da participação. In: GARCIA, Maria. Democracia, hoje: Um modelo político para o Brasil. São Paulo: IBDC, 1997. P. 253. 
racionalidade, afetividade e instintividade. ${ }^{674}$ Neste sentido, como Loewenstein sustenta,

[...] sendo a natureza humana como é, não nos cabe esperar que o detentor ou os detentores do poder sejam capazes, por autolimitação voluntária, de libertar os destinatários do poder e a si mesmos do trágico abuso do poder. Instituições para controlar o poder não nascem nem operam por si sós, visto que deveriam ser criadas de forma organizada e incorporadas conscientemente no processo do poder. ${ }^{675}$

Como resta evidente da análise até aqui empreendida, apesar da ampla previsão no ordenamento jurídico pátrio de normas e princípios atinentes a garantir a aproximação entre Estado e cidadãos pela consensualidade, estes lindes são insuficientes à concretização democrática do ideal traçado na Constituição Federal. Pode-se inferir, assim, que se trata de questão de fundo cultural, cuja solução ainda recebe formulações incipientes.

Para esse câmbio cultural, não basta a incorporação de técnicas e a adaptação de instrumentos; o desafio constitui-se em modificar os próprios hábitos e rotinas da administração, bem como os sistemas de convicção e valores que vêm do próprio modelo de seleção de agentes públicos. Assim, a mudança deve ser prioridade política para o gestor, evitando que as resistências internas e a falta de consolidação de mudanças - fruto da brevidade do ciclo político-eleitoral - levem à "perda da memória" da evolução administrativa. ${ }^{676}$

A preocupação com a postura do agente público e a relação desta postura com o dever de imparcialidade já há muito ocupa os estudos dos cultores

${ }^{674}$ NARANJO, Claudio. Cambiar la Educación para Cambiar el Mundo. Barcelona: La Llave, 2007. P. 65.

${ }^{675}$ LOEWENSTEIN, Karl. Teoria de la Constitución. Barcelona: Ariel, 1965. P. 149. Tradução nossa.

No original: "[...] siendo la naturaleza humana como es, no cabe esperar que el detentador o los detentadores del poder sean capaces, por autolimitación voluntaria, de liberar a los destinatarios del poder y a sí mismos del trágico abuso del poder. Instituciones para controlar el poder no nacen ni operan por sí solas, sino que deberían ser creadas ordenadamente e incorporadas conscientemente en el proceso del poder."

${ }^{676}$ LONGO, Francisco. Introducción. Los directivos públicos ante los retos de la gobernanza contemporánea. In: LONGO, Francisco; YSA, Tamyko (eds.). Los escenarios de la gestión pública del siglo XXI. Barcelona: Bellaterra, 2008. P. 21-22. 
do direito administrativo. Nesse sentido, interessante é a lição de Vieira de Andrade, para quem

[h]á-de ainda a lei salvaguardar a isenção dos funcionários, preferindo formas de recrutamento que facilitem a selecção (imparcial) com base no mérito (administrativo) - sobretudo nos escalóes médios e inferiores -, e tomando medidas para que a disciplina partidária ou os interesses pessoais ou de grupos não afectem os serviços públicos. [...] Mas realmente importante é que se evite qualquer domínio ideológico do aparelho administrativo, o que não implica a proibição da actividade política aos funcionários (em certa medida, pelo contrário, estimula a diversidade), nem proscreve a associação destes para defesa dos seus direitos e interesses, embora possa, especialmente nalguns setores, introduzir-lhes limitações. ${ }^{677}$

Consideradas as adaptações demandadas a evitar anacronismos, discordamos respeitosamente em parte do entendimento de Vieira de Andrade. À evidência, é importantíssima a adequação da postura administrativa dos agentes dos escalões de execução; no entanto, entendemos que o campo mais promissor para a transformação da postura administrativa visando à concretização de uma "abertura sincera" - e à realização, assim, do projeto de "Estado Honesto" ou "Administração de Boa Fé" - reside nos estratos de planejamento, gestão e direção públicas.

Com suporte nas lições de Georg Jellinek, Hegel e António Barbosa de Melo, Ana Raquel Gonçalves Moniz expõe que "o poder do Estado de escolher e modelar os princípios e as normas que hão integrar a ordem jurídica positiva se encontra limitado por um 'mínimo ético', por 'princípios primeiros' indisponíveis para os poderes públicos". ${ }^{678}$ Nesse sentido, o "imperativo do direito", na fórmula de Hegel, alcançaria o seu mínimo ético na dignidade humana, valor último que

677 VIEIRA DE ANDRADE, José Carlos. A imparcialidade da Administração como princípio constitucional. Boletim da Faculdade de Direito, Coimbra, v. 50, p. 219-246, 1974.

No mesmo sentido:

FOUGĖRE, Louis. La fonction publique. Bruxelles: Unesco, 1966. P. 336.

${ }^{678}$ MONIZ, Ana Raquel Gonçalves. Direito, ética e Estado: Brevíssimas reflexões em diálogo com Barbosa de Melo. In: CORREIA, Fernando Alves; SILVA, João Calvão da; VIEIRA DE ANDRADE, José Carlos; CANOTILHO, Joaquim José Gomes; CARDOSO DA COSTA, José Manuel M. Estudos em Homenagem a António Barbosa de Melo. Coimbra: Almedina, 2013. P. 33-71. 
vincularia toda a atuação estatal, seja do ponto de vista normativo, seja sob o prisma administrativo.

É significativa, nesse sentido, a lição de António Barbosa de Melo, para quem a autoridade administrativa deve atuar em busca do interesse público, organizando a sua ação com vistas à realização do que the parecer reto. ${ }^{679}$ Desse posicionamento podemos extrair não somente um, mas dois sentidos possíveis para a vinculação da Administração Pública por valores éticos, como interpreta Ana Raquel Gonçalves Moniz.

Num primeiro momento, exsurge da lição de António Barbosa de Melo o já consolidado posicionamento (topos que traria fundamento à própria autoridade estatal) de que a atuação do Estado deve ser orientada à consecução do interesse público, do bem comum, tema sobre o qual já nos debruçamos em capítulo anterior. Este primeiro aspecto ético seria carregado, pois, de uma perspectiva normativa, frente à subordinação da Administração à regra de precedência. ${ }^{680}$

Num segundo sentido, a penetração de valores na atuação estatal resultaria da "articulação privilegiada que [...] se faz sentir entre os princípios da democracia e do Estado de direito". Tais vinculações importariam na necessária defesa de um conjunto de valores públicos na administração pública, "quer de natureza substantiva (respeito pelos direitos fundamentais, proporcionalidade, imparcialidade, racionalidade), quer de índole procedimental/processual (transparência, garantias procedimentais e processuais)". ${ }^{6} 1$

À interpretação de Ana Raquel Gonçalves Moniz da lição de António Barbosa de Melo destacamos uma maior ênfase ao papel da postura pessoal do agente público na realização da ética administrativa. Quando Barbosa de Melo

679 BARBOSA DE MELO, António. Introdução às formas de concertação social. Boletim da Faculdade de Direito, Coimbra, v. 60, p. 115, 1984.

${ }^{680}$ MONIZ, Ana Raquel Gonçalves. Direito, ética e Estado: Brevíssimas reflexões em diálogo com Barbosa de Melo. In: CORREIA, Fernando Alves; SILVA, João Calvão da; VIEIRA DE ANDRADE, José Carlos; CANOTILHO, Joaquim José Gomes; CARDOSO DA COSTA, José Manuel M. Estudos em Homenagem a António Barbosa de Melo. Coimbra: Almedina, 2013. P. 33-71.

${ }^{681}$ MONIZ, Ana Raquel Gonçalves. Direito, ética e Estado: Brevíssimas reflexões em diálogo com Barbosa de Melo. In: CORREIA, Fernando Alves; SILVA, João Calvão da; VIEIRA DE ANDRADE, José Carlos; CANOTILHO, Joaquim José Gomes; CARDOSO DA COSTA, José Manuel M. Estudos em Homenagem a António Barbosa de Melo. Coimbra: Almedina, 2013. P. 33-71. 
revela a importância, para a concretização da ética pública, da atuação de seus agentes com vistas à realização do que lhe parecer reto ${ }^{682}$, concretiza-se um papel - por muitas vezes rejeitado pelos cultores do direito administrativo - da postura pessoal daquele agente na concretização do mister público.

Destaca-se, portanto, a importância da transição - ou conciliação ${ }^{683}$ _ entre os papeis de "servidor público" e de "ator moral independente", na lição de Mark Moore. 684

Os diferentes caminhos para a transformação administrativa foram objeto de interessante debate no cenário italiano, capitaneado pelos escritos de Domenico Sorace ${ }^{685}$, Bruno Dente ${ }^{686}$ e Carlo Marzuoli ${ }^{687}$.

Bruno Dente defende uma ação direta para a transformação do Estado, baseada em valores e objetivos estáveis. Seu posicionamento pressupõe como necessária a separação entre funções técnico-administrativas e políticas, com fins à obtenção de uma maior qualidade técnica e moral da atuação da Administração, ainda que atendendo os anseios advindos da investidura direta do governante pelo corpo eleitoral. Segundo seu pensamento, se os objetivos, valores e fundamentos da Administração são estáveis, não haveria motivos para que a sua realização não fosse baseada primariamente sobre o corpo permanente do Estado. Dente defende, assim, a separação entre departamentos - seções burocráticas da Administração - e ministérios - consistentes nos aparatos políticos do Estado -,

682 BARBOSA DE MELO, António. Introdução às formas de concertação social. Boletim da Faculdade de Direito, Coimbra, v. 60, p. 115, 1984.

${ }^{683}$ MONIZ, Ana Raquel Gonçalves. Direito, ética e Estado: Brevíssimas reflexões em diálogo com Barbosa de Melo. In: CORREIA, Fernando Alves; SILVA, João Calvão da; VIEIRA DE ANDRADE, José Carlos; CANOTILHO, Joaquim José Gomes; CARDOSO DA COSTA, José Manuel M. Estudos em Homenagem a António Barbosa de Melo. Coimbra: Almedina, 2013. P. 33-71.

${ }^{684}$ MOORE, Mark H. Creating public value. Cambridge: Harvard University Press, 1997. P. 294.

685 SORACE, Domenico. Come rifare la pubblica amministrazione italiana e il suo diritto? Diritto Pubblico, Padova, a. 2, n. 2, p. 381-405, mai.-ago. 1996.

${ }^{686}$ DENTE, Bruno. In un diverso Stato. Bologna: II Mulino, 1999.

${ }^{687}$ MARZUOLI, Carlo. Le privatizzazioni tra pubblico come soggetto e pubblico come regola. Diritto Pubblico, Padova, a. 1, n. 2, p. 393-421, 1995. 
submetendo os departamentos a controle político direto do parlamento, num modelo norteamericanizado de autoridades independentes. ${ }^{688}$

Ao expor suas ideias acerca da reforma, Dente expõe que a maior dificuldade de transformação decorre - ao menos no caso italiano - de uma "carência cultural", consistente na incapacidade dos gestores de conceber corretamente a "relação entre o direito e a ação pública". A solução para a correta concepção desta relação residiria na aplicação primária do direito privado à Administração Pública, que somente excepcionalmente estaria sujeita a regras de direito público. ${ }^{689}$

Carlo Marzuoli, apesar de não dedicar o seu texto especificamente à questão, acaba por tratar do tema ao convergir o seu pensamento com o de Bruno Dente, no sentido de que deveria ser aplicável à Administração o direito comum, exceção feita apenas àquelas atividades estatais que incidissem sobre a liberdade dos particulares - conclusão que coaduna, inclusive, com o nosso posicionamento sobre um dúplice regime de legalidade na Administração Pública, exposto como conclusão do tópico acerca dos desafios baseados na legalidade. O pensamento de Marzuoli se direciona especificamente à resolução da responsabilidade contratual do Estado junto a empresas privadas, mas propõe uma transformação na postura estatal como base em tal premissa. ${ }^{690}$

Domenico Sorace se opõe ao pensamento de Bruno Dente, sustentando que a questão da transformação administrativa não reside nas funções, mas sim nos atores, sejam políticos ou burocráticos, que servem de veículo à atuação estatal. Tal circunstância resta ainda mais clara ao analisarmos, na dicção de Sorace, que uma visão apartista sobre o papel das funções estatais para a transformação admnistrativa desconsidera as inúmeras implicações práticas da

\footnotetext{
${ }^{688}$ DENTE, Bruno. In un diverso Stato. Bologna: II Mulino, 1999.

${ }^{689}$ DENTE, Bruno. In un diverso Stato. Bologna: II Mulino, 1999.

${ }^{690}$ MARZUOLI, Carlo. Le privatizzazioni tra pubblico come soggetto e pubblico come regola. Diritto Pubblico, Padova, a. 1, n. 2, p. 393-421, 1995.
} 
questão, uma vez que, em sua maioria, as decisões adotadas pela Administração comungam aspectos burocráticos e políticos, por muitas vezes indissociáveis. ${ }^{691}$

Ainda, a Dente e Marzuoli, Domenico Sorace opõe o argumento de que a separação entre atividades de autoridade da Administração e as demais atividades estatais seria um parâmetro adequado para a aplicação do regime jurídico público ou privado e, por fim, para a transformação da postura administrativa. Sorace o faz lembrando que o direito administrativo serve justamente à garantia do bom andamento e da imparcialidade da Administração princípios da Administração Pública contemplados no regime constitucional italiano -, evitando tanto privilégios quanto a ineficiência. Uma reforma administrativa, assim, não pode ser utópica nem a-histórica. ${ }^{692}$

Aderimos em parte à posição de Domenico Sorace, no sentido de entender que o cerne da transformação da postura administrativa não reside em um rol específico de atribuições conferidas a cargos público - algo que, inclusive, já é contemplado por nosso direito administrativo -, mas sim na atuação sobre os próprios atores encarregados desses papéis. Entendemos, no entanto, que a segregação proposta inverteria os mecanismos de transformação administrativa, ao menos no caso brasileiro.

O apego a normas que instituam controles formais e procedimentais para a transformação administrativa constitui, justamente, um dos fatores de prejuízo à transformação administrativa. Como aqui desenvolvido, parece próprio do cenário cultural da Administração Pública - ou, ao menos, da Administração Pública iberoamericana - o descolamento entre a postura de gestores públicos e os movimentos de transformação administrativa expressos na Lei.

Assim, serve de pouco ou nada a instituição de medidas de transformação comportamental instituídas em normas que recorram a controles formais ou procedimentais, uma vez que a implementação de verdadeiras transformações na postura dos agentes públicos depende da sua adesão à ideia

691 SORACE, Domenico. Come rifare la pubblica amministrazione italiana e il suo diritto? Diritto Pubblico, Padova, a. 2, n. 2, p. 381-405, mai.-ago. 1996.

692 SORACE, Domenico. Come rifare la pubblica amministrazione italiana e il suo diritto? Diritto Pubblico, Padova, a. 2, n. 2, p. 381-405, mai.-ago. 1996. 
central da transformação e de seu comportamento ativo em direção à realização de tal ideia. É dizer, os agentes públicos logram cumprir o objetivo de conformidade com os controles formais e procedimentais ao adotar uma postura passiva diante dos desafios da Administração; essa circunstância, por si só, serve de desincentivo à transformação da postura administrativa que adota tais balizas, uma vez que o cumprimento de requisitos formais e procedimentais não garante o sucesso do projeto de transformação.

Deve-se atentar, pois, para o fato de que a evolução do direito administrativo - aqui, sob o prisma normativo - pode não passar de mera intenção ${ }^{693}$, caso não conte com a aderência dos agentes públicos e dos operadores do Direito. É o que se tem verificado em diversos casos contemporâneos, como na consolidação de garantias ao particular que, apesar de juridicamente ampliadas e reforçadas de maneira sensível pelo direito administrativo, "a prática administrativa e judicial manteve-as no nível anterior, quando não as diminuiu efetivamente". 694

Apesar da afirmação acima - formulada por Diogo Freitas do Amaral ainda na década de 1980 - referir-se ao cenário português, o seu conteúdo poderia ser transportado sem maiores adaptações para a realidade brasileira. Com se há visto, apesar de diversas disposições constitucionais elegerem a dignidade da pessoa humana e as garantias do cidadão como eixo central do Estado, ainda há inúmeros juristas e agentes públicos que enxergam a Administração Pública como um fim em si mesma, dotada de um mítico poder de conferir supremacia aos interesses conferidos à sua guarda, ainda que seja impossível, ou ao menos pouco provável, definí-los com precisão em todos os casos a si submetidos.

${ }^{693}$ RIBEIRO, Maria Teresa de Melo. O princípio da imparcialidade da Administração Pública. Coimbra: Almedina, 1996. P. 342.

${ }^{694}$ AMARAL, Diogo Freitas do. A Evolução do Direito Administrativo em Portugal nos últimos dez anos. Revista da Faculdade de Direito, São Paulo, v. 80, p. 237-249, jan. 1985. 
Destaca-se, portanto, o alerta de Rui Machete no sentido de que "mais ainda que o legislador, tem sido a prática administrativa e a jurisprudência que a aprecia, que se têm manifestado pouco sensíveis às mutações constitucionais". 695

A exemplo das instituições de controles formais e procedimentais, de origem normativa, que resultaram apenas parcialmente em transformações insuficientes da postura administrativa, o direito administrativo brasileiro ostenta a Reforma Administrativa concretizada pela Emenda Constitucional $n^{\circ}$ 19/1998. O seu propósito fundamental, como destacam Sérgio Ferras e Adilson Abreu Dallari, era a "[...] substituição do antigo modelo burocrático, caracterizado pelo controle rigoroso dos procedimentos, pelo novo modelo gerencial, no qual são abrandados os controles de procedimentos e incrementados os controles de resultados". 696 Vimos, por exemplo, a elevação da eficiência à categoria de princípio constitucional explícito da Administração Pública, o que significaria "[...] que é preciso superar concepções puramente burocráticas ou meramente formalísticas, dando-se maior ênfase ao exame da legitimidade, da economicidade e da razoabilidade, em benefício da eficiência". 697

Não se pode sustentar, no entanto, passados dezessete anos, uma virada de século e de milênio, que tal medida tenha surtido efeitos concretos na mudança da postura administrativa dos gestores estatais. Quando muito, obtevese mais um parâmetro de controle formal e procedimental, a acrescer-se à miríade de motivos para que a Administração Pública se torne cada vez mais uma atividade de justificação, e não de concretização.

Esse papel pouco eficiente - e, por vezes, tóxico - da preferência por mecanismos formais de conformação da Administração Pública é esclarecido por Dallari:

Formalismo é a antítese da garantia da forma. A exigência de requisitos formais para a produção de atos jurídicos visa proteger $o$

\footnotetext{
${ }^{695}$ MACHETE, Rui Chancerelle de. O processo administrativo gracioso perante a constituição portuguesa de 1976. Lisboa: Fundação Oliveira Martins, 1991. P.372.

${ }^{696}$ FERRAZ, Sérgio; DALLARI, Adilson Abreu. Processo administrativo. São Paulo: Malheiros, 2000. P. 77-78.

${ }^{697}$ FERRAZ, Sérgio; DALLARI, Adilson Abreu. Processo administrativo. São Paulo: Malheiros, 2000. P. 77-78.
} 
cidadão contra abusos de poder. Já o formalismo é um meio sutil de constranger o cidadão e comprometer o livre exercício de seus direitos. ${ }^{698}$

Qual seria, assim, o mecanismo adequado para que se alcance o ideal de uma "Administração afetuosa", ${ }^{699}$ apropriando-nos das palavras de Umberto Allegretti para se referir à gestão pública marcada pela consensualidade?

Um cenário em que se consolidasse a postura administrativa favorável à transação extrajudicial na administração pública seria o primeiro passo no caminho para a efetiva adoção de tais métodos como instrumento de reaproximação democrática entre Estado e sociedade. À continuidade desse caminho se dedica o derradeiro capítulo dessa tese, a seguir.

${ }^{698}$ DALLARI, Adilson Abreu. Formalismo e abuso de poder. Revista Eletrônica de Direito do Estado, Salvador, n. 16, out.-dez. 2008.

699 ALLEGRETTI, Umberto. Amministrazione pubblica e costituzione. Milão: Cedam, 1996. P. 225/236-238. 


\section{A CAMINHO DA TRANSAÇÃO EXTRAJUDICIAL NA SOLUÇÃO DE CONFLITOS DA ADMINISTRAÇÃO}

O capítulo que conclui a segunda parte da presente obra se dedica à investigação da realização, da concretização, da prática da transação extrajudicial na administração pública. Considera-se que as bases teóricas foram construídas de forma sólida nos capítulos antecedentes, e que os desafios conceituais e operacionais foram enfrentados de modo a não restarem oposições à adoção da transação extrajudicial como método preferencial de solução consensual de conflitos pela Administração Pública.

Como se vislumbra realizar, no entanto, a solução desse modo contruída ao longo da tese?

Como exposto na introdução ao texto, o tema proposto tem como essencial a preocupação não só com o delineamento teórico de um instituto, mas também com o enfrentamento dos desafios à sua efetiva aplicação para solucionar tão importante necessidade prática. Tais preocupações se refletem profundamente no plano da obra, e culminam com o desenvolvimento do presente capítulo.

Assim, procede-se com a apreciação da concretude da adoção da transação extrajudicial pela Administração Pública, em investigação que tem início por apreciar as experiências estatais nesse particular, sejam elas relativas ao cenário brasileiro, ou se relacionando com práticas estrangeiras.

Após tal exposição, o texto adota como foco o delineamento de parâmetros para a adoção da transação extrajudicial pela Administração Pública, que gravitam em torno da análise dos requisitos de validade material e procedimental do procedimento adotado, bem como da eumeração - não exaustiva, naturalmente - e apreciação de diversas hipóteses de cabimento do contrato.

Por fim, o movimento final do capítulo expõe algumas diretrizes, oriundas de diversas experiências, para a intensificação e consolidação do recurso à transação extrajudicial na administração pública brasileira, o que nos leva finalmente à conclusão da tese. 


\subsection{Experiências estatais na busca da consensualidade}

A primeira metade do capítulo final desta obra se debruça sobre algumas das mais destacadas experiências na adoção da transação extrajudicial pela Administração Pública brasileira e estrangeira. Esse se mostra um exercício de considerável importância já que, como expõe Pierre Moor, o desenvolvimento do direito administrativo pressupõe uma melhor apreensão e conhecimento das condições reais da sua implementação. ${ }^{700}$

Reproduz-se aqui, no entanto, a ressalva apresentada no delineamento metodológico da tese, empreendido na introdução ao texto. Como se observou ao longo da maior parte da obra, o tratamento dispensado à investigação de suas hipóteses é predominantemente teórico, calcado na abordagem analítica da literatura que se dedica ao tema de forma direta ou transversal, e na formulação de críticas e posicionamentos originais com base em suas constatações.

O estudo empírico a que se dedica o presente tópico, portanto, se apresenta sem pretensões de esgotamento, buscando nas experiências conhecidas de adoção de métodos consensuais de solução de conflitos pela Administração Pública elementos que possam colaborar com o enfrentamento do tema proposto. A eleição de tais experiências se baseia nas referências que a literatura a elas faz, adotando-se assim, como referencial, as práticas que mais ressoam nos debates doutrinários.

Procede-se, portanto, inicialmente com a apreciação dos casos brasileiros de adoção da transação extrajudicial na administração pública para, posteriormente, se dedicar o trabalho ao delineamento de algumas experiências relevantes nesse campo em ordenamentos estrangeiros, deles extraindo, ao fim, elementos que permitirão o estabelecimento das balizas para a adoção da transação extrajudicial pela Administração Pública que serão expostas na segunda parte do capítulo.

\footnotetext{
${ }^{700}$ MOOR, Pierre. Droit administratif. Berna: Stämpfli, 1991. P. 30. Tradução parcial de Bernardo Diniz de Ayala.
} 
5.1.1 A busca da transação pelo Estado: casos brasileiros

O cultor da ciência do Direito nunca deve descurar-se de evitar converter-se em um mero cronista das mudanças legislativas. Com especial foco sobre os administrativistas, Massimo Severo Giannini, como se vê em relato de Stelio Valentini, costumava dirigir a seus alunos a crítica sobre os que dedicavam sua atenção tão somente a temas de normatividade positiva, fugindo muitas vezes das problemáticas de maior relevo e, em geral, das implicações próprias da teoria geral do Direito. ${ }^{701}$

Cabe aqui, no entanto, após extensiva exposição teórico-dogmática acerca dos diversos temas de fundo sobre os quais se edifica o posicionamento que constitui a tese construída, dedicar algumas páginas aos aspectos de direito positivo que venham a enriquecer o debate proposto.

Como tema ainda tormentoso no direito administrativo brasileiro, a exposição das experiências práticas e de direito positivo acerca da adoção da transação extrajudicial pela Administração Pública traz agradáveis surpresas, uma vez que demonstra uma abertura a avanços neste campo, apesar da resistência de diversos setores da literatura.

A exposição proposta se baseia amplamente, assim, no direito positivo que se dedica direta ou indiretamente ao tema, exposto de forma sistematizada. Tal como exposto do delineamento metodológico da tese, a pesquisa normativa se orienta de modo diverso de acordo com a espécie da fonte e com a esfera de poder a que se refira a norma. No âmbito constitucional a exposição e análise dos dispositivos tidos como especialmente relacionados à prática em apreço foi realizada ao longo dos capítulos, restando aqui abordar o dispositivo que trata especificamente da responsabilidade extracontratual objetiva do Estado. Já no âmbito infraconstitucional, a pesquisa de normas nacionais e federais se deu de forma ampla, mormente pela ausência de uma norma específica a disciplinar a transação extrajudicial na administração pública.

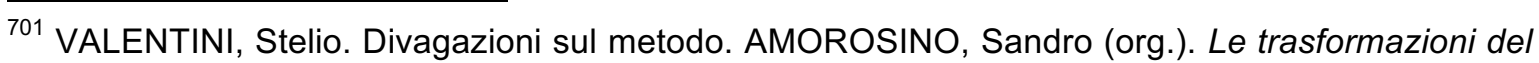
Diritto Amministrativo: Scriti degli allievi per gli ottanta anni di Massimo Severo Giannini. Milano: Giuffrè, 1995. 
Na sequência, a investigação de normas estaduais foi sistematizada de modo a obter o panorama mais amplo possível, mesmo em relação às Unidades da Federação sem experiências reconhecidas como relevantes pela literatura. Para tanto, a legislação referente ao processo administrativo de cada um dos entes, quando existente, foi analisada, destacando-se delas as disposições específicas sobre a composição administrativa de conflitos envolvendo a Administração Pública.

Por fim, na esfera municipal, tendo em vista o gigantesco número de municípios no Brasil, a investigação se ateve às duas experiências reconhecidas pela literatura como relevantes, com a busca e apreciação das fontes originais. Procede-se, portanto, com exposição que busca, de forma organizada, analisar as diversas experiências nacionais de transação extrajudicial na administração pública para, posteriormente, extrair-lhes as extrapolações que se possam mostrar de jaez geral.

A investigação de experiências de transação extrajudicial na Administração Pública com base na pesquisa do direito positivo pode parecer uma postura extremamente contraditória em relação ao posicionamento que esposamos em relação ao papel da juridicidade como base para a adoção de soluções consensuais de conflitos na administração pública, mas não o é. Muito pelo contrário, o resultado de tal investigação demonstra como ainda são equivocados os posicionamentos estatais quanto à necessidade de autorização legislativa específica para o recurso da Administração Pública a tais mecanismos, o que se mostra instrumental às críticas que aqui se propõe.

Ao longo da obra, mostrou-se que a hipótese exemplificativa que melhor colabora com a provocação dos debates acerca da transação extrajudicial na administração pública é a solução da responsabilidade extracontratual do Estado. Nesse particular, a Constituição Federal conta com dispositivo que, por si só, já sustentaria todo um sistema de solução consensual dos conflitos da Administração Pública nesse campo.

Assim dispõe o $\S 6^{\circ}$ do art. 37 da Constituição Federal: 
Art. 37. A administração pública direta e indireta de qualquer dos Poderes da União, dos Estados, do Distrito Federal e dos Municípios obedecerá aos princípios de legalidade, impessoalidade, moralidade, publicidade e eficiência e, também, ao seguinte:

$[\ldots]$

$\S 6^{\circ}$ As pessoas jurídicas de direito público e as de direito privado prestadoras de serviços públicos responderão pelos danos que seus agentes, nessa qualidade, causarem a terceiros, assegurado o direito de regresso contra o responsável nos casos de dolo ou culpa.

A análise desse dispositivo nos revela duas importantes circunstâncias a acolher, com plenitude, a possibilidade de transação extrajudicial para a solução da responsabilidade civil da Administração Pública. Em um primeiro momento, é de se destacar que o dispositivo, em nenhum momento, sustenta que seria necessária condenação judicial para que a responsabilidade civil do Estado tome lugar. Nesse sentido, ao instituir a regra de que os entes da Administração Pública "responderão [afirmação imperativa] pelos danos que seus agentes, nessa qualidade, causarem a terceiros", e não que poderão ser responsabilizados judicialmente, a Constituição Federal abre as portas para que tal responsabilidade seja resolvida administrativamente.

É que, de acordo com o posicionamento por esta obra construído ao propor tratamento teórico dos temas de legalidade e interesse público, essa disposição constitucional conforma a missão institucional do Estado e, assim, esse parâmetro de juridicidade condiciona a atuação da Administração Pública, caracterizando a objetiva indenização dos danos causados como interesse público material a ser perseguido pelos entes estatais.

Em segunda mirada, verifica-se que o dispositivo acolhe a responsabilidade extracontratual - ou civil - objetiva do Estado, ou seja, independentemente de demonstração de dolo ou culpa da Administração, bastando 
para tanto a demonstração do nexo de causalidade entre a conduta do agente estatal e o dano experimentado pelo particular. ${ }^{702}$

Essas circunstâncias levam a que a responsabilidade do Estado seja possível e mais facilmente apurável na seara administrativa - já que carece da demonstração de dolo ou culpa, exceto, é claro, para o regresso em face do servidor responsável -, viabilizando em grande medida que a apuração de tal responsabilidade possa se dar no bojo de processo administrativo que culminaria, no caso de deferimento, com a firmatura de transação extrajudicial entre a Administração e o particular.

Enxergamos, portanto, nesse dispositivo constitucional, o fundamento central para as práticas de transação extrajudicial na administração pública para a solução da responsabilidade civil estatal, hipótese que constitui a esmagadora maioria das práticas observadas adiante.

No âmbito federal, no tocante às normas infraconstitucionais, a Lei $n^{\circ}$ 9.469/1997 exerceu notável protagonismo ao expressamente admitir o recurso à transação para a terminação de litígios em que fosse parte a Administração Pública federal. Eis os dispositivos, em sua redação atualizada:

Art. $1^{\circ}$. O Advogado-Geral da União, diretamente ou mediante delegação, e os dirigentes máximos das empresas públicas federais poderão autorizar a realização de acordos ou transações, em juízo, para terminar o litígio, nas causas de valor até $\mathrm{R} \$$ $500.000,00$ (quinhentos mil reais).

$\S 1^{\circ}$. Quando a causa envolver valores superiores ao limite fixado neste artigo, o acordo ou a transação, sob pena de nulidade, dependerá de prévia e expressa autorização do Advogado-Geral da União e do Ministro de Estado ou do titular da Secretaria da Presidência da República a cuja área de competência estiver afeto o assunto, ou ainda do Presidente da Câmara dos Deputados, do Senado Federal, do Tribunal de Contas da União, de Tribunal ou Conselho, ou do Procurador-Geral da República, no caso de interesse dos órgãos dos Poderes Legislativo e Judiciário, ou do Ministério Público da União, excluídas as empresas públicas

\footnotetext{
${ }^{702}$ Ressalvamos que foge ao escopo da presente tese o tratamento teórico dos diversos sistemas de responsabilidade civil do Estado, desde as teorias de imunidade soberana (simbolizadas pelo brocardo "the king can do no wrong") até o reconhecimento da responsabilidade objetiva, passando pelas teorias baseadas na faute du service. Basta-nos, portanto, o reconhecimento de que o art. 37, $\S 6^{\circ}$, da Constituição Federal, acolhe a teoria da responsabilidade objetiva do Estado.
} 
federais não dependentes, que necessitarão apenas de prévia e expressa autorização de seu dirigente máximo.

\section{$[\ldots]$}

Essas disposições legais foram regulamentadas pelo Decreto $\mathrm{n}^{\circ}$ 2.346/1997, que acabou por restringir drasticamente - a somente um décimo do valor original - a autonomia originalmente estabelecida:

Art. $7^{\circ}$ O Advogado-Geral da União e os dirigentes máximos das
autarquias, das fundações e das empresas públicas federais
poderão autorizar a realização de acordos ou transações, em juízo,
para terminar o litígio, nas causas de valor até $\mathrm{R} \$ 50.000,00$
(cinqüenta mil reais), a não-propositura de ações e a não-
interposição de recursos, assim como requerimento de extinção
das ações em curso ou de desistência dos respectivos recursos
judiciais, para a cobrança de créditos, atualizados, de valor igual ou
inferior a $\mathrm{R} \$ 1.000,00$ (mil reais), em que interessadas essas
entidades na qualidade de autoras, rés, assistentes ou opoentes,
nas condições aqui estabelecidas

$\S 1^{\circ}$ Quando a causa envolver valores superiores ao limite fixado no caput, o acordo ou a transação, sob pena de nulidade, dependerá de prévia e expressa autorização do Ministro de Estado ou do titular de Secretaria da Presidência da República a cuja área de competência estiver afeto o assunto no caso da União, ou da autoridade máxima da autarquia, da fundação ou da empresa pública.

\section{$[\ldots]$}

Tais normas contam com duas restrições peculiares que acabam por the tolher do papel de protagonismo na adoção da transação pela Administração Pública federal. Num primeiro momento, fica patentemente determinado que as transações com base nelas entabuladas só o poderão na modalidade judicial, e nunca na modalidade preventiva; nesse particular, a norma acaba por descumprir a escala de preferencialidade construída na primeira parte da presente tese, carecendo assim de um posicionamento pela máxima efetividade da solução consensual de conflitos.

Em outro sentido, como bem destaca Roberto Gil Leal Faria, a instituição de restrições hierárquicas e procedimentos internos à Advocacia-Geral da União para que se viabilize, do ponto de vista da competência, o recurso à transação ainda que judicial - acaba por prejudicar em muito a efetividade da norma. É dizer, 
as normas administrativas acerca da matéria acabam por gerar verdadeiro "temor reverencial" nos Advogados Públicos federais, que ficam tolhidos na aplicação de seu "bom senso" para decidir, por si próprios, acerca do cabimento ou não da solução consensual do conflito. ${ }^{703}$

No caso específico dos Juizados Especiais Federais, avançou a Lei $n^{\circ}$ 10.259/2001 ao prever expressamente a possibilidade de transação nas causas de sua competência que, do ponto de vista cível, não atinge a amplitude de valores contemplada pelo art. $1^{\circ}$ da Lei $n^{\circ} 9.469 / 1997$. Assim dispõe a norma:

Art. 10. As partes poderão designar, por escrito, representantes para a causa, advogado ou não.

Parágrafo único. Os representantes judiciais da União, autarquias, fundações e empresas públicas federais, bem como os indicados na forma do caput, ficam autorizados a conciliar, transigir ou desistir, nos processos da competência dos Juizados Especiais Federais.

Art. 11. A entidade pública ré deverá fornecer ao Juizado a documentação de que disponha para o esclarecimento da causa, apresentando-a até a instalação da audiência de conciliação.

Parágrafo único. Para a audiência de composição dos danos resultantes de ilícito criminal, o representante da entidade que comparecer terá poderes para acordar, desistir ou transigir, na forma do art. 10.

Mais uma vez, a regulamentação da matéria acabou por impor-lhe restrições que contribuíram para o relativo insucesso da prática, como se observa das disposições da Portaria n 109/2007-AGU. Esta norma, apesar de reconhecer em seu art. $2^{\circ}$ a desnecessidade de autorização hierárquica para que o Advogado Público entabule transações extrajudiciais, acabou por restringir em seu art. $3^{\circ}$ as hipóteses de transação para os casos de "erro administrativo reconhecido pela autoridade competente ou [...] verificável pela simples análise das provas e dos documentos que instruem a ação" ou de inexistência de "controvérsia quanto ao fato e ao direito aplicado".

703 FARIA, Roberto Gil Leal. Por que são efetivados poucos acordos nos Juizados Especiais Federais? Revista da SJRJ, Rio de Janeiro, n. 24, p. 93-103, 2009. 
Tal ordenamento acaba por, também nos Juizados Especiais Federais, reproduzir as vicissitudes já observadas em relação à Lei $n^{\circ}$ 9.469/1997 e ao Decreto $n^{\circ} 2.346 / 1997$, tal como bem destaca Roberto Gil Leal Faria. ${ }^{704}$

Apesar de não se tratar de experiência específica de transação, cabe aqui brevemente expor o caso da Câmara de Conciliação e Arbitragem da Administração Federal - CCAF, criada pelo Ato Regimental $n^{\circ}$ 5/2007-CGU e estruturada pelo Decreto $n^{\circ} 7.392 / 2010$, por se mostrar como a experiência conciliatória de maior sucesso no âmbito da União. Em tal instância, os órgãos da Administração Pública Federal encontram um espaço para a conciliação dos conflitos que eventualmente se instaurem entre si - que, surpreendentemente, são de considerável frequência -, bem como resolver eventuais disputas entre si e os Estados, o Distrito Federal e os Municípios. ${ }^{705}$

No tocante às normas de abrangência nacional, a Lei no 12.153/2009, que trata dos Juizados Especiais da Fazenda Pública acabou por incluir o mesmo permissivo de transação judicial - já previsto nos Juizados Especiais Federais para os feitos de sua competência mas, ao exigir em seu art. $8^{\circ}$ a autorização legislativa específica para cada um dos entes da Administração Pública, deixou de concretamente viabilizar o recurso a mais este âmbito de solução consensual de conflitos do Estado.

Na esteira da Lei $n^{\circ} 13.129 / 2015$ - que ampliou o âmbito de aplicação da arbitragem para os entes da Administração Pública -, a recentíssima Lei $n^{\circ}$ 13.140/2015 ampliou o modelo da Câmara de Conciliação e Arbitragem da Administração Federal para os Estados, o Distrito Federal e os Municípios, expandindo ainda o seu escopo para que possam tais câmaras também dirimir

\footnotetext{
704 FARIA, Roberto Gil Leal. Por que são efetivados poucos acordos nos Juizados Especiais Federais? Revista da SJRJ, Rio de Janeiro, n. 24, p. 93-103, 2009.

${ }^{705}$ BERNARDO, Leandro Ferreira. A face conciliatória da Advocacia Pública. In: GREGO SANTOS, Bruno; et. al. Temas Avançados da Advocacia Pública. Maringá: UniCorpore, 2011.
}

E ainda:

BERNARDO, Leandro Ferreira. A Câmara de conciliação e o novo papel da Advocacia-Geral da União. Revista da AGU, Brasília, a. 9, n. 25, jul./set. 2010. 
conflitos entre estes entes e particulares, como expressamente dispõe o inciso II do seu art. 32:

Art. 32. A União, os Estados, o Distrito Federal e os Municípios poderão criar câmaras de prevenção e resolução administrativa de conflitos, no âmbito dos respectivos órgãos da Advocacia Pública, onde houver, com competência para:

I - dirimir conflitos entre órgãos e entidades da administração pública;

II - avaliar a admissibilidade dos pedidos de resolução de conflitos, por meio de composição, no caso de controvérsia entre particular e pessoa jurídica de direito público;

III - promover, quando couber, a celebração de termo de ajustamento de conduta.

\section{$[\ldots]$}

$\S 3^{\circ}$. Se houver consenso entre as partes, o acordo será reduzido a termo e constituirá título executivo extrajudicial.

\section{$[\ldots]$}

O novo Código de Processo Civil, ainda em vacatio legis, acolheu equivalente disposição em seu art. 174, pugnando pela criação de tais câmaras na Administração Direta das três esferas.

Merecem destaque, ainda, o parágrafo único do art. 33 e o art. 34 da Lei no 13.140/2015, que expressamente reconhecem a possibilidade de solução consensual de conflitos por "instauração de procedimento administrativo". No tocante especificamente à transação, a Lei $n^{\circ} 13.140 / 2015$, referindo-se nesse particular tão somente à Administração federal, instituiu a figura da "transação por adesão", refletindo assim a atávica resistência, já exaustivamente demonstrada ao longo dessa obra, à efetiva negociação da solução consensual entre a Administração e os particulares.

Tal circunstância se revela como grave falha da Lei $n^{0} 13.140 / 2015$, que acabou por perder a histórica oportunidade de consolidar, de modo definitivo, a admissibilidade legal - ainda que a consideremos desnecessária, diga-se - da verdadeira transação extrajudicial pela Administração Pública. Nesse sentido, ressaltamos que a "transação por adesão" não constitui verdadeira transação pois, como alerta Giovanni Sala, no acordo que se reduz à simples aquiescência do 
particular, esse continua a ser mero administrado, súdito da decisão administrativa de conformar a transação. ${ }^{706}$

A Lei no 13.140/2015 conta, não obstante, com notável inovação, apta a enfrentar um dos desafios operacionais aqui destacados, consistente no temor de injusta responsabilização dos servidores públicos que promovam a transação extrajudicial na administração pública. Determina o seu art. 40 que tais servidores "somente poderão ser responsabilizados civil, administrativa ou criminalmente quando, mediante dolo ou fraude, receberem qualquer vantagem patrimonial indevida, permitirem ou facilitarem sua recepção por terceiro, ou para tal concorrerem". Acreditamos que tal disposição, caso devidamente observada pelos órgãos de controle, em muito contribuirá para o avanço nas transformações da postura administrativa a que nos referimos ao final do capítulo anterior.

Concluindo as análises da legislação de âmbito nacional, verifica-se que o novo Código de Processo Civil reconhece explicitamente a possibilidade de transação pela Administração Pública no inciso VI de seu art. 525, inovando ainda de maneira notável ao reconhecer, no inciso IV de seu art. 784, que "o instrumento de transação referendado [...] pela Advocacia Pública” constitui título executivo extrajudicial, consolidando a natureza de "equivalente processual"707 da transação extrajudicial na administração pública, mobilizando a categoria de Carnelutti.

No âmbito estadual, como exposto no delineamento teórico, a investigação consistiu na sondagem do ordenamento de cada um dos Estados e do Distrito Federal para buscar, naqueles que contemplam norma específica de processo administrativo, disposições que se refiram à solução de conflitos no âmbito Administrativo. ${ }^{708}$

\footnotetext{
${ }^{706}$ SALA, Giovanni. Accordi sul contenuto discrezionale del provvedimento e tutela delle situazioni soggetive. Diritto Processuale Amministrativo, Milano, a. 10, n. 2, p. 206-254, jun. 1992.

${ }^{707}$ CARNELUTTI, Francesco. Instituições do Processo Civil. São Paulo: Classic Book, 2000. P. 157.

${ }^{708}$ Destacamos que, apesar das intensas investigações, não foi possível encontrar nos repositórios oficiais normas que instituam regras gerais para os processos administrativos em relação aos Estados que aqui não são citados. Em relação ao Estado do Rio Grande do Sul, destacamos a edição do Decreto Estadual $n^{\circ}$ 51.762/2014-RS, que institui Grupo de Trabalho com a finalidade de elaborar propostas para a organização e a regulamentação do Processo Administrativo no âmbito do Poder Executivo daquele ente.
} 
Referindo-se expressamente a um processo administrativo de reparação de danos, a legislação relativa ao processo administrativo de quatro estados contempla a regulamentação extensa de procedimentos, direitos e deveres dos particulares. No Estado da Bahia, a Lei Estadual no 12.209/2011-BA estabelece, em seus arts. 136 a 145, detalhado procedimento de apuração e reparação de danos ao administrado e em seus arts. 146 a 150, o procedimento de reparação de danos ao erário. A norma contempla considerável processualidade, com o julgamento em múltiplos estágios aqui sugerido para enfrentar alguns dos perigos da transação especificados no capítulo anterior.

Já o Estado de São Paulo conta em seu ordenamento com a Lei Estadual no 10.177/1998-SP, que contempla, em seu art. 65, o procedimento a ser adotado por "[a]quele que pretender, da Fazenda Pública, ressarcimento por danos causados por agente público, agindo nessa qualidade, [que] poderá requerê-lo administrativamente [...]."

O Estado do Rio Grande do Norte editou a Lei Complementar Estadual no 303/2005-RN, em cujos arts. 94 a 99 detalham o "processo de reparação de danos". A solução adotada por este Estado se torna peculiar ao instituir, para o ressarcimento administrativo, ordem cronológica de pagamentos à moda do regime de precatórios.

No Estado do Ceará, por sua vez, tramita o Projeto de Lei Estadual $\mathrm{n}^{\circ}$ 49/2007-CE, que institui procedimento de reparação de danos em seus arts. 65 a 71.

Já o Estado do Amazonas se diferencia dos demais por contemplar, na Lei Estadual $n^{\circ}$ 2.794/2003-AM, o "procedimento de outorga" que consiste no julgamento de "pedidos de reconhecimento, de atribuição ou de liberação de direito". Entendemos que essa modalidade, regulada nos arts. 74 a 78 daquela Lei Estadual, se diferencia substancialmente das anteriores por contemplar um espectro mais amplo de direitos do que aqueles relacionados com o ressarcimento de danos, institucionalizando de forma abrangente a solução extrajudicial de conflitos que envolvam a Administração Pública. 
Por fim, três Estados contemplam, em suas normas estaduais referentes a processo administrativo, o regulamento do exercício do direito de petição, que também poderá ser manejado para obter a solução consensual de conflitos. $O$ Estado do Maranhão conta com a Lei Estadual n 8.959/2009-MA, que regulamenta o direito de petição em seus arts. 29 a 33, "contra ilegalidade ou abuso de poder e para a defesa de direitos".

Nos mesmos moldes - de inspiração constitucional, destaque-se - o Estado do Mato Grosso editou a Lei Estadual n 7.692/2002-MT, que regulamenta o direito de petição em seus arts. 31 e 32; já o Estado de Sergipe, por meio da Lei Complementar Estadual $n^{\circ} 33 / 1996-S E$, igualmente procedeu em seus arts. $4^{\circ}$, inciso XII, e 109, relacionando o direito de petição à responsabilidade patrimonial do Estado.

Na esfera municipal destacam-se duas práticas reconhecidas como de relevância para a análise aqui proposta, sendo a primeira delas protagonizada pelo Município de São Paulo.

A Lei Municipal $n^{\circ} 14.141 / 2006$, do Município de São Paulo, não trata especificamente da adoção de soluções consensuais de conflitos em processo administrativo - assim como silenciava a Lei Municipal $n^{\circ} 8.777 / 1978$, à qual sucedeu. No entanto, o Município de São Paulo é pioneiro na realização de acordos extrajudiciais em matéria de desapropriações, como se vê do disposto na Portaria n 112/1989-SJ, de autoria de Odete Medauar enquanto Procuradora do Município de São Paulo no exercício da chefia daquele órgão jurídico. Assim determina a norma:

\footnotetext{
Uma vez publicado o decreto de declaração de interesse social, poderá o Diretor do Depto. de Desapropriações autorizar a propositura da competente ação expropriatória ou a celebração de acordo na esfera administrativa, independentemente de autorização específica deste Gabinete
}

Desse modo, a prática preconizada pelo Município de São Paulo mostrou-se vanguardista ao conferir efetividade às não tão recentes disposições do art. 10 do Decreto-Lei $n^{\circ} 3.365 / 1941$. 
Por fim, destaca-se a prática desenvolvida na Procuradoria-Geral do Município de Marialva, no Estado do Paraná, de "transação extrajudicial desburocratizada no âmbito da Administração", vencedora da VII edição do Prêmio Innovare, em 2010.

Pugnando por um procedimento simples e dispensando autorização legislativa específica, o Município implementou um programa de transação extrajudicial que, após apenas alguns anos de funcionamento, reduziu a drasticamente as demandas judiciais contra o Município fundadas em sua responsabilidade civil e the permitiu equalizar a sua fila de pagamentos de precatórios.

Ainda, a processualização adotada demonstrou-se bastante efetiva para conquistar a adesão dos particulares inclusive nos casos de indeferimento, uma vez que a adequada instrução do processo era suficiente à demonstração da eventual improcedência de seus pleitos. A prática contribuiu, assim, com a redução da carga de trabalho direcionada ao Judiciário, ao mesmo tempo em que se posicionou como símbolo de reaproximação democrática entre o Município e os cidadãos. ${ }^{709}$

Verifica-se, portanto, não faltarem experiências na Administração Pública brasileira de busca pela consensualidade lançando mão da transação extrajudicial. Cabe ao nosso direito administrativo, ainda por muitas vezes preso a atavismo injustificáveis, se debruçar sobre o tema e constituir-Ihe os fundamentos necessários para que as práticas sejam difundidas com segurança e solidez.

\subsubsection{A transação extrajudicial pelo Estado no direito estrangeiro}

Após a exposição das experiências brasileiras com a adoção da transação extrajudicial para a solução de conflitos que envolvam a Administração Pública, volta-se a análise do texto para os exemplos estrangeiros.

\footnotetext{
${ }^{709}$ GREGO-SANTOS, Bruno. Em prol da comunidade: Transação extrajudicial desburocratizada no âmbito da Administração. Revista Innovare, Brasília, a. 1, n. 1, ago. 2011.
} 
Em clássico curso sobre o tema, Jean Rivero nos exorta a nutrir nossos debates com a riqueza da análise intersistêmica. Com base nas lições de Gutteridge e René David, destaca com clareza a natureza metodológica, instrumental, da análise jurídica pelo método comparado. ${ }^{710}$ Esse método extrairia seu valor da capacidade de ser "instrumento de conhecimento dos direitos estrangeiros, elemento de compreensão do direito nacional", na tradução de José Cretella Júnior. ${ }^{711}$

Sob tal ponto de vista, Jean Rivero expõe raciocínio de destacada lucidez acerca da utilidade do método comparado de estudo do direito administrativo: não há, efetivamente, a obrigatoriedade de conhecimento do Direito estrangeiro para a qualidade de uma dada sondagem do Direito nacional. Há, no entanto, um indiscutível fruto a colher da análise comparada, não necessariamente para o conhecimento do Direito estrangeiro, mas sim para a melhor compreensão do Direito pátrio. ${ }^{712}$

É dizer: o estudo do direito administrativo pelo método comparado permite a melhor compreensão dos institutos do Direito nacional, com vantagens que o próprio Rivero classifica, categoricamente, como óbvias. ${ }^{713}$ Frente ao cenário que se delineia ao longo da presente tese, ousamos ampliar tal inferência, ao ponto de sustentar que a apreciação dos institutos no Direito estrangeiro permite, na ausência de figura suficientemente consolidada no ordenamento nacional, a ampliação do próprio Direito pátrio. Poderíamos, portanto, inovar no Direito nacional com maior propriedade ao analisar como tais inovações se procederam no Direito estrangeiro, lançando mão do método comparado.

Cabe, no entanto, tecer importante ressalva: este trabalho não se pretende um trabalho de direito administrativo comparado ou, para os que preferirem a terminologia de Rivero, um trabalho edificado sobre o método comparado. De fato, esta porção do trabalho se dedicará a relatar brevemente

\footnotetext{
${ }^{710}$ RIVERO, Jean. Cours de Droit Administratif comparé. Paris: Dalloz, 2011. P. $16-21$.

${ }^{711}$ RIVERO, Jean. Curso de direito administrativo comparado. Trad. José Cretella Júnior. São Paulo: Revista dos Tribunais, 1995. P. 19.

${ }^{712}$ RIVERO, Jean. Cours de Droit Administratif comparé. Paris: Dalloz, 2011. P. 16-21.

${ }^{713}$ RIVERO, Jean. Cours de Droit Administratif comparé. Paris: Dalloz, 2011. P. 20.
} 
experiências com a transação extrajudicial na administração pública estrangeira sem, no entanto, adotar o rigor científico que caracterizaria o método comparado.

Apesar disso, entendemos que os frutos destacados por Jean Rivero são também obtidos pelo procedimento aqui adotado. Na medida em que são expostas as experiências e normas atinentes à matéria adotadas em outros ordenamentos jurídicos, se revelam pontos importantes para a edificação de um entendimento autêntico sobre a transação extrajudicial na administração pública no Brasil.

E assim se procede por um motivo específico, já exposto no tópico anterior: ainda são poucas e raras as experiências de transação extrajudicial na administração pública no Brasil. Ainda, estas experiências encontram considerável resistência no cenário doméstico, o que faz parte, inclusive, do próprio valor de inovação da presente tese.

Faltar-nos-ia, portanto, um referencial jurídico sólido do Direito nacional para que o método comparado fosse aplicado, em sua plenitude, face aos ordenamentos jurídicos estrangeiros em matéria de transação extrajudicial na Administração Pública.

Pretendemos aqui obter um benefício específico que Jean Rivero atribui à comparação: aclarar o cenário posto para que se perceba que "as linhas essenciais que fazem a verdadeira originalidade do sistema" ${ }^{\text {"714 }}$ não impendem, necessariamente, à impossibilidade da adoção da transação extrajudicial pela Administração Pública, como tantos sustentam. Observar as experiências estrangeiras sobre o tema nos permite perceber que, como sustentado ao enfrentarmos os desafios conceituais expostos nessa obra, não há no Direito brasileiro qualquer fundamento para que se pretenda considerar vedada a transação extrajudicial na administração pública, qualquer seja o motivo invocado.

Ressalvamos ainda que, mesmo nos estudos comparativos baseados em dados - para os quais seria de se esperar uma maior objetividade e uma mais clara transposição de conclusões entre os cenários - cabe ao pesquisador proceder

\footnotetext{
${ }^{714}$ RIVERO, Jean. Curso de direito administrativo comparado. Trad. José Cretella Júnior. São Paulo: Revista dos Tribunais, 1995. P. 21.
} 
com uma acurada análise de transponibilidade de fatores. Assim, pode-se dizer que, em se tratando de Administrações Públicas, "conduzir pesquisa transnacional significativa requer a consideração da equivalência transnacional dos parâmetros de aferição", ${ }^{715}$ significando que nem na pesquisa por dados objetivos - e assim, quanto menos na pesquisa teórica - é possível, sem hercúleos esforços, traduzir perfeitamente entre um e outro cenário jurídico informações a ponto de se obter a perfeita comparabilidade.

Ainda tomando por inspiração o método delineado por Jean Rivero, apesar de não adotar tal posição radicalmente, buscaremos aqui nos ocupar de "fatos administrativos", e não de "direitos administrativos". ${ }^{116}$ Isso quer dizer que o maior relevo será apurado na efetiva adoção da transação extrajudicial nas Administrações Públicas abordadas e as respectivas normas aplicáveis, não importando, salvo exceções, a natureza e a qualificação dada a estas regras pelo Direito estrangeiro.

Assim, mais importam as peculiaridades - bem sucedidas ou não - da experiência estrangeira com a transação extrajudicial na administração pública que o fato de a adoção de tais mecanismos estar adstrita ao direito administrativo, ou se caracterizar, simplesmente, como o permissivo para que a Administração Pública daquele país adote a solução consensual por força da sua submissão ao direito privado, geral. Entendemos que tal ressalva não prejudica a importância de nossa edificação original sobre a natureza jurídica da transação extrajudicial na administração pública brasileira, tarefa sobre a qual nos debruçamos em capítulo anterior.

\footnotetext{
${ }^{715}$ JILKE, Sebastian; MEULEMAN, Bart; VAN DE WALLE, Steven. We need to compare, but how? Measurement equivalence in comparative public administration. Public Administration Review, Washington, v. 75, n. 1, p.36-47, jan./fev. 2015.
}

Nas palavras dos autores: "Within comparative public administratio survey research, it is common practice to assume the equivalence of latent traits and their accompanying survey items. Researchers often simply pool items from different countries and subsequently utilize the factor scores of the latent construct they measure. Seemingly, there is limited awareness among crossnational researchers within the field of public administration of the serious bias that may be induced by pursuing such an estimation strategy [...]. conducting meaningful cross-national analyses requires consideration of the cross-national equivalence of survey measures. Estimating inferential models from comparative data without taking into account the possibility of measurement nonequivalence can lead to spurious results and misleading conclusions."

${ }^{716}$ RIVERO, Jean. Cours de Droit Administratif comparé. Paris: Dalloz, 2011. P. 44-52. 
A análise aqui empreendida sofre um considerável recorte objetivo ao verificarmos que as experiências nos moldes italiano, alemão e espanhol de soluções consensuais de conflitos na Administração Pública - lançando mão da figura dos acordos substitutivos -, são condensadas e analisadas em detalhes, tanto do ponto de vista histórico quanto conceitual, ao longo do capítulo 3 da presente tese. Nesse sentido, considerando ser desnecessária a reprodução de tais análises também nesse capítulo, bem como a absoluta ausência de pretensões exaustivas, parte-se à análise das experiências tidas como relevantes a título de referencial comparativo no campo da transação extrajudicial na administração pública. A exposição tem início com as experiências de alguns países da Europa continental - além de Itália, Alemanha e Espanha, cuja experiência, de moldes próximos, já foi como visto abordada anteriormente -, passando à experiência comunitária europeia. Em sequência, são expostas as experiências de países da tradição da common law para, ao fim, adotar-se referencial comparativo relativo aos BRICS. $^{717}$

Iniciando pela análise do cenário francês de adoção da transação extrajudicial pela Administração Pública, configura-se de pronto um panorama de grande protagonismo daquele país na matéria. É célebre o pioneiro estudo aprovado pela assembleia do Conselho de Estado francês em 4 de fevereiro de 1993, "Régler autrement les conflits: Conciliation, transaction, arbitrage en matière administrative", ${ }^{718}$ que adotou e regulamentou a transação como instrumento de resolução dos conflitos que tenham como parte a Administração Pública.

A transação no direito administrativo francês, de acordo com Nathalie Vinci, se configura como um elemento de qualidade do serviço público, na medida em que permite uma solução rápida das contendas, uma melhor gestão dos

\footnotetext{
${ }^{717}$ A literatura em macroeconomia utiliza o acrônimo BRICS para indicar um grupo peculiar de países - Brasil, Rússia, China, Índia e, posteriormente, África do Sul - que, apesar de diferenças culturais e geográficas, compartilham características e potenciais de crescimento. $O$ termo foi cunhado pelo economista Jim O'Neil em estudo de 2001 e, curiosamente, acabou por ser adotado oficialmente por aqueles países em um grupo de cooperação internacional (O'NEIL, Jim. Building Better Global Economic BRICs. Global Economics Paper, Goldman Sachs, New York, n. 66, nov. 2001).

${ }^{718}$ FRANÇA. CONSELHO de Estado Francês. Régler autrement les conflits (coleção Les Études du Conseil d'Etat). Paris: Documentation Française, 1993.
} 
recursos públicos e um acréscimo de eficácia dos procedimentos contenciosos ${ }^{719}$ - posicionamento que corrobora os elementos por nós eleitos para a constituição da preferencialidade da transação extrajudicial, tal como desenvolvido na primeira parte do trabalho.

A adoção da transação pela Administração Pública, assim como preconizada pela assembleia do Conselho de Estado, se consolidou pela edição, pelo Primeiro Ministro francês, de uma circular relativa ao desenvolvimento do recurso à transação para a solução consensual dos conflitos da Administração Pública, em 15 de fevereiro de 1995. A posição administrativa favorável à transação foi, ainda, confirmada por uma circular de 7 de setembro de 2009, relativa ao recurso à transação para a prevenção e solução de litígios em matéria de contratos administrativos, e por uma circular de 6 de abril de 2011, relativa ao manejo da transação para a solução consensual de conflitos.

O complexo de circulares adotado no direito administrativo francês, apesar de não constituir regra jurídica na acepção estrita do termo, constituiria uma "diretiva de discricionariedade", direcionada a condicionar a conduta doa agentes públicos franceses em direção às práticas consensuais. ${ }^{720}$

O cenário dos Países Baixos é descrito na obra de Oswald Jansen, que diferencia a questão civil da responsabilidade - contratual ou não - do Estado daquela responsabilidade que pode advir da prática de atos administrativos submetidos ao controle judicial. No caso holandês, Jansen destaca que o recurso a métodos alternativos de resolução de conflitos, como a transação e a arbitragem, é comum tanto sob o aspecto de direito civil quanto sob o aspecto de direito administrativo da responsabilidade do Estado. No entanto, em se tratando de transação, o contrato só terá efeitos extintivos em relação à responsabilidade

\footnotetext{
${ }^{719} \mathrm{VINCI}$, Nathalie. Guide de la transaction en droit administratif. Paris: Territorial, 2012. Passim. ${ }^{720}$ ABREU, José Manuel Coutinho de. Sobre os regulamentos administrativos e o princípio da legalidade. Coimbra: Almedina, 1987. p. 175-179.
} 
fundada no direito civil, mantendo-se a sindicabilidade das soluções que tenham por objeto questões de direito administrativo. ${ }^{721}$

No âmbito comunitário europeu, O Comitê de Ministros do Conselho da Europa - órgão normativo da União Europeia -, em 5 de setembro de 2001, adotou a Recomendação $n^{\circ} \operatorname{Rec}(2001) 9,{ }^{722}$ que trata de "alternativas à litigância entre autoridades administrativas e partes privadas".

Tal Recomendação foi editada na esteira das Recomendações $n^{\circ}$ $\operatorname{Rec}(1981) 7$ e $\operatorname{Rec}(1986) 12$, que tratam, respectivamente, da facilitação do acesso à justiça com a adoção de medidas de conciliação e mediação, e da adoção de medidas para prevenir e reduzir o excessivo recurso aos tribunais, incluindo a preferência pela solução consensual de conflitos.

A Recomendação $n^{\circ} \operatorname{Rec}(2001) 9$, apesar da brevidade e objetividade próprias dos instrumentos de recomendação, reconhece de forma significativa que "[...] o procedimento judicial pode, na prática, nem sempre ser o mais apropriado para a solução de questões administrativas". ${ }^{723}$ Tal posicionamento é inovador pois, apesar de não o afastar absolutamente, acaba por relativizar o princípio da inafastabilidade da jurisdição, não por força de seus fundamentos, mas sim em busca dos melhores resultados.

Diante de tal cenário, o Comitê de Ministros recomenda aos estados membros da União Europeia, no apêndice da Recomendação no $\operatorname{Rec}(2001) 9$, a adoção de cinco modalidades de solução consensual de conflitos: recursos administrativos, conciliação, mediação, acordos negociados e arbitragem. Podemos traçar um claro paralelo entre a categoria de "acordos negociados" e a

\footnotetext{
${ }^{721}$ JANSEN, Oswald. Administration by negotiation in the Netherlands, national report. In: RIEDEL, Eibe; SCHMIDT-ASSMANN, Eberhard (eds.). Die Bedeutung von Verhandlungslosungen im Verwaltungsrecht. Baden-Baden: Nomos, 2002. P. 68-120.

722 UNIÃO EUROPEIA. CONSELHO da Europa. Recommendation 2001-9 of the Committee of Ministers to member states on alternatives to litigation between administrative authorities and private parties. Estrasburgo: Éditions du Conseil de l'Europe, 2001.

${ }^{723}$ UNIÃO EUROPEIA. CONSELHO da Europa. Recommendation 2001-9 of the Committee of Ministers to member states on alternatives to litigation between administrative authorities and private parties. Estrasburgo: Éditions du Conseil de l'Europe, 2001. Tradução nossa.
}

No original: "[...] the courts' procedures in practice may not always be the most appropriate to resolve administrative disputes". 
transação extrajudicial aqui abordada, demonstrando que, também nesse particular - assim como observado na constitucionalização do direito fundamental à boa administração pública -, a União Europeia ocupa posição de considerável protagonismo.

$\mathrm{Na}$ Inglaterra, a análise da solução consensual de conflitos na administração pública tem como maior expoente o trabalho de Patrick Birkinshaw. O autor expõe o regime de "reparação extrajudicial de queixas" em face do Estado que, no caso inglês, é concentrado nas metodologias de reparação política, reparação judicialiforme em cortes administrativas ou por arbitragem, consultas e audiências públicas - para os casos de interesse difuso e coletivo - e, naquilo que mais toca ao tema dessa tese, a resolução interna, formal ou informal, de querelas. ${ }^{724}$

O autor demonstra que, no caso inglês, é ampla a admissão da solução de conflitos no âmbito administrativo, seja perante a própria autoridade relacionada ao caso, seja perante autoridades internas especializadas na apreciação de demandas. Simbolicamente, o texto relega ao seu final a análise da solução judicial dos conflitos entre particulares e a Administração. Cabe ressaltar, no entanto, a preocupação demonstrada, no cenário inglês, com as possíveis distorções que podem advir das metodologias informais de solução consensual interna de conflitos. $^{725}$

Ainda no círculo de influência da common law, destaca-se a iniciativa dos Estados Unidos da América para a extensa implementação de práticas de solução consensual de conflitos (alternative dispute resolution) na Administração Pública. Em 1998, por um Memorando Presidencial expedido em $1^{\circ}$ de maio, o governo Clinton criou o Interagency Alternative Dispute Resolution Working Group, grupo de trabalho que reúne representantes de cada uma das agências

${ }^{724}$ BIRKINSHAW, Patrick. Grievances, remedies and the State. Oxford Journal of Legal Studies, Oxford, v. 7, n. 1, p. 125-135, prim. 1987.

Ampliado para:

BIRKINSHAW, Patrick. Grievances, remedies and the State. London: Sweet \& Maxwell, 1994. Passim.

${ }^{725}$ BIRKINSHAW, Patrick. Grievances, remedies and the State. London: Sweet \& Maxwell, 1994. Passim. 
governamentais federais no sentido de implementar programas e políticas de solução consensual de conflitos que envolvam a Administração Pública estadunidense. A criação do grupo de trabalho visou à plena efetividade do Alternative Dispute Resolution Act, lei daquele país que procurou consolidar o manejo de soluções consensuais de conflitos por todo o sistema jurídico. ${ }^{726}$

\section{A atuação do Interagency Alternative Dispute Resolution Working Group} tem como foco a implementação de programas de solução consensual de conflitos em quatro áreas específicas: conflitos no ambiente de trabalho, licitações e contratos, poder de polícia e regulação, e litígios instaurados. A atuação do grupo de trabalho é liderada pelo Office of Dispute Resolution do Departamento de Justiça estadunidense, órgão que se dedica, entre outras incumbências, a "facilitar o efetivo uso de soluções consensuais de conflitos em litígios e em questões administrativas perante as agências". ${ }^{727}$

No entanto, entre os países integrantes da tradição do direito consuetudinário, de raízes britânicas, o sistema que mais se destaca é o australiano, com uma intrincada rede de tribunals destinada à solução de questões administrativas e, muitas vezes, destinados exclusivamente à solução consensual de conflitos na Administração. No sistema da common law, tribunal é conceituado como sendo

[...] o órgão criado por lei para decidir pleitos e disputas conectas à administração de sistemas legislativos [ou seja, a atividade do Poder Executivo], normalmente de natureza prestacional ou regulatória. Eles existem fora do Poder Judiciário, mas suas decisões são sujeitas a controle judicial [...]. ${ }^{728}$

Assim, nem todos os tribunals são necessariamente caracterizados como órgãos de julgamento de questões administrativas, uma vez que muitos deles têm características de espaços de conciliação, de solução de conflitos intermediada

\footnotetext{
${ }^{726}$ ESTADOS UNIDOS DA AMÉRICA. Alternative Dispute Resolution Act. Public Law, Washington, v. 105, n. 315 , p. 2.993-2.998, 30 out. 1998.

${ }^{727}$ ESTADOS UNIDOS DA AMÉRICA. INTERAGENCY Alternative Dispute Resolution Working Group. Report for The President on the use and results of alternative dispute resolution in the Executive branch of the Federal Government. Washington: Department of Justice, 2007.

${ }^{728}$ MARTIN, Elizabeth. The Oxford Dictionary of Law. Oxford: Oxford University, 2003. P. 13 (Tradução nossa).
} 
pela Administração Pública, ou de regulação profissional, e não necessariamente contam com a natureza de órgão dedicado à atuação judicialiforme em demandas perante a Administração. É o caso, por exemplo, do estado da Tasmania, que conta com oito tribunals, entre eles o Medical Practitioners Tribunal, o Motor Accidents Compensation Tribunal e o Workers Rehabilitation and Compensation Tribunal.

Quatro estados australianos e o Australia Capital Territory contam com órgãos de julgamento administrativo que se caracterizam como entes quasijudiciais para a solução de conflitos com a Administração Pública. Em Western Australia há o State Administrative Tribunal; Queensland conta com o Queensland Civil and Administrative Tribunal; em New South Wales estão instalados o NSW Civil and Administrative Tribunal e o Administrative Decisions Tribunal; em Victoria há o Victorian Civil and Administrative Tribunal; há, ainda, o Australian Capital Territory Civil and Administrative Tribunal.

Esses Tribunals servem tanto de espaços para a veiculação de pleitos perante a Administração Pública quanto de órgãos de segundo grau para recursos em face de atos administrativos praticados pelos diversos órgãos estatais. Suas decisões estão sujeitas ao controle judicial mas, via de regra, tal controle é exercido pelos órgãos de segundo grau da justiça estadual, havendo assim verdadeira supressão de instância - uma vez que o primeiro grau jurisdicional é substituído pela decisão do Tribunal -, tal como pretendido, no Brasil, pelo art. 205 da Emenda Constitucional no 1/1969 à Constituição de 1967, com a redação dada pela Emenda Constitucional $n^{\circ} 7 / 1977$.

No âmbito federal há, por sua vez, o Administrative Appeals Tribunal, criado pelo Administrative Appeals Tribunal Act de 1975 e iniciando as suas atividades em 1976. ${ }^{729} \mathrm{O}$ Administrative Appeals Tribunal não possui, no entanto, uma competência geral de revisão de quaisquer atos administrativos praticados pelos órgãos da administração pública federal australiana; assim como ocorre com as inferior courts, a competência do Administrative Appeals Tribunal é fixada pela

\footnotetext{
${ }^{729}$ AUSTRALIA. Administrative Appeals Tribunal Act 1975. Canberra: Commonwealth Consolidated Acts, 2013.
} 
lei - ou act - que regulamenta aquela matéria, cabendo ao diploma determinar que caberá recurso da decisão administrativa ao Administrative Appeals Tribunal. ${ }^{730}$

Tal circunstância, no entanto, não deságua em um estreitamento da competência desse tribunal, uma vez que mais de quatrocentos instrumentos legislativos australianos preveem a revisão de atos administrativos pelo AAT. As suas principais áreas de atuação, com base em tais disposições, gravitam em torno da assistência familiar e social, previdência, tributação, veteranos de guerra, servidores públicos, regulação econômica, cidadania e imigração, aviação civil, liberdade de informação e transparência, questões aduaneiras e segurança pública. $^{731}$

O Administrative Appeals Tribunal exerce um importantíssimo papel na resolução de conflitos com a administração pública na Australia, em especial no tocante à eficientização de procedimentos e viabilização do acesso à justiça. Enquanto 7.263 procedimentos foram iniciados entre 2013 e 2014, 6.748 procedimentos foram julgados no mesmo período, ${ }^{732}$ o que demonstra a considerável contribuição que um sistema organizado de solução consensual de conflitos na administração pública pode trazer à eficiência no julgamento das demandas perante o Estado.

A experiência da África do Sul - cuja comparação com o Brasil já é usual em matéria econômica no âmbito dos BRICS, como já mencionado - é apreciada por Geo Quinot, notando que o recurso administrativo a soluções consensuais de conflitos naquele país é consideravelmente raro, não havendo normas específicas para a solução de tais disputas pelo método extrajudicial. Quinot destaca, no entanto, o recente desenvolvimento de precedentes acerca da adoção de métodos consensuais de resolução de conflitos - entre eles, da transação - para a solução de questões relacionadas a licitações e contratos administrativos, em que o Judiciário tem se posicionado, tal como no caso holandês, pela impossibilidade da

\footnotetext{
730 PEARCE, Dennis. Administrative Appeals Tribunal. Sidney: Butterworths, 2007.

${ }^{731}$ AUSTRALIA. Administrative Appeals Tribunal 2013-14 Report. Sidney: AAT, 2013.

${ }^{732}$ AUSTRALIA. Administrative Appeals Tribunal 2013-14 Report. Sidney: AAT, 2013. P. 23-38.
} 
adoção de métodos consensuais de solução de conflitos em matérias afetas ao direito administrativo. ${ }^{733}$

Ainda em relação aos BRICS, a Índia conta com tímidas iniciativas no campo de solução consensual de conflitos na administração pública, concentradas especialmente em matéria de direito do consumidor, tributação da renda e danos causados pelo transporte ferroviário estatal. Nesse particular, o cenário indiano contempla alguns órgãos judicialiformes, no modelo de tribunals, aos quais incumbe cumprir com tal função. ${ }^{734}$

O confronto do cenário brasileiro com o dos países expostos revela importantes traços acerca dos inúmeros desafios opostos à adoção da transação extrajudicial pela Administração Pública brasileira. O que se verifica é que, apesar da tendência historicamente consolidada de importação de institutos estrangeiros, em especial do direito administrativo francês, quando tratamos da postura do gestor público nossas características se aproximam muito mais de países de estatura econômica semelhante, como a África do Sul.

Essa análise comparativa revela a necessidade, já detectada como último dos desafios operacionais à transação extrajudicial na administração pública, de um câmbio cultural que implique na mudança da postura dos gestores públicos. Após a abordagem dos requisitos e das hipóteses de cabimento da transação extrajudicial, que se desenvolve a seguir, o trabalho é concluído com o delineamento de diretrizes gerais para que se obtenha esse câmbio, como se procede a seguir.

\subsection{Balizas para a adoção administrativa da transação extrajudicial}

O estudo das diversas experiências, tanto brasileiras quanto estrangeiras, de transação extrajudicial na Administração Pública, faz transparecer

\footnotetext{
${ }^{733}$ QUINOT, Geo. Public procurement. Juta's Quarterly Review of South African Law, Lansdowne, n. 1, p. 5, jan.-mar. 2013.

734 ÍNDIA. DEPARTMENT of Legal Affairs. Good governance: Department of Legal Affairs. New Delhi: Ministry of Law and Justice, 2014.
} 
a necessidade de que se estabeleçam balizas razoáveis para o aprimoramento do seu manejo no direito administrativo brasileiro.

É que, como o extenso estudo dos casos observados no Brasil faz transparecer, as iniciativas brasileiras nesse campo ainda não dão plena vazão a todas as potencialidades da transação extrajudicial como método de aproximação democrática pela consensualidade entre Estado e cidadãos. Nesse sentido, observa-se que as experiências da União e as normas relativas à transação judicial nos Juizados Especiais Federais e da Fazenda Pública adotam um fetiche legalista que não coaduna com todo o exposto nessa tese acerca do verdadeiro sentido de juridicidade no direito administrativo, acabando por deitar por terra a aplicação prática da transação pela Administração Pública.

As experiências dos Estados e dos Municípios, por sua vez, apesar de ter o interessante foco sobre o protagonismo do processo administrativo na solução de conflitos, são por mais das vezes direcionadas a casos específicos, e não se dedicam a instituir uma aplicação ampla da transação para a solução dos diversos conflitos em que se envolve a Administração Pública.

Em geral, observa-se que as experiências brasileiras em soluções consensuais de conflitos na Administração Pública recorrem pouco à transação extrajudicial - tendo um maior comprometimento com a conciliação e a arbitragem -, deixando assim de lograr proveito da preferencialidade comparativa que a transação extrajudicial guarda em relação às demais modalidades, tal como exposto na primeira parte da tese.

Diante de tal cenário, o modelo de câmaras de conciliação e arbitragem da Administração Pública, ainda incipiente, propugnado pela Lei $n^{\circ}$ 13.140/2015 e pelo novo Código de Processo Civil, deixa igualmente de revolucionar a visão brasileira sobre a transação extrajudicial na Administração Pública. Em primeiro lugar, como é evidente, o seu foco sobre medidas de conciliação e arbitragem deixa de conferir proveito das potencialidades da transação extrajudicial, que é distorcida na figura da "transação por adesão". Ainda, a postura formalista adotada guarda em si os riscos de tornar a solução de conflitos com a Administração Pública ainda 
mais burocrática e vagarosa, fomentando medidas desnecessárias como a figura dos quasi-precatórios observada na experiência do Rio Grande do Norte.

O confronto do cenário brasileiro com as experiências estrangeiras é igualmente revelador.

Aqui, a longa tradição do direito administrativo brasileiro de importar figuras jurídicas do direito europeu - em especial da França -, que se revela desde os seus primórdios ${ }^{735}$ e se espraia até os nossos dias, ${ }^{736}$ falhou em trazer as positivas experiências consolidadas naquele continente para a prática de nossa Administração.

É curioso observar que o Brasil se afasta mais da tradição continental do que os próprios países da common law que, apesar de discursarem pela aplicação irrestrita do direito comum, contam com notáveis experiências de estruturação e normatização administrativas com vistas à efetiva adoção de soluções consensuais de conflitos, inclusive a transação extrajudicial, pela Administração Pública.

Resta visto, pois, que a postura brasileira se aproxima muito mais de seus pares econômicos, representados aqui pela Índia e pela África do Sul, em que as experiências com a solução consensual de conflitos na administração pública ainda são tímidas e, ademais, questionadas em sua validade pelo Poder Judiciário.

O cenário assim delineado reclama, portanto, o delineamento de algumas balizas para a conformação de programas de transação extrajudicial na administração pública brasileira. Cabe ressaltar que boa parte desses parâmetros do ótimo foram expostos ao longo da tese, motivo pelo qual os tópicos seguintes se dedicam a duas particularidades: a delimitação dos requisitos de validade e a exemplificação de hipóteses de cabimento para a transação extrajudicial que tenha como parte a Administração Pública. Com base nesses parâmetros, o trabalho

\footnotetext{
${ }^{735}$ URUGUAY, Paulino José Soares de Sousa, Visconde do. Ensaio sobre o direito administrativo. Rio de Janeiro: Typographia Nacional, 1862. V. 1, p. XVII.

${ }^{736}$ SCHIRATO, Vitor Rhein. A interação entre Administração Pública e particulares nos contratos administrativos. Fórum de Contratação e Gestão Pública, Belo Horizonte, a. 12, n. 138, p. 51-69, jun. 2013.
} 
intenta, enfim, expor diretrizes para que a experiência brasileira possa cada vez mais se aproximar das melhores técnicas observadas no cenário internacional.

\subsubsection{Requisitos de Validade}

O presente trabalho se posiciona contundentemente pela desnecessidade de autorização legislativa específica para que a Administração Pública lance mão da transação extrajudicial na solução dos conflitos em que se envolva. Tal postura, no entanto, não impede que sejam adotados parâmetros normativos de validade para as transações entabuladas pelos entes estatais, seja em decorrência do regime juridico civil próprio da transação, seja por força das sujeições de Direito do Estado a que se encontra adstrita a Administração.

A análise é cindida, assim, em dois momentos, sendo que o primeiro se dedica aos requisitos de validade baseados no regime privatístico, enquanto 0 derradeiro relaciona os requisitos que tocam ao direito administrativo.

Onofre Alves Batista Júnior elege cinco requisitos, tidos como "elementos básicos", para que a Administração Pública se utilize da transação, na via administrativa ou judicial: "1. relação jurídico-administrativa controvertida [...]; 2. vontade de transigir; 3 . capacidade do interessado e competência administrativa para transigir; 4. objeto litigioso transacionável (direito disponível ou lei que autorize a transação); 5. concessões recíprocas". ${ }^{737}$ À evidência, como já exposto, a diferença de tratamento por nós dispensado à natureza jurídica da transação extrajudicial da Administração Pública distancia nosso posicionamento em parte do de Batista Júnior, em especial quanto à desnecessidade de "lei que autorize a transação".

Tratando da transação extrajudicial da Administração Pública, em relatório de pesquisa dedicado ao tema, o Centro Nacional de Pesquisa Científica francês (CNRS - Centre National de la Recherce Scientifique) indica quatro requisitos de validade para os contratos de transação na administração pública: a

${ }^{737}$ BATISTA JÚNIOR, Onofre Alves. Transações administrativas: um contributo ao estudo do contrato administrativo como mecanismo de prevenção e terminação de litígios e como alternativa à atuação administrativa autoritária, no contexto de uma administração pública mais democrática. São Paulo: Quartier Latin, 2007. P. 328. 
capacidade das partes para transigir (neste caso, da contraparte privada), incluída aí a competência do representante da parte para transigir e o cumprimento de procedimentos autorizativos específicos exigidos para o objeto da transação; a licitude do objeto da transação; a existência de um litígio efetivo, seja potencial ou corrente; o consentimento acerca das concessões recíprocas, que devem ter uma "consistência mínima", ainda que não equivalentes. ${ }^{738}$

No cenário italiano, Domenico Sorace destaca que as submissões relacionadas ao regime privatístico consistiriam na aplicação de princípios gerais de direito civil em matéria de obrigações e contratos, na adoção da forma escrita, na possibilidade de indenização ao particular em caso de revogação do acordo, e na ausência de prejuízos a terceiros. ${ }^{739}$

Especificamente no cenário brasileiro, tendo em vista as disposições atuais do direito positivo brasileiro, somente pela forma escrita é que se celebra a transação, nos termos do art. 842 do Código Civil. ${ }^{740}$ Tal disposição o difere substancialmente de outros ordenamentos, como o da Inglaterra, que acaba por admitir a solução informal de conflitos na seara admnistrativa. ${ }^{741}$

\footnotetext{
${ }^{738}$ FRANÇA. CENTRE National de la Recherce Scientifique. Accords transactionnels. Paris: CNRS, 2003.

739 SORACE, Domenico. Diritto delle amministrazioni pubbliche: Una introduzione. Bologna: ॥ Mulino, 2000. P. 303-312.

${ }^{740}$ NERY JUNIOR, Nelson; NERY, Rosa Maria de Andrade. Código Civil Comentado. São Paulo: Revista dos Tribunais, 2013. P. 888.
}

No mesmo sentido:

MALUF, Carlos Alberto Dabus. Da transação. In: FIUZA, Ricardo. Novo Código Civil comentado. São Paulo: Saraiva, 2003.

${ }^{741}$ BIRKINSHAW, Patrick. Grievances, remedies and the State. London: Sweet \& Maxwell, 1994. Passim.

Parte da literatura confere elasticidade tal à possibilidade de recurso pela Administração a instrumentos privados que propõe cenários dificilmente admissíveis como padrão aos olhos da doutrina tradicional. Bernardo Diniz de Ayala reconhece, por exemplo, a possibilidade de tutela jurisdicional das negociações informais realizadas entre o Estado e os particulares, com base na aplicabilidade do princípio da boa fé ao regime juspublicístico. A penetração do Estado na seara privada de atuação, assim, atrairia ainda mais a exigência de boa fé - conforme seu entendimento, de raízes milenares no regime jurídico privado -, não servindo o apego à legalidade estrita como impeditivo ao seu reconhecimento. Sumariza o autor: "[...] muito embora as concertações informais não produzam efeitos jurídicos válidos de direito administrativo, os intervenientes no respectivo procedimento terão a tutela que, em cada caso, resultar da incidência, também inafastável, do princípio da boa fé. [...] Dir-se-ia, pois, que as implicações da boa fé, no terreno da actuação administrativa informal, são fundamentalmente as que resultam dos mecanismos de responsabilidade civil [grifos do autor]." (AYALA, Bernardo Diniz. Actividade contratual e 
Ainda com base no direito civil brasileiro, é de se ressaltar que a transação extrajudicial da Administração Pública deve limitar os seus efeitos às partes que dela tomam parte, não sendo oponível contra terceiros, uma vez que, nas palavras de Orlando Gomes, a "transação é res inter alios acta. Não aproveita, nem prejudica, senão aos que nela intervieram". ${ }^{742}$

De especial importância - e considerável problemática - é o elemento "concessões mútuas" do conceito de transação. Com origem no Código de Justiniano, ${ }^{743}$ a necessidade de concessões recíprocas entre as partes de uma transação significaria que, para a essência da transação, seria necessário que cada parte realizasse um "sacrifício real e quantificável" de seu direito. ${ }^{744}$

Assim, como destaca Maria Helena Diniz, a transação no direito romano - tanto no entendimento de Ulpiano ${ }^{745}$ quanto no Código de Justiniano - "destinavase a extinguir uma obrigação, por ser uma convenção em que alguém renunciava a um direito em litígio, recebendo, porém, uma retribuição", de modo que a existência de concessões recíprocas "constituía pressuposto essencial, verdadeira condição jurídica, da transação" ${ }^{746}$ Como expõe a autora, o direito brasileiro herdou tal disposição, exigindo a onerosidade da transação constituída pela reciprocidade de concessões. É o que sustenta Pontes de Miranda, de importantíssima visão

negociações informais da administração: Dois modos comuns de actuação administrativa com oscilações na tutela jurisdicional do particular. In: FACULDADE de Direito da Universidade de Lisboa. Estudos em homenagem ao Prof. Doutor Sérvulo Correia. V. II. Coimbra: Coimbra Editora, 2010. P. 239-276). O presente estudo não adere a tal esgarçamento, seja por uma questão de carência fundamental em seu bojo, seja pela própria desnecessidade de tal concessão para que se admita a transação extrajudicial - notadamente ritualística - pela Administração Pública.

${ }^{742}$ GOMES, Orlando. Contratos. Rio de Janeiro: Forense, 1988. P. 546.

743 JARROSSON, Charles. Les concessions réciproques dans la transaction. Recueil Dalloz, Paris, chroniques, p. 267-273, 1997.

É interessante notar que, como Jarrosson destaca, mesmo que o Código Civil francês não enumere, em seu art. 2.044, as concessões recíprocas como elemento do conceito de transação, a jurisprudência francesa exige a existência de concessões recíprocas como condição de validade conceitual da transação.

744 JARROSSON, Charles. Les concessions réciproques dans la transaction. Recueil Dalloz, Paris, chroniques, p. 267-273, 1997. Tradução nossa.

A expressão original: "sacrifice réel et chiffrable".

${ }^{745}$ Como destaca Pontes de Miranda, Ulpiano trata da transação na L. 11, D., de transactionibus (MIRANDA, Francisco Cavalcanti Pontes de. Tratado de Direito privado: Parte especial. V. 25. Rio de Janeiro: Borsoi, 1959. P. 122).

${ }^{746}$ DINIZ, Maria Helena. Curso de Direito Civil Brasileiro: Teoria das Obrigações Contratuais e Extracontratuais. Sâo Paulo: Saraiva, 2010. P. 604. 
histórica, ao afirmar que "se não há concessão, de um e de outro, não há transação: o que pode haver é reconhecimento, renúncia, desistência, ou outra figura." 747

No entanto, como Jarrosson destaca, o entendimento jurisprudencial e doutrinário evoluiu para flexibilizar-se, no sentido de aceitar que a renúncia de recorrer ao judiciário para obter um pronunciamento sobre o litígio constituiria concessão suficiente para caracterizar a transação. ${ }^{78}$

O pensamento de Géraldine Chavrier contribui para a problematização ao destacar que, frente ao poder de autotutela que assiste à Administração, a renúncia ao recurso ao judiciário poderia ser considerada insuficiente a título de concessão da parte pública, o que poderia, inclusive, afastar a natureza civil da transação celebrada pelo Estado. A autora conclui, analisando o direito francês, que a "transação procedural" - nome que confere à transação cuja concessão é a dita renúncia - seria possível, assim, em relação às transações indenizatórias, que discutam puramente o direito patrimonial privado. ${ }^{749}$ Ressalvamos aqui não aderir à posição de Chavrier, uma vez que entendemos não assistir à Administração, ao firmar transação extrajudicial, a prerrogativa de revogá-la por motivos de conveniência ou oportunidade; no entanto, podemos atingir o mesmo resultado de aceitar a renúncia ao recurso ao judiciário como um elemento de concessão apto a caracterizar a transação que tenha como parte um ente estatal.

Diante de tal panorama, a lição de Pontes de Miranda já nos direcionava no sentido de que a concessão pode consistir em alteração da eficácia ou do conteúdo da relação jurídica e, assim, consiste concessão, para fins de transação, mesmo modulações do tempo para o cumprimento da obrigação. ${ }^{750}$ Nesse sentido,

[a] concessão, que se faz, é em relação ao que cada um dos transatores sustenta (= crê que é o seu direito, pretensão, ação, ou exceção), não em relação ao que, em verdade, no mundo jurídico,

\footnotetext{
${ }^{747}$ MIRANDA, Francisco Cavalcanti Pontes de. Tratado de Direito privado: Parte especial. V. 25. Rio de Janeiro: Borsoi, 1959. P. 132.

748 JARROSSON, Charles. Les concessions réciproques dans la transaction. Recueil Dalloz, Paris, chroniques, p. 267-273, 1997.

${ }^{749}$ CHAVRIER, Géraldine. Réflexions sur la transaction administrative. Revue Française de Droit Administratif, Paris, n. 3, p. 548-566, mai.-jun. 2000.

${ }^{750}$ MIRANDA, Francisco Cavalcanti Pontes de. Tratado de Direito privado: Parte especial. V. 25. Rio de Janeiro: Borsoi, 1959. P. 132-133.
} 
que independe do que pensam os interessados, é o direito, a pretensão, a ação ou a exceção de cada um [grifos no original]. ${ }^{751}$

Também Luiz da Cunha Gonçalves dispensava ao tema tratamento hoje invulgar, sustentando que as concessões, apesar de recíprocas, poderiam não ser equivalentes. Nessa medida, em alguns casos, a concessão poderia resultar em vantagens tão somente morais para a outra parte, como "evitar escândalo por efeito de certo litígio". ${ }^{752}$

A célebre Circular de 6 de fevereiro de 1995, em que o Primeiro Ministro francês recomenda a adoção da transação para solucionar conflitos da Administração Pública, dá solução a este problema ao sustentar que, mesmo não sendo exigido um equilíbrio absoluto, as transações entabuladas pelo Estado devem ser dotadas de uma "consistência mínima" em termos sinalagmáticos.

Enfim, para Onofre Alves Batista Júnior, "[a] transação administrativa é instituto essencialmente pragmático que surgiu da prática social, portanto, o simples abrir mão de manter o conflito não deixa de ser uma possível concessão". ${ }^{753}$

Já quanto à abordagem dos requisitos próprios do direito administrativo, podemos extrair da experiência italiana, tal como destacado por Domenico Sorace, que os acordos da Administração Pública, sejam integradores ou substitutivos, se submetem a uma disciplina que Ihes vincula, sob o regime publicístico, ao necessário perseguimento do interesse público, à possibilidade de revogação por motivos supervenientes de interesse público, à sua inserção em um procedimento administrativo, e à submissão à jurisdição exclusiva do juiz administrativo. ${ }^{754}$

\footnotetext{
${ }^{751}$ MIRANDA, Francisco Cavalcanti Pontes de. Tratado de Direito privado: Parte especial. V. 25. Rio de Janeiro: Borsoi, 1959. P. 132.

${ }^{752}$ GONÇALVES, Luiz da Cunha. Tratado de Direito Civil. São Paulo: Max Limonad, 1956. V. 9, t. 1, p. 439.

753 BATISTA JÚNIOR, Onofre Alves. Transações administrativas: um contributo ao estudo do contrato administrativo como mecanismo de prevenção e terminação de litígios e como alternativa à atuação administrativa autoritária, no contexto de uma administração pública mais democrática. São Paulo: Quartier Latin, 2007. P. 329.

754 SORACE, Domenico. Diritto delle amministrazioni pubbliche: Una introduzione. Bologna: II Mulino, 2000. P. 303-312.
} 
Ressalvamos aqui, tal como já exposto em relação ao entendimento de Géraldine Chavrier, que nos posicionamos contrários à possibilidade de revogação administrativa do contrato de transação. No entanto, nesse particular, o pensamento de Domenico Sorace se destaca ao sustentar que a Administração deverá indenizar o particular caso revogue a transação por superveniente motivo de interesse público. De mesmo modo, frente à jurisdição una que se observa no Brasil, o último de seus requisitos se torna irrelevante e, não fosse o caso, não se aplicaria no cenário brasileiro, em que a transação extrajudicial entabulada pelo Estado ostenta natureza jurídica de contrato privado da Administração.

Jorge Ulisses Jacoby Fernandes destaca, por sua vez, os requisitos que acredita exigíveis do processo administrativo em que se entabule a transação extrajudicial, no sentido em que: haja a concreta quantificação da vantajosidade da avença para a Administração; haja manifestação expressa de órgão de controle interno; sejam adotadas as cautelas instrutórias que se mostrem necessárias; e seja exarado parecer do órgão jurídico, que indique "fundamentadamente, a impossibilidade de êxito ou possibilidade muito remota" em eventual demanda judicial, consolidando assim a vantajosidade no manejo do contrato. ${ }^{755}$

É de se destacar que, como já procedido no capítulo que se dedicou à ressignificação do dever de juridicidade na Administração Pública, apesar de não ser exigível autorização legislativa específica para que seja admissível a transação extrajudicial na administração pública, é possível que seja necessária norma que fixe a competência para a firmatura de um contrato de transação. Trata de diferencia-se, desse modo, uma norma acerca da função da Administração de uma norma que trate de sua estrutura.

Nesse sentido, admitimos ser possível a exigência de uma regra para que certo agente público tenha a competência para celebrar transações em nome do órgão a que pertença. ${ }^{756}$ No entanto, isso não implicaria em uma necessidade

\footnotetext{
${ }^{755}$ FERNANDES, Jorge Ulisses Jacoby. Acordos administrativos e judiciais. Forum Administrativo, Belo Horizonte, a. 6, n. 59, jan. 2006.

${ }^{756}$ Ana Celeste Carvalho entende que a adoção de métodos de solução consensual de conflitos pela Administração Pública dependeria de autorização legislativa, não pela incidência pura do princípio da legalidade, mas sim por uma necessidade de fixação adequada de competência para que a Administração Pública recorresse à solução consensual (CARVALHO, Ana Celeste. A
} 
a priori de norma que fixe a competência já que, na sua ausência, o chefe de poder - ocupante, portanto, da mais alta posição hierárquica na Administração - sempre contará com a competência para tanto. Igualmente se posiciona Adilson Abreu Dallari, expondo o entendimento de que a atribuição genérica de competência para representar o ente em relações jurídicas ou para celebrar contratos, comumente presente em constituições e leis orgânicas de entes da Administração Direta, seria autorização legal suficiente para que o chefe do Poder Executivo celebrasse contratos de transação extrajudicial em nome do ente. ${ }^{757}$

Por fim, cabe ainda especificar, como já antecipado no capítulo que representa a metade anterior da segunda parte dessa obra, que a submissão aos procedimentos e limites do regime de precatórios não é considerada um requisito de validade da transação extrajudicial da Administração Pública, frente à natureza contratual da avença.

\subsubsection{Hipóteses de cabimento}

Estabelecidos, em linhas gerais, os parâmetros para a apuração da validade de um contrato privado de transação extrajudicial da Administração Pública, o trabalho volta o seu foco a aclarar as hipóteses em que se considere cabível o recurso à transação extrajudicial para a solução de controvérsias estatais. No entanto, cabe aqui ressaltar que o tratamento dado a tais hipóteses é meramente exemplificativo, e visa brevemente a despertar a visão do leitor às inúmeras potencialidades que residem no bojo da transação extrajudicial na administração pública.

Isso se sustenta pois, como destacam Carlos Ari Sundfeld e Jacintho Arruda Câmara, "[n]ão existe regra jurídica expressa que proíba a adoção do acordo (judicial ou extrajudicial) por parte da Administração Pública". ${ }^{758}$ Nesse sentido, considera-se recomendável que as eventuais normas que venham a tratar

mediação em matéria administrativa: uma possibilidade com futuro. Cadernos de Justiça Administrativa, Braga, n. 109, p. 3-12, jan./fev. 2015).

${ }^{757}$ DALLARI, Adilson Abreu. Viabilidade da transação entre o poder público e particular. Interesse Público, Belo Horizonte, a. 4, n. 13, jan.-mar. 2002.

758 SUNDFELD, Carlos Ari. CÂMARA, Jacintho Arruda. Acordos na execução contra a Fazenda Pública. Revista Eletrônica de Direito Administrativo Econômico, Salvador, n. 23, ago.-out. 2010. 
do assunto, quando existentes, admitam a transação de forma ampla, para que ela se conforme como um método de solução consensual de conflitos, e não de uma categoria de conflitos em particular.

É dizer, como sustenta o Comitê de Ministros do Conselho da Europa, que

[m]étodos alternativos à litigância deveriam ser ou geralmente permitidos, ou permitidos nos casos em que se consideram apropriados, em particular naqueles referentes a atos administrativos de efeitos individuais, contratos, responsabilidade civil e, de maneira geral, demandas que se relacionem a prestações pecuniárias. ${ }^{759}$

Os acordos integradores e substitutivos, figuras típicas do direito administrativo italiano - que, como visto, servem de base a diversos posicionamentos nacionais em torno da transação extrajudicial na administração pública -, são cabíveis, de acordo com Domenico Sorace, em matéria de concessões, desapropriação, urbanismo e limitações administrativas. ${ }^{760}$ Veja-se que tais figuras não são admitidas para a solução da responsabilidade extracontratual do Estado, o campo mais promissor para a aplicação da transação extrajudicial no Brasil, circunstância que enfraquece consideravelmente os modelos que tomam tal referencial para a sua conformação.

Já no cenário Francês, que trata especificamente da figura da transação extrajudicial na administração pública, Géraldine Chavrier destaca a possibilidade de transação em relação a direitos objetivos, direitos subjetivos e direitos repressivos. Nesse sentido de admissibilidade ampla, portanto, o "respeito à ordem pública" se postaria como limite à liberdade contratual na transação. ${ }^{761}$ Chavrier destaca, ainda, que o estudo do Conselho de Estado francês "Régler autrement les

759 UNIÃO EUROPEIA. CONSELHO da Europa. Recommendation 2001-9 of the Committee of Ministers to member states on alternatives to litigation between administrative authorities and private parties. Estrasburgo: Éditions du Conseil de l'Europe, 2001. Tradução nossa.

No original: "Alternative means to litigation should be either generally permitted or permitted in certain types of cases deemed appropriate, in particular those concerning individual administrative acts, contracts, civil liability, and generally speaking, claims relating to a sum of money".

760 SORACE, Domenico. Diritto delle amministrazioni pubbliche: Una introduzione. Bologna: II Mulino, 2000. P. 313.

${ }^{761}$ CHAVRIER, Géraldine. Réflexions sur la transaction administrative. Revue Française de Droit Administratif, Paris, n. 3, p. 548-566, mai.-jun. 2000. 
conflits: Conciliation, transaction, arbitrage en matière administrative"762 cita especificamente a possibilidade de transação no tocante aos mercados públicos e contratos, enquanto a Circular de 15 de fevereiro de 1995 do Primeiro Ministro francês, relativa ao desenvolvimento do recurso à transação para a solução consensual dos conflitos da Administração Pública, não limite as suas disposições a quaisquer hipóteses específicas.

No cenário brasileiro, a hipótese de cabimento de transação extrajudicial na administração pública que mais evidentemente se destaca é a solução da responsabilidade civil do Estado, mais detidamente apreciada no tópico que se dedicou, no início do presente capítulo, ao estudo das experiências brasileiras no recurso à transação extrajudicial pela Administração Pública. Nesse particular, como exposto, o grande fundamento para todo um sistema de solução consensual dos conflitos da Administração Pública reside nas disposições do $\S 6^{\circ}$ do art. 37 da Constituição Federal, que institui a responsabilidade civil objetiva do Estado, independentemente de qualquer procedimento judicial.

A aplicação da transação extrajudicial nesse particular, no entanto, não repousa livre de riscos. É de grande valia, pois, destacar a necessidade de que sejam tomadas as preocupações para que a responsabilidade civil do Estado não seja ampliada a ponto de transformá-lo em segurador universal, devendo sempre ser observado o estrito e decisivo nexo de causalidade entre a atividade estatal e o dano experimentado pelo particular.

Cabe resguardar-se, portanto, como alerta Alexandre Santos de Aragão, par que o patrimônio estatal não seja visto "menos como uma res publica e mais como uma res nullius".

Tais cuidados não devem, no entanto, impossibilitar o recurso à transação extrajudicial para a solução da responsabilidade civil do Estado, como pretendem alguns autores, frente à eventual possibilidade de que a Administração afaste a sua obrigação de indenizar por circunstâncias próprias do procedimento

762 FRANÇA. CONSELHO de Estado Francês. Régler autrement les conflits (coleção Les Études du Conseil d'Etat). Paris: Documentation Française, 1993.

${ }^{763}$ ARAGÃO, Alexandre Santos de. Os Fundamentos da Responsabilidade Civil do Estado. Revista Eletrônica de Direito do Estado, Salvador, n. 27, jul.-set. 2011. 
judicial. ${ }^{764}$ Essa postura, como visto, decorre de uma grave distorção do verdadeiro sentido da indisponibilidade dos interesses públicos, e não coaduna com a missão institucional do Estado brasileiro que decorre de sua atual ordem constitucional.

Também em matéria de licitações e contratos administrativos vislumbrase a potencialidade de recurso à transação extrajudicial. Num primeiro momento, é de se observar que, apesar da extensão das normas publicísticas do regime brasileiro de contratações públicas, o art. 54 da Lei no 8.666/1993 admite que se apliquem aos contratos administrativos, "supletivamente, os princípios da teoria geral dos contratos e as disposições de direito privado".

Nesse sentido, destaca-se o exemplo do direito administrativo da União Europeia, que admite tanto a flexibilidade nas propostas em licitações quanto a superação administrativa de irregularidades e a negociação posterior de cláusulas contratuais no "procedimento de adjudicação de contratos públicos", como destacado por Paulo Otero. ${ }^{765}$ Isso seria observado de modo incipiente no cenário nacional, em especial com os permissivos dos arts. $43, \S 3^{\circ}$, e 48 , $\S 3^{\circ}$, da Lei $n^{\circ}$ 8.666/1993, que admitem de forma limitada a superação de eventuais irregularidades ao longo do procedimento licitatório.

Em matéria de concessões públicas, a Lei $n^{\circ}$ 8.987/1995 inovou ao determinar, no inciso XV de seu art. 23, que as disposições acerca do "modo amigável de solução das divergências contratuais" constituem "cláusulas essenciais do contrato de concessão". Tais disposições, no entanto, são frequentemente direcionadas à previsão da solução de litígios por arbitragem, restando ainda grande campo a ser preenchido pela transação nesse particular.

Em matéria de exercício do poder de polícia, apesar do caráter vinculado usualmente conferido às suas disposições, transparecem casos notáveis de recurso a formas consensuais de atuação. Nesse sentido, nos apropriando do

\footnotetext{
${ }^{764}$ SCHIRMER, Mário Sérgio de Albuquerque. Impossibilidade de realização de acordos no âmbito do direito administrativo sem a existência de lei expressamente autorizando a avença. Repositório do Centro de Apoio Operacional das Promotorias de Justiça de Proteção ao Patrimônio Público e à Ordem Tributária. Curitiba: CAOP-MPPR, [s.d.].

765 OTERO, Paulo. Da negociação no procedimento de adjudicação de contratos públicos. In: ATHAYDE, Augusto de; CAUPERS, João; GARCIA, Maria da Glória F. P. D. Em homenagem ao Professor Doutor Diogo Freitas do Amaral. Coimbra: Almedina, 2012. P. 921-961.
} 
pensamento de Carlos Ari Sundfeld, vislumbra-se a possibilidade de soluções consensuais não só nos atos de gestão, mas também nos atos de império da Administração Pública. ${ }^{766}$

Como exemplos já tidos como clássicos, exsurgem os Termos de Ajustamento de Conduta previstos no $\S 6^{\circ}$ do art. $5^{\circ}$ da Lei $n^{\circ} 7.347 / 1985$, referentes às matérias próprias da Ação Civil Pública, bem como os Termos de Compromisso de Cessação, previstos no art. 53 da Lei no 8.884/1994, relativos ao espectro de atuação do Conselho Administrativo de Defesa Econômica. ${ }^{767}$ Ainda nesse particular, frente aos exemplos dados, verifica-se grande potencial para o manejo da transação extrajudicial como método de solução de conflitos em matéria de mercados regulados e mercado de valores mobiliários.

No tocante à intervenção do Estado sobre a propriedade privada, a possibilidade de solução consensual em matéria de desapropriações é considerada um exemplo clássico, ${ }^{768}$ com fundamento no art. 10 do Decreto-Lei no $3.365 / 1941$, e já foi estudada mais detidamente ao tratarmos da experiência do Município de São Paulo com a transação extrajudicial.

Em matéria tributária, apesar dos questionamentos acerca de sua constitucionalidade, ${ }^{769}$ o Código Tributário Nacional prevê a transação como causa de extinção do crédito tributário no inciso III de seu art. 156, regulando-a no art. 171. No entanto, as obrigações de vinculatividade plena ${ }^{770}$ próprias do direito tributário acabam por exigir a autorização legislativa específica para que se lance mão da transação, o que reduz em muito sua aplicação prática. Não obstante, observa-se o crescente recurso da Fazenda Pública aos programas de recuperação

\footnotetext{
${ }^{766}$ SUNDFELD, Carlos Ari. CÂMARA, Jacintho Arruda. Acordos na execução contra a Fazenda Pública. Revista Eletrônica de Direito Administrativo Econômico, Salvador, n. 23, ago.-out. 2010.

${ }^{767}$ SCHIRATO, Vitor Rhein. PALMA, Juliana Bonacorsi de. Consenso e legalidade: Vinculação da atividade administrativa consensual ao Direito. Revista Eletrônica de Reforma do Estado, Salvador, n. 24, fev. 2011.

768 DALLARI, Adilson Abreu. Acordo para recebimento de crédito perante a Fazenda Pública. Revista de Direito Público da Economia, Belo Horizonte, a. 3, n. 9, p. 9-26, jan.-mar. 2005.

769 MACHADO, Hugo de Brito; MACHADO SEGUNDO, Hugo de Brito. Transação em matéria tributária: Limites e inconstitucionalidades. Tributação em Revista, Brasília, a. 16, n. 56, p. 14-22, jan.-jun. 2010.

770 JARDIM, Eduardo Marcial Ferreira. Arts. 170 a 172. In: MARTINS, Ives Gandra da Silva (coord.). Comentários ao Código Tributário Nacional. São Paulo: Saraiva, 1998. V. 2, p. 402.
} 
fiscal que, feitas as devidas adaptações, se enquadrariam na categoria de "transação por adesão" da Lei nº 13.140/2015.

Por fim, em matéria de pagamento de precatórios, apesar de o pagamento de precatórios fora da ordem cronológica constituir crime de responsabilidade, sustenta Adilson Abreu Dallari que redução no seu estoque precatórios é matéria essencial para a responsabilidade fiscal. ${ }^{771}$ Diante de tal cenário, propugna o autor, assim como o fazem Carlos Ari Sundfeld e Jacintho Arruda Câmara, pela possibilidade de acordos para o recebimento de crédito perante a Fazenda Pública, desde que adotadas as precauções já abordadas e demonstrada a patente vantajosidade para a Administração Pública. ${ }^{772}$

Apesar das inúmeras possibilidades para que a Administração Pública lance mão da transação extrajudicial para solucionar os seus conflitos, essa prática ainda é muito pouco difundida na gestão pública brasileira. Se mostra necessário, portando, tecer diretrizes para que seja fomentado o gradual crescimento do manejo da transação extrajudicial pela Administração Pública brasileira, tarefa a que se dedica o movimento derradeiro do presente capítulo.

\subsection{Diretrizes para a intensificação do recurso à transação extrajudicial pela} Administração Pública

O capítulo que se dedicou ao minucioso enfrentamento dos desafios à admissibilidade da transação extrajudicial como método preferencial de solução de conflitos da Administração Pública foi concluído com a exposição da decisiva importância da postura do gestor público no sucesso de programas de solução consensual de conflitos estatais. Tal como visto, o caráter democratizante das práticas de consensualidade só pode ser atingido com uma "abertura sincera" das instâncias administrativas ao agir consensual e, nessa medida, a instituição de

\footnotetext{
771 DALLARI, Adilson Abreu. Acordo para recebimento de crédito perante a Fazenda Pública. Revista de Direito Público da Economia, Belo Horizonte, a. 3, n. 9, p. 9-26, jan.-mar. 2005.

772 SUNDFELD, Carlos Ari. CÂMARA, Jacintho Arruda. Acordos na execução contra a Fazenda Pública. Revista Eletrônica de Direito Administrativo Econômico, Salvador, n. 23, ago.-out. 2010.
} 
controles meramente formais e procedimentais é insuficiente a fomentar o aumento do manejo da transação extrajudicial pela Administração Pública.

Já a exposição empreendida no presente capítulo nos permite concluir que, apesar das inúmeras potencialidades para a adoção da transação extrajudicial pelo Estado brasileiro e dos diversos casos de sucesso internacionais, ainda é incipiente o recurso proativo da Administração Pública à consensualidade pela transação extrajudicial. Esse panorama desperta a necessidade de investigação de balizas para que os estratos de planejamento da gestão pública possam conformar modelos que deságuem no efetivo protagonismo da transação extrajudicial como método de solução consensual de conflitos na Administração Pública.

Entendemos que essas diretrizes residem na adoção de programas e políticas que possam, de modo eficiente, conquistar a adesão dos agentes públicos, o seu comprometimento com o sucesso de práticas de transação extrajudicial do Estado. Vislumbramos que a efetividade de tais programas não residiria na simples instituição de regras acerca da transação extrajudicial na Administração Pública, mas sim de medidas que visem a conformar o comportamento administrativo, de "diretivas de discricionariedade", para se utilizar da feliz expressão de José Manuel Coutinho de Abreu. ${ }^{773}$

Não é o caso, portanto, de se obrigar o agente público a manejar a transação, mas sim de construir um ambiente no qual, quando defrontado com a escolha entre transigir ou não, o agente público opte ativamente pela realização dos interesses públicos pela transação extrajudicial.

É o que se observa nas experiências internacionais de sucesso, estudadas no início do presente capítulo, observadas na França, na União Europeia e nos Estados Unidos da América. Naqueles enteso sucesso no fomento às soluções consensuais de conflitos na Administração não se deu por regras, mas sim por instrumentos de incentivo, como se observa do estudo do Conselho de Estado francês de 1993, "Régler autrement les conflits: Conciliation, transaction,

\footnotetext{
${ }^{773}$ ABREU, José Manuel Coutinho de. Sobre os regulamentos administrativos e o princípio da legalidade. Coimbra: Almedina, 1987. p. 175-179.
} 
arbitrage en matière administrative", ${ }^{774}$ da Circular de 15 de fevereiro de 1995 do Primeiro Ministro francês sobre o desenvolvimento do recurso à transação para a solução consensual dos conflitos da Administração Pública, do Memorando Presidencial do governo Clinton que criou o Interagency Alternative Dispute Resolution Working Group em 1998, e da Recomendação $n^{\circ} \operatorname{Rec}(2001) 9$ do Comitê de Ministros do Conselho da Europa. ${ }^{775}$

Permeadas de tal espírito, algumas experiências sobre a mudança de cultura administrativa em outros campos pode trazer alguma luz sobre o tema proposto.

No sistema dos Estados Unidos da América, reflexos político-eleitorais e o posicionamento da opinião pública exercem grande importância como incentivo à atuação do Poder Executivo. No cenário político-administrativo daquele país, encontramos o entendimento de que a modificação da postura administrativa de gestores públicos de alto escalão é muito mais eficiente quando baseada em incentivos relacionados com o posicionamento da opinião pública em relação à conduta do gestor e com os reflexos político-eleitorais de tal posicionamento. ${ }^{776}$

Procedendo com tal análise - com especial foco sobre a atuação do Presidente dos Estados Unidos da América no efetivo cumprimento de normas administrativas -, Kate Andrias destaca que, apreciada extensa estatística histórica, aquele país experimentou efeitos mais concretos na mudança de comportamentos de gestores com base em incentivos consistentes no posicionamento da opinião pública e em reflexos político-eleitorais. No mesmo estudo, apurou-se que os resultados foram significativamente menores em função de incentivos (ou desincentivos) relacionados à atuação da Suprema Corte, à formação de maiorias no Congresso Nacional, ou mesmo ao relacionamento com o mercado. A pesquisa revela, inclusive, que a valorização da autonomia do agente

\footnotetext{
${ }^{774}$ FRANÇA. CONSELHO de Estado Francês. Régler autrement les conflits (coleção Les Études du Conseil d'Etat). Paris: Documentation Française, 1993.

${ }^{775}$ UNIÃO EUROPEIA. CONSELHO da Europa. Recommendation 2001-9 of the Committee of Ministers to member states on alternatives to litigation between administrative authorities and private parties. Estrasburgo: Éditions du Conseil de l'Europe, 2001.

${ }^{776}$ ANDRIAS, Kate. The President's enforcement power. NYU Law Review, New York, v. 88, n. 4, p. 102-200, out. 2013.
} 
público para a transformação positiva da realidade por meio da atuação administrativa gera incentivos para o crescimento da transparência e, assim, para um reconhecimento ainda maior desse papel, gerando um círculo virtuoso de consolidação da atuação administrativa positiva. ${ }^{777}$

Em trabalho que analisa, sob o prisma da ciência política, a adesão de agentes públicos a diretrizes gerais da Administração no cenário norte-americano, Sean Gailmard e John Patty sugerem que três fatores contribuem para tal objetivo: a identificação pessoal do agente com o conteúdo daquela política pública; a oportunidade dada ao agente para influenciá-la positivamente; e a estabilidade funcional do agente em relação àquele campo de atuação. ${ }^{778}$

No mesmo sentido, mas tendo como pano de fundo o estudo dos conselhos locais na Dinamarca, extensa investigação empírica de Lene Pedersen levou à conclusão de que os agentes públicos se comprometiam mais significativamente à realização do interesse público quando submetidos a fatores motivacionais extrínsecos relacionados à imagem pública de competência, autonomia e relacionalidade. ${ }^{779}$

Aparte dos evidentemente inúmeros fatores culturais que afastam tais experiências do cenário brasileiro, pode-se assumir, ao menos como ponto de partida, que a transformação da postura dos agentes públicos está relacionada mais a fatores motivacionais externos que a controles formais e procedimentais.

Estudo da Escola de Direito da New York University, amplamente suportado na análise de dados e experimentos, analisa o papel da exposição visual de dados e estatísticas para o convencimento de agentes específicos. A pesquisa conclui que os principais fatores que levam os agentes a não mudarem sua opinião sobre determinado tema são relacionados ao ceticismo quanto a dados e fontes, o ceticismo quanto à lógica da exposição, o apego a valores pessoais, a

\footnotetext{
777 ANDRIAS, Kate. The President's enforcement power. NYU Law Review, New York, v. 88, n. 4, p. 176, out. 2013.

${ }^{778}$ GAILMARD, Sean; PATTY, John W. Learning while governing: expertise and accountability in the executive branch. Chicago: University of Chicago Press, 2013.

${ }^{779}$ PEDERSEN, Lene Holm. Committed to the public interest? Motivation and bahavioural outcomes among local councillors. Public Administration, Hoboken: Wiley-Blackwell, v. 92, n. 4, p. 886-901, 2014.
} 
complexidade do tema exposto, e o convencimento prévio em sentido contrário à exposição. Já os fatores que contribuem para o convencimento do agente consistem, principalmente, no impacto das provas apresentadas e a inclinação prévia no sentido da exposição. ${ }^{780}$

Sem pretender discutir os estágios evolutivos ou de maturação dos sistemas políticos e administrativos entre o Brasil e outros países, é de se destacar que o caso brasileiro é marcado pela preferência por meios formais e procedimentais de controle da conduta de gestores. No entanto, como a experiência brasileira revela e os modelos expostos permitem prever, é de se esperar que a aplicação de métodos baseados em incentivos, e não em controles, seria mais eficiente na transformação da postura administrativa.

Não falamos aqui do abandono dos modelos de amplo controle formal e procedimental a que os juristas e legisladores brasileiros tanto se apegam; entendemos, no entanto, que tais métodos servem mais para fazer surgir manobras que Ihes permitam a burla do que, efetivamente, para a conformação da conduta dos gestores a padrões ótimos de atuação administrativa.

Tal comparativo, ademais, mostra-se consideravelmente especulativo. Não podemos sustentar com algum grau de certeza que o câmbio na visão sobre os métodos de conformação da postura dos gestores públicos vá, de fato, trazer os resultados esperados. No entanto, podemos afirmar com segurança a falência do atual modelo de conformação comportamental da administração pública, baseado em controles formais e procedimentais: os recentes acontecimentos relacionados à responsabilidade fiscal e às políticas econômicas no Brasil, bem como a crescente deterioração moral observada nos escalões superiores da Administração, fazem premente a necessidade de busca por novos caminhos para o condicionamento da postura administrativa entre balizas que correspondam ao ótimo esperado.

780 PANDEY Anshul Vikram; MANIVANNAN, Anjali; NOV, Oded; SATTERTHWAITE, Margaret; BERTINI, Enrico. The Persuasive Power of Data Visualization. Public Law \& Legal Theory Research Paper Series, New York University, n. 14-37, jul. 2014. 
Muitos autores enxergam a solução para tal cenário nas autovinculações administrativas, que consistiriam em uma voluntária "[...] redução da discricionariedade, no âmbito dos atos concretos da Administração Pública, de invocação especialmente útil para impedir atuações caprichosas de agentes públicos ou alterações repentinas no padrão decisório do Poder Público". ${ }^{781}$

O recurso às autovinculações administrativas poderia fomentar a alteração concreta da postura dos gestores públicos - tendo em vista, principalmente, seu caráter autóctone -, relacionando-se sobremaneira à impessoalidade como continuidade dos governos, a que nos referimos no capítulo que trata detidamente deste princípio como desafio à transação extrajudicial na administração pública.

Como destaca Paulo Modesto, a autovinculação administrativa tomaria lugar no cenário em que o cidadão, observando a adoção reiterada de uma forma de "agir, decidir ou interpretar disposições jurídicas" ${ }^{\text {"82 }}$ da Administração Pública, é surpreendido com o abandono desse padrão decisório - que marcava a confiabilidade do Estado - sem fundamento ou motivação suficientes. Nesse cenário,

[...] em face do princípio da igualdade, da boa-fé e da segurança jurídica, a reiteração de um mesmo modo de decidir em casos concretos impõe que o mesmo padrão seja adotado nas demandas futuras de mesma natureza, salvo motivação especial, fundada em alteração das circunstâncias e na necessidade de reformar o atendimento anterior em face do interesse público.

A Administração Pública, como regra, portanto, mesmo diante de competência aparentemente discricionária, deve considerar-se "autovinculada ao precedente", isto é, predeterminada na escolha de uma decisão dentre as possíveis no exercício de competência discricionária em razão da reiterada adoção por ela mesma de um mesmo padrão decisório.

O princípio da igualdade é percebido, nesta hipótese, sob um ângulo diacrônico ou dinâmico, associando-se ainda à proteção da confiança, inerente a exigência de previsibilidade e lealdade da boa-fé objetiva. Não se cogita aqui de discriminação desarrazoada em face de situações concretas, ou sujeitos concretos, aqui e agora (perspectiva estática, sincrônica, tradicional do princípio da igualdade). Mas constata-se discriminação desarrazoada entre

${ }^{781}$ MODESTO, Paulo. Autovinculação da Administração Pública. Revista Eletrônica de Direito do Estado, Salvador, n. 24, out.-dez. 2010.

782 MODESTO, Paulo. Autovinculação da Administração Pública. Revista Eletrônica de Direito do Estado, Salvador, n. 24, out.-dez. 2010. 
casos análogos, ou equivalentes, ao longo do tempo, no transcurso do tempo, a partir de uma abordagem que reclama coerência no padrão decisório da Administração Pública. ${ }^{783}$

Vislumbra-se, assim, que a combinação dos precedentes administrativos com os princípios da isonomia e da boa-fé produziria um denominado "efeito externo indireto" das prescrições administrativas, na dicção de Hartmut Maurer. ${ }^{784}$

Nesse sentido, como destaca Alexandre dos Santos Aragão, a "teoria das autolimitações administrativas" constituir-se-ia em método para, indiretamente, "assegurar a razoabilidade, a coerência e a isonomia no tratamento conferido pela Administração Pública aos cidadãos, em uma expressão do Estado Democrático de Direito e do devido processo legal substancial, que vedam as iniqüidades estatais". 785

Concluímos o presente capítulo, pois, defendendo a formulação e adoção de mecanismos que venham a concretizar a abertura sincera dos gestores públicos à adoção da transação extrajudicial como meio preferencial de consensualidade na solução de conflitos da Administração Pública. A aplicação de metodologias de autolimitação administrativa se apresenta promissora, uma vez que os métodos baseados em controles meramente formais e procedimentais se mostram insuficientes à efetiva transformação da postura administrativa. No entanto, a simples exigência coercitiva das autovinculações administrativas não surgiria efeitos positivos na transformação da postura administrativa, servindo tão somente à criação de maiores resistências.

Conclui-se, portanto, que o sucesso de políticas e programas que visem modificar a postura administrativa, em prol do manejo sistemático da transação extrajudicial pela Administração Pública, deve basear-se na combinação ótima entre a mobilização da opinião pública favorável ao tema, a demonstração eficiente

\footnotetext{
${ }^{783}$ MODESTO, Paulo. Autovinculação da Administração Pública. Revista Eletrônica de Direito do Estado, Salvador, n. 24, out.-dez. 2010.

${ }^{784}$ MAURER, Hartmut. Elementos de direito administrativo alemão. Porto Alegre: Sergio Fabris, 2001. p. 37.

785 ARAGÃO, Alexandre Santos de. Teoria das autolimitações administrativas: Atos próprios, confiança legítima e contradição entre órgãos administrativos. Revista Eletrônica de Direito Administrativo Econômico, Salvador, n. 14, mai.-jul. 2008.
} 
de resultados positivos e a coordenação nacional de incentivos à adoção, pelos diversos entes, da transação extrajudicial, despertando assim a adesão dos agentes públicos ao espírito de consensualidade. 


\section{CONCLUSÕES}

A transação extrajudicial na administração pública é tema árido e ainda pouco explorado no direito administrativo brasileiro. Diante de tais circunstâncias, o seu adequado tratamento demandou da presente tese uma estrutura de racionalidade que não se destinou apenas à conformação e categorização teórica do instituto em relação ao Estado, mas que também se preocupou em consolidar as bases para a sua efetiva adoção pela Administração Pública.

Para cumprir com essa missão, o plano da obra foi organizado em duas partes, sendo que a primeira delas se ocupou do delineamento teórico objetivo da adoção da transação extrajudicial pela Administração Pública brasileira, enquanto a segunda parte da tese se dedicou a investigar e estabelecer balizas para a concretização - efetiva, sistemática e perene - do manejo pelos entes estatais da transação extrajudicial para a solução dos conflitos em que se envolvam.

Essa organização se destina a investigar as hipóteses metodologicamente formuladas:

a) qual é o papel da transação extrajudicial como meio preferencial de solução consensual de conflitos, em comparação com as demais modalidades de consensualidade aceitas pela literatura, como arbitragem, conciliação, mediação e transação judicial?

b) qual é a natureza jurídica da transação extrajudicial adotada pela Administração Pública, frente às suas origens no direito privado, uma vez que a parte da literatura que se dedica especificamente ao tema a classifica como contrato administrativo?

c) constitui a transação extrajudicial, de fato, um método consensual de solução de conflitos cuja adoção seja franqueada à Administração Pública, tendo em vista as prerrogativas e sujeições próprias do direito administrativo?

d) como se deve dar a calibragem da transação extrajudicial, com origem no direito civil, para que ela se adeque à juridicidade própria do direito do Estado?

A resposta aos questionamentos enfrentados é exposta nas conclusões seguintes, que sintetizam as construções teóricas e as constatações empíricas construídas ao longo da tese. 
A Administração Pública brasileira conta, na contemporaneidade, com novos paradigmas para a sua atuação, que visam a renová-la, a adequá-la para o enfrentamento dos desafios da pós-modernidade. Essas tendências contemporâneas se relacionam axialmente com a adoção da transação extrajudicial pela Administração Pública, em um caminho de movimentos e tendências que, apesar de não ser linear, permite-nos traçar convergências.

A partir de um câmbio pós-positivista, em que a vinculação normativa da Administração Pública evolui de um referencial de Lei para a obediência ao Direito, observa-se o crescente protagonismo da ordem constitucional e dos princípios como balizas para o esterçamento da gestão pública. Esta tendência, que implica em movimentos de transparência, protagonismo social e razoabilidade, tem como consentâneo a crescente processualização dos mecanismos de tomada de decisão estatal, em um movimento que gradualmente abandona posicionamentos adotados por ato unilateral em favor de soluções construídas dialogicamente com os interessados.

Nesse cenário, denota-se uma mudança essencial no entendimento acerca do interesse público, abrangendo especialmente a titularidade e o método para a sua definição. Assim como na passagem do ato para o processo administrativo, a nova visão acerca do interesse público implica no reconhecimento de que a Administração Pública não repousa sozinha na posição de protagonista e artífice da definição unilateral do interesse público a ser promovido por si, mesmo porque o estado atual da sociedade implica na multiplicidade de interesses aos quais pode ser aposto tal rótulo e aplicada a proteção dele consequente.

A combinação do cenário de renovação do referencial de juridicidade da Administração, da processualização de suas atividades e de centralidade do interesse público na realização dos direitos fundamentais dos cidadãos leva a que a boa gestão desses interesses públicos, com vistas à melhor realização possível dos misteres estatais, passa a ser vista como um direito que assiste ao cidadão, fazendo surgir a figura do direito fundamental à boa administração pública.

A atuação da Administração Pública na realização desse novo interesse público - ou desses novos interesses públicos -, em busca da realização do direito 
fundamental à boa administração pública, demanda um ferramental que não é suficientemente contemplado pela simples aplicação das figuras tradicionais típicas do direito administrativo. Surge, assim, o recurso às formas tipicamente privadas, especialmente em matéria contratual, que abrem caminho para um relacionamento mais próximo entre entes públicos e particulares.

Essa aproximação viria cumprir um papel curativo do distanciamento observado nas relações entre o Estado e suas bases de legitimação democrática. Esse movimento de reaproximação se fia grandemente na busca pelo aprofundamento das relações entre os entes estatais e os cidadãos, abandonandose os velhos posicionamentos marcados pela oposição público versus privado em favor da postura cooperativa em busca da realização dos interesses públicos legitimamente definidos - o Estado relacional.

Ocorre, no entanto, que o potencial transformador desses novos paradigmas não tem sido realizado em sua plenitude. Pelo contrário, esse novo cenário é gravemente ameaçado por uma tendência contraditória a todos os elementos evolutivos expostos: o comportamento da Administração Pública brasileira é marcado por uma crescente judicialização das relações entre os entes estatais e os cidadãos, ao ponto em que a Administração Pública se caracteriza, hoje, como o maior litigante no judiciário nacional. A situação posta reclama, portanto, por uma nova postura da Administração Pública, voltada à crescente adoção de métodos consensuais de solução de conflitos, dentre os quais se destaca a transação extrajudicial, objeto central desta obra.

Vislumbra-se como instrumento ótimo à superação do distanciamento entre Estado e sociedade - decorrente grandemente, como visto, da sobrejudicialização de suas relações - a consolidação de uma postura de consensualidade na Administração Pública. No campo das demandas dos particulares em face da Administração - campo fértil para a judicialização exacerbada das relações -, a adoção de soluções consensuais de conflitos se revela como comportamento promissor para a promoção da proximidade entre Estado e cidadãos, colaborando assim com a consolidação da legitimidade democrática das instâncias estatais e o resgate dos valores representados pelos novos paradigmas a vincular a Administração. 
Partindo, portanto, da apreciação desse cenário ótimo de consensualidade e transportando-o para o campo dos conflitos jurídicos entre a Administração Pública e os particulares, a apreciação comparativa das diversas modalidades de solução consensual de conflitos contempladas pelo Direito brasileiro - arbitragem, conciliação, mediação e transação - nos permite estabelecer uma escala de preferencialidade entre tais modalidades.

O posicionamento da arbitragem como primeira modalidade consensual exposta se fundamenta tendo em vista o grau de dependência das partes em relação a terceiros para a obter-se a solução para a lide. Nesse sentido, a arbitragem acaba sendo a mais complexa e, por consequência, a mais dispendiosa das modalidades, com a probabilidade de se mostrar, também, como a mais vagarosa. A escala de preferencialidade avança para abordar, num segundo momento, a conciliação e a mediação.

Em tais modalidades, as partes já não dependem de terceiro para a composição do conteúdo da solução buscada, mas ainda o terceiro é essencial para o progresso do procedimento no sentido da sua obtenção. Entre essas duas modalidades, a conciliação guarda maior dependência do terceiro, já que o conciliador assume o comando do processo de negociação; já a mediação tem essa dependência relativamente reduzida, uma vez que o terceiro atua tão somente na aproximação entre as partes, que procedem por si mesmas com as negociações em busca da solução.

A comparação assim estruturada nos leva à transação como o método de solução consensual de conflitos em que as partes, por sua própria iniciativa, adotam concessões mútuas com o fim de prevenir ou terminar o litígio. O confronto entre a transação e as demais modalidades abordadas mostra que ela está no estágio mais avançado na escala de preferencialidade proposta, uma vez que, na transação, as partes obtêm a solução para o seu potencial ou efetivo litígio sem depender da atuação de terceiros, sejam eles árbitros, conciliadores ou mediadores. Sustenta-se, assim, que a maior autonomia das partes traria à transação extrajudicial vantagens operacionais de maior celeridade, menores custos e, com o seu desenvolvimento, uma maior adesão das partes à solução dialogicamente construída. 
A tese constrói, nesse sentido, um cenário de preferencialidade dos mecanismos que é inversamente proporcional à dependência de terceiros para se chegar à solução. É dizer, a escala crescente de preferência entre as modalidades de solução consensual de conflitos se organiza em uma escala decrescente de protagonismo de terceiros para a obtenção de uma solução final para a controvérsia.

Conclui-se, portanto, que a transação extrajudicial é a modalidade de solução consensual de conflitos que guarda a maior carga de protagonismo das partes. O seu caráter preventivo único, não observado em qualquer dos outros métodos, combinado à autonomia das partes na busca da solução - prescindindo de terceira parte que a homologue, viabilize, proponha ou determine - acabam por consolidar a prevalência da transação extrajudicial em relação à transação judicial, à mediação, à conciliação e à arbitragem.

Considera-se, pois, suficientemente constituída a solução à primeira hipótese que orientou a presente investigação.

Frente ao cenário de descumprimento dos novos paradigmas do direito administrativo por uma Administração Pública que se mostra cada vez mais belicosa em suas relações com os particulares, também o Estado é alcançado pela premente necessidade de adotar métodos consensuais de solução de conflitos e, dentre eles, se destaca especialmente a transação extrajudicial.

A solução consensual de conflitos na Administração Pública se mostra como um dos instrumentos mais efetivos para a concretização do direito fundamental de acesso à justiça e, desse modo, é papel das instâncias de gestão estatal promover transformações e criar instrumentos para que os agentes públicos competentes possam buscar, sempre que possível e recomendável, uma solução consensual para conflito que envolva a Administração Pública.

Nesse cenário, a notável preferencialidade da transação extrajudicial a coloca em posição de destaque, também em relação à Administração Pública. Partindo-se da análise de sua natureza na seara civil - que se revela por debates que remontam aos primórdios do direito privado -, o trabalho sonda a sua natureza quando inserida no regime jurídico a que se submete a Administração Pública. 
Com vistas a formular resposta a este questionamento, o trabalho aborda os posicionamentos contemporâneos acerca da natureza jurídica da transação extrajudicial na administração pública - inclusive com a análise dos raros posicionamentos presentes na literatura pátria. Atendo-nos à natureza contratual da transação, revelada pelos debates civilistas em torno do instituto, verificamos que tanto o cenário francês quanto o italiano propugnam pela natureza de contrato administrativo da transação entabulada pela Administração.

Estes posicionamentos, principalmente com base no direito administrativo italiano, servem de referencial para o posicionamento que se destaca no direito administrativo brasileiro, no sentido de se defender que a transação manejada pela Administração Pública se revestiria da natureza de contrato administrativo alternativo. Este panorama revela por ser essencial, para sua análise crítica, a eleição de um marco diferencial entre o contrato administrativo e o contrato privado da Administração, que a tese encontra na combinação do critério estatutário, baseado na previsão legal de um regramento próprio para o instituto, e na presença, no bojo contratual, do poder de autoexecutoriedade em favor da Administração.

Com base na aplicação desses dísticos essenciais ao contrato de transação que tenha como parte a Administração Pública, vislumbra-se ser possível a edificação posicionamento original acerca da natureza de tal contrato. Observase que, de fato, esses critérios diferenciais não são contemplados pela transação extrajudicial na administração pública, motivo pelo qual tal modalidade de contrato da Administração não pode ser caracterizada como contrato administrativo.

Conclui-se, assim, a primeira parte da tese, definindo-se que a transação extrajudicial que tenha como parte ente da Administração Pública conta com natureza jurídica de contrato privado da Administração, a ela se aplicando, em regra, as disposições do regime privatístico, moduladas por eventuais derrogações que, mesmo presentes no direito administrativo, não desvirtuam ou descaracterizam a natureza privada da transação extrajudicial entabulada.

Essa contribuição original constitui enfrentamento adequado, portanto, à segunda hipótese a orientar as investigações entabuladas. 
Apesar dos contundentes fundamentos das conclusões até aqui obtidas, a sua edificação teórica não se mostra suficiente para, na prática administrativa, alcançar a plena efetividade da adoção da transação extrajudicial pela Administração Pública brasileira. Isso porque a literatura e a jurisprudência nacionais são pródigas em construir oposições à aceitabilidade da transação extrajudicial no direito administrativo, oposições estas ora conceituais, ora operacionais.

$\mathrm{O}$ direito administrativo brasileiro tem se mostrado consideravelmente árido à adoção de métodos de solução consensual de conflitos pela Administração Pública, o que se agrava quando tratamos da transação extrajudicial. Diante do exposto cenário de conflituosidade e judicialização das relações entre Estado e cidadãos, a análise da inserção da transação extrajudicial no regime jurídico da Administração Pública, deve ser seguida do enfrentamento a estas oposições.

Detecta-se que, no cenário brasileiro, abundam as oposições à adoção da transação extrajudicial pela Administração Pública com base na exigência de lei autorizativa para a celebração da avença; na incompatibilidade entre a transação extrajudicial e o princípio da impessoalidade administrativa; em uma suposta supremacia e indisponibilidade insuperáveis do interesse público; na incompatibilidade entre a transação extrajudicial e o direito administrativo quanto à certeza jurídica; na submissão dos efeitos da transação ao regime de precatórios; nos riscos que a prática da transação extrajudicial na administração pública pode representar; e, finalmente, na postura refratária dos agentes públicos em se comprometer com a efetiva e sistemática adoção da transação extrajudicial como método de solução consensual de conflitos pela Administração.

No tocante à necessidade de autorização legislativa específica para a transação extrajudicial pela Administração Pública, verifica-se que os novos referenciais de juridicidade do direito administrativo não acolhem tal exigência.

Entendemos ser a lei obrigatória para o exercício das prerrogativas estatais, num regime de legalidade estrita; a lei não pode ser exigida, no entanto, para a plena efetividade das sujeições estatais, num modelo próximo ao da legalidade ampla. 
É dizer, quando tratamos das limitações negativas, que buscam conter o Estado, protegendo o cidadão de seus possíveis arbítrios, o princípio da legalidade se caracteriza pelo sentido de reserva de lei, ou conformidade, aplicando-se um regime de legalidade estrita em que a administração somente poderia proceder nos termos daquilo que Ihe é expressamente franqueado por Lei. No entanto, quando tratamos de limitações positivas, que visam a conformar a condita estatal no sentido de prestações à sociedade, o princípio da legalidade se caracteriza pelo sentido de precedência de lei, ou compatibilidade, sendo elemento essencial do cumprimento de sua missão institucional do Estado o recurso a todos os meios possíveis para a realização dos direitos fundamentais do cidadão, desde que a Administração não contrarie as eventuais proibições legais.

Conclui-se que, na medida em que o recurso à transação extrajudicial se relaciona axialmente à realização da missão institucional do Estado - tratando-se, assim, do campo das limitações positivas, que impõem prestações materiais à Administração -, o duplo regime de legalidade aqui definido se aplica em sua face de precedência de lei, sendo apenas vedado que a Administração Pública contrarie eventual proibição legal. Não subsiste qualquer necessidade de autorização legislativa específica para que a Administração Pública recorra à transação extrajudicial para a melhor realização de seus misteres constitucionais, sendo-Ihe tão somente vedado o recurso a tal modalidade contratual quando a lei assim expressamente proíba.

Já em relação à suposta incompatibilidade entre o recurso à transação extrajudicial e a impessoalidade administrativa, a tese constrói, de forma instrumental, duas novas acepções para o princípio da impessoalidade.

Num primeiro momento, relaciona-se o princípio da impessoalidade com o dever de continuidade administrativa no Estado. Nesse sentido, apesar da mudança de projetos políticos que é ínsita à alternância de poderes, o dever de impessoalidade implica em que a transição entre governos não prejudique a continuidade de práticas e políticas constituídas anteriormente e que sejam objeto de expectativas legítimas dos cidadãos. Esse tema se revelará de importância chave para a edificação de posicionamento acerca da importância da postura 
pessoal dos gestores para o sucesso de programas de transação extrajudicial na administração pública, adiante.

Em segundo lugar a tese se posiciona pela existência de uma impessoalidade relacional a vincular a Administração Pública, de modo que, ao decidir administrativamente pleitos de cidadãos em face de si, o Estado seja obrigado a julgar a relação entre si e o interessado como se terceiro fosse. Tratase, portanto, de uma acepção de impessoalidade da Administração em relação a si mesma, que se mostra diferenciada em relação aos demais sentidos de impessoalidade contemplados pela literatura por exigir um distanciamento da Administração em relação a si para julgar os processos administrativos em que seja parte de modo pessoal.

Conclui-se, nesse particular, que a aplicação do princípio da impessoalidade obriga, e não impede, a Administração a proceder com o recurso à transação extrajudicial sempre que se apure a procedência do pleito do particular. O julgamento administrativo da demanda reclama uma postura de impessoalidade relacional da Administração, que deverá proceder como se terceiro fosse, abstendo-se de adotar uma posição defensiva que seja injusta em relação aos direitos efetivamente detidos pelo cidadão.

No particular relativo à incompatibilidade da transação da Administração Pública com a indisponibilidade e a suposta supremacia do interesse público, opera-se uma ressignificação do conteúdo do indicado princípio.

Num primeiro momento, uma vez que por meio da transação extrajudicial se realiza a missão institucional do Estado, com a defesa dos direitos fundamentais do cidadão, é justamente o princípio da indisponibilidade do interesse público que recomenda a firmatura da transação extrajudicial pela Administração Pública, mormente frente ao fato de que os interesses públicos são assim mais eficientemente protegidos do que se o gestor público relegasse a solução da contenda ao Poder Judiciário.

Ainda, deve-se observar que o direito administrativo contemporâneo não mais admite - se é que a algum tempo admitiu - uma visão unitária do interesse público. Como apreciado no tocante aos novos paradigmas da gestão pública, 
verifica-se que caberá à análise ponderativa, executada nas instâncias competentes - no caso em análise, à Administração Pública em colaboração com a sociedade -definir se um dado interesse se qualifica a ser objeto de especial proteção estatal, com base nas balizas constitucionais.

Em uma terceira frente de análise, verifica-se que não se pode apor aos interesses públicos o qualificativo de supremo, já que isso the constituiria uma absolutez que não coaduna com a ponderação de interesses e com o protagonismo constitucional dos direitos fundamentais. Isso não quer dizer, no entanto, que a atuação estatal não deva ser orientada pela realização dos interesses públicos. Podemos nos posicionar, portanto, no sentido de que impera no direito administrativo brasileiro um princípio de prevalência do interesse público.

No caso específico da transação extrajudicial da Administração Pública, em caso de procedência do pleito do cidadão, é justamente a prevalência do interesse público que faz com que o ente estatal nunca possa deixar de buscar o interesse público onde ele se revelar mais premente, ainda que isso signifique deferir administrativamente um pleito do particular. Constituir-se-ia, assim, pela prevalência do interesse público - que vincula permanentemente à Administração -, verdadeiro dever estatal de transigir, sempre que esta se mostre a solução mais adequada para a correta ponderação dos interesses públicos que se apresentam no caso.

Por fim, cabe destacar que muitas das oposições que gravitam em torno do interesse público contam com grande dificuldade em identificar o atendimento de um pleito de titularidade privada como interesse público, bem comum. Propõese, assim, a didática adaptação da teoria da bipartição a conceitos que contemplem a coexistência, e não a oposição das categorias - não se tratando, a rigor, de bipartição, mas sim de dualidade de natureza -, com a categorização do interesse público entre interesse público formal e interesse público material, abandonandose as categorias de interesse público primário e interesse público secundário.

Nesse sentido, interesse público formal seria aquele interesse que tenha como titular o Estado, enquanto detentor de direitos ou do dever de cuidado objetivo. Não resta adstrito aos interesses patrimoniais, portanto, mas abrange 
todos aqueles que tenham ente estatal como seu titular. Por sua vez, o interesse público material abrange os interesses de qualquer titularidade que sejam permeados pelos objetivos da coletividade e tenham relação com a missão institucional do Estado. Nesse sentido, o interesse público é caracterizado pelo seu conteúdo, de acordo com as ponderações valorativas realizadas pela Constituição Federal.

O perímetro que delimita a abrangência dos dois conceitos interage como círculos secantes, e não como campos de oposição. Nessa medida, ao contrário dos conceitos de interesse público primário e de interesse público secundário, as acepções de interesse público formal e interesse público material, na grande maioria dos casos, serão em sua maior parte coincidentes.

Nesse sentido, sustenta-se, também, não haver conflito entre aqueles que entendem que o elemento central do direito administrativo se constitui pelo interesse público e aqueles que enxergam na satisfação dos direitos fundamentais o papel último do Estado. O verdadeiro papel a que deve se dedicar o Estado é a sua missão institucional constitucionalmente definida: tanto interesses públicos quanto direitos e garantias fundamentais são constituintes dessa missão já que, ao fim e ao cabo, todos eles constituem interesses públicos materialmente considerados.

No enfrentamento aos desafios operacionais, o primeiro campo de análise que se revela é o da suposta incongruência entre o caráter extintivo da transação e o poder de autotutela conferido à Administração Pública. Nesse particular a tese firma entendimento pela existência de três hipóteses distintas para a apuração da possibilidade ou não de anulação de transação extrajudicial na administração pública.

Em havendo, no contrato de transação, erro ou ilegalidade que implique em sua nulidade, caso não se configure dolo, má-fé, culpa ou qualquer reponsabilidade do agente administrativo ou da contraparte privada, não caberá a anulação do contrato de transação. Isso porque a presença de tal nulidade não tem o condão de desconstituir o verdadeiro interesse público obtido, consistente na 
prevenção do litígio, e a boa-fé do particular lhe protege o direito adquirido com o ato jurídico perfeito.

Na segunda hipótese, em se configurando a nulidade do contrato privado de transação da Administração por dolo ou culpa do agente administrativo, mas estando o particular imbuído de boa-fé, igualmente caberá a manutenção da transação entabulada, pugnando-se pela realização do interesse público consistente na pacificação da contenda e protegendo-se a segurança jurídica do cidadão. Caberá aqui, no entanto, a responsabilização pessoal do agente pelos danos eventualmente causados ao Estado, de acordo com apuração adequada.

Por fim, estabelece-se que a única possibilidade de anulação da transação extrajudicial da Administração Pública reside na hipótese em que o agente público, em conluio com o particular, ou este último fazendo aquele incorrer em erro, acarretam de má-fé a nulidade do contrato. Proceder-se-ia, nesse caso, com a responsabilização daqueles que tenham dado causa a prejuízo ao erário. No entanto, mesmo diante de tais circunstâncias, poderia ser a transação mantida caso se constate que os benefícios dela advindos superam a necessidade de seu desfazimento, tendo em vista o interesse público residir, verdadeiramente, na pacificação das relações da Administração pela solução da contenda.

Já em relação à suposta incompatibilidade entre eventuais pagamentos do Estado ao particular em decorrência de transação extrajudicial e a sistemática de precatórios, os que se posicionam nesse sentido demonstram, em realidade, o desconhecimento dos mecanismos de direito financeiro, contabilidade pública e regularidade fiscal. Como se observa, pelo regime de empenho, liquidação e pagamento, as despesas decorrentes de obrigações contratuais da Administração Pública brasileira já se submetem a um rígido regime de controle.

Nesse sentido, a natureza contratual da transação extrajudicial na administração pública a exclui terminantemente do regime de precatórios - exceto, evidentemente, no caso de recorrer o credor à sua execução pela via judicial -, medida em que o recurso a tal figura contratual não encontra qualquer óbice advindo dessa sistemática. 
A obra não se abstém de expor os riscos potencialmente advindos da transação extrajudicial na administração pública que, em sua maioria, se relacionam com os desafios teóricos enfrentados, em especial os relacionados à impessoalidade e à defesa dos interesses públicos. Conclui-se, no entanto, que o caráter prático desses riscos não implica na impossibilidade teórica de recurso da Administração à transação extrajudicial; assim como em toda atividade administrativa, os riscos existem e devem ser combatidos pelos instrumentos de controle interno e externo à disposição do Estado.

Essa constatação leva ao enfrentamento do derradeiro desafio à adoção da transação extrajudicial pela Administração Pública, consistente na resistência dos próprios agentes estatais.

Verifica-se que o sucesso da prática só pode ser obtido por postura proativa da administração em relação aos instrumentos de consensualidade ou, na expressão cunhada, pela "abertura sincera" do gestor público à solução consensual de conflitos com os particulares. Essa postura se revela, no entanto, passível de transformação, o que desperta a possibilidade de consolidação de práticas sistemáticas de transação extrajudicial na administração pública.

O extenso enfrentamento aos inúmeros desafios à receptividade da transação extrajudicial como método de solução consensual dos conflitos da Administração Pública revela, assim, que nenhum deles resiste a um acurado tratamento científico. Verifica-se, portanto, por não restarem quaisquer impedimentos à adoção da transação extrajudicial pela Administração Pública, de modo que se constitui a plena satisfação da terceira hipótese a guiar a investigação realizada.

Essas conclusões nos levam ao enfrentamento da hipótese final proposta, que tem início com a apreciação das experiências do direito administrativo brasileiro e internacional em matéria de transação extrajudicial.

Esse estudo revela que o cenário brasileiro carece do estabelecimento de balizas razoáveis para que se aprimore o manejo da transação extrajudicial por nossa Administração Pública. 
Isso decorre de que, como o extenso estudo dos casos observados no Brasil faz transparecer, as iniciativas brasileiras nesse campo ainda não tomam proveito das inúmeras potencialidades da transação extrajudicial como método de solução consensual de conflitos da Administração. Observa-se que as experiências da União e as normas relativas à transação judicial nos Juizados Especiais Federais e da Fazenda Pública se apegam a um fetiche legalista que não coincide com os novos paradigmas de vinculação ao Direito na Administração Pública, rendendo infértil a aplicação prática da transação pelos entes estatais.

Já as experiências dos Estados e dos Municípios, apesar de se dedicarem ao protagonismo do processo administrativo na solução de conflitos, são consideravelmente direcionadas a casos específicos, e não se dedicam a aplicar de forma ampla a transação para a solução dos diversos conflitos em que se envolve a Administração Pública.

De modo geral, conclui-se que as experiências brasileiras em soluções consensuais de conflitos na Administração Pública recorrem pouco à transação extrajudicial - tendo um maior comprometimento com a conciliação e a arbitragem -, deixando assim de lograr proveito da preferencialidade comparativa que a transação extrajudicial guarda em relação às demais modalidades, tal como exposto na primeira parte da tese.

O confronto do cenário brasileiro com as experiências estrangeiras é igualmente revelador, na medida em que a longa tradição do direito administrativo brasileiro de importar figuras jurídicas do direito europeu falhou em trazer as positivas experiências consolidadas naquele continente para a prática de nossa Administração. Pelo contrário, que a postura brasileira se aproxima muito mais de seus pares econômicos, representados pela Índia e pela África do Sul, em que as experiências com a solução consensual de conflitos na administração pública ainda são tímidas e, ademais, questionadas em sua validade pelo Poder Judiciário.

Revela-se, pois, a necessidade de que sejam delineadas balizas para a adoção da transação extrajudicial pela Administração Pública, de modo a ampliar substancialmente as experiências já observadas. 
Num primeiro momento, pode-se fixar os requisitos de validade para o contrato de transação da Administração Pública. Do ponto de vista civil, tal contrato será válido quando se fizer presente litígio em potencial a ser prevenido; a parte privada for capaz; o objeto for disponível; forem adotadas concessões recíprocas; os efeitos se adstrinjam às partes; e seja adotada a forma escrita. Já em decorrência do regime administrativo, a validade do contrato de transação da Administração Pública depende da comprovação da vantajosidade para o interesse público; da realização de processo administrativo, com a manifestação de órgãos técnicos e jurídicos; a submissão às instâncias de controle; e a competência do representante da Administração.

Já as hipóteses de cabimento da transação extrajudicial na administração pública são as mais diversas possíveis, na medida em que se estabelece $\mathrm{o}$ entendimento por ser recomendável que as possibilidades de transação sejam abordadas, pelos entes estatais, em um quadro aberto.

Enfim, diante da ainda incipiente adoção da transação extrajudicial pela Administração Pública brasileira, faz-se necessário sugerir balizas para que tal prática seja intensificada de forma sistemática.

Entende-se que essas diretrizes residam na adoção de programas e políticas que possam, de modo eficiente, conquistar a adesão dos agentes públicos, o seu comprometimento com o sucesso de práticas de transação extrajudicial do Estado. Nesse sentido, a simples instituição de regras acerca da transação extrajudicial na Administração Pública se mostra inefetiva, revelando-se a necessidade de de medidas que visem a conformar o comportamento administrativo. Não se mostra ser o caso, assim, de se obrigar o agente público a manejar a transação, mas de construir um ambiente que o leve, quando defrontado com a escolha entre transigir ou não, a optar ativamente pela transação extrajudicial.

Conclui-se com a defesa da formulação e adoção de mecanismos que venham a concretizar a abertura sincera dos gestores públicos à adoção da transação extrajudicial como meio preferencial de consensualidade na solução de conflitos da Administração Pública. O sucesso de políticas e programas que visem 
modificar a postura administrativa, em prol do manejo sistemático da transação extrajudicial pela Administração Pública, deve basear-se na combinação ótima entre a mobilização da opinião pública favorável ao tema, a demonstração eficiente de resultados positivos e a coordenação nacional de incentivos à adoção, pelos diversos entes, da transação extrajudicial, despertando assim a adesão dos agentes públicos ao espírito de consensualidade.

Os caminhos estão pavimentados para que a Administração Pública brasileira se destine à tão desejada realização de sua missão institucional, com a satisfação plena dos direitos fundamentais do cidadão, para tanto se utilizando de forma efetiva da transação extrajudicial como instrumento de consensualidade. Cabe agora aos juristas acolher esse fundamentos, cultivando-os, e aos gestores públicos implementar essa nova postura. 


\section{REFERÊNCIAS}

ABREU, José Manuel Coutinho de. Sobre os regulamentos administrativos e o princípio da legalidade. Coimbra: Almedina, 1987.

ALESSI, Renato. Diritto amministrativo. Milano: Giuffrè, 1949.

Sistema istituzionale del diritto amministrativo italiano.

Milano: Giuffrè, 1958.

. L'imparzialità amministrativa. Padova: Cedam, 1965.

. Instituciones de derecho administrativo. Barcelona: Bosch,

1970.

ALLEGRETTI, Umberto. Amministrazione pubblica e costituzione. Milão: Cedam, 1996. P. 15-16.

Basi giuridiche della democrazia partecipativa in Italia:

alcuni orientamenti. Democrazia e diritto, Roma, n. 3, p. 151-166, 2006.

ALMEIDA, Fernando Dias Menezes de. Mecanismos de consenso no direito administrativo. In: ARAGÃO, Alexandre Santos de; MARQUES NETO, Floriano de Azevedo. Direito administrativo e seus novos paradigmas. Belo Horizonte: Fórum, 2008.

Teoria do contrato administrativo: Uma abordagem

histórico-evolutiva com foco no Direito Brasileiro. 2010. Tese (Livre-docência em direito) - Faculdade de Direito, Universidade de São Paulo, São Paulo, 2010.

ALMEIDA, Mário Aroso de. Manual de Processo Administrativo. Coimbra: Almedina, 2015.

AMARAL, Antônio Carlos Cintra do. Validade e Invalidade do Ato Administrativo. Revista Eletrônica de Direito do Estado, Salvador, n. 9, jan.-mar. 2007.

AMARAL, Diogo Freitas do. A Evolução do Direito Administrativo em Portugal nos últimos dez anos. Revista da Faculdade de Direito, São Paulo, v. 80, p. 237-249, jan. 1985. 
AMOROSINO, Sandro (org.). Le trasformazioni del Diritto Amministrativo: Scriti degli allievi per gli ottanta anni di Massimo Severo Giannini. Milano: Giuffrè, 1995. ANDRIAS, Kate. The President's enforcement power. NYU Law Review, New York, v. 88, n. 4, p. 102-200, out. 2013.

ARAGÃO, Alexandre Santos de; MARQUES NETO, Floriano de Azevedo (orgs.). Direito administrativo e seus novos paradigmas. Belo Horizonte: Fórum, 2008. . Teoria das autolimitações administrativas: Atos próprios, confiança legítima e contradição entre órgãos administrativos. Revista Eletrônica de Direito Administrativo Econômico, Salvador, n. 14, mai.-jul. 2008.

Os Fundamentos da Responsabilidade Civil do Estado. Revista Eletrônica de Direito do Estado, Salvador, n. 27, jul.-set. 2011. ARAÚJO, Edmir Netto de. Curso de direito administrativo. São Paulo: Saraiva, 2010.

ARIÑO ORTIZ, Gaspar. Lecciones de Administración y políticas públicas. Madrid: lustel, 2013.

ASSO, Bernard; MONERA, Frédéric. Contentieux Administratif. Paris: Panorama du Droit, 2009.

ASSUNÇÃO, Matheus Carneiro. Transação em matéria tributária. Revista Fórum de Direito Tributário, Belo Horizonte, a. 9, n. 53, set.-out. 2011.

AUSTRALIA. Administrative Appeals Tribunal 2013-14 Report. Sidney: AAT, 2013. Administrative Appeals Tribunal Act 1975. Canberra:

Commonwealth Consolidated Acts, 2013.

ÁVILA, Humberto Bergmann. Teoria dos princípios: Da definição à aplicação dos princípios jurídicos. São Paulo: Malheiros, 2005.

AYALA, Bernardo Diniz. Actividade contratual e negociações informais da administração: Dois modos comuns de actuação administrativa com oscilações na tutela jurisdicional do particular. In: FACULDADE de Direito da Universidade de 
Lisboa. Estudos em homenagem ao Prof. Doutor Sérvulo Correia. V. II. Coimbra: Coimbra Editora, 2010.

AZZARITI, Antonella. I principi generali in materia di affidamento dei contratti pubblici. 2007. Tese (Doutorado em Direito Público - orient. Prof. Girolamo Sciullo) - Università degli Studi di Bologna, Bolonha. 2007.

BACELLAR FILHO, Romeu Felipe. Direito Administrativo e o Novo Código Civil. Belo Horizonte: Fórum. 2007.

BAPTISTA, Patrícia. Transformações do direito administrativo. Rio de Janeiro: Renovar, 2003.

BARBOSA DE MELO, António. Introdução às formas de concertação social. Boletim da Faculdade de Direito, Coimbra, v. 60, p. 115, 1984.

BARROS, Henrique do Rego. Apontamentos sobre o contencioso administrativo e sobre os privilégios e prerrogativas da administração nos contractos e transacções que celebra como poder publico. Rio de Janeiro: Laemmert, 1874.

BARROSO, Luís Roberto. Prefácio. In: SARMENTO, Daniel (org.). Interesses públicos versus interesses privados: Desconstruindo o princípio da supremacia do interesse público. Rio de Janeiro: Lumen Juris, 2007.

Curso de direito constitucional contemporâneo: os conceitos fundamentais e a construção do novo modelo. São Paulo: Saraiva, 2009.

BELLANGER, François. La légalité lorsque l'Etat agit par des moyens de Droit Privé. In: MORAND, Charles-Albert. La légalité: Un principe à géométrie variable. Genève: Helbing \& Lichtenhahn, 1992. P. 67-90.

BENISH, Avishai. Outsourcing, discretion, and administrative justice: exploring the acceptability of privatized decision making. Jerusalem Papers in Regulation \& Governance, Jerusalem, The Hebrew University, n. 64, mar. 2014.

BERMAN, Harold J. Law and Revolution: The Formation of the Western Legal Tradition. Cambridge: Harvard University Press, 1983. 
BERNARDO, Leandro Ferreira. A Câmara de conciliação e o novo papel da Advocacia-Geral da União. Revista da AGU, Brasília, a. 9, n. 25, jul./set. 2010. A face conciliatória da Advocacia Pública. In: GREGO

SANTOS, Bruno; et. al. Temas Avançados da Advocacia Pública. Maringá: UniCorpore, 2011.

BERTI, Giorgio. Le antinomie del diritto pubblico. Diritto Pubblico, Padova, a. 2, n. 2, p. 273-292, mai.-ago. 1996.

BIELSA, Rafael. Los conceptos juridicos y su terminología. Buenos Aires: DePalma, 1954. Principios de derecho administrativo. Buenos Aires:

DePalma, 1963.

BINENBOJM, Gustavo. Da supremacia do interesse público ao dever de proporcionalidade: um novo paradigma para o direito administrativo. In: SARMENTO, Daniel (org.). Interesses públicos versus interesses privados: desconstruindo o princípio da supremacia do interesse público. Rio de Janeiro: Lumen Juris, 2007.

A constitucionalização do direito administrativo no Brasil: um inventário de avanços e retrocessos. Revista Eletrônica sobre a Reforma do Estado, Salvador, n. 13, mar.-mai. 2008. . Uma teoria do direito administrativo. Rio de Janeiro:

Renovar, 2014.

BIRKINSHAW, Patrick. Grievances, remedies and the State. Oxford Journal of Legal Studies, Oxford, v. 7, n. 1, p. 125-135, prim. 1987. . Grievances, remedies and the State. London: Sweet \& Maxwell, 1994.

BOBBIO, Norberto. As ideologias e o poder em crise. Brasília: UnB/Polis, 1988. 
BÓLGAR, Vera. L'intérêt général dans la théorie et dans la pratique. Revue Internationale de Droit Comparé, Paris, v. 17, n. 2, p. 335, 1965.

BORGES, Alice Gonzalez. Reflexos do Código Civil dos contratos administrativos. Revista Eletrônica de Direito Administrativo Econômico, Salvador, n. 9, fev.-abr. 2007.

Supremacia do interesse público: desconstrução ou reconstrução? Revista Eletrônica de Direito Administrativo Econômico, Salvador, n. 26, mai.-jul. 2011.

BOUSTA, Rhita. Essai sur la notion de bonne administration en droit public. Paris: L'Harmattan, 2010.

BRASIL. CONSELHO Nacional de Justiça. Os 100 maiores litigantes. Brasília: CNJ, 2012.

BRASIL. SUPERIOR Tribunal de Justiça. Mandado de Segurança $n^{\circ}$ 18.522/DF. Rel. Min. Arnaldo Esteves Lima. Diário de Justiça Eletrônico, Brasília, 21 out. 2013.

Recurso em Mandado de Segurança $n^{\circ}$ 36.294/RS. Rel.

Min. Benedito Gonçalves. Diário de Justiça Eletrônico, Brasília, 19 ago. 2013. . Recurso Especial no 1.198.424/PR. Rel. Min. Mauro

Campbell Marques. Diário de Justiça Eletrônico, Brasília, 18 abr. 2012.

BRASIL. SUPREMO Tribunal Federal. Mandado de Segurança $n^{\circ}$ 24.379. Rel. Min. Dias Toffoli. Diário de Justiça Eletrônico, Brasília, n. 108, 8 jun. 2015. Mandado de Segurança $n^{\circ}$ 28.720. Rel. Min. Ayres Britto. Diário de Justiça Eletrônico, Brasília, p. 66, 2 abr. 2012. . Mandado de Segurança $n^{\circ}$ 29.305. Rel. Min. Marco Aurélio. Diário de Justiça Eletrônico, Brasília, p. 200, 11 out. 2012. Recurso Extraordinário $n^{\circ}$ 216.443. Rel. Min. Marco Aurélio. Diário de Justiça Eletrônico, Brasília, p. 26, 7 fev. 2013. 
Recurso Extraordinário n 253.885. Rel. Min. Ellen Gracie.

Diário de Justiça da União, Brasília, p. 118, 21 jun. 2002.

. Recurso no Mandado de Segurança $n^{\circ}$ 27.998. Rel. Min.

Dias Toffoli. Diário de Justiça Eletrônico, Brasília, 21 set. 2012.

BRASIL. TRIBUNAL de Contas da União. Consulta n007.425/2000-3. Rel. Min.

Guilherme Palmeira. Diário de Justiça da União, Brasília, 24 jan. 2001.

CABO MARTÍN, Carlos. Sobre el concepto de ley. Madrid: Trotta, 2000.

CAETANO, Marcello. Manual de direito administrativo. Coimbra: Coimbra Editora, 1951.

CÂMARA, Alexandre Freitas. Arbitragem. Rio de Janeiro: Lumen Juris, 1997.

CAMPOS, Diogo Leite de. A indisponibilidade dos créditos tributários e a arbitragem. Revista de Finanças Públicas e Direito Fiscal, Lisboa, a. 2, n. 2, p. 6373, prim. 2009.

CANOTILHO, Joaquim José Gomes. Direito constitucional e teoria da constituição. Coimbra: Almedina, 2003.

CAPOTOSTI, Piero Alberto. Concertazione e riforma dello Stato sociale nelle democrazie pluraliste. Quaderni Costituzionali, Bologna, a. 11, n. 3, p. 475-490, dez. 1999.

CARBONNIER, Jean. Flexible Droit: Pour une sociologie du droit sans rigueur. Paris: LGDJ, 2001.

CARMONA, Carlos Alberto. Arbitragem e processo: Um comentário à Lei $n^{\circ}$ 9.307/96. São Paulo: Atlas, 2007.

CARNELLUTTI, Francesco. Sulla causa della transazione. Rivista di Diritto Comerciale, Roma, p. 575, 1914.

Note sull'accertamento negoziale. Rivista di Diritto

Processuale Civile, v. 1, p.3-24, 1940. 
La transazione è un contratto? Rivista di Diritto

Processuale, Padova, v. 8, t. 1, p. 185-190, 1953.

. Instituições do Processo Civil. São Paulo: Classic Book,

2000.

CARRESI, Franco. Concetto e natura giuridica della transazione. Rivista Trimestrale di Diritto e Procedura Civile, Milano, a. 8, p. 62-104,1954.

CARVALHAES NETO, Eduardo Hayden. Contratos privados da Administração Pública: Uma análise do regime jurídico aplicável. 2011. Tese (Doutorado em direito) - Faculdade de Direito, Universidade de São Paulo, São Paulo, 2011.

CARVALHO E SOUZA, Guilherme. A responsabilidade civil do Estado e o princípio da confiança legítima. Revista de Direito Administrativo, Rio de Janeiro, v. 258, p. 115-140, set./dez. 2011.

CARVALHO FILHO, José dos Santos. Interesse público: verdades e sofismas. In: DI PIETRO, Maria Sylvia Zanella; RIBEIRO, Carlos Vinicius Alves (coords.). Supremacia do interesse público e outros temas relevantes do Direito administrativo. São Paulo: Atlas, 2010.

CARVALHO NETO, Tarcísio Vieira de. O princípio da impessoalidade nas decisões administrativas. 2014. Tese (Doutorado em direito) - Faculdade de Direito, Universidade de São Paulo, São Paulo, 2014.

CARVALHO, Ana Celeste. A mediação em matéria administrativa: uma possibilidade com futuro. Cadernos de Justiça Administrativa, Braga, n. 109, p. 312, jan./fev. 2015.

CASSESE, Sabino. Imparzialità amministrativa e sindacato giurisdizionale. Milano: Giuffrè, 1973.

. L'arbitrato nel Diritto Amministrativo. Rivista Trimestrale di Diritto Pubblico, Roma, a. 46, n. 2, p. 311-328, $2^{\circ}$ trim. 1996. 
Quattro paradossi sui rapporti tra poteri pubblici ed autonomie private. Rivista Trimestrale di Diritto Pubblico, Roma, a. 50, n. 2, p. 389-394, $2^{\circ}$ trim. 2000.

. Le trasformazioni del diritto amministrativo dal XI al XXI secolo. Rivista Trimestrale di Diritto Pubblico, Roma, a. 52, n. 1, p. 27-40, $1^{\circ}$ trim. 2002.

. Corso di Diritto Amministrativo: Istituzioni di Diritto Amministrativo. V. I. Milano: Giuffrè, 2004.

CASTRO, Augusto Olympio Viveiros de. Tratado de sciencia da administração e direito administrativo. Rio de Janeiro: Jacintho Ribeiro dos Santos, 1914.

CAVALCANTI, Themistocles Brandão. Instituições de direito administrativo brasileiro. V. 1. Rio de Janeiro: Freitas Bastos, 1938.

Instituições de direito administrativo brasileiro. V. 2. Rio de Janeiro: Freitas Bastos, 1938.

CERRI, Augusto. Imparzialitè ed indirizzo politico nella Pubblica Amministrazione. Padova: Cedam, 1973.

CERULLI IRELLI, Vincenzo. Corso di diritto amministrativo. Torino: Giappichelli, 2001.

Amministrazione pubblica e diritto privato. Torino:

Giappichelli, 2011.

CHATEAUBRIAND FILHO, Hindemburgo. Negócio de acertamento: Uma abordagem histórico-dogmática. Belo Horizonte: Del Rey, 2005.

CHAVRIER, Géraldine. Réflexions sur la transaction administrative. Revue Française de Droit Administratif, Paris, n. 3, p. 548-566, mai.-jun. 2000.

CHEVALLIER, Jacques. La dimension symbolique du principe de légalité. Revue du Droit Public et de la Science Politique, Paris, v. 106, p. 1.652-1.677, 1990. 
A governança e o direito. Revista de Direito Público da Economia, Belo Horizonte, a. 3, n. 12, p. 129-146, out.-dez. 2005.

CHITI, Mario P. Diritto amministrativo europeo. Milano: Giuffrè, 1999. Monismo o dualismo in diritto amministrativo: vero o falso dilema? Rivista Trimestrale di Diritto Pubblico, Roma, a. 50, n. 2, p. 301-320, $2^{\circ}$ trim. 2000.

La carta europea dei diritti fondamentali: Una carta di carattere funzionale? Rivista Trimestrale di Diritto Pubblico, Roma, a. 52, n. 1, p. 1-26, $1^{\circ}$ trim. 2002.

CLAMOUR, Guylain. Intérêt général et concurrence: essai sur la pérennité du droit public en économie de marché. Paris: Dalloz, 2006.

CLÉVE, Clèmerson Merlin. O cidadão, a administração pública e a Constituição. Revista Eletrônica de Direito do Estado, Salvador, n. 31, jul.-set. 2012.

COPOLA, Gina. A arbitragem nos contratos administrativos. Fórum de Contratação e Gestão Pública, Belo Horizonte, a. 13, n. 146, p. 34-40, fev. 2014. CORNU, Julie. La transaction en matière administrative. 2008. Dissertação (Mestrado em direito público) - Université Panthéon-Assas Paris II, Paris, 2008.

CORREIA, José Manuel Sérvulo. Os princípios constitucionais da administração pública. In: MIRANDA, Jorge. Estudos sobre a Constituição. Lisboa: Petrony, 1979. Legalidade e autonomia contratual nos contratos administrativos. Coimbra: Almedina, 1987.

COSTA E SILVA, Paula. Os meios de impugnação de decisões proferidas em arbitragem voluntária no direito interno português. Revista da Ordem dos Advogados, Lisboa, a. 56, v. 1, p. 188, 1996. 
COSTA, Elisson Pereira da. O alcance da arbitragem nos contratos administrativos de concessão de serviço público. Revista Síntese Direito Administrativo, n. 94, p. 28, out. 2013.

COSTA, Newton Carneiro Affonso da. On the theory of inconsistent formal systems. Notre Dame Journal of Formal Logic, Notre Dame, n. 15, p. 497-510, 1974.

COUTINHO, Nilton Carlos de Almeida. Supremacia do interesse público e celebração de acordos pelo poder público: Juizados Especiais e eficiência administrativa. In: CONGRESSO NACIONAL DE PROCURADORES DE ESTADO, 37, 2011, Belo Horizonte. Anais... Brasília: ANAPE, 2011.

CRETELLA JÚNIOR, José. As categorias jurídicas e o direito público. Revista da Faculdade de Direito da USP, São Paulo, a. 62, n. 2, 1967.

Dos contratos administrativos. Rio de Janeiro: Forense 1997.

CRUZ, Alcides. Noções de Direito administrativo brasileiro: Exposição summaria e abreviada. Porto Alegre: Germano Gundlach, 1910.

CUNHA, Leonardo José Carneiro da. A Fazenda Pública em juízo. São Paulo: Dialética, 2008.

D'ALBERTI, Marco. La concertazione fra Costituzione e amministrazione. Quaderni Costituzionali, Bologna, a. 11, n. 3, p. 491-500, dez. 1999.

Diritto amministrativo e diritto privato: nuove emersioni di una questione antica. Rivista Trimestrale di Diritto Pubblico, Roma, a. 68, n. 4, p. 1.019-1.028, out-dez. 2012.

D'ONOFRIO, Paolo. La transazione e il contratto. Rivista di Diritto Commerciale, Milano, a. 51, n. 1, p. 490-493, 1953.

DAGNINO, Evelina. Sociedade civil, espaços públicos e a construção democrática no Brasil: limites e possibilidades. In: DAGNINO, Evelina (org.). Sociedade civil e espaços públicos no Brasil. São Paulo: Paz e Terra, 2002. 
DALLARI, Adilson Abreu. Viabilidade da transação entre o poder público e particular. Interesse Público, Belo Horizonte, a. 4, n. 13, jan.-mar. 2002. Acordo para recebimento de crédito perante a Fazenda Pública. Revista de Direito Público da Economia, Belo Horizonte, a. 3, n. 9, p. 926, jan.-mar. 2005.

Formalismo e abuso de poder. Revista Eletrônica de Direito do Estado, Salvador, n. 16, out.-dez. 2008.

DALY, Paul. Prescribing greater protection for rights: Administrative Law and Section 1 of the Canadian Charter of Rights and Freedoms. University of Ottawa Working Paper Series, Ottawa, n. 13, nov. 2013.

DENTE, Bruno. In un diverso Stato. Bologna: II Mulino, 1999.

DI PIETRO, Maria Sylvia Zanella. Do Direito privado na Administração Pública. São Paulo: Atlas, 1989.

. O princípio da supremacia do interesse público. Revista Interesse Público, Belo Horizonte, n. 56, p. 43, jul./ago. 2009.

. Os princípios da proteção à confiança, da segurança jurídica e da boa-fé na anulação do ato administrativo. Fórum Administrativo, Belo Horizonte, ano 9, n. 100, p. 155-166, jun. 2009.

. RIBEIRO, Carlos Vinicius Alves (coords.). Supremacia do interesse público e outros temas relevantes do Direito administrativo. São Paulo: Atlas, 2010.

Parcerias na Administração Pública: Concessão, permissão, franquia, terceirização, parceria público-privada e outras formas. São Paulo: Atlas, 2012.

Direito administrativo. São Paulo: Atlas, 2014.

DICIONÁRIO Michaelis da Língua Portuguesa. São Paulo: Melhoramentos, 2015. 
DIEMER, Marie-Odile. La jurisdiction gracieuse en droit administratif. 2013. Tese (Doutorado em direito) - École Doctorale de Droit, Université MontesquieuBordeaux IV, Bordeaux, 2013.

DINIZ, Maria Helena. Curso de Direito Civil Brasileiro: Teoria das Obrigações Contratuais e Extracontratuais. Sâo Paulo: Saraiva, 2010.

DUGUIT, Léon. Les transformations du Droit Public. Paris: Armand Colin, 1913.

EASTON, Peter. Sénégal: Fonctionnement de la démocratie à la base. Notes CA, Paris, Banque Mondiale, n. 16, p. 3, jan. 2000.

EICHENBERGER, Kurt. Verwaltungsprivatrecht. Festgabe sum Schweizerischen Juristentag, Basel, p. 79 ss., 1985.

EISENMANN, Charles. Cours de droit administratif: Année 1952-1953. Paris: LGDJ, 1982.

ESCOLA, Hector Jorge. El interés publico como fundamento del derecho administrativo. Buenos Aires: Depalma, 1989.

ESTADOS UNIDOS DA AMÉRICA. Alternative Dispute Resolution Act. Public Law, Washington, v. 105, n. 315, p. 2.993-2.998, 30 out. 1998.

. INTERAGENCY Alternative Dispute Resolution Working

Group. Report for The President on the use and results of alternative dispute resolution in the Executive branch of the Federal Government. Washington: Department of Justice, 2007.

ESTEVES, Maurício Cramer. Da possibilidade e dos limites da transação em processos judiciais por parte do Poder Público Municipal. Revista Interesse Público, Belo Horizonte, v. 38, jul.-ago. 2006.

ESTORNINHO, Maria João. Algumas questões de contencioso dos contratos da Administração Pública. Cadernos de Ciência da Legislação, Lisboa, n. 15, p. 3637, jan.-mar. 1996. 
Fuga para o Direito privado: Contributo para o estudo da atividade de direito privado da Administração Pública. Coimbra: Almedina, 1999. Réquiem pelo contrato administrativo. Coimbra: Almedina, 2003. . Direito europeu dos contratos públicos: um olhar português.

Coimbra: Almedina, 2006.

FAGUNDES, Miguel Seabra. O controle dos atos administrativos pelo Poder Judiciário. Rio de Janeiro: Forense, 1979.

FARIA, José Eduardo. Antinomias jurídicas e gestão econômica. Lua Nova, São Paulo, n. 25, p. 167-184, abr. 1992.

FARIA, Roberto Gil Leal. Por que são efetivados poucos acordos nos Juizados Especiais Federais? Revista da SJRJ, Rio de Janeiro, n. 24, p. 93-103, 2009. FERNANDES, Jorge Ulisses Jacoby. Acordos administrativos e judiciais. Forum Administrativo, Belo Horizonte, a. 6, n. 59, jan. 2006.

FERRARI, Regina Maria Macedo Nery. Desenvolvimento da democracia como resultado da participação. In: GARCIA, Maria. Democracia, hoje: Um modelo político para o Brasil. São Paulo: IBDC, 1997. Efeitos da declaração de inconstitucionalidade. São Paulo: RT, 2004.

FERRAZ, Sérgio; DALLARI, Adilson Abreu. Processo administrativo. São Paulo: Malheiros, 2000.

FERREIRA FILHO, Manuel Gonçalves. A democracia possível. São Paulo: Saraiva, 1979.

FIGUEIREDO, Lúcia Valle. Curso de direito administrativo. São Paulo: Malheiros, 2008.

FIORAVANTI, Maurizio. Los derechos fundamentales: apuntes de historia de las constituciones. Madrid: Trotta, 2007. 
FLEINER, Fritz. Derecho administrativo. Barcelona: Labor, 1933.

Instituciones de derecho administrativo. Madrid: Labor,

1933.

FONSECA, Rui Guerra da. Identificações metodológicas da doutrina jusadministrativa portuguesa na parte central do séc. XX: Marcello Caetano, José Carlos Moreira, Armando Marques Guedes e Afonso Queiró. In: FACULDADE de Direito da Universidade de Lisboa. Estudos em homenagem ao Prof. Doutor Sérvulo Correia. V. II. Coimbra: Coimbra Editora, 2010. P. 1.127-1.145.

FOUGĖRE, Louis. La fonction publique. Bruxelles: Unesco, 1966.

FRACCHIA, Fabrizio. L'accordo sostitutivo: Studio sul consenso disciplinato dal diritto amministrativo in funzione sostitutiva rispetto agli strumenti unilaterali di esercizio del potere. Padova: Cedam, 1998.

FRANÇA. CENTRE National de la Recherce Scientifique. Accords transactionnels. Paris: CNRS, 2003.

FRANÇA. CONSELHO de Estado Francês. Régler autrement les conflits: conciliation, transaction, arbitrage (coleção Les Études du Conseil d'Etat). Paris: Documentation Française, 1993. Tradução nossa.

FRANCO SOBRINHO, Manoel de Oliveira. Contratos administrativos. São Paulo: Saraiva, 1981.

FURNO, Carlo. Intorno alla natura della transazione. Rivista di Diritto Commerciale, Milano, a. 48, n. 1, p. 453-468, 1950.

GABARDO, Emerson; HACHEM, Daniel Wunder. O suposto caráter autoritário da supremacia do interesse público e das origens do direito administrativo: uma crítica da crítica. In: DI PIETRO, Maria Sylvia Zanella; RIBEIRO, Carlos Vinicius Alves (coords.). Supremacia do interesse público e outros temas relevantes do Direito administrativo. São Paulo: Atlas, 2010. 
GAILMARD, Sean; PATTY, John W. Learning while governing: expertise and accountability in the executive branch. Chicago: University of Chicago Press, 2013.

GARCEZ, José Maria Rossani. Negociação, ADRS, Mediação, Conciliação e Arbitragem. Rio de Janeiro: Lumen Juris, 2004.

GARCÍA DE ENTERRÍA, Eduardo; FERNANDES, Tomas-Ramón. Curso de derecho administrativo. Madri: Civitas, 2000.

GARCIA LUENGO, Javier. El principio de protección de la confianza em el derecho administrativo. Madrid: Civitas, 2002.

GARRIDO FALLA, Fernando. Las transformaciones del régimen administrativo. Madrid: Instituto de Estudios Politicos, 1962.

GASPARINI, Diógenes. Direito administrativo. São Paulo: Saraiva, 2008.

GAUTIER, Alfred. Cours de droit administratif: Précis des matières administratives dans leurs rapports avec le droit public. Paris: Lahure, 1880.

GAZDA, Emmerson. Administração Pública em juízo: poder-dever de transigir. Revista da Associação dos Juízes Federais do Brasil, Brasília, v. 23, n. 83, p.131158, jan.-mar. 2006.

GHERA, Edoardo. La pratica della concertazione in Italia. Quaderni Costituzionali, Bologna, a. 11, n. 3, p. 501-521, dez. 1999.

GIACOMUZZI, José Guilherme. Estado e contrato: Supremacia do interesse público versus igualdade. São Paulo: Malheiros, 2011.

GIANNINI, Massimo Severo. Vita e opere di Guido Zanobini. Rivista Trimestrale di Diritto Pubblico, Roma, a. 11, n. 1, p. 15, $1^{\circ}$ trim. 1965.

GODOY, Arnaldo Sampaio de Moraes. Transação tributária: contexto, texto e argumentos. Revista Fórum de Direito Tributário, Belo Horizonte, a. 7, n. 39, mai.jun. 2009. 
GOMES, João Salis. Interesse público, controle democrático do Estado e cidadania. In: ATHAYDE, Augusto de; CAUPERS, João; GARCIA, Maria da Glória F. P. D. Em homenagem ao Professor Doutor Diogo Freitas do Amaral. Coimbra: Almedina, 2012.

GOMES, Maria Teresa Salis. Comunicação pública para uma democracia participada. In: GOMES, Maria Teresa Salis (coord.). A face oculta da governança: cidadania, Administração pública e sociedade. Coimbra: INA, 2003.

GOMES, Orlando. Contratos. Rio de Janeiro: Forense, 1988.

GONÇALVES, Luiz da Cunha. Tratado de Direito Civil. V. 9, t. 1. São Paulo: Max Limonad, 1956.

GONÇALVES, Pedro Costa. Administração Pública e arbitragem: em especial, o princípio legal da irrecorribilidade de sentenças arbitrais. In: CORREIA, Fernando Alves; SILVA, João Calvão da; VIEIRA DE ANDRADE, José Carlos; CANOTILHO, Joaquim José Gomes; CARDOSO DA COSTA, José Manuel M. Estudos em Homenagem a António Barbosa de Melo. Coimbra: Almedina, 2013. P. 777-801.

GRANDO, Artur Antônio. O princípio da imparcialidade como limite ao exercício do poder discricionário. Polis, Lisboa, n. 18/21, p. 31-55, 2012.

GRANZIERA, Maria Luiza Machado. Contratos Administrativos. São Paulo: Atlas, 2002.

GRANZOTTO, Claudio Geoffroy. Advogado de Estado. Defesa do interesse público. Independência funcional mitigada. Jus Navigandi, Teresina, ano 12, n. 1334, 25 fev. 2007.

GRAU, Eros Roberto. O direito posto e o direito pressuposto. São Paulo: Malheiros, 2000.

GREGO-SANTOS, Bruno. Em prol da comunidade: Transação extrajudicial desburocratizada no âmbito da Administração. Revista Innovare, Brasília, a. 1, n. 1, ago. 2011. 
Nivelamento versus igualdade: Aspectos subjetivo e objetivo do posicionamento da Administração Pública em relação ao particular. In: DI PIETRO, Maria Sylvia Zanella (org.). Direito privado administrativo. São Paulo: Atlas, 2013. P. 122-147.

GRIMM, Dieter. Constitucionalismo y derechos fundamentales. Madrid: Trotta, 2006.

GUEDES, Armando Marques. La loi dans un État de Droit. In: FACULDADE de Direito da Universidade de Lisboa. Estudos em homenagem ao Professor Doutor Marcello Caetano. Coimbra: Coimbra Editora, 2006. P. 229-236.

HABERMAS, Jürgen. Direito e Democracia: entre facticidade e validade. V. II. Rio de Janeiro: Tempo Brasileiro, 1997.

HANICOTE, Robert. Devoirs de l'homme et constituitions: contribuition à une théorie générale du devoir. Paris: L’Harmattan, 2007.

HAURIOU, Andre. A utilização em direito administrativo das regras e princípios do direito privado. Revista de Direito Administrativo, Rio de Janeiro, v. 1, n. 2, p. 465473, 1945.

HESSE, Konrad. A Força Normativa da Constituição. Porto Alegre: Sérgio Antônio Fabris, 1991.

\section{Elementos de Direito Constitucional da República Federal} da Alemanha. Porto Alegre: Sérgio Antônio Fabris, 1998.

ÍNDIA. DEPARTMENT of Legal Affairs. Good governance: Department of Legal Affairs. New Delhi: Ministry of Law and Justice, 2014.

ITÁLIA. CORTE di Cassazione del Regno d'Italia. Sezione II civile: Scotto di Santolo v Secondo. II Foro Italiano, Roma, v. 60, n. 13, p. 907, 1935.

Sezione III civile: Fantoni v Alfieri. II Foro Italiano, Roma, v. 61, n. 14, p. $1.141,1936$. 
ITÁLIA. TRIBUNALE Milano. Soc. Fratelli Borletti $v$ Azienda Rilievo Alienazione Residuati A.R.A.R. Giurisprudenza Italiana, Torino, v. 103, p. 139-147, 1951.

JANSEN, Oswald. Administration by negotiation in the Netherlands, national report. In: RIEDEL, Eibe; SCHMIDT-ASSMANN, Eberhard (eds.). Die Bedeutung von Verhandlungslosungen im Verwaltungsrecht. Baden-Baden: Nomos, 2002.

JARDIM, Eduardo Marcial Ferreira. Arts. 170 a 172. In: MARTINS, Ives Gandra da Silva (coord.). Comentários ao Código Tributário Nacional. V. 2. São Paulo: Saraiva, 1998.

JARROSSON, Charles. Les concessions réciproques dans la transaction. Recueil Dalloz, Paris, chroniques, p. 267-273, 1997.

JELLINEK, Georg. Gesetz und Verordnung. Freiburg: Mohr, 1887.

JĖZE, Gaston. Cours de droit public. Paris: Giard, 1924.

JILKE, Sebastian; MEULEMAN, Bart; VAN DE WALLE, Steven. We need to compare, but how? Measurement equivalence in comparative public administration. Public Administration Review, Washington, v. 75, n. 1, p.36-47, jan./fev. 2015.

JUSTEN FILHO, Marçal. Teoria geral das concessões de serviço público. São Paulo: Dialética, 2003.

. Comentários à Lei de licitações e contratos administrativos.

São Paulo: Revista dos Tribunais, 2014. . Curso de direito administrativo. São Paulo: Revista dos

Tribunais, 2014.

KEANE, John. Democracy: the rule of nobody? Berlim: Wissenschaftszentrum Berlin für Sozialforschung, 2004.

KELSEN, Hans. A democracia. São Paulo: Martins Fontes, 2000.

KOMESAR, Neil K. Imperfect Alternatives: Choosing institutions in Law, Economics and Public Policy. Chicago: University of Chicago Press, 1997. 
KUUSIKKO, Kirsi. Advice, good administration and legitimate expectations: some comparative aspects. European Public Law, Hull, v. 7, n. 3, p. 455-472, 2001.

LAFERRIÈRE, Firmin. Cours théorique et pratique de droit public et administratif. Paris: Cotillon, 1850.

LASSALLE, Ferdinand. A Essência da Constituição. Rio de Janeiro: Liber Juris, 1985.

LAUBADĖRE, André de; MODERNE, Franck; DELVOLVÉ, Pierre. Traité des contrats administratifs. Paris: LGDJ, 1983.

LEGUINA VILLA, Jesús. A Constituição Espanhola e a fuga do direito administrativo. Revista de Direito Administrativo Aplicado, a. 2, n. 6, set. 1995.

LIPPMANN, Walter. The Public Philosophy. New Jersey: Transaction, 2009.

LOEWENSTEIN, Karl. Teoria de la Constitución. Barcelona: Ariel, 1965.

LONGO, Francisco. Introducción. Los directivos públicos ante los retos de la gobernanza contemporánea. In: LONGO, Francisco; YSA, Tamyko (eds.). Los escenarios de la gestión pública del siglo XXI. Barcelona: Bellaterra, 2008.

LOPES, Miguel Maria de Serpa. Curso de Direito Civil: Obrigações em Geral. Rio de Janeiro: Freitas Bastos, 1989.

MABBOTT, J. D. The State and the Citizen: An introduction to political philosophy. Londres: Hutchinson, 1965.

MACHADO, Hugo de Brito. Transação e arbitragem no âmbito tributário. Revista Forum de Direito Tributário, Belo Horizonte, a. 5, n. 28, jul.-ago. 2007. MACHADO SEGUNDO, Hugo de Brito. Transação em matéria tributária: Limites e inconstitucionalidades. Tributação em Revista, Brasília, a. 16, n. 56, p. 14-22, jan.-jun. 2010.

MACHETE, Pedro. A subordinação da Administração Pública ao direito e a dogmática do Direito Administrativo no âmbito do Estado de direito democrático. In: ATHAYDE, Augusto de; CAUPERS, João; GARCIA, Maria da Glória F. P. D. 
Em homenagem ao Professor Doutor Diogo Freitas do Amaral. Coimbra: Almedina, 2012. P. 192-238.

MACHETE, Rui Chancerelle de. O processo administrativo gracioso perante a constituição portuguesa de 1976. Lisboa: Fundação Oliveira Martins, 1991.

MADUREIRA, Claudio Penedo. Poder público, litigiosidade e responsabilidade social. Fórum Administrativo, Belo Horizonte, a. 11, n. 126, p. 9-22, ago. 2011.

MAGALHÃES, Marco Túlio Reis. Hermenêutica constitucional: comparação das teorias de Konrad Hesse e Friedrich Müller. Revista Jurídica da Presidência da República, Brasília, v. 7, n. 75, p. 1-25, out.-nov. 2005.

MALUF, Carlos Alberto Dabus. Da transação. In: FIUZA, Ricardo. Novo Código Civil comentado. São Paulo: Saraiva, 2003.

MANFRO, Lorenzo. I reati di falso tra staturaria Veronese e diritto comune. 1997. Tese (Doutorado em Direito - orient. Prof. Giorgio Zordan) - Facoltà di Giurisprudenza, Università degli Studi di Padova, Padua. 1997.

MARQUES NETO, Floriano de Azevedo. Regulação Estatal e Interesses Públicos. São Paulo: Malheiros, 2002.

. La moderna regulación: entre público y privado la búsqueda del equilibrio. In: DE LA CUÉTERA, J. M; LÓPEZ-MUNIZ, José Luiz Martínez; VILLAR ROJAS, Francisco J. Derecho administrativo y regulación económica: liber amicorum Gaspar Ariño Ortiz. Madrid: La Ley, 2011. Interesses públicos e privados na atividade estatal de regulação. In: MARRARA, Thiago (org.). Princípios de direito administrativo: legalidade, segurança jurídica, impessoalidade, publicidade, motivação, eficiência, moralidade, razoabilidade, interesse público. São Paulo: Atlas, 2012.

MARRARA, Tiago (org.). Direito administrativo: Transformações e tendências. São Paulo: Almedina, 2014.

MARTIN, Elizabeth. The Oxford Dictionary of Law. Oxford: Oxford University, 2003. 
MARTINS, Alexandre de Soveral. Processo e direito processual: Processos heterocompositivos. Coimbra: Centelha, 1986. V. 2.

MARTINS, Licínio Lopes. Empreitada de obras públicas: O modelo normativo do regime do contrato administrativo e do contrato público (em especial, o equilíbrio económico-financeiro). Coimbra: Almedina, 2015.

MARZUOLI, Carlo. Le privatizzazioni tra pubblico come soggetto e pubblico come regola. Diritto Pubblico, Padova, a. 1, n. 2, p. 393-421, 1995.

MAURER, Hartmut. Elementos de direito administrativo alemão. Porto Alegre: Sergio Antônio Fabris, 2001.

Direito administrativo geral. São Paulo: Manole, 2006.

MAXIMILIANO, Carlos. Hermenêutica e aplicação do Direito. Rio de Janeiro: Forense, 1984.

MAYER, Otto. Deutsches verwaltungsrecht. Berlim: Duncker \& Humblot, 1924. Derecho administrativo alemán. Buenos Aires: De Palma, 1949.

MAZZILLI, Hugo Nigro. Regime jurídico do Ministério Público. São Paulo: Saraiva, 2000.

MEDAUAR, Odete. Licitação e contrato administrativo. São Paulo: Malheiros, 1990.

. O direito administrativo em evolução. São Paulo: Revista dos Tribunais, 1992.

O direito administrativo em evolução. São Paulo: Revista dos Tribunais, 2003.

Administração Pública: do ato ao processo. In: ARAGÃO, Alexandre Santos de; MARQUES NETO, Floriano de Azevedo (coords.). Direito administrativo e seus novos paradigmas. Belo Horizonte: Fórum, 2008. 
. Controle da Administração Pública. São Paulo: Revista dos

Tribunais, 2012.

. Direito administrativo moderno. São Paulo: Revista dos

Tribunais, 2015.

MEIRELLES, Hely Lopes. Direito administrativo brasileiro. São Paulo: Revista dos Tribunais, 1991.

MELLO, Celso Antônio Bandeira de. Discricionariedade e controle jurisdicional. São Paulo: Malheiros, 2007. A estabilidade dos Atos Administrativos e a Segurança Jurídica, Boa-Fé e Confiança Legítima ante os atos estatais. In: Grandes Temas de Direito Administrativo. São Paulo: Malheiros, 2010. . Grandes temas de Direito Administrativo. São Paulo:

Malheiros, 2010. . Curso de direito administrativo. São Paulo: Malheiros, 2014.

MELLO, Oswaldo Aranha Bandeira de. Princípios gerais de Direito administrativo. Rio de Janeiro: Forense, 1969. P. 668-672.

MENDOZA, Xavier; VERNIS, Alfred. El Estado relacional y la transformación de las administraciones públicas. In: LONGO, Francisco; YSA, Tamyko (eds.). Los escenarios de la gestión pública del siglo XXI. Barcelona: Bellaterra, 2008.

MERLAND, Guillaume, L'interêt général dans la jurisprudence du Conseil Constitutionnel. Paris: LGDJ, 2004.

MERRYMAN, John Henry; PÉREZ-PERDOMO, Rogelio. The Civil Law tradition: An introduction to the legal systems of Europe and Latin America. Stanford: Stanford University Press, 2007.

MIRANDA, Francisco Cavalcanti Pontes de. Tratado de Direito privado: Parte especial. V. 25. Rio de Janeiro: Borsoi, 1959. 
MODESTO, Paulo. Autovinculação da Administração Pública. Revista Eletrônica de Direito do Estado, Salvador, n. 24, out.-dez. 2010.

MONIZ, Ana Raquel Gonçalves. Direito, ética e Estado: Brevíssimas reflexões em diálogo com Barbosa de Melo. In: CORREIA, Fernando Alves; SILVA, João Calvão da; VIEIRA DE ANDRADE, José Carlos; CANOTILHO, Joaquim José Gomes; CARDOSO DA COSTA, José Manuel M. Estudos em Homenagem a António Barbosa de Melo. Coimbra: Almedina, 2013. P. 33-71.

MONTESQUIEU, Charles de Secondat de. De L'Esprit des Lois. Genéve: Barilot et Fils, 1.758.

MOOR, Pierre. Droit administratif. Berna: Stämpfli, 1991.

MOORE, Mark H. Creating public value. Cambridge: Harvard University Press, 1997.

MORAES, Alexandre. Direito constitucional administrativo. São Paulo: Atlas, 2007.

MORAND-DEVILLER, Jacqueline. Cours de droit administratif. Paris:

Montchréstien, 2007.

MOREIRA NETO, Diogo de Figueiredo. Mutações do direito administrativo. Rio de Janeiro: Renovar, 2000.

. O futuro das cláusulas exorbitantes nos contratos administrativos. In: ARAGÃO, Alexandre Santos de; MARQUES NETO, Floriano de Azevedo. Direito administrativo e seus novos paradigmas. Belo Horizonte: Fórum, 2008.

O direito administrativo do século XXI: um instrumento de realização da democracia substantiva. A\&C Revista de Direito Administrativo \& Constitucional, Belo Horizonte, a. 11, n. 45, p. 13-37, jul./set. 2011.

MORGADO, Cíntia. Direito à boa administração: Recíproca dependência entre direitos fundamentais, organização e procedimento. Revista de Direito da Procuradoria Geral, Rio de Janeiro, n. 65, p. 68-94, 2010. 
MOTA Júnior, João Francisco da. A transação administrativa e a SUSPAD mineira: Medidas alternativas e o sistema punitivo disciplinar. Série Biblioteca Virtual sobre Corrupção. Brasília: Controladoria-Geral da União, 2007.

MOTTA, Fabrício. O paradigma da legalidade e o Direito Administrativo. In: DI PIETRO, Maria Sylvia Zanella; RIBEIRO, Carlos Vinicius Alves (coords.). Supremacia do interesse público e outros temas relevantes do Direito administrativo. São Paulo: Atlas, 2010.

MUÑOZ, Jaime Rodríguez-Arana. Derecho Administrativo y Constitución. Granada: CEMCl, [s.d.].

NANNI, Giovanni Ettore. O negócio de acertamento como espécie de negócio jurídico. Letrado IASP, São Paulo, n. 100, p. 78-79, mai.-jun. 2012.

NARANJO, Claudio. Cambiar la Educación para Cambiar el Mundo. Barcelona: La Llave, 2007.

NERY JUNIOR, Nelson; NERY, Rosa Maria de Andrade. Código de processo civil comentado. São Paulo: Revista dos Tribunais, 2007. Código civil comentado. São Paulo: Revista dos Tribunais, 2013.

NOHARA, Irene Patricia. Reflexões críticas acerca da tentativa de desconstrução do sentido da supremacia do interesse público no direito administrativo. In: DI PIETRO, Maria Sylvia Zanella; RIBEIRO, Carlos Vinicius Alves (coords.). Supremacia do interesse público e outros temas relevantes do Direito administrativo. São Paulo: Atlas, 2010.

O'NEIL, Jim. Building Better Global Economic BRICs. Global Economics Paper, Goldman Sachs, New York, n. 66, nov. 2001.

ORGANIZAÇÃO PARA A COOPERAÇÃO E O DESENVOLVIMENTO ECONÔMICO. Citizens as partners: OECD handbook on information, consultation and public participation in policy-making. Paris: OCDE, 2001. 
OLIVEIRA SANTOS, Eurico de. Direito administrativo e sciencia da administração. Rio de Janeiro: Jacintho Ribeiro dos Santos, 1919.

OPPO, Giorgio. Diritto privato e interessi pubblici. Studi Economico-Giuridici, Napoli, v. 55, p. 421-446, 1993-1994.

OTERO, Paulo. Legalidade e administração pública: o sentido da vinculação administrativa à juricidade. Coimbra: Almedina, 2003.

Arbitragem interna de litígios de Direito público: a publicização da arbitragem interna de Direito privado. Revista Internacional de Arbitragem e Conciliação, Lisboa, a. 5, n. especial, p. 180-193, 2012.

Da negociação no procedimento de adjudicação de contratos públicos. In: ATHAYDE, Augusto de; CAUPERS, João; GARCIA, Maria da Glória F. P. D. Em homenagem ao Professor Doutor Diogo Freitas do Amaral. Coimbra: Almedina, 2012.

. Equidade e arbitragem administrativa. In: CORDEIRO, António Menezes. Centenário do nascimento do Professor Doutor Paulo Cunha: Estudos em homenagem. Coimbra: Almedina, 2012.

PANDEY Anshul Vikram; MANIVANNAN, Anjali; NOV, Oded; SATTERTHWAITE, Margaret; BERTINI, Enrico. The Persuasive Power of Data Visualization. Public Law \& Legal Theory Research Paper Series, New York University, n. 14-37, jul. 2014.

PEARCE, Dennis. Administrative Appeals Tribunal. Sidney: Butterworths, 2007. PEDERSEN, Lene Holm. Committed to the public interest? Motivation and bahavioural outcomes among local councillors. Public Administration, Hoboken: Wiley-Blackwell, v. 92, n. 4, p. 886-901, 2014.

PÉREZ, Jesús Gonzales. El administrado. Madrid: Abella, 1966.

POGGI, Gianfranco. The development of the modern State: A sociological introduction. Stanford: Stanford University Press, 1978. 
PORTUGAL. Codigo Philippino ou Ordenações e Leis do Reino de Portugal Recopiladas por Mandado D'EI-Rey D. Philippe I. Rio de Janeiro: Typographia do Instituto Philomathico, 1870. V. 4.

PRADIER-FODÉRÉ, Paul Louis Ernest. Précis de droit administratif. Paris: Guilaumin, 1872.

PROSPERETTI, Ubaldo. Le rinunce e le transazioni del pubblico impiegato. Rivista Trimestrale di Diritto Pubblico, Roma, a. 5, p. 349-359, 1955.

QUINOT, Geo. Public procurement. Juta's Quarterly Review of South African Law, Lansdowne, n. 1, p. 5, jan.-mar. 2013.

RAMOS, José Saulo Pereira. Responsabilidade civil do Estado - Culpa recíproca Transação. Revista de Direito Administrativo, Rio de Janeiro, v. 166, p. 156-166, 1986.

REIS, Aarão. Direito administrativo brazileiro. Rio de Janeiro: Villas-Boas, 1923.

RETORTILLO, Sebastián. II diritto civile nella genesi del diritto amministrativo e dei suoi istituti. Rivista Trimestrale di Diritto Pubblico, Milano, a. 9, n. 4, p. 698735, out.-dez. 1959.

RIBEIRO, Carlos Vinicius Alves. Interesse público: um conceito jurídico determinável. In: DI PIETRO, Maria Sylvia Zanella; RIBEIRO, Carlos Vinicius Alves (coords.). Supremacia do interesse público e outros temas relevantes do Direito administrativo. São Paulo: Atlas, 2010.

RIBEIRO, Maria Teresa de Melo. O princípio da imparcialidade da Administração Pública. Coimbra: Almedina, 1996.

$\mathrm{RICCl}$, Jean-Claude. Le pouvoir discrétionnaire de l'administration fiscale. Marseille: Presses Universitaires d'Aix-Marseille, 1977.

RICHARDSON, Henry S. Democratic intentions. In: BOHMAN, James; REHG, William (eds.). Deliberative democracy: essays on reason and politics. Cambridge: MIT, 1997. P. 349-382. 
RICHER, Laurant. Les contrats administratifs. Paris: Dalloz, 1991.

RIVERO, Jean. Droit administratif. Paris: Dalloz, 1975.

Curso de direito administrativo comparado. Trad. José

Cretella Júnior. São Paulo: Revista dos Tribunais, 1995.

. Cours de Droit Administratif comparé. Paris: Dalloz, 2011.

RODRIGUES, Silvio. Direito Civil: Dos contratos e das declarações unilaterais da vontade. São Paulo: Saraiva, 2004.

ROUSSEAU, Jean-Jacques. Du Contract Social, ou principes du Droit Politique. Amsterdam: Marc Michel, 1762.

SALA, Giovanni. Accordi sul contenuto discrezionale del provvedimento e tutela delle situazioni soggetive. Diritto Processuale Amministrativo, Milano, a. 10, n. 2, p. 206-254, jun. 1992.

SALOMONI, Jorge Luis. Interés público y emergencia. Actualidad en Derecho Publico, Buenos Aires, n. 18-20, p. 136, jan.-dez. 2002.

SANTA CATARINA. TRIBUNAL de Justiça de Santa Catarina. Agravo de Instrumento n. 2000.001639-0. Rel. Des. Francisco Oliveira Filho. Diário de Justiça de Santa Catarina, Florianópolis, n. 11.113, 20 jan. 2003.

SANTORO-PASSARELLI, Francesco. L'accertamento negociale e la transazione. Rivista Trimestrale di Diritto e Procedura Civile, Milano, a. 10, p. 1-26,1956.

Nozione della transazione. Rivista di Diritto Civile, Padova,

a. 2, p. 303-313, 1956 .

SANTOS, Luiz Alberto dos. Desafios da Governança regulatória no Brasil. In: RAMALHO, Pedro Ivo Sebba (org.). Regulação e Agências Reguladoras: Governança e Análise de Impacto Regulatório. Brasília: ANVISA, 2009.

SARMENTO, Daniel (org.). Interesses públicos versus interesses privados: Desconstruindo o princípio da supremacia do interesse público. Rio de Janeiro: Lumen Juris, 2007. 
SCHIRATO, Vitor Rhein. A interação entre Administração Pública e particulares nos contratos administrativos. Fórum de Contratação e Gestão Pública, Belo Horizonte, a. 12, n. 138, p. 51-69, jun. 2013.

PALMA, Juliana Bonacorsi de. Consenso e Legalidade: vinculação da atividade administrativa consensual ao direito. Revista Eletrônica sobre a Reforma do Estado, Salvador, n. 24, jan.-fev. 2011.

SCHIRMER, Mário Sérgio de Albuquerque. Impossibilidade de realização de acordos no âmbito do direito administrativo sem a existência de lei expressamente autorizando a avença. Repositório do Centro de Apoio Operacional das Promotorias de Justiça de Proteção ao Patrimônio Público e à Ordem Tributária. Curitiba: CAOP-MPPR, [s.d.].

SCHMIDT-ASSMANN, Eberhard. La teoría general del derecho administrativo como sistema. Madrid: INAP, 2003.

SCHWANKA, Cristiane. Administração Pública consensual: A transação como método alternativo de solução de conflitos nos contratos administrativos. 2009. Dissertação (Mestrado em direito) - UniBrasil, Curitiba, 2009.

SERRANO, Maria Luisa González-Cuellar. Los procedimientos tributarios: Su terminación transaccional. Madrid: Colex, 1998.

SILVA, Vasco Pereira da. Em busca do acto administrativo perdido. Coimbra: Almedina, 1998.

. É sempre a mesma cantiga: o contencioso da responsabilidade civil pública. In: FACULDADE de Direito da Universidade de Lisboa. Estudos em homenagem ao Prof. Doutor Sérvulo Correia. V. II. Coimbra: Coimbra Editora, 2010.

SIMON, Yves. Philosophie de le gouvernement démocratique. (Filosofia do governo democrático / trad. Edgard Godói de Mata-Machado). Rio de Janeiro: Agir, 1955. P. 15-55. 
SMITH, Andy. Governança de múltiplos níveis: o que é e como pode ser estudada. In: PETERS, Guy; PIERRE, Jon (orgs.). Administração pública: coletânea. São Paulo: UNESP; Brasília: ENAP, 2010.

SOARES, Rogério. Interesse público, legalidade e mérito. Coimbra: Atlântida, 1955.

SORACE, Domenico. Come rifare la pubblica amministrazione italiana e il suo diritto? Diritto Pubblico, Padova, a. 2, n. 2, p. 381-405, mai.-ago. 1996.

Diritto delle amministrazioni pubbliche: Una introduzione.

Bologna: II Mulino, 2000.

SOUTO, João Carlos. A União Federal em juízo. São Paulo: Saraiva, 2000.

SOUZA, Carlos Alberto Sobral de. Da Transação e da Indisponibilidade do Interesse Público. Fórum Administrativo Direito Público, Belo Horizonte, a. 1, n. 8, out. 2001.

SPADE, Paul Vincent. William of Ockham. In: ZALTA, Edward N. (ed.). The Stanford Encyclopedia of Philosophy. Stanford: Stanford University, 2008.

SPASIANO, Mario R. L'interesse pubblico e l'attività della P.A. nelle sue diverse forme. Il Foro Amministrativo, Milano, v. 4, n. 5, p. 1.820-1.829, mai. 2005.

STRECK, Lênio Luiz. Ministros do STJ não devem se aborrecer com a lei. Revista Consultor Jurídico, São Paulo, 7 jun. 2012.

SUNDFELD, Carlos Ari; CÂMARA, Jacintho Arruda. Acordos na execução contra a Fazenda Pública. Revista Brasileira de Direito Público, Belo Horizonte, a. 8, n. 30, jul.-set. 2010.

Direito administrativo para céticos. São Paulo: Malheiros,

2012.

SUSTEIN, Cass R.; VERMEULE, Adrian. Libertarian Administrative Law. University of Chicago Law Review, Chicago, n. 82, p. 393-473, 2015. 
TIMM, Luciano Benetti; SILVA, Thiago Tavares e. Os contratos administrativos e a arbitragem. Revista Síntese Direito Administrativo, n. 94, p. 23, out. 2013.

TOCQUEVILLE, Alexis de. Democracy in America. V. I. New York: Vintage Books, 1945.

Democracy in America. V. II. New York: Vintage Books,

1945.

UNIÃO EUROPEIA. CONSELHO da Europa. Recommendation 2001-9 of the Committee of Ministers to member states on alternatives to litigation between administrative authorities and private parties. Estrasburgo: Éditions du Conseil de l'Europe, 2001.

URUGUAY, Paulino José Soares de Sousa, Visconde do. Ensaio sobre o direito administrativo. Rio de Janeiro: Typographia Nacional, 1862.

VAINER, Bruno Zilberman. Aspectos básicos da segurança jurídica. Revista de Direito Constitucional e Internacional, São Paulo, ano 14, n. 56, p. 5-26, jul./set. 2006.

VALENTINI, Stelio. Divagazioni sul metodo. AMOROSINO, Sandro (org.). Le trasformazioni del Diritto Amministrativo: Scriti degli allievi per gli ottanta anni di Massimo Severo Giannini. Milano: Giuffrè, 1995.

VALLE, Vanice Regina Lírio do. Controle social: promovendo a aproximação entre administração pública e a cidadania. In: BRASIL. Tribunal de Contas da União. Prêmio Serzedello Corrêa 2001: monografias vencedoras: perspectivas para o controle social e a transparência da administração pública. Brasília: TCU, 2002.

VALSECCHI, Emilio. Ancora sulla natura della transazione. Rivista di Diritto Commerciale, Milano, a. 48, n. 1, p. 468-483, 1950.

VARUHAS, Jason N. E. The public interest conception of public law: Its procedural origins and substantive implications. Legal Studies Research Paper Series, University of Cambridge, Cambridge, n. 61, out. 2014. 
VEDEL, Georges. Droit administratif. Paris: Presses Universitaires de France, 1984.

VENOSA, Silvio de Salvo. Direito Civil: Teoria Geral das Obrigações e Teoria Geral dos Contratos. São Paulo: Atlas, 2005.

VERMEULE, Adrian. The Administrative State: Law, democracy, and knowledge. In: TUSHNET, Mark; GRABER, Mark A.; LEVINSON, Sanford. The Oxford handbook of the U.S. Constitution. Oxford: Oxford Univertsity Press, 2015.

VIEIRA DE ANDRADE, José Carlos. A imparcialidade da Administração como princípio constitucional. Boletim da Faculdade de Direito, Coimbra, v. 50, p. 219246, 1974.

VILLATA, Ricardo. Riflessioni in tema di partecipazione al procedimento e legitimazione processuale. Diritto Processuale Amministrativo - Rivista Trimestrale, Milano, a. 10, n. 2, p. 172-205, jun. 1992.

VILLORIA MENDIETA, Manuel. La modernización de la administración como instrumento al servicio de la democracia. Madrid: Inap, 1996.

VINCI, Nathalie. Guide de la transaction en droit administratif. Paris: Territorial, 2012.

WAGNER, Wendy E. The Participation-Centered Model meets administrative process. Wisconsin Law Review, Madison, n. 671, p.671-692, 2013.

WAKEFIELD, Jill. The Right to Good Administration. Amsterdam: Kluwer Law, 2007.

WALD, Arnoldo. O Direito de parceria e a Nova Lei de Concessões. São Paulo: Revista dos Tribunais, 1996.

WALDRON, Jeremy. Public rule of Law. Public Law \& Legal Theory Research Paper Series, New York University, New York, n. 14-41, set. 2014.

WINDSCHEID, Bernhard. Diritto delle pandette. Torino: Torinese, 1902. 
YOSHIDA, Consuelo Yatsuda Moromizato. O Ministério Público e sua função institucional de defesa do patrimônio público lesado ou ameaçado de lesão. Boletim dos Procuradores da República, Brasília, v. 2, n. 18, 1999. 